\title{
Hanford Site Environmental Report for Calendar Year 1993
}

Scientific Editors

R. L. Dirkes

R. W. Hanf

R. K. Woodruff

Technical Editor

R. E. Lundgren

June 1994

Prepared for

the U.S. Department of Energy

under Contract DE-AC06-76RLO 1830

Pacific Northwest Laboratory

Richland, Washington 99352

\% Battelle 


\section{DISCLAIMER}

This report was prepared as an account of work sponsored by an agency of the United States Government. Neither the United States Government nor any agency thereof, nor any of their employees, make any warranty, express or implied, or assumes any legal liability or responsibility for the accuracy, completeness, or usefulness of any information, apparatus, product, or process disclosed, or represents that its use would not infringe privately owned rights. Reference herein to any specific commercial product, process, or service by trade name, trademark, manufacturer, or otherwise does not necessarily constitute or imply its endorsement, recommendation, or favoring by the United States Government or any agency thereof. The views and opinions of authors expressed herein do not necessarily state or reflect those of the United States Government or any agency thereof. 


\section{DISCLAIMER}

\section{Portions of this document may be illegible in electronic image products. Images are produced from the best available original document.}




\title{
Department of Energy
}

\author{
Richland Operations Office \\ P.O. Box 550 \\ Richland, Washington 99352
}

\section{JUL 111994}

\section{DISTRIBUTION: RECIPIENTS OF PNL-9823}

HANFORD SITE ENVIRONMENTAL REPORT FOR CALENDAR YEAR 1993 (PNL-9823), PACIFIC NORTHWEST LABORATORY (PNL), RICHLAND, WASHINGTON, JUNE 1994

Enclosed is a copy of the 1993 Environmental Report for the U.S. Department of Energy (DOE), Richland Operations Office (RL), Hanford Site. This report is prepared and published annually for distribution to local, State, and Federal government agencies; Congress; the public; and the news media. The purpose of the report is to present a summary of the environmental status of the site. It describes environmental management activities and the continuing programs to achieve compliance with environmental standards and requirements.

The report contains sections summarizing compliance status, current issues and actions, and conformance to environmental permits for the period January 1 through Apri1 1, 1994. The purpose of this report is to provide the reader with the most recent information available and thus upgrade the quality and usefuiness of the report.

The report was prepared for RL by PNL and describes programs conducted by PNL, the Research and Development contractor and Westinghouse Hanford Company, the operations and engineering contractor for the Hanford Site.

If you have any questions or desire additional information, please contact John B. Hall of the RL Quality, Safety, and Health Programs Division at (509) 372-1677.

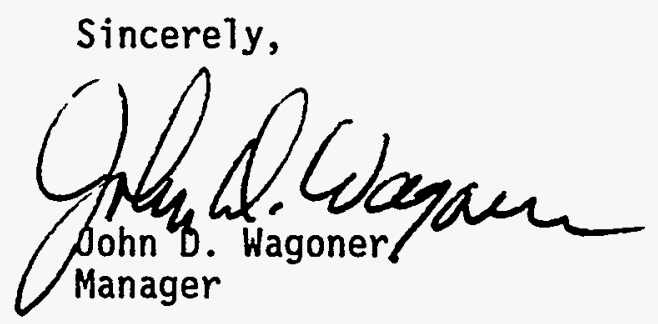

Enciosure:

Hanford Site Environmental

Report for 1993 


\section{Preface}

U.S. Department of Energy (DOE) Order 5400.1, "General Environmental Protection Program," establishes the requirement for environmental protection programs at DOE sites and facilities. These programs ensure that DOE operations comply with applicable federal, state, and local environmental laws and regulations, executive orders, and department policies. The DOE, Richland Operations Office, has established a plan for implementing this order, United States Department of Energy Richland Operations Office Environmental Protection Implementation Plan, November 9, 1993, to November 9, 1994 (DOE 1993d). This plan is updated annually.

The Hanford Site Environmental Report is prepared annually pursuant to DOE Order 5400.1 to summarize environmental data that characterize Hanford Site environmental management performance and demonstrate compliance status. The report also highlights significant environmental programs and efforts. More detailed environmental compliance, monitoring, surveillance, and study reports may be of value; therefore, to the extent practical, these additional reports have been referenced in the text.

Although this report was written to meet DOE reporting requirements and guidelines, it was also intended to be useful to members of the public, public officials, regulators, and Hanford Site contractors. The report's "Summary" was written with a minimum of technical terminology. The "Helpful Information" section lists acronyms, abbreviations, conversion information, and nomenclature useful for understanding the report.

This report is prepared for the Richland Operations Office, Quality, Safety, and Health Programs Division by the Pacific Northwest Laboratory's Office of Health and Environment as part of the Public Safety and Resource Protection Program. Pacific Northwest Laboratory is operated for DOE by Battelle Memorial Institute, a notfor-profit independent contract research institute. Major portions of the report were written by staff from the Pacific Northwest Laboratory (the Site research and development contractor) and Westinghouse Hanford Company (the Site operating and engineering contractor). The U.S. Fish and Wildlife Service, the Washington Department of Fish and Wildlife, and the Richland office of the U.S. Army Corps of Engineers provided input to Section 4.2, "Wildlife." Support for the facility effluent monitoring section was provided by a Science Application International Corporation (SAIC) staff member.

Inquiries regarding this report may be directed to the Richland Operations Office, Quality, Safety, and Health Programs Division, P.O. Box 550, Richland, Washington 99352, or to Pacific Northwest Laboratory, Office of Health and Environment, P.O. Box 999, Richland, Washington 99352 . A brief general summary of this report in pamphlet form is also available and can be obtained by contacting the Pacific Northwest Laboratory at the address given above. 



\section{Summary}

The Hanford Site Environmental Report is prepared annually to summarize environmental data and information, describe environmental management performance, and demonstrate the status of compliance with environmental regulations. The report also highlights major environmental programs and efforts.

The report is written to meet reporting requirements and guidelines of the U.S. Department of Energy (DOE) and to meet the needs of the public. This summary has been written with a minimum of technical terminology.

Individual sections of the report are designed to

- describe the Hanford Site and its mission

- summarize the status in 1993 of compliance with environmental regulations

- describe the environmental programs at the Hanford Site

- discuss estimated radionuclide exposure to the public from 1993 Hanford activities

- present information on effluent monitoring and environmental surveillance, including ground-water protection and monitoring

- discuss activities to ensure quality.

More detailed information can be found in the body of the report, the appendixes, and the cited references.

\section{The Hanford Site and its Mission}

The Hanford Site in southcentral Washington State is about 1,450 square kilometers ( 560 square miles) of semi-arid shrub and grasslands located just north of the confluence of the Snake and Yakima rivers with the Columbia River. This land, with restricted public access, provides a buffer for the smaller areas historically used for the production of nuclear materials, waste storage, and waste disposal. About $6 \%$ of the land area has been disturbed and is actively used. This $6 \%$ is divided into operational areas:

- the 100-B/C, 100-D, 100-F, 100-H, 100-K, and $100-\mathrm{N}$ Areas, which lie along the south shore of Columbia River in the northern portion of the Hanford Site

- the 200-East and 200-West Areas, which lie in the center of the Hanford Site near the basalt outcrops of Gable Mountain and Gable Butte

- the 300 Area, near the southern border of the Hanford Site

- the 400 Area, between the 300 and 200 Areas [home of the Fast Flux Test Facility (FFTF)]

- the 1100 Area, a corridor northwest of the city of Richland used for vehicle maintenance and other support activities.

The 600 Area is the designation for land between the operational areas. Areas off the Hanford Site used for research and technology development and administrative functions can be found in Richland, Kennewick, and Pasco, the nearest cities.

The Hanford Site was acquired by the federal government in 1943 and for many years was dedicated primarily to the production of plutonium for national defense and the management of the resulting wastes. With the shutdown of the production facilities in the 1970s and 1980 s, missions were diversified to include research and development in the areas of energy, waste management, and environmental restoration.

The DOE has ended the production of nuclear materials at the Hanford Site for weapons. The current mission being implemented by the DOE, Richland Operations Office, is now: 
- waste management/cleanup

- technology development

- economic diversification.

Current waste management activities at the Hanford Site include primarily managing wastes with high and low levels of radioactivity (from the nuclear materials production activities) in the 200-East and 200-West Areas. Key waste management facilities include the waste storage tanks, Plutonium Uranium Extraction (PUREX) Plant, Plutonium Finishing Plant, Central Waste Complex, Low-Level Burial Grounds, B Plant, and 242-A Evaporator. In addition, irradiated nuclear fuel is stored in the $100-\mathrm{K}$ Area in fuel storage basins.

Environmental restoration includes activities to decontaminate and decommission facilities and to clean up or restore inactive waste sites. The Hanford surplus facilities program conducts surveillance and maintenance of such facilities, and has begun to clean up and dispose of more than 100 facilities. Current activities include decommissioning of the strontium semiworks and the $183-\mathrm{H}$ Solar Evaporation Basins.

Research and technology development activities are intended to improve the techniques and reduce the costs of waste management, environmental protection, and Site restoration.

Operations and activities on the Hanford Site are managed by the Richland Operations Office through four prime contractors and numerous subcontractors. Each contractor is responsible for the safe, environmentally sound maintenance and management of its facilities and operations, waste management, and monitoring of operations and effluents for environmental compliance.

The principal contractors include:

- Westinghouse Hanford Company

- Battelle Memorial Institute

- ICF Kaiser Hanford Company

- Hanford Environmental Health Foundation.

Non-DOE operations and activities include commercial power production by the Washington Public Power
Supply System's WNP-2 Reactor (near the 400 Area) and commercial low-level radioactive waste burial at a site leased and licensed by the state of Washington and operated by U.S. Ecology (near the 200 Areas). Siemens Power Corporation operates a commercial nuclear fuel fabrication facility, and Allied Technology Group Corporation operates a low-level radioactive waste decontamination, supercompaction, and packaging disposal facility near the southern boundary of the Hanford Site.

\section{Compliance With Environmental Regulations}

The DOE Order 5400.1, "General Environmental Protection Program," describes the environmental standards and regulations applicable at DOE facilities. These environmental standards and regulations fall into three categories: 1) DOE directives, 2) federal legislation and executive orders, and 3) state and local statutes, regulations, and requirements. The following subsections summarize the status of Hanford's compliance with these applicable regulations and list environmental occurrences for 1993.

A key element in Hanford's compliance program is the Hanford Federal Facility Agreement and Consent Order (Tri-Party Agreement). The Tri-Party Agreement is an agreement among the U.S. Environmental Protection Agency (EPA), Washington State Department of Ecology (Ecology), and DOE for achieving compliance with the remedial action provisions of the Comprehensive Environmental Response, Compensation, and Liability Act (CERCLA) [including Superfund Amendments and Reauthorization Act (SARA)] and with treatment, storage, and disposal unit regulation and corrective action provisions of the Resource Conservation and Recovery Act (RCRA).

\section{Comprehensive Environmental Response, Compensation, and Liability Act}

The CERCLA established a program to ensure that sites contaminated by hazardous substances are cleaned up by responsible parties or the government. The SARA 
broadened CERCLA and established provisions for federal facilities. CERCLA primarily covers waste cleanup of inactive sites.

The preliminary assessments conducted for the Hanford Site revealed approximately 1,100 known individual waste sites where hazardous substances may have been disposed of in a manner that requires further evaluation to determine impact to the environment.

The DOE is actively pursuing the remedial investigation/ feasibility study process at some operable units on the Hanford Site. The selection of the operable units currently under investigation is a result of Tri-Party Agreement negotiations. All milestones established for 1993 related to this process were achieved, and the Hanford Site was in compliance with these CERCLA/ SARA requirements. Several milestones were delayed until 1994 through the change request process.

\section{Emergency Planning and Community Right-To-Know Act}

The Emergency Planning and Community Right-ToKnow Act requires that the public be provided with information about hazardous chemicals in the community and establishes emergency planning and notification procedures to protect the public from a release. Subtitle A of the law calls for creation of state emergency response commissions to guide planning for chemical emergencies. State commissions have also created local emergency planning committees to ensure community participation and planning.

To provide the public with the basis for emergency planning, Subtitle B of the Act contains requirements for periodic reporting on hazardous chemicals stored and/or used near the community. The 1993 Hanford Tier Two Emergency and Hazardous Chemical Inventory (DOE 1994a) was issued to the State Emergency Response Commission, local county emergency management committees, and local fire departments. The report contained information on hazardous materials in storage across the Hanford Site. The 1992 Hanford Toxic Chemical Release Inventory (DOE 1993e) was issued July 1, 1993, to the EPA and the state. This report contains information on releases to the environment of chemicals that were in excess of mandated thresholds. Accordingly, during 1993, the Hanford Site was in compliance with the reporting and notification require-ments contained in this Act.

\section{Resource Conservation and Recovery Act}

The RCRA establishes regulatory standards for the generation, transportation, storage, treatment, and disposal of hazardous wastes. Ecology has been authorized by the EPA to implement its dangerous waste program in lieu of the EPA for Washington State, except for some provisions of the Hazardous and Solid Waste Amendments of 1984. Ecology also implements the state's regulations, which are often more stringent. RCRA primarily covers ongoing waste management at active facilities.

At the Hanford Site, approximately 63 treatment, storage, and disposal units have been identified that must be permitted or closed in accordance with RCRA and Washington State regulations. These units are required to operate under Ecology's interim-status compliance requirements. Approximately one-half of the units will be closed.

Subtitle I of RCRA deals with regulation of underground storage tank systems. These regulations were added to RCRA by the Hazardous and Solid Waste Amendments of 1984. The EPA has developed regulations implementing technical standards for tank performance and management, including standards governing the cleanup and closure of leaking tanks. These regulations do not apply to the single- and double-shell nuclear waste tanks, which are regulated as treatment, storage, and disposal facilities.

\section{Clean Air Act}

The purpose of the Clean Air Act is to protect public health and welfare by safeguarding air quality, bringing polluted air into compliance, and protecting clean air from degradation. In Washington State, the provisions of the Act are implemented by EPA, Ecology, Washington State Department of Health, and local air authorities.

The Hanford Site is operated under a Prevention of Significant Deterioration permit (No. PSD-X80-14) issued by the EPA in 1980. The permit sets specific limits for emissions of nitrogen oxides from the PUREX and Uranium-Oxide Plants.

The Washington State Department of Health, Division of Radiation Protection, Air Emissions and Defense Waste 
Section, has developed regulatory controls for radioactive air emissions under Section 116 of the Clean Air Act. Washington State regulations [Washington Administration Code (WAC) 246-247] require registration of all radioactive air emission point sources with the Washington State Department of Health. All significant Hanford Site stacks emitting radiation have been registered in accordance with applicable regulations.

Revised Clean Air Act requirements for radioactive air emissions were issued December 15, 1989, under National Emission Standards for Hazardous Air Pollutants, 40 Code of Federal Regulations 61 (40 CFR 61), Subpart $\mathrm{H}$. Emissions from the Hanford Site are well within the new EPA offsite emissions standard of 10 millirem/ year [effective dose equivalent (see Appendix B, "Glossary")]. Hanford Site sources are in the process of meeting the new procedural requirements for flow measurement, emissions measurement, quality assurance, and sampling documentation.

Pursuant to this program, EPA has developed regulations specifically addressing asbestos emissions (40 CFR 61 , Subpart M). These regulations apply at the Hanford Site in building demolition/disposal and waste disposal operations. During 1993, 1,507 cubic meters $(53,212$ cubic feet) of asbestos were removed.

The local air authority, the Benton-Franklin Counties Clean Air Authority, enforces Regulation 1. This regulation pertains to detrimental effects, fugitive dust, incineration products, open burning, odor, opacity, asbestos, emissions, and the air operating-permit program. The Authority has also been delegated responsibility to enforce the EPA asbestos regulations under the National Emission Standards for Hazardous Air Pollutants. The Site remains in compliance with the regulations.

\section{Clean Water Act}

The Clean Water Act applies to all discharges to waters of the United States. At the Hanford Site, the regulations are applied through a National Pollutant Discharge Elimination System permit governing effluent discharges to the Columbia River. The permit (No. WA-000374-3) specifies discharge points (called outfalls, of which there are eight), effluent limitations, and monitoring requirements. There were no instances of noncompliance in 1993.

\section{Safe Drinking Water Act}

The National Primary Drinking Water Regulations of the Safe Drinking Water Act apply to the drinking water supplies at the Hanford Site. These regulations are enforced by the Washington State Department of Health. During 1993, all Hanford Site water systems were in compliance with the requirements of the applicable regulations.

\section{Toxic Substances Control Act}

The application of Toxic Substances Control Act requirements to the Hanford Site essentially involves regulation of the chemicals called polychlorinated biphenyls (PCBs). The Hanford Site is currently in compliance with regulations for nonradioactive PCBs. All radioactive PCB wastes are being stored with EPA approval, pending development of treatment and disposal technologies and capabilities.

\section{Federal Insecticide, Fungicide, and Rodenticide Act}

The EPA is responsible for ensuring that a chemical, when used according to label instructions, will not present unreasonable risks to human health or the environment. This Act and the Revised Code of Washington (RCW) 17.21, "Washington Pesticide Application Act, 1961 ," as implemented by WAC 16-228, "General Pesticides Regulations," apply to storage and use of pesticides. In 1993, the Hanford Site was in compliance with the Act's requirements and WAC 16-228 regulations pertaining to storage and application of pesticides.

\section{Endangered Species Act}

A few rare species of native plants and animals are known to occur on the Hanford Site. Some of these are listed by the U.S. Fish and Wildlife Service as endangered or threatened (federally listed). Others are listed by the Washington Department of Fish and Wildlife as endangered, threatened, or sensitive species. The Site monitoring program is discussed in Section 4.2, "Wildlife." Hanford Site activities complied with the Endangered Species Act in 1993. 


\section{National Historic Preservation Act, Archaeological Resources Protection Act, Native American Graves Protection and Repatriation Act, and American Indian Religious Freedom Act}

Cultural resources on the Hanford Site are subject to the provisions of these Acts. Compliance with these Acts is accomplished through a management and monitoring program, which is described in Section 4.3, "Hanford Cultural Resources Laboratory." In 1993, Hanford Site operations complied with these Acts.

\section{National Environmental Policy Act}

The National Environmental Policy Act (NEPA) establishes environmental policy to prevent or eliminate damage to the environment and to enrich our understanding of ecological systems and natural resources. The NEPA requires that major federal projects with significant impacts be carefully reviewed and reported to the public in environmental impact statements (EISs). Other NEPA documents such as environmental assessments are also prepared in accordance with NEPA requirements.

Several EISs related to programs or activities on the Hanford Site are in process or in the planning stage.

\section{Environmental Occurrences}

Onsite and offsite environmental occurrences (spills, leaks, etc.) of radioactive and nonradioactive effluent materials during 1993 were reported to DOE as specified in DOE Order 5000.3B and to other federal and state agencies as required by law. All emergency, unusual, and off-normal occurrence reports, including event descriptions and corrective actions, are available for review in the DOE Public Reading Room, Washington State University Tri-Cities campus, Richland, Washington. There were no emergency occurrences reported in 1993. There were 130 unusual occurrence reports for 1993. There were 1,391 off-normal environmental occurrence reports filed at the Hanford Site during 1993, covering everything from leaks from overheated motor vehicle cooling systems to leaking waste oil drums. Because of the volume of reported off-normal occurrences, event summaries are not included here.

\section{Environmental Programs}

Environmental programs were conducted at the Hanford Site to restore environmental quality, manage waste, develop appropriate technology for cleanup activities, and study the environment. These programs are discussed below.

Wildlife inhabiting the Hanford Site is monitored to determine the status and condition of the populations, and to assess effects of Hanford Site operations. Particular attention is paid to species that are rare, threatened, or endangered nationally or statewide and those species that are of commercial, recreational, or aesthetic importance statewide or locally. These species include the bald eagle, chinook salmon, Rocky Mountain elk, mule deer, Canada goose, several species of hawk, and other bird species. Fluctuations in wildlife and plant species on the Hanford Site appear to be a result of natural ecological factors and management of the Columbia River system.

The Hanford Cultural Resources Laboratory was established by the Richland Operations Office in 1987 as part of the Pacific Northwest Laboratory. Cultural resources on the Hanford Site are closely monitored, and projects are relocated in cases where there is a possibility of altering any significant historical sites.

It appears that erosive processes and human activities are the most significant factors affecting most of the historical sites. Wind erosion from off-road-vehicle use plays a big part in the deterioration of sites inside and outside of the security perimeter.

Technical work done in 1993 on the Hanford Environmental Dose Reconstruction Project consisted of restructuring models to enhance their capabilities, developing detailed estimates of releases of radioactive materials, and evaluating additional information needed to produce estimates of past radiation dose to humans.

The community-operated environmental surveillance program was initiated in 1990 to increase the public's involvement in and awareness of Hanford's surveillance program. Three surveillance stations continued operation in 1993. 


\section{Environmental Monitoring Information}

Environmental monitoring of the Hanford Site consists of 1) effluent monitoring and 2) environmental surveillance including ground-water monitoring. Effluent monitoring is performed as appropriate by the operators at the facility or at the point of release to the environment. Additional monitoring is conducted in the environment near facilities that discharge or have discharged effluents. Environmental surveillance consists of sampling and analyzing environmental media on and off the Hanford Site to detect and quantify potential contaminants, and to assess their environmental and human health significance.

The overall objectives of the monitoring and surveillance programs are to demonstrate compliance with applicable federal, state, and local regulations; confirm adherence to DOE environmental protection policies; and support environmental management decisions.

The following sections discuss the doses calculated from environmental data, and effluent monitoring and environmental surveillance on or near the Hanford Site in 1993.

\section{Potential Radiation Doses from 1993 Hanford Operations}

In 1993, potential public doses resulting from exposure to Hanford liquid and gaseous effluents were evaluated to determine compliance with pertinent regulations and limits. These doses were calculated from reported effluent releases and environmental surveillance data using Version 1.485 of the GENII code (Napier et al. 1988a, $1988 b, 1988 \mathrm{c}$ ) and Hanford site-specific parameters. Specific information on sample collection and analyses and the sample results used in these calculations are briefly discussed in the following summary sections discussing effluent monitoring and environmental surveillance.

The potential dose to the hypothetical maximally exposed individual (MEI) in 1993 from Hanford operations was 0.03 mrem $\left(3 \times 10^{-4} \mathrm{mSv}\right)$, compared to 0.02 mrem ( $2 \times 10^{-4} \mathrm{mSv}$ ) calculated for 1992 . The small additional dose to the MEI was a result of new experimental work initiated in the 300 Area during September 1993. This work entailed the release of radon isotopes to the atmos- phere from a 327 Building stack. The potential dose to the local population of 380,000 persons from 1993 operations was 0.4 person-rem ( 0.004 person-Sv), compared to 0.8 person-rem (0.008 person-Sv) reported for 1992 . The 1993 average dose to the population was 0.001 mrem ( $\left.1 \times 10^{-5} \mathrm{mSv}\right)$ per person. The current DOE radiation limit for an individual member of the public is $100 \mathrm{mrem} / \mathrm{yr}(1 \mathrm{mSv} / \mathrm{yr})$, and the national average dose from natural sources is $300 \mathrm{mrem} / \mathrm{yr}(3 \mathrm{mSv} / \mathrm{yr})$. The MEI potentially received $0.03 \%$ of the DOE dose limit and $0.01 \%$ of the national average background dose from natural sources. The average individual potentially received $0.001 \%$ of the standard and $0.0003 \%$ of the $300 \mathrm{mrem} / \mathrm{yr}$ received from typical natural sources.

Special exposure scenarios not included in the above dose estimates include the potential consumption of game residing on the Hanford Site and exposure to radiation at the publicly accessible location with the maximum exposure rate. Doses from these sources would also have been small compared to the dose limit.

Dose through the air pathways was $0.2 \%$ of the EPA limit of $10 \mathrm{mrem} / \mathrm{yr}$ (40 CFR 61).

\section{Effluent Monitoring}

Effluent monitoring includes facility effluent monitoring (monitoring effluents at the point of release to the environment) and near-facility environmental monitoring (monitoring the environment near operating facilities).

\section{Facility Effluent Monitoring}

Liquid and gaseous effluents that may contain radioactive and hazardous constituents are continually monitored at the Hanford Site. Facility operators monitor effluents mainly through analyzing samples collected near points of release into the environment. Effluent monitoring data are evaluated to determine their degree of compliance with applicable federal, state, and local regulations and permits.

Measuring devices are used to quantify most facility effluent flows, with a smaller number of flows calculated using process information. Liquid and gaseous effluents with a potential to contain radioactivity at prescribed threshold levels are monitored for total alpha and total beta activity and, as warranted, specific gamma-emitting radionuclides. Nonradioactive hazardous constituents are also monitored, as applicable. 
Radioactive effluents from many facilities on the Site are approaching levels practically indistinguishable from the natural occurring radioactivity present everywhere. This decrease translates to a very small offsite radiation dose attributable to Site activities. A new Site mission of environmental restoration rather than nuclear materials production is largely responsible for this trend. Consistent with these conditions of diminishing releases, totals of radionuclides in effluents released at the Site in 1993 are not significantly different from totals in 1992.

\section{Near-Facility Environmental Monitoring}

The near-facility environmental monitoring program operated by Westinghouse Hanford Company provides environmental monitoring to protect the environment adjacent to facilities and ensure compliance with local, state, and federal environmental regulations.

Specifically, the near-facility environmental monitoring program monitored new and existing sites, processes, and facilities for potential impacts and releases; fugitive emissions and diffuse sources from contaminated areas; and surplus facilities before decontaminating or decommissioning. External radiation dose, ambient air particulates, soil, surface water, sediment, and biota were sampled. Parameters included, as appropriate, radionuclides, radiation exposure, hazardous constituents, $\mathrm{pH}$, and water temperature.

The analytical results showed a large degree of variability; in general, the samples collected from media located on or directly adjacent to the waste disposal and other nuclear facilities had significantly higher concentrations than those farther away. As expected, certain radionuclides were found in higher concentrations within different operational areas. Generally speaking, the predominant radionuclides were activation products/gamma emitters in the 100 Areas, fission products in the 200/600 Areas, and uranium in the 300 Area.

Air Monitoring. Radioactivity in air was sampled by a network of continuously operated samplers at 38 locations near facilities: 4 located in the 100-N Area, 31 in the 200/600 Areas, 2 background stations collocated with the Surface Environmental Surveillance Project and the Washington State Department of Health at the Yakima and Wye Barricades, and 1 background station collocated with a sampler operated by the Washington State Department of Health at the old Hanford townsite. Air samplers were primarily located at or near sites and/or facilities having the potential or history for release, with an emphasis on the prevailing downwind directions. Of the radionuclide analyses performed, ${ }^{90} \mathrm{Sr},{ }^{137} \mathrm{Cs},{ }^{239.240} \mathrm{Pu}$, and uranium were consistently detectable in the 200 Areas; ${ }^{60} \mathrm{Co}$ was detectable in the $100-\mathrm{N}$ Area. Air concentrations for these radionuclides were elevated near facilities when compared to the concentrations measured offsite by the Surface Environmental Surveillance Project.

\section{Monitoring of Surface-Water Disposal Units and} Seeps. Sampling of surface-water disposal units included water, sediment, and aquatic vegetation. Samples taken at river shoreline seeps included water only. Radiological analysis of liquid samples from surface-water disposal units included total alpha, total beta, ${ }^{3} \mathrm{H},{ }^{239,240} \mathrm{Pu}$, and gamma-emitting radionuclides. Radiological analysis of sediment and aquatic vegetation included ${ }^{90} \mathrm{Sr},{ }^{239,240} \mathrm{Pu}$, uranium, and gamma-emitting radionuclides. Nonradiological analysis performed included $\mathrm{pH}$, temperature, and nitrates.

Radionuclide concentrations in surface-water disposal units were below the applicable Derived Concentration Guides used as indexes of performance and in most cases at or below the analytical detection limit. Although some elevated levels were seen in both aquatic vegetation and sediment, in all cases the radiological analytical results were well below the standards for radiological control. The results for $\mathrm{pH}$ were well within the $\mathrm{pH}$ range of 2.0 - 12.5 standard for liquid effluent discharges as required by RCRA. The analytical results for nitrates were all below the $45-\mathrm{mg} / \mathrm{L}$ Drinking Water Standard.

Ground-water seeps along the $100-\mathrm{N}$ Area shoreline are sampled to verify the reported radionuclide releases to the Columbia River from past operations of the $\mathrm{N}$ Reactor. By characterizing the radionuclide concentrations in the seeps along the shoreline, the results can be compared to the concentrations measured in the facility effluent monitoring well.

In 1993, the concentrations detected in the seep samples were highest in those seeps nearest the facility effluent monitoring well, although the seep concentrations were considerably lower than those measured in the well.

Radiological Surveys. There were approximately 1,200 hectares ( 3,000 acres) of outdoor posted surface contamination and 400 hectares (1,000 acres) of posted underground radioactive material Sitewide in 1993. These areas were typically associated with cribs, burial grounds, tank farms, and covered ponds, trenches, and 
ditches. The number of posted surface contamination areas varied because of an ongoing effort to clean, stabilize, and remediate areas of known contamination while new areas of contamination were being identified. New areas may have been identified because of contamination migration or the increased effort being made to investigate outdoor areas for radiological contamination. It was estimated that the external dose rate for $80 \%$ of the identified outdoor surface contamination areas was less than $1 \mathrm{millirem} /$ hour, although isolated radioactive specks (less than 0.6 centimeters or 0.25 inches) could be considerably higher. Contamination levels of this type would not significantly add to external dose rates for the public or Site employees.

Soil and Vegetation Monitoring. Soil and vegetation samples were also collected on or adjacent to waste disposal units and from locations downwind and within the operating environment of facilities. Special samples were taken where physical or biological transport problems were identified. Soil and vegetation sample concentrations for some radionuclides were elevated near facilities when compared to the concentrations measured offsite. The concentrations show a large degree of variance; in general, samples collected on or directly adjacent to waste disposal facilities had significantly higher concentrations than those collected farther away.

External Radiation. External radiation fields were surveyed near operating facilities and waste-handling, storage, and disposal sites to measure, assess, and control the impacts of operations.

Hand-held microroentgen meters (to measure low-level radiation exposure) were used in the 100-N Area to survey points near and within the N Springs area, 1301-N Liquid Waste Disposal Facility , and 1325-N Liquid Waste Disposal Facility. The radiation rates measured in the $\mathrm{N}$ Springs area continued to decline in 1993, reflecting discontinued discharges to the 1301-N Liquid Waste Disposal Facility and the continuing decay of its radionuclide inventory. Radiation measurements taken at the 1325-N Liquid Waste Disposal Facility in 1993 and in the previous year were slightly elevated. Discontinued discharges to the facility resulted in the loss of the water that formerly provided shielding for the gamma-emitting radionuclides in sediments of the facility.

Radiation levels measured with thermoluminescent dosimeters were highest near facilities that had contained or received liquid effluent from $\mathrm{N}$ Reactor, primarily the
1325-N Liquid Waste Disposal Facility and the 1301-N Liquid Waste Disposal Facility. Dose rates for 1993 for these two facilities increased approximately $6 \%$ compared to 1992.

The highest dose rates measured in the 200/600 Areas were near waste-handling facilities such as tank farms. The average annual dose rate for 1993 in the 200/ 600 Areas was $130 \mathrm{mrem} /$ year, which remain unchanged from 1992.

The highest dose rates measured in the 300 Area were near waste-handling facilities such as the 340 Waste Handling Facility. The average annual dose rate for 1993 in the 300 Area was $200 \mathrm{mrem} /$ year, which was a $25 \%$ increase of the average dose rate of $160 \mathrm{mrem} / \mathrm{year}$ measured in 1992.

The highest dose rates measured in the 400 Area were near the main gate of the Fuels and Materials Examination Facility. The average annual dose rate for 1993 in the 400 Area was $100 \mathrm{mrem} /$ year, an increase of $11 \%$ of the average annual dose rate of $90 \mathrm{mrem} /$ year in 1992.

\section{Environmental Surveillance}

Environmental surveillance at the Hanford Site includes sampling environmental media on and off the Site for potential chemical and radiological contaminants originating from Site operations. The media sampled included air, surface water, soil and vegetation, fish and wildlife, food and farm products, external radiation levels, and ground water.

\section{Air Surveillance}

Atmospheric releases of radioactive and non-radioactive materials from the Hanford Site to the surrounding region represent a potential pathway for human exposure. Radioactive materials in air were sampled continuously at 36 locations onsite, at the Site perimeter, and in nearby and distant communities. Samples were also collected at 3 community-operated environmental surveillance stations that were managed and operated by local school teachers. Air sampling was discontinued at several locations in 1993 to reflect the substantial decrease in Hanford Site air emissions following the 1990 reduction in operations at the PUREX Plant. Particulates were filtered from the air at all locations and analyzed for radionuclides. Air was sampled and analyzed for selected gaseous radionuclides at key locations. Several 
radionuclides released at the Hanford Site are also found world-wide from two other sources: naturally occurring radionuclides and radioactive fallout from nuclear activities worldwide. The potential influence of emissions from Site activities on local radionuclide concentrations was evaluated by comparing differences between concentrations measured at distant locations within the region and concentrations measured at the Site perimeter.

For 1993, no differences were observed between the annual average total alpha and total beta air concentrations measured at the Site perimeter and distant community locations. Numerous specific radionuclides in quarterly composite samples were analyzed using gamma scan analysis; however, no radionuclides of Hanford origin were detected consistently.

Tritium concentrations for 1993 were similar to values reported for previous years and did not show the highly elevated and variable results reported for January to May 1992. The ${ }^{3} \mathrm{H}$ samples collected from January to May 1992 may have been contaminated during the analytical process because most locations including the distant communities reported unusually high concentrations. Tritium concentrations for 1993 were elevated for a few individual samples but consistently elevated concentrations were not seen at any location, and there was little difference between concentrations at the distant locations and those at the Site perimeter.

Air concentrations of ${ }^{90} \mathrm{Sr}$ and ${ }^{238} \mathrm{Pu}$ for samples collected both onsite and offsite were below detection limits. Average uranium and ${ }^{239,240} \mathrm{Pu}$ concentrations in airborne particulate matter were similar at the Site perimeter and distant locations. Iodine- 129 concentrations were statistically elevated at the Site perimeter relative to the distant locations; however, the average concentration at the Site perimeter was only $0.000002 \%$ of the Derived Concentration Guide of 70 picocuries/cubic meter. The Derived Concentration Guide is the air concentration that would result in a radiation dose equal to the DOE public dose limit (100 millirem/year).

Air samples were collected at several Hanford Site locations for volatile organic compounds and polychlorinated biphenyls (PCBs). All measured air concentrations of these organic compounds were well below applicable maximum allowable concentration standards for air contaminants.

\section{Surface-Water Surveillance}

The Columbia River was one of the primary environmental exposure pathways to the public during 1993 as a result of operations at the Hanford Site. Radiological and chemical contaminants entered the river along the Hanford Reach primarily through the seepage of contaminated ground water. Water samples were collected from the river at various locations throughout the year to determine compliance with applicable standards.

Although radionuclides associated with Hanford operations continued to be routinely identified in Columbia River water during the year, concentrations remained extremely low at all locations and were well below applicable standards. The concentrations of ${ }^{3} \mathrm{H},{ }^{129} \mathrm{I}$, and uranium were higher at the Richland Pumphouse (downstream from the Site) than at Priest Rapids Dam (upstream from the Site). Differences in concentrations measured at the two locations were statistically significant (5\% significance level), indicating a contribution along the Hanford Reach. For chemical water quality constituents measured in Columbia River water during 1993, metals and anions were generally similar upstream and downstream and in compliance with applicable standards. Volatile organic compounds were generally less than analytical detection levels.

During 1993 samples were collected from three Columbia River shoreline springs, contaminated as a result of past waste disposal practices at the Hanford Site. Contaminant concentrations in the springs were similar to those found in the ground water. Radionuclide concentrations were generally less than the DOE Derived Concentration Guides. However, ${ }^{90} \mathrm{Sr}$ in $\mathrm{N}$ Springs water was greater than the Derived Concentration Guide (see near-facility monitoring) as well as the Drinking Water Standard. Tritium, while less than the Derived Concentration Guide, was greater than the Drinking Water Standard at the old Hanford townsite springs.

Samples of Columbia River surface sediments were collected from behind McNary Dam (downstream from the Site) and Priest Rapids Dam and from four shoreline locations along the Hanford Reach of the Columbia River during 1993. As in the past, radionuclide concentrations in sediments behind McNary Dam were generally slightly higher than those observed in sediments collected from behind Priest Rapids Dam and along the Site. 
Three onsite ponds were sampled to determine radionuclide concentrations. These ponds are accessible to migratory waterfowl and other animals. As a result, a potential biological pathway exists for the removal and dispersal of contaminants that may be in the ponds. Concentrations of radionuclides in water collected from these ponds during 1993 were similar to those observed during past years. In all cases, radionuclide concentrations in the onsite pond water were below applicable DOE Derived Concentration Guides.

Offsite water, used for irrigation and/or drinking water, was sampled to determine radionuclide concentrations in water used by the nearby public. Elevated total alpha and total beta concentrations, attributed to naturally occurring uranium, were observed at some locations. Average radionuclide concentrations in offsite water during 1993 were within applicable Drinking Water Standards.

\section{Soil and Vegetation Surveillance}

In 1993, a total of 36 surface soil samples were collected on and off the Hanford Site; 19 from onsite locations, 14 from near the Hanford Site perimeter, and one each from the communities of Benton City, Sunnyside, and Yakima. Radionuclides, potentially from the Hanford Site, consistently detected in soil samples were ${ }^{90} \mathrm{Sr}$, ${ }^{137} \mathrm{Cs},{ }^{238} \mathrm{U},{ }^{239.240} \mathrm{Pu}$, and ${ }^{241} \mathrm{Am}$.

An evaluation of potential Hanford impacts was made by comparing onsite and offsite results. Specific comparisons were also made using results from distant and perimeter locations and by splitting the perimeter locations into upwind and downwind groups. No comparisons were made using the ${ }^{241} \mathrm{Am}$ data due to the small number of positive results.

No statistical differences in analytical results were identified for the above comparisons, except for ${ }^{90} \mathrm{Sr}$. Onsite soils had higher ${ }^{90} \mathrm{Sr}$ concentrations than the offsite soils and the upwind perimeter locations also had higher ${ }^{90} \mathrm{Sr}$ concentrations than the downwind perimeter locations. Higher ${ }^{90} \mathrm{Sr}$ concentrations at upwind perimeter locations may indicate the influence of historical fallout activity from atmospheric weapons testing.

In 1993, six onsite, two distant, and five perimeter locations were sampled for perennial vegetation. Vegetation results were compared using the same rationale as soil sampling. Radionuclides, potentially from the Hanford
Site, consistently detected in vegetation samples were ${ }^{90} \mathrm{Sr}$, ${ }^{238} \mathrm{U}$, and ${ }^{239,240} \mathrm{Pu}$. No significant differences were identified during the comparisons made, except for ${ }^{90} \mathrm{Sr}$ where onsite results were higher on average than offsite concentrations.

No offsite accumulation of radionuclides of Hanford origin was identifiable from the soil and vegetation samples collected and analyzed in 1993.

\section{Fish and Wildlife Surveillance}

The Hanford Site contains large tracts of undeveloped land that serve as refuges for many species of wildlife. The Columbia River, which borders the Site, also provides habitat for wildlife and fish that are of economic and recreational importance to the area. Terrestrial wildlife like deer, rabbits, and upland gamebirds have access to parts of the Site that contain low levels of radionuclides attributable to current and past Site operations. Wildlife are monitored for radionuclides as indicators of possible exposure to the Site surface contamination. Similarly, Columbia River fish are monitored to detect any radioactivity that may arise from Site activities as well as to help estimate the dose to those who may consume these fish.

Analysis of wildlife for radioactivity indicated that some species had accumulated levels of radioactivity greater than background levels. Background samples collected for a number of species over the past 4 years are summarized in this year's report. Strontium- 90 was detected in deer and rabbit bone as well as Columbia River fish carcasses at levels exceeding concentrations reported in background locations. Cesium-137 was detected at higher concentrations in the muscle of deer collected in 1992 from a background location in Stevens County, north of Spokane, than has been observed in Hanford Site populations of mule deer. The levels of ${ }^{137} \mathrm{Cs}$ in the deer from Stevens County were attributed to past atmospheric fallout from weapons testing. Collectively, the observations of radioactivity in Hanford fish and wildlife indicate accumulation of small amounts of specific radionuclides originating from the Hanford Site.

The radionuclide concentrations measured in fish and wildlife were used to estimate potential doses to hunters and fishers who might have consumed Hanford Site game. The resulting doses were much less than applicable guidelines developed to protect the public. 


\section{Food and Farm Product Surveillance}

The Hanford Site is situated in a large agricultural area that produces a wide variety of food products and alfalfa. Milk, eggs, poultry, beef, vegetables, fruit, wheat, alfalfa, and wine were collected from areas generally downwind from the Site and upwind and distant locations. The principal downwind locations include Wahluke, Sagemoor, and Riverview. Alfalfa and farm products were analyzed for ${ }^{3} \mathrm{H},{ }^{60} \mathrm{Co},{ }^{90} \mathrm{Sr},{ }^{99} \mathrm{Tc},{ }^{129} \mathrm{I},{ }^{137} \mathrm{Cs},{ }^{234} \mathrm{U}$, ${ }^{235} \mathrm{U},{ }^{238} \mathrm{U},{ }^{238} \mathrm{Pu}$, and ${ }^{239.240} \mathrm{Pu}$.

Most of the farm products sampled did not contain measurable concentrations of radionuclides. Tritium was measured at levels very close to the detection level, and there was no apparent upwind or downwind effect noted. Iodine-129 was found at slightly elevated levels in downwind milk samples, but the levels were very low and have been decreasing over the past 6 years.

\section{External Radiation Surveillance}

In 1993, radiological dose rates were measured at a number of locations on and off the Hanford Site using thermoluminescent dosimeters (TLDs). Contributors to the radiological doses measured included natural (uranium, thorium and their progeny in soil and other primordial radionuclides) and artificial sources. Onsite dose rates were unchanged while offsite dose rates increased slightly compared to 1992 .

The average background radiological dose rate, calculated from TLDs at Yakima and Sunnyside (both locations are distant and upwind relative to Hanford), was $88 \mathrm{mrem} /$ year $\pm 6 \%$ as compared to the average downwind perimeter dose rate of $100 \mathrm{mrem} / \mathrm{year} \pm 6 \%$. These represent an approximate $6 \%$ decrease in the background and a $2 \%$ decrease in the perimeter locations when compared to 1992 measurements. Dose rates at the Columbia River shoreline near the 100-N Area were approximately two to three times the typical shoreline dose rates and the higher dose rates may be attributable to radiation from the 100-N Area liquid waste disposal facilities. Onsite dose rates measured near operational areas were slightly higher than the average background dose rate.

Road surveys for radiological contaminants were performed during the first half of 1993 with no contamination found. In an effort to coordinate and consolidate monitoring activities, the road/rail monitor was transferred to Westinghouse Hanford Company's RCRA and Operational Monitoring Program in June 1993.

An aerial survey, for radiological contamination, of the Hanford Site perimeter and around the 200 Areas did not identify new areas having above-background exposure rates.

\section{Ground-Water Protection and Monitoring}

Radiological and chemical constituents in ground water were monitored during 1993 throughout the Hanford Site in support of the overall objectives described in Section 5.0. Monitoring activities were conducted to identify and quantify existing, emerging, or potential ground-water quality problems; assess the potential for contaminants to migrate off the Hanford Site; and prepare an integrated assessment of the condition of ground water on the Site. To comply with RCRA, additional monitoring was conducted to assess the impact that specific facilities have had on ground-water quality. During 1993, approximately 770 Hanford Site wells were sampled to satisfy ground-water monitoring needs. As discussed in Section 5.3, four additional wells located across the Columbia River and east of the Site were sampled to determine whether Hanford operations had affected water quality offsite.

Analytical results for samples were compared with EPA's Drinking Water Standards (Tables C.2 and C.3, Appendix C) and DOE's Derived Concentration Guides (Table C.6, Appendix C). Ground water beneath the Hanford Site is used for drinking at five locations. Only the drinking water in the 400 Area at the FFTF Visitors Center is available for public consumption; this source is discussed in Section 5.8. In addition, water supply wells for the city of Richland are located adjacent to the southern boundary of the Hanford Site.

Radiological monitoring results indicated that total alpha, total beta, ${ }^{3} \mathrm{H},{ }^{60} \mathrm{Co},{ }^{90} \mathrm{Sr},{ }^{99} \mathrm{Tc},{ }^{129} \mathrm{I},{ }^{137} \mathrm{Cs}$, uranium, and plutonium concentrations were detected in levels greater than the Drinking Water Standard in one or more wells onsite. Concentrations of ${ }^{3} \mathrm{H}$ greater than the Derived Concentration Guide were detected in the 200 Areas and $100-\mathrm{K}$ Area. Concentrations of ${ }^{90} \mathrm{Sr}$ greater than the Derived Concentration Guide were detected in the 100-N Area. Concentrations of uranium greater than the Derived Concentration Guide were detected in the 200-West Area. 
Extensive ${ }^{3} \mathrm{H}$ plumes extend from the 200-East and 200-West Areas into the 600 Area. The plume from the 200-East Area extends east and southeast, discharging to the Columbia River. This plume has impacted ${ }^{3} \mathrm{H}$ concentrations in the 300 Area but at levels less than the Drinking Water Standard. The spread of this plume farther south than the 300 Area is restricted by the ground-water flow away from the Yakima River and the North Richland well field. Ground water with ${ }^{3} \mathrm{H}$ at levels above the Drinking Water Standard also discharges to the Columbia River in the $100 \mathrm{~N}$-Area and immediate vicinity. A small but high concentration ${ }^{3} \mathrm{H}$ plume near the 100-K East Reactor also may discharge to the river. Tritium at levels greater than the Drinking Water Standard was also found in the 100-D and 100-F Areas.

Cobalt- 60 was detected in the northeastern part of the 200-East Area and parts of the surrounding 600 Area but at levels less than the Drinking Water Standard. Cobalt-60 detections in the 100-N Area at levels greater than the Drinking Water Standard appear to be related to high suspended sediments in the samples and are not indicative of ground-water concentrations.

Concentrations of ${ }^{90} \mathrm{Sr}$ at levels greater than the Derived Concentration Guide were measured in the 100-N Area. This plume discharges to the Columbia River. A very localized area in the 200-East Area also contains ground water with ${ }^{90} \mathrm{Sr}$ at levels greater than the Derived Concentration Guide. Strontium-90 at levels greater than the Drinking Water Standard is found in the 100-B, 100-F, $100-\mathrm{H}$, and $100-\mathrm{K}$ Areas. These plumes extend to the Columbia River. Only one well in the 100-D Area showed ${ }^{90} \mathrm{Sr}$ at levels greater than the Drinking Water Standard.

Technetium-99 at concentrations greater than the Drinking Water Standard was found in the northeastern part of the 200-East Area and adjacent 600 Area. Technetium-99 was also detected at levels greater than the Drinking Water Standard in the 200-West Area and extends into the 600 Area.

Antimony-125 was found at levels greater than the Drinking Water Standard in one well in the 100-N Area. It appears to be related to high suspended sediments in the sample and is not indicative of ground-water concentrations.

Iodine-129 was detected at levels greater than the Drinking Water Standard in the 200-East Area and in an extensive part of the 600 Area to the east and southeast. The ${ }^{129} \mathrm{I}$ and ${ }^{3} \mathrm{H}$ share common sources; however, there is no indication that ${ }^{129} \mathrm{I}$ is present at concentrations greater than the Drinking Water Standard in the ground water currently discharging to the Columbia River. Iodine-129 at levels greater than the Drinking Water Standard also extends into the 600 Area to the northwest of the 200-East Area. The southern part of the 200-West Area is also a source of ${ }^{129} \mathrm{I}$ extending into the 600 Area. There is a less extensive ${ }^{129}$ I plume at levels greater than the Drinking Water Standard in the north-central part of the 200-West Area.

Cesium-137 was only detected in the 200-East Area. The concentrations detected were greater than the Drinking Water Standard but were restricted to the immediate vicinity of one well.

Uranium was detected at levels greater than the Drinking Water Standard in wells in the 100-F, 100-H, 200-East, $200-$ West, and 300 Areas. Ground water with uranium concentrations greater than the Drinking Water Standard appears to be discharging to the Columbia River from the $100-\mathrm{H}$ and 300 Areas. One well in the 200-West Area had concentrations greater than the Derived Concentration Guide.

Plutonium was only detected in ground-water samples near one well in the 200-East Area. There is no explicit Drinking Water Standard for plutonium; however, the levels were greater than the Drinking Water Standard for gross alpha.

Certain nonradioactive chemicals regulated by the EPA and the State of Washington were also present in Hanford Site ground water. These constituents were also characterized by the monitoring programs.

Nitrate concentrations exceeded the Drinking Water Standard at locations in all 100 Areas with the exception of the 100-B Area. Those ground-water plumes discharge to the Columbia River. Nitrate from the 200-East Area extends east and southeast in the same area as the tritium plume. Nitrate from sources in the northwestern part of the 200-East Area is present in the adjacent 600 Area at levels greater than the Drinking Water Standard. Nitrate is present at levels greater than the Drinking Water Standard in the 200-West Area and adjoining 600 Area locations. Some of the nitrate in the 600 Area, 1100 Area, and North Richland area is believed to result from offsite sources. 
Cyanide has been detected at levels greater than the proposed Drinking Water Standard in the 200-West Area. Cyanide has also been detected in the 200-East Area and part of the 600 Area to the north. Cyanide concentrations in wells in this part of the 600 Area have been decreasing with time. The cyanide is associated with the ${ }^{60} \mathrm{Co}$ plume.

Fluoride was measured at levels greater than the primary Drinking Water Standard in the 200-West Area. Fluoride was also detected in the 200-East Area but at lower levels.

Chromium was found at levels greater than the Drinking Water Standard in the 100-D, 100-F, 100-H, and 100-K Areas. Chromium at levels greater than the Drinking Water Standard in the 100-N Area appears related to particulate matter in the samples. Chromium at concentrations greater than the Drinking Water Standard in the 200-East Area and 600 Area usually also appear related to particulate matter.

An extensive plume of carbon tetrachloride at levels greater than the Drinking Water Standard was found in ground water at the 200-West Area and extends into the 600 Area. This plume is associated with a less extensive plume of chloroform which may be a degradation product of the carbon tetrachloride. Maximum chloroform levels are also greater than its Drinking Water Standard.

Trichloroethylene was found at levels greater than the Drinking Water Standard in the 100-F Area and in the 600 Area to the west. Trichloroethylene was also detected at levels greater than the Drinking Water Standard in the 100-K Area. Trichloroethylene was found at levels greater than the Drinking Water Standard in some 200-West Area wells. Trichloroethylene in the 300 Area was also measured at levels greater than the Drinking Water Standard.

Tetrachloroethylene was found at levels greater than the Drinking Water Standard near the Solid Waste Landfill in the 600 Area.
Samples from monitoring wells in the deeper confined aquifer onsite contained no radiological or chemical constituents at levels greater than the Drinking Water Standard although a few wells near source areas exhibited impacts of past site disposal practices.

A comprehensive review of all ground-water monitoring work on the Site is published annually. Before 1989, these reports contained complete listings of all radiological and chemical data collected during the reporting periods. Currently, complete listings for ground-water data can be found in a companion volume to this annual report and in data listings published by other programs.

\section{Quality Assurance}

Comprehensive quality assurance (QA) programs, which include various quality control practices and methods to verify data, are maintained to ensure data quality. The QA programs are implemented through QA plans designed to meet requirements in the American National Standards Institute/American Society of Mechanical Engineers NQA-1 QA program document and DOE Orders. Quality assurance plans are maintained for all activities, and conformance is verified through auditors. Quality control methods include but are not limited to replicate sampling and analysis, analysis of field blanks and blind reference standards, participation in interlaboratory cross-check studies, and splitting samples with other laboratories. Sample collection and laboratory analyses are conducted using documented and approved procedures. When sample results are received, they are screened for anomalous values by comparing them to recent results and historical data. Analytical laboratory performance on the submitted double-blind samples, the EPA Laboratory Intercomparison Studies Program, and the national DOE Quality Assessment Program indicated that laboratory performance was adequate overall; was excellent in some areas; and needed improvement in others. 
Environmental Monitoring:

Facility Effluent Monitoring, including

Airborne Emissions '

- Radioactive and Nonradioactive

Chemical Releases

- Radionuclides and Nonradioactive Constituents Discharged to the Atmosphere

Liquid Effluents

- Radioactive Liquid Effluents

- Nonradioactive Hazardous Constituents in Potentially Radioactive Liquid Effluents

Near-Facility Environmental Monitoring, including results of

Air Monitoring

External Radiation Measurements

Investigative Sampling

Radiological Surveys

Soil and Vegetation Sampling from Operational Areas

Surface-Water Disposal Units and Seep Monitoring

Wildlife Resource Monitoring Results

Environmental Occurrences

CERCLA -- Reportable Releases

Unusual Occurrences

Environmental Surveillance

Air Sampling/Radiological and Nonradiological Results

External Radiation Surveillance

- External Radiation Measurements/Results

- Radiation Survey Results

Fish and Wildlife Surveillance/Sampling Results

Food and Farm Product Surveillance/Sampling Results

Soil and Vegetation Surveillance/Sampling Results

Surface-Water Surveillance

- Columbia River/Radiological and Nonradiological Results

- Onsite Ponds Sampling Results

- Offsite Water Sampling Results 
For more information about

$\underline{\text { See Section }}$

Ground-Water Protection and Monitoring Program Results

Plutonium Uranium Extraction and Uranium Oxide Plants Status

Plutonium Finishing Plant Restart

Pollution Prevention Program Reporting

Potential Radiation Doses from 1993 Hanford Operations

Quality Assurance

Effluent Monitoring

Environmental Surveillance

Site Restoration

Waste Management and Chemical Inventories

Waste Receiving and Processing Facility

Waste Tank Safety Issues 



\section{Report Contributors}

The production of the Hanford Site Environmental Report requires the knowledge, skills, experience, and cooperation of many people and several organizations. The contributions and cooperation, often under

\section{Pacific Northwest Laboratory}

E. J. Antonio

L. L. Cadwell

A. T. Cooper

C. E. Cushing

R. L. Dirkes

P. E. Dresel

B. M. Gillespie

R. W. Hanf

D. J. Hoitink

R. E. Lundgren

G. W. Patton

T. M. Poston

K. Rhoads

D. B. Shipler

J. K. Soldat

R. K. Woodruff

M. K. Wright

\section{U. S. Army Corps of Engineers}

W. D. Perro demanding time constraints, of the following individuals are gratefully acknowledged. The lead authors are listed on each main section of the report.

\section{U.S. Fish and Wildlife Service}

R. Hill

\section{Washington Department of Fish and} Wildlife
J. Tabor
R. D. Kent

\section{Westinghouse Hanford Company}
B. L. Curn
L. P. Diediker
A. R. Johnson
C. R. Joseph
S. M. McKinney
J. M. Nickels
C. J. Perkins
J. W. Schmidt
D. J. Rokkan (SAIC) 


\section{Acknowledgments}

The Pacific Northwest Laboratory programs described in this report were managed by the Office of Health and Environment under the direction of R. E. Jaquish. Environmental samples were collected for the Pacific Northwest Laboratory by Senior Radiation Protection Technologists M. E. Almarode, G. L. Andersen, L. L. Belt, L. W. Hankel, J. D. Harrison, J. A. Jahnke, J. J. Lopez, D. L. Mackliet, A. M. Marschman, D. A. Mueller, and J. J. Reck. The environmental monitoring supervisor is E. W. Lusty. B. E. Optiz is the Technical Group Manager of the Field Sampling and Analysis Group. Technical assistance for sample collection was provided by A. T. Cooper.

The authors appreciate the reviews by J. B. Hall, R. D. Hildebrand, and E. B. Dagan of the U.S. Department of Energy, Richland Operations Office; J. J. Dorian and R. J. Landon of Westinghouse Hanford Company; J. L. Erickson of the Washington Department of Health; and R. E. Gephart, G. L. Koller, T. A. Ikenberry, E. B. Moore, Jr., R. M. Smith, and R. D. Stenner of the Pacific Northwest Laboratory.

Community-operated environmental surveillance stations were managed by local teachers who were responsible for collecting the samples and maintaining the stations. The managers and alternate managers for each station included:

\section{Leslie Groves Park, Richland}

C. A. Wagner, Manager

D. R. Johns, Alternate Manager

\section{Basin City Elementary School, Basin City \\ C. L. Stevenson, Manager \\ E. A. Corrales, Alternate Manager}

\section{Edwin Markham Elementary School,} North Franklin County

M. P. Madison, Manager

K. A. Darrington, Alternate Manager
The Westinghouse Hanford Company programs described in this report were managed by the Regulatory Support Department under the direction of G. W. Jackson. Nearfacility environmental samples were collected by the Site Surveillance Health Physics group: D. R. Borup, R. L. Bumgarner, L. Corgatelli, R. M. Frederick, B. M. Markes, R. G. Mikulecky, and R. Olveda, managed by D. S. Gunnink with the support of H. A. Besel and K. S. Steffen.

Groups and organizations participating in the Westinghouse Hanford Company monitoring programs include Health Physics technicians and supervisors, facility operators, cognizant facility environmental engineers, Process Analytical Laboratories, Ventilation Balance, and Field Maintenance. Individuals in these organizations collected and analyzed samples, maintained monitoring and sampling equipment, measured stack flow rates, ensured that facility operations adhered to environmental process controls, identified needed monitoring upgrades, aided in the interpretation and implementation of environmental regulations, and ensured that effluent data reported are accurate.

This report was produced on Macintosh using Aldus Pagemaker. Valuable text processing support was provided by R. M. Watt, S. M. Daly, A. Jewell, and K. R. Neiderhiser. Publication assistance was provided by M. K. DeSmet and L. F. Morasch. Graphics for the report were designed by J. P. Noland, D. A. Diven, K. A. Corcoran, K. K. Kachele, and L. G. Wattenburger (Boeing Computer Services, Richland) and T. B. Walters and W. R. Gorst using Aldus Freehand, DeltaPoint Inc. Delta Graph, and Environmental Research Systems Institute ARC/INFO. Cover and dividers were designed by R. D. Muir (Boeing Computer Services, Richland). 


\section{Contents}

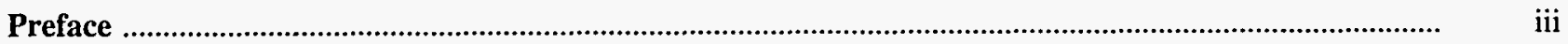

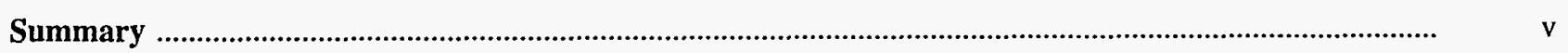

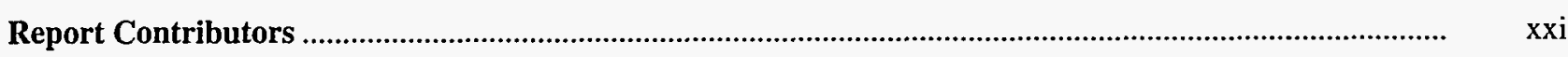

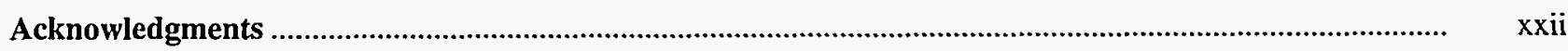

Helpful Information ...........................................................................................................................

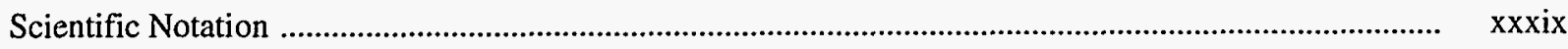

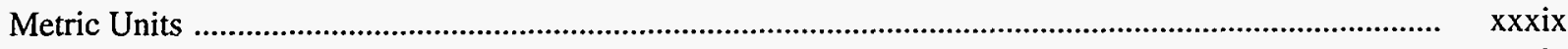

Radioactivity Units …….......................................................................................................................

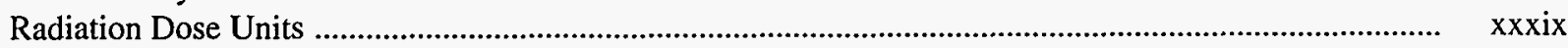

Understanding the Data Tables .........................................................................................................

Understanding Graphical Information ................................................................................................. x xlii

Greater Than $(>$ ) or Less Than $(<)$ Symbols ..............................................................................................

Elemental and Chemical Constituent Nomenclature ……............................................................................ xliv

Conversion Table ................................................................................................................................. xliv

Acronyms and Abbreviations ...............................................................................................................

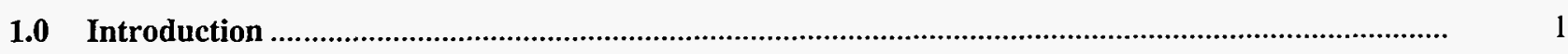

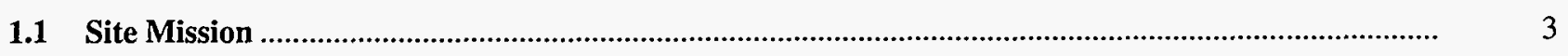

1.2 Introduction to the Hanford Site ................................................................................................

1.3 Major Operations and Activities .........................................................................................

Waste Management …...........................................................................................................................

Site Restoration ................................................................................................................................

Corrective Activities ..............................................................................................................................

Research and Technology Development ...............................................................................................

Site Management ............................................................................................................................... 9

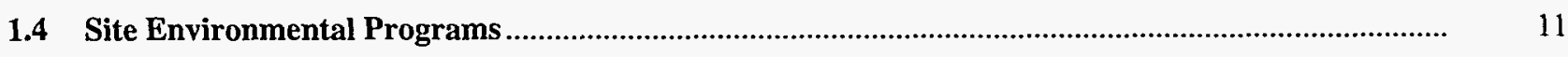

Effluent Monitoring Programs ....................................................................................................

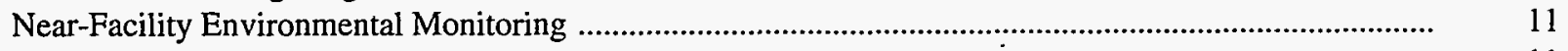

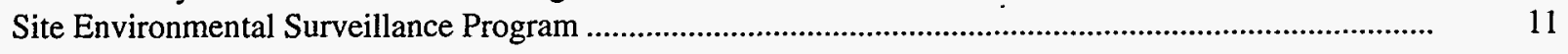

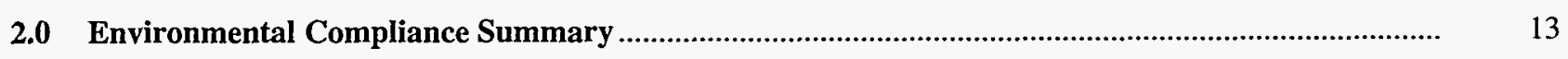


2.1 Environmental Compliance and Cleanup

Regulatory Oversight

The Hanford Federal Facility Agreement and Consent Order ................................................................

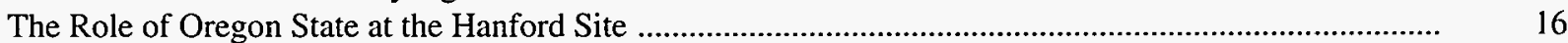

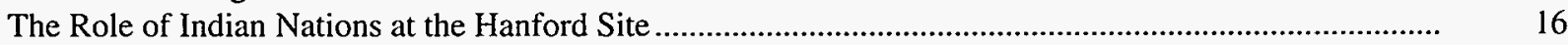

Natural Resource Damage Assessment Activities at the Hanford Site ..................................................... 17

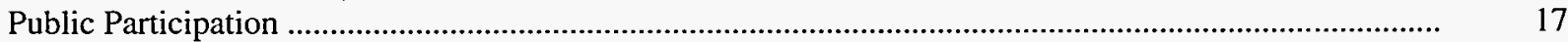

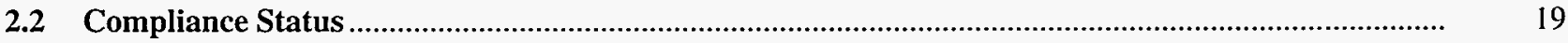

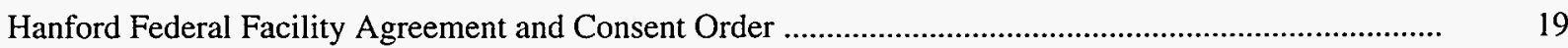

Comprehensive Environmental Response, Compensation, and Liability Act ........................................... 20

Emergency Planning and Community Right-To-Know Act and Pollution Prevention Act,

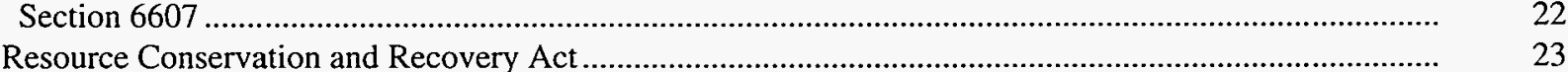

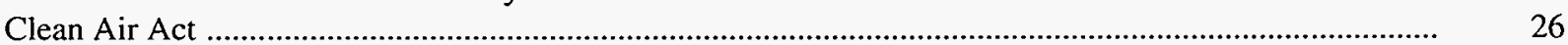

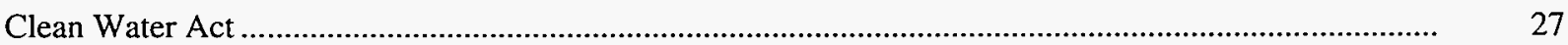

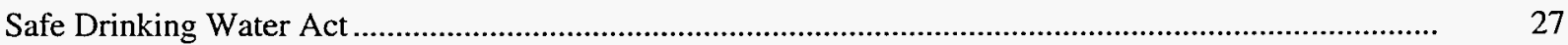

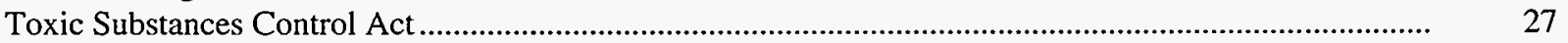

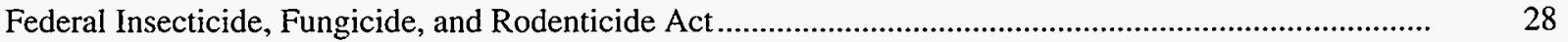

Endangered Species Act ..............................................................................................................

National Historic Preservation Act, Archaeological Resources Protection Act,

Native American Graves Protection and Repatriation Act, and American

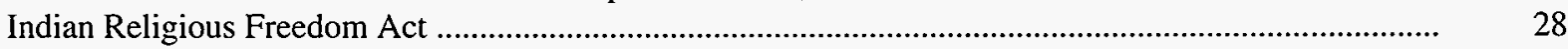

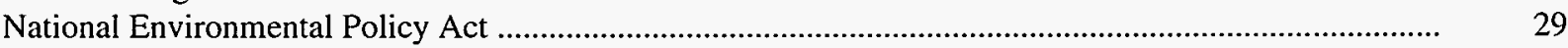

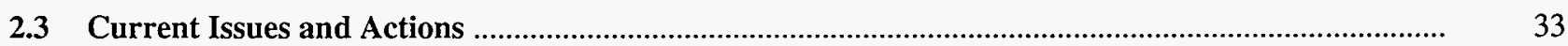

Hanford Federal Facility Agreement and Consent Order .......................................................................

Hanford Summary I: A National Forum on Environment, Technology, and the Economy ........................ 35

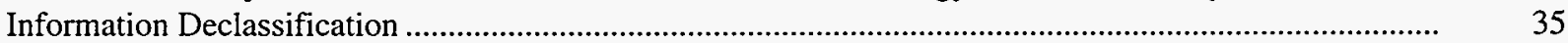

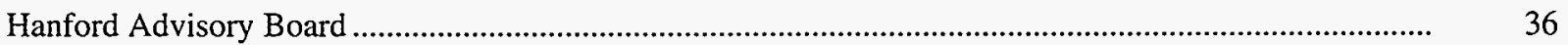

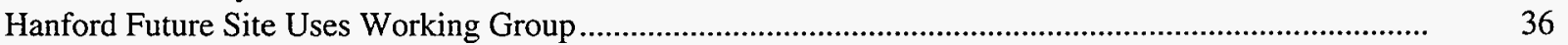

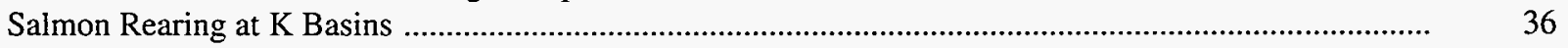

Tiger Team Assessment Corrective Actions ......................................................................................... 36

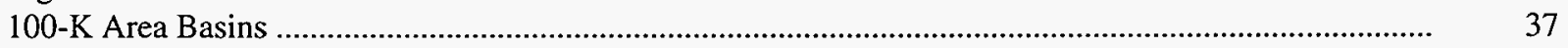

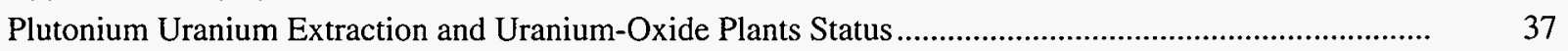

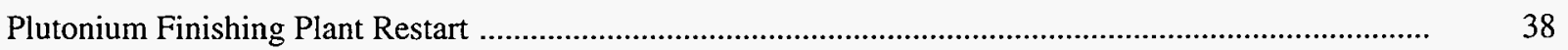

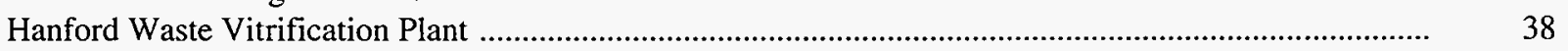

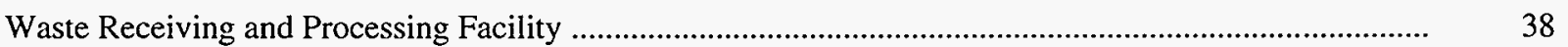

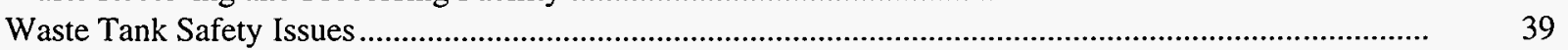

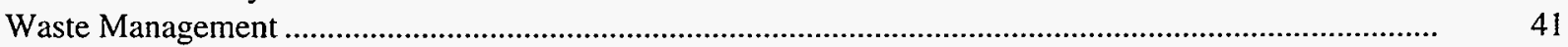

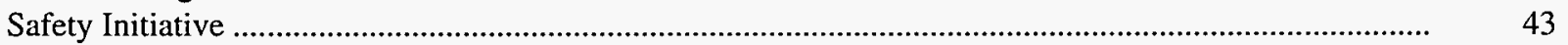

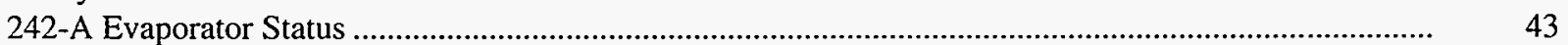

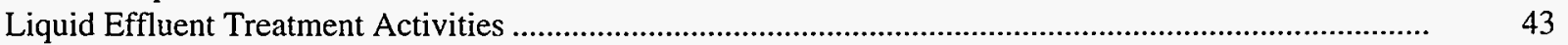

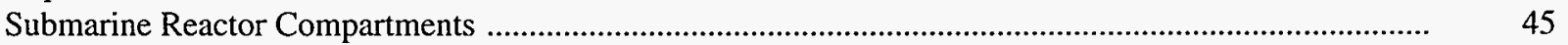

International Environmental Institute .......................................................................................................... 45

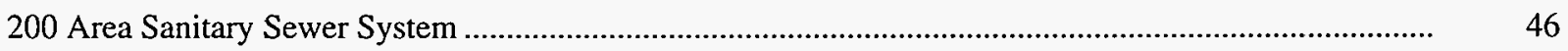

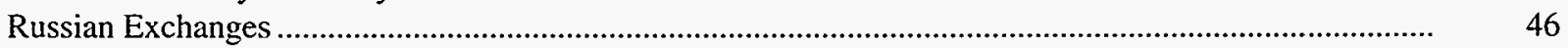

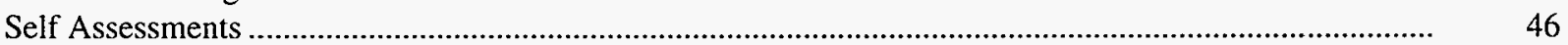




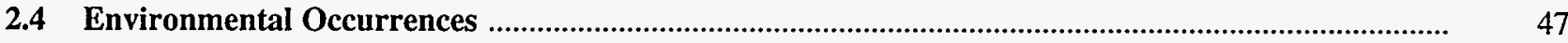

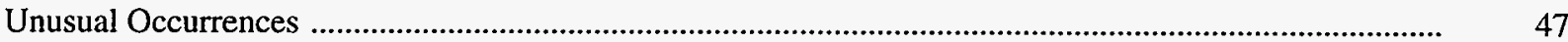

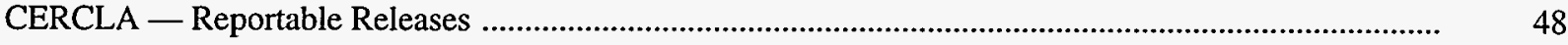

3.0 Effluent Monitoring, Waste Management, and Chemical Inventory Information ..............................

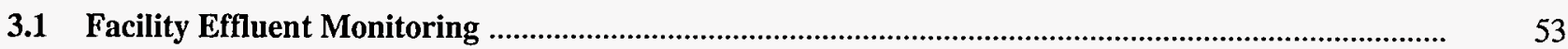

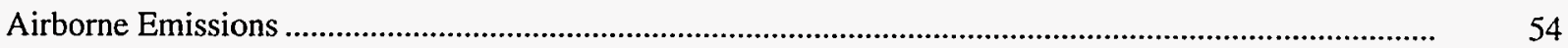

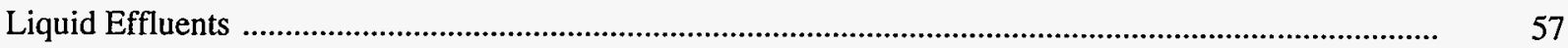

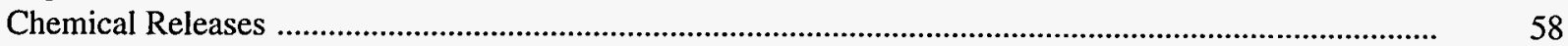

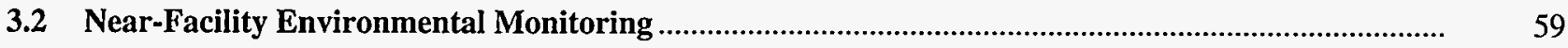

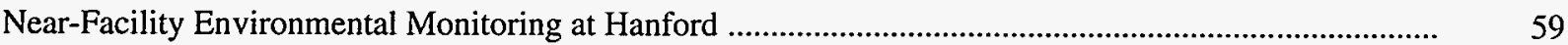

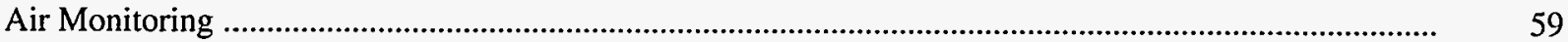

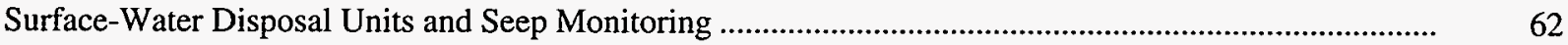

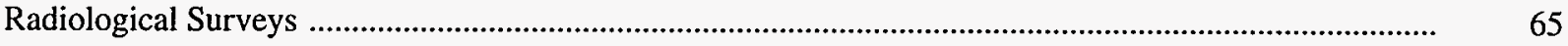

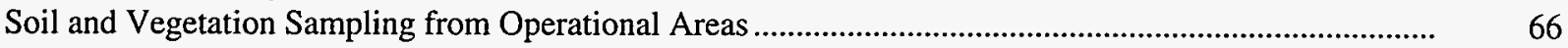

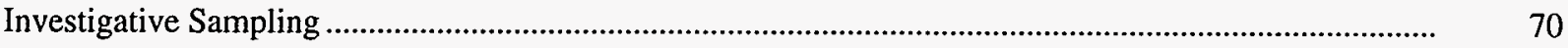

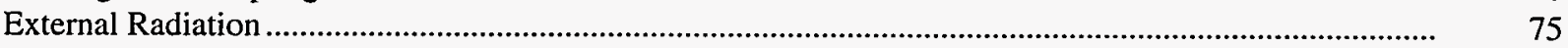

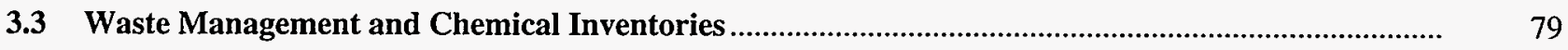

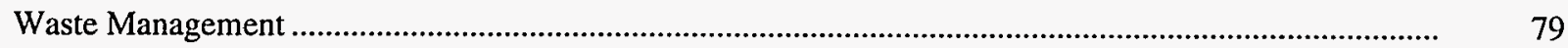

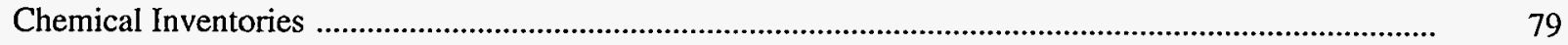

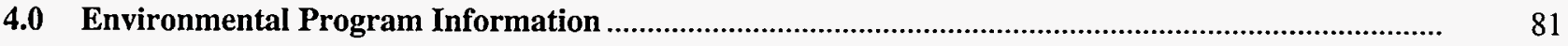

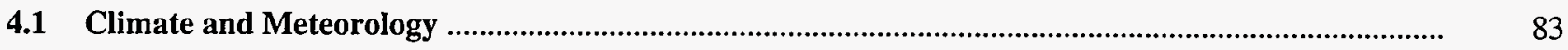

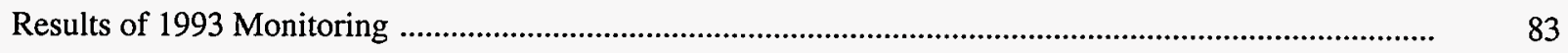

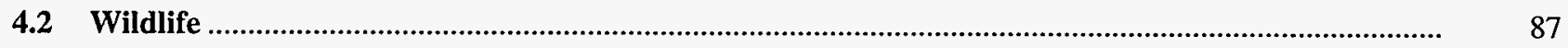

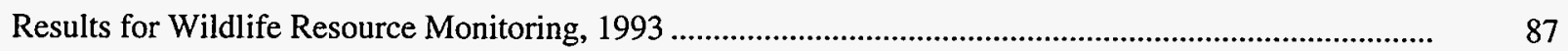

Wildlife Monitoring of Non-DOE Managed Hanford Site Land .............................................................

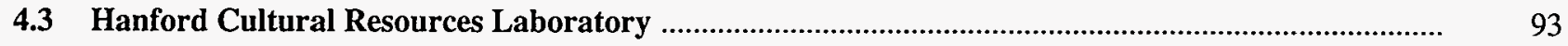

4.4 Community-Operated Environmental Surveillance Program ........................................................... 95

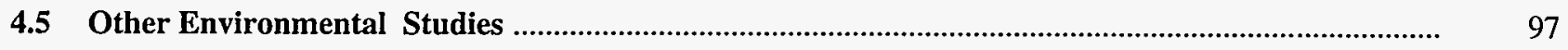

Hanford Environmental Dose Reconstruction Project …....................................................................

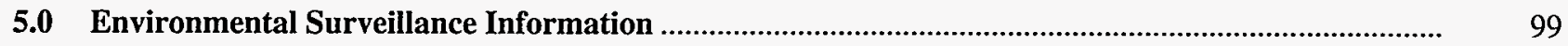




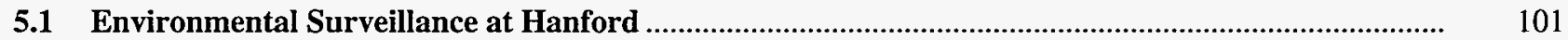

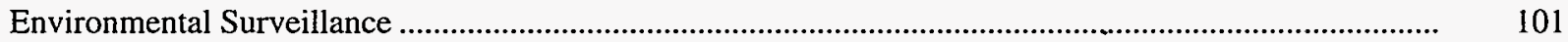

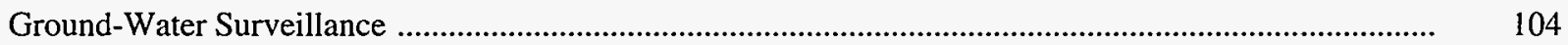

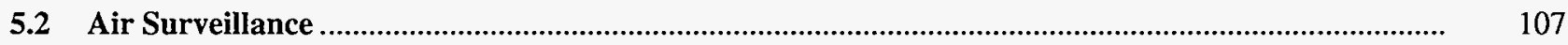

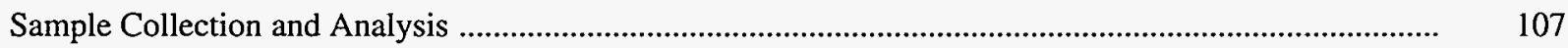

Results .........................................................................................................................................

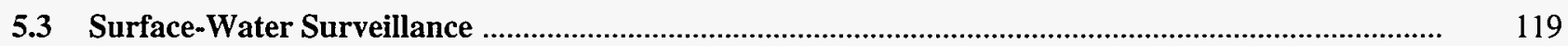

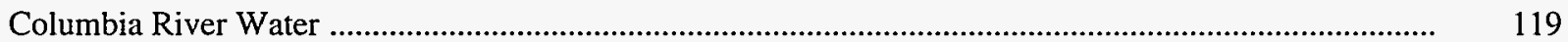

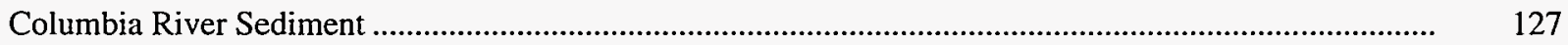

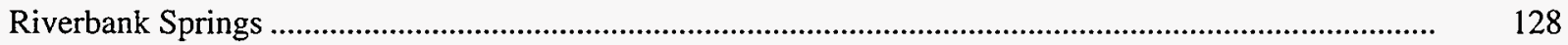

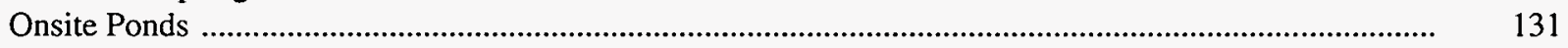

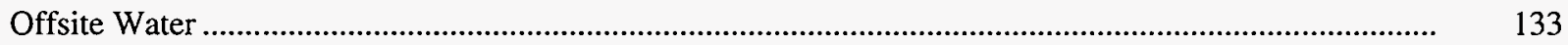

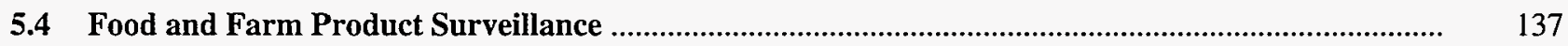

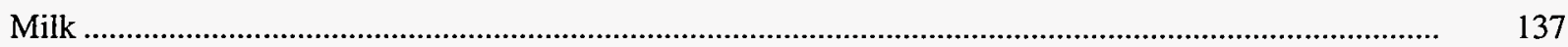

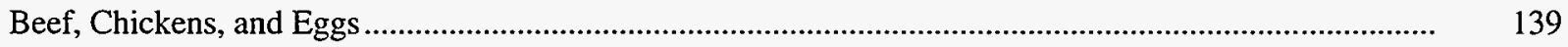

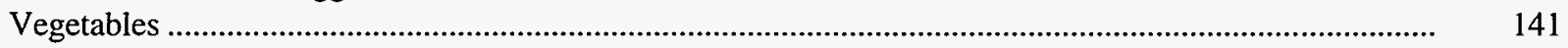

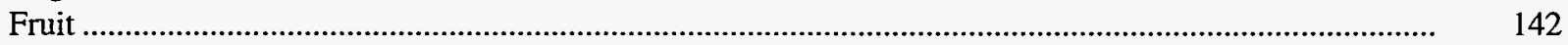

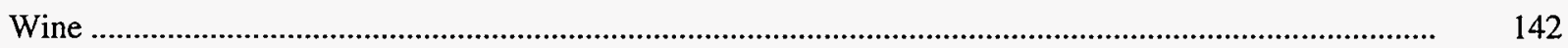

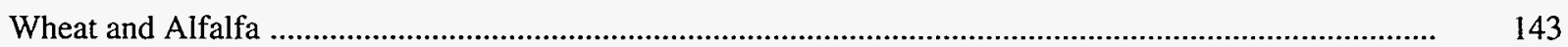

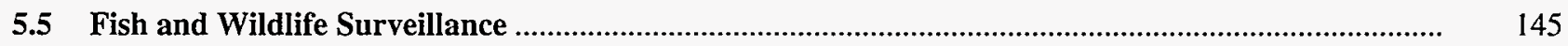

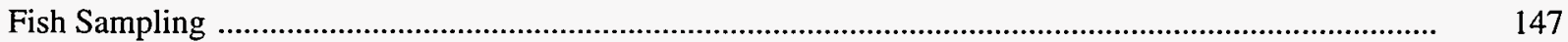

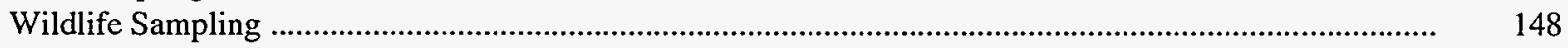

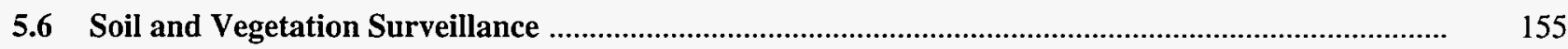

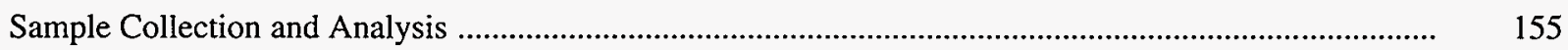

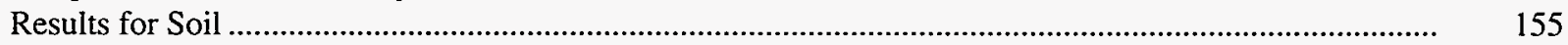

Results for Vegetation ....................................................................................................................

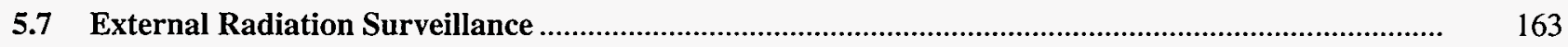

External Radiation Measurements _............................................................................................... 163

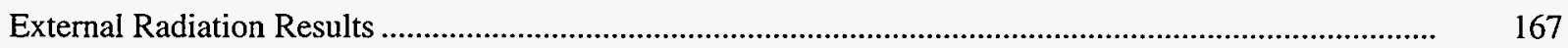

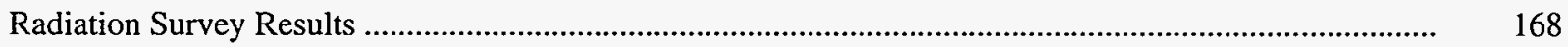

5.8 Ground-Water Protection and Monitoring Program .....................................................................

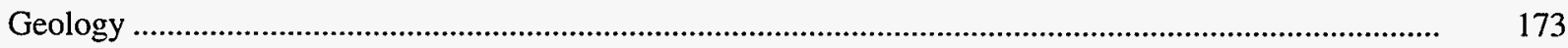

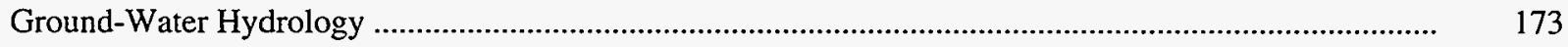

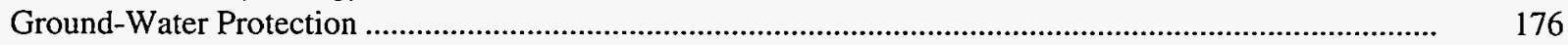

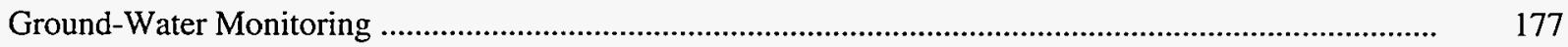

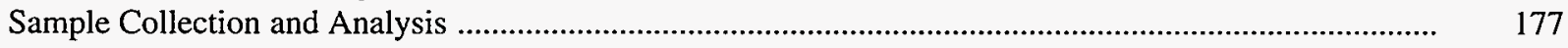

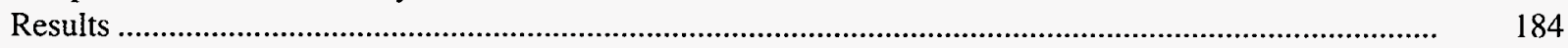




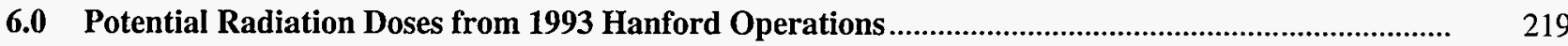

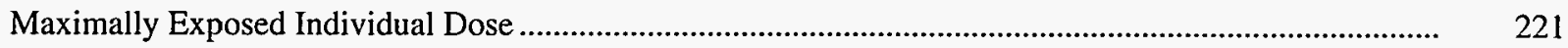

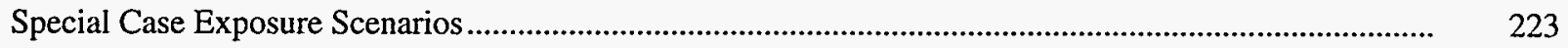

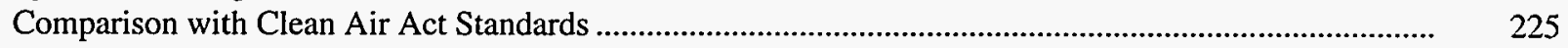

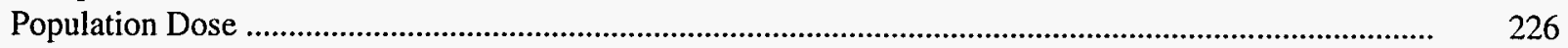

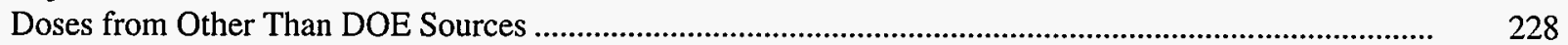

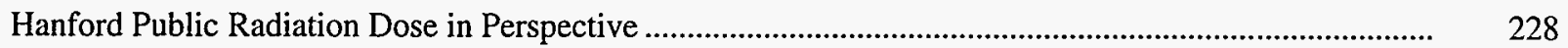

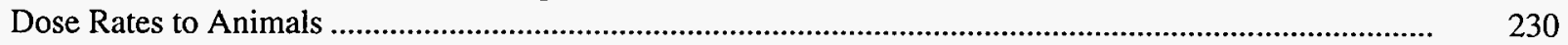

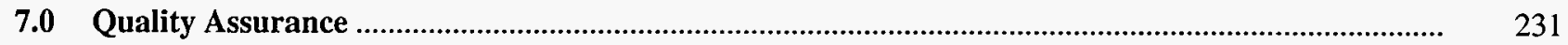

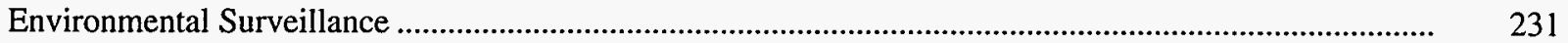

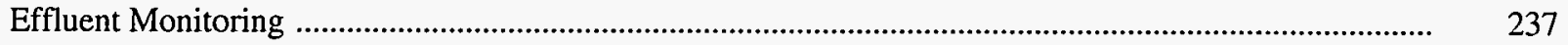

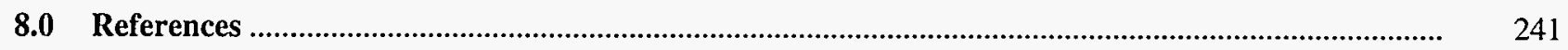

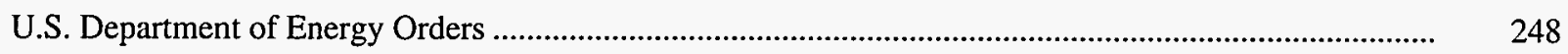

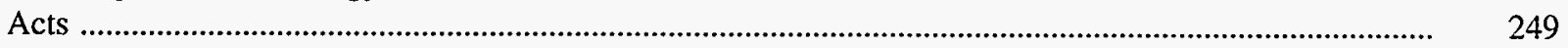

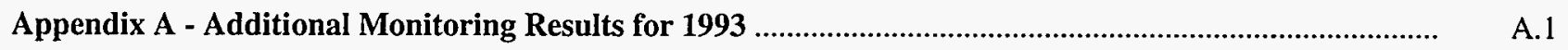

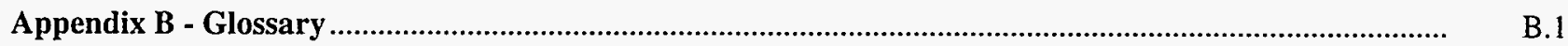

Appendix C - Applicable Standards and Permits …............................................................................... C.

Appendix D - Dose Calculations ............................................................................................................ D.

Appendix E - RCRA and CERCLA Monitoring Documents ................................................................ E. E

Appendix F - Radionuclides Detected by Gamma Spectroscopy ...................................................... F.1

Appendix G - Threatened and Endangered Species ....................................................................... G.1

Appendix H - Erratta from 1992 Hanford Site Environment Report ....................................................... H.1

\section{Figures}

H.1 Data Plotted Using a Linear Scale ........................................................................................................ xlii

H.2 Data Plotted Using a Logarithmic Scale ................................................................................................. xliii

H.3 Data With Error Bars Plotted Using a Linear Scale ............................................................................ xliii

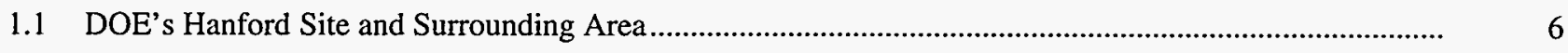

3.1 Liquid Releases of Selected Radionuclides from Site Facilities, 1988 Through 1993 .............................. 53

3.2 Airborne Relẹases of Selected Radionuclides from Site Facilities, 1988 Through 1993 ........................... 54 
3.3 Concentrations of Selected Radionuclides in Near-Facility Air Samples Compared to

Those in Distant Communities, 1988 Through 1993.

3.4 Concentrations of Selected Radionuclides in Near-Facility Soil Samples Compared to

Those in Distant Communities, 1988 Through 1993

3.5 Concentrations of Selected Radionuclides in Near-Facility Vegetation Compared to

Those in Distant Communities, 1988 Through 1993

3.6 Radiation Survey Measurements Along the 100-N Area Shoreline, 1988 Through 1993 ............................ 76

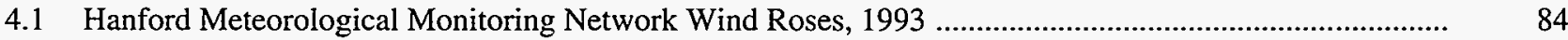

4.2 Bald Eagles Observed Along the Hanford Reach, Fall and Winter Months, 1961 Through 1993 .............. 88

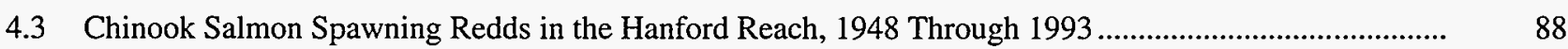

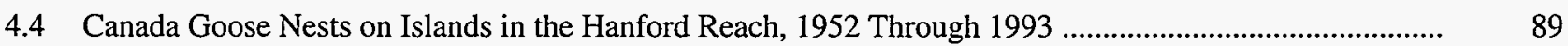

4.5 Red-Tailed, Swainson's, and Ferruginous Hawks on the Hanford Site, 1975 Through 1993 ...................... 89

4.6 Elk on the Hanford Site Counted by Aerial Surveillance During the Post-Calving

Period: August Through September; and the Post-Hunting Period: December

Through January, 1975 Through 1993.

4.7 Community Members Can See Environmental Surveillance in Action at Three Local

Community-Operated Environmental Surveillance Stations

4.8 Area Considered in Estimating Doses from Past Hanford Operations in the Hanford Environmental Dose Reconstruction Project ....................................................................................

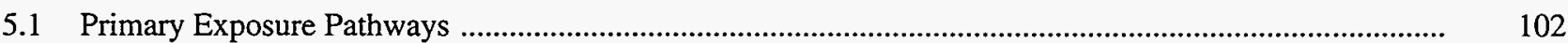

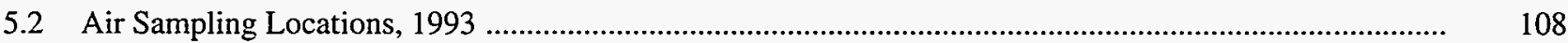

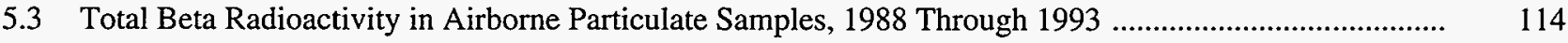

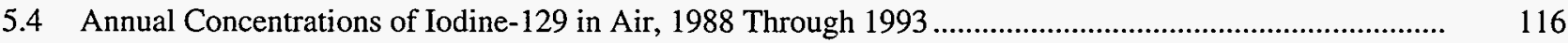

5.5 Annual Average Concentrations of Plutonium-239,240 in Air, 1988 Through 1993 .................................. 116

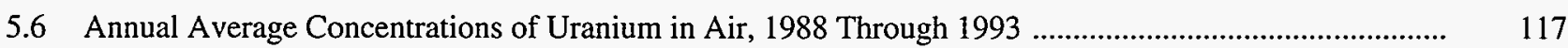

5.7 Average Concentrations of Selected Volatile Organic Compounds Air on the Hanford Site, $1993 \ldots \ldots \ldots . . . . . \quad 118$

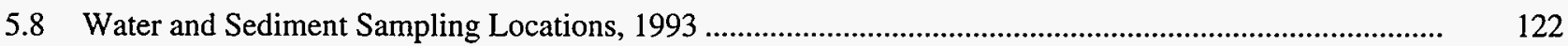

5.9 Annual Average Total Alpha Concentrations in Columbia River Water, 1988 Through 1993

5.10 Annual Average Total Beta Concentrations in Columbia River Water, 1988 Through 1993 
5.11 Annual Average Tritium Concentrations in Columbia River Water, 1988 Through 1993

5.12 Annual Average Strontium-90 Concentrations in Columbia River

Water, 1988 Through 1993

5.13 Annual Average Uranium Concentrations in Columbia River Water, 1988 Through 1993

5.14 Annual Average Iodine-129 Concentrations in Columbia River Water, 1988 Through 1993

5.15 Columbia River Water Quality Measurements, 1988 Through 1993

5.16 Monthly Average Columbia River Flow Rates, 1993

5.17 Radionuclide Concentrations in Columbia River Sediments at Priest Rapids Dam and McNary Dam, 1989 Through 1993

5.18 Radionuclide Concentrations in Riverbank Springs near the Old Hanford Townsite, 1988 Through 1993

5.19 Constituents of Concern in 300 Area Riverbank Springs, 1988 to 1993

5.20 Annual Average Radionuclide Concentrations in B Pond, 1988 Through 1993

5.21 Average Total Beta and Tritium Concentrations in FFTF Pond, 1988 Through 1993

5.22 Annual Average Radionuclide Concentrations in West Lake, 1988 Through 1993

5.23 Food and Farm Product Sampling Locations, 1993

5.24 Strontium-90 Concentrations in Milk, 1988 Through 1993

5.25 Average Iodine-129 Concentrations in Milk, 1988 Through 1993

5.26 Annual Average Strontium-90 Concentrations in Vegetables, 1988 Through 1993

5.27 Strontium-90 Concentrations in Alfalfa Routinely Collected at Riverview, Horn Rapids, and Richland and All Other Sampling Locations, 1988 Through 1993

5.28 Fish and Wildlife Sampling Locations, 1993

5.29 Concentrations of Cesium-137 in Muscle Samples from Resident Ducks from

B Pond, 1988 Through 1993

5.30 Soil and Vegetation Sampling Locations, 1993 
5.31 Selected Radionuclide Maximum, Median, and Minimum

Concentrations in Soil, 1988 Through 1993

5.32 Selected Radionuclide Maximum, Median, and Minimum Concentrations

in Soil at Perimeter and Distant Locations, 1988 Through 1993

5.33 Selected Radionuclide Maximum, Median, and Minimum

Concentrations in Vegetation, 1988 Through 1993

5.34 Thermoluminescent Dosimeter Locations and Station Numbers on the Hanford Site, 1993

5.35 Thermoluminescent Dosimeter Measurement Locations and Station Numbers for Community, Distant, and Perimeter Sites, 1993

5.36 Thermoluminescent Dosimeter Locations and Station Numbers on the Hanford Reach of the Columbia River, 1993

5.37 Annual Average Dose Rates, 1988 Through 1993

5.38 Flight Patterns Used for Aerial Radiation Surveys, 1993

5.39 Road Survey Routes, 1993

5.40 Geologic Cross Section of the Hanford Site

5.41 Water-Table Elevations for the Unconfined Aquifer at Hanford and Parts of Franklin County, June 1993

5.42 Hanford Site Unconfined Aquifer Monitoring Well Locations, 1993

5.43 Hanford Site Confined Aquifer Monitoring Well Locations, 1993

5.44 Monitoring Well Locations in the 200-East Area, 1993

5.45 Monitoring Well Locations in the 200-West Area, 1993

5.46 Locations of RCRA Ground-Water Monitoring Projects and

Landmarks on the Hanford Site

5.47 Tritium Concentrations in the Unconfined Aquifer, 1993

5.48 Tritium Concentrations in Well 199-K-30, 1981 Through 1993

5.49 Tritium Concentrations in Well 299-E17-9, 1980 Through 1993

5.50 Tritium Concentrations in Well 699-24-33, 1962 Through 1993

5.51 Tritium Concentrations in Well 699-40-1, 1962 Through 1993

5.52 Historical Tritium $\left({ }^{3} \mathrm{H}\right)$ Concentrations on the Hanford Site 
5.53 Tritium Concentrations in Well 699-S19-E13, 1975 Through 1993

5.54 Tritium Concentrations Near the 300 Area, 1993

5.55 Tritium Concentrations in Well 299-W22-9, 1976 Through 1993

5.56 Concentrations of Strontium-90 in the Unconfined Aquifer in the 100-B Area, 1993

5.57 Concentrations of Stronium-90 $\left({ }^{90} \mathrm{Sr}\right)$ and Uranium in the Unconfined Aquifer in the 100-F Area, 1993

5.58 Concentrations of Stronium-90 $\left({ }^{90} \mathrm{Sr}\right)$ and Uranium in the Unconfined Aquifer in the 100-H Area 1993

5.59 Concentrations of Stronium-90 $\left({ }^{90} \mathrm{Sr}\right)$ and Chromium in the Unconfined Aquifer in the $100-\mathrm{K}$ and $100-\mathrm{N}$ Areas, 1993

5.60 Stronium-90 ( $\left.{ }^{90} \mathrm{Sr}\right)$ Concentrations in Well 199-N-14, 1973 Through 1993

5.61 Concentrations of Stronium-90 $\left({ }^{90} \mathrm{Sr}\right)$ and Technetium-99 $\left({ }^{99} \mathrm{Tc}\right)$ in the Unconfined Aquifer Near the 200-East Area, 1993

5.62 Concentrations of Technetium-99 ( $\left.{ }^{99} \mathrm{Tc}\right)$ and Uranium in the Unconfined Aquifer in the 200-West Area, 1993

5.63 Distribution of Iodine-129 in the Unconfined Aquifer, 1993

5.64 Uranium Concentrations in Well 299-W-13, 1987 Through 1993

5.65 Uranium Concentrations in the Unconfined Aquifer in the 300 Area, 1993.

5.66 Uranium Concentrations in Well 399-1-17A, 1987 Through 1993

5.67 Distribution of Nitrate in the Unconfined Aquifer, 1993

5.68 Nitrate Concentrations in Well 299-W19-3, 1986 Through 1993

5.69 Concentrations of Fluoride in the 200-West Area, 1993

5.70 Distribution of Chromium in the 100-D and 100-H Areas, 1993.

5.71 Distribution of Carbon Tetrachloride in the 200-West Area, 1993

5.72 Distribution of Chloroform in the Unconfined Aquifer in the 200-West Area, 1993

6.1 Locations Important to Dose Calculations

6.2 Calculated Effective Dose Equivalent to the Hypothetical Maximally

Exposed Individual, 1989 Through 1993 
6.3 Calculated Effective Dose Equivalent to the Population Within

$80 \mathrm{~km}$ of the Hanford Site, 1989 Through 1993

6.4 National Annual Average Radiation Doses from Various Sources

\section{Tables}

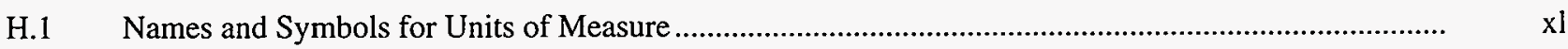

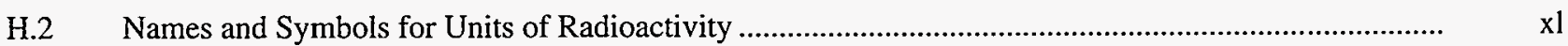

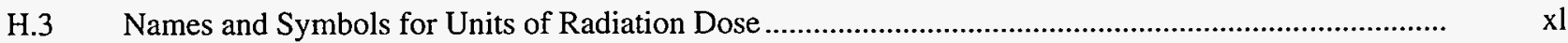

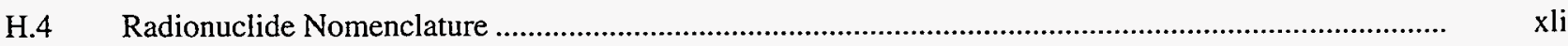

2.1 Status of Hanford Site RCRA Interim-Status Ground-Water Monitoring Projects as of December 31, 1993

3.2 Nonradioactive Constituents Discharged to the Atmosphere, 1993

3.3 Radionuclides in Liquid Effluents Discharged to Ground Disposal

Facilities, 1993

3.4 Radionuclides in Liquid Effluents Discharged to the Columbia River

from the 100 Areas, 1993

3.5 Near-Facility Routine Environmental Samples and Locations, 1993

3.6 Radiological Results for Liquid Samples from Surface-Water

Disposal Units, 200/600 Areas, 1993

3.7 Radiological Results for Aquatic Vegetation Samples from

Surface-Water Disposal Units, 200/600 Areas, 1993

3.8 Radiological Results for Sediment Samples from Surface-Water

Disposal Units, 200/600 Areas, 1993

3.9 Concentrations of Radionuclides in 100-N Area Columbia River Shoreline Seeps, 1993

3.10 Nonradiological Results for Liquid Samples from Surface-Water

Disposal Units, 1993

3.11 Outdoor Contamination Status, 1993

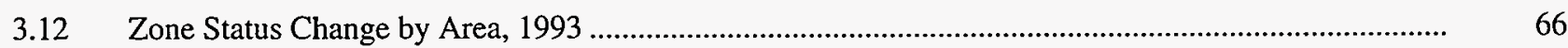

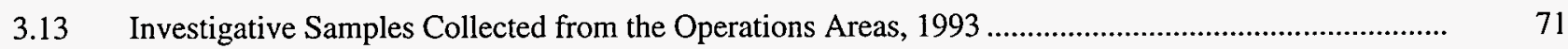


3.14 100-N Liquid Waste Disposal Facilities Direct Radiation

Measurements, 1992 and 1993

3.15 Thermoluminescent Dosimeter Results for Waste-Handling

Facilities in the Operations Areas, 1992 and 1993

3.16 Hanford Site Tier-Two Emergency and Hazardous Chemical Inventory

Average Balance of Ten Chemicals Stored in Greatest Quantity, 1993

4.1 Monthly Climatological Data from the Hanford Meteorology Station, 1993

5.1 Environmental Surveillance Sample Types and Measurement Locations, 1993

5.2 Air Sampling Locations, Sample Composite Groups, and Analyses, 1993

109

5.3 Airborne Radionuclide Concentrations in the Hanford Environs,

1993 Compared to Values from the Previous 5 Years

5.4 Airborne Concentrations of Tritium in the Hanford Environs, 1988 Through 1993.

5.5 PCB Results for Air Samples Collected on the Hanford Site in 1993

5.6 Average Concentrations of Selected Volatile Organic Compounds

in Air on the Hanford Site, 1993

5.7 Surface-Water Surveillance, 1993

5.8 Sediment Surveillance, 1993

5.9 Selected Radionuclide Concentrations in Riverbank Spring Water

During the Years 1988 through 1993

5.10 Numbers of Locations, Sampling Frequency, and Analyses Performed

for Routinely Sampled Food and Farm Products, 1993

5.11 Radionuclide Concentrations in Milk, 1993 Compared to Values

from the Previous 5 Years

5.12 Tritium Concentrations in Wine, 1993 Compared to Values

from the Previous 5 Years

5.13 Radionuclide Concentrations in Wine, 1993.

5.14 Strontium-90 in Alfaifa Samples, 1993.

5.15 Locations, Species, and Radionuclides Sampled for Fish and

Wildlife, 1993

5.16 Trace Metal Analysis of Pigeon and Deer Samples Collected

from the 200 Area Plateau, 1993 
5.17 Summary of Cesium-137 in Rabbit Muscle, 1993 Compared to Values

from the Previous 5 Years

5.18 Summary of Strontium-90 in Rabbit Bone, 1993 Compared to Values

from the Previous 5 Years

5.19 Summary of Cesium-137 in Duck Muscle, 1993 Compared to Values

from the Previous 5 Years

5.20 Concentrations of Strontium-90 in Goose Egg Shells, Selected Years

5.21 Summary of Cesium-137 in Upland Gamebird Muscle, 1993 Compared

to Values from the Previous 5 Years

5.22 Soil and Vegetation Sample Collected 1993

5.23 Radionuclide Concentrations in Soil Samples on and off the

Hanford Site, 1993 Compared to Values from the Previous 5 Years

5.24 Radionuclide Concentrations in Vegetation Samples on and off

the Hanford Site, 1993 Compared to Values from the Previous 5 Years

5.25 Dose Rates Measured by Thermoluminescent Dosimeters at Perimeter and

Community Locations, 1993 Compared to Values from the Previous 5 Years

5.26 Dose Rates Measured Along the Hanford Reach of the Columbia River, 1993 Compared to Values from the Previous 5 Years

5.27 Dose Rates for Thermoluminescent Dosimeter Locations on the

Hanford Site, 1993 Compared to Values from the Previous 5 Years

5.28 Radionuclides and Chemicals Analyzed for in Ground Water

5.29 Major Chemical and Radiological Ground-Water Contaminants

and Their Link to Site Operations

6.1 Doses to the Hypothetical Maximally Exposed Individual from

Hanford Operations, 1993

6.2 Population Doses from Hanford Operations, 1993

6.3 Summary of Doses to the Public in the Vicinity of Hanford

from Various Sources, 1993

6.4 Estimated Risk from Various Activities and Exposures

6.5 Activities Comparable in Risk to That from the 0.03-mrem Dose Calculated

for the 1993 Maximally Exposed Individual.

7.1 Summary of Ground-Water Surveillance Full Trip Blank Samples, 1993 
7.3 Summary Results of DataChem Laboratories EPA Water Pollution and Water

Supply Performance Evaluation Studies, 1993

7.4 Summary of International Technology Corporation Performance on

DOE Quality Assessment Program Samples, 1993

7.5 Summary of International Technology Corporation Performance on

EPA Intercomparison Program Samples, 1993

7.6 Summary of Ground-Water Surveillance Project Quarterly Blind Sample Determinations

7.7 Summary of Surface Environmental Surveillance Project Blind

Sample Determinations, 1993

7.8 Comparison of Food and Drug Administration Cosampling, 1993

7.9 Comparison of Thermoluminescent Dosimeter Results with Known Exposure, 1993

7.10 222-S Analytical Laboratory Performance on DOE Quality

Assessment Program Samples, 1993

7.11 222-S Analytical Laboratory Performance on EPA Intercomparison

Program Samples, 1993

A.1 Radionuclide Concentrations Measured in Columbia River Water at Priest Rapids Dam, 1992 Compared to Values from the Previous 5 Years

A.2 Radionuclide Concentrations Measured in Columbia River Water at the 300 Area, 1992

Compared to Values from the Previous 5 Years

A.3 Radionuclide Concentrations Measured in Columbia River Water at the Richland Pumphouse, 1992 Compared to Values from the Previous 5 Years

A.4 Radionuclide Concentrations Measured in Columbia River Water Along

Cross Sections Established Along the Hanford Reach, 1993

A.5 Columbia River Water Quality Data, 1993

A.6 Radionuclide Concentrations in Columbia River Sediment, 1993 Compared to Values from the Previous 4 Years

A.7 Radionuclide Concentrations Measured in Riverbank Spring Water During 1993

A.8 Summary of Cesium-137 in Milk, 1993 Compared to Values from

the Previous 5 Years

A.9 Strontium-90 in Leafy Vegetables, 1993 Compared to Values from the Previous 5 Years.

A.10 Cobalt-60, Strontium-90, and Cesium-137 in Riverview Carrots, 1993

Compared to Values from the Previous 5 Years 
A.11 Annual Average Concentration of Strontium-90 in Alfalfa, 1982 to 1993

A. 12

A.12 Summary of Strontium-90 in Carp Carcass and Cesium-137 in Carp

Muscle, 1993 Compared to Values from 1990 and 1992

A.13 Concentrations of Strontium-90 in Whitefish Carcass and Cesium-137 in

Whitefish Muscle, 1993 Compared to Values from the Previous 5 Years

A.14 Summary of Strontium-90 in Deer Bone and Cesium-137 in Deer Muscle,

1993 Compared to Values from the Previous 5 Years

A.15 Summary of Plutonium-238 and Plutonium-239,240 in Rabbit Liver,

1993 Compared to Values from the Previous 5 Years

A.16 Strontium-90 Concentrations in Soil, 1988 Through 1993

A.17 Cesium-137 Concentrations in Soil, 1987 Through 1993

A.18 Plutonium-239,240 Concentrations in Soil, 1987 Through 1993

A.19 Uranium Concentrations in Soil, 1987 Through 1993

C.1 Washington State Water Quality Standards for the Hanford Reach

of the Columbia River

C.2 Selected Radiological Drinking Water Standards

C.3

C.3 Selected Chemical Drinking Water Standards

C.4

C.4 Benton-Franklin-Walla Walla Counties Air Pollution Control

Authority Ambient Air Quality Standards

C. 4

C.5 Radiation Standards for Protection of the Public from All Routine DOE Activities

C.5

C.6 Selected Derived Concentration Guides

C. 6

C.7 Environmental Permits

C.7

D.1 Food Pathway Parameters Used in Dose Calculations, 1993

D.3

D.2 Dietary Parameters Used in Dose Calculations, 1993

D.4

D.3 Residency Parameters Used in Dose Calculations, 1993

D.4

D.4 Recreational Parameters Used in Dose Calculations, 1993

D.5

D.5 Documentation of 100-N Area Airborne Release Dose Calculations, 1993

D.6

D.6 Documentation of 100-N Area Liquid Release Dose Calculations, 1993

D.7

D.7 Documentation of 200 Area Airborne Release Dose Calculations, 1993

D.8 
D.8 Documentation of 300 Area Airborne Release Dose Calculations, 1993 ............................................ D.9

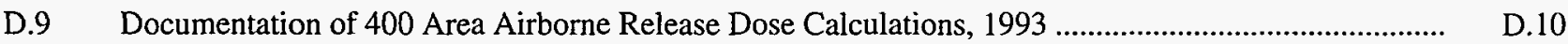

F.1 Radionuclides Analyzed by Gamma-Spectroscopy …....................................................................... F.

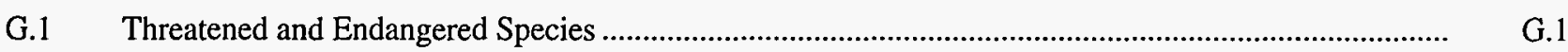

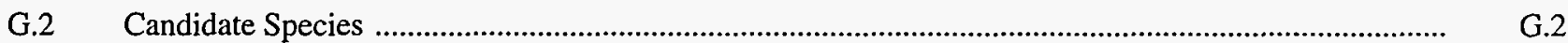

G.3 Washington State Plant Species of Concern Occurring on the Hanford Site .......................................... G.3 

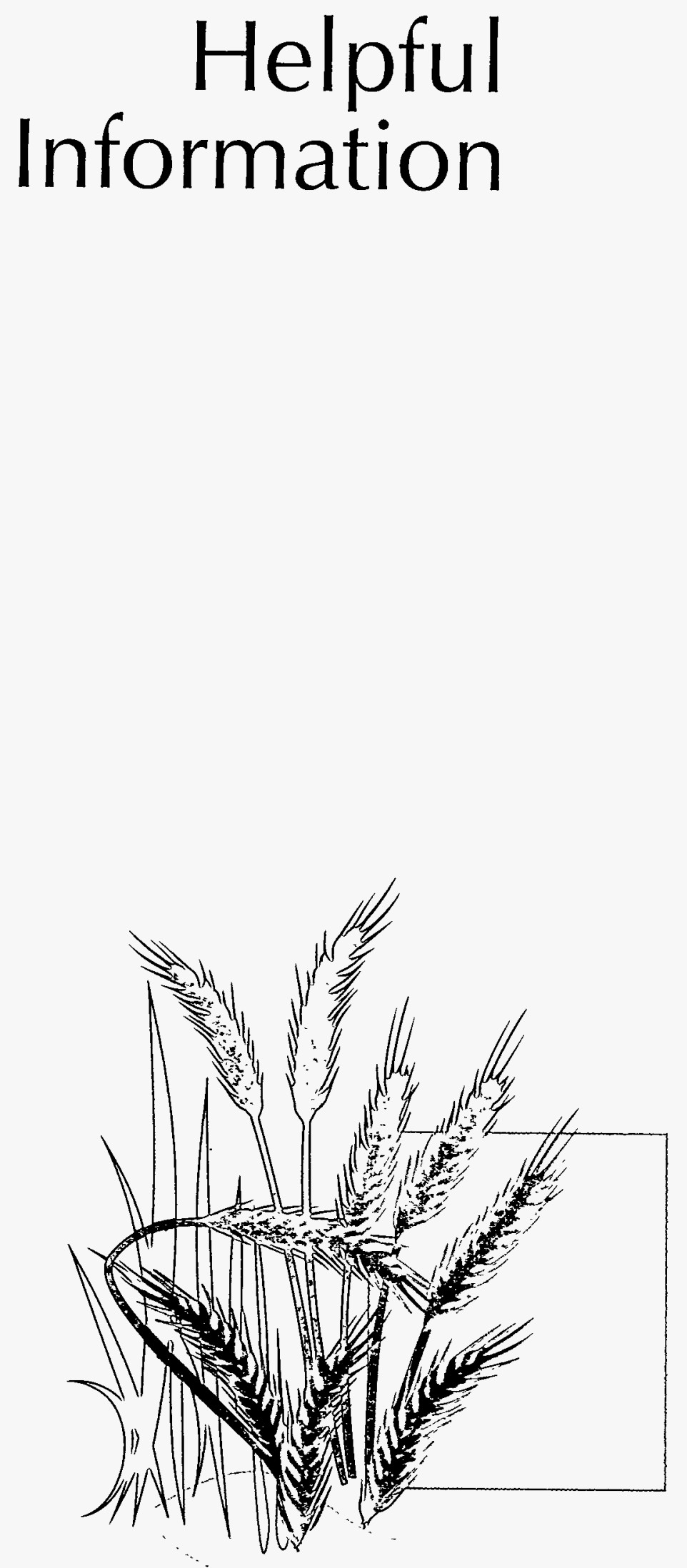


\title{
Helpful Information
}

\author{
R. W. Hanf
}

The following information is provided to assist the reader in understanding the report. Definitions of technical terms can be found in Appendix B, "Glossary." A public information summary pamphlet is available by following the directions in the "Preface."

\section{Scientific Notation}

Scientific notation is used in this report to express very large or very small numbers. For example, the number 1 billion could be written as $1,000,000,000$ or using scientific notation as $1 \times 10^{9}$. Translating from scientific notation to a more traditional number requires moving the decimal point either left or right from the number. If the value given is $2.0 \times 10^{3}$, the decimal point should be moved three numbers (insert zeros if no numbers are given) to the right of its present location. The number would then read 2,000. If the value given is $2.0 \times 10^{-5}$, the decimal point should be moved five numbers to the left of its present location. The result would become 0.00002 .

\section{Metric Units}

The primary units used in this report are metric.

Table H. 1 summarizes and defines the terms and corresponding symbols (metric and nonmetric) found throughout this report.

\section{Radioactivity Units}

Much of this report deals with levels of radioactivity in various environmental media. Radioactivity in this report is usually discussed in units of curies ( $\mathrm{Ci}$ )

(Table H.2). The curie is the basic unit used to describe the amount of radioactivity present, and concentrations are generally expressed in terms of fractions of curies per unit mass or volume. One curie is equivalent to 37 billion disintegrations per second or is a quantity of any radionuclide that decays at the rate of 37 billion disintegrations per second. Disintegrations generally produce spontaneous emissions of alpha or beta particles, gamma radiation, or combinations of these. In some instances in this report, radiation values are expressed with two sets of units. One set of units is usually included in parenthesis or footnotes. These units belong to the International System of Units (SI), and their inclusion in this report is mandated by DOE. SI units are the internationally accepted units and will eventually be the standard for reporting radioactivity and radiation dose in the United States. The basic unit for discussing radioactivity, the curie, can be converted to the equivalent SI unit, the becquerel $(\mathrm{Bq})$, by multiplying the number of curies by $3.7 \times 10^{10}$. One becquerel is equivalent to one nuclear disintegration per second.

\section{Radiation Dose Units}

The amount of radiation received by a living organism is expressed in terms of radiation dose. Radiation dose in this report is usually written in terms of effective dose equivalent and reported numerically in units of rem or in the SI unit, sievert (Sv) (Table H.3). Rem (sievert) is a term that relates ionizing radiation and biological effect or risk. A dose of 1 millirem has a biological effect similar to the dose received from about a 1-day's exposure to natural background radiation (see "Hanford Public Radiation Dose in Perspective" in Section 6.0 for a more indepth discussion of risk comparisons). To convert the most commonly used dose term in this report, the millirem, to the SI equivalent, the millisievert, multiply millirem by 0.01 .

Additional information on radiation and dose terminology can be found in the glossary of this report (Appen$\operatorname{dix} B$ ). A list of the radionuclides discussed in this report and their half-lives is included in Table H.4.

General information on radiation and radiation dose (as well as Hanford's Environmental Monitoring Program, Hanford's Cultural Resource Program, and Hanford's wildlife) has been compiled in informational pamphlets 
Table H.1. Names and Symbols for Units of Measure

\begin{tabular}{lll}
\multicolumn{2}{c}{ Length } \\
\cline { 1 - 2 } \cline { 1 - 2 } $\mathrm{cm}$ & & \multicolumn{1}{c}{ Name } \\
$\mathrm{ft}$ & fontimeter $\left(1 \times 10^{-2} \mathrm{~m}\right)$ \\
$\mathrm{in}$. & inch \\
$\mathrm{km}$ & kilometer $\left(1 \times 10^{3} \mathrm{~m}\right)$ \\
$\mathrm{m}$ & meter \\
$\mathrm{mi}$ & mile \\
$\mathrm{mm}$ & millimeter $\left(1 \times 10^{-3} \mathrm{~m}\right)$ \\
$\mu \mathrm{m}$ & micrometer $\left(1 \times 10^{-6} \mathrm{~m}\right)$
\end{tabular}

\begin{tabular}{cll}
\multicolumn{2}{c}{ Time } \\
\cline { 1 - 1 } \cline { 1 - 2 } Symbol & & Name \\
\cline { 1 - 1 } $\mathrm{d}$ & & day \\
$\mathrm{h}$ & & hour \\
$\mathrm{min}$ & & minute \\
$\mathrm{s}$ & & second \\
$\mathrm{yr}$ & & year
\end{tabular}

\begin{tabular}{|c|c|}
\hline & Area \\
\hline Symbol & Name \\
\hline ha & hectare $\left(1 \times 10^{4} \mathrm{~m}^{2}\right)$ \\
\hline $\mathrm{km}^{2}$ & square kilometer \\
\hline $\mathrm{mi}^{2}$ & square mile \\
\hline $\mathrm{ft}^{2}$ & square foot \\
\hline
\end{tabular}

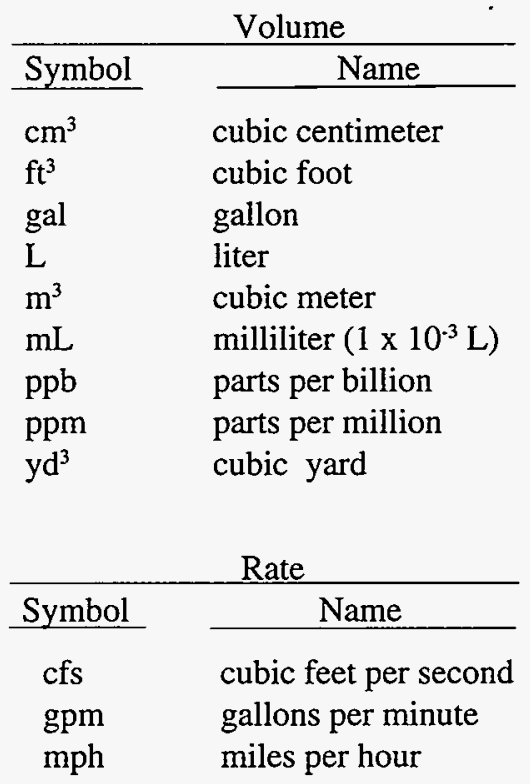

Mass

\begin{tabular}{cll}
\hline Symbol & & \multicolumn{2}{c}{ Name } \\
\cline { 1 - 1 } $\mathrm{g}$ & & gram \\
$\mathrm{kg}$ & & kilogram $\left(1 \times 10^{3} \mathrm{~g}\right)$ \\
$\mathrm{mg}$ & & milligram $\left(1 \times 10^{-3} \mathrm{~g}\right)$ \\
$\mu \mathrm{g}$ & & microgram $\left(1 \times 10^{-6} \mathrm{~g}\right)$ \\
$\mathrm{ng}$ & & nanogram $\left(1 \times 10^{-9} \mathrm{~g}\right)$ \\
$\mathrm{lb}$ & & pound \\
$\mathrm{wt} \%$ & & weight percent
\end{tabular}

Temperature

\begin{tabular}{|c|c|}
\hline Symbol & Name \\
\hline${ }^{\circ} \mathrm{C}$ & degrees Centigrade \\
\hline${ }^{\circ} \mathrm{F}$ & degrees Fahrenheit \\
\hline
\end{tabular}

Table H.2. Names and Symbols for Units of Radioactivity

\begin{tabular}{lll}
\multicolumn{2}{c}{ Radioactivity } \\
\cline { 1 - 1 } \cline { 1 - 2 } Symbol & & Name \\
$\mathrm{Cpm}$ & & courie \\
$\mathrm{cp}$ & & millicurie $\left(1 \times 10^{-3} \mathrm{Ci}\right)$ \\
$\mathrm{mCi}$ & & microcurie $\left(1 \times 10^{-6} \mathrm{Ci}\right)$ \\
$\mu \mathrm{Ci}$ & & nanocurie $\left(1 \times 10^{-9} \mathrm{Ci}\right)$ \\
$\mathrm{nCi}$ & & picocurie $\left(1 \times 10^{-12} \mathrm{Ci}\right)$ \\
$\mathrm{pCi}$ & & attocurie $\left(1 \times 10^{-18} \mathrm{Ci}\right)$ \\
$\mathrm{aCi}$ & & becquerel
\end{tabular}

Table H.3. Names and Symbols for Units of Radiation Dose

\begin{tabular}{|c|c|}
\hline \multicolumn{2}{|c|}{ Radiation Dose } \\
\hline Symbol & Name \\
\hline $\operatorname{mrad}$ & millirad $\left(1 \times 10^{-3} \mathrm{rad}\right)$ \\
\hline mrem & millirem $\left(1 \times 10^{-3} \mathrm{rem}\right)$ \\
\hline Sv & sievert \\
\hline $\mathrm{mSv}$ & millisievert $\left(1 \times 10^{-3} \mathrm{~Sv}\right)$ \\
\hline$\mu \mathrm{Sv}$ & microsievert $\left(1 \times 10^{-6} \mathrm{~Sv}\right)$ \\
\hline $\mathbf{R}$ & roentgen \\
\hline $\mathrm{mR}$ & milliroentgen $\left(1 \times 10^{-3} \mathrm{R}\right)$ \\
\hline$\mu \mathrm{R}$ & microroentgen $\left(1 \times 10^{-6} \mathrm{R}\right)$ \\
\hline Gy & gray \\
\hline
\end{tabular}


Table H.4. Radionuclide Nomenclature ${ }^{(\mathrm{a})}$

\begin{tabular}{|c|c|c|c|c|c|}
\hline Symbol & Radionuclide & Half-Life & Symbol & Radionuclide & Half-Life \\
\hline${ }^{3} \mathrm{H}$ & tritium & $12.3 \mathrm{yr}$ & ${ }^{144} \mathrm{Ce}$ & cerium-144 & $284 \mathrm{~d}$ \\
\hline${ }^{7} \mathrm{Be}$ & beryllium-7 & $53.4 \mathrm{~d}$ & ${ }^{147} \mathrm{Pm}$ & promethium-147 & $2.6 \mathrm{yr}$ \\
\hline${ }^{14} \mathrm{C}$ & carbon-14 & $5730 \mathrm{yr}$ & ${ }^{152} \mathrm{Eu}$ & europium-152 & $13.3 \mathrm{yr}$ \\
\hline${ }^{22} \mathrm{Na}$ & sodium-22 & $2.6 \mathrm{yr}$ & ${ }^{154} \mathrm{Eu}$ & europium-154 & $8.8 \mathrm{yr}$ \\
\hline${ }^{40} \mathrm{~K}$ & potassium-40 & $1.3 \times 10^{8} \mathrm{yr}$ & ${ }^{155} \mathrm{Eu}$ & europium-155 & $5 \mathrm{yr}$ \\
\hline${ }^{41} \mathrm{Ar}$ & argon-41 & $1.8 \mathrm{~h}$ & ${ }^{208} \mathrm{Tl}$ & thallium-208 & $3.1 \mathrm{~min}$ \\
\hline${ }^{51} \mathrm{Cr}$ & chromium-51 & $27.7 \mathrm{~d}$ & ${ }^{212} \mathrm{Bi}$ & bismuth-212 & $61 \mathrm{~min}$ \\
\hline${ }^{54} \mathrm{Mn}$ & manganese-54 & $312 \mathrm{~d}$ & ${ }^{212} \mathrm{~Pb}$ & lead-212 & $10.6 \mathrm{~h}$ \\
\hline${ }^{57} \mathrm{Co}$ & cobalt-57 & $270.9 \mathrm{~d}$ & ${ }^{212} \mathrm{Po}$ & polonium-212 & $0.3 \times 10^{-6} \mathrm{~s}$ \\
\hline${ }^{60} \mathrm{Co}$ & cobalt- 60 & $5.3 \mathrm{yr}$ & ${ }^{216} \mathrm{Po}$ & polonium-216 & $0.15 \mathrm{~s}$ \\
\hline${ }^{63} \mathrm{Ni}$ & nickel-63 & $96 \mathrm{yr}$ & ${ }^{220} \mathrm{Rn}$ & radon-220 & $56 \mathrm{~s}$ \\
\hline${ }^{65} \mathrm{Zn}$ & zinc-65 & $243.9 \mathrm{~d}$ & ${ }^{222} \mathrm{Rn}$ & radon-222 & $3.8 \mathrm{~d}$ \\
\hline${ }^{85} \mathrm{Kr}$ & krypton-85 & $10.7 \mathrm{yr}$ & ${ }^{226} \mathrm{Ra}$ & radium-226 & $1600 \mathrm{yr}$ \\
\hline${ }^{89} \mathrm{Sr}$ & strontium-89 & $50.5 \mathrm{~d}$ & ${ }^{228} \mathrm{Ra}$ & radium-228 & $5.8 \mathrm{yr}$ \\
\hline${ }^{90} \mathrm{Sr}$ & strontium-90 & $21.1 \mathrm{yr}$ & ${ }^{232} \mathrm{Th}$ & thorium-232 & $1.4 \times 10^{10} \mathrm{yr}$ \\
\hline${ }^{95} \mathrm{Nb}$ & niobium-95 & $35 \mathrm{~d}$ & $\mathrm{U}$ or uranium ${ }^{(\mathbf{b})}$ & uranium total & -- \\
\hline${ }^{95} \mathrm{Zr}$ & zirconium-95 & $64 d$ & ${ }^{234} \mathrm{U}$ & uranium-234 & $2.4 \times 10^{5} \mathrm{yr}$ \\
\hline${ }^{99} \mathrm{Mo}$ & molybdenum-99 & $66 \mathrm{~h}$ & ${ }^{235} \mathrm{U}$ & uranium-235 & $7 \times 10^{8} \mathrm{yr}$ \\
\hline${ }^{99} \mathrm{Tc}$ & technetium-99 & $2.1 \times 10^{5} \mathrm{yr}$ & ${ }^{236} \mathrm{U}$ & uranium-236 & $2.3 \times 10^{7} \mathrm{yr}$ \\
\hline${ }^{103} \mathrm{Ru}$ & ruthenium-103 & $39.3 \mathrm{~d}$ & ${ }^{238} \mathrm{U}$ & uranium-238 & $4.5 \times 10^{9} \mathrm{yr}$ \\
\hline${ }^{106} \mathrm{Ru}$ & ruthenium-106 & $368 d$ & ${ }^{238} \mathrm{Pu}$ & plutonium-238 & $87.7 \mathrm{yr}$ \\
\hline${ }^{125} \mathrm{Sb}$ & antimony-125 & $2.8 \mathrm{yr}$ & ${ }^{239} \mathrm{~Np}$ & neptunium-239 & $2.4 \mathrm{~d}$ \\
\hline${ }^{129} \mathrm{I}$ & iodine-129 & $1.6 \times 10^{7} \mathrm{yr}$ & ${ }^{239} \mathrm{Pu}$ & plutonium-239 & $2.4 \times 10^{4} \mathrm{yr}$ \\
\hline${ }^{131} I$ & iodine- 131 & $8 \mathrm{~d}$ & ${ }^{240} \mathrm{Pu}$ & plutonium-240 & $6.5 \times 10^{3} \mathrm{yr}$ \\
\hline${ }^{133} \mathrm{Ba}$ & barium-133 & $10.7 \mathrm{yr}$ & ${ }^{241} \mathrm{Pu}$ & plutonium-241 & $14.4 \mathrm{yr}$ \\
\hline${ }^{134} \mathrm{Cs}$ & cesium-134 & $2.1 \mathrm{yr}$ & ${ }^{241} \mathrm{Am}$ & americium-241 & $432 \mathrm{yr}$ \\
\hline${ }^{137} \mathrm{Cs}$ & cesium-137 & $30 \mathrm{yr}$ & & & \\
\hline
\end{tabular}

(a) From Shleien 1992.

(b) Total uranium may also be indicated by U-natural (U-nat) or U-mass.

that can be obtained, free, by writing to Richard $\mathrm{E}$. Jaquish, Manager, Public Safety and Resource Protection Program, P.O. Box 999, Richland, Washington 99352. More comprehensive readings on radiation and radiation dose can be found in most public libraries and in many local book stores.

\section{Understanding the Data Tables}

Measuring any physical quantity (for example, temperature, distance, time, or radioactivity) has some degree of inherent uncertainty. This uncertainty results from the combination of all possible inaccuracies in the measurement process, including such factors as the reading of the result, the calibration of the measurement device, and numerical rounding errors. In this report, individual radioactivity measurements are accompanied by a plus or minus $( \pm)$ value (sometimes expressed as a percentage of the related concentration value), which is an uncertainty term known as either the two-sigma counting error or the total propagated error (see Sections 5.4 and 5.6). Total propagated error includes counting error and analytical error. Because measuring a radionuclide requires a process of counting random radioactive emissions from a sample, the counting error gives information on what the 
measurement might be if the same sample were counted again under identical conditions. The counting error implies that approximately $95 \%$ of the time, a recount of the same sample would give a value somewhere between the reported value minus the counting error and the reported value plus the counting error. Values in the tables that are less than the counting error indicate that the reported result might have come from a sample with no radioactivity. Such values are considered as below detection. Also note that each radioactive measurement must have the random background radioactivity of the measuring instrument subtracted; therefore, negative results are possible, especially when the sample has very little radioactivity.

Just as individual values are accompanied by counting errors, mean values are accompanied by two times the standard error of the calculated mean (2SEM). In this report, 2SEM is sometimes expressed as a percentage of the mean concentration value. If the data fluctuate randomly, then the 2 SEM is a measure of the uncertainty in the estimated mean of the data from this randomness. If trends or periodic (for example, seasonal) fluctuations are present, then the 2 SEM is primarily a measure of the variability in the trends and fluctuations about the mean of the data.

\section{Understanding Graphical Information}

Presenting data on a graph is useful when comparing numbers collected at several locations or at one location over time. Graphs make it easier to visualize differences where they exist. However, while graphs may make it easier to evaluate data, they may also lead the reader to incorrect conclusions if they are not interpreted correctly. Careful consideration should be given to the scale (linear or logarithmic) concentration units, and the type of uncertainty used.

Some of the data graphed in this report are plotted using logarithmic (or compressed) scales. Logarithmic scales are useful when plotting two or more numbers that differ greatly in size. For example, a sample with a concentration of $5 \mathrm{~g} / \mathrm{L}$ would get lost at the bottom of the graph if plotted on a linear scale with a sample having a concentration of $3000 \mathrm{~g} / \mathrm{L}$ (Figure H.1). A logarithmic plot of these same two numbers allows the reader to clearly see both data points (Figure H.2).
The mean values graphed in this report have vertical lines extending above and below the data point. These lines (called error bars), which are usually capped at both ends with a short horizontal line, indicate the amount of uncertainty (2SEM) in the reported result. The error bars in this report represent a $95 \%$ chance that the mean is between the upper and lower ends of the error bar, and a $5 \%$ chance that the true mean is either lower or higher than the error bar. ${ }^{(a)}$ For example, in Figure H.3, the first plotted mean is $2.0 \pm 1.1$, so there is a $95 \%$ chance that the actual result is between 0.9 and 3.1 , a $2.5 \%$ chance it is less than 0.9 , and a $2.5 \%$ chance it is greater than 3.1 . Error bars are computed statistically employing all of the information used to generate the data point plotted on the graph. These bars provide a quick visual indication that one mean may be statistically similar to or different from another mean. If the error bars (or range of values) of two or more means overlap, as is the case with means 1 and 3 and means 2 and 3, the means may be similar, statistically. If the error bars do not overlap (means 1 and 2), the means may be statistically different. Means that appear to be very different visually (means 2 and 3 ) may actually be quite similar when compared statistically.

Uncertainties (error bars) are not plotted in Section 5.6, "Soil and Vegetation Surveillance." Instead, sample median, maximum, and minimum values are illustrated.

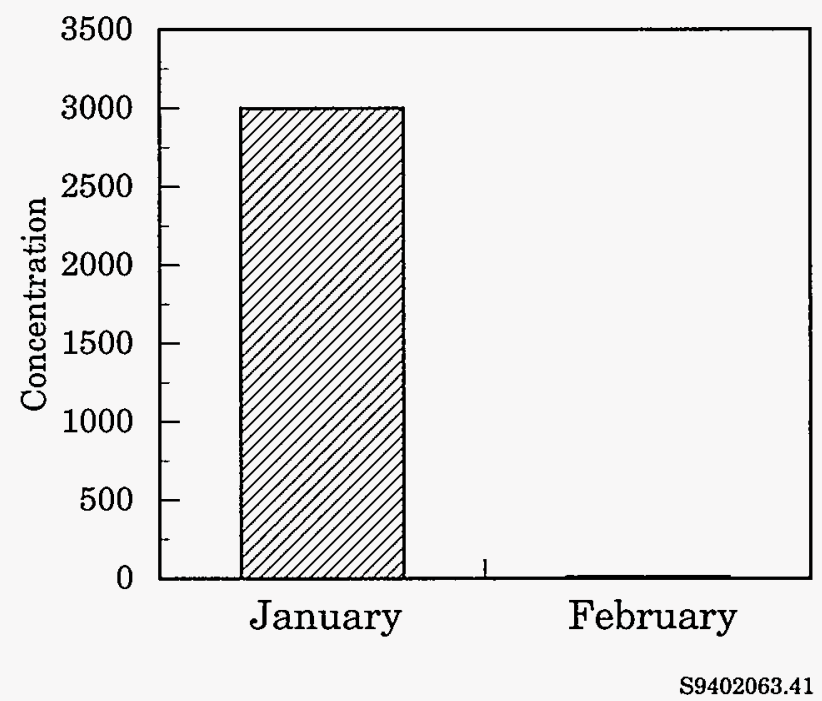

Figure H.1. Data Plotted Using a Linear Scale

(a) Assuming the Normal statistical distribution of the data. 


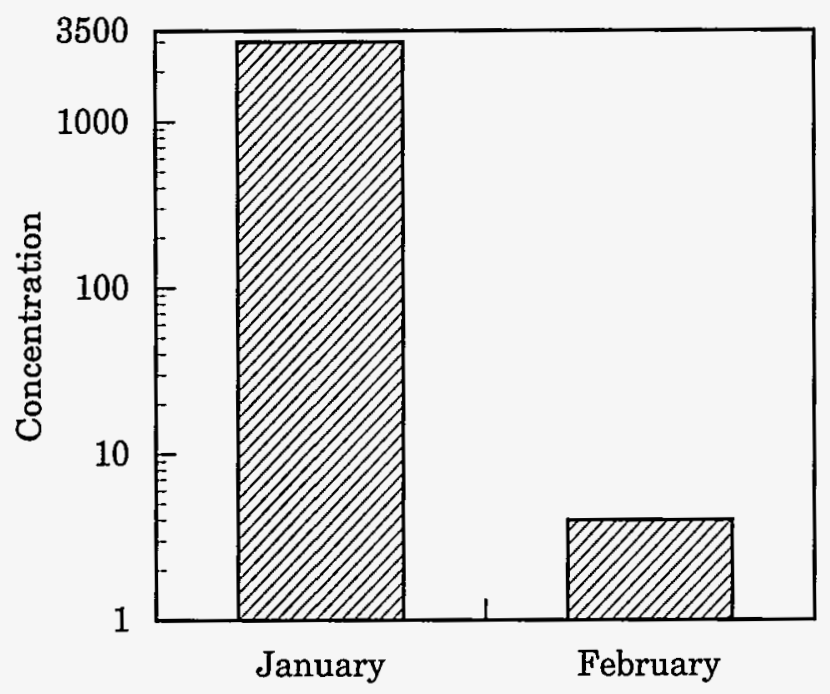

S9402063.42

Figure H.2. Data Plotted Using a Logarithmic Scale

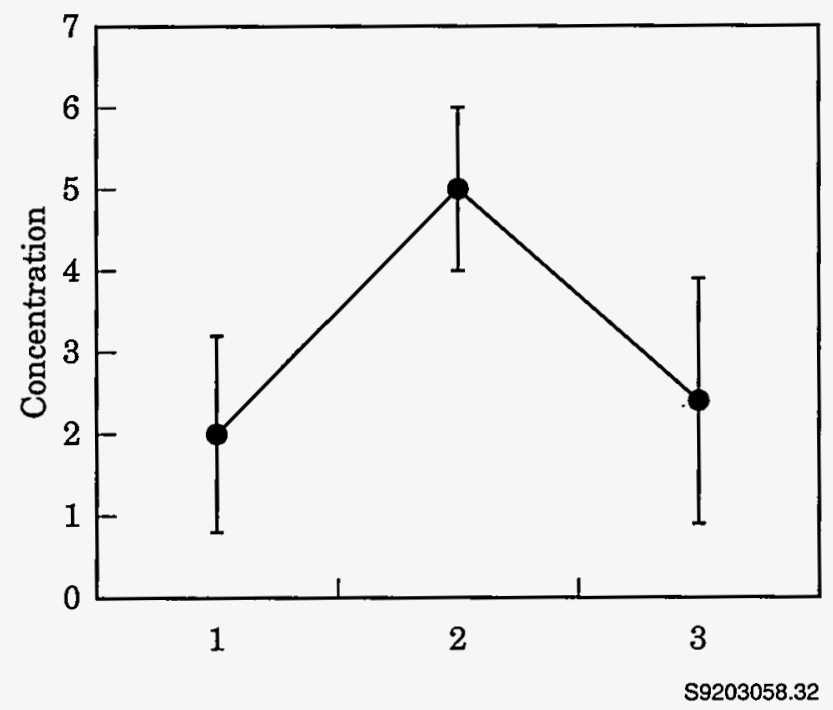

Uncertainties are not used because of the small number of soil and vegetation samples collected and analyzed during the year.

\section{Greater Than $(>)$ or Less Than (<) Symbols}

Greater than $(>)$ or less than $(<)$ symbols are used to indicate that the actual value may either be larger than the number given or smaller than the number given. For example, $>0.09$ would indicate that the actual value is greater than 0.09 . An inequality symbol pointed in the opposite direction $(<0.09)$ would indicate that the number is less than the value presented. If an inequality symbol is used in association with an underscore ( $\leq$ or $\geq$ ), this indicates that the actual value is less-than-orequal-to or greater-than-or-equal-to the number given, respectively.

Figure H.3. Data With Error Bars Plotted Using a Linear Scale 


\section{Elemental and Chemical Constituent Nomenclature}

\begin{tabular}{|c|c|}
\hline Symbol & Constituent \\
\hline $\mathrm{Ag}$ & silver \\
\hline $\mathrm{AI}$ & aluminum \\
\hline As & arsenic \\
\hline $\mathrm{B}$ & boron \\
\hline $\mathrm{Ba}$ & barium \\
\hline $\mathrm{Be}$ & beryllium \\
\hline $\mathrm{Br}$ & bromine \\
\hline $\mathrm{C}$ & carbon \\
\hline $\mathrm{Ca}$ & calcium \\
\hline $\mathrm{CaF}_{2}$ & calcium fluoride \\
\hline $\mathrm{CCl}_{4}^{2}$ & carbon tetrachloride \\
\hline $\mathrm{Cd}$ & cadmium \\
\hline $\mathrm{CHCl}_{3}$ & trichloromethane \\
\hline $\mathrm{Cl}^{-3}$ & chloride \\
\hline $\mathrm{CN}^{-}$ & cyanide \\
\hline $\mathrm{Cr}^{+6}$ & chromium (species) \\
\hline $\mathrm{Cr}$ & chromium (total) \\
\hline $\mathrm{CO}_{3}^{-2}$ & carbonate \\
\hline $\mathrm{Co}^{3}$ & cobalt \\
\hline $\mathrm{Cu}$ & copper \\
\hline Dy & dysprosium \\
\hline$F^{-}$ & fluoride \\
\hline $\mathrm{Fe}$ & iron \\
\hline $\mathrm{HCO}_{3}^{-}$ & bicarbonate \\
\hline $\mathrm{Hg}^{-3}$ & mercury \\
\hline
\end{tabular}

\begin{tabular}{ll} 
Symbol & Constituent \\
\cline { 2 - 3 } $\mathrm{K}$ & potassium \\
$\mathrm{LiF}$ & lithium fluoride \\
$\mathrm{Mg}$ & magnesium \\
$\mathrm{Mn}$ & manganese \\
$\mathrm{Mo}$ & molybdenum \\
$\mathrm{NH}_{3}$ & ammonia \\
$\mathrm{NH}_{4}^{+}$ & ammonium \\
$\mathrm{N}^{\mathrm{Na}}$ & nitrogen \\
$\mathrm{Ni}$ & sodium \\
$\mathrm{NO}_{2}^{-}$ & nickel \\
$\mathrm{NO}_{3}^{-}$ & nitrate \\
$\mathrm{Pb}^{-3}$ & nitrate \\
$\mathrm{PO}_{4}^{-3}$ & lead \\
$\mathrm{P}$ & phosphate \\
$\mathrm{Sb}$ & phosphorus \\
$\mathrm{Se}$ & antimony \\
$\mathrm{Si}$ & selenium \\
$\mathrm{Sr}$ & silicon \\
$\mathrm{SO}_{4}^{-2}$ & strontium \\
$\mathrm{Ti}$ & sulfate \\
$\mathrm{Tl}$ & titanium \\
$\mathrm{V}$ & thallium \\
$\mathrm{Zn}$ & vanadium \\
& zinc \\
&
\end{tabular}

\section{Conversion Table}

\begin{tabular}{|c|c|c|c|c|c|}
\hline Multiply & By & To Obtain & Multiply & By & To Obtain \\
\hline in. & 2.54 & $\mathrm{~cm}$ & $\mathrm{~cm}$ & 0.394 & in. \\
\hline $\mathrm{ft}$ & 0.305 & $\mathrm{~m}$ & $\mathrm{~m}$ & 3.28 & $\mathrm{ft}$ \\
\hline $\mathrm{mi}$ & 1.61 & $\mathrm{~km}$ & $\mathrm{~km}$ & 0.621 & $\mathrm{mi}$ \\
\hline Ib & 0.454 & $\mathrm{~kg}$ & $\mathrm{~kg}$ & 2.205 & $\mathrm{lb}$ \\
\hline gal & 3.785 & $\mathrm{~L}$ & $\mathrm{~L}$ & .0264 & gal \\
\hline $\mathrm{ft}^{2}$ & 0.093 & $\mathrm{~m}^{2}$ & $\mathrm{~m}^{2}$ & 10.76 & $\mathrm{ft}^{2}$ \\
\hline acres & 0.405 & ha & ha & 2.47 & acres \\
\hline $\mathrm{mi}^{2}$ & 2.59 & $\mathrm{~km}^{2}$ & $\mathrm{~km}^{2}$ & 0.386 & $\mathrm{mi}^{2}$ \\
\hline $\mathrm{ft}^{3}$ & 0.028 & $\mathrm{~m}^{3}$ & $\mathrm{~m}^{3}$ & 35.7 & $\mathrm{ft}^{3}$ \\
\hline $\mathrm{nCi}$ & 0.001 & $\mathrm{pCi}$ & $\mathrm{pCi}$ & 1,000 & $\mathrm{nCi}$ \\
\hline $\mathrm{pCi} / \mathrm{L}$ & $10^{-9}$ & $\mu \mathrm{Ci} / \mathrm{mL}$ & $\mu \mathrm{Ci} / \mathrm{mL}$ & $10^{9}$ & $\mathrm{pCi} / \mathrm{L}$ \\
\hline $\mathrm{pCi} / \mathrm{m}^{3}$ & $10^{-12}$ & $\mathrm{Ci} / \mathrm{m}^{3}$ & $\mathrm{Ci} / \mathrm{m}^{3}$ & $10^{12}$ & $\mathrm{pCi} / \mathrm{m}^{3}$ \\
\hline $\mathrm{pCi} / \mathrm{m}^{3}$ & $10^{-15}$ & $\mathrm{mCi} / \mathrm{cm}^{3}$ & $\mathrm{mCi} / \mathrm{cm}^{3}$ & $10^{15}$ & $\mathrm{pCi} / \mathrm{m}^{3}$ \\
\hline $\mathrm{mCi} / \mathrm{km}^{2}$ & 1.0 & $\mathrm{nCi} / \mathrm{m}^{2}$ & $\mathrm{nCi} / \mathrm{m}^{2}$ & 1.0 & $\mathrm{mCi} / \mathrm{km}^{2}$ \\
\hline becquerel & $2.7 \times 10^{-11}$ & curie & curie & $3.7 \times 10^{10}$ & becquerel \\
\hline gray & 100 & $\mathrm{rad}$ & $\mathrm{rad}$ & 0.01 & gray \\
\hline sievert & 100 & rem & rem & 0.01 & sievert \\
\hline $\mathrm{ppb}$ & 0.001 & $\mathrm{ppm}$ & ppm & 1,000 & $\mathrm{ppb}$ \\
\hline${ }^{\circ} \mathrm{F}$ & $\left({ }^{\circ} \mathrm{F}-32\right) \div 9 / 5$ & ${ }^{\circ} \mathrm{C}$ & ${ }^{\circ} \mathrm{C}$ & $\left({ }^{\circ} \mathrm{C} \times 9 / 5\right)+32$ & ${ }^{\circ} \mathrm{F}$ \\
\hline g & .035 & $\mathrm{oz}$ & $\mathrm{oz}$ & 28.349 & g \\
\hline
\end{tabular}




\section{Acronyms and Abbreviations}

\begin{tabular}{|c|c|c|c|}
\hline AALG & ambient air level goals & HCRL & Hanford Cultural Resources Laboratory \\
\hline ALE & Arid Lands Ecology (Reserve) & ICRP & $\begin{array}{l}\text { International Commission on } \\
\text { Radiological Protection }\end{array}$ \\
\hline ANSI & American National Standards Institute & ICP & inductively coupled plasma (method) \\
\hline ASME & $\begin{array}{l}\text { American Society of Mechanical } \\
\text { Engineers }\end{array}$ & IT & International Technology Corporation \\
\hline ASTM & $\begin{array}{l}\text { American Society for Testing and } \\
\text { Materials }\end{array}$ & LEPS & low-energy photon \\
\hline & & MEI & maximally exposed individual \\
\hline Btu & British thermal units & NASQAN & Natural Stream Quality Accounting \\
\hline CERCLA & $\begin{array}{l}\text { Comprehensive Environmental Response, } \\
\text { Compensation, and Liability Act }\end{array}$ & & Network \\
\hline CFR & Code of Federal Regulations & NCRP & $\begin{array}{l}\text { National Council on Radiation Protection } \\
\text { and Measurements }\end{array}$ \\
\hline DCG & Derived Concentration Guide & NEPA & National Environmental Policy Act \\
\hline DDT & dichlorodiphenyltrichloroethane & NRC & U.S. Nuclear Regulatory Commission \\
\hline DHHS & $\begin{array}{l}\text { U.S. Department of Health and Human } \\
\text { Services }\end{array}$ & NS & no standard or no sample \\
\hline & & NTU & nephelometric turbidity unit \\
\hline & & PCB & polychlorinated biphenyl \\
\hline DOH & Washington State Department of Health & PNL & Pacific Northwest Laboratory \\
\hline DOI & U.S. Department of the Interior & PSD & prevention of significant deterioration \\
\hline DWS & Drinking Water Standard & PUREX & Plutonium Uranium Extraction (Plant) \\
\hline Ecology & Washington State Department of Ecology & QA & quality assurance \\
\hline EDE & effective dose equivalent & QC & quality control \\
\hline EIS & environmental impact statement & RCRA & Resource Conservation and Recovery Act \\
\hline EPA & U.S. Environmental Protection Agency & RCW & Revised Code of Washington \\
\hline FFTF & Fast Flux Test Facility & REDOX & Reduction-Oxidation (Plant) \\
\hline FR & Federal Register & & \\
\hline HAMMER & $\begin{array}{l}\text { Hazardous Materials Management and } \\
\text { Emergency Response (Training Center) }\end{array}$ & SAIC & $\begin{array}{l}\text { Science Application International } \\
\text { Corporation }\end{array}$ \\
\hline
\end{tabular}


-

SARA Superfund Amendments and

Reauthorization Act

SE standard error

SEM standard error of the mean

SI International System of Units

TLD thermoluminescent dosimeter

UNSCEAR United Nations Science Committee on the Effects of Atomic Radiation
USGS U.S. Geological Survey

VOC volatile organic compound

WAC Washington Administrative Code

WDSHS Washington Department of Social and Health Services

WHC Westinghouse Hanford Company 
Introduction

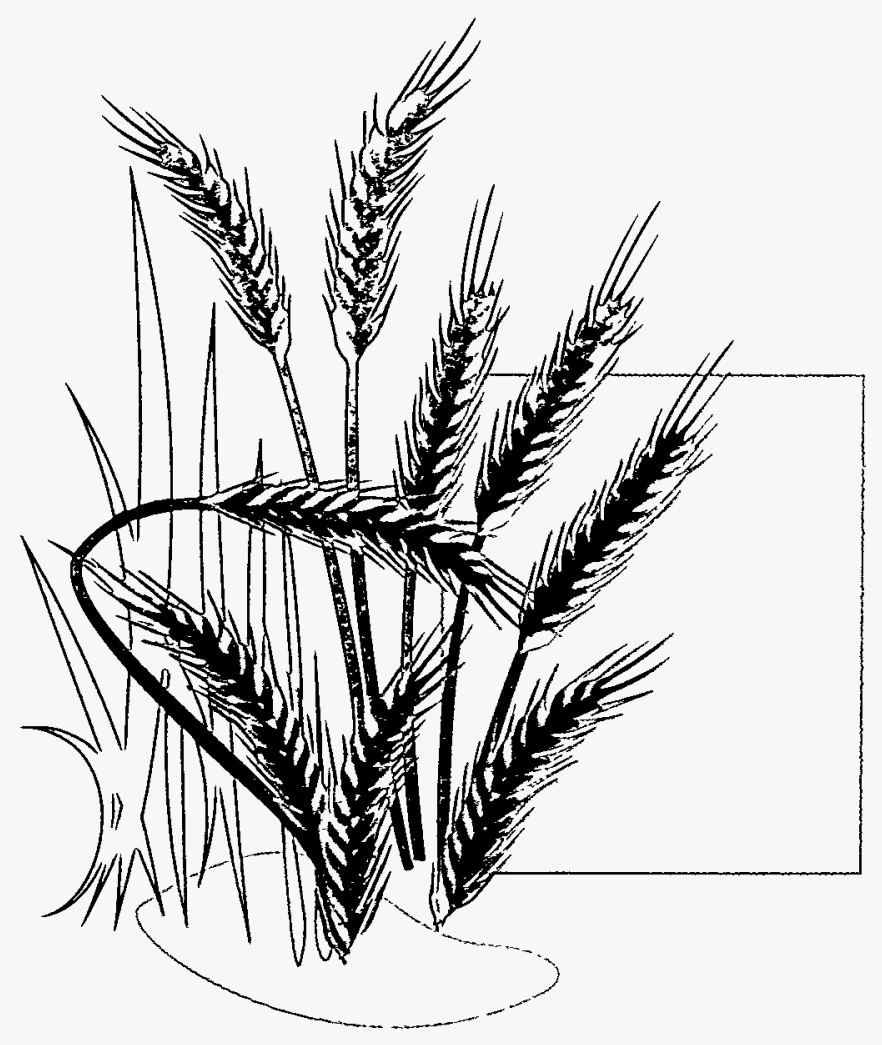




\subsection{Introduction}

The purpose of this report is to summarize information and data that characterize Hanford Site environmental management performance and demonstrate the status of compliance with applicable federal, state, and local environmental laws and regulations. The report also highlights significant environmental programs and efforts.

The report describes the Site mission and activities, general environmental features, radiological and chemical releases from operations, status of compliance with environmental regulations, status of programs to accomplish compliance, and environmental monitoring activities and results.
Those interested in more detail than the summary information presented in this report are referred to the technical reports cited in the text. Report sources include local community libraries and the National Technical Information Center, Springfield, Virginia 22161. Descriptions of analytical and sampling methods, formerly part of this report, are contained in the Hanford Site Environmental Monitoring Plan (DOE 1991b). Readers less familiar with the concepts, terminology, and units used in this report may find the preceding "Helpful Information" section useful. 



\title{
1.1 Site Mission
}

\author{
R. K. Woodruff and J. M. Nickels
}

The Hanford Site was acquired by the federal government in 1943. For more than 20 years, Hanford Site facilities were dedicated primarily to the production of plutonium for national defense and management of the resulting wastes. In later years, programs at the Hanford Site were diversified to include research and development for advanced reactors, renewable energy technologies, waste disposal technologies, and cleanup of contamination from past practices.

The U.S. Department of Energy (DOE) is establishing a new mission for Hanford including:

- Waste Management of stored defense wastes and the handling, storage, and disposal of radioactive, hazardous, mixed, or sanitary wastes from current operations

- Environmental Restoration of approximately 1,100 inactive radioactive, hazardous, and mixed waste sites and about 100 surplus facilities
- Research and Development in energy, health, safety, environmental sciences, molecular sciences, environmental restoration, waste management, and national security

- Technology Development of new environmental restoration and waste management technologies, including site characterization and assessment methods; waste minimization, treatment, and remediation technology; and education outreach programs.

The DOE has set a goal of cleaning up Hanford's waste sites and bringing its facilities into compliance with local, state, and federal environmental laws by 2028 . In addition to supporting the environmental management mission, DOE is also supporting space energy, isotope production, and other special initiatives in accomplishing its national objective. 


\title{
1.2 Introduction to the Hanford Site
}

\author{
C. E. Cushing
}

The Hanford Site lies within the semi-arid Pasco Basin of the Columbia Plateau in southeastern Washington State (Figure 1.1). The Site occupies an area of about $1,450 \mathrm{~km}^{2}$ (approximately $560 \mathrm{mi}^{2}$ ) north of the confluences of the Snake and Yakima rivers with the Columbia River. This land, with restricted public access, provides a buffer for the smaller areas historically used for production of nuclear materials, waste storage, and waste disposal; about $6 \%$ of the land area has been disturbed and is actively used. The Columbia River flows eastward through the northern part of the Hanford Site and then turns south, forming part of the eastern boundary. The Yakima River runs along part of the southern boundary and joins the Columbia River downstream from the city of Richland. Adjoining lands to the west, north, and east are principally range and agricultural lands in Benton, Grant, and Franklin counties. The cities of Richland, Kennewick, and Pasco (Tri-Cities) constitute the nearest population center and are located southeast of the Hanford Site.

Population estimates for 1993 by the Forecasting Division of the Office of Financial Management of the state of Washington place the totals for Benton, Franklin, and Grant counties at $122,800,41,100$, and 60,300 , respectively. The 1993 estimates for the Tri-Cities populations are Richland, 34,080; Kennewick, 45,110; and Pasco, 21,370. The estimated populations of Benton City, Prosser, and West Richland totaled 10,900 in 1993. Estimates of the percent of the population exceeding 65 years of age are 9.87, 9.73, and 13.09 in Benton, Franklin, and Grant counties, respectively, in 1993. The census for 1990 (U.S. Bureau of the Census) revealed that the population of Benton and Franklin counties is young, with $56 \%$ of the total population under the age of 35 , compared with $54 \%$ of the total state population. An examination of age groups in 5-year increments reveals that the largest age group in Benton and Franklin counties ranges from 5 to 9 years old, representing 9.3\% of the total bicounty population; the largest age group in the state ranges from 30 to 34 years, which represents about $9 \%$ of the total state population.
The entire Hanford Site was designated a National Environmental Research Park (one of four nationally) by the former Energy Research and Development Administration, a precursor to $\mathrm{DOE}$.

The major operational areas on the Site include the following:

- The 100 Areas, on the south shore of the Columbia River, are the sites of eight retired plutonium production reactors and the $\mathrm{N}$ Reactor, which has been permanently shut down since 1991 . The 100 Areas occupy about $11 \mathrm{~km}^{2}\left(4 \mathrm{mi}^{2}\right)$.

- The 200-West and 200-East Areas are located on a plateau and are about 8 and $11 \mathrm{~km}$ (5 and $7 \mathrm{mi}$ ), respectively, south of the Columbia River. These areas historically have been dedicated to fuel reprocessing and waste management and disposal activities. The 200 Areas cover about $16 \mathrm{~km}^{2}\left(6 \mathrm{mi}^{2}\right)$.

- The 300 Area, located just north of the city of Richland, is the site of nuclear and non-nuclear research and development. This area covers $1.5 \mathrm{~km}^{2}$ $\left(0.6 \mathrm{mi}^{2}\right)$.

- The 400 Area is about $8 \mathrm{~km}(5 \mathrm{mi})$ northwest of the 300 Area and is the site of the Fast Flux Test Facility (FFTF), used in the testing of breeder reactor systems. Also included in this area is the Fuels and Materials Examination Facility.

- The 600 Area includes all of the Hanford Site not occupied by the $100,200,300$, and 400 Areas.

Support areas near the Site in north Richland include the 1100, 3000, and Richland North Areas. The 1100 Area includes Site support services such as general stores and transportation maintenance. The 3000 Area includes the facilities for ICF Kaiser Hanford Company. The Richland North Area includes the DOE and DOE contractor facilities located between the 300 Area and the city of Richland that are not in the 1100 and 3000 Areas. 


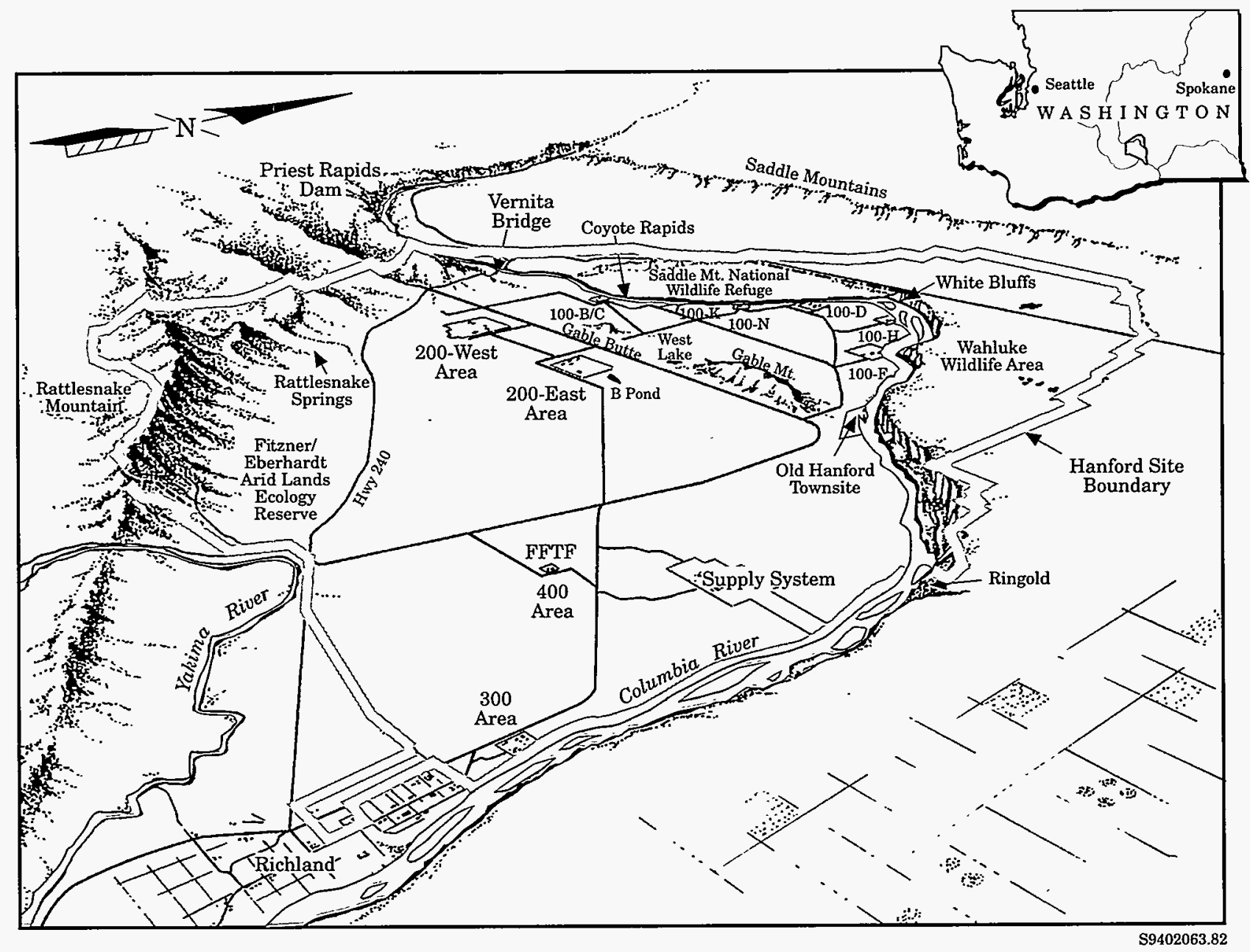

Figure 1.1. DOE's Hanford Site and Surrounding Area

Other facilities are located in the Richland Central Area (located south of Saint Street and Highway 240 and north of the Yakima River), the Richland South Area (located between the Yakima River and Kennewick) and the Kennewick/Pasco area.

Several areas of the Site, totaling $665 \mathrm{~km}^{2}\left(257 \mathrm{mi}^{2}\right)$, have been designated as the Fitzner/Eberhardt Arid Lands Ecology (ALE) Reserve, the U.S. Fish and Wildlife Service Saddle Mountain National Wildlife Refuge, and the Washington State Department of Game Reserve Area (Wahluke Slope Wildlife Recreation Area) (DOE 1986). The ALE Reserve was established in 1967 by the Atomic Energy Commission, a precursor to DOE. In 1971, the reserve was classified a Research Natural Area as a result of a federal interagency cooperative agreement.
Land use in surrounding environs includes urban and industrial development, irrigated and dry-land farming, and grazing. In 1992, wheat represented the largest single crop in terms of area planted in Benton, Franklin, and Grant counties. Total acreage planted in the three counties was 119,789 ha (296,000 acres) and 50,384 ha $(124,500$ acres) for winter and spring wheat, respectively. Corn, alfalfa, potatoes, asparagus, apples, cherries, and grapes are other major crops in Benton, Franklin, and Grant counties. Several processors in Benton and Franklin counties produce food products including potato products, canned fruits and vegetables, wine, and animal feed.

Much of the above information is from Cushing (1992), where more detailed information can be found. 


\title{
1.3 Major Operations and Activities
}

\author{
J. M. Nickels
}

The primary DOE operations and activities on the Hanford Site in 1993 included waste management, site restoration, environmental corrective actions, research and technology development, and site management. The majority of these activities were conducted under the Environmental Restoration and Waste Management Program for the Hanford Site.

\section{Waste Management}

Current waste management activities at the Site include the management of high- and low-activity defense wastes in the 200-East and 200-West Areas (Figure 1.1) and the storage of irradiated defense fuel in the $100-\mathrm{K}$ Area. Key facilities include the waste storage tanks, Central Waste Complex, Low-Level Burial Grounds, 100K Fuel Storage Basins, Plutonium Uranium Extraction (PUREX) Plant, Plutonium Finishing Plant, B Plant, T Plant, 616 Storage Facility, and 242-A Evaporator.

Waste management activities involving single-shell and double-shell tanks currently include ensuring safe storage of wastes through surveillance and monitoring of the tanks and upgrading monitoring instrumentation. Concerns have been raised about the potential of a ferrocyanide explosion and hydrogen gas accumulation in the waste tanks. One issue is that under certain conditions of chemical concentration, moisture, and temperature, ferrocyanide and nitrates in the single-shell tanks could release heat and potentially become explosive. The other issue is that in five double-shell tanks and 18 single-shell tanks flammable explosive hydrogen gases may be trapped beneath the crust. DOE and external oversight groups have concluded that there is no imminent danger to the public from either situation. A Tank Waste Remediation System Division has the responsibility to identify any hazards associated with the waste tanks and implement the necessary actions to mitigate or remediate those hazards.

The 100-K West and the deteriorating 100-K East Fuel Storage Basins are currently being used to store $\mathrm{N}$ Reactor irradiated fuel and will be used in the future for other test fuels. In 1993, operational readiness was reviewed. Schedules for each basin are now being integrated to allow encapsulation of the 105-K East basin fuel and clean up of the bottom debris and sludge. Washington State Department of Health has approved air emissions expected from this activity, following negotiations and establishment of administrative controls and control technologies to be used.

The PUREX Plant formerly processed irradiated reactor fuel to extract plutonium. Plant operation was stopped in December 1988 for safety reasons. From December 1989 through March 1990, the facility completed a stabilization run to process fuel remaining in the plant. The PUREX Plant has not operated since the stabilization run. Solvent and nuclear materials remain, including dilute liquid uranyl nitrate hexahydrate, spent fuel from Hanford single-pass reactors, and organic materials. During 1992, the PUREX Plant began a transition from a "standby condition" to an orderly shutdown. Preparations have begun to deactivate systems and proceed to permanent shutdown.

The Uranium-Oxide Plant began preparations in 1992 to process the remaining liquid uranyl nitrate hexahydrate from the PUREX Plant. After completing an operational readiness review, the plant began operating in April 1993, finishing in June 1993. The plant's stabilization campaign completed processing the last of the stored liquid that was converted into stable uranium trioxide. The final phase of the run produced almost 200 metric tons of uranium, which is stored in 45 steel storage containers at the plant. The stored product, now in its reusable powder form, will be made available by DOE for purchase by commercial power plants. The plant is being prepared for shutdown.

The Plutonium Finishing Plant was used in the past to convert liquid plutonium from the PUREX Plant to plutonium oxide or metal. The Plutonium Finishing Plant has not produced a product since 1987 . The plant also processed and stabilized scrap plutonium materials. Reactivation of the Plutonium Reclamation Facility, one of the operations at the plant, was scheduled to begin in 
June 1993. The reactivation was placed on hold because an environmental impact statement is needed to determine if such operations are the most appropriate alternative for safe stabilization.

There are no production activities currently taking place at B Plant but several operating systems are required to accomplish the B Plant facility mission, which is to ensure safe storage and management of radiological inventories. Approximately 400 of about $770 \mathrm{DOE}-$ leased cesium capsules, manufactured during the late 1970s and early 1980s at the Waste Encapsulation Storage Facility adjacent to B Plant, have been safely returned and transferred to that facility. The capsules had been leased to commercial facilities in several states to be used to sterilize medical products. DOE has recalled all of the capsules as a precautionary measure after one leaked a very small amount of radioactivity at a Georgia facility in 1988. There will be one shipment monthly for about 2 years until the remaining capsules are received. The capsules received to date have been inspected and are intact and free of leaks or deterioration. They are currently stored under $4 \mathrm{~m}(13 \mathrm{ft})$ of water in the Waste Encapsulation Storage Facility storage pools.

The Grout Treatment Facility began in 1985 as a way to stabilize, treat, and dispose of low-level mixed waste liquid removed from the double-shell tanks. The facility combined liquid wastes with dry materials such as cement, limestone, fly ash, and blast furnace slag to produce a grout slurry that was pumped into an underground concrete vault, where it solidified. Facility systems were being prepared. Construction was completed on four new vaults for a scheduled operation in October 1993, when the grout program was cancelled in favor of vitrification. Reasons the program was cancelled were concern from Hanford interest groups about waste retrievability, volume, and other issues.

The 242-A Evaporator is used to reduce the volume of liquid wastes from double-shell tanks. The process condensate will then be stored in liquid effluent retention facilities until the liquid effluent treatment facility is complete. The concentrated waste will be returned to the double-shell tanks. Operational readiness reviews are being conducted on the retention facilities. The liquid effluent treatment facility is being designed and constructed in the 200-East Area to remove regulated chemical constituents from the 242-A Evaporator process condensate.

\section{Site Restoration}

Site restoration includes activities to decontaminate and decommission facilities and to clean up or restore inactive waste sites.

The Decontamination and Decommissioning Program conducts surveillance and maintenance of surplus facilities and has begun to clean up and dispose of more than 100 facilities. Current activities include decommissioning of the 201-C Strontium Semiworks and the 183-H Solar Evaporation Basins. Demolition of the 190-B Building was completed in December 1993. The 190-B Building, also called the Pump House, supported B Reactor from 1944 until 1968. The record of decision for the final environmental impact statement, Decommissioning of Eight Surplus Production Reactors at the Hanford Site, Richland, Washington (58 FR 48509) was published in the Federal Register in September 1993. The decision was to proceed with removing eight surplus plutonium production reactors at Hanford. The reactors will be removed to Hanford's central plateau for final disposition following a safe storage period. The decision covers the reactors, their associated fuel storage basins and the buildings that house them, and ancillary and support buildings at each of the reactors. The current plan calls for decommissioning the $\mathrm{C}$ Reactor first, with a target completion date of 1997 to 1999.

The world's first full-scale production reactor, B Reactor, was placed on the National Register of Historic Places in April 1992. B Reactor was constructed in 1943 as part of the Manhattan Project and remained in active service until it was retired in 1968. Because of strong local public interest in preserving B Reactor, DOE will work closely with concerned groups to decide the final fate of the reactor.

During 1993, T Plant began sampling and repackaging over 200 tank farm drums containing unknown wastes. Workers also began an inventory of 58 boxes of unknown waste. Upgrades to the 2706-T Facility were conducted during 1992 through 1993, including the installation of an air filtration and air monitoring system. The facility will be used for future decontamination and repackaging of wastes onsite. Many upgrade projects are planned for the future so that the plant may continue to support future decontamination. 
The Environmental Restoration Remedial Action Program was established to clean up about 1,100 inactive waste sites. In 1993, the program initiated Expedited Response Actions on three individual waste sites. Over 40 drums containing more than $5,678 \mathrm{~L}(1,500 \mathrm{gal})$ of solvent were removed from the 618-9 Burial Ground, preventing the solvent from reaching the ground water. In another action, work was completed at the 300 Area Process Trenches, with approximately $5,300 \mathrm{~m}^{3}$ $\left(7,000 \mathrm{yd}^{3}\right)$ of contaminated soil being removed from the trenches and isolated. The third action was a carbon tetrachloride vapor extraction unit for removing the chemical from soil in the 200 Areas.

\section{Corrective Actions}

Corrective actions consist of activities to comply with regulatory requirements or compliance agreements with federal, state, or local regulatory agencies. Corrective actions in 1993 are addressed in Section 2.0, "Environmental Compliance Summary."

\section{Research and Technology Development}

Research and technology development activities on the Hanford Site are a relatively minor contributor to Site releases. Most of these activities are located in the 200, 300, 400, and Richland North Areas, and releases occur primarily from the operation of research laboratories and pilot facilities. Many of these activities are intended to improve the techniques and reduce the costs of waste management, environmental protection, and Site restoration.

DOE's Underground Storage Tank Integrated Demonstration Program is funding the development of a mobile robotic system called the Light Duty Utility Arm System. This new robotic arm technology will be used to support cleanup of Hanford's defense wastes and the cleanup of other DOE underground storage tank sites throughout the country. Testing on the robotic arm will begin in the spring of 1995. The robotic arm will be used for surveillance, inspection, and retrieval applications in Hanford's single-shell tanks. The robotic arm will be capable of positioning a variety of scientific instruments, cameras, and retrieval devices within the tanks. These tools will help reveal the condition of the tank structures and also provide information about the nature of the waste materials inside. Hanford's Fuels and Materials Examination Facility in the 400 Area is being readied to test the robotic system before actually using the robotic arm in a single-shell tank in 1996. Another remotely operated robotic system has been developed to vacuum sediment and debris from Hanford's nuclear fuels storage pools. The Remotely Operated Sediment Extraction Equipment will be operational in the spring of 1994.

The FFTF was shut down in 1992. A DOE directive was issued in 1992 to place the facility in a "hot" standby condition. This condition means that facility systems can readily start up on demand. FFTF remained in this condition during most of 1993, pending Congressional authorization to fund future operations and determination of a new mission, as directed by DOE. In December, 1993, DOE announced that no mission had been identified which could justify continuing operation of the reactor. The Secretary of Energy ordered a phased process to place the FFTF into a safe shutdown condition. The original long-term mission was lost when Congress decided to terminate the country's breeder reactor program. It will take about 5 years to shut down the FFTF in a safe manner.

\section{Site Management}

Hanford Site operations and activities are managed by the Richland Operations Office through the following prime contractors and numerous subcontractors. Each contractor is responsible for safe, environmentally sound maintenance and management of its facilities and operations; for waste management; and for monitoring of operations and effluents to ensure environmental compliance.

The principal contractors and their respective responsibilities include:

- Westinghouse Hanford Company, the operating and engineering contractor, conducts environmental restoration, manages wasteș, operates FFTF, maintains $\mathrm{N}$ Reactor and its fuel fabrication facilities, and provides support services such as fire protection, stores, and electrical power distribution. In October 1993, the ICF Kaiser Hanford Company contract was assigned to Westinghouse Hanford 
Company. ICF Kaiser is responsible for fabrication, custodial work, maintenance, design/drafting, and computer-aided mapping, and operates the utilities, bus fleets, roads, and other transportation systems.

- Battelle Memorial Institute, the research and development contractor, operates Pacific Northwest Laboratory for DOE, conducting research and development in environmental restoration and waste management, environmental science, molecular science, energy, health and safety, and national security.

- Hanford Environmental Health Foundation is the occupational and environmental health services contractor.
- In 1994, Bechtel Hanford, Incorporated, will become the primary environmental restoration contractor for decontamination and decommissioning activities at the Hanford Site.

Non-DOE operations and activities on Hanford Site leased land include commercial power production by the Washington Public Power Supply System WNP-2 reactor and commercial low-level radioactive waste burial by U.S. Ecology, Inc. Immediately adjacent to the southern boundary of the Site, Siemens Power Corporation operates a commercial nuclear fuel fabrication facility, and Allied Technology Group Corporation operates a low-level radioactive waste decontamination, super compaction, and packaging disposal facility. 


\title{
1.4 Site Environmental Programs
}

\author{
J. W. Schmidt and R. W. Hanf
}

It is DOE's policy to conduct effluent monitoring and environmental surveillance programs that can determine whether the public and the environment are protected during DOE operations and whether operations are in compliance with DOE and other federal, state, and local standards, regulations, and requirements. A number of environmental programs are conducted onsite. These programs monitor for impacts from operations in several areas. The first area consists of the point of possible release into the environment; this area is covered by the effluent monitoring programs operated by both Pacific Northwest Laboratory and Westinghouse Hanford Company. The second area consists of possible contamination immediately adjacent to facilities and is covered by the near-facility environmental monitoring program operated by Westinghouse Hanford Company. The third area consists of contamination in the environment and is covered by the Site environmental surveillance program operated by Pacific Northwest Laboratory.

In addition, aspects of the environment are studied for reasons other than specific impacts from possible contamination. These aspects include climate, wildlife, and cultural resources. These studies are summarized in Section 4.0, "Environmental Program Information."

\section{Effluent Monitoring Programs}

Facility effluent monitoring programs monitor liquid and airborne effluents and manage solid waste and chemical inventories. The programs are designed to measure effluents at their point of release into the environment, whenever possible. Results for the effluent monitoring programs are summarized in Sections 3.1, "Facility Effluent Monitoring," and 3.3, "Waste Management and Chemical Inventories."

\section{Near-Facility Environmental Monitoring}

The near-facility environmental monitoring program provides facility-specific environmental monitoring adjacent to facilities on the Site that are managed by Westinghouse Hanford Company. This monitoring is conducted to ensure compliance with Westinghouse Hanford Company requirements and local, state, and federal environmental regulations. The program is also designed to measure effluents from diffuse and nonpoint sources whenever possible and to evaluate the effectiveness of effluent treatments and controls and waste management practices. Results for this program are summarized in Section 3.2, "Near-Facility Environmental Monitoring."

\section{Site Environmental Surveillance Program}

The Site environmental surveillance program is conducted by the Pacific Northwest Laboratory independent of monitoring programs conducted by other Site contractors. The program's main focus is on assessing the impacts of radiological and chemical contaminants on the environment and human health, and to confirm compliance with pertinent environmental regulations and federal policies. Surveillance operations are conducted both on and off the Site and monitor contaminants from the Hanford Site generally, rather than from specific Site facilities. Results for the Site environmental surveillance program are summarized in Section 5.0, "Environmental Surveillance Information." 


\section{Environmental Compliance Summary}

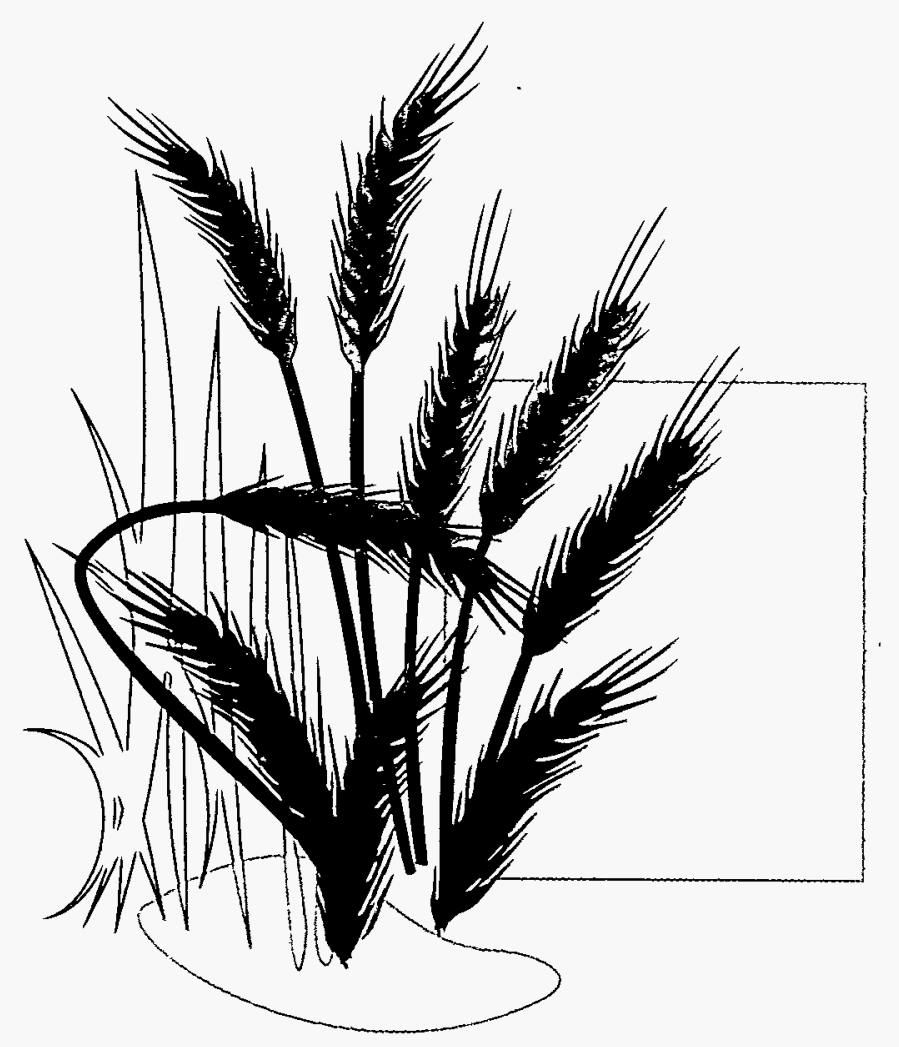




\subsection{Environmental Compliance Summary}

This section briefly describes how environmental compliance is being achieved for the Hanford Site. Included are subsections describing 1) the regulations and oversight of compliance at the Site, 2) the current status of the Site's compliance with the principal regulations, 3) issues and actions arising from these compliance efforts, and 4) environmentally significant unusual occurrences. 



\title{
2.1 Environmental Compliance and Cleanup
}

\author{
J. M. Nickels
}

Many entities have a role in the DOE's new mission of environmental restoration and waste management. These include federal, state, and local regulatory agencies; environmental groups; regional communities; Indian Nations; and individual citizens. The following section describes the roles of the principal agencies, organizations, and public in environmental compliance and cleanup of the Hanford Site.

\section{Regulatory Oversight}

Several federal, state, and local government agencies are responsible for enforcing and overseeing environmental regulations at the Hanford Site. These agencies include the U.S. Environmental Protection Agency (EPA), Washington Department of Ecology (Ecology), Washington State Department of Health, and the BentonFranklin Counties Clean Air Authority. These agencies issue permits, review compliance reports, participate in joint monitoring programs, inspect facilities and operations, and oversee compliance with applicable regulations. The DOE, through compliance audits and its directives to field offices, initiates and assesses actions for conforming to environmental requirements.

EPA is the principal federal environmental regulator. EPA develops, promulgates, and enforces environmental protection regulations and technology-based standards as directed by statutes passed by Congress. In some instances, EPA has delegated environmental regulatory authority to the state or authorized the state program to operate in lieu of the federal program when the state's program meets or exceeds EPA's requirements. For instance, EPA has delegated or authorized enforcement authority to Ecology for air pollution control and many areas of hazardous waste management. In other activities, the state program is assigned direct oversight over federal agencies as provided by federal law. For example, the Washington State Department of Health has authority to implement the state program for radionu- clide air emissions to the atmosphere at the Hanford Site in accordance with the federal facilities section of the Clean Air Act and 1990 amendments. Where regulatory authority is not delegated or authorized to the state, EPA Region 10 is responsible for reviewing and enforcing compliance with EPA regulations as they pertain to the Hanford Site.

\section{The Hanford Federal Facility Agreement and Consent Order}

The Hanford Federal Facility Agreement and Consent Order (Tri-Party Agreement) is an agreement among EPA, Ecology, and DOE for achieving environmental compliance at the Hanford Site with the Comprehensive Environmental Response, Compensation, and Liability Act (CERCLA), including the Superfund Amendments and Reauthorization Act (SARA) remedial action provisions, and with Resource Conservation and Recovery Act (RCRA) treatment, storage, and disposal unit regulation and corrective action provisions. The TriParty Agreement 1) defines RCRA and CERCLA cleanup commitments, 2) establishes responsibilities, 3) provides a basis for budgeting, and 4) reflects a concerted goal of achieving regulatory compliance and remediation, with enforceable milestones, in an aggressive manner. The Tri-Party Agreement was also established with input from the public.

Negotiations to make major changes to the Tri-Party Agreement were conducted in 1993, and a renegotiated agreement was signed by the three agencies in January 1994. Copies of the agreement and Site Management System progress reports of activities are publicly available for inspection at the DOE Public Reading Room in Richland, Washington, and at information repositories in Seattle and Spokane, Washington, and Portland, Oregon. 
To get on the mailing list to obtain Tri-Party Agreement information, contact the EPA or DOE directly, or call Ecology on 1-800-321-2008. Requests by mail can be sent to:

Hanford Mailing List: Informational Mailings

P.O. Box 1970 B3-35

Richland, WA 99352

or

Hanford Update

Department of Ecology

P.O. Box 47600

Olympia, WA $98504-7600$

The Tri-Party Agreement consists of a legal agreement and an action plan. The legal agreement establishes jurisdictions, authorities, and other legal determinations among the parties. The five specific areas of involvement defined by the legal agreement are the following:

1. Identify RCRA treatment, storage, and disposal units that require permits, and establish schedules to comply with interim and final status requirements. Where applicable, RCRA Part B permit applications will be completed, closures accomplished, and postclosure care implemented.

2. Identify interim-action alternatives appropriate to implement the final RCRA corrective and CERCLA remedial actions.

3. Establish requirements for performing investigations to determine the nature and extent of threats to public health or the environment caused by actual or possible releases, and perform studies to identify, evaluate, and select alternatives for controlling possible releases.

4. Identify the nature, objective, and schedule of response actions for cleanup of hazardous material spills.

5. Implement the selected interim and final RCRA corrective and CERCLA remedial actions.

The action plan implements the legal agreement by 1) defining how the parties will work together, 2) describing the processes and procedures to be followed, 3) defining the units to be addressed, and 4) scheduling the work. The action plan, through enforceable mile- stones, establishes a plan and schedule for bringing the Hanford Site into compliance with applicable requirements of RCRA and all remedial action requirements of CERCLA.

\section{The Role of Oregon State at the Hanford Site}

Although the State of Oregon does not have a direct regulatory role at the Hanford Site, DOE recognizes that Oregon has an interest in Hanford Site cleanup because of the state's location downstream on the Columbia River and because of the potential for shipping radioactive wastes from the Hanford Site through Oregon. Oregon participates in the State and Tribal Government Working Group for the Hanford Site, which reviews the Site's cleanup plans.

The Oregon Department of Energy has the lead in the state's involvement at the Hanford Site. It is performing a 4-year research program on a contract to determine the effects of Hanford Site radioactive waste activities on the environment and on the health of Oregon residents. The Oregon Department of Energy provides information to the public, Oregon's Congressional delegation, and state and local officials on proposed cleanup, transport, and disposal activities and costs. It also supports the Oregon Hanford Waste Board, which recommends policy to the governor and legislature. The board was reauthorized by the 1991 legislature and is composed of agency heads, members of the legislature, and citizens.

\section{The Role of Indian Nations at the Hanford Site}

The Hanford Site is located on land ceded in treaties in the year 1855 with the Yakama Indian Nation and the Confederated Tribes of the Umatilla Indian Reservation (the Umatilla, Cayuse, and Walla Walla Tribes). The Nez Perce Tribe has treaty rights on the Columbia River. The tribes retain rights and privileges in the ceded areas, including the right to take fish at usual and accustomed places, to erect temporary buildings for curing, to hunt, to gather roots and berries, and to pasture horses and cattle on open and unclaimed land. 
In addition to the treaties of 1855 , the following laws apply to Native American rights and culture at the Hanford Site: the American Indian Religious Freedom Act, the Archaeological Resources Protection Act, the National Historic Preservation Act, the Native American Graves Protection and Repatriation Act, and the Antiquities Preservation Act.

The DOE Richland Operations Office provides grants to the Yakama Indian Nation, the Confederated Tribes of the Umatilla Indian Reservation, and the Nez Perce Tribe to ensure their involvement in the environmental restoration and waste management activities for cleanup of the Hanford Site.

The tribes advise the Richland Operations Office and DOE Headquarters through direct consultation in recognition of the government-to-government relationship established in federal policy. The tribes also participate in formal groups such as the State and Tribal Government Working Group, the Hanford Advisory Board, the Hanford Summit Steering Committee, and the Hanford Environmental Dose Reconstruction Project's Native American Working Group. In 1993, tribes made presentations on treaty rights, tribal sovereignty, the U.S. Government's trust responsibility, and the unique status of tribal governments for DOE and the contractors. Tribal members also made presentations at the Hanford Summit, a public involvement quarterly meeting, and a variety of other meetings.

\section{Natural Resource Damage Assessment Activities at the Hanford Site}

Executive Order 12580 and the National Oil and Hazardous Substances Pollution Contingency Plan (40 CFR 300) designates federal Natural Resource Trustees to include the Secretaries of the Departments of Interior, Commerce, Defense, Energy and Agriculture. In addition, it requires the governor of each state to designate state trustees. Native American Tribes are also trustees for their resources, functioning much as state trustees for resources related to tribal lands or for resources to which they otherwise may have treaty rights. For response actions undertaken at DOE facilities, CERCLA designates DOE the "responsible party" in charge of cleaning up the release. As such, DOE has a dual role. The roles of trustee and responsible party are authorized by different sections of CERCLA and carry separate regulatory requirements. DOE has a trust responsibility to the citizens of the United States and Native Americans to protect and appropriately manage natural resources present on the Hanford Site. The Richland Operations Office believes that to fulfill this trust responsibility it must identify appropriate natural resource values, which must be considered in its management decisions affecting those resources.

Currently, the Richland Operations Office is establishing a strategy whereby natural resource values are integrated into the remedial investigation/feasibility study process as set forth in CERCLA. Additionally, the Richland Operations Office held three meetings in 1993 with potential trustees of the Hanford Site to begin formulating a collaborative working group to address natural resource issues.

\section{Public Participation}

Individual citizens of Washington State and neighboring states may participate in determining how Hanford Site cleanup is conducted. A plan for community relations and public involvement is included in the Tri-Party Agreement. The community relations plan was developed and negotiated among DOE, Ecology, and EPA Region 10 with public comment and was jointly approved in 1990. The renegotiated agreement also covers community relations. The Hanford Advisory Board was also established to help make Site public involvement more meaningful. The Board will be launched in January 1994 to look at broad policy issues and major Hanford decisions.

Quarterly information meetings are held in the Tri-Cities (Kennewick, Pasco, and Richland), Washington, and one other city alternated within the Northwest to update the public on Tri-Party Agreement activities. Meeting dates are announced approximately 3 weeks in advance through the quarterly Hanford Update newsletter, news releases, and newspapers. DOE encourages public participation in these activities. Before each meeting, the press is informed of the issues to be discussed, and notices are sent to elected officials, community leaders, and special interest groups. 
The public can obtain up-to-date information on the Hanford Site cleanup effort at the following four repositories:

1. DOE Public Reading Room

Washington State University at Tri-Cities Campus

100 Sprout Road

Room 130 West

Richland, Washington 99352

The telephone number is (509) $376-8583$.

2. Suzzallo Library

Government Publications Room FM-25

University of Washington

Seattle, Washington 98195

The telephone number is (206) 543-4664.

3. Foley Center

Gonzaga University

E. 502 Boone
Spokane, Washington 99258

The telephone number is (509) 328-4220, extension 3125 .

4. Branford-Price Miller Library

Portland State University

S.W. Harrison and Park

P.O. Box 1151

Portland, Oregon 97201

The telephone number is (503) $725-3690$.

The repositories receive copies of Tri-Party Agreement action plan quarterly progress reports, CERCLA/SARA and RCRA environmental restoration activities reports, closure and post-closure plans, RCRA permit applications, meeting summaries, and other publications related to the Site's cleanup. 


\title{
2.2 Compliance Status
}

\author{
J. M. Nickels
}

This section summarizes the activities conducted to ensure the Hanford Site is in compliance with federal environmental protection statutes and related Washington State and local environmental protection regulations, and the status of Hanford's compliance with these requirements. Environmental permits required under the environmental protection regulations are discussed under the applicable statute.

\section{Hanford Federal Facility Agreement and Consent Order}

Originally signed in May 1989, the Tri-Party Agreement is an agreement among EPA, Ecology, and DOE to achieve environmental compliance for the Hanford Site with CERCLA remedial action provisions and with RCRA treatment, storage, and disposal unit regulation and corrective action provisions. At the end of 1993, a total of 286 enforceable milestones (including those from 1989 through 1993) has been completed on or ahead of schedule. The following are some of the more significant accomplishments for 1993:

- Milestone M-14-00, "Complete construction and initiate operations of a low-level mixed waste laboratory," was not completed as originally established. DOE determined that analytical needs at the Hanford Site would be better satisfied through the use of commercial laboratory facilities. Dispute resolution was entered as provided by the Tri-Party Agreement. A final resolution was reached in January 1993, which included an agreement to use locally provided commercial laboratories, but with penalties imposed for failure to comply with the TriParty Agreement.

- The new multifunction waste tank facility reached the final design stage.
- Improved in-tank monitoring, a revised contingency plan for leaks, and all physical preparations for emergency pumping of liquids were implemented for single-shell tank T-101, one of the tanks of concern (see Section 2.3, "Current Issues and Actions").

- Leak detection and site characterization were upgraded at tanks 241-C-105 and 241-C-106 (two other potentially hazardous tanks).

- Discharges to the 300 Area Process Trenches were limited to $1,230 \mathrm{~L} / \mathrm{min}$ (325 gpm).

- The 300 Area treated effluent disposal facility was designed.

- Seven core samples from three single-shell tanks and five dip samples from five double-shell tanks were obtained.

- Integrated general investigations and studies for the 100 Areas were completed.

- The waste sampling and characterization facility was constructed.

- Closed-loop cooling for selected equipment in the 325 Building was completed.

- Construction began on the Hanford Waste Vitrification Plant Canister Storage Building/Multipurpose Storage Building.

In March 1993, the Richland Operations Office and Westinghouse Hanford Company received a Notice of Penalty Incurred and Due $(\$ 100,000)$ from Ecology for failure to designate approximately 2,000 containers of solid waste as dangerous or extremely hazardous to public health and the environment. In April 1993, the Richland Operations Office invoked dispute resolution. 


\section{Comprehensive Environmental Response, Compensation, and Liability Act}

The CERCLA requires that specific procedures be implemented to assess inactive waste sites for the release of hazardous substances. The process is divided into three tiers of activity: 1) preliminary assessments, 2) remedial investigation/feasibility studies, and 3 ) remedial actions. The EPA has established procedures that the Hanford Site must comply with to conduct the threetiered process.

Preliminary assessments conducted for the Hanford Site revealed that there are approximately 1,100 known individual waste sites where hazardous substances may have been disposed. These 1,100 sites have been grouped into 78 operable units, which have been further grouped into four aggregate areas using identifiable geographic boundaries. The four aggregate areas have been placed on the EPA's National Priorities List, which requires a schedule and actions for their remediation.

DOE is actively pursuing the remedial investigation/ feasibility studies at some operable units on the Hanford Site. The selection of the operable units is a result of Tri-Party Agreement negotiations. The Tri-Party Agreement provides the framework for meeting CERCLA cleanup requirements. All milestones related to the process established for 1993 were achieved, and the Hanford Site was in compliance with these CERCLA/SARA requirements.

\section{Expedited Response Actions}

In October 1990, the Secretary of Energy proposed three accelerated cleanup actions. These actions would be completed as Expedited Response Actions (a way to hasten cleanup at sites to prevent further spread of contamination). Two of these actions were completed in 1991 and the final reports were issued in 1992. One action, the removal of carbon tetrachloride from the soil at two ground disposal sites, is still ongoing. Six more accelerated cleanup actions were proposed by the Secretary of Energy in 1992. These actions would 1) characterize and identify physical hazards associated with the 100 Area North Slope Disposal Site, 2) characterize and identify chemical hazards to the soil from the
100 Area Pickling Acid Cribs, 3) excavate and remove debris in the 100 Area Sodium Dichromate Landfill, 4) characterize and identify residual contamination of the 34- $\mathrm{km}^{2}\left(13 \mathrm{mi}^{2}\right)$ area in the northwest corner of the Hanford Site (Riverland), 5) identify and characterize hazards in the soil in the burial grounds north of the 300 Area, and 6) mitigate flow of contaminated ground water to the Columbia River through the pump hydraulic controls and grouting curtain of $\mathrm{N}$ Springs in the 100 Area.

\section{Carbon Tetrachloride Vapor Extraction}

Vapor extraction from the contaminated vadose zone beneath the 200-West Area began in 1992 and continued through 1993. This Expedited Response Action incorporates three vapor extraction systems to draw the carbon tetrachloride out of the soil column and absorb it into granulated activated-charcoal canisters. The canisters will be shipped offsite for treatment. In 1994, this work will continue.

\section{North Slope}

In April 1992, the North Slope was selected as an Expedited Response Action by Ecology and EPA. The area covers approximately 36,000 ha $(89,000$ acres $)$ and is located north of the Columbia River. The area contains potential environmental hazards, such as the remains of three missile sites, seven anti-aircraft artillery sites, several homestead sites, ten military landfills, several disposal sites, and three oil-contaminated sites. The area also contains potential physical and ordinance hazards, such as open cisterns, concrete foundations, subsurface shelters, surface debris, an artillery and small arms firing range, and open well-head structures, covering about 162 ha ( 400 acres) of the total area. As part of this action, in September 1993, a cleanup was performed by DOE and the U.S. Army Corps of Engineers on one anti-aircraft battery site in which 5 tons of debris were removed. By December 1993, approximately $90 \%$ of the physical hazards in this one area were cleared.

Meanwhile, in March 1993, an agreement was signed by the Richland Operations Office, Ecology, and EPA Region 10 to identify additional measures to accelerate cleanup of the Hanford Site. As a result of the newly renegotiated Tri-Party Agreement, a new milestone (M-16-82) was established. This milestone requires that the remediation of the North Slope be completed by October 1994. 
The final report for the 1992/1993 Expedited Response Action recommended characterization and hazard mitigation as the preferred alternative for North Slope cleanup. As such, removal of physical hazards and asbestos will be the primary focus. This includes the removal and examination of one military landfill thought to be the greatest potential problem in this area. The remaining nine landfills will also be investigated.

\section{Pickling Acid Cribs}

Nitric and hydrofluoric acids were used in the 1940s to clean or "pickle" galvanized pipe before using the pipe in the construction of the 100 Area reactors. The Pickling Acid Cribs, located south of the White Bluffs townsite, were used to dispose of used acid. No radiological hazards are believed to be associated with this site. Expedited Response Action characterization activities conducted in 1993 included soil sampling, groundpenetrating radar surveillance, and test pit excavations. The characterization concluded that no contaminants were present that would be a risk to human health or the environment. No remedial action is required.

\section{Sodium Dichromate Landfill}

During Hanford's early production years, sodium dichromate was added to reactor cooling water to prevent pipe corrosion. Empty chemical drums were placed in a ravine and covered with soil. Construction debris may also have been disposed of at this site. In January 1993, EPA and Ecology recommended excavation and removal of the debris. Characterization activities included soil sampling and geophysical surveys. Field screening and laboratory analysis have not revealed any contamination. Cleanup and excavation activities were completed in April 1993. Over 4,000 crushed drums were excavated and sent to the Central Landfill.

\section{Riverland}

Riverland is located in the northwest corner of the Hanford Site, west of Highway 240. The site was used for steam-cleaning and decontaminating railroad cars of grease and low-level radioactivity from 1943 to 1957 and as a disposal area for empty pesticide cans. The area covers approximately $34 \mathrm{~km}^{2}\left(13 \mathrm{mi}^{2}\right)$ and contains two anti-aircraft gun emplacements. Both facilities were decommissioned in 1963. Recent site characterization has been accomplished to determine if any residual contamination exists that would conflict with current release criteria. It was determined the major contaminate of concern was residual diesel fuel in the soil and concrete. Aldrin and dieldrin were identified in the soils at the pesticide can disposal area. During 1993, Expedited Response Action activities excavated contaminated soils and concrete. Hazardous waste was drummed for offsite disposal. The U.S. Army Corps of Engineers will perform a detailed ordinance survey to identify any ammunition in the area.

\section{8-11 Burial Grounds}

The 618-11 Burial Ground is located $12 \mathrm{~km}(7.5 \mathrm{mi})$ north of the 300 Area, adjacent to Washington Public Power Supply System WNP-2. Low-level, intermediate, and high-level activity, and transuranic wastes from 300 Area research facilities were disposed of into trenches, caissons, and pipe storage units from 1962 to 1967. Because of the complexity of issues involved with this waste site, remediation will be incorporated into the 300 FF-2 characterization activity work plan. This is no longer an Expedited Response Action.

\section{N Springs}

The Richland Operations Office, EPA, and Ecology agreed that an Expedited Response Action would be initiated at the N Springs, which is located in the 100-N Area. The objective of the Expedited Response Action is to substantially reduce ${ }^{90} \mathrm{Sr}$ transport into the Columbia River through the ground water. An engineering study was conducted in April 1993 for the N Springs. The Expedited Response Action proposal was developed and submitted to the EPA Region 10 and Ecology for review and approval. In February 1994 the proposal will be submitted to the public for review. Once the public review period is complete, the regulatory agencies will submit an action memorandum to the Richland Operations Office. Based on the action memorandum, the preferred alternative action will be implemented.

\section{Arid Lands Ecology (ALE)}

A new Tri-Party Agreement milestone (M-16-81) was negotiated and due to be established in January 1994 to accelerate the remediation of the Fitzner/Eberhardt ALE Reserve by October 1994. The ALE Reserve is located in the southwestern part of the Hanford Site and covers approximately $311 \mathrm{~km}^{2}\left(120 \mathrm{mi}^{2}\right)$. In 1971, the ALE Reserve was designated as the Rattlesnake Hills Research Natural Area. The area contains 25 abandoned gas wells that predate Hanford Site activities, several abandoned lysimeter plots, two concrete cisterns, and 
other potential physical hazards. The 1100-IU-1 Operable Unit, located within the ALE Reserve, contains a NIKE missile launch site and control center. In August 1993, temporary fences were installed around the abandoned gas wells for safety reasons. Characterization activities on the operable unit will commence in March 1994.

\section{Emergency Planning and Community Right-To-Know Act and Pollution Prevention Act, Section 6607}

The Emergency Planning and Community Right-to-Know Act provides the public with information about hazardous chemicals on the Site and establishes emergency planning and notification procedures to protect the public from a release. Subtitle A of the Act calls for creation of state emergency response commissions to guide planning for chemical release emergencies. State commissions have also created local emergency planning committees to ensure community participation and planning. Subtitle B contains requirements for periodic reporting on hazardous chemicals stored and/or used on the Site, to provide the public with the basis for emergency planning.

The 1993 Hanford Tier Two Emergency and Hazardous Chemical Inventory (DOE 1994a) was issued to the State Emergency Response Commission, local county emergency planning committees, and local fire departments. The report contained information on hazardous materials in storage across the Hanford Site. The 1992 report Hanford Toxic Chemical Release Inventory (DOE 1993e) was issued in July 1993 to the EPA and state. Accordingly, the Hanford Site was in compliance with the reporting requirements contained in this Act.

EPA is proposing expanding the list of toxic chemicals requiring reporting under Section 313 of the Act and Section 6607 of the Pollution Prevention Act of 1990. The additional chemicals and chemical categories will be considered in the 1995 report for the 1994 calendar year.

\section{Reporting and Pollution Prevention Program}

As part of Section 313 of the Emergency Planning and Community Right-To-Know Act, toxic chemical release inventory reporting program, a pollution prevention program has been established that requires an annual evaluation of the use and release of 17 specific priority chemicals. This program seeks to reduce releases of pollutants through avoidance or reduction in the generation of pollutants at their source.

The 17 priority chemicals targeted for reduction in this program are a subset of the chemicals listed in Section 313 of this Act. The thresholds listed in the Act are used to determine participation. DOE is committed to reducing the releases of these 17 priority chemicals by $50 \%$ (compared to the 1988 baseline) by 1995 . Each DOE site annually evaluates its use and release of these 17 priority chemicals. The information is provided to DOE Headquarters, where it is aggregated for an annual progress report provided to the EPA.

Hanford did not exceed the reporting threshold for the use of any of the 17 priority chemicals during 1993. The first annual summary report of the program will be completed for the Hanford Site by August 1994.

The Hanford Site Pollution Prevention Program was designed to meet the requirements of DOE Orders 5400.1, and 5820.2A, the DOE Waste Minimization Cross Cut Plan (DOE 1994c) and EPA program guidance, and State of Washington Pollution Prevention Planning requirements. The major elements of the program were 1) establishment of management support; 2) identification and implementation of pollution prevention opportunities through a systematic assessments process; 3 ) setting and measuring the progress of waste reduction goals; 4) development of waste generation baseline and tracking systems; 5) creation of employee awareness, training, and incentives programs; 6) championing sitewide pollution prevention initiatives; and 7) technology transfer, information exchange, and public outreach.

The Pollution Prevention Opportunity Assessment is the cornerstone of the pollution prevention program and the primary mechanism used to identify and prioritize 
options to prevent pollution and reduce waste. These assessments are performed on waste-generating activities by a team of individuals selected for their process knowledge.

These assessments are a systematic approach to identify the materials entering, the pollutants and wastes exiting, and the activities that make up a waste-generating process. Potential pollution prevention opportunities are identified, evaluated, and prioritized according to environmental, health, safety, and economic criteria. Once pollution prevention opportunities are identified, schedules are developed, and the opportunities are implemented.

In 1993, these program elements and a methodology specific to Hanford's needs were developed. In 1994, a baseline of waste generated will be developed, priority waste streams will be identified, the process will be tested on a pilot scale, and then will be implemented Sitewide.

\section{Resource Conservation and Recovery Act}

\section{Enforcement Action}

The DOE and its Hanford contractors are working to resolve outstanding notices of violation and warning letters of noncompliance from Ecology that were received during 1993. Each of these notices lists specific violations. The following is a brief summary of these noncompliance letters:

1. Ecology issued an inspection report for Tank 241SY-101 that alleged violation of the state's dangerous waste regulations. The primary violations include the failure to inspect monitoring systems, failure to provide and operate adequate leak detection, failure to allow inspectors to access training records, and failure to properly identify personnel in the training plan required by the regulations. All corrective actions were completed. DOE is now awaiting verification from Ecology.

2. Ecology issued an "Order and Notice of Penalty Incurred and Due" in 1993 for failure to adequately designate approximately 2,000 containers of solid waste. Ecology agreed to resolutions of disputed portions of the Order, and a settlement agreement was reached. The settlement agreement requires the submittal of a waste analysis plan to confirm the designation of the waste in question. Ecology approved the plan in November 1993. As part of the settlement agreement, an Environmental Protection Scholarship endowment of $\$ 40,000$ was established at Columbia Basin College in Pasco, Washington, and $\$ 60,000$ was provided to Pacific Northwest Laboratory and the Washington Department of Wildlife for a sagebrush restoration project on the ALE Reserve.

3. Ecology issued a compliance letter for alleged violations related to a spill of ethylene glycol that was released to the 300 Area Process Trenches. The violations were related to timely reporting of the incident and access to information. All corrective actions required by Ecology have been completed. $D O E$ is now awaiting verification from Ecology.

4. The Washington State Department of Health issued several reports detailing the results of inspections at the 200-East tank farms, B Plant, and UraniumOxide Plant facilities. Corrective actions have begun.

\section{Hanford Site Facility RCRA Permit}

The Draft Hanford Facility RCRA Permit is expected to be issued by Ecology and EPA for public comment in late 1994. This Draft RCRA Permit was last issued for public comment in January 1992. When the RCRA Permit is finally issued, the permit will provide the foundation for all future RCRA permitting at Hanford in accordance with provisions of the Tri-Party Agreement.

\section{RCRA/Dangerous Waste Permit Applications and Closure Plans}

For purposes of RCRA and Ecology's Dangerous Waste Regulations, the Hanford Site is considered to be a single facility encompassing over 60 treatment, storage, and disposal units. The Tri-Party Agreement recognizes that all of the treatment, storage, and disposal units cannot be permitted simultaneously and sets up a schedule for submitting unit-specific Part B RCRA/dangerous waste permit applications and closure plans to Ecology and EPA. During 1993, 11 Part A Form 3's, two revised closure plans, one revised research, development, and demonstration permit application, and one Part B unit 
application documentation package were submitted. A draft research, development, and demonstration permit for the Waste Water Pilot Plant was issued for public comment in October 1993 by Ecology and EPA.

\section{Management of Listed-Waste- Contaminated Soil}

Part of RCRA consists of a "contained-in" policy. This policy states that any waste mixture containing a listed hazardous waste is considered a hazardous waste, regardless of what percentage of the mixture is composed of listed hazardous wastes.

To facilitate implementation of this policy, the Richland Operations Office is developing sampling and analysis plans for the tank farms. These sampling and analysis plans will describe the protocol necessary to characterize tank farm soil and to ultimately allow Ecology to determine what type of waste contaminated soils at these facilities should be considered.

\section{RCRA Ground-Water Monitoring Project Management}

Table 2.1 lists all the RCRA facilities and waste management areas and their ground-water monitoring program status. During fiscal year 1993, the RCRA projects drilled 12 new monitoring wells and collected samples at 356 existing wells. Six ground-water monitoring wells were constructed at three RCRA treatment, storage, and disposal facilities to meet a Tri-Party Agreement milestone. The RCRA ground-water monitoring wells were constructed at the following treatment, storage, and disposal facilities in 1993:

- Low-Level Burial Grounds, Waste Management Area 3

- Grout Treatment Facility

- $1325-\mathrm{N}$ Crib.

\section{Ground-Water Impact Assessments}

As a part of Tri-Party Agreement renegotiations, DOE, Ecology, and EPA agreed that discharge of effluents from the processing of nuclear waste to the soil column will be stopped by June 1995 (Milestone 17-17 and 18) and that the impact to the subsurface will be determined by conducting ground-water impact assessments (Milestone 17-13A). Renegotiations concluded with the three parties agreeing that ground-water impact assessments are needed at 13 effluent-receiving sites. Ground-water impact assessments were eliminated at 10 sites and delayed at 3 others because effluent discharges were suspended or the facility was permanently retired.

Five ground-water and perched-water monitoring wells were drilled in support of ground-water impact assessments in 1993. The wells were used to better define stratigraphy, ground-water flow direction and flow rates, and the nature and extent of any contamination. Three test pits were excavated to determine the vertical and lateral extent of contamination within the vadose zone. In addition, two wells were drilled for the 200 Area Effluent Treatment Facility and the 242-A Liquid Effluent Retention Facility.

\section{RCRA Waste Characterization Methods}

Efforts continue to identify the scope of compliance with Test Methods for Evaluating Solid Waste: Physical/ Chemical Methods (EPA 1986a) for highly radioactive laboratory analytical activities. A proposal detailing a procedure for notifying the regulators of deviations between analytical methods currently used on the Site and EPA RCRA guidance is being developed. A schedule to complete the proposal and implement its findings is progressing. In addition, a list of deviations is being generated that will be submitted in accordance with the procedures developed in the proposal.

\section{Hanford Site Backlog Waste Program}

A backlog of dangerous wastes had accumulated in generator facilities in excess of the 90-day regulatory limit. After an inspection of the tank farms identified container management problems, a 1992 survey of generating units Sitewide indicated that approximately 6,000 containers with suspect dangerous wastes or with unknown contents had accumulated. Additional drums were identified that contained nonregulated low-level or transuranic wastes. From November 1992 to May 1993, all suspect containers were moved to compliant storage or disposal facilities. 
Table 2.1. Status of Hanford Site RCRA Interim-Status Ground-Water Monitoring Projects as of December 31, 1993 (see Figure 5.46 for locations)

Project

(Date Initiated)

100-D Ponds (4/92)

183-H Solar Evaporation Basin (6/85)

1301-N Liquid Waste

Disposal Facility (12/87)

1324-N/NA Ponds (12/87)

1325-N Liquid Waste Disposal

Facility (12/87)

Grout Treatment Facility $(8 / 85)$

216-B-3 Pond (11/88)

216-A-29 Ditch (11/88)

216-A-36B Crib (5/88)

216-A-10 Crib (11/88)

216-B-63 Trench (8/91)

216-S-10 Pond (8/91)

216-U-12 Crib (9/91)

Liquid Effluent Retention

Facility (7/91)

2101-M Pond (8/88)

Low-Level Burial Grounds

Waste Management Area 1 (9/88)

Low-Level Burial Grounds

Waste Management Area 2 (9/88)

Low-Level Burial Grounds

Waste Management Area 3 (10/88)

Low-Level Burial Grounds

Waste Management Area 4 (10/88)

Low-Level Burial Grounds

Waste Management Area 5 (3/92)

Single-Shell Tank Waste Management Area A-AX (2/90)

Single-Shell TankWaste Management Area

B-BX-BY (2/90)

Single-Shell Tank Waste Management Area C (2/90)

Single-Shell Tank Waste Management Area S-SX (10/91)

Single-Shell Tank Waste Management Area T (2/90)

Single-Shell Tank Waste Management Area

TX-TY (10/91)

Single-Shell Tank Waste Management Area U (10/91)

300 Area Process Trenches (6/85)

Nonradioactive Dangerous Waste

Landfill (10/86)

Solid Waste Landfill
Status

\begin{tabular}{|c|c|c|}
\hline \multicolumn{3}{|c|}{ Status } \\
\hline & Individual & Ground-Water \\
\hline Background & Parameter & Quality \\
\hline Monitoring & Evaluation & Assessment \\
\hline & $X$ & \\
\hline
\end{tabular}

X

X

X

$\mathrm{X}$

$\mathrm{X}$

$\mathrm{X}$

X

X

X

$\mathrm{X}$

$\mathrm{X}$

X

$\mathrm{X}$

$\mathrm{X}$

X

X

X

X

$\mathrm{X}$

$\mathrm{X}$ 
A subset of the backlog waste is the "unknowns," now located at T Plant. Processing of these wastes (including opening, sampling, and repackaging) began in February 1993. Approximately 201 drums have been processed and are now being shipped to the Central Waste Complex to await analysis results and completion of necessary documentation. Processing of 58 waste boxes began in the fall of 1993 and is expected to be completed by spring 1994.

A report was published of the Type $B$ investigation of the Hanford Site backlog waste program that took place between May and July 1993 (DOE 1993c). In August 1993, the Richland Operations Office announced the results of the investigation. The investigation findings required a response and plan of action, which were delivered to the Richland Operations Office. Follow-up status reports will be prepared bimonthly.

\section{Clean Air Act}

EPA has established the Prevention of Significant Deterioration program [40 Code of Federal Regulations (CFR) 52] to protect air quality while allowing a margin for future growth. The EPA has delegated authority to Ecology for regulation in Washington State of new emission sources under the program.

DOE was issued a Prevention of Significant Deterioration permit by the EPA in 1980 for the Hanford Site. The permit sets specific limits for nitrogen oxides emissions from the PUREX and Uranium-Oxide Plants. Significant increases in emissions from the Hanford Site of any criteria pollutant regulated by the Clean Air Act require agency review of potential impacts to regional air quality. Additional limits may be necessary in accordance with the permit.

Washington State Department of Health, Division of Radiation Protection, has promulgated regulatory controls for radioactive air emissions under Section 118 of the Clean Air Act. These controls are applicable to federal facilities such as the Hanford Site. Washington Administrative Code (WAC) 246-247 requires registration of all radioactive air emission point sources with the Washington State Department of Health. A license on this registration will be included in the upcoming Hanford air operating permit, required by Title $\mathrm{V}$ of the Clean Air Act and 1990 amendments.
EPA has retained authority in Washington State for regulating certain hazardous pollutants under the National Emission Standards for Hazardous Air Pollutants, in accordance with 40 CFR 61 . These standards are designed to protect the public from hazardous air pollutants (for example, arsenic, asbestos, beryllium, mercury, radionuclides, and vinyl chloride).

Pursuant to this program within the Clean Air Act, the EPA has promulgated regulations specifically addressing asbestos emissions. These regulations apply at the Hanford Site in building demolition and/or disposal and waste disposal operations. Approximately 1,400 facilities on the Hanford Site have asbestos-containing material. During 1993, approximately $1,507 \mathrm{~m}^{3}$ $\left(53,212 \mathrm{ft}^{3}\right)$ of asbestos were removed and disposed of in the Hanford Central Landfill in accordance with applicable regulations.

Revised Clean Air Act requirements for radioactive air emissions were issued in December 1989 under 40 CFR 61, Subpart H. Emissions from the Hanford Site are within the new EPA offsite emission standards of $10 \mathrm{mrem} / \mathrm{yr}$ (effective dose equivalent). The 1989 requirements for flow and emissions measurements, quality assurance, and sampling documentation are in the process of being implemented at all Hanford Site sources.

These specific reporting and monitoring requirements necessitate additional effort. The Richland Operations Office received a 2-year compliance extension for the Subpart H requirements until December 1991. During this extension period, evaluations were conducted to determine the need for any additional continuous sampling equipment and other actions to meet EPA criteria. Negotiations continued with the EPA in 1992 and 1993 toward the development of a Federal Facilities Compliance Agreement regarding continued evaluations and scheduling of any required equipment upgrades.

Hanford Site contractors have prepared Facility Effluent Monitoring Plans for facilities across the Site. The plans include sections that outline compliance with 40 CFR 61 (atmospheric emissions). Plans were completed in late 1991. A summary of each plan appeared in the site environmental monitoring plan covering effluent monitoring and environmental surveillance (DOE 1991b). Several plans were revised during 1993.

The local air authority, Benton-Franklin Counties Clean Air Authority, enforces Regulation 1, which pertains to 
detrimental effects, fugitive dust, incineration products, open burning, odor, opacity, asbestos disposal, sulfur oxide emissions, and air operating-permit program. They have been delegated authority to enforce EPA asbestos regulations under National Emission Standards for Hazardous Air Pollutants. In 1993, the Site was in compliance with the regulations.

During 1993, Hanford Site air emissions remained below all regulatory limits set for radioactive and other pollutants. Routine reports of air emissions were provided to each air quality agency, in accordance with requirements.

\section{Clean Water Act}

The Clean Water Act applies to point discharges to waters of the United States. At the Hanford Site, the regulations are applied through a National Pollutant Discharge Elimination System permit governing effluent discharges to the Columbia River.

Eight permitted outfalls operated within the permit. No instances of noncompliance occurred during 1993.

Permit applications have been submitted to the EPA Region 10 for three new facilities (outfalls) planned for the 100 and 300 Areas. These new facilities include a treatment facility for process waste water $(1325-\mathrm{N})$, as well as filter backwash/ash sluicing wastewater disposal facility (315/384), and the 300 Area Treated Effluent Disposal Facility.

\section{Liquid Effluent Consent Order}

Washington State 216 Consent Order (Agreement DE 91NM-177) regulating Hanford Site liquid effluent discharges to the ground contains compliance milestones for Hanford Site liquid effluent streams designated as Phase I, Phase II, and Miscellaneous Streams. State waste discharge permit applications have been submitted to Ecology for 400 Area secondary cooling water, the 200 Area Effluent Treatment Facility, and the 200 Area Phase II Stream Treated Effluent Disposal Facility. In addition, engineering reports (including best available technology and all known and reasonable methods of treatment) for the 200 Area Effluent Treatment Facility, 200 Area Treated Effluent Disposal Facility, and the 200 Area Phase II Stream Treated Effluent Disposal Facility have been submitted to Ecology.

\section{Lawsuits Filed}

Heart of America Northwest et al., filed a lawsuit against both Westinghouse Hanford Company and DOE in April 1992. The suit alleged violations of the Clean Water Act resulting from discharges of pollutants without a permit and for failure to notify the appropriate agencies of releases of hazardous substances from high-level waste tanks. In April 1993, U.S. District Court granted a Motion to Dismiss and dismissed all claims made by the plaintiffs. The plaintiffs appealed to the Ninth District Circuit Court of Appeals in October 1993.

In July 1993, a class-action lawsuit (Durfey et al. versus E. I. DuPont de Nemours and Company et al.) was filed against Westinghouse Hanford Company and Westinghouse Electric Corporation in Yakima Superior Court in Yakima, Washington. The plaintiffs are seeking damages for medical monitoring and an injunction against further discharges to the environment. A response to this suit is being prepared.

\section{Safe Drinking Water Act}

The National Primary Drinking Water Regulations of the Safe Drinking Water Act apply to the drinking water supplies at the Hanford Site. These regulations are enforced by the Washington State Department of Health. The Hanford Site water supplies are monitored for the contaminants listed in the rules and regulations of the Washington State Department of Health regarding public water systems. In 1993, all water systems were in compliance with requirements and agreements.

\section{Toxic Substances Control Act}

The application of Toxic Substances Control Act requirements to the Hanford Site essentially involves regulation of polychlorinated biphenyls (PCBs). Federal regulations for use, storage, and disposal of PCBs are found in $40 \mathrm{CFR} 761$. State of Washington dangerous waste regulations for managing PCB wastes are listed in WAC 173-303.

Various concentrations of PCBs are found in electrical equipment throughout the Hanford Site. The majority of 
transformers have been sampled and characterized. Many PCB-containing transformers and large capacitors (those with PCB concentrations greater than $500 \mathrm{ppm}$ ) have been replaced or modified.

Defueled, decommissioned submarine reactor compartments shipped by the U.S. Navy to the Hanford Site for disposal contain small quantities of PCBs bound within the matrix of nonmetallic materials such as thermal insulation, electrical cables, and some synthetic rubber items. Because of the presence of PCBs, the reactor compartments are regulated under this Act. A compliance agreement between EPA and DOE defines the process by which a chemical waste landfill approval under this Act will be issued for the disposal trench. A dangerous waste permit must be in place before EPA will grant a permit under the Toxic Substances Control Act.

Nonradioactive PCB waste is stored and disposed of in accordance with the 40 CFR 761 requirements. Effective nationwide treatment and disposal capacity and technologies have not been developed for radioactive PCB waste. This waste remains in storage pending the development of adequate treatment and disposal technologies and capacities.

\section{Federal Insecticide, Fungicide, and Rodenticide Act}

Ecology administers the Federal Insecticide, Fungicide, and Rodenticide Act of 1975 certification and storage requirements under authority granted by EPA. The Act and the Revised Code of Washington 17.21, Washington Pesticide Application Act, as implemented by WAC 16-228, "General Pesticides Regulations," apply to storage and use of pesticides. At the Hanford Site, pesticides are applied by personnel licensed by Ecology as commercial pesticide applicators. In 1993, the Hanford Site was in compliance with the Act's requirements and WAC 16-228 regulations pertaining to storage and application of pesticides.

\section{Endangered Species Act}

A few rare species of native plants and animals are known to occur on the Hanford Site. Some of these are listed by the U.S. Fish and Wildlife Service as endangered or threatened. Others are listed by the Washington State Department of Fish and Wildlife as endangered, threatened, or sensitive species (see Appendix G). The Site wildlife monitoring program is discussed in Section 4.2, "Wildlife."

Bald eagles, a threatened species, are seasonal visitors to the Hanford Site. During 1992-1993, a pair of bald eagles began nesting onsite. In compliance with the Bald Eagle Management Plan for the Hanford Site and Section 7 of the Endangered Species Act, several access roads in the nesting area were closed to protect the pair's nesting environment. The area has been posted for the 1993-1994 season.

During 1993, the Richland Operations Office directed that an ecological review be conducted on all projects both on and off the Site which have the potential to affect the biological environment. The scope of the review includes evaluating whether any species protected by the Act occur in a proposed project area, quantifying any impacts that might result, and identifying mitigation to minimize or eliminate impacts. During 1993, 42 reviews were completed with approximately 800 more to be completed during 1994. There were no additional compliance issues during 1993.

\section{National Historic Preservation Act, Archaeological Resources Protection Act, Native American Graves Protection and Repatriation Act, and American Indian Religious Freedom Act}

Cultural resources on the Hanford Site are subject to the provisions of these four Acts. Compliance with the applicable regulations is accomplished through an active management and monitoring program that includes review of all proposed projects to assess potential impacts on cultural resources and periodic inspections of known archaeological and historical sites to determine their condition and eligibility for listing on the National 
Register of Historic Places, and the effects of land management policies on the sites. Approximately 600 reviews and inspections were conducted on the Site in 1993.

The American Indian Religious Freedom Act requires federal agencies to help protect and preserve the Native American's right to practice their traditional religion. The Richland Operations Office cooperates with Native Americans by providing Site access for organized religious activities.

There were no additional compliance issues during 1993.

\section{National Environmental Policy Act}

The National Environmental Policy Act (NEPA) requires that any major federal actions with the potential to significantly impact the human environment be carefully reviewed and reported to the public through environmental impact statements (EISs). Other documents such as environmental assessments are also prepared in accordance with NEPA requirements to determine whether a proposed action is a major federal action or has potential to significantly impact the environment and therefore requires full analysis in an EIS. NEPA documents are prepared and reviewed in accordance with the Council on Environmental Quality regulations in 40 CFR 1500 to 1508, 10 CFR 1021, and DOE Order 5440.1E (dated November 1992).

\section{Recently Approved Environmental Impact Statements}

The Final Environmental Impact Statement, Decommissioning of Eight Surplus Production Reactors at the Hanford Site, Richland, Washington (DOE 1992a) was recently approved. This EIS assessed potential environmental impacts of decommissioning eight water-cooled, graphite-moderated reactors on the Hanford Site. The EIS evaluated five alternatives, including immediate onepiece removal, safe storage followed by deferred dismantlement, and in situ decommissioning. The scope of this EIS does not include decommissioning of the $N$ Reactor.
The final EIS was issued as an addendum to the draft EIS in December 1992. The Record of Decision was published in the Federal Register in September 1993 (58 FR 48509). DOE has decided on safe storage followed by deferred one-piece removal of these eight surplus production reactors at the Hanford Site. DOE intends to complete this decommissioning action consistent with the proposed Hanford cleanup schedule for remedial actions included in the Tri-Party Agreement. Therefore, the safe storage period would be shorter than the 75 years outlined in the final EIS. Until decommissioning is initiated, DOE will continue to conduct routine maintenance, surveillance, and radiological monitoring activities to ensure continued protection of the public and the environment during the safe-storage period.

\section{Environmental Impact Statements in Progress}

Several related programmatic and site-specific EISs are in progress. One is the Programmatic Environmental Impact Statement, DOE Headquarters, Office of Environmental Restoration and Waste Management. The purpose of this EIS is to evaluate the potential nationwide environmental impacts of DOE's environmental management program. It could include actions for remediations, compliance with RCRA and CERCLA, restoration, waste management, and repositories. The Notice of Intent was published in the Federal Register (55 FR 42633) in October 1990. DOE Headquarters issued an implementation plan for public comment in 1992 (DOE 1992a).

Another EIS in progress is the Weapons Complex Reconfiguration Modernization Programmatic Environmental Impact Statement, DOE Headquarters, Office of Defense Programs. The purpose of this programmatic EIS is to assess the potential environmental impacts of the overall restructuring of the DOE defense program and its facilities, on both a programmatic and sitespecific level. With the end of the Cold War, the U.S. is reducing its stockpile of nuclear weapons. This reduction requires DOE to reevaluate its earlier alternatives for reconfiguring the nuclear weapons complex. A revised Notice of Intent was published in the Federal Register in July 1993 (58 FR 39528). Significant changes include the addition of consolidated long-term storage facilities for plutonium and uranium, and consolidation of all 
weapons-complex functions at one site. The Nevada Test Site has been proposed as a new candidate site, and the Hanford Site was dropped from further consideration. The scope is continuing to be reviewed.

The National Parks Service released a draft EIS in June 1992 (National Parks Service 1992) that covers options for the future management of the Hanford Reach of the Columbia River. The agency's proposed action is to make Hanford's North Slope a National Wildlife Refuge and to designate the Hanford Reach as a recreational river under the Wild and Scenic River system. This would transfer responsibility for the river, a quarter-milewide strip of land on both shores, and the North Slope to the U.S. Fish and Wildlife Service. The Richland Operations Office would retain responsibility for remediation and Hanford Site security. The final EIS is in preparation and is expected to be published in 1994.

Potential environmental impacts of CERCLA and RCRA past-practices remediation activities at the Hanford Site, particularly cumulative impacts, will be assessed in the Hanford Remedial Action EIS. This EIS could cover environmental restoration of past-practices liquid effluent disposal sites, buried solid low-level wastes, pre1970 transuranic wastes, high-activity wastes associated with storage tanks and their piping, and miscellaneous dangerous and nondangerous waste sites. Additional NEPA documentation could be prepared, as needed, for specific remediation of individual operable units or construction of waste management facilities.

The Tri-Party Agreement regulators have the final authority to determine the appropriate level of cleanup for each operable unit. The Hanford Remedial Action EIS will not make site-specific level-of-cleanup decisions. Instead, the final decision on this EIS may establish a range of future site uses that in turn can be used in the regulatory framework for establishing cleanup levels. The scope of this EIS will be clear once the implementation plan is issued. The Notice of Intent (57 FR 37959) was published in the Federal Register during August 1992. Scoping meetings began in September, and scoping was to have closed in November 1992. However, in response to a public request, the comment period was extended into February 1993. The final decision is targeted for 1995.

Another EIS is the DOE Programmatic Spent Nuclear Fuel Management and Idaho National Engineering Laboratory Environmental Restoration and Waste Management Programs EIS. The purpose of this EIS is to evaluate the direct and indirect environmental effects of all DOE actions involving the transportation, receipt, processing, and storage of spent nuclear fuel at the Idaho National Engineering Laboratory in Idaho Falls, Idaho. Reasonable alternatives include transporting, receiving, processing, and storing spent nuclear fuel at other sites. The EIS will evaluate the use of Hanford and Savannah River as potential sites for spent nuclear fuel storage. This EIS is on an accelerated schedule. In August 1993, Hanford was requested to support the preparation of this EIS. DOE issued an implementation plan (DOE-IO 1993) in October 1993 that reflects the results of additional scoping activities.

\section{Planned Environmental Impact Statements}

Several EIS are currently being planned. One is the Tank Waste Remediation System EIS. This EIS has its origin in two DOE decisions. The first was an October 1990 commitment by the Secretary of Energy to prepare a supplemental EIS to the Hanford Defense Waste EIS (DOE 1987b) to address tank management and safety issues. The second was a December 1991 decision by the Secretary of Energy to revise the entire tank safety/ tank waste treatment and disposal program, and to accelerate retrieval of single-shell tank wastes. This EIS combines the scope of the originally planned supplemental EIS and the tank safety mitigation/remediation issues EIS. The draft Notice of Intent is being revised to reflect the recent Tri-Party Agreement renegotiation results and preliminary DOE Headquarters comments.

Another EIS being planned is the Proposed Multifunction Waste Tank Facility EIS. This NEPA document would review the potential environmental impacts associated with the construction and operation of six new one-million-gallon double-shell waste tanks. An action description memorandum was submitted to the Richland Operations Office in 1991. The Notice of Intent (59 FR 4052) (January 1994) for the Tank Waste Remediation System EIS also included the new tanks. The facility will be addressed under NEPA by an interim action EIS. The schedule for completion of the Record of Decision, the authority for which has been delegated to the Richland Operations Office, is October 1994.

An EIS addressing the proposed operation of the Plutonium Finishing Plant to stabilize reactive materials is being prepared. An environmental assessment was originally prepared regarding the proposed scope. 
However, the scope of the project was changed in 1993, resulting in an announcement of the preparation of an EIS for terminal cleanout. An interim action environmental assessment is planned for the Plutonium Reclamation Facility stabilization.

Another EIS is the Irradiated Fuels EIS. This EIS will assess future management alternatives, such as interim storage for irradiated fuel at the Hanford Site. A draft Notice of Intent was being reviewed by DOE in 1993. The scope and schedule of this EIS could be affected by the Idaho National Engineering Laboratory Environmental Restoration and Waste Management EIS.

\section{Recently Approved Environmental Assessments}

\section{Environmental Assessment Tank 241-C-103 Vapor Phase Characterization (WHC 1993) addressed the sampling of the organic vapor and liquid in Tank 241-C-103. The environmental assessment assesses worker and public risk from an explosion, uncontrolled releases to the atmosphere caused by rapid chemical reactions, and toxic vapors. The finding of no significant impact was issued in August 1993. \\ Environmental Assessments in Progress}

Several environmental assessments are in progress. One is for proposed operation of the Plutonium Finishing Plant to stabilize reactive materials. Public meetings on the scope and reasonable alternatives were held in cities around the Pacific Northwest during the fall of 1993. As a result of input from the public, further engineering studies of alternatives are planned. An environmental assessment was originally prepared regarding the proposed scope. The scope of the project was changed, resulting in the preparation of an EIS for terminal cleanout of the Plutonium Finishing Plant. An interim action environmental assessment is being prepared for Plutonium Finishing Plant sludge stabilization. A schedule for completion of this environmental assessment is under discussion.

The preparation of an environmental assessment for interim stabilization of eight single-shell tanks containing ferrocyanide was initiated August 1992. The proposed environmental assessment was submitted to the Richland Operations Office in January 1993 for DOE review. Their comments were returned. This document was canceled, and the scope was absorbed into the unreviewed safety question environmental assessment.

A proposed NEPA document would analyze actions to mitigate unresolved safety questions at tank farms, including characterization of tank waste. In 1993, a draft annotated outline of a proposed environmental assessment was submitted for comment to the Richland Operations Office and DOE Headquarters. The schedule for the action description memorandum and NEPA document is being expedited. Comments from the Yakama Indian Nation will be addressed in February 1994. The environmental assessment should be approved by late February 1994 .

An environmental assessment of the proposed replacement of the Cross-Site Transfer System addresses the replacement of the cross-site waste transfer line between the 200-East and 200-West Areas. The final draft of the environmental assessment was submitted to DOE Headquarters in August 1993 for review and approval. Additional DOE Headquarters comments were received, and the document will be resubmitted to DOE Headquarters in February 1994.

Another environmental assessment will evaluate impacts from projects that will replace aging drain lines from the 222-S Analytical Laboratory to the 241-SY Tank Farm and upgrade the 219-S Waste Handling Facility, which treats the liquid waste from the laboratory. The environmental assessment was submitted to the Richland Operations Office in December 1992 and went through several rounds of comments and revisions involving both the Richland Operations Office and DOE Headquarters. The final draft environmental assessment was resubmitted to DOE Headquarters in September 1993.

An environmental assessment that addressed the proposed Solid Waste Retrieval Complex Phase I and Enhanced Radioactive Waste Storage Facility Phase V was originally submitted in January 1993. The Richland Operations Office directed that the environmental assessment be revised to include the transuranic drum retrieval operation as well. As currently written, the environmental assessment addresses the proposed retrieval of transuranic waste drums from an onsite burial trench and the construction and operation of a waste storage complex. The revised environmental assessment was submitted to the Richland Operations Office for comment in September 1993. The Richland Operations Office comments are currently being addressed. 
An environmental assessment that addressed a proposal to upgrade the existing 300 Area process sewer lines leading to the 300 Area Treated Effluent Disposal Facility was submitted to the Richland Operations Office in March 1993. This office has since directed that the environmental assessment be revised to include discharge of the process sewer effluent from the 300 Area Treated Effluent Disposal Facility to the City of Richland Publicly Owned Treatment Works. The environmental assessment was revised accordingly and submitted to the Richland Operations Office in June 1993. Minor revisions were made to the environmental assessment in October 1993 and January 1994. The Richland Operations Office is currently reviewing the revised environmental assessment.

An environmental assessment on the proposed rotarymode sampling of ferrocyanide waste storage tanks addresses a proposal to characterize tank waste by installing and operating a rotary-mode sampling system to obtain samples of tank waste salt cake. Existing characterization devices can obtain samples of the soft tank wastes, such as liquids and sludge. However, characterization efforts require that hard wastes be sampled as well. Methods must be available to do this. Environmental assessment preparation began in February 1993. The Richland Operations Office comments were incorporated, and the environmental assessment was to be resubmitted to the office by the end of October 1993. However, the document was canceled, and the scope was absorbed into the unreviewed safety question environmental assessment.

An environmental assessment on a proposed new access road addresses the construction of a new access spur from State Route 240 to Beloit Avenue in the 200-West Area. This proposal addresses a potential safety concern regarding traffic congestion on the existing access to the 200 Areas. The new road would be $3.5 \mathrm{~km}$ (2.2 mi) long and is expected to reduce the peak traffic load by as much as $30 \%$. Because of the potential safety concern, the environmental assessment preparation and review is being expedited. The environmental assessment was sent to the Richland Operations Office in May 1993, revised to address comments received, and sent to DOE Headquarters in July 1993. The draft environmental assessment was distributed for review to the Native American tribes and Washington State in September 1993. The environmental assessment was revised reflecting environmental concerns of all stakeholders and was submitted to DOE Headquarters in December 1993.

Another environmental assessment addresses the need to retrieve the high-heat waste in single-shell tank 241-C-106 and transfer it to double-shell tank 241-AY-102. The removal of the waste would stabilize the tank and eliminate the need to add cooling water. Final comments are being incorporated, and the environmental assessment is scheduled to be resubmitted to the Richland Operations Office for approval in March 1994.

An environmental assessment of interim cask storage of irradiated FFTF fuel analyzes the proposed procurement and use of interim storage casks for storage of irradiated fuel at the FFTF, and the construction and operation of an interim storage facility for the casks. Initiated in 1991, the document was revised to eliminate the Maintenance and Storage Facility upgrades and fuel washing. The latest revision (with the above scope) was submitted to DOE Headquarters in April 1993. The document has been cancelled by DOE Headquarters. The design and procurement of 10 casks have gone forward under a change request, and the interim storage facility will be addressed in a future FFTF shutdown environmental assessment.

An environmental assessment will address the conversion of a gravel pit known as Pit 9 to an inert/demolition landfill. The action description memorandum was sent to the Richland Operations Office in August 1992. After revisions were made to reflect their comments, the action description memorandum was submitted to DOE Headquarters in February 1993. In September 1993, DOE determined that an environmental assessment should be prepared. Environmental assessment schedule decisions are awaiting funding determinations.

\section{Proposed Environmental Assessments}

A NEPA document will analyze actions to offload bulk sodium from test loops and disposition residuals and hardware. The draft action description memorandum was submitted to the Richland Operations Office in September 1993, and a revised action description memorandum, reducing the scope, will be submitted in January 1994. 


\title{
2.3 Current Issues and Actions
}

\author{
J. M. Nickels
}

Progress has been made toward achieving full regulatory compliance at the Hanford site. Ongoing self-assessments of the compliance status, implementation of the Tri-Party Agreement, and public meetings continue to identify environmental compliance issues. These issues are discussed openly with the regulatory agencies and with the public to ensure that all environmental compliance issues are addressed.

\section{Hanford Federal Facility Agreement and Consent Order (Tri-Party Agreement)}

Fifty-three milestones scheduled for 1993 were completed. Included in these completed milestones were the following activities:

- One RCRA Part B permit application and one closure plan for Hanford treatment, storage, and disposal facilities were submitted to Ecology.

- Seventeen remedial investigation reports and plans were submitted to EPA and Ecology.

- Actions to meet four Tri-Party Agreement milestones dealing with management of liquid effluents at the Hanford Site were completed.

At the end of 1993, a total of 286 enforceable Tri-Party Agreement milestones (to include 1989 through 1993) had been completed on or ahead of schedule.

In December 1991, the DOE determined that a systems approach to managing, treating, and immobilizing Hanford tank wastes was necessary to ensure that all activities and schedules were fully integrated and that lessons learned and knowledge obtained elsewhere were appropriately applied to Hanford tank waste activities. In light of this, the DOE began a 15-month study to reevaluate the actions and schedules that were planned for management, treatment, and immobilization of Hanford's tank wastes. In March 1993, DOE submitted proposed changes to the Tri-Party Agreement to Ecology and EPA. These proposed changes reflected the new technical strategy to manage, treat, and dispose of the wastes stored in the 149 single-shell tanks and 28 double-shell tanks.

In March 1993, the three parties signed an "Agreement in Principle" that the proposed changes should be explored further and that a series of negotiations should be conducted to reach final agreement on any necessary changes. The regulatory agencies further responded in April 1993 with a number of items to be addressed as part of the negotiations. These items fell into three general areas:

1. changes to the Tank Waste Remediation System

2. changes to environmental restoration and waste management activities

3. procedural changes to the Tri-Party Agreement or how the Tri-Party Agreement is implemented.

Formal negotiations began in May 1993 and ended in September 1993. During this time, the three parties met to try to understand the issues and to reach acceptable positions on each of them. In addition, 10 public meetings were held in cities around the states of Washington and Oregon. These meetings were held to obtain the public's views on the issues and to incorporate them into the negotiations. The Tank Waste Task Force, another citizens group, also addressed the issues and provided input to the negotiating teams. The negotiated package of changes also underwent a public comment period from October through December 1993. In all, more than 650 comments were received. 
The final package of changes will be approved in January 1994. The new requirements will establish 244 new enforceable milestones and 113 new unenforceable target dates.

A summary of the significant changes follows.

\section{Area 1}

- Construct new double-shell tanks. A minimum of four new tanks will be constructed, two in the 200-West Area by February 1998 and two in the 200-East Area by December 1998.

- Deliver tank characterization reports for all waste tanks by September 1999. The previous Tri-Party Agreement date to complete analysis of two cores from each single-shell tank was September 1998.

- Complete single-shell tank interim stabilization by September 2000. The previous Tri-Party Agreement date was September 1995.

- Start high-level waste vitrification by December 2009. The previous Tri-Party Agreement date was December 1999. Construction will begin in 2002.

- Retrieve single-shell tank waste by 2018 (new to Tri-Party Agreement).

- Close single-shell tank farm by September 2024. The previous Tri-Party Agreement listed closure by 2018.

- Begin pretreatment facility operations for low-level waste for cesium and strontium removal by December 2004, and for high-level waste by June 2008 .

- Upgrade tank safety and tank farms (new to TriParty Agreement). Resolve safety issues by September 2001 .

- Eliminate planned grout campaigns. The previous Tri-Party Agreement milestone was to complete fourteen campaigns by December 1996. However, public comment resulted in the elimination of the grout program.

- Treat low-activity waste by vitrification, with operations starting by December 2004 (new to TriParty Agreement). Construction will begin in 1997.
- $\quad$ Prepare Sitewide systems analysis by January 1995 for integrated solid materials storage and processing.

\section{Area 2}

- Begin operating the Environmental Restoration Disposal Facility by September 1996 (new to TriParty Agreement).

- Add milestones to transition facilities to decontamination and decommissioning, after a shutdown decision is made (new to Tri-Party Agreement).

- Conduct limited field investigations in the 300 Area (modification to previous Tri-Party Agreement scope). Consolidate four 300 Area operable units.

- Pump and treat ground water (pilot-scale) by August 1994 (first of three) (new to Tri-Party Agreement).

- Remove 100-D Island pipeline, remove contamination, and survey river banks (new to Tri-Party Agreement).

- Remediate the North Slope and Fitzner/Eberhardt ALE by October 1994 (new to Tri-Party Agreement).

- Remediate K-East Basin (new to Tri-Party Agreement). If $\mathrm{K}$-East fuel can be moved to $\mathrm{K}$-West Basin, remove $\mathrm{K}$-East contaminated water by September 2000. If such transfer is infeasible, replace contaminated $\mathrm{K}$-East water starting September 1996.

- Conduct a large-scale treatability test at a 100-B Area burial ground, schedule to be determined.

- Prepare annual ${ }^{3} \mathrm{H}$ treatment technology status reports (new to Tri-Party Agreement).

\section{Area 3}

- Strengthen enforcement provisions by adding RCRA stipulated penalties and providing a regulator option to assess higher penalties.

- Streamline the dispute resolution process, with no dispute resolution for enforcement actions and 
permitting actions. Eliminate automatic schedule slip unless a change request is submitted 110 days in advance.

- Involve regulators in the budget and planning process. Send monthly Site Management System reports to regulators. Provide up-front involvement in planning/budget cycle.

- Provide regulators access to data management, including access to all relevant databases. Modify turnaround times (laboratory analysis and quality assurance documentation).

- Include more detail in work plan schedules. Establish enforceable milestones at least every 12 months.

- Provide for oversight funding including acknowledging the state's mixed waste fee and providing a CERCLA oversight grant for the state.

\section{Hanford Summit I: A National Forum on Environment, Technology, and the Economy}

The Secretary of Energy and the Governor of Washington State co-hosted the Hanford Summit at the Tri-Cities Coliseum in Kennewick in September 1993. The Hanford Summit was a national conference to examine opportunities and new relationships to make the Hanford Site a model economic-development partnership. Members of the summit also looked at the barriers to reaching that goal.

The Secretary committed DOE to specific actions in these areas:

- taking major steps to reduce secrecy and classification

- re-examining DOE policy on consultation with Native Americans

- exploring funding for public involvement activities

- assisting the state in forming a Hanford advisory committee free from DOE involvement
- addressing labor concerns about privatization

- including construction funds for the Hazardous Material Management and Emergency Response training facility in the 1995 budget

- developing plans to return government lands to the public

- making payments to local governments in lieu of property taxes lost during the past 50 years

- endorsing a new process for dealing with employee concerns.

The Secretary and Governor spoke following reports from the moderators of five Summit sessions on public involvement, regulatory issues, training and education, technology transfer, and economic development and partnerships. In the Secretary's closing remarks, she said that recommendations made at the summit which can be accomplished in short order will be implemented quickly, and immediate attention will be given to other suggestions.

\section{Information Declassification}

The Secretary of Energy announced in December the largest declassification of information in DOE's history. Information will be released to the public as an official sign that the Cold War is over and that DOE is concerned about building the public's trust in future DOE operations. The declassification includes information on nuclear testing, plutonium production and inventory, research on fusion energy, mercury inventories, nuclear fuel assessments, and human experiments conducted within the DOE complex. According to DOE, the Hanford Site produced 53 metric tons of weapons-grade plutonium between 1945 and 1988. Today, 10.5 metric tons of plutonium remain at Hanford. Of that amount, 4 metric tons are N Reactor fuel, 3.2 metric tons are FFTF fuel, and 3.3 metric tons are in the form of metal, oxide, and scrap. DOE has promised to improve the process of getting information released in a timely manner. 


\section{Hanford Advisory Board}

In 1993, DOE, EPA, and Ecology established the Hanford Advisory Board. The Board has 35 seats representing the broad range of interests affected by the Hanford cleanup, such as local businesses, tribes, regional environmental and citizen groups, and the public-at-large. The Board's purpose is to provide advice and recommendations to the agencies on major policy issues related to cleanup. The Board's primary mission is to serve as an independent, nonpartisan, and broadly representative body to provide informed recommendations and advice to the Tri-Party agencies on major policy issues related to cleanup. The Board's first meeting will be in January 1994.

\section{Hanford Future Site Uses Working Group}

The purpose of the Hanford Future Site Uses Working Group was to obtain substantive external input on cleanup and supplement scoping for the Hanford Remedial Action EIS. The Working Group had 49 members representing federal, state, tribal, and local government agencies; business, labor, agriculture, and economic development organizations; and environmental and special interest groups.

The Working Group recommendations are being considered in early cleanup decisions. For example, siting for the proposed Environmental Restoration Disposal Facility is being re-evaluated to minimize disturbances of new land. Other examples include the accelerated cleanup of the Fitzner/Eberhardt ALE Reserve and North Slope to be completed in 1994 to make the land available for other productive uses more quickly, the consideration of Working Group results in remedial investigation/feasibility studies for operable units, and the consideration of results as part of the programmatic input to land use and the Site development planning process.

\section{Salmon Rearing at $\mathrm{K}$ Basins}

In April 1993, 150,000 50-cm (2-in.) long chinook salmon were reared in the water basins of the $100-\mathrm{K}$ East
Area. There are six basins in all in 100-K East that can hold river water. These water treatment basins are not the same basins used to store $N$ Reactor fuel. The $\mathrm{K}$ basins were built to receive water directly from the river. They were used to remove natural sediments so that very clean water was sent to the reactors for cooling. The basins are upstream of the reactors and were never subject to contamination. Today, one of the basins supplies drinking water to $\mathrm{K}$ Area employees. Filled almost to the top, each basin can hold seven million gallons. One basin alone is one third the volume of the Ringold salmon release pond. The salmon were transported back to the Priest Rapids Hatchery in May to allow them to become imprinted with migratory information before releasing them into the Columbia River just upstream from the Hanford Reach. About 500 of the fish will be tagged so that their outward migration can be tracked as they pass McNary Dam at Umatilla. (McNary and Priest Rapids Dam bound the Hanford Reach.) The fish were originally hatched at Priest Rapids Dam in October 1992.

In late August 1993, 550 white sturgeon were released into the basins and are currently being studied. These cooperative efforts involve federal, state, tribal, and private agencies.

\section{Tiger Team Assessment Corrective Actions}

In June 1989, the Secretary of Energy announced a 10-point initiative to strengthen safety, environmental protection, and waste management activities at DOE production, research, and testing facilities. Tiger Team assessments, one of the 10 points in the initiative, were one of the Secretary's highest priorities for DOE.

The Hanford Site Tiger Team began evaluating Site operations in May 1990. The Tiger Team presented its findings to the Richland Operations Office and state officials in July 1990. The team's report listed 503 separate findings and 4 special issues; no findings were characterized as representing an imminent danger. One hundred thirty-nine findings were related to environmental issues. The documentation of the results of the assessment is published in Tiger Team Assessment of the Hanford Site (DOE 1990).

For 1992, 424 out of 503 environmental actions have been completed and are awaiting closure by DOE 
Headquarters. Seventy-nine actions have been completed but are awaiting verification by Quality Assurance for closure, after which these actions will be submitted to DOE Headquarters for final closure.

In May 1992, the Secretary of Energy issued the Environment, Safety and Health Progress Assessment of the Hanford Site (DOE 1992d). The progress assessment used as a point of reference the previous Tiger Team report and assessed the adequacy and effectiveness of DOE and contractor management structures, resources, and systems to address the environmental, safety and health problems and requirements. The report documented seven environmental concerns, one environmental improvement item, and three environmental strengths. The status of Tiger Team and progress assessment action items is carefully monitored, and failure to meet committed completion dates is reported to the responsible organization managers for action. Dedicated independent verification and closure personnel assure continuity of the processing and closure of these items. If difficulties are encountered with closing the action items or meeting the approved schedules, a revised action plan is submitted to the Richland Operations Office for approval.

\section{0-K Area Basins}

Restrictions associated with February's Notice of Violation issued by the Washington State Department of Health for radioactive airborne emission issues related to the proposed fuel encapsulation activities at the 100-K East Fuel Storage Basins were lifted in September 1993. The Notice of Violation had stopped all work at the 100-K East Basins. The Richland Operations Office formally responded to the Notice of Violation and initiated a Notice of Construction. Formal discussions were held with the Washington State Department of Health. Conditional approval was granted, contingent on establishing operating limits for water radionuclide concentration action levels. All other details of the Notice of Construction requiring resolution have been expedited but will not delay approval for the preencapsulation activities. The encapsulation is planned to begin June 1994.

\section{Plutonium Uranium Extraction and Uranium- Oxide Plants Status}

In December 1992, DOE Headquarters directed the Richland Operations Office to proceed with shutdown of the PUREX Plant. This placed the plant in a minimum surveillance mode awaiting final decontamination and decommissioning. PUREX Plant management submitted a project management plan for deactivation of the PUREX Plant to the Richland Operations Office in September 1993. The deactivation is expected to take approximately 5 years.

The Uranium-Oxide Plant completed its final campaign in June. During this campaign, $757,080 \mathrm{~L}(200,000 \mathrm{gal})$ of liquid uranyl nitrate hexahydrate that had been in storage at the PUREX and Uranium-Oxide Plants were converted to approximately 199 metric tons (219 tons) of uranium-oxide powder. The powder is being stored at the plant pending transfer to a vendor. In July, $378,000 \mathrm{~L}(100,000 \mathrm{gal})$ of recovered nitric acid was shipped back to the PUREX Plant for storage. Flushing of residual process solutions from the plant piping and tanks was completed as part of the transition to cold shutdown. This transition is expected to be complete by June 1995.

\section{Plutonium Finishing Plant Restart}

Reactivation of two process areas in the Plutonium Finishing Plant will stabilize materials held in the facility. This materials stabilization campaign is in response to direction from DOE Headquarters to operate the plant as necessary to stabilize and prepare materials for long-term storage and to conduct cleanout activities needed to improve the safety of the facility.

Operation of the Plutonium Reclamation Facility, one of two active process facilities and the first step in the stabilization process, will be resumed following completion of the readiness review process. Residual in-process 
chemically active recyclable liquids, sludge, fluoride powder, and rags containing plutonium will be processed to produce plutonium nitrate solutions. These solutions will then be converted in the other process facility, the Remote Mechanical C Line, to an oxide form. Plutonium oxide is a stable form suitable for extended storage. Reactivation of the Plutonium Reclamation Facility was scheduled for mid-June 1993. However, public meetings were held in July and September to determine whether an environmental assessment or an EIS is required. A decision was made later in 1993 that the activity requires an EIS to determine the acceptability of stabilizing the Plutonium Finishing Plant.

Several environmental upgrade projects at the Plutonium Finishing Plant are nearing completion. A closed-loop cooling system that will reduce the liquid effluents discharged to the 216-Z-20 Crib from 189 to $377 \mathrm{~L} / \mathrm{min}$ (50 to $100 \mathrm{gpm}$ ) to approximately 38 to $57 \mathrm{~L} / \mathrm{min}$ (10 to $15 \mathrm{gpm})$ is nearly complete. A waste-water treatment facility has also been constructed and will be activated by May 1994 . The new facility will be used to treat the remaining 216-Z-20 Crib effluents from the Plutonium Finishing Plant before they are discharged to the environment.

\section{Hanford Waste Vitrification Plant}

The Hanford Waste Vitrification Plant project was approved in 1987. The detailed plant design was initiated by Fluor Daniel Incorporated in January 1991. The plant preliminary design was completed in 1992. Site preparation, conducted by United Engineers and Constructors-Catalytic Incorporated, began in April 1992. In October 1992, notice of construction permit applications for airborne emissions from the plant were submitted to Washington State Department of Health, Ecology, and EPA. In February 1993, the plant was granted "Interim Status" under RCRA. The notice of construction was approved in March 1993. In April, limited construction of the canister storage building, sanitary waste system, and office buildings was initiated. The initiation of the Tank Waste Remediation System and its rebaselining study by DOE caused the construction and permitting efforts to be temporarily put on hold so that DOE, EPA, and Ecology could examine vitrification options. As a result of this study, as well as negotiations by the Tri-Party agencies, new milestones were established in the renegotiated Tri-Party Agreement.
The new date for start of construction is now June 2002, with operations to begin by December 2009 and complete vitrification of high-level tank wastes by December 2028 .

\section{Waste Receiving and Processing Facility}

During 1993, DOE granted approval to begin construction of the first major solid waste processing facility associated with cleanup of the Hanford Site. Scheduled to begin operations in March 1997, the Waste Receiving and Processing Facility Module 1 will analyze and prepare for disposal drums and boxes of waste resulting from plutonium operations at Hanford. The Tri-Party Agreement mandates construction and operation of this module. Wastes destined for this module include Hanford's current inventory of more than 37,000 drums of stored waste, as well as materials generated by future site cleanup activities. Consisting primarily of clothing, gloves, face masks, small tools, and dirt suspected of being contaminated with plutonium, wastes in the 55-gal drums may also contain other radioactive materials and hazardous components. Assay capabilities at this module will likely establish that as much as half of the materials processed will qualify as low-level waste suitable for disposal at Hanford. The remaining wastes will be certified and packaged for eventual shipment to the Waste Isolation Pilot Plant in New Mexico. Materials requiring further processing to meet disposal criteria will be retained at Hanford pending treatment.

The 4,831- $\mathrm{m}^{2}\left(52,000-\mathrm{ft}^{2}\right)$ facility will be constructed in 1997 near the Central Waste Complex in the 200-West Area, the central plateau that the public and Tri-Party agencies have designated for waste processing and longterm storage. The facility is designed to process 6,800 drums of waste annually for 30 years.

\section{Waste Tank Safety Issues}

In August 1993, nonessential work activities in the tank farms were put on administrative hold by senior management of the operating and engineering contractor until operators, supervisors, and managers were retrained to perform their duties safely and accountably. This action was taken in response to several safety incidents that occurred during 1993, which indicated a lack of operational facilities control. Plant implementation teams 
were established to review and approve certain critical program activities. Some of these, such as the preparation for the emergency pumping of tank 241-BX-111 and embarking on a more extensive set of tests using the mixer pump in tank 241-SY-101 have been approved and are in progress. Discussion of this return to work process is contained in the Waste Tank Operations Resumption of Work Performance Upgrade Plan, which was submitted to the Richland Operations Office in October (Lee 1993).

\section{Waste Tank Status}

The status of waste tanks is reported monthly in Tank Farm Surveillance and Waste Status Summary Report (Hanlon 1993). The summary reported the following:

- Number of waste tanks

- 149 single-shell tanks

- 28 double-shell tanks

- Number of tanks that are assumed to leak

- 67 single-shell tanks

- 0 double-shell tanks

- Chronology of single-shell tanks

- 1956: first tank reported as suspected of leaking (Tank 241-U-104)

- 1973: largest estimated leak reported (Tank 241-T-106; 435,320 L [115,000 gal])

- 1988: Tanks 241-AX-102, 241-C-201, 241-C-202, 241-C-204, 241-SX-104 reported as confirmed leakers

- 1993: 67 single-shell tanks assumed leakers to date.

So far, 106 single-shell tanks have been stabilized, with the program to be completed in 1996. In June 1993, 98 single-shell tanks had intrusion prevention devices completed, and 51 single-shell tanks achieved partial interim isolation.

The previously published leak estimates were $2,051,690 \mathrm{~L}(542,000 \mathrm{gal})$ for 38 tanks. Loss was determined by measurement in nine tanks at $132,490 \mathrm{~L}$
(35,000 gal). Leaks were statistically determined by median in 19 tanks for $617,020 \mathrm{~L}(163,000 \mathrm{gal})$. The total estimated volume of radioactive waste leakage is $2,271,240$ to $3,406,860 \mathrm{~L}(600,000$ to $900,000 \mathrm{gal})$.

\section{Watch List Tanks}

Fifty-one high-level waste storage tanks ( 45 single-shell tanks and 6 double-shell tanks) are on the "Watch List." These are the tanks identified in accordance with "Safety Measures for Waste Tanks at Hanford Nuclear Reservation," Section 3137 of the Public Law 101-510, Subsection 3137(a) (the Wyden Amendment). More detailed characterization of tank contents and associated risk factors resulted in tanks 241-BX-110, 241-BX-111, 241-BY-101, and 241-T-101 being removed from the Watch List in July. By law, removing any tank from the list requires that the Secretary of Energy determine that the tank no longer poses a serious potential for releasing high-level nuclear waste.

\section{Issues}

\section{Tank 241-T-101}

Tank 241-T-101 was declared an assumed leaker in October 1992. Total leakage is assumed to be approximately $28,400 \mathrm{~L}$ (7,500 gal). Approval to pump the tank was received from DOE Headquarters in February 1993. In March, a saltwell screen and saltwell pump were installed and pumping began. Therefore, the commencement-date deadline required by Tri-Party Agreement milestone M-05-16 for pumping T-101 was met. Pumping activities were shut down after the double-container receiving tank had reached maximum liquid level for this transfer; $68,898 \mathrm{~L}$ (18,203 gal) were transferred from T-101 to 244-TX. After sampling, the contents of 244-TX were transferred to double-shell tank SY-102. Pumping from T-101 to 244-TX was resumed in late March. Pumping was completed in April; $95,761 \mathrm{~L}$ $(25,300 \mathrm{gal})$ total were pumped. In-tank photographs were taken and showed a pockmarked, moist sludge surface, surface-cracked near the outer perimeter of the tank. From the in-tank photographs, the quantity of remaining supernatant in the tank was estimated as $2650 \mathrm{~L}$ (700 gal), with 59,803 L (15,800 gal) of drainable interstitial liquid and $62,453 \mathrm{~L}(16,500 \mathrm{gal})$ drainable liquid remaining. The evaluation for meeting 
interim stabilization criteria was completed in mid-April; official notification to regulating agencies declared the tank interim stabilized in late May.

\section{Tank 241-SX-102}

The quarterly liquid observation well reading taken in April 1993 indicated a decrease of $6 \mathrm{~cm}(0.2 \mathrm{ft})$ from the established baseline. The rerun requested and taken in May indicated a decrease of $9 \mathrm{~cm}(0.3 \mathrm{ft})$, which equals the established decrease criteria. Previous neutron liquid observation well readings had been stable, fluctuating between the baseline and a $6 \mathrm{~cm}(0.2 \mathrm{ft})$ decrease, but the May 5 reading was the first indication of a $9 \mathrm{~cm}(0.3 \mathrm{ft})$ or larger decrease. An off-normal report was issued at that time, and the liquid observation well frequency was increased from quarterly to weekly. The neutron liquid observation well is the primary means of liquid level detection because this tank has a solid surface. The readings taken on May 20 indicated a further decrease to $12 \mathrm{~cm}(0.4 \mathrm{ft})$ below the established baseline. The previous off-normal report was upgraded to an unusual occurrence report, and proper notifications were initiated. Because of the decreasing trend, this tank was declared an "assumed leaker." The well readings taken in June indicated a further decrease to $30 \mathrm{~cm}$ (1.0 ft) below the established baseline. However, an improved method for measuring the interstitial liquid level using the well data does not show a decreasing trend. Using the improved method, well data were re-evaluated. This re-evaluation indicated that the interstitial liquid level has been on a very steady decline since at least 1987 , with no acceleration of the established decrease rate. Similar constant rates of decline in interstitial liquid levels are also seen in other tanks, with the decreases normally being attributed to evaporation. An evaporation study derived estimated evaporation rates that closely matched those seen in the revised well analyses. After reviewing all available information, no surveillance data indicated a loss of liquid attributed to a breach of integrity at this time. Tank 241-SX-102 meets the definition of a sound tank, and was reclassified from an assumed leaker to a sound tank in July based upon the new improved method for evaluating neutron scan data.

\section{Tank 241-SY-101}

The predicted gas release from Tank 241-SY-101 began in June 1993. The initial surface level decrease was $15 \mathrm{~cm}$ ( $6 \mathrm{in}$.) followed by smaller decreases over the next few days. At least an 18-cm (7-in.) drop in surface level is required before the tank can be opened. On June 30, the tank level had decreased $20 \mathrm{~cm}(8 \mathrm{in}$.) and an opening was approved for 30 days. In July, the $19.5-\mathrm{m}$ (64-ft), 8618-kg (19,000-lb) mixing pump was installed in Tank 241-SY-101. The pump is expected to circulate liquid waste from the tank's upper layer down toward the bottom where two jet nozzles will discharge the fluid

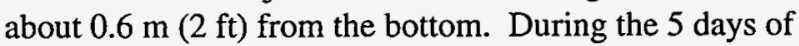
Phase A testing, the pump was run for short periods each day. The pump continued to be tested throughout August and September, with successful results. In October, it was announced the first tests of Phase B testing were also successful. Phase B testing will last for 1 to 2 months and consist of 27 different runs, with the nozzles circulating from all directions. It is expected that when Phase B testing ends, a determination can be made as to whether the mixer pump alone will solve the tank's gas buildup problem. After that, a series of full-scale tests on the mixer pump will be run through May 1994 .

\section{Tank 241-C-105}

The status of Tank 241-C-105 was changed from highheat load to normal after the heat-generation rate was reevaluated while the forced ventilation system was inoperative. The thermal analysis indicated the bestestimate heat generation rate for this tank is approximately $20,000 \mathrm{Btu} / \mathrm{h}$, with a conservative upper boundary of about $25,000 \mathrm{Btu} / \mathrm{h}$. This is considerably less than the high-heat criterion of $40,000 \mathrm{Btu} / \mathrm{h}$. Cooling water additions to this tank ceased as of July 1993. It is conservatively predicted that the maximum waste temperature during the heat-up phase would not exceed $73.9^{\circ} \mathrm{C}$ $\left(165^{\circ} \mathrm{F}\right)$ with the ventilation completely shut off. No changes will be made to the surveillance monitoring requirements at this time. Psychrometric readings are required to be taken monthly to verify evaporation rate and confirm air flow rates. In-tank photographs will be required when the surface level reaches the previous lower evaporation limit of $1.2 \mathrm{~m}(4 \mathrm{ft})$. Tank C- 105 is a partially interim-stabilized tank.

\section{Tank 241-U-111}

In May, it was recommended to the Richland Operations Office that Tank 241-U-111 be included on the Watch List. This recommendation was based on information discovered during review of historical records, which suggest that the total organic carbon content of interstitial liquid in this tank is approximately $14 \mathrm{wt} \%$ (dry basis). The criteria for adding a tank to the Watch List because of its organic content is $3 \mathrm{wt} \%$ (dry basis). A total organic carbon content of $14 \mathrm{wt} \%$ (dry basis) for 
the interstitial liquid does not indicate that the total organic carbon content of the tank's waste, averaged over the entire inventory (interstitial liquid, saltcake, and sludge) is near $14 \mathrm{wt} \%$ (dry basis); the average total organic carbon content of waste is much less than 14 wt\% (dry basis). Tank U-111 has been evaluated against unresolved safety question criteria, and the tank has been determined not to have met the requirements. Tank U-111 was added to the Watch List in August 1993.

\section{Tank 241-T-107}

Tank T-107 is being reviewed for inclusion on the Watch List because of its hydrogen content.

\section{Tanks 241-BX-102, BX-106, BX-110, BX-111, BY-101, and T-101}

In March 1993, approval was requested from the Richland Operations Office to remove six tanks (241-BX-102, BX-106, BX-110, BX-111, BY-101, $T-101)$ from the Watch List because these tanks do not contain meaningful amounts of ferrocyanide sludge. This request followed a study that concluded that these tanks contain less than 1,000 gram-moles of ferrocyanide. In July, the Richland Operations Office granted authorization to close the ferrocyanide unreviewed safety question associated with these four tanks and remove them from the Watch List. The need for special monitoring of the temperature in these tanks is being reviewed. The Richland Operations Office requested an additional evaluation and a revised approval request for BX-102 and BX-106.

\section{Tank Waste Task Force}

A Hanford Tank Waste Task Force was formed in May to focus on tank waste issues. The group represents local and county government, environmental and special interest groups, business interests, agriculture and labor groups, and members of the Washington and Oregon State Hanford Advisory Boards. The group plays an active role in involving all stakeholders with the TriParty Agreement renegotiations. The group participated in public meetings held in Richland, Washington, Portland, Oregon, Hood River, Oregon, Spokane and Seattle, Washington during November 1993.

\section{Waste Management}

\section{Pollution Prevention Program}

The Hanford Site Pollution Prevention Program (formerly Waste Minimization) is an organized, comprehensive, and continual effort to systematically reduce the quantity and toxicity of hazardous, radioactive, mixed, and sanitary wastes; conserve resources and energy; reduce hazardous substance use; and prevent or minimize pollutant releases to all environmental media from all operations and Site cleanup activities.

It is designed to satisfy DOE requirements, recent Presidential Executive Orders, and other state and federal regulations and requirements. In accordance with sound environmental management, preventing pollution through source reduction is the first priority in the Hanford Site's Pollution Prevention Program, followed by environmentally safe recycling. Waste treatment to reduce the quantity, toxicity, or mobility (or a combination of these) will be considered oniy when prevention or recycling are not possible or practical. Environmentally safe disposal is the last option.

By adopting this hierarchy into Hanford environmental management activities the following successes in minimizing waste were accomplished:

- Hanford Site pollution prevention efforts in 1992 and 1993 helped to minimize 21.3 million $\mathrm{kg}$ (47 million $\mathrm{lb}$ ) of solid waste and 989 million $\mathrm{L}$ (261 million gal) of liquid waste for a cost savings of approximately $\$ 2.9$ million.

- The Hanford Site was presented an award from DOE for its efforts to minimize sanitary waste and establish affirmative procurement programs for the purchase of products containing recycled material.

- Implementation of the Hazardous Materials Reduction Initiative will minimize hazardous materials purchased and hazardous wastes generated through the review of purchase requisitions for product substitution opportunities.

- In support of the DOE-Headquarters Waste Cost Avoidance Model Program, Hanford Site waste generation cost numbers were developed. The waste cost avoidance model determines the life cycle cost 
of waste generation, storage, treatment, and disposal. Additionally, the cost model data have been used to highlight the cost impact for managing wastes; project future waste management costs to support prioritization of pollution prevention alternatives; and provide an order-of-magnitude estimate of economic payback from waste avoidance.

- The Pollution Prevention Design Guideline and the Orientation to Pollution Prevention for Facility Design training courses were created to assist DOE design engineers in preventing pollution during the design of new or modified facilities across the DOE complex. These project deliverables were created and completed at Hanford. Complex-wide distribution and Hanford Site implementation of these tools will be completed in 1994 .

- A project was implemented involving the beneficial use (and reuse) of slightly contaminated solids, and sludge in place of clean materials as fill in radioactive and mixed waste landfills and burial trenches. The benefits of the concept include prevention of settlement and subsidence within landfills and burial grounds; decreased occupational and radiological health and safety hazards; stabilization and solidification of waste packages, mitigating collapse and migration of contaminants; and cost savings achieved through increased efficiency and waste minimization. This concept has been chosen by DOE-Headquarters as an Assistant Secretary cost savings initiative, was presented at the Tri-Party Agreement senior management meeting in November, and will be open for public participation and review in 1994.

- The Hanford Site recycled nearly 517 metric tons of office paper in 1993. The Hanford Site also recycled 36.3 metric tons of lead acid batteries; 10,000 laser jet toner cartridges; 757,000 L (200,000 gal) and 50 metric tons of surplus chemical products; and 1,224 metric tons of scrap metal.

Besides the Sitewide programs mentioned above, numerous generator-specific initiatives were put into place. These initiatives are specific to a particular area or process and, in most cases, were thought of and implemented by the people onsite who handle the waste daily. To celebrate these pollution prevention activities, an "Accomplishments Book" was published in October covering activities in 1993. This book outlines 34 significant initiatives that were implemented and are now in use at locations throughout the Hanford Site. A few of these initiatives are:

- using $\mathrm{CO}_{2}$ pellets rather than solvent to remove paint

- $\quad$ selling clean, excess chemicals rather than disposing of them

- expanding the paper recycling program

- reusing clean, noncontaminated steel drums

- modifying processes to reduce waste water.

These activities, plus the 29 others, resulted in significant reductions in hazardous waste, radioactive waste, and solid sanitary waste, as well as promoted resource conservation and technology transfer. Most of the ideas were simple improvements in processes, enacted by changing the methods of remediation or disposal. The focus was on generating less waste in the first place and reusing or recycling the waste that was generated. Although not all the waste savings from these generatorspecific ideas were quantifiable, those that were resulted in the following reductions compared to 1992:

- 1.14 million L (300,000 gal) of hazardous waste (solvents, oil, chemicals)

- $\quad 5,600$ metric tons of solid sanitary waste (steel, cement, paper, rags)

- 984 million L (260 million gal) of waste water

- nine 55-gal drums of radioactive and mixed waste.

These reductions are estimated for all of 1993. In addition to these and the nonquantifiable waste reductions, numerous other benefits were realized, including significant cost savings, reduced worker exposure, improved public relations, and an overall improvement in quality of operations. These activities also earned two awards; one was the Federal Energy Efficiency, Renewable and Water Conservation Award for a 984 million L (260 million gal) reduction in waste water by the 300 Area. 


\section{Safety Initiative}

During the second half of 1993 , safety was raised to the level of a management initiative. Improvement was called for in all areas at the Hanford Site. After a series of incidents, the safety issue resulted in the tank farms being placed in an "operations safety requirement" surveillance-only mode. Only work that was necessary for safety and legal compliance was performed. Meetings were held with operations personnel at all levels in tank farms along with grout operations to look more closely at the true cause of the serious safety/conduct of operations problems, and to listen to suggestions for solving them.

The operations contractor president announced a formal policy that working safely is a condition of employment at Hanford. The president stated:

"Working safely as a condition of employment means that every one of us is responsible and accountable for ensuring the safety of ourselves and our coworkers. It means that each of us obeys safety rules, recognizes and reports unsafe conditions, and stops any act that may be unsafe until it can be evaluated. Ultimately, involvement from every employee is what will make Hanford the safest place in the nation to work-and that is what we must all be striving for.

"Four things must be clear to all employees and managers at all levels:

- Safety is a condition of employment.

- We demand excellence in conduct of operations.

- Every manager is accountable for safety in his or her operation, and every employee is accountable for his or her own safety and that of co-workers.

- We will require managers to spend more time in the field."

\section{2-A Evaporator Status}

In May 1993, the operational readiness review was finished and the Richland Operations Office declared readiness to start up the facility. The DOE Headquarters readiness review team visited Hanford for 2 weeks in June and overviewed the work performed. This review resulted in 18 prestart items. Since the team left, field efforts have focused on completing the prestart items and conducting additional operator training. On August 12, the 242-A Evaporator went on administrative hold with the rest of the tank farms. A meeting with Ecology was held in September 1993 to discuss compliance with environmental regulations. On September 13, a plant improvement team was chartered to start up the facility. This improvement team is currently working to complete tasks that were on the restart list before August 12 and determine what additional tasks are required. The improvement team felt that the additional tasks will be minimal. The start-up date is April 1994.

\section{Liquid Effluent Treatment Activities}

\section{Liquid Effluent Retention Facility}

Construction of the Liquid Effluent Retention Facility for interim storage of 242-A Evaporator process condensate suspected of containing listed waste is near completion. The Liquid Effluent Retention Facility is scheduled to accept the 242-A Evaporator effluents for 12 to 15 months, then store the effluents until an effluent treatment facility is completed in October 1994. On completion of the effluent treatment facility, the effluents stored in the Liquid Effluent Retention Facility basins will be piped to that facility for treatment and disposal. Studies are being conducted to identify possible uses for the Liquid Effluent Retention Facility once the basins are emptied. The operational readiness review was conducted during 1993, and final prestartup activities remain.

\section{Area Effluent Treatment Facility}

The 242-A Evaporator/PUREX Plant Process Condensate Treatment Facility (200 Area Effluent Treatment Facility) is being constructed to provide effluent treatment and disposal capability required to restart the 242-A Evaporator. The facility will provide collection for the three effluent streams, a treatment system to reduce the concentration of radioactive and hazardous waste constituents in the effluent streams to acceptable levels, tanks to allow verification of treated effluent 
characteristics before discharge, and a state-approved land disposal structure for effluents.

Secondary waste generated by the treatment facility (e.g., filter backwash, ion exchange regenerate, and permeate from reverse osmosis) will be concentrated and packaged to meet the requirements by the state for storage and/or disposal of solid waste.

Initial testing of the facility processes will be completed in June 1994. All regulatory permits required for the facility and disposal site have been submitted to the regulators as required in the Tri-Party Agreement and Washington State 216 Consent Order (Agreement DE 91NM-177). Because process condensate was not available for waste characterization, the Federal Delisting Petition, State Waste-water Discharge Permit, and RCRA Dangerous Waste Permit applications were based on a surrogate solution. This surrogate was developed and tested under pilot-scale conditions to determine a broad-based envelope of constituents that the facility can successfully treat.

\section{Area Treated Effluent Disposal Facility}

The 200 Area Treated Effluent Disposal Facility will be a permitted system for the collection, sampling, and disposal of thirteen effluent streams in the 200-East and 200-West Areas. Based on data derived in preparing the 240 Engineering Report required by the state Waste Discharge Permit Program, it has been determined that the best available technology and all known and reasonable treatments will be implemented at each waste-water generating facility. Effluents will meet the requirements of best available technology before discharge to the collection and disposal system. The construction of the collection system began in April 1993. The disposal facility design is complete. A request for proposal was issued for the construction contract in September 1993. The construction is scheduled to start in February 1994.

\section{Area Treated Effluent Disposal Facility}

The 300 Area Treated Effluent Disposal Facility is a system for collection, treatment, and disposal of effluents from the 300 Area. Currently, these effluents are discharged to the 300 Area Process Trenches. The project consists of a collection system, effluent treatment facility designed for a flow rate of $1,136 \mathrm{~L} / \mathrm{min}$ (300 gpm), holdup diversion basins, and discharge via an outfall to the Columbia River under a National Pollutant Discharge Elimination System permit. A parallel option is under way to pursue discharging to the City of Richland Publicly Owned Treatment Works.

Design of the 300 Area Treated Effluent Disposal Facility has been completed, and construction of the facility was started by Humphrey Construction, Inc., of Woodenville, Washington. The Shoreline Permit was approved at a Benton County Shoreline Hearings Board meeting.

\section{Interim Compliance}

Liquid effluent commitments required by the Tri-Party Agreement and the WAC 173-216 Compliance Agreement (Consent Order) include the preparation of stream sampling and analysis plans, stream characterization, preparation of ground-water impact assessments, and preparation of WAC 173-216 permit applications. Twenty-three sampling and analysis plans have been developed and implemented, and at least one full set of samples has been collected for 22 effluent streams thus far. Nine ground-water impact assessment plans have been prepared, and six assessments have been completed. A computerized data management system has been developed to allow rapid access to effluent stream characterization data.

\section{Area Phase II Stream Treated Effluent Disposal Facility}

As part of the October 1991 negotiations to supplement the Tri-Party Agreement and to create the WAC 173-216 Consent Order, the Richland Operations Office committed by October 1997 to implement best available technology for the nine Phase II streams that will not go to the 200 Area Treated Effluent Disposal Facility.

The scope of the 200 Area Phase II Stream Treated Effluent Disposal Facility is to eliminate, minimize, or treat effluents currently being discharged to the 100-D Ponds and the 216-B-3 Pond. The facilities involved include the 183-D Water Treatment Facility, the 241-A Tank Farms, the 242-A Evaporator, the 244-AR Vault, B Plant, and the 284-E Powerhouse. The conceptual design report was completed in June 1993. Advanced conceptual design began in October. 


\section{Miscellaneous Streams}

Miscellaneous liquid waste streams (e.g., sanitary wastes and small volume or intermittent discharges from heating, ventilation, and air conditioning systems, and floor drains and sumps from noncontaminated or nonchemical-handling facilities) originally were not included within the scope of the Tri-Party Agreement or the liquid effluent treatment program. Initial actions are intended to inventory and identify these streams.

An inventory of all effluent streams was developed that identified more than 300 small discharges. These discharges were evaluated against criteria developed to determine if they had any potential to cause harm to the environment or ground water. This inventory and these criteria will be used to develop the overall plan and schedule for regulatory compliance, which is due to be submitted to Ecology in January 1994.

\section{Submarine Reactor Compartments}

Seven defueled submarine reactor compartment disposal packages were received and placed in Trench 94 in the 200-East Area during 1993.

The reactor compartment disposal packages are being regulated by Ecology as dangerous waste because of the presence of lead used as shielding, and by EPA because of the presence of small amounts of PCBs bound within the matrix of nonmetallic materials such as thermal insulation, electrical cables, and some synthetic rubber items. In December 1989, DOE submitted to the state a draft Part B permit application for low-level waste burial grounds, including Trench 94. A revised application was submitted in April 1993. No response has been received from Ecology.

\section{International Environmental Institute}

The International Environmental Institute was established in March 1992 to make the most of lessons learned during the environmental restoration of Hanford and to provide others around the world with the benefits of these lessons. The institute has been accomplishing this by utilizing the Hanford Site as a unique environmental laboratory to create and nurture partnerships among industry, government, academia, and the public. It is anticipated that agreements, joint programs, and information exchanges will be created to share Hanford's assets with other sectors.

Recent institute activities in the technology area include development and execution of the first Cooperative Research and Development Agreements between the Site operating contractor and industry, and development of Hanford opportunities and needs information for external entities, with dissemination through a regional bidding initiative with the economic development offices of Washington, Oregon, and Idaho. About 60 invention disclosures were also processed for technology developed at Hanford. Another 29 technologies are being explored with external entities for potential application to the Hanford environmental mission. The institute played a lead role in using the $\mathrm{K}$ basins for rearing salmon and sturgeon. Work is also under way to use parts of the Hanford Site for commercial purposes.

In 1993, the institute adopted the Hazardous Materials Management and Emergency Response (HAMMER) Training Center as a key initiative. The HAMMER Training Center is a unique, nonprofit training facility that would provide integrated training for both chemical and radioactive hazards response.

The institute, labor officials, and the Tri-City Industrial Development Council presented the HAMMER Training Center to Assistant Secretary of Energy for Environmental Restoration and Waste Management and secured support for startup activities beginning in 1994 and construction in 1995. During the Hanford Summit, the Secretary of Energy publicly committed to fund construction during 1994-1995.

In 1993, DOE Headquarters agreed to fund two transportation emergency preparedness courses, including an orientation course and Advanced Transportation Emergency Preparedness. The courses were taught in July and August with extremely favorable evaluations from the participants. 


\section{Area Sanitary Sewer System}

Most of the 200 Areas' sanitary systems are in the process of failing, are projected to fail in the future, are underdesigned for the current discharge, or require modification because of additional personnel. A number of these sanitary systems have failed.

In April 1991, the Richland Operations Office initiated an engineering study to identify alternatives and recommend a preferred solution. This study was issued in March 1993, and the functional design criteria were issued in June. The conceptual design was initiated in July, and project validation is expected in May 1994. The study's preferred alternative is a sewage collection system for the 200-East and 200-West Areas that discharges to plastic-membrane-lined evaporative lagoons (one in each area). This alternative is preferred because the system would not discharge waste water to the soil and would be inexpensive to operate.

\section{Russian Exchanges}

During 1993, several Russian high-level officials and scientists visited Hanford to exchange new ideas and technologies. Because of the collaboration of Russian and Hanford scientists and engineers during a February meeting, a new laser technology will be demonstrated at Hanford that could radically change the present methods of decontaminating large surface areas. Using lasers to vaporize waste from concrete surfaces is being explored for Hanford. In June, a high-level team of Russian officials visited Hanford and the Tri-Cities to establish a formal relationship and plan for future exchange. This meeting was promoted by the Kennewick School District to establish a "sister city" relationship with a nuclearcentered city in Russia called Krasnoyarsk-26. From October to November, two Russian officials and their interpreters visited Hanford's N Reactor and discussed the Site's cleanup mission and history. Once again, this visit was part of a Kennewick School District initiative.

\section{Self Assessments}

Ninety-three compliance self-assessments were scheduled during 1993. Seventy-four of the 93 assessments were completed on schedule. Of these, 37 identified unsatisfactory conditions. Thirty-one deficiencies were identified in the area of hazardous waste management, five were identified in the area of effluent monitoring, and one was related to Toxic Substances and Control Act waste management. The remaining assessments were delayed because of the number of audits and appraisals during the year. New self-assessments are conducted yearly and are reported to the Richland Operations Office. 


\title{
2.4 Environmental Occurrences
}

\author{
J. M. Nickels
}

Onsite and offsite environmental releases of radioactive and regulated materials during 1993 were reported to DOE and to federal and state agencies as required by law. The specific agencies notified depended on the type, amount, and location of the individual occurrences. In some cases an occurrence may be under continuing observation and evaluation. During 1993, all unusual and off-normal occurrences at the Hanford Site were reported to the Hanford Site Occurrence Notification Center. This Center is responsible for maintaining both a computer database and a hardcopy file of event descriptions and corrective actions. Copies of occurrence reports are made available for public review in the DOE Public Reading Room located on the Washington State University Tri-Cities campus in Richland, Washington.

As defined in DOE Order 5000.3B, emergency occurrences "are the most serious occurrences and require an increased alert status for onsite personnel and, in some specified cases, for offsite authorities." There were no Emergency Occurrence Reports filed in 1993.

Unusual occurrences are defined as nonemergency occurrences that may have a "significant impact or potential for impact on safety, environment, and health." There were 130 unusual occurrence reports filed during 1993 for Site contractors. Several unusual occurrences of environmental significance are summarized below.

Off-normal environmental occurrences are referred to as "abnormal or unplanned events or conditions that adversely affect, potential affect, or are indicative of degradation in, the safety, environmental or health protection performance or operation of a facility." There were 1,391 off-normal environmental occurrence reports filed at the Hanford Site during the year covering everything from 17 ethylene glycol spills to releases of used oil. Because of the volume of reported off-normal occurrences, event summaries are not included here.

\section{Unusual Occurrences}

\section{Carbon Tetrachloride Continuous Release}

A notification of a continuous release of carbon tetrachloride from the Plutonium Reclamation Facility in the 200 Area was given to the National Response Center in January 1993. During normal operation of this facility, carbon tetrachloride evaporates and is continuously released to the atmosphere. The Plutonium Reclamation Facility began preparing for restart during January and exceeded the reportable quantities of $4.5 \mathrm{~kg} / \mathrm{d}(10 \mathrm{lb} / \mathrm{d})$ of carbon tetrachloride on January 21. Additional verbal notifications of a continuous release were made to the Local Emergency Planning Committee and the State Emergency Planning Commission. In return, the National Response Center has issued a continuous release reporting number (CR-ERNS 154457) for reference on future carbon tetrachloride releases from this facility.

\section{Supernate Liquid Spill}

In April 1993, a potential release of $10,200 \mathrm{~L}(2,700 \mathrm{gal})$ of radioactive constituents from Tank 241-SX-111 was reported. Notifications were made to the EPA, Ecology, National Response Center, State Emergency Response Commission, and the Local Emergency Planning Committee. The notifications were made based upon analytical data that indicated the reportable quantities for ${ }^{137} \mathrm{Cs}$ and ${ }^{238} \mathrm{U}$ would be exceeded if a leak had actually occurred. At that time, the data were not conclusive, and a leak had not been confirmed. Subsequent calculations of the potential amounts released showed that the CERCLA requirements would only have been exceeded for cesium. The data for uranium were incorrect. Since the notification, $265,000 \mathrm{~L}$ ( $70,000 \mathrm{gal}$ ) of pumpable 
liquids have been removed from the tank. Permanent corrective actions and cleanup will be addressed by the Tri-Party Agreement.

\section{Used-Oil Spill}

An underground storage tank (number 3000-12) near the 1226 Building Loading Dock in the 3000 Area was removed in April. One of the soil sample analyses indicated total petroleum hydrocarbon $(2,400 \mathrm{ppm})$ was in excess of the soil action level defined by Ecology (200 ppm). The excavation was expected to be clean because the cathodically protected tank was recently installed (1983), was in extremely good shape when it came out of the ground, and did not contain any piping runs. Field screening instruments did not indicate petroleum contamination during any phase of the removal. It was assumed that the contamination was very local and a direct result of overfills when used oil was placed into the tank. The contaminated soil was removed and disposed of according to federal and state requirements.

\section{Oil/Lead-Removal Contaminated-Soil}

In November, five 55-gal drums of oil/lead-contaminated soils, designated and labeled as hazardous waste, were removed from the Hanford North Slope. The removal was conducted by a U.S. Army Corps of Engineers contractor and disposed of in the city of Richland landfill. The waste was under the control and management of Westinghouse Hanford Company. The contractor was not authorized to remove or transport the waste drums, and the landfill was not approved to receive hazardous waste. The U.S. Army Corps of Engineers was directed by the Richland Operations Office to contact the Richland landfill and attempt to recover the waste or have the barrels of waste segregated and held. Efforts to locate the drums have been unsuccessful. Efforts are continuing.

\section{Potential Leak in the 100-K East Fuel Storage Basins}

In February 1993, liquid level indicators at the 105-K East Fuel Storage Basin indicated that water contaminated with radioactive and hazardous materials may be leaking from the basin to the ground. Drawdown tests conducted during 1993 indicated that a leak may exist and that fluid loss may be on the order of $189 \mathrm{~L} / \mathrm{h}$ (50 gal/h). However, visual inspections of the leak observation test wells and leak collection membrane discharge sump found no evidence of a leak. Additional level monitoring equipment has been installed in the basin to confirm initial readings and enhance monitoring capabilities. Acoustic sensing devices are being used to characterize the condition of the basin and to help locate any leaks that may exist. If a leak is discovered, a repair plan will be developed and implemented. Current plans to encapsulate fuel at the facility may be significantly altered depending on the outcome of the investigation. This information was summarized from a 10-day update report issued in Septmber 1993. At the time this annual report was prepared the final report on this occurrence had not been issued.

\section{CERCLA-Reportable Releases}

There were 20 releases under the CERCLA-reportable quantity requirements in 1993. Sixteen of the releases were ethylene glycol spills, with one being of notable concern. It is listed as number two below.

1. Carbon tetrachloride was released during the solvent extraction process at the Plutonium Reclamation Facility.

2. A small amount of antifreeze (ethylene glycol) was released to an asphalt roadway in the $100-\mathrm{H}$ Area.

3. A small amount of highly concentrated PCBcontaminated soil was released in the 100-D Area. The quantity of spilled material was below the CERCLA-reportable quantity, but was required to be reported per 40 CFR 761.125(c)(1)(i).

4. On May 20, 1993, Tank 241-SX-102 was declared to be an "assumed leaker." Calculations for radionuclides ${ }^{90} \mathrm{Sr},{ }^{137} \mathrm{C}$, and ${ }^{239,240} \mathrm{Pu}$ show that the daily CERCLA-reportable quantities were exceeded. Emergency pumping efforts for Tank 241-SX-102 have been initiated. Tank $241-S X-102$ contains complex concentrate waste and will require detailed sampling and evaluation to ensure that the waste is compatible with the chosen receiver tank. The liquid level decrease is documented in Occurrence Report RL-WHC-TANKFARM-1993-0044. 
5. In November 1993, five 55-gal drums of oil/leadcontaminated soils designated and labeled hazardous waste were removed from the Hanford North Slope by a U.S. Army Corps of Engineers contractor and disposed of in the city of Richland landfill. The waste was under the control and management of Westinghouse Hanford Company. The contractor was not authorized to remove or transport the waste drums, and the landfill was not approved to receive hazardous waste. The U.S. Army Corps of Engineers was directed by the Richland Operations Office to contact the Richland landfill and attempt to recover the waste. Efforts to locate the drums have been unsuccessful. Efforts are continuing.
6. Approximately $10,220 \mathrm{~L}(2,700 \mathrm{gal})$ of radioactive constituents were thought to have been released from Tank 241-SX-111. Appropriate notifications were made to EPA, Ecology, National Response Center, the State Emergency Response Commission, and the Local Emergency Planning Committee. The notifications were made based upon analytical data that indicated the reportable quantities for ${ }^{137} \mathrm{Cs}$ and ${ }^{238} \mathrm{U}$ would be exceeded if a leak were to occur. An engineering evaluation of this potential occurrence recommends that new in-tank photographs and vapor samples be taken to help determine changes in the tank. The evaluation also recommends that steps be taken to pump the remaining liquid from the tank. 


\section{Effluent \\ Monitoring Information}

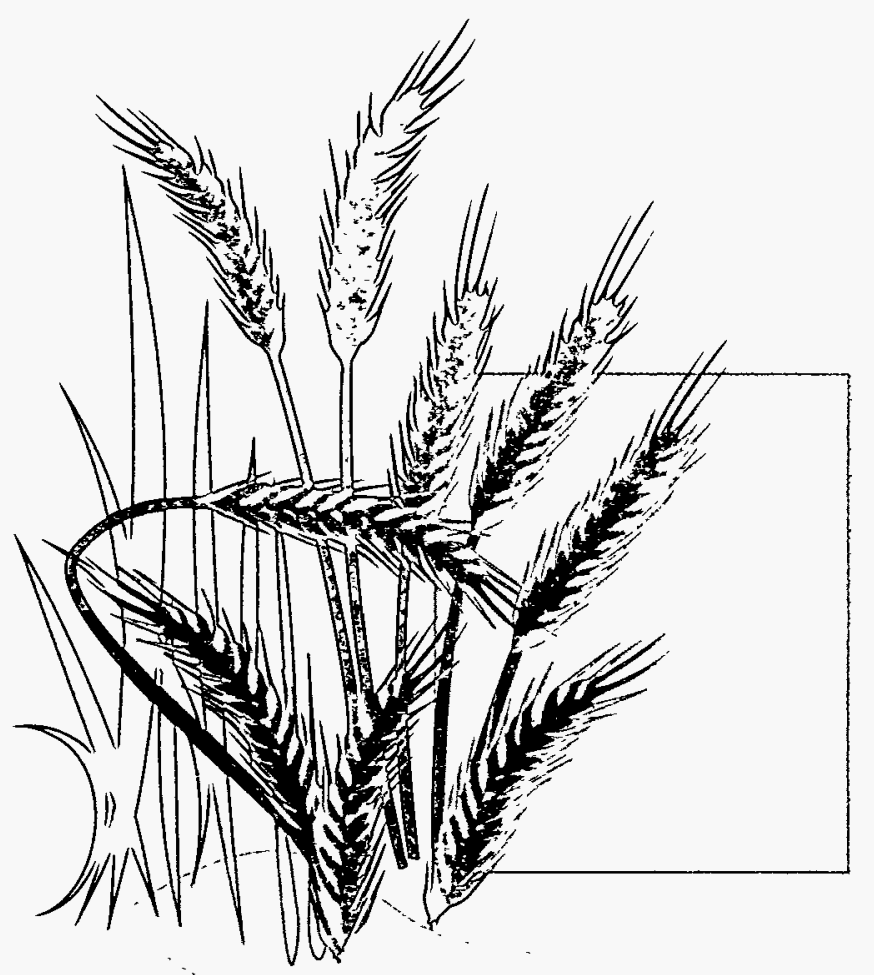




\subsection{Effluent Monitoring, Waste Management, and Chemical Inventory Information}

Monitoring effluents and managing waste and chemical inventories at Hanford Site facilities are essential to determine the effects these materials may have on the public, workers at the Site, and the surrounding environment. Hanford Site contractors have programs to monitor liquid and airborne effluents and manage solid waste and chemical inventories. Facility effluent monitoring programs are designed to measure effluents at their point of release into the environment, whenever possible. The effectiveness of effluent treatment and control and waste management practices are evaluated through near-facility monitoring. Types, quantities, and locations of chemicals are also tracked. This section summarizes the data collected in 1993 by these programs. More detailed program, sampling, and waste management information is contained in the volumes, Westinghouse Hanford Company Operational Environmental Monitoring Annual Report, Calendar Year 1993 (Schmidt et al. 1994), Westinghouse Hanford Company Operational Groundwater Status Report (Johnson 1993), 1993 Hanford Tier Two Emergency and Hazardous Chemical Inventory (DOE 1994a), the Hanford Site Annual Dangerous Waste Report for Calendar Year 1993 (DOE 1994b) and Summary of Radioactive Solid Waste Received in the 200 Areas During Calendar Year 1993 (Anderson and Hagel 1994). 



\title{
3.1 Facility Effluent Monitoring
}

\author{
B. L. Curn
}

Liquid and airborne effluents that may contain radioactive or hazardous constituents are continually monitored when released at the Hanford Site. Facility operators perform the monitoring mainly through analyzing samples collected near points of release into the environment. Effluent monitoring data are evaluated to determine the degree of regulatory compliance for each respective facility or the entire Site, as appropriate. The evaluations are also useful in assessing the effectiveness of effluent treatment and control systems and management practices. Data evaluations are important components in sound environmental management decisions. Major facilities have their own individual effluent monitoring plans, which are part of the comprehensive Site environmental monitoring plan required by DOE (DOE 1991b).

Measuring devices quantify most facility effluent flows, with a smaller number of flows calculated using process information. Effluent sampling ranges from being continuous for most radioactive air emissions to proportional or grab sampling for most liquid effluents. Liquid and airborne effluents with a potential to contain

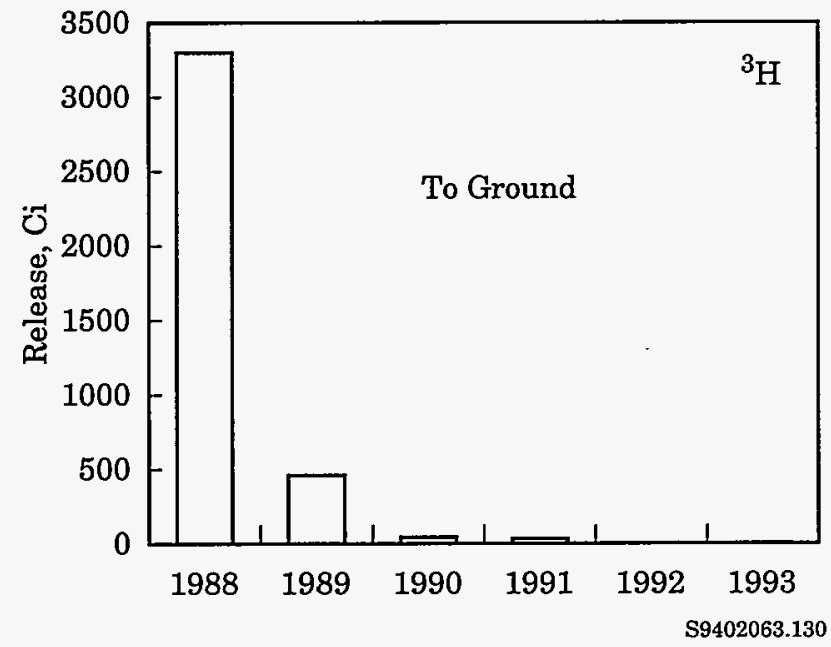

radioactive materials at prescribed threshold levels are measured for total alpha and total beta activity and, as warranted, specific gamma-emitting radionuclides. Nonradioactive constituents are also monitored, as applicable.

Most radioactive effluents at the Site are approaching levels practically indistinguishable from naturally occurring radionuclides present everywhere. A new Site mission of environmental restoration rather than nuclear materials production is largely responsible for this favorable trend, which translates to a very small offsite radiation dose attributable to Site activities. With two exceptions, the totals of radionuclides in effluents released at the Site in 1993 are not significantly different from totals in 1992. Section 6.0 discusses those exceptions, which relate to unexpected releases of ${ }^{220} \mathrm{Rn}$ and ${ }^{222} \mathrm{Rn}$ from new experimental work in the 327 Building (300 Area). Small quantities of the radionuclides ${ }^{3} \mathrm{H},{ }^{41} \mathrm{Ar},{ }^{90} \mathrm{Sr},{ }^{129} \mathrm{I},{ }^{212} \mathrm{~Pb},{ }^{238} \mathrm{Pu},{ }^{239.240} \mathrm{Pu}$, and ${ }^{241} \mathrm{Am}$ continue to be released, contributing most of the small Site-related public dose. Figures 3.1 and 3.2 depict amounts of several long-lived prominent dose-

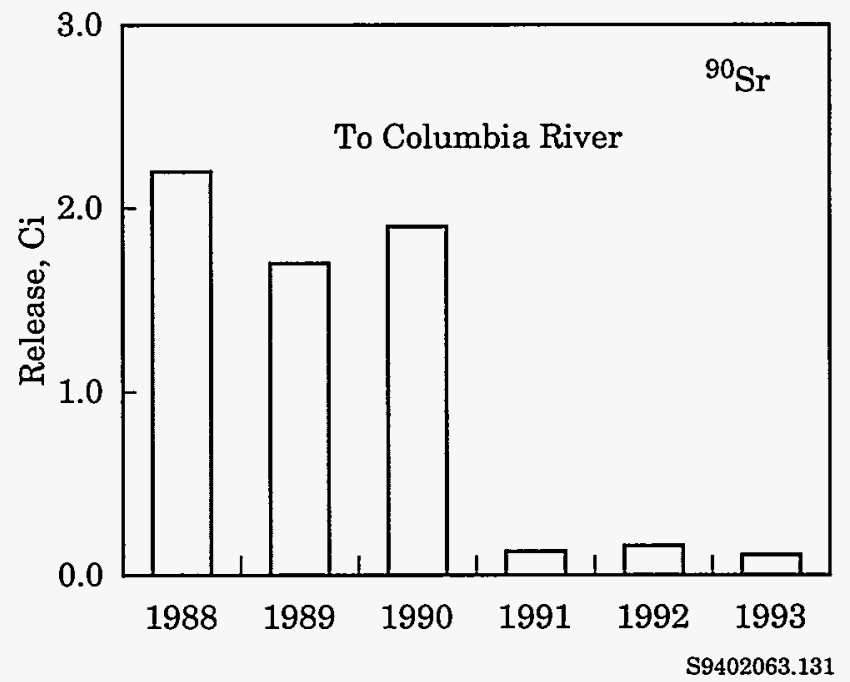

Figure 3.1. Liquid Releases of Selected Radionuclides from Site Facilities,1988 Through 1993. Releases of ${ }^{3} \mathrm{H}$ have been very low over the last few years and appear to be zero for 1992 and 1993 on the graph. 

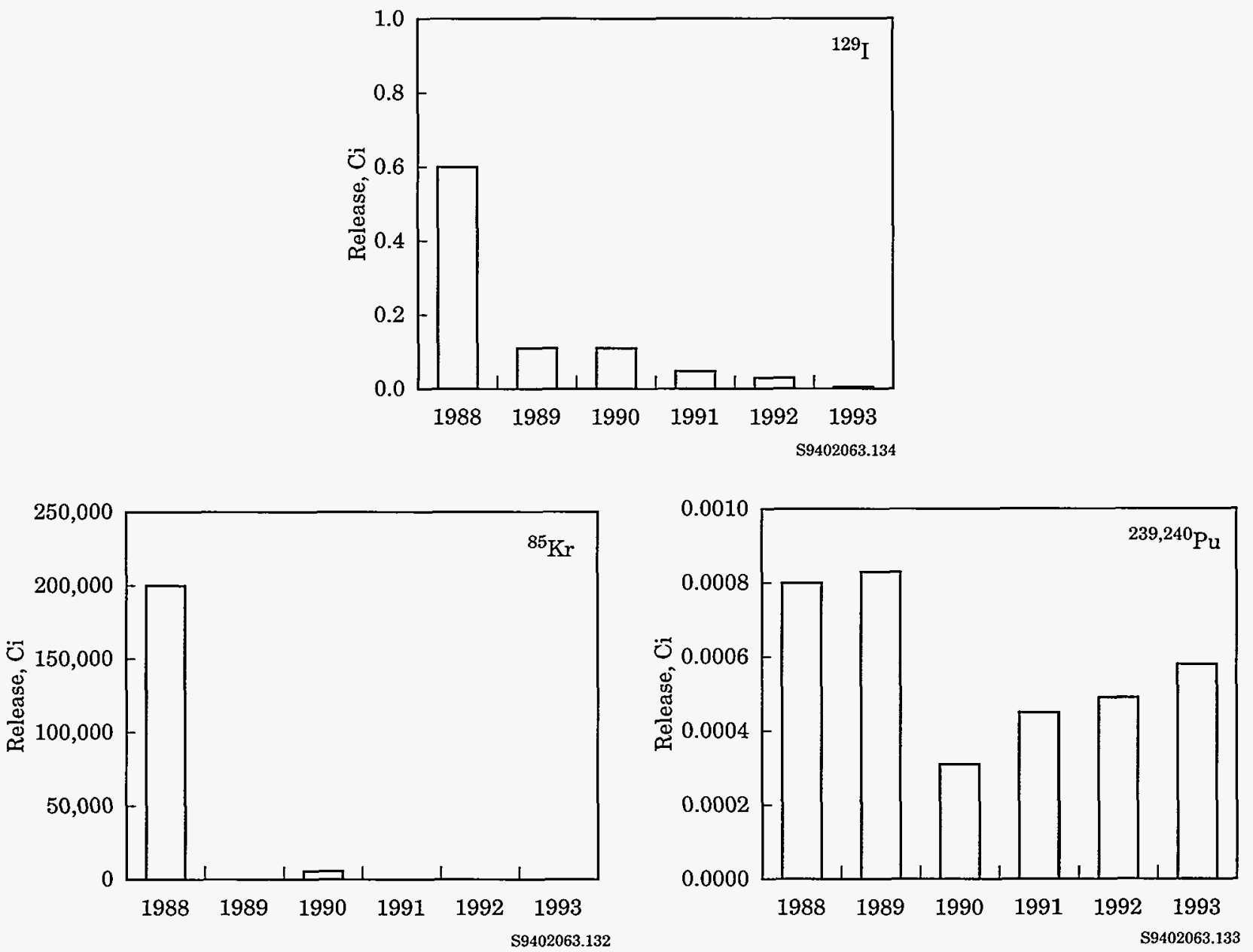

Figure 3.2. Airborne Releases of Selected Radionuclides from Site Facilities, 1988 Through 1993. Releases of ${ }^{85} \mathrm{Kr}$ are zero for 1989 and 1991 through 1993.

contributing radionuclides released from the Site over the past 6 years. In 1993, releases of radioactive and nonradioactive constituents in effluents were less than applicable standards.

Several reports besides this one document effluent release data, and all are available to the public. For instance, the Richland Operations Office annually submits to EPA a report of radioactive airborne emissions from the Site, in compliance with National Emission Standards for Hazardous Air Pollutants. Data quantifying radioactive liquid and airborne effluents discharged from Site facilities and activities are reported each year to the Idaho National Engineering Laboratory by way of the Effluent Information System-Onsite Discharge Information System (DOE 1987a).

Monitoring results for liquid streams regulated by the National Pollutant Discharge Elimination System permit are reported monthly to EPA. Through 1992 , yearly data on nonradioactive emissions from fossil-fuel boilers have been reported to the Benton-Franklin Counties Clean Air Authority. Beginning with data for 1993, the reports are being sent to Ecology.

\section{Airborne Emissions}

\section{Radioactive Airborne Emissions}

Radioactive airborne emissions from Site activities contain at least one of these forms of radionuclides: particles, noble gases, and volatile elements. Emissions having the potential to exceed $1 \%$ of the $10-\mathrm{mrem} / \mathrm{yr}$ standard for offsite doses are continuously monitored. 
Monitoring of radioactive emissions mainly involves analyzing samples collected continuously at points of discharge to the environment, usually a stack or vent. Samples are analyzed for total alpha and total beta activity and selected gamma-emitting radionuclides. Selecting the specific radionuclides that will be sampled, analyzed, and reported is based on 1) an evaluation of emissions expected from known radionuclide inventories in a facility or activity area, 2) sampling criteria given in contractor environmental compliance manuals, and 3) the potential each radionuclide has to contribute to the offsite public dose. Continuous radiation monitoring systems are also used at certain discharge points when a potential exists for emissions to exceed normal operating ranges by amounts requiring immediate personnel alert.

Radioactive emission discharge points are located in the 100, 200, 300, 400, and 600 Areas. The sources for these emissions are summarized below:

- In the 100 Areas, emissions originate from the shutdown N Reactor, the two 100-K Area water-filled storage basins containing irradiated fuel, a recirculation facility that filters radioactive water from the $\mathrm{N}$ Reactor basin which had been used for storage of irradiated fuel, a room used for cleaning contaminated tools and equipment, and a radiochemistry laboratory. Eight radioactive emission points were active during 1993.

- The 200 Areas contain facilities for nuclear-fuel chemical separations, processing, waste-handling and disposal, and steam generation using fossil fuels. Primary sources of radionuclide emissions are the PUREX Plant, the Uranium-Oxide Plant, the Plutonium Finishing Plant, T Plant, the 222-S Analytical Laboratory, underground tanks for storage of highlevel radioactive waste, and waste evaporators. During 1993, 59 radionuclide emission discharge points were active in the 200 Areas.

- The 300 Area primarily contains laboratories, research facilities, and a fossil-fuel-powered steam plant. Primary sources of radionuclide emissions are the 324 Waste Technology Engineering Laboratory, the 325 Applied Chemistry Laboratory, the 327 PostIrradiation Laboratory, and the 340-A Building. Radioactive emissions arise from research and development and waste-handling activities. During 1993, 38 radioactive emission discharge points were active. Releases of ${ }^{220} \mathrm{Rn}$ and ${ }^{222} \mathrm{Rn}$ from a Pacific Northwest Laboratory experiment in the 300 Area are discussed in Section 6.0.
- The 400 Area has the FFTF, the Maintenance and Storage Facility, and the Fuels and Materials Examination Facility. Operations and support activities at FFTF and the Maintenance and Storage Facility released small quantities of radioactive emissions. The 400 Area had four active radioactive emission discharge points during 1993.

- The 600 Area encompasses the remaining portions of the Hanford Site not assigned to other areas. One minor potential radioactive emission discharge point was active during 1993 (the 6652-H Ecology Laboratory on the Fitzner/Eberhardt ALE Reserve).

A summary of radioactive emissions at the Hanford Site in 1993 is given in Table 3.1.

\section{Nonradioactive Airborne Emissions}

Nonradioactive air pollutants emitted from powergenerating and chemical-processing facilities are monitored when activities at a facility are known to potentially generate pollutants of concern. Nitrogen oxides, for instance, would be potentially present in emissions from the Uranium-Oxide Plant should it operate again. If that happens, continuous monitoring for nitrogen oxides would be conducted. This type of monitoring is required by the Prevention of Significant Deterioration permit (No. PSD-X80-14). Operating powerhouses on the Site emit particulate matter, sulfur oxides, nitrogen oxides, volatile organic compounds, carbon monoxide, and lead. The total annual releases of these constituents are reported in accordance with the air quality standards established by Ecology. Powerhouse emissions are calculated from amounts of fossil fuel consumed, using EPA-approved formulas. More applicable coal-fired boiler emission factors were used to calculate 1993 emissions, resulting in an apparent increase in particulate matter and nitrogen oxide emissions when compared to 1992 emissions. Should activities in the 200 Areas lead to chemical emissions in excess of quantities reportable under Superfund, the release totals are reported immediately to EPA, or, with their permission, on an annual basis if emissions remain stable at predicted levels. Table 3.2 summarizes emissions of nonradioactive constituents (the 100,400 , and 600 Areas have no nonradioactive emission sources of concern). 
Table 3.1. Radionuclides Discharged to the Atmosphere, 1993

\begin{tabular}{|c|c|c|c|c|c|c|}
\hline \multirow[b]{2}{*}{ Radionuclide } & \multicolumn{6}{|c|}{ Release, $\mathrm{Ci}^{(\mathrm{a})}$} \\
\hline & Half-Life & 100 Areas & 200-East Area & 200-West Area & 300 Area & 400 Area \\
\hline${ }^{3} \mathrm{H}\left(\right.$ as HTO) ${ }^{(\mathbf{b})}$ & $12.3 \mathrm{yr}$ & $\mathrm{NM}$ & NM & NM & 11 & 2.1 \\
\hline${ }^{3} \mathrm{H}(\text { as } \mathrm{HT})^{(\mathrm{c})}$ & $12.3 \mathrm{yr}$ & $\mathrm{NM}$ & NM & NM & 10 & $\mathrm{NM}$ \\
\hline${ }^{60} \mathrm{Co}$ & $5.3 \mathrm{yr}$ & $5.2 \times 10^{-6}$ & ND & ND & $1.4 \times 10^{-8}$ & $\mathrm{NM}$ \\
\hline${ }^{90} \mathrm{Sr}^{(\mathrm{d})}$ & $21.1 \mathrm{yr}$ & $5.4 \times 10^{-5}$ & $1.4 \times 10^{-4}$ & $1.3 \times 10^{-4}$ & $4.3 \times 10^{-5}$ & NM \\
\hline${ }^{106} \mathrm{Ru}$ & $368 d$ & $1.3 \times 10^{-5}$ & ND & $4.0 \times 10^{-6}$ & ND & $\mathrm{NM}$ \\
\hline${ }^{125} \mathrm{Sb}$ & $2.8 \mathrm{yr}$ & $6.0 \times 10^{-6}$ & ND & ND & $1.5 \times 10^{-6}$ & $\mathrm{NM}$ \\
\hline${ }^{129} \mathrm{I}$ & $1.6 \times 10^{7} \mathrm{yr}$ & $\mathrm{NM}$ & $4.8 \times 10^{-3}$ & NM & NM & NM \\
\hline${ }^{134} \mathrm{Cs}$ & $2.1 \mathrm{yr}$ & $8.9 \times 10^{-8}$ & ND & ND & $3.3 \times 10^{-7}$ & NM \\
\hline${ }^{137} \mathrm{Cs}^{(\mathrm{e})}$ & $30 \mathrm{yr}$ & $1.6 \times 10^{-4}$ & $1.5 \times 10^{-3}$ & $2.3 \times 10^{-4}$ & $9.3 \times 10^{-7}$ & $8.2 \times 10^{-6}$ \\
\hline${ }^{147} \mathrm{Pm}$ & $2.6 \mathrm{yr}$ & ND & $1.1 \times 10^{-4}$ & ND & ND & $\mathrm{NM}$ \\
\hline${ }^{154} \mathrm{Eu}$ & $8.8 \mathrm{yr}$ & $6.3 \times 10^{-6}$ & ND & ND & $1.5 \times 10^{-6}$ & NM \\
\hline${ }^{155} \mathrm{Eu}$ & $5 \mathrm{yr}$ & $2.8 \times 10^{-6}$ & ND & ND & $2.6 \times 10^{-8}$ & NM \\
\hline${ }^{212} \mathrm{~Pb}$ & $10.6 \mathrm{~h}$ & $\mathrm{NM}$ & $9.7 \times 10^{-4}$ & NM & NM & NM \\
\hline${ }^{220} \mathrm{Rn}$ & $56 \mathrm{~s}$ & NM & $12^{(n)}$ & NM & 85 & NM \\
\hline${ }^{222} \mathrm{Rn}$ & $3.8 \mathrm{~d}$ & $\mathrm{NM}$ & NM & NM & 1.5 & $\mathrm{NM}$ \\
\hline $\begin{array}{l}\text { Uranium, } \\
\text { total }\end{array}$ & --- & $\mathrm{NM}$ & NM & $1.7 \times 10^{-5}$ & $3.6 \times 10^{-8(g)}$ & NM \\
\hline${ }^{234} \mathrm{U}$ & $2.4 \times 10^{6} \mathrm{yr}$ & $\mathrm{NM}$ & NM & NM & $5.9 \times 10^{-9}$ & $\mathrm{NM}$ \\
\hline${ }^{235} \mathrm{U}$ & $7 \times 10^{8} \mathrm{yr}$ & $\mathrm{NM}$ & NM & NM & $6.2 \times 10^{-10}$ & $\mathrm{NM}$ \\
\hline${ }^{238} \mathrm{U}$ & $4.5 \times 10^{9} \mathrm{yr}$ & $\mathrm{NM}$ & NM & NM & $5.9 \times 10^{-9}$ & $\mathrm{NM}$ \\
\hline${ }^{238} \mathrm{Pu}$ & $87.7 \mathrm{yr}$ & $1.0 \times 10^{-6}$ & $3.2 \times 10^{-6}$ & ND & NM & $\mathrm{NM}$ \\
\hline${ }^{239.240} \mathrm{Pu}^{(\mathrm{h})}$ & $2.4 \times 10^{4} \mathrm{yr}$ & $8.2 \times 10^{\cdot 6}$ & $1.1 \times 10^{-5}$ & $5.5 \times 10^{-4}$ & $7.0 \times 10^{-6}$ & $2.4 \times 10^{-6}$ \\
\hline${ }^{241} \mathrm{Pu}$ & $14.4 \mathrm{yr}$ & $\mathrm{NM}$ & $3.3 \times 10^{-5}$ & $3.4 \times 10^{-3}$ & NM & $\mathrm{NM}$ \\
\hline${ }^{241} \mathrm{Am}$ & $432 \mathrm{yr}$ & $5.4 \times 10^{-6}$ & $2.8 \times 10^{-5}$ & $9.9 \times 10^{-5}$ & $5.5 \times 10^{-8}$ & NM \\
\hline
\end{tabular}

(a) $1 \mathrm{Ci}=3.7 \times 10^{10} \mathrm{~Bq} ; \mathrm{NM}=$ not measured; $\mathrm{ND}=$ none detected.

(b) $\mathrm{HTO}=$ tritiated water vapor.

(c) $\mathrm{HT}=$ elemental tritium.

(d) ${ }^{90} \mathrm{Sr}$ values in the 200 and 300 Areas include total beta measurements for facilities from which samples are not analyzed for ${ }^{90} \mathrm{Sr}$. Also factored into this value was a small total beta release from a single emission point in the 600 Area.

(e) ${ }^{137} \mathrm{Cs}$ value for the 400 Area is derived fully from total beta measurements.

(f) ${ }^{220} \mathrm{Rn}$ value is calculated from ${ }^{212} \mathrm{~Pb}$ measurements.

(g) Uranium value is derived fully from total alpha measurements for facilities at which processes involving plutonium have not occurred and analysis for uranium is not done.

(h) Except for the 100 Areas, ${ }^{239,240} \mathrm{Pu}$ values include total alpha measurements for facilities from which samples are not analyzed for ${ }^{239,240} \mathrm{Pu}$. Also factored into this value was a small total alpha release from a single emission point in the 600 Area. 
Table 3.2. Nonradioactive Constituents Discharged to the Atmosphere, $1993^{(a)}$

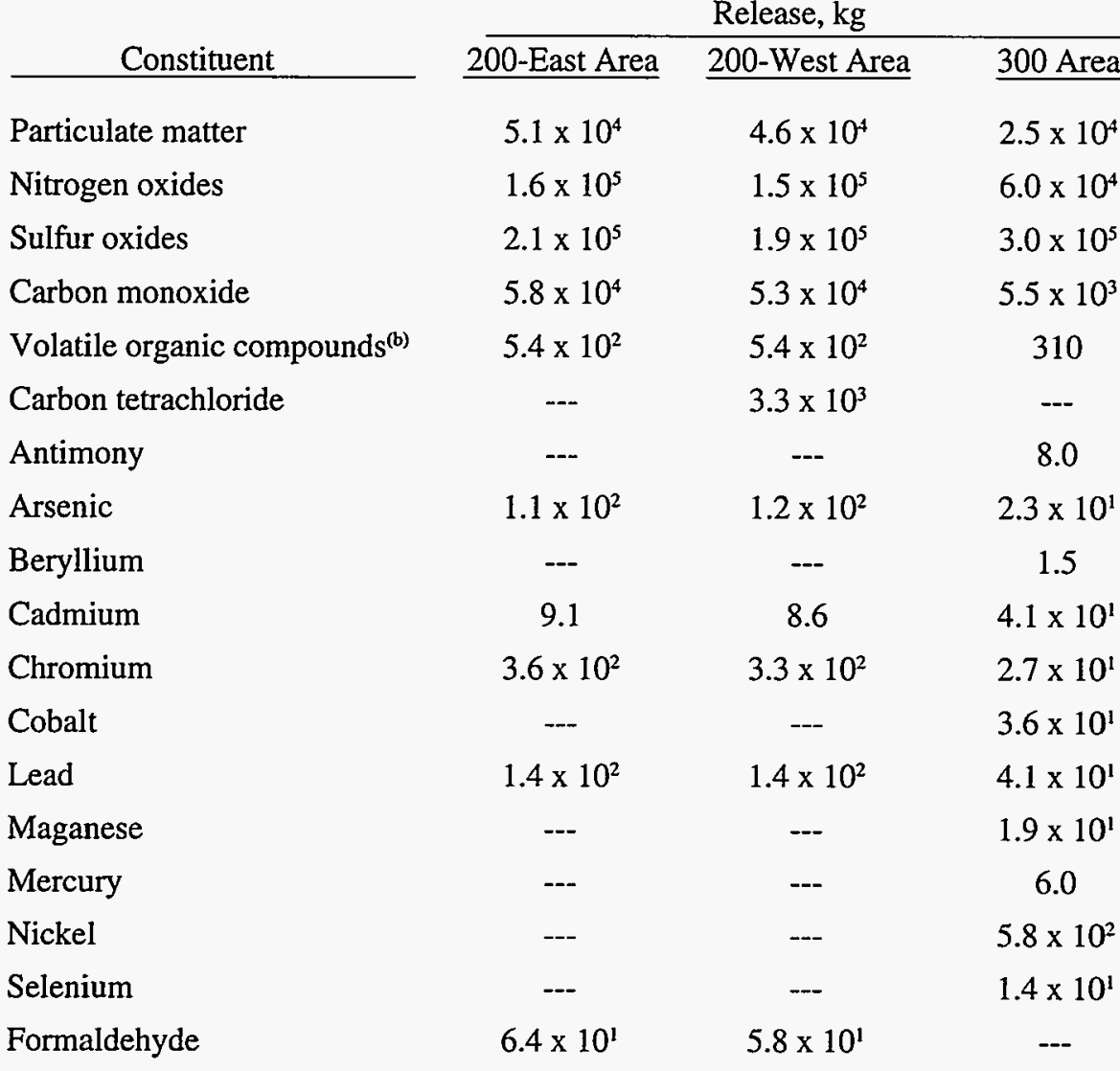

(a) The estimates of volatile organic compound emissions do not include emissions from certain laboratory operations.

(b) From steam generation using fossil fuels.

\section{Liquid Effluents}

\section{Radioactive Liquid Effluents}

Liquid effluents are discharged from facilities in all areas of the Hanford Site. Effluents that normally or potentially contain radionuclides include cooling water, steam condensates, process condensates, laundry waste water, and waste water from laboratories and chemical sewers. These waste-water streams are sampled and analyzed for total alpha and total beta activity and selected radionuclides.

A summary of radioactive liquid effluents discharged to ground disposal facilities in 1993 is given in Table 3.3. Table 3.4 summarizes data on radionuclides released from the 100 Areas to the Columbia River. Releases entering the river via ground water are not measured directly but are assessed through river water environmental surveillance (Section 5.3). These measurements are used with the direct effluent measurements in determining potential public doses.

\section{Nonradioactive Hazardous Constituents in Potentially Radioactive Liquid Effluents}

Nonradioactive hazardous constituents in potentially radioactive liquid effluents are monitored in the 100 , 200,300 , and 400 Areas. These effluents are typically discharged to cribs, ponds, ditches, trenches, and the Columbia River. Effluents entering the Columbia River 
Table 3.3. Radionuclides in Liquid Effluents Discharged to Ground Disposal Facilities, 1993

\begin{tabular}{|c|c|c|c|}
\hline \multirow[b]{2}{*}{ Radionuclide } & \multicolumn{3}{|c|}{ Release, $\mathrm{Ci}^{(\mathrm{a})}$} \\
\hline & Half-Life & 200 Areas & 300 Area \\
\hline${ }^{3} \mathrm{H}$ & $12.3 \mathrm{yr}$ & 15 & NM \\
\hline${ }^{90} \mathrm{Sr}$ & $21.1 \mathrm{yr}$ & 0.071 & $0.022^{(b)}$ \\
\hline${ }^{99} \mathrm{Tc}$ & $2.1 \times 10^{5} \mathrm{yr}$ & 0.048 & NM \\
\hline${ }^{137} \mathrm{Cs}$ & $30 \mathrm{yr}$ & 0.22 & NM \\
\hline Uranium, total & --- & 0.0017 & $0.052^{(\mathrm{c})}$ \\
\hline${ }^{238} \mathrm{Pu}$ & $87.7 \mathrm{yr}$ & 0.0014 & NM \\
\hline${ }^{239.240} \mathrm{Pu}$ & $2.4 \times 10^{4} \mathrm{yr}$ & 0.1 & NM \\
\hline${ }^{241} \mathrm{Pu}$ & $14.4 \mathrm{yr}$ & 0.024 & NM \\
\hline${ }^{241} \mathrm{Am}$ & $432 \mathrm{yr}$ & 0.14 & NM \\
\hline
\end{tabular}

(a) $1 \mathrm{Ci}=3.7 \times 10^{10} \mathrm{~Bq} ; \mathrm{NM}=$ not measured.

(b) Reported as total beta; assumed to be ${ }^{90} \mathrm{Sr}$ for dose calculations.

(c) Reported as total alpha; assumed to be uranium, total, for dose calculations.

at designated discharge points are sampled and analyzed to determine compliance with the National Pollutant Discharge Elimination System permit for the Site. In the 200 Areas, should chemicals in liquid effluents exceed a quantity reportable under Superfund, a report is made immediately to EPA, or, with their permission, on an annual basis if the discharges remain stable at predicted levels.

Liquid effluents containing both radioactive and hazardous constituents are stored at the 200 Areas in underground waste storage tanks or monitored interimstorage facilities. Activities in the 600 and 1100 Areas generate neither radioactive nor nonradioactive hazardous liquid effluents.

\section{Chemical Releases}

Releases of hazardous substances exceeding certain quantities but that are continuous and stable in quantity and rate must be reported as required by Section 103(f)(2) of the CERCLA as amended. In past years, gaseous ammonia has been emitted from the PUREX Plant and the 241-AP and 241-AW Tank Farms. Ammonium hydroxide from the 242-A Evaporator was also emitted in that period. Emissions are monitored for those compounds only when activities at a facility could generate them. None of these compounds was generated above reportable quantities in 1993.

Table 3.4. Radionuclides in Liquid Effluents Discharged to the Columbia River from the 100 Areas, 1993

\begin{tabular}{|c|c|c|}
\hline Radionuclide & Half-Life & Release, $\mathrm{Ci}^{(\mathrm{a})}$ \\
\hline${ }^{3} \mathrm{H}$ & $12.3 \mathrm{yr}$ & 0.38 \\
\hline${ }^{60} \mathrm{Co}$ & $5.3 \mathrm{yr}$ & 0.0036 \\
\hline${ }^{90} \mathrm{Sr}$ & $21.1 \mathrm{yr}$ & 0.11 \\
\hline${ }^{106} \mathrm{Ru}$ & $368 d$ & 0.0016 \\
\hline${ }^{125} \mathrm{Sb}$ & $2.8 \mathrm{yr}$ & 0.00013 \\
\hline${ }^{134} \mathrm{Cs}$ & $2.1 \mathrm{yr}$ & 0.000047 \\
\hline${ }^{137} \mathrm{Cs}$ & $30 \mathrm{yr}$ & 0.00044 \\
\hline${ }^{239.240} \mathrm{Pu}$ & $2.4 \times 10^{4} \mathrm{yr}$ & $1.4 \times 10^{-7}$ \\
\hline
\end{tabular}

(a) $1 \mathrm{Ci}=3.7 \times 10^{10} \mathrm{~Bq}$. 


\title{
3.2 Near-Facility Environmental Monitoring
}

\author{
J. W. Schmidt, A. R. Johnson, S. M. McKinney, and C. J. Perkins
}

Several types of environmental media are sampled near nuclear facilities to monitor the effectiveness of waste management, and effluent treatment and control practices. These media include air, surface water and seeps, surface contamination, soil and vegetation, investigative sampling (which can include wildlife), and external radiation. Sampling and analysis information, and analytical results, for 1993 for each of these media are summarized below. Additional information may be found in Westinghouse Hanford Company Operational Environmental Monitoring Annual Report, Calendar Year 1993 (Schmidt et al. 1994).

\section{Near-Facility Environmental Monitoring at Hanford}

Near-facility environmental monitoring is defined principally as routine monitoring near facilities discharging or having discharged radioactive or hazardous contaminants. The monitoring locations are associated mostly with major nuclear facilities, such as the PUREX Plant and $\mathrm{N}$ Reactor, and waste disposal facilities, such as burial grounds, tank farms, ponds, cribs, trenches, and ditches.

Much of the program consists of collecting and analyzing environmental samples and methodically surveying areas near facilities releasing effluents and waste streams. The program also evaluates acquired analytical data, determines the effectiveness of facility effluent monitoring and controls, measures the adequacy of containment at waste disposal units, and detects and monitors unusual conditions. The program implements applicable portions of DOE Orders 5400.1, 5484.1, 5400.5, and $5820.2 \mathrm{~A}$.
Monitoring activities routinely include sampling and monitoring near-facility ambient air, water from surfacewater disposal units, external radiation dose, soil, sediment (both surface and core), vegetation, and animals. Some of the parameters typically monitored are $\mathrm{pH}$, radionuclide concentrations, radiation exposure, and hazardous constituents. Samples are collected in known or expected effluent pathways. These pathways generally are downwind of potential or actual airborne releases and downgradient of liquid discharges. The annual routine activities of near-facility monitoring are summarized in Table 3.5, which shows the type, quantity, and location of samples collected. A detailed discussion of results for ground-water wells used specifically to monitor operating facilities may be found in Westinghouse Hanford Company Operational Groundwater Status Report (Johnson 1993).

Waste disposal sites and the terrain surrounding them are surveyed to detect and characterize any radioactive surface contamination. The location of these surveys include cribs, trenches, retention basin perimeters, pond perimeters, ditch banks, solid waste disposal sites (for example, burial grounds, trenches), unplanned release sites, tank farm perimeters, stabilized waste disposal sites, roads, and firebreaks in and around the Site operational areas. In 1993, radiological surveys were conducted at 411 sites in the operational areas (100 in 100 Areas; 297 in the 200 and 600 Areas; and 14 in the 300 and 400 Areas) (DOE 1991a).

\section{Air Monitoring}

Near-facility air sampling monitors the effectiveness of waste management, and effluent treatment and controls in reducing effluents and emissions; these systems also monitor diffuse source emissions. 
Table 3.5. Near-Facility Routine Environmental Samples and Locations, 1993

\begin{tabular}{|c|c|c|c|c|}
\hline Samples & Total & 100 Areas & 200/600 Areas & $300 / 400$ Areas \\
\hline Air & 38 & 4 & 34 & 0 \\
\hline Surface water & 17 & 7 & 10 & 0 \\
\hline External radiation & 286 & $213^{(a)}$ & 58 & 15 \\
\hline Soil & 156 & 31 & 110 & 15 \\
\hline Vegetation & 94 & 39 & 40 & 15 \\
\hline
\end{tabular}

(a) 41 thermoluminescent dosimeters and 172 survey points.

\section{Sample Collection and Analysis}

Radioactivity in air was sampled by a network of continuously operated samplers at 38 locations near nuclear facilities: 4 located in the 100-N Area, 31 in the 200/ 600 Areas, 2 background stations collocated with samplers operated by the Surface Environmental Surveillance Project and the Washington State Department of Health at the Wye and Yakima Barricades, and 1 background. station collocated with a sampler operated by the Washington State Department of Health at the old Hanford townsite. To avoid duplication of sampling, the nearfacility environmental monitoring program used existing Surface Environmental Surveillance Project air samplers in the 300 and 400 Areas. Results for these areas are reported in Section 5.2, "Air Surveillance," and are not discussed here. Air samplers were primarily located at or near (approximately $500 \mathrm{~m}$ or $1500 \mathrm{ft}$ ) sites and/or facilities having the potential for, or history of, release, with an emphasis on the prevailing downwind directions.

Samples were collected according to a schedule established before the monitoring year. Airborne particles were sampled at each of these stations by drawing air through a glass-fiber filter. The filters were collected biweekly, field-surveyed for gross radioactivity to detect any unusual trends or off-normal occurrences, held for at least 7 days, and then analyzed for total alpha and beta activity. The 7-day holding period was necessary to allow for the decay of naturally occurring radionuclides that would otherwise obscure detection of longer-lived radionuclides associated with emissions from nuclear facilities. The total radioactivity measurements were used to indicate changes in trends in the near-facility environment.
For most radionuclides, the amount of radioactive material collected on a single filter during a 2-week sampling period was too small to be measured accurately. The accuracy of the sample analysis was increased by compositing the samples into a biannual composite for each location. Each biannual composite was then sent to International Technology Corporation, Inc. (Richland, Washington), to be analyzed for strontium, plutonium, uranium, and gamma-emitting radionuclides.

\section{Results}

Of the radionuclide analyses performed, ${ }^{90} \mathrm{Sr},{ }^{137} \mathrm{Cs}$, ${ }^{239,240} \mathrm{Pu}$, and uranium were consistently detectable in the 200 Areas; ${ }^{60} \mathrm{Co}$ was detectable in the $100-\mathrm{N}$ Area. Air concentrations for these radionuclides were elevated near facilities when compared to the concentrations measured offsite. Figure 3.3 shows average values for 1993 and the preceding 5 years for selected radionuclides compared to the Derived Concentration Guides as reference values to be used as indexes of performance and the background air concentration as measured by the Surface Environmental Surveillance Project. As the data indicate, the concentrations show a large degree of variability. In general, the samples collected from air samplers located at or directly adjacent to waste disposal and other nuclear facilities had significantly higher concentrations than those farther away. The data also show, as expected, that certain radionuclides had higher concentrations within different operational areas. Generally speaking, the predominant radionuclides are activation products (i.e., gamma emitters) in the 100 Areas and fission products in the 200/600 Areas. A more detailed data summary is provided by Schmidt et al. (1994). 

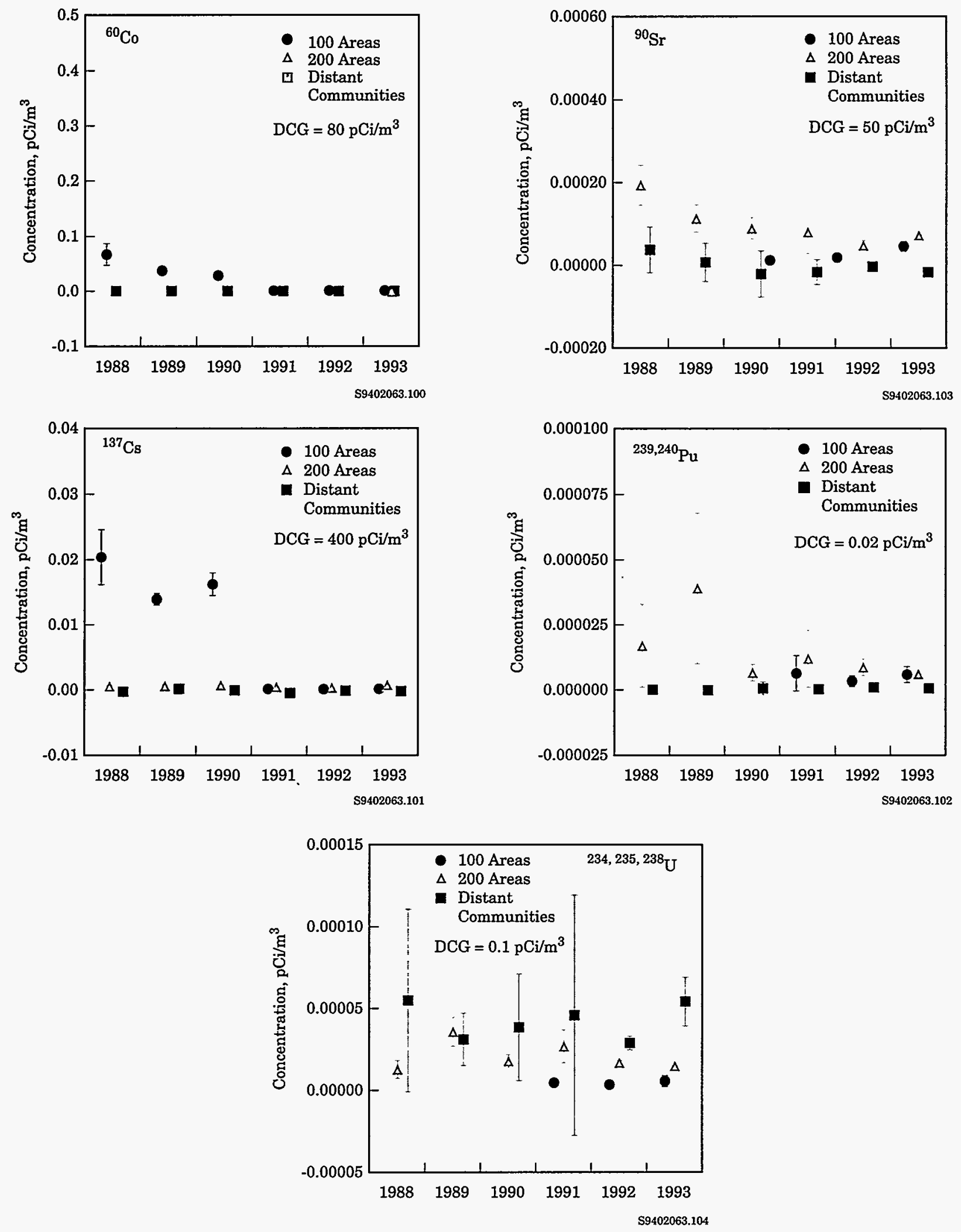

Figure 3.3. Concentrations ( \pm 2 SEM) of Selected Radionuclides in Near-Facility Air Samples Compared to Those in Distant Communities, 1988 Through 1993. As a result of figure scale, some uncertainties (error bars) are concealed by point symbol. 


\section{0-N Area}

Analytical results from air samples taken in the $100-\mathrm{N}$ Area were on a downward trend for most radionuclides as a result of facility shutdowns, better effluent controls, and improved waste management practices. These levels were much less than the Derived Concentration Guides; however, they were greater than levels measured offsite.

\section{Areas}

Analytical results from air samples taken in the 200/ 600 Areas were on a downward trend for most radionuclides as a result of facility shutdowns, better effluent controls, and improved waste management practices. These levels, although much less than the Derived Concentration Guides, were greater than levels measured offsite and were higher for ${ }^{90} \mathrm{Sr},{ }^{239.240} \mathrm{Pu}$, and uranium when compared to levels in the $100-\mathrm{N}$ Area.

\section{Surface-Water Disposal Units and Seep Monitoring}

Surface-water disposal units (open ponds and ditches) used by the operating facilities, and seeps, are monitored to assess the effectiveness of effluent and contamination controls.

\section{Sample Collection and Analysis}

Samples from surface-water disposal units and Columbia River shoreline seeps were collected from various locations in the operational areas. A more detailed description of sample locations is given by Schmidt et al. (1994). Sampling of surface-water disposal units included water, sediment, and aquatic vegetation. Samples taken at river shoreline seeps included water only. The sampling methods are discussed in detail in the manual Operational Environmental Monitoring (WHC 1991b). To avoid duplication of sampling, the nearfacility environmental monitoring program used surfacewater sample data collected by the Surface Environmental Surveillance Project for the 400 Area. Results are reported in Section 5.3, "Surface-Water Surveillance," and are not discussed here.
Radiological analysis of water samples from surfacewater disposal units included total alpha, total beta, ${ }^{3} \mathrm{H}$, ${ }^{239.240} \mathrm{Pu}$, and gamma-emitting radionuclides. Alpha and beta measurements provided a general indication of radionuclide contamination. Radiological analysis of sediment and aquatic vegetation included ${ }^{90} \mathrm{Sr},{ }^{239,240} \mathrm{Pu}$, uranium, and gamma-emitting radionuclides. Nonradiological analysis performed included $\mathrm{pH}$, temperature, and nitrates. Analytes of interest were selected based on their presence in effluent discharges and their importance in verifying effluent control and determining compliance with applicable effluent discharge standards. Surfacewater disposal units that received potentially radioactively contaminated effluents were within posted radiological control areas.

\section{Radiological Results}

\section{Surface-Water Disposal Units}

Radiological analytical results for individual surfacewater disposal units (ponds and ditches) located in the 200 Areas are summarized in Table 3.6. In all cases, radionuclide concentrations in surface-water disposal units were less than the applicable Derived Concentration Guides as reference values to be used as indexes of performance, and in most cases equal to or less than the analytical detection limit.

Radiological analytical results for aquatic vegetation and sediment (surface and core) samples taken from surfacewater disposal units located in the 200 Areas are summarized in Tables 3.7 and 3.8, respectively. Although some elevated levels can be seen in both aquatic vegetation and sediment, in all cases the radiological analytical results were much less than the standards for radiological control.

A more detailed data summary for samples taken to monitor surface-water disposal units is provided by Schmidt et al. (1994).

\section{Seeps}

Radioactive effluent streams sent to the $1325-\mathrm{N}$ Liquid Waste Disposal Facility in the 100-N Area contribute to the release of radionuclides to the Columbia River through their migration with the ground water. Releases into the river are calculated based on the analysis of 
Table 3.6. Radiological Results for Liquid Samples from Surface-Water Disposal Units ( $\mathrm{pCi} / \mathrm{L})$, 200 Areas, 1993

\begin{tabular}{|c|c|c|c|c|c|c|c|}
\hline Sample Locations ${ }^{(a)}$ & $\begin{array}{c}\text { No. of } \\
\text { Samples }\end{array}$ & & Total Alpha & Total Beta & ${ }^{3} \mathrm{H}$ & ${ }^{90} \mathrm{Sr}$ & ${ }^{137} \mathrm{Cs}$ \\
\hline \multirow[t]{2}{*}{ 200-West Area Ditches } & 24 & Mean & 0.05 & 50 & 1,700 & 7.1 & 35 \\
\hline & & Maximum & 1.6 & 98 & 7,000 & 13 & 43 \\
\hline \multirow[t]{2}{*}{ 200-West Area Ponds } & 24 & Mean & 0.6 & 19 & $450^{(b)}$ & 6.1 & 35 \\
\hline & & Maximum & 5.1 & 290 & 450 & 9.9 & 36 \\
\hline \multirow[t]{2}{*}{ 200-East Area Ditch } & 12 & Mean & 1.2 & 3.2 & 450 & 6.8 & 34 \\
\hline & & Maximum & 9.5 & 36 & 450 & 9.6 & 36 \\
\hline \multirow[t]{3}{*}{ 200-East Area Ponds } & 60 & Mean & 0.5 & 5.6 & 800 & 6.2 & 34 \\
\hline & & Maximum & 4.5 & 290 & 2,300 & 10 & 49 \\
\hline & & $\mathrm{DCG}^{(\mathrm{c})}$ & $30^{(d)}$ & $1,000^{(e)}$ & $2,000,000$ & 1,000 & 3,000 \\
\hline
\end{tabular}

(a) 200-West Area Ditches: 216-T-4, 216-U-14.

200-West Area Ponds: $\quad 216-Z-21$ Basin, Powerhouse Pond.

200-East Area Ditch: 216-B-3-3.

200-East Area Ponds: $\quad$ 216-B-3 (East), 216-B-3 (South), 216-B-3A, 216-B-3C, Powerhouse Pond.

(b) The detection limit for ${ }^{3} \mathrm{H}$ is $450 \mathrm{pCi} / \mathrm{L}$.

(c) $\mathrm{DCG}=$ Derived Concentration Guide (see Appendix C)

(d) Using ${ }^{239} \mathrm{Pu}$ DCG for comparison.

(e) Using ${ }^{90} \mathrm{Sr} \mathrm{DCG}$ for comparison.

Table 3.7. Radiological Results for Aquatic Vegetation Samples from Surface-Water Disposal Units (pCi/g), 200 Areas, 1993

\begin{tabular}{|c|c|c|c|c|c|c|}
\hline Sample Locations ${ }^{(a)}$ & $\begin{array}{c}\text { No. of } \\
\text { Samples }\end{array}$ & & ${ }^{90} \mathrm{Sr}$ & ${ }^{137} \mathrm{Cs}$ & ${ }^{239.240} \mathrm{Pu}$ & U total \\
\hline \multirow[t]{2}{*}{ 200-West Area Ditches } & 2 & Mean & 0.56 & 4.0 & 0.001 & 0.007 \\
\hline & & Maximum & 0.96 & 5.3 & 0.001 & 0.007 \\
\hline \multirow[t]{2}{*}{ 200-West Area Ponds } & 2 & Mean & 0.07 & 0.03 & 0.004 & 0.003 \\
\hline & & Maximum & 0.09 & 0.03 & 0.007 & 0.004 \\
\hline 200-East Area Ditch & 1 & Maximum & 0.7 & 2.0 & $N^{(b)}$ & NR \\
\hline \multirow[t]{2}{*}{ 200-East Area Ponds } & 5 & Mean & 0.35 & 0.96 & 0.0003 & 0.004 \\
\hline & & Maximum & 0.98 & 2.9 & 0.0007 & 0.007 \\
\hline
\end{tabular}

(a) 200-West Area Ditches: 216-T-4, 216-U-14.

200-West Area Ponds: $216-Z-21$ Basin, Powerhouse Pond.

200-East Area Ditch: $\quad$ 216-B-3-3.

200-East Area Ponds: $\quad$ 216-B-3 (East), 216-B-3 (South), 216-B-3A, 216-B-3C, Powerhouse Pond.

(b) $\mathrm{NR}=$ not reported. 
Table 3.8. Radiological Results for Sediment (Surface and Core) Samples from Surface-Water Disposal Units (pCi/g), 200 Areas, 1993

\begin{tabular}{|c|c|c|c|c|c|c|}
\hline Sample Locations ${ }^{(a)}$ & $\begin{array}{c}\text { No. of } \\
\text { Samples }\end{array}$ & & ${ }^{90} \mathrm{Sr}$ & ${ }^{137} \mathrm{Cs}$ & ${ }^{239,240} \mathrm{Pu}$ & $U$ total \\
\hline \multicolumn{7}{|l|}{ Surface } \\
\hline \multirow[t]{2}{*}{ 200-West Area Ditches } & 2 & Mean & 0.17 & 66 & 0.53 & 25 \\
\hline & & Maximum & 0.22 & 95 & 0.54 & 50 \\
\hline \multirow[t]{2}{*}{ 200-West Area Ponds } & 2 & Mean & 0.03 & 0.24 & 0.34 & 0.64 \\
\hline & & Maximum & 0.05 & 0.34 & 0.54 & 0.83 \\
\hline 200-East Area Ditch & 1 & Maximum & 0.06 & 8.5 & 1.0 & 0.57 \\
\hline \multirow[t]{2}{*}{ 200-East Area Ponds } & 5 & Mean & 0.03 & 38 & 4.1 & 1.9 \\
\hline & & Maximum & 0.05 & 150 & 18 & 4.4 \\
\hline \multicolumn{7}{|l|}{ Core } \\
\hline \multirow[t]{2}{*}{ 200-West Area Ditches } & 2 & Mean & 0.18 & 50 & 0.25 & 5 \\
\hline & & Maximum & 0.23 & 65 & 0.26 & 10 \\
\hline \multirow[t]{2}{*}{ 200-West Area Ponds } & 2 & Mean & 0.05 & 0.15 & 0.08 & 1.2 \\
\hline & & Maximum & 0.09 & 0.26 & 0.12 & 2.0 \\
\hline 200-East Area Ditch & 1 & Maximum & 0.38 & 35 & 2.1 & 0.95 \\
\hline \multirow{2}{*}{ 200-East Area Ponds } & 5 & Mean & 0.18 & 42 & 6.0 & 1.2 \\
\hline & & Maximum & 0.46 & 100 & 21 & 2.5 \\
\hline
\end{tabular}

(a) 200-West Area Ditches: 216-T-4, 216-U-14.

200-West Area Ponds: $216-Z-21$ Basin, Powerhouse Pond.

200-East Area Ditch: $\quad 216-B-3-3$.

200-East Area Ponds: $\quad$ 216-B-3 (East), 216-B-3 (South), 216-B-3A, 216-B-3C, Powerhouse Pond.

weekly samples collected from a monitoring well located near the shoreline. Radionuclides enter the Columbia River along the riverbank region known as the N Springs. A more detailed discussion of this subject may be found in the report, Environmental Releases for Calendar Year 1993 (Curn and Thomas 1994).

Ground-water seeps along the 100-N Area shoreline are sampled annually to verify that the reported radionuclide releases to the Columbia River from the past operation of the N Reactor are conservative. Release reporting utilizes conservatively based radionuclide concentrations in samples collected from the facility effluent monitoring well, multiplied by the estimated ground-water discharge into the river. The $\mathrm{N}$ Springs ground-water flow rate was estimated using a computer model developed by Gilmore et al. (1992). The estimated ground-water flow rate used to calculate 1993 releases from N Springs was 10 gallons per minute $(38 \mathrm{~L} / \mathrm{min})$. By characterizing the radionuclide concentrations in the seeps along the shoreline, these results can then be compared to the concentrations measured in the facility effluent monitoring well ensuring that the effluent monitoring well is located in the ground-water migration route that contains the highest concentrations of radionuclides.

In 1993, the concentrations detected in the seep samples were highest in seeps nearest the facility effluent monitoring well, although seep concentrations were

Table 3.9. Concentrations ( $\mathrm{pCi} / \mathrm{L}$ ) of Radionuclides in 100-N Area Columbia River Shoreline Seeps, 1993

\begin{tabular}{|c|c|c|c|c|}
\hline \multirow[b]{2}{*}{ Radionuclide } & \multirow{2}{*}{$\begin{array}{c}\text { Facility } \\
\text { Effluent } \\
\text { Monitoring Well } \\
(09 / 08 / 93)\end{array}$} & \multicolumn{3}{|c|}{ Seeps } \\
\hline & & Maximum & Mean & $\mathrm{DCG}^{(2)}$ \\
\hline${ }^{3} \mathrm{H}$ & 27,000 & 560 & 232 & $2,000,000$ \\
\hline${ }^{60} \mathrm{Co}$ & $<2.8$ & 1.6 & 0.8 & 5,000 \\
\hline${ }^{90} \mathrm{Sr}$ & 7,400 & 410 & 113 & 1,000 \\
\hline
\end{tabular}

(a) $\mathrm{DCG}=$ Derived Concentration Guide (see Appendix C). 
considerably lower than those measured in the well. The data from seep sampling are summarized in Table 3.9. A more detailed data summary is provided by Schmidt et al. (1994).

\section{Nonradiological Results for Surface-Water Disposal Units}

Nonradiological analytical results for water samples taken from surface-water disposal units located in the 200 Areas are summarized in Table 3.10. The results for $\mathrm{pH}$ were well within the $\mathrm{pH}$ standard of 2.0 to 12.5 for liquid effluent discharges based on the discharge limits listed in RCRA. The analytical results for nitrates were all less than the detection limit of $1.4 \mathrm{mg} / \mathrm{L}$ and less than the 45-mg/L Drinking Water Standard for public water supplies.

\section{Radiological Surveys}

Another aspect of the near-facility environmental monitoring program is radiological surveying, which monitors and helps direct the reduction of the radiologically controlled areas on the Hanford Site. There are two types of posted radiological controlled areas: underground radioactive materials and surface contamination areas.
Underground radioactive material areas are posted areas with contamination contained below the soil surface. These areas are typically "stabilized" cribs, burial grounds, and covered ponds, trenches, and ditches. Barriers over the contamination sources are used to inhibit radionuclide transport to the surface environs. These areas are routinely surveyed (at least annually) to document the current radiological status.

Surface contamination areas may or may not have been associated with an underground radioactive material structure. A breech in the barrier of an underground radioactive materials area may have resulted in the growth of contaminated vegetation. Insects or animals might have burrowed into an underground radioactive materials area and brought contamination to the surface. Vent pipes or risers from an underground structure could have been a source of speck contamination. Fallout from stacks, or unplanned releases from previously operating facilities, may have caused an area of surface contamination that was not related to a subsurface structure. All types of surface contamination areas are susceptible to contamination migration. Surface contamination areas are routinely surveyed (at least annually) to document the current radiological status.

There were approximately 1,200 ha (3,000 acres) of posted outdoor surface contamination areas and 400 ha (1,000 acres) of posted underground radioactive materials areas, not including active facilities, at Hanford.

Table 3.10. Nonradiological Results for Liquid Samples from Surface-Water Disposal Units, 1993

\begin{tabular}{|c|c|c|c|c|c|c|c|}
\hline \multirow[b]{2}{*}{ Sample Locations ${ }^{(a)}$} & \multicolumn{4}{|c|}{$\mathrm{pH}$} & \multicolumn{3}{|c|}{ Nitrate $\left(\mathrm{NO}_{3}\right), \mathrm{mg} / \mathrm{L}$} \\
\hline & $\begin{array}{l}\text { No. of } \\
\text { Samples } \\
\end{array}$ & Mean & $\underline{\text { Maximum }}$ & $\underline{\text { Minimum }}$ & $\begin{array}{l}\text { No. of } \\
\text { Samples }\end{array}$ & Mean & $\underline{\text { Maximum }}$ \\
\hline 200-West Area Ditches & 102 & 7.4 & 8.5 & 5.8 & 8 & $<1.4$ & $<1.4$ \\
\hline 200-West Area Ponds & 98 & 8.4 & 10.1 & 4.5 & 8 & $<1.4$ & $<1.4$ \\
\hline 200-East Area Ditch & 53 & 8.4 & 8.5 & 7.0 & 4 & $<1.4$ & $<1.4$ \\
\hline 200-East Area Ponds & 263 & 8.6 & 9.5 & 7.3 & 20 & $<1.4$ & $<1.4$ \\
\hline $\begin{array}{l}\text { (a) 200-West Area Ditches: } \\
\text { 200-West Area Ponds: } \\
\text { 200-East Area Ditch: } \\
\text { 200-East Area Ponds: }\end{array}$ & $\begin{array}{l}216-\mathrm{T}-\mathrm{C} \\
216-\mathrm{Z}-2 \\
216-\mathrm{B}-3 \\
216-\mathrm{B}-3\end{array}$ & $\begin{array}{l}\text { Bas-U-1 } \\
\text { Basin, } \mathrm{P} \\
\text { East), } 21\end{array}$ & $\begin{array}{l}\text { erhouse } P \\
\text {-3 (South }\end{array}$ & $216-\mathrm{B}-3 \mathrm{~A}, 2$ & $-3 C$, Po & louse Po & \\
\hline
\end{tabular}


Table 3.11. Outdoor Contamination Status, 1993 (approximate surface area in acres)

\begin{tabular}{|c|c|c|c|c|}
\hline Hanford Site Area & Surface Contamination $^{(a)}$ & $\begin{array}{c}\text { Net } \\
\text { Change( }^{(b)}\end{array}$ & $\begin{array}{c}\text { Underground } \\
\text { Radioactive Material }^{(\mathrm{c})}\end{array}$ & $\begin{array}{c}\text { Net } \\
\text { Change }\end{array}$ \\
\hline 100 Areas & 160 & 0 & 460 & 0 \\
\hline 200 Areas & $318^{(d)}$ & -11 & 380 & 14 \\
\hline 600 Area & $127^{(\mathrm{d})}$ & 7 & 230 & 0 \\
\hline BC Control Area & $2,500^{(e)}$ & 0 & 30 & 0 \\
\hline 300 Area & 45 & 0 & 30 & 0 \\
\hline Totals & 3,150 & -4 & 1,130 & 14 \\
\hline
\end{tabular}

(a) Includes areas posted as "Surface Contamination Areas" or as "Radiologically Controlled Areas" and areas that had both underground and surface contamination.

(b) $-=$ decreases.

(c) Includes areas with only underground contamination. Does not include areas that had surface as well as underground radioactive material.

(d) The change reflects contamination migration to previously uncontaminated areas.

(e) Radiologically Controlled Area.

The number of acres of surface contamination areas was three times larger than the underground radioactive materials acres primarily because of the $\mathrm{BC}$ Controlled Area located south of the 200-East Area. This area was posted as a Radiologically Controlled Area in 1959 because of widespread speck contamination, and encompasses approximately 1,000 ha (2,500 acres). Table 3.11 contains the acreage for surface contamination areas and underground radioactive material areas, showing the net change from 1992 to 1993 . Table 3.12 summarizes the number of contaminated acres that changed status in 1993. Approximately 13 acres were reclassified from

Table 3.12. Zone Status Change by Area, 1993

\begin{tabular}{|c|c|c|}
\hline Location & Zone Change $^{(a)}$ & Acreage \\
\hline 100 Areas & SCA to URM & 0 \\
\hline 200-East Area & SCA to URM & 2.2 \\
\hline 200-West Area & SCA to URM & 11.2 \\
\hline 300 Area & SCA to URM & 0 \\
\hline 400 Area & SCA to URM & 0 \\
\hline 600 Area & SCA to URM & 0 \\
\hline
\end{tabular}

surface contamination areas to underground radioactive material areas, and 10 acres were posted as surface contamination areas.

The area of posted surface contamination varied because of an ongoing effort to clean, stabilize, and remediate areas of known contamination while new areas of contamination were being identified. Table 3.12 indicates the changes resulting from stabilization activities during 1993. Newly identified areas may be from contamination migration or the result of an increased effort to investigate outdoor areas for radiological contamination. Vehicles equipped with radiation detection devices and an ultrasonic ranging and data system have identified areas of contamination that were previously undetected.

It was estimated that the external dose rate at $80 \%$ of the identified outdoor surface contamination areas was less than $1 \mathrm{mrem} / \mathrm{h}$, although external doses from isolated radioactive specks (less than $0.6 \mathrm{~cm}$ or 0.25 in.) could have been considerably higher. Contamination levels of this magnitude would not significantly add to dose rates for the public or Hanford Site workers in 1993.

(a) $\mathrm{SCA}=$ surface contamination area; URM = under ground radioactive materials. 


\section{Soil and Vegetation Sampling from Operational Areas}

Soil and vegetation samples were collected on or adjacent to waste disposal units and from locations downwind and near or within the boundaries of the operating facilities. Samples were collected to detect potential migration and deposition of facility effluents. Migration can occur as the result of resuspension from radioactively contaminated surface areas, absorption of radionuclides by the roots of vegetation growing on or near underground and surface-water disposal units, or by waste site intrusion by animals. Special samples were also taken where physical or biological transport problems were identified. The results of the sampling effort are discussed below.

\section{Sample Collection and Analysis}

The sampling methods and locations used are discussed in detail in the manual Operational Environmental Monitoring (WHC 1991b). Radiological analysis of soil and vegetation samples included ${ }^{90} \mathrm{Sr},{ }^{239,240} \mathrm{Pu}$, uranium, and gamma-emitting radionuclides.

\section{Soil Results}

Of the radionuclide analyses performed, ${ }^{60} \mathrm{Co},{ }^{90} \mathrm{Sr},{ }^{137} \mathrm{Cs}$, ${ }^{239.240} \mathrm{Pu}$, and uranium were consistently detectable. Soil concentrations for these radionuclides were elevated near and within facility boundaries when compared to the concentrations measured offsite. Figure 3.4 shows average values for 1993 and the preceding 5 years. As the data indicate, the concentrations show a large degree of variability. In general, the samples collected on or directly adjacent to the waste disposal facilities had significantly higher concentrations than those farther away. The data also show, as expected, that certain radionuclides have higher concentrations within different operational areas. Generally speaking, the predominant radionuclides are activation products (i.e., gamma emitters) in the 100 Areas, fission products in the $200 / 600$ Areas, and uranium in the 300 Area. A more detailed data summary is provided by Schmidt et al. (1994).

\section{Areas}

Analytical results from soil samples collected in the 100 Areas were on a downward trend, showing effects of the shutdown of the production reactors and the effectiveness of effluent controls that have been implemented in recent years. However, these levels were greater than those measured offsite, and the concentrations of ${ }^{60} \mathrm{Co}$ were greater than those measured in the 200/600 and $300 / 400$ Areas. The ${ }^{60} \mathrm{Co}$ in the 100 Areas was the result of past discharges to waste disposal structures, primarily the 1301-N Liquid Waste Disposal Facility. Measures have been taken in recent years to identify and minimize the migration of contamination from these disposal structures (for example, installation of cover blocks on the facility).

\section{0/600 Areas}

Analytical results from soil samples taken in the 200/ 600 Areas were on a downward trend for most radionuclides as a result of facility shutdowns, better effluent controls, and waste management practices. However, these levels were greater than those measured offsite, and were shown to be higher for ${ }^{90} \mathrm{Sr},{ }^{137} \mathrm{Cs}$, and ${ }^{239.240} \mathrm{Pu}$ when compared to values from the 100 and $300 /$ 400 Areas.

\section{$300 / 400$ Areas}

This was the third sampling year for the 300/400 Areas' near-facility environmental monitoring program. The data for these areas were compared to results for other operational areas and those measured offsite. The levels measured for uranium were higher than those from the 100 and 200/600 Areas. This difference is expected because the uranium is the result of past fuel fabrication operations conducted in the 300 Area.

\section{Vegetation Results}

Of the radionuclide analyses performed, ${ }^{60} \mathrm{Co},{ }^{90} \mathrm{Sr},{ }^{137} \mathrm{Cs}$, ${ }^{239.240} \mathrm{Pu}$, and uranium were consistently detectable. Concentrations of these radionuclides in vegetation were elevated near and within facility boundaries compared to the concentrations measured offsite. Figure 3.5 shows average values for 1993 and the preceding 5 years. As 

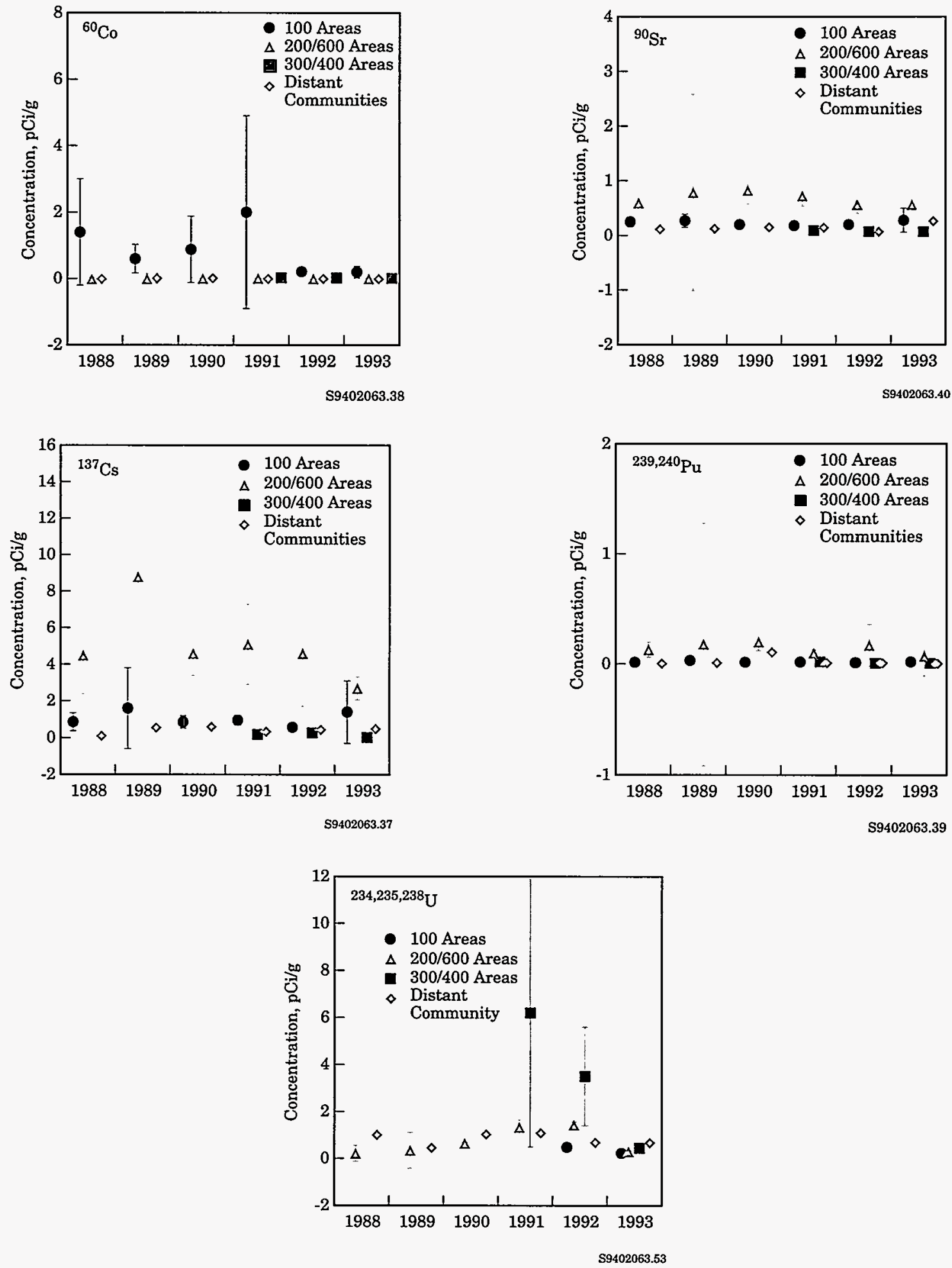

Figure 3.4. Concentrations ( \pm 2 SEM) of Selected Radionuclides in Near-Facility Soil Samples Compared to Those in Distant Communities, 1988 Through 1993. As a result of figure scale, some uncertainties (error bars) are concealed by point symbol. 

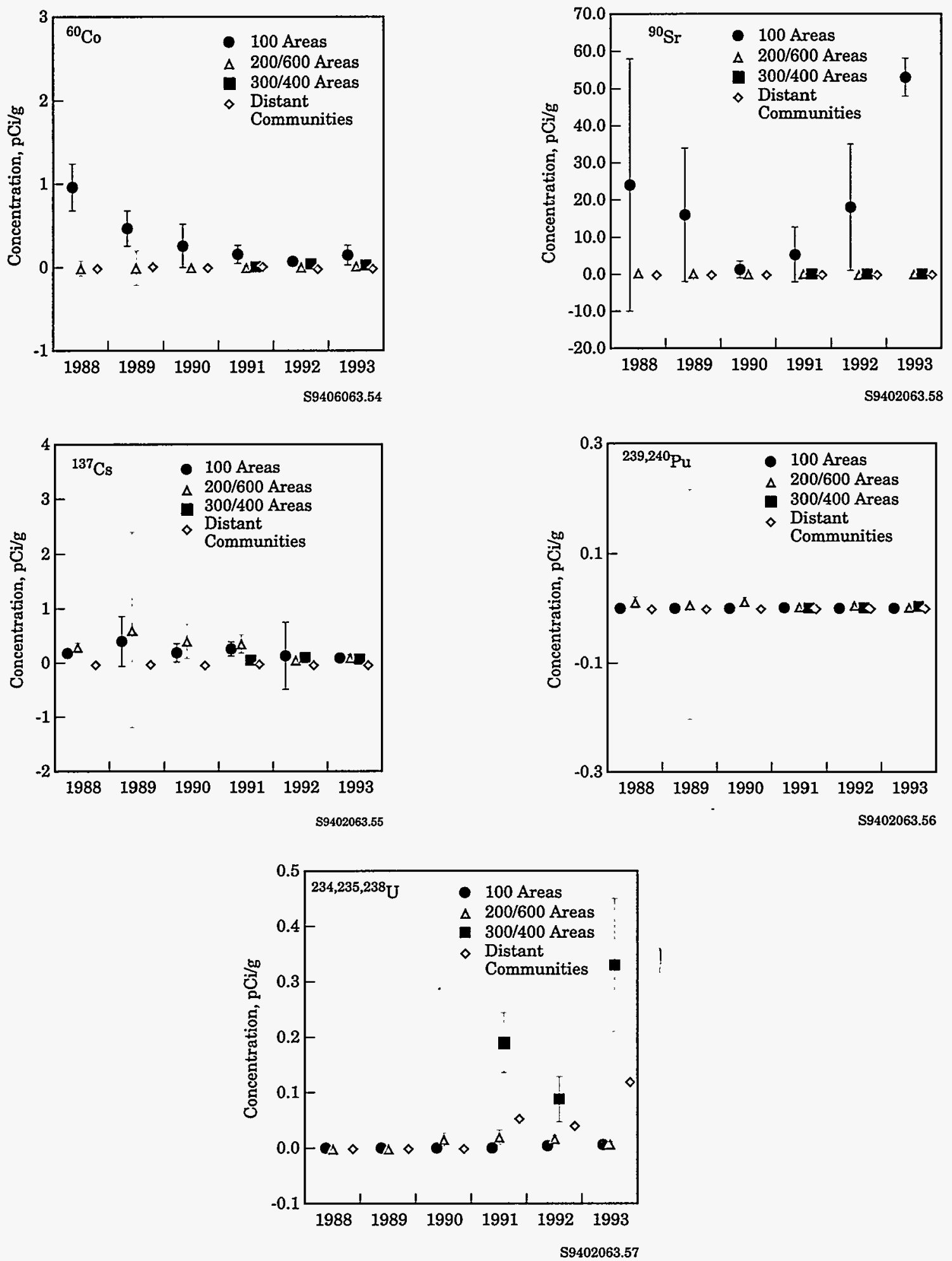

Figure 3.5. Concentrations ( \pm 2 SEM) of Selected Radionuclides in Near-Facility Vegetation Compared to Those in Distant Communities, 1988 Through 1993. As a result of figure scale, some uncertainties (error bars) are concealed by point symbol. 
the data indicate, the concentrations show a large degree of variability. In general, the samples collected on or directly adjacent to the waste disposal facilities had significantly higher concentrations than those farther away. As with the soil samples, the data show that certain radionuclides will be found in higher concentrations in vegetation within different operational areas. Except for ${ }^{90} \mathrm{Sr}$ (a fission product) detected in vegetation from the N Springs, generally speaking the predominant radionuclides are activation products (i.e., gamma emitters) in the 100 Areas, fission products in the 200/600 Areas, and uranium in the 300 Area. A more detailed data summary is provided by Schmidt et al. (1994).

\section{Areas}

Analytical results from vegetation samples collected in the 100 Areas in 1993 were generally comparable to those seen in 1992. The maximum values were for ${ }^{90} \mathrm{Sr}$ from samples collected near the N Springs (100-N Area). These values were higher than those measured in 1991 and 1992, but were comparable to the values seen in the mid1980s. The 1993 levels were also greater than those measured offsite and were higher for ${ }^{60} \mathrm{Co}$ and ${ }^{90} \mathrm{Sr}$ compared to the $200 / 600$ and $300 / 400$ Areas.

\section{0/600 Areas}

Analytical results from vegetation samples taken in the 200/600 Areas were on a downward trend for most radionuclides as a result of facility shutdowns, better effluent controls, and improved waste management practices. Before 1992, radionuclide levels in these areas were greater than those measured offsite and were higher for ${ }^{137} \mathrm{Cs}$ and ${ }^{239.240} \mathrm{Pu}$ compared to the 100 and $300 /$ 400 Areas. During 1993, the average concentrations onsite, offsite, and within the various operational areas were similar for these two radionuclides.

\section{$300 / 400$ Areas}

This was the third sampling year for the $300 / 400$ Areas' near-facility environmental monitoring program. Generally, the levels of most radionuclides measured in the 300 Area were greater than those measured offsite and were higher for uranium compared to the 100 and 200/ 600 Areas. This difference was expected because uranium was released during past fuel fabrication operations conducted in the 300 Area. The levels measured in the 400 Area were at or near those measured offsite.

\section{Investigative Sampling}

These data include the maximum concentrations of radioactivity from analytical results of investigative samples. Complete data results are listed by Schmidt et al. (1994).

The purpose of investigative sampling was to determine whether effluent controls and waste containment were adequate. An important part of the near-facility program, investigative sampling was conducted in the operations areas to confirm the absence of or to detect the presence of radioactive contaminants. This investigative sampling took place near facilities such as storage and disposal sites for at least one of the following reasons:

- because radiological surface surveys had indicated that radioactive contamination was present

- to quantify the radiological condition of a site before facility construction or operation

- to quantify the radiological condition of a site before remediation

- to determine if biotic intrusion (e.g., animal burrows or deep-rooted vegetation) had created a potential for the spread of contaminants

- to determine the integrity of waste containment systems.

Generally speaking, the predominant radionuclides are activation products (i.e., gamma emitters) in the 100 Areas, fission products in the 200/600 Areas, and uranium in the 300 Area.

\section{Sample Collection and Analysis}

Types of investigative samples collected over the years have included air; water; snow; sediments; soil; vegetation such as grasses, tumbleweeds (also known as Russian thistle), sagebrush, trees, and fruits; and various organisms such as spiders, termites, ants, fish, toads, snakes, birds, mice, rabbits, coyotes, and bobcats.

Investigative samples in 1993 included air, soil (including sediment and radioactive specks), water, a wood chip, asphalt, vegetation (aquatic vegetation, rabbitbrush, 
Table 3.13. Investigative Samples Collected from the Operations Areas, 1993

\begin{tabular}{|c|c|c|c|}
\hline Sample Type & $\begin{array}{c}\text { Collection Area } \\
\text { (Number of Samples) }\end{array}$ & $\begin{array}{c}\text { Elevated } \\
\text { Radionuclides }\end{array}$ & Maximum Concentration \\
\hline \multirow[t]{10}{*}{ Air } & $100-\mathrm{F}(7)$ & ${ }^{60} \mathrm{Co}$ & $0.00039 \mathrm{pCi} / \mathrm{m}^{3}$ \\
\hline & & ${ }^{90} \mathrm{Sr}$ & $0.00014 \mathrm{pCi} / \mathrm{m}^{3}$ \\
\hline & & ${ }^{137} \mathrm{Cs}$ & $0.00082 \mathrm{pCi} / \mathrm{m}^{3}$ \\
\hline & & ${ }^{239,240} \mathrm{Pu}$ & $0.000014 \mathrm{pCi} / \mathrm{m}^{3}$ \\
\hline & & $\mathrm{U}$ total & $0.000045 \mathrm{pCi} / \mathrm{m}^{3}$ \\
\hline & $618-10(1)$ & ${ }^{60} \mathrm{Co}$ & $0.0056 \mathrm{pCi} / \mathrm{m}^{3}$ \\
\hline & & ${ }^{90} \mathrm{Sr}$ & $-0.00029 \mathrm{pCi} / \mathrm{m}^{3}$ \\
\hline & & ${ }^{137} \mathrm{Cs}$ & $0.00024 \mathrm{pCi} / \mathrm{m}^{3}$ \\
\hline & & ${ }^{239,240} \mathrm{Pu}$ & $-0.0000062 \mathrm{pCi} / \mathrm{m}^{3}$ \\
\hline & & $\mathrm{U}$ total & $<0.00005 \mathrm{pCi} / \mathrm{m}^{3}$ \\
\hline \multirow[t]{7}{*}{ Soil } & 200 Areas (70) & ${ }^{60} \mathrm{Co}$ & $1.2 \mathrm{pCi} / \mathrm{g}$ \\
\hline & & ${ }^{90} \mathrm{Sr}$ & $20,000 \mathrm{pCi} / \mathrm{g}$ \\
\hline & & ${ }^{137} \mathrm{Cs}$ & $75,000 \mathrm{pCi} / \mathrm{g}$ \\
\hline & & ${ }^{239,240} \mathrm{Pu}$ & $180 \mathrm{pCi} / \mathrm{g}$ \\
\hline & & $\mathrm{U}$ total & $21 \mathrm{pCi} / \mathrm{g}$ \\
\hline & 600 Area (8) & ${ }^{137} \mathrm{Cs}$ & $1.3 \mathrm{pCi} / \mathrm{g}$ \\
\hline & & ${ }^{239,240} \mathrm{Pu}$ & $1 \mathrm{pCi} / \mathrm{g}$ \\
\hline \multirow[t]{4}{*}{ Water } & 200 Areas (1) & ${ }^{90} \mathrm{Sr}$ & $3,900 \mathrm{pCi} / \mathrm{L}$ \\
\hline & & ${ }^{137} \mathrm{Cs}$ & $43 \mathrm{pCi} / \mathrm{L}$ \\
\hline & & ${ }^{239.240} \mathrm{Pu}$ & $<20 \mathrm{pCi} / \mathrm{L}$ \\
\hline & & $\mathrm{U}$ total & $0.83 \mathrm{pCi} / \mathrm{L}$ \\
\hline \multirow[t]{4}{*}{ Wood chip } & 200 Areas (1) & ${ }^{90} \mathrm{Sr}$ & $2,500 \mathrm{pCi}$ \\
\hline & & ${ }^{137} \mathrm{Cs}$ & $<2,700,000 \mathrm{pCi}$ \\
\hline & & ${ }^{239,240} \mathrm{Pu}$ & $<940,000 \mathrm{pCi}$ \\
\hline & & U total & $0.49 \mathrm{pCi}$ \\
\hline \multirow[t]{2}{*}{ Asphalt } & 200 Areas (1) & ${ }^{90} \mathrm{Sr}$ & $140 \mathrm{pCi} / \mathrm{g}$ \\
\hline & & ${ }^{137} \mathrm{Cs}$ & $5.2 \mathrm{pCi} / \mathrm{g}$ \\
\hline \multirow[t]{9}{*}{ Vegetation } & 100 Areas (4) & ${ }^{90} \mathrm{Sr}$ & $<0.0004 \mathrm{pCi} / \mathrm{g}$ \\
\hline & & ${ }^{137} \mathrm{Cs}$ & $1.9 \mathrm{pCi} / \mathrm{g}$ \\
\hline & & ${ }^{239.240} \mathrm{Pu}$ & $<0.13 \mathrm{pCi} / \mathrm{g}$ \\
\hline & & U total & $0.023 \mathrm{pCi} / \mathrm{g}$ \\
\hline & 200 Areas (6) & ${ }^{60} \mathrm{Co}$ & $0.017 \mathrm{pCi} / \mathrm{g}$ \\
\hline & & ${ }^{90} \mathrm{Sr}$ & $0.73 \mathrm{pCi} / \mathrm{g}$ \\
\hline & & ${ }^{137} \mathrm{Cs}$ & $<0.42 \mathrm{pCi} / \mathrm{g}$ \\
\hline & & ${ }^{239,240} \mathrm{Pu}$ & $<0.27 \mathrm{pCi} / \mathrm{g}$ \\
\hline & & U total & $0.1 \mathrm{pCi} / \mathrm{g}$ \\
\hline
\end{tabular}


Table 3.13. Investigative Samples Collected from the Operations Areas, 1993 (contd)

\begin{tabular}{|c|c|c|c|}
\hline Sample Type & $\begin{array}{c}\text { Collection Area } \\
\text { (Number of Samples) }\end{array}$ & $\begin{array}{c}\text { Elevated } \\
\text { Radionuclides }\end{array}$ & Maximum Concentration \\
\hline \multirow[t]{2}{*}{$\begin{array}{l}\text { Vegetation } \\
\text { (contd) }\end{array}$} & 300 Area (2) & $\begin{array}{l}{ }^{90} \mathrm{Sr} \\
{ }^{137} \mathrm{Cs} \\
{ }^{239,240} \mathrm{Pu} \\
\text { U total }\end{array}$ & $\begin{array}{c}<0.07 \mathrm{pCi} / \mathrm{g} \\
1.4 \mathrm{pCi} / \mathrm{g} \\
<0.1 \mathrm{pCi} / \mathrm{g} \\
0.0074 \mathrm{pCi} / \mathrm{g}\end{array}$ \\
\hline & 600 Area (2) & $\begin{array}{l}{ }^{60} \mathrm{Co} \\
{ }^{90} \mathrm{Sr} \\
{ }^{137} \mathrm{Cs} \\
{ }^{239,240} \mathrm{Pu} \\
\text { U total }\end{array}$ & $\begin{array}{l}0.0021 \mathrm{pCi} / \mathrm{g} \\
0.048 \mathrm{pCi} / \mathrm{g} \\
0.13 \mathrm{pCi} / \mathrm{g} \\
0.0037 \mathrm{pCi} / \mathrm{g} \\
0.19 \mathrm{pCi} / \mathrm{g}\end{array}$ \\
\hline $\begin{array}{l}\text { Western } \\
\text { rattlesnake }\end{array}$ & 600 Area (1) & $\begin{array}{l}{ }^{90} \mathrm{Sr} \\
{ }^{137} \mathrm{Cs} \\
{ }^{239.240} \mathrm{Pu} \\
\mathrm{U} \text { total }\end{array}$ & $\begin{aligned} & 0.42 \mathrm{pCi} / \mathrm{g} \\
< & 0.12 \mathrm{pCi} / \mathrm{g} \\
<0.07 \mathrm{pCi} / \mathrm{g} & <0.003 \mathrm{pCi} / \mathrm{g}\end{aligned}$ \\
\hline $\begin{array}{l}\text { Western } \\
\text { kingbird }\end{array}$ & 100 Areas (2) & $\begin{array}{l}{ }^{60} \mathrm{Co} \\
{ }^{90} \mathrm{Sr} \\
{ }^{137} \mathrm{Cs} \\
{ }^{239.240} \mathrm{Pu} \\
\text { U total }\end{array}$ & $\begin{array}{c}4.9 \mathrm{pCi} / \mathrm{g} \\
<0.5 \mathrm{pCi} / \mathrm{g} \\
340 \mathrm{pCi} / \mathrm{g} \\
130 \mathrm{pCi} / \mathrm{g} \\
0.39 \mathrm{pCi} / \mathrm{g}\end{array}$ \\
\hline Cliff swallow & 200 Areas (1) & $\begin{array}{l}{ }^{90} \mathrm{Sr} \\
{ }^{137} \mathrm{Cs} \\
{ }^{239.240} \mathrm{Pu} \\
\mathrm{U} \text { total }\end{array}$ & $\begin{array}{r}2,200 \mathrm{pCi} / \mathrm{g} \\
28,000 \mathrm{pCi} / \mathrm{g} \\
<1.2 \mathrm{pCi} / \mathrm{g} \\
0.03 \mathrm{pCi} / \mathrm{g}\end{array}$ \\
\hline $\begin{array}{l}\text { Long-legged } \\
\text { myotis (bat) }\end{array}$ & 200 Areas (1) & $\begin{array}{l}{ }^{90} \mathrm{Sr} \\
{ }^{137} \mathrm{Cs} \\
{ }^{239,240} \mathrm{Pu} \\
\mathrm{U} \text { total }\end{array}$ & $\begin{array}{r}2,000 \mathrm{pCi} / \mathrm{g} \\
11,000 \mathrm{pCi} / \mathrm{g} \\
580 \mathrm{pCi} / \mathrm{g} \\
1.2 \mathrm{pCi} / \mathrm{g}\end{array}$ \\
\hline $\begin{array}{l}\text { Nuttall's } \\
\text { cottontail }\end{array}$ & 200 Areas (1) & $\begin{array}{l}{ }^{90} \mathrm{Sr} \\
{ }^{137} \mathrm{Cs} \\
{ }^{239.240} \mathrm{Pu} \\
\mathrm{U} \text { total }\end{array}$ & $\begin{array}{l}<0.001 \mathrm{pCi} / \mathrm{g} \\
<0.043 \mathrm{pCi} / \mathrm{g} \\
<0.03 \mathrm{pCi} / \mathrm{g} \\
<0.0013 \mathrm{pCi} / \mathrm{g}\end{array}$ \\
\hline Deer mouse & 100 Areas (2) & $\begin{array}{l}{ }^{90} \mathrm{Sr} \\
{ }^{137} \mathrm{Cs} \\
{ }^{239,240} \mathrm{Pu} \\
\mathrm{U} \text { total }\end{array}$ & $\begin{array}{c}5.5 \mathrm{pCi} / \mathrm{g} \\
1,800 \mathrm{pCi} / \mathrm{g} \\
<0.48 \mathrm{pCi} / \mathrm{g} \\
0.0054 \mathrm{pCi} / \mathrm{g}\end{array}$ \\
\hline & 200 Areas (15) & $\begin{array}{l}{ }^{90} \mathrm{Sr} \\
{ }^{137} \mathrm{Cs} \\
{ }^{239,240} \mathrm{Pu} \\
\mathrm{U} \text { total }\end{array}$ & $\begin{array}{c}980,000 \mathrm{pCi} / \mathrm{g} \\
5,500 \mathrm{pCi} / \mathrm{g} \\
3.3 \mathrm{pCi} / \mathrm{g} \\
0.21 \mathrm{pCi} / \mathrm{g}\end{array}$ \\
\hline
\end{tabular}


Table 3.13. Investigative Samples Collected from the Operations Areas, 1993 (contd)

\begin{tabular}{|c|c|c|c|}
\hline Sample Type & $\begin{array}{c}\text { Collection Area } \\
\text { (Number of Samples) }\end{array}$ & $\begin{array}{c}\text { Elevated } \\
\text { Radionuclides }\end{array}$ & Maximum Concentration \\
\hline \multirow[t]{2}{*}{ House mouse } & 100 Areas (1) & $\begin{array}{l}{ }^{90} \mathrm{Sr} \\
{ }^{137} \mathrm{Cs} \\
{ }^{239,240} \mathrm{Pu} \\
\mathrm{U} \text { total }\end{array}$ & $\begin{array}{c}14,000,000 \mathrm{pCi} / \mathrm{g} \\
80 \mathrm{pCi} / \mathrm{g} \\
0.39 \mathrm{pCi} / \mathrm{g} \\
0.018 \mathrm{pCi} / \mathrm{g}\end{array}$ \\
\hline & 200 Areas (8) & $\begin{array}{l}{ }^{90} \mathrm{Sr} \\
{ }^{137} \mathrm{Cs} \\
{ }^{239,240} \mathrm{Pu} \\
\text { U total }\end{array}$ & $\begin{array}{c}32,000 \mathrm{pCi} / \mathrm{g} \\
42 \mathrm{pCi} / \mathrm{g} \\
1.3 \mathrm{pCi} / \mathrm{g} \\
0.018 \mathrm{pCi} / \mathrm{g}\end{array}$ \\
\hline $\begin{array}{l}\text { Bushy-tailed } \\
\text { woodrat }\end{array}$ & 200 Areas (1) & $\begin{array}{l}{ }^{90} \mathrm{Sr} \\
{ }^{137} \mathrm{Cs} \\
{ }^{239.240} \mathrm{Pu} \\
\mathrm{U} \text { total }\end{array}$ & $\begin{array}{c}0.0014 \mathrm{pCi} / \mathrm{g} \\
260 \mathrm{pCi} / \mathrm{g} \\
0.19 \mathrm{pCi} / \mathrm{g} \\
0.0011 \mathrm{pCi} / \mathrm{g}\end{array}$ \\
\hline \multirow[t]{2}{*}{ Coyote feces } & 200 Areas (2) & $\begin{array}{l}{ }^{90} \mathrm{Sr} \\
{ }^{137} \mathrm{Cs} \\
\mathrm{U} \text { total }\end{array}$ & $\begin{aligned} & 0.65 \mathrm{pCi} / \mathrm{g} \\
< & 1.1 \mathrm{pCi} / \mathrm{g} \\
< & 0.004 \mathrm{pCi} / \mathrm{g}\end{aligned}$ \\
\hline & 600 Area (1) & $\begin{array}{l}{ }^{90} \mathrm{Sr} \\
{ }^{137} \mathrm{Cs} \\
\mathrm{U} \text { total }\end{array}$ & $\begin{array}{c}2.2 \mathrm{pCi} / \mathrm{g} \\
<1.1 \mathrm{pCi} / \mathrm{g} \\
0.019 \mathrm{pCi} / \mathrm{g}\end{array}$ \\
\hline
\end{tabular}

sagebrush, Russian olive tree, asparagus, and tumbleweeds), a rattlesnake, western kingbirds, a cliff swallow, a bat, a Nuttall's cottontail rabbit, two species of mice, a bushy-tailed woodrat, and coyote feces (Table 3.13).

Methods for collecting or otherwise obtaining investigative samples are found in the manual Operational Environmental Monitoring (WHC 1991b). Field monitoring was conducted to detect radioactivity before collecting samples. Field monitoring results were expressed as counts per minute (cpm) when using a Geiger-Mueller detector or as millirads per hour $(\mathrm{mrads} / \mathrm{h})$ when using an ion chamber. Laboratory sample analysis results are expressed in $\mathrm{pCi} / \mathrm{g}$. Maximum concentrations of radionuclides rather than averages are presented in this subsection.

\section{Results}

Investigative samples were collected where known or suspected radioactive contamination was present, or to verify radiological conditions at project sites. In 1993, 139 such samples were analyzed for radionuclides, and 43 showed some level of contamination. An additional 181 contamination incidents were resolved during cleanup operations. A more detailed data summary is provided by Schmidt et al. (1994).

\section{Air}

Eight investigative air samples were taken in 1993. Seven were taken at the 100 -F Area to support decontamination and decommissioning work. One was taken at the 618-10 Burial Trench in support of scheduled Expedited Response Actions. Radionuclides monitored included ${ }^{60} \mathrm{Co},{ }^{90} \mathrm{Sr},{ }^{137} \mathrm{Cs},{ }^{239.240} \mathrm{Pu}$, and total uranium. Analytical results of radionuclide concentrations were well below the Derived Concentration Guide values (Table 3.13). 


\section{Soil}

In 1993, 78 investigative soil samples were taken. The radionuclides of highest concentration were ${ }^{60} \mathrm{Co}$ (1.2 pCi/g) from the 216-U-14 Ditch in the 200-West Area; ${ }^{\circ} \mathrm{Sr}(20,000 \mathrm{pCi} / \mathrm{g})$ near the $241-\mathrm{SX}$ Tank Farm in the 200 -West Area; ${ }^{137} \mathrm{Cs}(75,000 \mathrm{pCi} / \mathrm{g})$ near the 241-SX Tank Farm in the 200-West Area; ${ }^{239,240} \mathrm{Pu}$ ( $180 \mathrm{pCi} / \mathrm{g}$ ) near the $241-\mathrm{SX}$ Tank Farm in the 200 -West Area; and total uranium $(21 \mathrm{pCi} / \mathrm{g})$ from south of the 276-C facility (Hot Semi-works) in the 200-East Area. In addition, 130 contaminated specks were found during cleanup operations and disposed of in low-level burial grounds.

The number of contamination incidents, the radioactivity levels, and the range of radionuclide concentrations were not unusual. Areas of special soil sampling that were outside radiological control areas and that had levels greater than Westinghouse Hanford Company radiological control limits (WHC 1991a) were posted as surface contamination areas.

\section{Vegetation}

In 1993, there were 14 vegetation samples analyzed for radionuclide concentrations (Table 3.13). Analytical results were well below Westinghouse Hanford Company radiological control limits (WHC 1991a). In addition, 41 instances of contaminated tumbleweed were recorded in operational areas in 1993. These tumbleweeds were found during remedial operations and disposed of so that only field-instrument readings of radioactivity were available. Field-instrument readings ranged from less than $1 \mathrm{mrad} / \mathrm{h}(100 \mathrm{cpm})$ to $35 \mathrm{mrad} / \mathrm{h}$, which were within the ranges reported for the past few years. The number of samples found to be contaminated with radioactivity was not unusual. The past greatest number of contaminated vegetation samples (42) submitted for analyses was in 1978. In the 200 Areas before 1980 , when vegetation control was limited or nonexistent, contaminated vegetation was counted in acres rather than individual specimens. Vegetation control in 1993, as in 1992 and 1991, was noticeably more effective than in 1990 and 1989 and suggests a return to an improving trend. An improving trend had been evident from 1981 up to 1989 , when resistance to the herbicide in use at that time was first noted. Improved vegetation control was probably the result of improved surveillance, better equipment, and use of more effective herbicides.

\section{Wildlife}

Animals were collected either as a result of a pest control program designed to limit the exposure and potential contamination of animals to radioactive material or as a result of finding a dead animal. Animals were collected directly from or near facilities to identify problems in preventative measures designed to inhibit animal intrusion. Surveys were performed after collection to determine whether an animal was radioactively contaminated. If a live animal was found free of contamination, it was taken to a suitable habitat area and released. If an animal was contaminated, a decision was made to collect a sample or dispose of the animal. This decision was based on the level of contamination, sampling facility, and frequency of occurrence.

There were 36 special animal (including nests and feces) samples analyzed in 1993, of which 30 showed some level of contamination. There were 10 cases of contaminated animals or feces found during cleanup operations and disposed of without being analyzed. The radionuclides found at the maximum concentrations were ${ }^{60} \mathrm{Co}(4.9 \mathrm{pCi} / \mathrm{g})$ in a kingbird from $105-\mathrm{K}$ West, ${ }^{90} \mathrm{Sr}$ $(14,000,000 \mathrm{pCi} / \mathrm{g})$ in a house mouse from $170-\mathrm{E},{ }^{137} \mathrm{Cs}$ $(28,000 \mathrm{pCi} / \mathrm{g})$ in a cliff swallow from $241-\mathrm{A}$ Tank Farm Complex, and ${ }^{239,240} \mathrm{Pu}(130 \mathrm{pCi} / \mathrm{g})$ in a kingbird from 105-K West (see Table 3.13). The total number of animals found to be contaminated with radioactivity, the radioactivity levels, and the range of radionuclides concentrations were not unusual; however, the number of incidents increased slightly compared to 26 in 1992; there were 32 incidents in 1991. The greatest number of contaminated animals submitted for analysis was found in 1982 (44, mostly pigeons); however, before 1981 fewer samples were submitted for radionuclide analyses.

Practical results of these data, in addition to those mentioned in the beginning paragraph of this section, were to identify where pest control, waste containment, and biotic barriers needed to be improved or added. Benefits were to provide humans safe and healthy work conditions, to reduce exposures, and to reduce cleanup costs by early identification of loss of containment control.

\section{Special Characterization Projects}

Special characterization projects were conducted to verify the radiological status of the ambient air at the $100-F$ Area during decontamination and decommission- 
ing; of the soil and vegetation at the 200 Areas CrossSite Transfer Line Replacement project; of the soil at the 618-10 and 618-11 Burial Grounds; and of the soil at the 200 Areas Effluent Treatment Facility and Pipeline. Radionuclide concentrations at these sites were near background levels (Table 3.13).

\section{External Radiation}

External radiation fields were measured near facilities and waste handling, storage, and disposal sites to measure, assess, and control the impacts of operations.

\section{Field Measurements and Analysis}

Two methods of measurement were employed, one being hand-held microroentgen $(\mu R)$ meters used to survey multiple survey points and the other being thermoluminescent dosimeters (TLDs). The measurement methods used for external radiation measurements and sample locations are discussed in detail in the manual Operational Environmental Monitoring (WHC 1991b).

\section{Results}

\section{Radiation Measurements}

Hand-held $\mu \mathrm{R}$ meters were used to survey points near and within three waste disposal locations in the 100-N Area: the N Springs area, 1301-N Liquid Waste Disposal Facility, and 1325-N Liquid Waste Disposal Facility. These radiation measurements were taken at a height of approximately $1 \mathrm{~m}(3.28 \mathrm{ft})$ to assess the effects of Site operational changes and are not necessarily a true measurement of exposure rate. The hand-held $\mu \mathrm{R}$ meters are known to over-respond to low-energy gamma radiation. The radiation rate measured along the $100-\mathrm{N}$ Area shoreline was still declining in 1993 and is compared to rates during the past 5 years in Figure 3.6. The shift in the dose rate levels shows the effects of the decreased discharges to the 1301-N Liquid Waste Disposal Facility and the continuing decay of ${ }^{60} \mathrm{Co}$, the principal residual radionuclide. The radiation measurements taken at the 1301-N Liquid Waste Disposal Facility in 1993, as in previous years, continue to show the decay of ${ }^{60} \mathrm{Co}$ (Table 3.14). The radiation measurements taken at the 1325-N Liquid Waste Disposal Facility in 1993 and in the previous year were elevated, compared to earlier years. This increase indicates the effect of decreased discharges of liquid waste to that facility (Table 3.14). The decreased discharges resulted in the loss of the water that normally provided shielding from the gammaemitting radionuclides contained in the sediments of the facility, principally ${ }^{60} \mathrm{Co}$ and ${ }^{137} \mathrm{Cs}$. A more detailed data summary is provided by Schmidt et al. (1994).

\section{TLDs}

100 Areas. TLDs in the 100 Areas were located in the $100-\mathrm{N}$ and 100-K Areas; results are presented in Table 3.15. The 1993 TLD results indicate that direct radiation levels were highest near facilities that had contained or received liquid effluent from the $\mathrm{N}$ Reactor. These facilities primarily include the 1301-N Liquid Waste Disposal Facility and 1325-N Liquid Waste Disposal Facility. While the results were noticeably higher than those for other 100-N Area TLD locations, the overall results for these two facilities increased in exposure rate by approximately $6 \%$ when compared to 1992.

In 1993, eleven TLDs were relocated from the 100-N Area and placed at the 100-K Area, surrounding the 105-K East and 105-K West reactor buildings. Elevated readings in the 100-K Area were due to radiologically contaminated materials such as internally contaminated ion-exchange modules used in maintaining water quality in the nearby $105-\mathrm{KE}$ fuel storage basin. A more detailed data summary and description is provided by Schmidt et al. (1994).

200/600 Areas. TLD results for 1993 are compared to those of 1992 for the 200/600 Areas in Table 3.15. The highest dose rates were measured near waste-handling facilities such as tank farms. The highest dose rate was measured at the 241-A Tank Farm complex located in the 200-East Area. The average annual dose rate measured in 1993 by TLDs in the 200/600 Areas was $130 \mathrm{mrem} / \mathrm{yr}$, which equalled the average dose rate measured in 1992. A more detailed data summary is provided by Schmidt et al. (1994).

300/400 Areas. Table 3.15 compares 1993 TLD results to those of 1992 for the 300/400 Areas. The highest dose rates in the 300 Area were measured near waste-handling facilities such as the 340 Waste Handling Facility. The average annual dose rate measured in 1993 by TLDs in the 300 Area was $200 \mathrm{mrem} / \mathrm{yr}$, which was an increase of $25 \%$ over the average dose rate of $160 \mathrm{mrem} / \mathrm{yr}$ measured in 1992. 

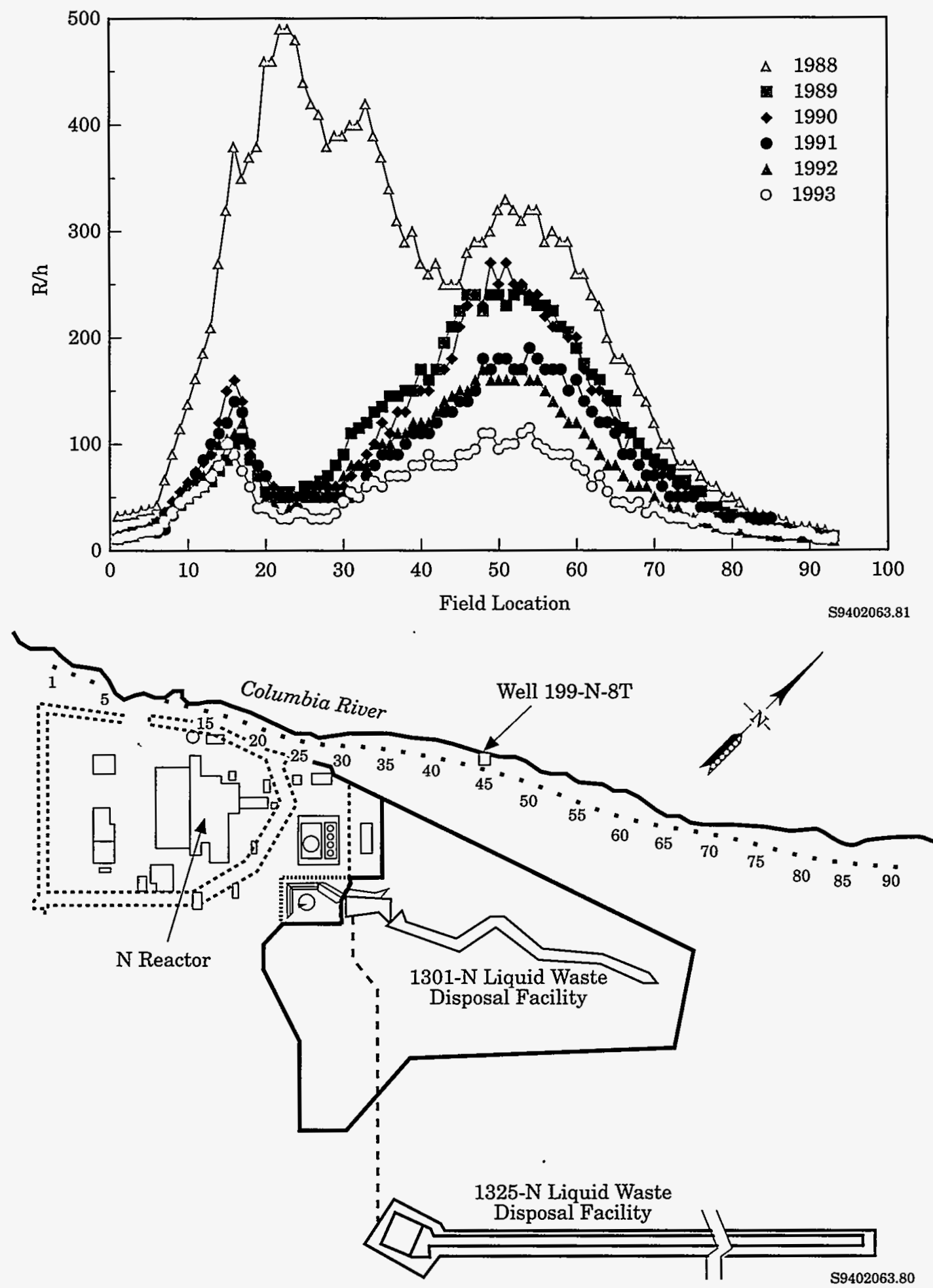

Figure 3.6. Radiation Survey Measurements Along the 100-N Area Shoreline, 1988 Through 1993 
Table 3.14. 100-N Liquid Waste Disposal Facilities

(LWDF) Direct Radiation Measurements $(\mu \mathrm{R} / \mathrm{h})$, 1992 and 1993

\begin{tabular}{|c|c|c|}
\hline LWDF & 1992 Average & 1993 Average \\
\hline $1301-\mathrm{N}$ & 2,000 & 1,600 \\
\hline $1325-\mathrm{N}$ & 940 & 730 \\
\hline
\end{tabular}

Table 3.15. Thermoluminescent Dosimeter (TLD) Results for Waste-Handling Facilities in the Operations Areas (mrem/yr, based on $24 \mathrm{~h} / \mathrm{d}), 1992$ and 1993

\begin{tabular}{|c|c|c|c|c|c|c|}
\hline \multirow[b]{2}{*}{ Area } & \multirow{2}{*}{$\begin{array}{l}\text { No. of } \\
\text { Sites, } 1993 \\
\end{array}$} & \multicolumn{2}{|c|}{ 1992, Annual Average } & \multicolumn{2}{|c|}{ 1993, Annual Average } & \multirow[b]{2}{*}{$\%$ Change $^{(a)}$} \\
\hline & & Maximum & Mean & Maximum & Mean & \\
\hline $100-K$ & 11 & $N S^{(b)}$ & NS & 13,800 & 820 & NA \\
\hline $100-\mathrm{N}$ & 30 & 13,280 & 1,600 & 14,640 & 1,700 & 6 \\
\hline $200 / 600$ & 58 & 700 & 130 & 1,100 & 130 & 0 \\
\hline 300 & 8 & 610 & 160 & 830 & 200 & 25 \\
\hline 400 & 7 & 110 & 90 & 130 & 100 & 11 \\
\hline
\end{tabular}

(a) Numbers indicate a decrease (-) or increase from 1992. NA = not applicable.

(b) NS = not sampled.

The highest dose rates, although not significantly elevated above background, measured in the 400 Area were near the main gate of the Fuels and Materials Examin- . ation Facility. The average dose rate measured in 1993 by TLDs in the 400 Area was $100 \mathrm{mrem} / \mathrm{yr}$, which was an increase of $11 \%$ over the average dose rate of $90 \mathrm{mrem} / \mathrm{yr}$ measured in 1992. A more detailed data summary is provided by Schmidt et al. (1994). 



\title{
3.3 Waste Management and Chemical Inventories
}

\author{
B. L. Curn
}

\section{Waste Management}

Waste produced at the Hanford Site is classified as either radioactive, nonradioactive, or mixed waste. Radioactive waste is categorized as transuranic, high-level, and lowlevel. Mixed waste has both radioactive and hazardous nonradioactive substances. Nonradioactive waste is composed of hazardous or nondangerous wastes or both. Hazardous waste contains dangerous wastes or extremely hazardous wastes or both, as defined in Ecology's Dangerous Waste Regulations.

Radioactive and mixed waste is currently handled in several ways. High-level waste is stored in single- and double-shell tanks. Low-level waste also is stored in double-shell tanks or on storage pads or is buried, depending on the source, composition, and concentration of the waste. Transuranic waste is stored in vaults or on underground storage pads from which it can be retrieved.

Approximately 200 Hanford Site facilities have the capacity to generate dangerous waste. An annual report lists the dangerous wastes and extremely hazardous wastes generated, treated, stored, and disposed of onsite and offsite (DOE 1994b). Dangerous wastes are treated, stored, and prepared for disposal at several Hanford Site facilities. Dangerous wastes generated at the Site are shipped offsite for disposal, destruction, or recycling.

Nondangerous wastes generated at the Hanford Site are buried in the Solid Waste Landfill, located in the 200 Areas. These wastes originate at a number of areas across the Site. Examples of these wastes are construction debris, office trash, cafeteria waste, and packaging materials. Other materials and items classified as waste are solidified filter backwash and sludge from the treatment of river water, failed and broken equipment and tools, air filters, uncontaminated used gloves and other clothing, and certain chemical precipitates such as oxalates. Nonradioactive friable asbestos is buried in designated areas at the Solid Waste Landfill. Ash generated at powerhouses in the 200-East and 200-West Areas is buried in designated sites near those powerhouses. Demolition waste from 100 Areas decommissioning projects is buried in situ or in designated sites in the 100 Areas.

Annual reports document the quantities and types of radioactive solid waste disposed of at the Hanford Site (Anderson and Hagel 1994). Solid waste program activities are regulated by the Resource Conservation and Recovery Act and Toxic Substances Control Act, discussed in Section 2.0, "Environmental Compliance Summary."

\section{Chemical Inventories}

\section{Emergency Planning and Community Right-To-Know Act}

Title III of the Superfund Amendments and Reauthorization Act is a free-standing law, called the Emergency Planning and Community Right-To-Know Act. This Act requires that the public be given information about hazardous chemicals in their communities. It also established emergency planning and notification procedures to protect the public in the event of a hazardous chemical release.

Subtitle B of the Act contains requirements for reporting information to local communities on hazardous materials existing in or released from a facility near those locales. The Hanford Site was in compliance with the reporting and notification requirements of the Act in 1993. The 1993 Hanford Tier-Two Emergency and Hazardous Chemical Inventory (DOE 1994a) report will be issued in March 1994 to the State Emergency Response Commission, local county emergency management 
committees, and the local fire departments. This report contains information on hazardous materials stored across the Hanford Site. Table 3.16 summarizes the information reported, listing the 10 chemicals stored in greatest quantity on the Hanford Site.

Table 3.16. Hanford Site Tier-Two Emergency and Hazardous Chemical Inventory Average Balance of Ten Chemicals Stored in Greatest Quantity, 1993

Hazardous Material

Coal

Sodium

Fuel oil, No. 6

Uranium nitrate hexahydrate

Montmorillonite

Mineral oil

Bentonite

Diesel fuel

Heat transfer oil

Sodium dioxide
Average Daily

Balance, $\mathrm{kg}$

$6.8 \times 10^{6}$

$1.2 \times 10^{6}$

$4.6 \times 10^{5}$

$3.1 \times 10^{5}$

$1.9 \times 10^{5}$

$4.3 \times 10^{4}$

$4.0 \times 10^{4}$

$1.6 \times 10^{4}$

$1.1 \times 10^{4}$

$1.0 \times 10^{4}$ 


\section{Environmental Program Information}

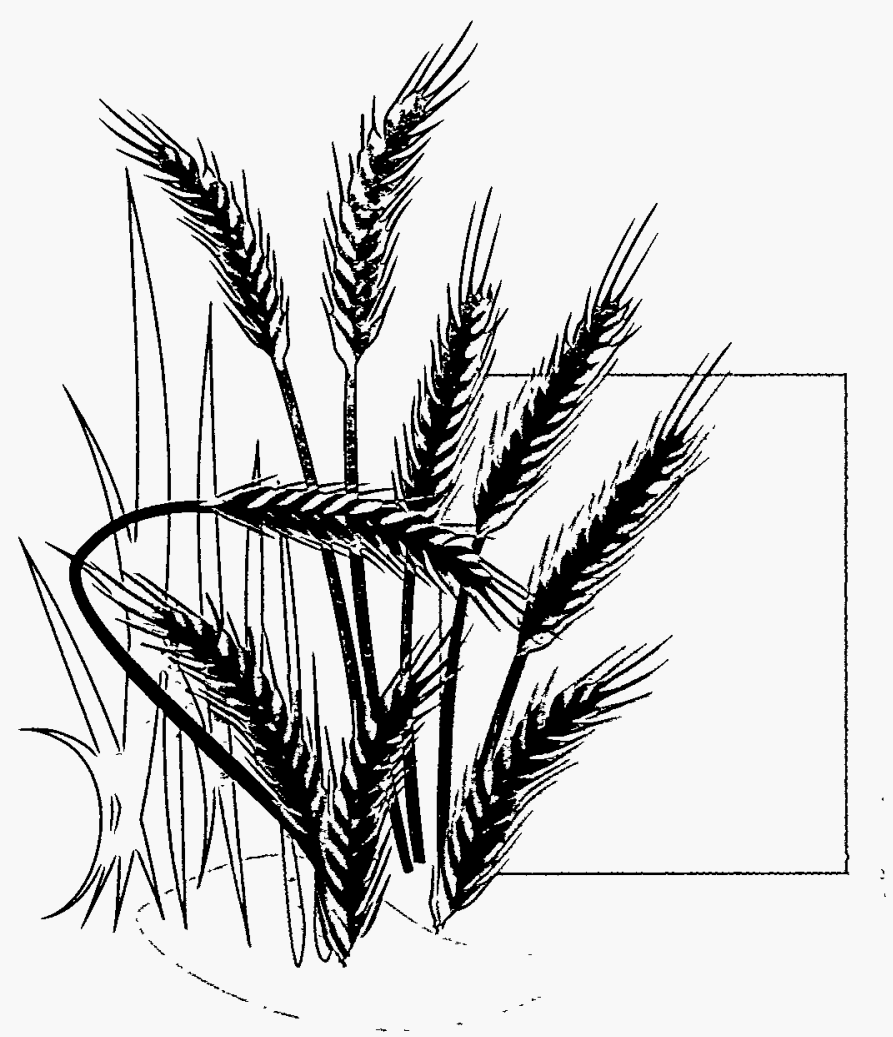




\subsection{Environmental Program Information}

It is DOE's policy to conduct its operations in an environmentally responsible manner and comply with applicable environmental standards. At the Hanford Site, a variety of environmental activities are performed to comply with laws and regulations, enhance environmental quality, and monitor the impact of environmental pollutants from Site operations.
Section 2.0 summarized the status of Hanford's compliance with applicable regulations, activities under way to achieve compliance, and programs to manage and improve environmental quality.

This section summarizes significant activities conducted in 1993 to monitor the meteorology and climatology of the Site, assess the status of wildlife and cultural resources, and conduct special environmental programs. 


\title{
4.1 Climate and Meteorology
}

\author{
D. J. Hoitink
}

Meteorological measurements are taken to support 1) Hanford Site emergency preparedness and response, 2) atmospheric dispersion calculations, and 3) Hanford Site operations. Support is provided through weather forecasting and the maintenance and distribution of climatological data. Forecasting is provided to help manage weather-dependent operations. Climatological data are provided to help plan weather-dependent activities and are used as a resource to assess the environmental effects of operations.

The Cascade Mountains beyond Yakima to the west greatly influence the climate of the Hanford Site. This range creates a rain shadow effect and also serves as a source of cold air drainage, which has a considerable effect on the wind regime.

The prevailing wind direction on the 200 Area plateau, the location of the Hanford Meteorology Station, is from the northwest in all months of the year. The secondary wind direction is from the southwest. Summaries of wind direction indicate that winds from the northwest quadrant occur most often during the winter and summer. During the spring and fall, the frequency of southwesterly winds increases, with a corresponding decrease in northwest flow. Monthly average wind speeds are lowest during the winter months, averaging 10 to $11 \mathrm{~km} / \mathrm{h}$ ( 6 to $7 \mathrm{mph}$ ), and highest during the summer, averaging 14 to $16 \mathrm{~km} / \mathrm{h}$ (9 to $10 \mathrm{mph}$ ). Wind speeds that are well above average are usually associated with southwesterly winds. However, the summertime drainage winds are generally northwesterly and frequently reach $50 \mathrm{~km} / \mathrm{h}(30 \mathrm{mph})$. These winds are most prevalent over the northern portion of the Site.

Daily and monthly averages and extremes of temperature, dew point, and humidity are given by Stone et al. (1983). The record maximum temperature is $46^{\circ} \mathrm{C}$ $\left(115^{\circ} \mathrm{F}\right)$, and the record minimum temperature is $-32.8^{\circ} \mathrm{C}$ $\left(-27^{\circ} \mathrm{F}\right)$. For the period 1912 through 1980 , the average monthly temperatures ranged from a low of $-1.5^{\circ} \mathrm{C}$ $\left(29.3^{\circ} \mathrm{F}\right)$ in January to a high of $24.7^{\circ} \mathrm{C}\left(76^{\circ} \mathrm{F}\right)$ in July. During the winter, the highest monthly average tempera- ture at the Hanford Meteorology Station was $6.9^{\circ} \mathrm{C}$ $\left(44.5^{\circ} \mathrm{F}\right)$ in February, and the record lowest was $-11.1^{\circ} \mathrm{C}$ $\left(12.1^{\circ} \mathrm{F}\right)$ in January. During the summer, the record maximum monthly average temperature was $27.9^{\circ} \mathrm{C}$ $\left(82.2^{\circ} \mathrm{F}\right.$ ) (in July), and the record lowest was $17.2^{\circ} \mathrm{C}$ $\left(63^{\circ} \mathrm{F}\right)$ (in June). The annual average relative humidity at the Hanford Meteorology Station is 54\%. It is highest during the winter months, averaging about $75 \%$, and lowest during the summer, averaging about $35 \%$. Average annual precipitation at the Hanford Meteorology Station is $16 \mathrm{~cm}$ (6.3 in.). Most of the precipitation occurs during the winter, with nearly half of the annual amount occurring November through February.

Atmospheric dispersion is a function of wind speed, duration and direction, atmospheric stability, and mixing depth. Dispersion conditions are generally good if winds are moderate to strong, the atmosphere is of neutral or unstable stratification, and there is a deep mixing layer. Good dispersion conditions associated with neutral and unstable stratification exist about $57 \%$ of the time during the summer. Less favorable dispersion conditions may occur when the wind speed is light and the mixing layer is shallow. These conditions are most common during the winter, when moderately to extremely stable stratification exists about $66 \%$ of the time. Occasionally there are extended periods, primarily during winter months, of poor dispersion conditions that are associated with stagnant air in stationary high-pressure systems.

\section{Results of 1993 Monitoring}

The weather in 1993 was slightly cooler and wetter than normal. The average temperature for 1993 was $11.0^{\circ} \mathrm{C}$ $\left(51.8^{\circ} \mathrm{F}\right), 0.8^{\circ} \mathrm{C}\left(1.5^{\circ} \mathrm{F}\right)$ below normal $\left[11.8^{\circ} \mathrm{C}\left(53.3^{\circ} \mathrm{F}\right)\right]$. Eight months during 1993 were cooler than normal, with four months at least $3.0^{\circ} \mathrm{C}\left(5.4^{\circ} \mathrm{F}\right)$ below normal. Only four months were warmer than normal, and only two months were more than $2.0^{\circ} \mathrm{C}\left(3.6^{\circ} \mathrm{F}\right)$ above normal. May temperatures were the highest above normal at $2.9^{\circ} \mathrm{C}\left(5.2^{\circ} \mathrm{F}\right)$ greater; while February temperatures, at $4.0^{\circ} \mathrm{C}\left(7.2^{\circ} \mathrm{F}\right)$ below normal, were the most below. 
Precipitation for 1993 totaled $19.9 \mathrm{~cm}$ ( 7.8 in.), $125 \%$ of normal [ $16 \mathrm{~cm}(6.3 \mathrm{in}$.$) ], with 92.0 \mathrm{~cm}$ (36.2 in.) of snow [compared to an annual normal of $35.1 \mathrm{~cm}$ (13.8 in.)]. Because 1993 was only slightly cooler than normal, with above normal precipitation and no extended cold outbreaks, little adverse impact to either flora or fauna is anticipated.
The average wind speed for 1993 was $10.7 \mathrm{~km} / \mathrm{h}$ $(6.7 \mathrm{mph}), 1.6 \mathrm{~km} / \mathrm{h}(1.0 \mathrm{mph})$ below normal, and the peak gust for the year was $108 \mathrm{~km} / \mathrm{h}(67 \mathrm{mph})$ on November 3. Figure 4.1 shows the 1993 wind roses (diagrams showing direction and frequencies of wind) for meteorological monitoring stations on and around the Hanford Site.

Table 4.1 provides monthly climatological data from the Hanford Meteorology Station for 1993.

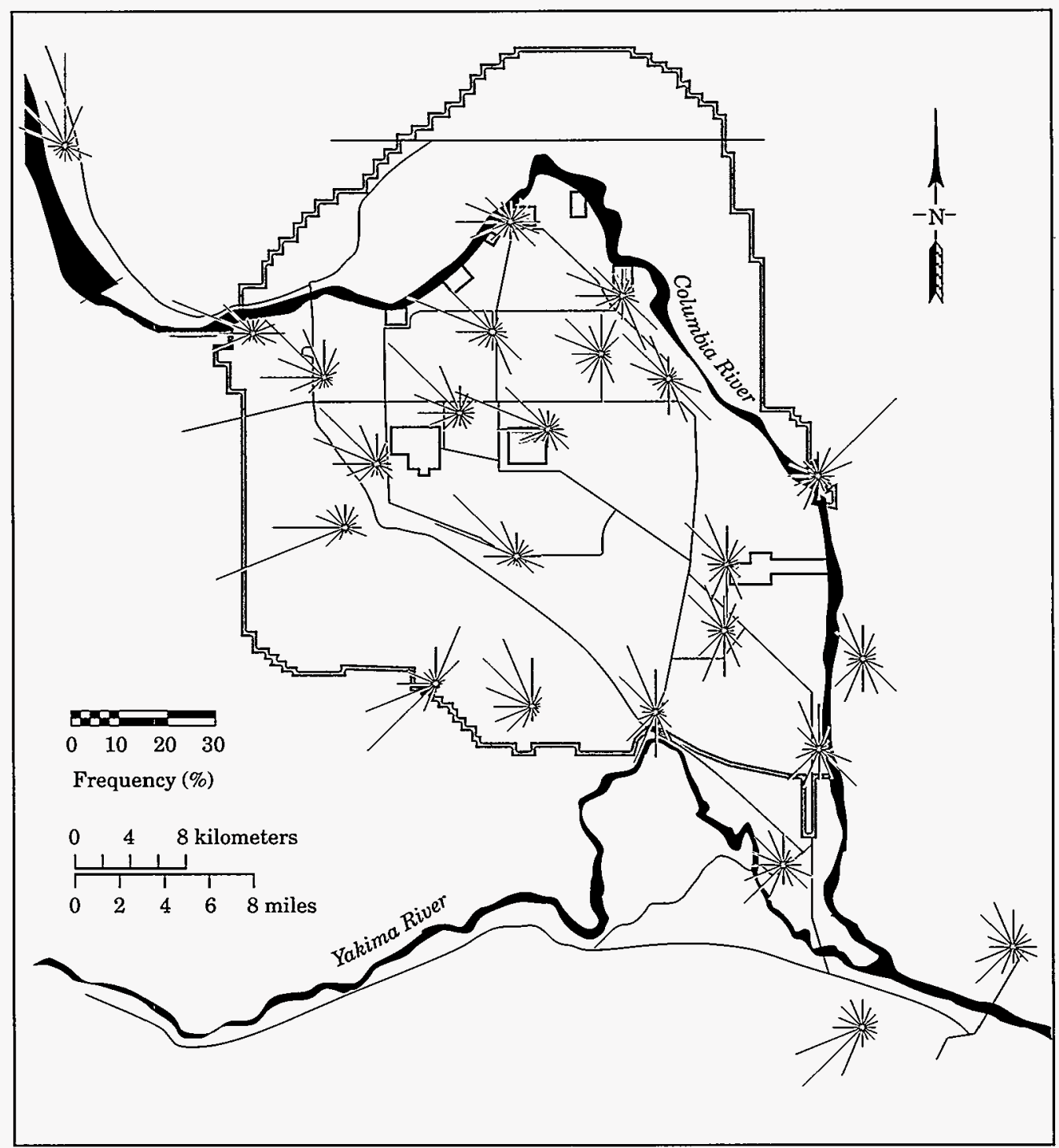

$\$ 9402063.2$

Figure 4.1. Hanford Meteorological Monitoring Network Wind Roses, 1993. Individual lines indicate direction from which wind blows. Length of line is proportional to frequency of occurrence from a particular direction. 
Table 4.1. Monthly Climatological Data from the Hanford Meteorology Station, 1993

Hanford Meteorology Station, 25 Miles N.W. of Richland, WA

Latitude $46^{\circ} 34^{\prime} \mathrm{N}$, Longitude $119^{\circ} 35^{\prime} \mathrm{W}$, Elevation $733 \mathrm{Ft}$

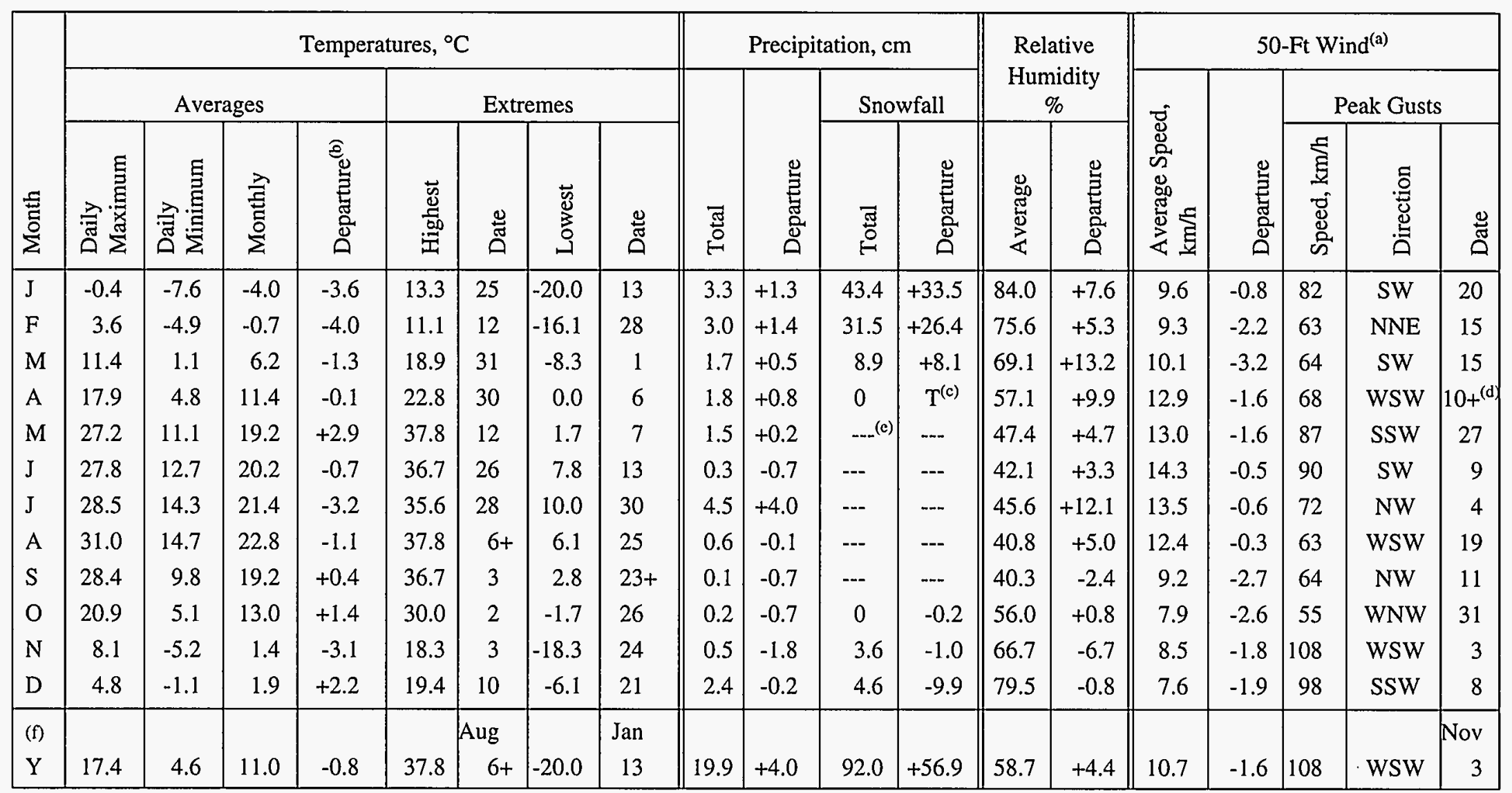

(a) Measured on a tower $50 \mathrm{ft}(15 \mathrm{~m})$ above the ground.

(b) Departure columns indicate positive or negative departure of meteorological parameters from 30-year (1961-1990) climatological normals.

(c) Trace.

(d) + after date indicates latest of several occurrences.

(e) --- means no record of any snow fall during these months.

(f) Yearly averages, extremes, and totals. 


\subsection{Wildlife}

L. L. Cadwell

The Hanford Site is a relatively large, undisturbed area of shrub-steppe that contains numerous plant and animal species adapted to the region's semi-arid environment. The vegetation mosaic of the Site consists of ten major plant communities: 1) sagebrush/bluebunch wheatgrass, 2) sagebrush/cheatgrass or sagebrush/Sandberg's bluegrass, 3) sagebrush-bitterbrush/cheatgrass, 4) grease wood/cheatgrass-saltgrass, 5) winterfat/Sandberg's bluegrass, 6) thyme buckwheat/Sandberg's bluegrass, 7) cheatgrass-tumble mustard, 8) willow or riparian, 9) spiny hopsage, and 10) sand dunes (Cushing 1992). Nearly 600 species of plants have been identified on the Hanford Site (Sackschewsky et al. 1992). Cheatgrass is the dominant plant on old fields that were cultivated approximately 50 years ago.

More than 300 species of terrestrial and aquatic insects, 12 species of reptiles and amphibians, 44 species of fish, 187 species of birds, and 39 species of mammals have been found on the Hanford Site (Cushing 1992). Deer and elk are the major large mammals on the Site; coyotes are plentiful, and the Great Basin pocket mouse is the most abundant mammal. Waterfowl are numerous on the Columbia River, and the bald eagle is a regular winter visitor along the river. Salmon and steelhead are the fish species of most interest.

There are two types of natural aquatic habitats on the Hanford Site; one is the Columbia River, and the other is provided by the small spring-streams and seeps located mainly on the ALE Reserve in the Rattlesnake Hills. These include Rattlesnake Springs, Dry Creek, Snively Springs, and West Lake, a small, natural pond near the 200 Areas. Several artificial water bodies, both ponds and ditches, have been formed as a result of waste-water disposal practices associated with the operation of the reactors and separation facilities; these water bodies form established aquatic ecosystems complete with representative flora and fauna (Emery and McShane 1980).

No plants or mammals on the federal list of Endangered and Threatened Wildlife and Plants (50 CFR 17.11, 17.12) are known to reside fulltime on the Hanford Site. However, several plant species, mammals, birds, and molluscs occurring on the Hanford Site are currently candidates for formal listing by the federal government and/or Washington State. The federal government lists the peregrine falcon as endangered and the bald eagle and Aleutian Canada goose as threatened. The peregrine falcon and Aleutian Canada goose are migrants through the Hanford Site, and the bald eagle is a common winter resident. Appendix G lists special-status species that could occur on the Hanford Site.

\section{Results for Wildlife Resource Monitoring, 1993}

Wildlife populations inhabiting the Hanford Site are monitored to measure the status and condition of the populations and assess effects of Hanford operations. Particular attention is paid to species that are rare, threatened, or endangered nationally or statewide and those species that are of commercial, recreational, or aesthetic importance statewide or locally. These species include the bald eagle, chinook salmon, Canada goose, ferruginous hawk, Rocky Mountain elk, mule deer, loggerhead shrike, and other bird species.

Fluctuations in wildlife and plant species on the Hanford Site appear to be a result of natural ecological factors and management of the Columbia River system. The establishment and management of the Hanford Site has helped to maintain wildlife populations relative to probable alternative uses of the Site.

\section{Bald Eagle}

The bald eagle is listed as a federally threatened species and also a Washington state threatened species. Historically, bald eagles have wintered along the Hanford Reach of the Columbia River. However, when monitoring began in the early 1960s, numbers were very low (Figure 4.2). Following the passage of the Endangered Species Act in 1973, the number of wintering bald eagles increased. Possible reasons for the observed increase are 
the added protection of bald eagles at nesting locations off the Hanford Site and the nationwide elimination of dichlorodiphenyltrichloroethane (DDT) as an agricultural pesticide in 1972. On a local scale, changes in the number of eagles on the Hanford Site generally correspond to changes in the number of salmon carcasses, a major fall and winter food source for eagles. Most of the eagles using the Hanford Reach are concentrated in the section between the abandoned old Hanford townsite and the $100-\mathrm{K}$ Area.

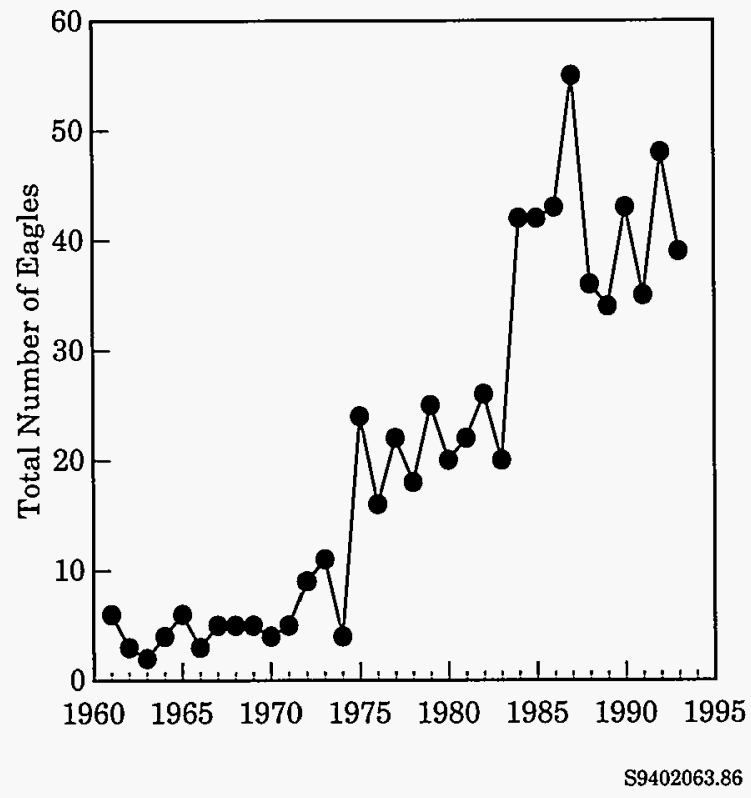

Figure 4.2. Bald Eagles Observed Along the Hanford Reach, Fall and Winter Months, 1961 Through 1993

The Hanford Reach is expected to continue providing wintering habitat, as long as the critical resources such as food, perches, and relative freedom from human activities are maintained. Limited nest building by bald eagles has been observed at the Hanford Site in recent years, although none of the attempts has been successful.

\section{Chinook Salmon}

Chinook salmon are an important resource to the citizens of the Pacific Northwest. Salmon are caught commercially and for recreation. The commercial and recreational catch is carefully managed to sustain the resource. Today the most important natural spawning area in the mainstream Columbia River for the fall chinook salmon is found in the free-flowing Hanford Reach. In the early years of the Hanford Site, there were few spawning nests (redds) in the Hanford Reach (Figure 4.3). In the years between 1943 and 1971, a number of dams were constructed on the Columbia River. The reservoirs created behind the dams eliminated most mainstem spawning areas and increased salmon spawning in the Hanford Reach. Fisheries management strategies aimed at maintaining spawning populations in the mainstem Columbia River have also contributed to the observed increases. In recent years, numbers of fall chinook salmon spawning in the Hanford Reach have declined consistent with reduced run sizes returning to the Columbia River. The number of salmon varies each year depending on hatching success, survival of downstream juveniles, and the size of the commercial and recreational catches. The Hanford Reach under existing management practices continues to provide valuable salmon spawning habitat.

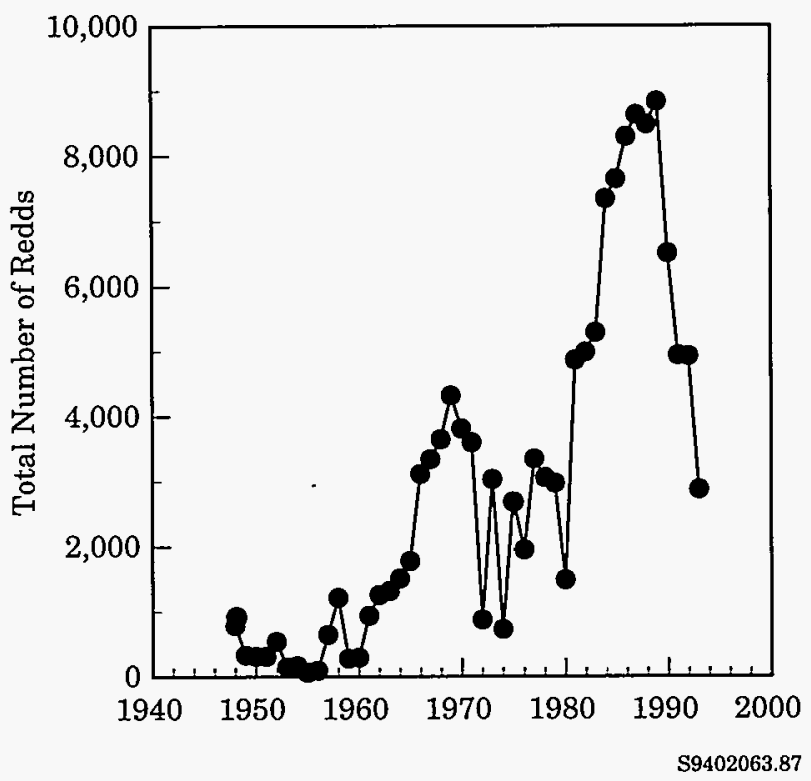

Figure 4.3. Chinook Salmon Spawning Redds in the Hanford Reach, 1948 Through 1993

\section{Canada Goose}

Nesting Canada geese are valuable recreational and aesthetic resources along the Snake and Columbia rivers in eastern Washington. Goose nesting surveys began in the 1950s to monitor changes in response to reactor operations (Figure 4.4). The gradual decline observed in the late 1960s and early 1970s is attributed to persistent 
coyote predation, mostly on the Columbia River islands upstream from the old Hanford townsite. Since the 1970 s, the center of the nesting population has shifted from upstream to downstream islands near Richland, which in recent years have been relatively free from coyote predation. The recent peak in Canada goose nests eclipsed the previous record from the late 1950 s.

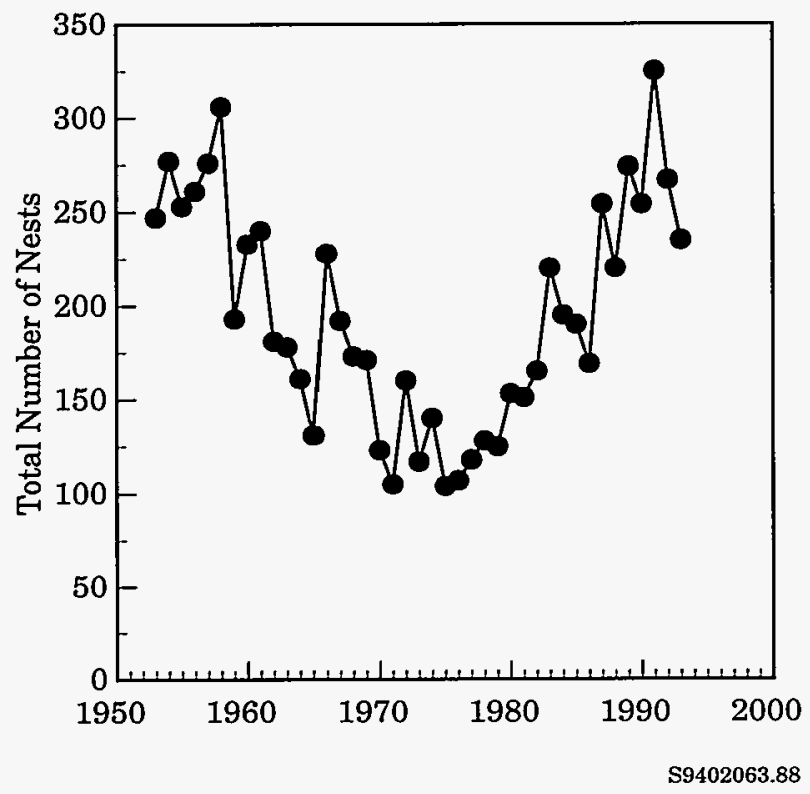

Figure 4.4. Canada Goose Nests on Islands in the Hanford Reach, 1953 Through 1993

Canada goose populations are successful on the Hanford Reach because the islands are restricted from human uses during the nesting period and because shoreline habitats provide adequate food and cover for broods (Eberhardt et al. 1989).

\section{Hawks}

The undeveloped land of the semi-arid areas of the Hanford Site provides nest sites and food for three species of migratory buteo hawks: Swainson's, redtailed, and ferruginous. Under natural conditions, these hawks nest in trees, on cliffs, or on the ground. Powerline towers and poles also can serve as nest sites, and these structures are well used by nesting hawks on the Hanford Site because of the relative scarcity of trees and cliffs. The ferruginous hawk is a U.S. Fish and Wildlife Service candidate species for listing as threatened and/or endangered. In recent years, the number of ferruginous hawks nesting on the Hanford Site has increased
(Figure 4.5). The Site continues to provide hawk nesting habitats administratively protected from human intrusions, as well as providing suitable foraging areas. The sharp declines in red-tailed and Swainson's hawk nests in the late 1980 s are probably not a result of Hanford Site activities because the number of nests for the very sensitive ferruginous hawk did not decline (Figure 4.5). Decreases in nesting red-tailed and Swainson's hawks may have been related to impacts that occurred during their migration and/or while they were on their wintering grounds. Nesting pairs of red-tailed hawks increased in 1991 and 1992 to approximately 25 , which represents a high for the species. In 1993, survey data were incomplete for both red-tailed and Swainson's hawks.

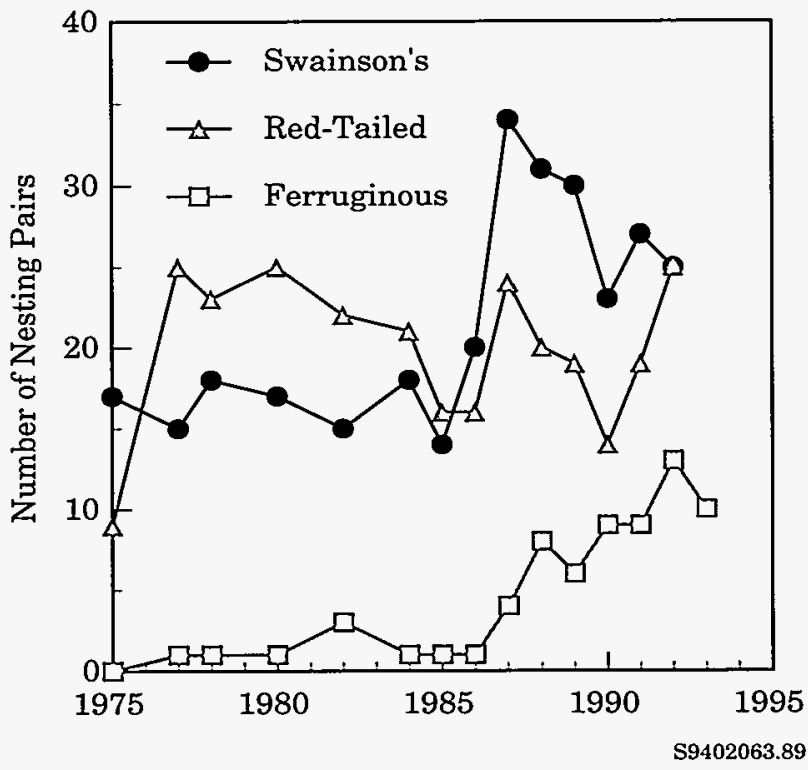

Figure 4.5. Red-Tailed, Swainson's, and Ferruginous Hawks on the Hanford Site, 1975 Through 1993. Survey data were unavailable for red-tailed and Swainson's hawks for 1993.

\section{Rocky Mountain Elk}

Rocky Mountain elk did not inhabit the Hanford Site when it was established in 1943. Elk appeared on the ALE Reserve in the winter of 1972. A few animals stayed and reproduced. The greatest number of elk recorded was 238 , before the 1993 offsite hunting season (Figure 4.6). With a regulated hunting season on private lands adjoining the ALE Reserve, the elk population appeared to be holding at less than 100 animals until the 
spring of 1990 . However, comparatively few elk were killed during recent offsite hunting seasons, and the herd has expanded to its current population of 224 animals.

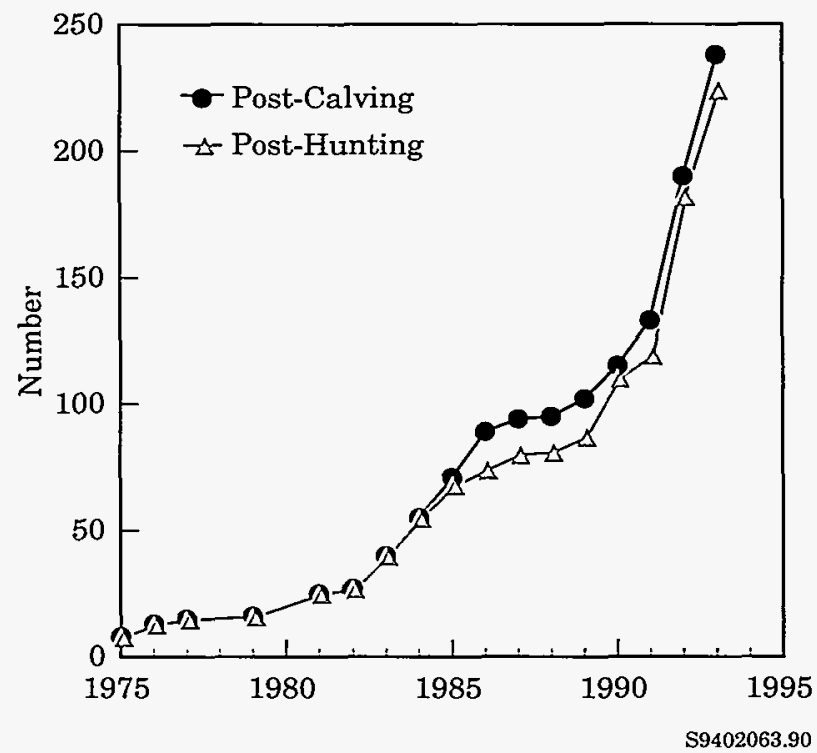

Figure 4.6. Elk on the Hanford Site Counted by Aerial Surveillance During the Post-Calving Period: August Through September; and the Post-Hunting Period: December Through January, 1975 Through 1993

Elk are successful on the ALE Reserve because of 1) available forage without competition from domestic livestock; 2) unrestricted access to drinking water at springs located on the ALE Reserve; 3) relatively mild winters; 4) ability to accommodate extreme summer temperatures, even in the absence of shade; and 5) absence of hunting on the Site.

\section{Mule Deer}

Mule deer are a common resident of the Hanford Site and are important because of the recreational (offsite hunting) and aesthetic values they provide. Because mule deer have been protected from hunting on the Hanford Site for approximately 50 years, the herd has developed a number of unique population characteristics that are in contrast to most other herds in the semi-arid region of the Northwest. These characteristics include a large proportion of old-age animals (older than 5 years) and large-antlered males. This herd provides a unique opportunity for comparison to other more heavily harvested herds in this region.
Because of the unique nature of the herd and high degree of public interest, a study was initiated in 1990 to 1) obtain estimates of the number of deer on the Hanford Site, 2) determine the extent and frequency of offsite movements by Hanford Site deer, and 3) evaluate the level of ${ }^{90} \mathrm{Sr}$ in deer from the 100 Areas (see Section 5.5, "Wildlife Surveillance"). Additional work was initiated in 1993 to identify possible causes for abnormal antler development and reduced testicle size observed in some mule deer residing along the Columbia River corridor. The condition was recently observed in old buck deer.

\section{Shrub-Steppe Birds of Special Concern}

The Washington Department of Fish and Wildlife has listed several shrub-steppe birds as species of special concern because their populations have been diminished by massive losses of native shrub-steppe habitat as a result of expanding agriculture and urbanization. The Hanford Site contains large contiguous areas of relatively undisturbed shrub-steppe habitat that provides nesting habitat for these birds. To determine the spatial distribution and relative abundance of species of special concern (sage sparrows, sage thrashers, loggerhead shrikes, and long-billed curlews), two transects have been monitored on the Hanford Site over the past 6 years using U.S. Fish and Wildlife Service procedures. These transects cross a variety of habitats including relatively undisturbed shrub-steppe, recently burned shrub-steppe, and agricultural fields that were abandoned in the early 1940 s and are now dominated by cheatgrass.

The only shrub-steppe species of special concern that nested in the abandoned fields was the long-billed curlew. The sage thrasher was seldom seen along either transect route, which is in agreement with other studies of shrub-steppe birds that indicate that sage thrashers are not abundant in low-elevation shrub-steppe habitats. Sage sparrows were most common in places that supported stands of sagebrush which had escaped burning by recent wildfires. Loggerhead shrikes were less plentiful than sage sparrows and occurred in places that supported either sagebrush or bitterbrush shrubs.

The lower elevations of the Hanford Site provide habitat suitable for viable populations of long-billed curlews, sage sparrows, and loggerhead shrikes but not sage thrashers. The long-billed curlew nests on the ground and is not dependent on desert shrubs for nest placement. However, sage sparrows and loggerhead shrikes place 
their nests in the branches of desert shrubs; thus, the loss of sagebrush and bitterbrush shrubs through burning is detrimental to these species.

\section{Special Plants and Invertebrate Animals}

The Washington Natural Heritage Program (1990) has identified three species of vascular plants that could be jeopardized by construction and/or cleanup activities performed on the Hanford Site. These species are Columbia yellowcress, Columbia milk vetch, and Hoover's desert parsley. Columbia yellowcress is listed as an endangered taxon in Washington State. It occurs along the shoreline of the Columbia River on the Hanford Site. Columbia milk vetch is listed as a threatened taxon and occurs on dry land of the Hanford Site upstream from the Vernita Bridge. Hoover's desert parsley, also listed as a threatened taxon, occurs on talus slopes of the Hanford Site in the same general area as Columbia milk vetch.

The U.S. Fish and Wildlife Service lists the Columbia pebblesnail as candidate species for protection as threatened or endangered species. The Columbia pebblesnail inhabits the Hanford Reach of the Columbia River and appears to have been widespread historically in the mainstem Columbia River Basin before the installation of dams. It is now apparently reduced within the Columbia Basin to isolated populations that are separated by large areas of unsuitable habitat.

Only two sizable populations of Columbia pebblesnail remain: those in the Methow and Okanogan rivers of north central Washington. Neither of these larger populations are protected. Smaller populations survive in the Hanford Reach and elsewhere. Because of the lack of habitat protection and the substantial reduction in the species' historical range, the Columbia pebblesnail will probably be listed federally as endangered.

\section{Wildlife Monitoring on Non-DOE Managed Hanford Site Land}

DOE property north of the Columbia River is managed for wildlife and recreation by two separate agencies. The Saddle Mountain National Wildlife Refuge (Figure 1.1) is the western-most portion of the "North Slope" area and is managed by the U.S. Fish and Wildlife Service through the Columbia National Wildlife Refuge Office located in Othello, Washington. The Wahluke Wildlife Area, which lies generally east and north of the Saddle Mountain refuge, is managed by the Washington Department of Fish and Wildlife as an outdoor recreation area. A third agency, the U.S. Army Corps of Engineers, was involved during 1993 in activities to clean up any residual contamination on all of the lands north of the Columbia River in anticipation of the DOE's final decision to disposition those properties. That activity has commonly been referred to as "North Slope clean up."

The Saddle Mountain refuge is managed as a natural preserve with relatively little resources dedicated to habitat management. This management approach is being used because the refuge is deemed to be temporary as a result of the 30-day revocation clause in the U.S. Fish and Wildlife permit from DOE. Habitat management will likely be given a higher priority if Saddle Mountain becomes a permanent part of the refuge system.

Management activities on the refuge during 1993 included controlling three wildfires (each exceeding 100 acres), scanning the shoreline of Saddle Mountain Lake for purple loosestrife and salt cedar, and monitoring upland portions of the refuge for knapweeds and Russian olive plants. Refuge staff initiated a kestrel (sparrow hawk) study in 1993 and confirmed the success of efforts to establish the birds as a breeding species on the refuge. The Columbia River shoreline was surveyed for sensitive plant species by botanists from both the Washington Natural Heritage Program and the Yakama Indian Nation. Waterfowl surveys were conducted throughout the year on the refuge.

Activities conducted on the Wahluke Wildlife Area by Washington Department of Fish and Wildlife included inspection of North Slope clean up areas, investigation of suspected trespass grazing on the area, hunter success checks, and a number of other site management activities consistent with use of the area as a public outdoor recreation area. Specific wildlife habitat management activities included planting approximately 20 acres of land for wildlife food and cover.

Breeding-pair duck surveys were conducted on a portion of the area. Other portions normally surveyed were omitted in 1993 because access was impeded by high water levels. 



\title{
4.3 Hanford Cultural Resources Laboratory
}

\author{
M. K. Wright
}

The Hanford Cultural Resources Laboratory was established by the Richland Operations Office in 1987 as part of the Pacific Northwest Laboratory. The cultural resources laborabory provides support for managing the archaeological, historical, and traditional cultural resources of the Hanford Site in a manner consistent with the National Historic Preservation Act, the Native American Graves Protection and Repatriation Act, the Archaeological Resources Protection Act, and the American Indian Religious Freedom Act.

Pursuant to Section 106 of National Historic Preservation Act, cultural resource reviews are conducted before each proposed ground-disturbing or building alteration/ demolition project on the Hanford Site. During 1993, Hanford contractors requested 437 such reviews, 24 of which required archaeological surveys. The surveys covered a total of $15.31 \mathrm{~km}^{2}\left(9.49 \mathrm{mi}^{2}\right)$ and resulted in discovery of 3 prehistoric archaeological sites, 79 historic archaeological sites, and 4 archaeological sites with historic and prehistoric components.

Three large projects were undertaken in 1993: the Environmental Restoration Disposal Facility, the North Slope Waste Site, and the 100 Area Operable Unit. Fifty-three archaeological sites and nine isolated finds were recorded during fieldwork conducted for these three projects. Most of the sites recorded are historic in nature and contain information ranging from lifeways of early settlers in the Hanford area to military installations in the 1950s.

One large project, the 300 Area Treated Effluent Disposal Facility, was redesigned to avoid a known archaeological site. This redesign was a very successful preservation effort and included the placement of a pipeline across the surface of the site instead of underground, as originally planned. The redesign eliminated the need to mitigate the impacts of trenching through the archaeological site and avoided disturbance of the site.
Section 110 of the National Historic Preservation Act requires that agencies undertake a program to identify historic properties; maintain and use a management inventory of documentation; integrate its management inventory with property management, land use planning, and project planning systems; consider the effects of proposed undertakings on historic properties early in the planning process; consider the use and re-use of historic properties; and seek opportunities for cooperative efforts with others in the preservation and use of historic properties. During 1993, efforts were initiated to develop a Multiple Property Document that would include several historic contexts dealing with prehistoric and historic periods, including the Manhattan Project and Cold War eras on the Hanford Site. The historic context for the Manhattan Project era was initiated in 1993. The final Multiple Property Document will provide the vehicle whereby historic buildings and prehistoric/ historic archaeological sites can be evaluated for their National Register eligibility and if determined eligible, be nominated to the National Register.

The archaeological site monitoring program, devised to comply with Section 110 of the National Historic Preservation Act, is designed to document the current condition of cultural resources, and thus to determine whether cultural resource management and protection policies are effective. Results of monitoring are used in planning cultural resource site management and protection. Following procedures established in the Hanford Cultural Resources Management Plan (Chatters 1989), cultural resource staff monitored the condition of 40 sites. The conclusions from this year's monitoring are very similar to those of previous years. Natural erosive and anthropogenic processes are the most significant factors impacting the majority of sites and could be reduced by revegetation and increased surveillance. Sites with public access receive the heaviest impacts from looters and vandalism. Another impact on sites inside and outside the security perimeter is wind erosion enhanced by off-road vehicle use. 
The archaeological survey of areas of the Hanford Site that are not targeted for development is a requirement of Section 110 of the National Historic Preservation Act and of 1988 amendments to Archaeological Resources Protection Act. The Hanford Cultural Resources Management Plan specifies that a $10 \%$ stratified random sample of Hanford Site lands will be surveyed to refine an existing model of archaeological site distributions. Sample plots were considered to be a low priority in 1993, and none were surveyed.

Educational activities associated with the cultural resources program included presenting lectures to groups of all ages and developing a series of displays to be used in Hanford Site facilities for worker education. Lectures were presented to groups ranging from primary school rockhounds to civic groups. Work on a video about the cultural resources program concluded this year.
The Hanford Cultural Resources Laboratory participated in the Teacher Research Associate and Northwest College and University Association for Science programs. A total of four Teacher Research Associate researchers were involved in researching past stream conditions using archaeological shell samples. Three Northwest College and University Association for Science students were also involved in field and laboratory work.

Research activities were conducted when possible as part of compliance work. Research in the field of archaeology and history focuses on several general areas of interest: interaction between prehistoric inhabitants and their plant and animal resources; the cultural interface between Native Americans and early settlers; early settlement patterns of Euro-Americans; and the privateto-public land transfer during the early 1940s for the Manhattan Project. 


\title{
4.4 Community-Operated Environmental Surveillance Program
}

\author{
R. W. Hanf
}

The Community-Operated Environmental Surveillance Program at Hanford was started in 1989 as an integral part of the Surface Environmental Surveillance Project (see Section 5.1). The DOE wanted to actively involve local citizens in the collection of environmental samples at locations around the Hanford Site to 1) increase the public's awareness of, and stimulate interest in,

Hanford's environmental surveillance activities;

2) increase public understanding of surveillance results;

3) provide a means for the public to address Hanford-

related environmental issues; and 4) provide an educa-

tional resource for local schools.

Three special air sampling stations were constructed and began operating in March 1991. These stations were located downwind of the Hanford Site at Basin City Elementary School in Basin City and Edwin Markham Elementary School in north Franklin County, and in Leslie Groves Park in Richland, the community closest to Hanford (see Figure 5.2). Stations were constructed on school- or city-owned property. Each station is similar in design and consists of equipment for collecting air samples and monitoring ambient radiation levels, and a large, lighted and covered informational display containing real-time meteorological and radiological information (Figure 4.7). All areas of the stations are publicly accessible, and stations have been designed and outfitted to stimulate public interest.

Two teachers working in schools close to the stations were hired to operate each station. One teacher acts as station manager, and the other acts as an alternate, or backup, manager. Teachers were chosen as managers because of their education and science backgrounds and because they have the opportunity to work with and discuss environmental sampling results in their classrooms.

The teacher's current responsibilities include collecting a variety of air samples, preparing samples and collection records for submission to a radioanalytical laboratory, monitoring the performance of station equipment, performing minor station maintenance, and participating in scheduled training. The managers also serve as public spokespersons for the Community-Operated Environmental Surveillance Program and function as points of contact for local citizens. Surface Environmental Surveillance Project staff work closely with station managers to maintain the equipment and coordinate sampling and analytical efforts with other Hanford environmental surveillance activities. Teachers are also supported by Site contractors through various education outreach programs.

Air sampling equipment has been installed at each station to monitor concentrations of airborne ${ }^{3} \mathrm{H},{ }^{131} \mathrm{I}$, and radioactive particles. Thermoluminescent dosimeters

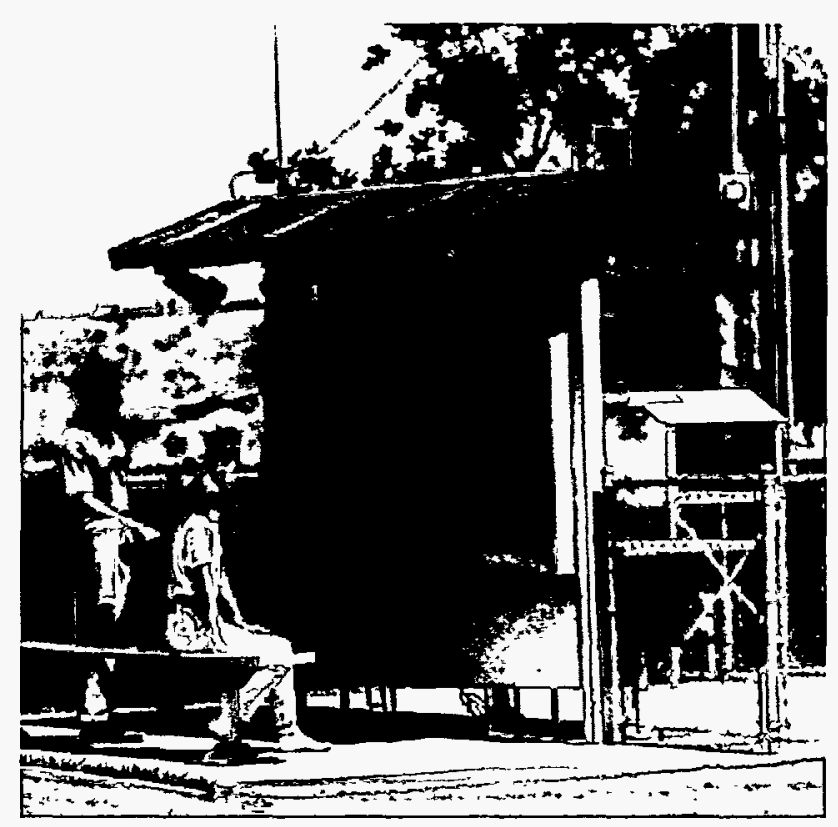

Figure 4.7. Community Members Can See Environmental Surveillance in Action at Three Local Community-Operated Environmental Surveillance Stations 
and pressurized ionization chambers are used to measure and record levels of gamma radiation. Small, inexpensive weather instruments have also been located at each station to provide weather information to teachers and students, and for the benefit of citizens living nearby. Station displays provide the public with general information on station equipment, sample types, and analyses. The station manager's name and phone number are provided on the display in the event a citizen desires additional information. In 1993, brochure boxes were installed on the display panel at the stations in Leslie Groves Park and Edwin Markham Elementary School. These boxes contain a variety of free pamphlets and brochures discussing Hanford environmental programs. A brochure box will be installed at the Basin City Elementary School station in 1994.

Sampling procedures used at Community-Operated Environmental Surveillance Program stations are identical to those used at other Surface Environmental Surveillance Project air sampling stations and are documented in the Surface Environmental Surveillance Procedures Manual (PNL 1992a). Procedures related to the operation of station meteorological and radiation measurement equipment have been provided separately. Supplemental or refresher training is provided for the teachers periodically each year.

During 1993, a computer (with software), modem, and printer were provided to each station manager for communication and data manipulation. The computers are located in classrooms and allow the teachers to contact contractor and DOE personnel, and other Community-Operated Environmental Surveillance Program station managers, via computer mail if they have questions or problems. The computers are also used to summarize or review environmental data that are collected at each Community-Operated Environmental Surveillance Program station and forwarded to the teachers by SESP staff for use in the classroom.
Sampling in 1993 also involved the acquisition of selected crop samples from students participating in school 4-H activities. A number of student 4-H members in the sampling areas downwind of the Site were asked to grow small plots of crops for the Hanford monitoring program. Quantities of these crops were purchased from the students and analyzed. Following analysis and data review, Surface Environmental Surveillance Project staff met with the students to discuss and interpret the analytical results.

In 1993, plans were developed to modify station displays and data collection and transmission capabilities at existing Community-Operated Environmental Surveillance Program stations. Some equipment was purchased, and computer software was developed that will provide the public with more information and an easier-to-read display, and will enhance data access and display capabilities in the classroom. Currently, real-time meteorological readings and ambient gamma radiation levels are displayed electronically at each station. Periodic gamma readings are also stored on computer disks that are downloaded to a desktop computer monthly. The new systems will feed meteorological and ambient radiation levels, including maximum and minimum values, and daily and/or monthly summaries, into a data logger and computer located at the station. The data logger will be connected via modem to a computer located in the teacher's classroom. This will allow the teacher to continuously display weather data in the classroom, or to access gamma radiation measurements from their own station, or from other CommunityOperated Environmental Surveillance Program stations that are outfitted with similar equipment. A prototype station using the new equipment and software should be ready for testing in early 1994 , and modification of existing stations should begin in summer of 1994. 


\title{
4.5 Other Environmental Studies
}

\author{
D. B. Shipler
}

Besides the meteorological and wildlife resource monitoring on the Hanford Site, other studies and programs investigate environmental issues. These studies and programs include the Hanford Environmental Dose Reconstruction Project and others.

\section{Hanford Environmental Dose Reconstruction Project}

In 1987, after receiving a recommendation by the Hanford Health Effects Review Panel the previous year, DOE directed the Pacific Northwest Laboratory to begin the Hanford Environmental Dose Reconstruction Project. (The Hanford Health Effects Review Panel had been formed to consider the potential health implications of historical Hanford Site releases of radioactive materials.) The objective of this project is to develop estimates of the radiation doses that people may have received from past Hanford operations. An independent Technical Steering Panel was selected by the Vice Presidents for Research at major universities of Washington and Oregon to direct the work of the project. The $18-\mathrm{mem}-$ ber panel consists of experts in various technical fields relevant to project work and representatives from the states of Washington, Oregon, and Idaho; Native American tribes; and the public. In 1991, responsibility for managing the project transferred to the U.S. Department of Health and Human Services through the Centers for Disease Control and Prevention. The Technical Steering Panel continues its role as the technical director of the work.

In 1990, scientists completed the first phase of the project, which was to determine whether enough information of sufficient quality existed to develop and demonstrate a dose-estimating method. The product of this phase was a set of more than 20 documents that describe:

- the preliminary information found or reconstructed

- preliminary dose-estimating models and computer codes

- preliminary estimates of dose and their uncertainties for representative individuals who may have lived near the Hanford Site during early years of operations.

Work since 1990 has concentrated on improving the tools and data to be used in dose calculations. Technical work for 1992 consisted of restructuring models to enhance their capabilities, developing detailed estimates of releases of radioactive materials, and identifying, acquiring, and evaluating additional information needed to produce estimates. This information is being developed for the $194,000-\mathrm{km}^{2}\left(75,000-\mathrm{mi}^{2}\right)$ study area highlighted in Figure 4.8, for major exposure pathways, and for the full history of the Hanford Site from 1944 through 1991.

Technical work during 1993 consisted of completing 1) the reconstruction of releases of key radionuclides to the atmosphere and Columbia River, 2) the modeling of atmospheric dispersion and deposition of ${ }^{131} I$ within the project area, 3) the description of transport and dilution of key radionuclides in the Columbia River, 4) the description of the historical commercial production and distribution system for milk within the project area, 5) the description of the historical commercial production and distribution system for fruits and vegetables within the project area, and 6) the reconstruction of diets and food consumption of representative individuals in 
the Northwest. In addition, the project 1) revised the atmospheric pathway environmental accumulation and dose codes, 2) developed all of the data and parameter input files to run all of the Hanford Environmental Dose Reconstruction integrated codes, 3) estimated doses for representative individuals for four Native American Tribes using information developed by the tribes, 4) estimated several hundred doses for real individuals included in the Hanford Thyroid Disease Study, and 5) completed preliminary estimates of doses and their uncertainties for representative individuals throughout the project area.
The key deliverable of the project is a set of "tool-box" computer codes and the data and parameter values to run them. These codes will be used for estimating doses to individuals who may have been exposed to releases of radionuclides from the Hanford Site from 1944 to 1972 when facilities shut down. These codes are scheduled to be delivered to the Centers for Disease Control and Prevention by the end of May 1994.

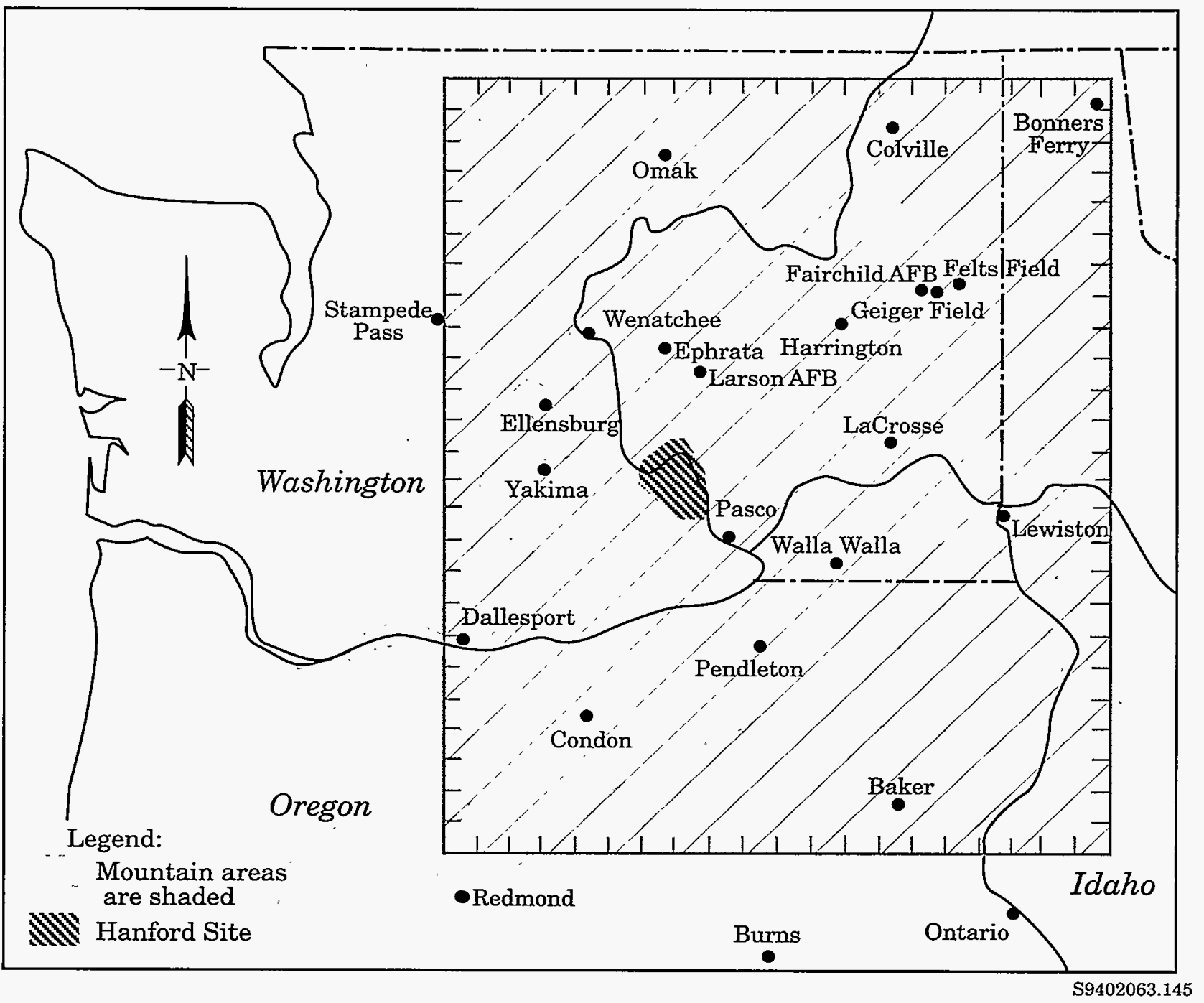

Figure 4.8. Area Considered in Estimating Doses from Past Hanford Operations in the Hanford Environmental Dose Reconstruction Project 


\section{Environmental Surveillance Information}

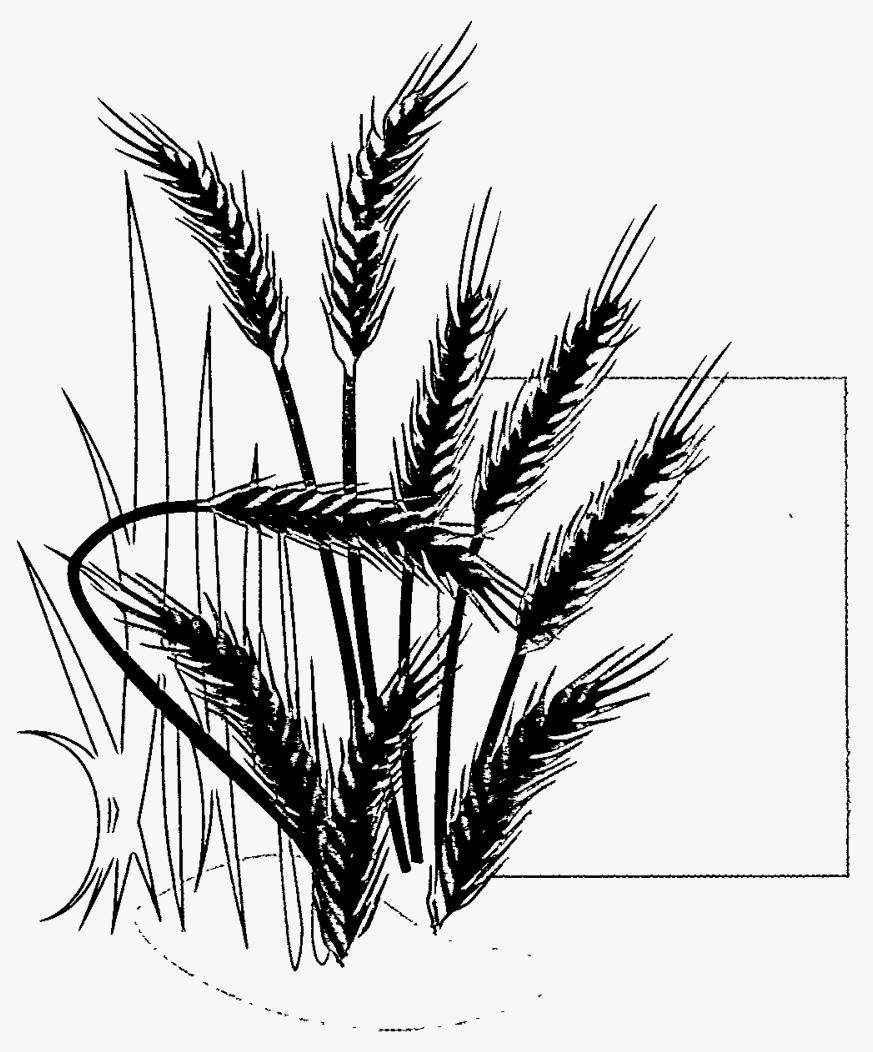




\subsection{Environmental Surveillance Information}

Environmental monitoring of the Hanford Site consists of effluent monitoring and environmental surveillance. Effluent monitoring is conducted at or near facilities on the Site and is discussed in this report in Section 3.0, "Effluent Monitoring Information." Environmental surveillance activities are conducted routinely both on and off the Site with the intent of detecting and quantifying radiological and nonradiological contaminants and assessing their environmental and human health significance. Section 5.2 through 5.8 describe the results of the Hanford Site environmental and ground-water surveillance programs for 1993 and include, where applicable, information on both radiological and nonradiological monitoring. Radiological doses associated with the surveillance results are discussed in Section 6.0, "Potential Radiation Doses from 1993 Hanford Operations," and the quality assurance and quality control programs developed for ensuring the value of surveillance data are described in Section 7.0, "Quality Assurance."

Many samples are collected and analyzed for the Hanford Site environmental surveillance program, and data obtained from the analytical laboratory are compiled in large computer databases. As it is not practical or desirable to include a listing of individual results in this report, the following sections include summary information emphasizing those radionuclides or chemicals of Hanford origin that are important for environmental or human health concerns. Supplemental data for some sections can be found in Appendix A of this report. More detailed results for specific surface environmental surveillance sampling locations are contained in the volume, Hanford Site Environmental Data 1993Surface and Columbia River (Bisping 1994). Additional information on Hanford Site ground-water monitoring can be found in the annual Hanford Site ground-water monitoring report (e.g., Dresel et al. 1993). The intent of the following summaries is to provide the reader with the most current surveillance data, compare the 1993 data to past data and to existing and accepted standards so that concentrations can be viewed in perspective, and present a general overview of Hanford Site surveillance activities. 


\title{
5.1 Environmental and Ground-Water Surveillance at Hanford
}

\author{
R. K. Woodruff and S. P. Luttrell
}

Environmental surveillance of the Hanford Site and surrounding region is conducted to demonstrate compliance with environmental regulations, confirm adherence to DOE environmental protection policies, support DOE environmental management decisions, and provide information to the public. Surveillance is conducted as an independent program under DOE Orders 5400.1, "General Environmental Protection Program," and 5400.5, "Radiation Protection of the Public and Environment," and the guidance in Environmental Regulatory Guide for Radiological Effluent Monitoring and Environmental Surveillance (DOE 1991a). The objectives, criteria, design, and description of the program are summarized below and provided in detail in the Hanford Site Environmental Monitoring Plan (DOE 1991b).

Ground-water surveillance at the Hanford Site is conducted to assess the impacts of Hanford operations on ground water, both on and off the Site. Radiological and nonradiological contaminants are monitored to determine the movement and distribution of existing contamination, and to identify emerging ground-water contamination problems. Ground-water surveillance at Hanford is an integral part of the Hanford Site Ground-Water Protection Management Program (DOE 1993b) but is conducted independently of the operating contractor's programs. A brief description of the program is included below and provided in detail in the Hanford Site GroundWater Protection Management Program (DOE 1989).

\section{Environmental Surveillance}

Environmental surveillance encompasses sampling and analyzing for potential radiological and chemical contaminants on and off the Hanford Site. Emphasis is placed on surveillance of those pathways and radionuclides, or chemicals, constituting the greatest potential risk to humans and the environment. The program has always been focused on radionuclides and nonradiologi- cal water quality parameters. In the last few years, however, surveillance for hazardous chemicals has been initiated. The environmental surveillance program focuses on routine releases from DOE facilities on the Hanford Site; however, the program is also responsive to unplanned releases and releases from non-DOE operations on and near the Site. Surveillance results are provided annually through this report series. In addition, unusual results or trends are reported to DOE and the appropriate facility managers when they occur. Whereas effluent and near-facility environmental monitoring are conducted by the facility operating contractor, environmental surveillance is conducted under an independent program that reports directly to the DOE Quality, Safety, and Health Programs Division.

\section{Objectives}

Key surveillance objectives in 1993 included:

- verifying compliance with DOE and EPA radiological dose standards for public protection

- independently assessing the adequacy of facility pollution controls

- assessing the environmental and public health impacts of Hanford operations

- identifying and quantifying potential environmental quality problems

- providing information to DOE for environmental management of the Site, to the public, and to regulatory agencies.

\section{Criteria}

The criteria for environmental surveillance are derived from DOE Order 5400.1, guidance published for DOE sites (DOE 1991a), and the above-stated objectives. These criteria, pathway analyses to determine the radionuclides and media contributing to the dose to 
humans, and local needs and interests have been used in establishing the surveillance program. Experience gained from environmental surveillance activities and studies conducted at the Hanford Site for more than 45 years have provided valuable technical background for planning and data interpretation.

\section{Surveillance Design}

Environmental surveillance at Hanford is designed to meet the previously listed objectives, considering the environmental characteristics of the Site and the potential and actual releases from Site activities. The main focus is on determining environmental impacts and compliance with public health standards, as well as environmental standards or protection guides, rather than on detailed radiological and chemical characterization.

The primary pathways for movement of radioactive materials and chemicals from the Site to the public are the atmosphere, surface water, and ground water.

Figure 5.1 illustrates these potential primary routes and the possible exposure pathways to humans. The significance of each pathway is determined from measurements

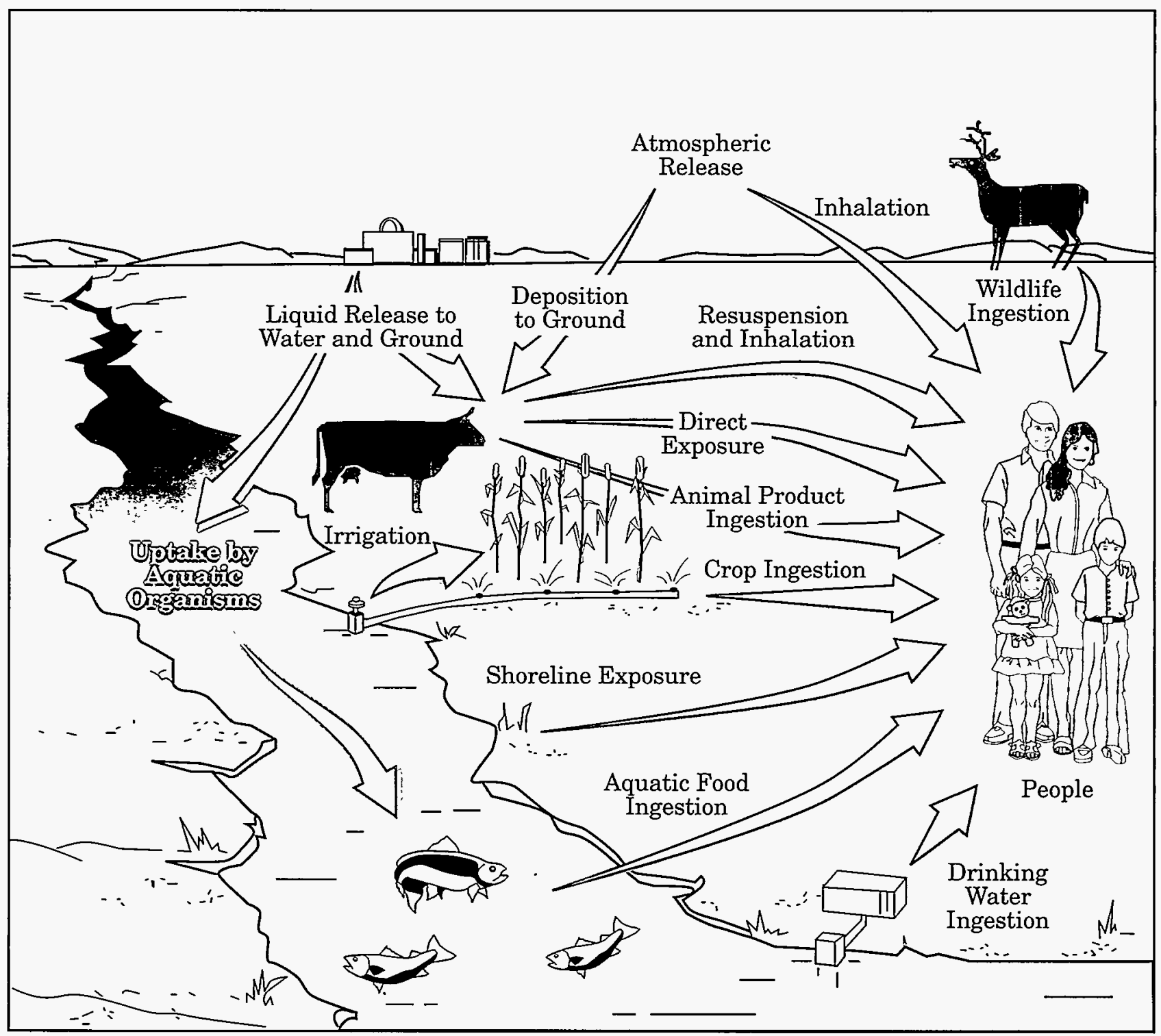

S9203058.131C

Figure 5.1. Primary Exposure Pathways 
and calculations that estimate the amount of radioactive material transported along each pathway and by comparing the concentrations or doses to environmental and public health protection standards or guides. Pathways are also evaluated based on prior studies and observations of radionuclide and chemical movement through the environment and food chains. Calculations based on effluent data show the expected concentrations off the Hanford Site to be low for all radionuclides and generally below the level that can be detected by monitoring technology. To ensure that radiological analyses of samples are sufficiently sensitive, minimum detectable concentrations of key radionuclides in air, water, and food are established at levels well below the levels that correspond to the standards.

Environmental and food-chain pathways are monitored near the facilities releasing effluents and at potential offsite receptor locations. The surveillance design at Hanford uses a stratified sampling approach to monitor these pathways. Samples are collected and radiation is measured in three general surveillance zones that extend from onsite operational areas to the offsite environs.

The first zone extends from near the operational areas to the Site perimeter. The environmental concentrations of releases from facilities and fugitive sources (those released from other than monitored sources such as contaminated soils) will generally be the highest, and therefore most easily detected, in this zone. The second surveillance zone consists of a series of perimeter sampling stations positioned near or just inside the Site boundary. Exposures at these locations are typically the maximum that any member of the public could receive. The third surveillance zone consists of nearby and distant community locations within an 80-km (50-mi) radius of the Site. Surveillance is conducted in communities to provide measurements at locations where a large number of people may potentially be exposed to Hanford releases and to provide assurance to the communities that contaminant levels are well below standards established to protect public health.

Background concentrations are measured at distant locations and compared with concentrations measured onsite and at perimeter and community locations. Background locations are locations that are essentially unaffected by Hanford operations, that is locations which can be used to measure ambient environmental levels of chemicals and radionuclides. Comparing background concentrations to concentrations measured on or near the Site provides an indication of the impact of Hanford operations.

To the extent possible, radiation dose assessments should be based on direct measurements of radiation dose rates and radionuclide concentrations in environmental media. However, the amounts of most radioactive materials released from Hanford operations in recent years have generally been too small to be measured directly once dispersed in the offsite environment. For the measurable radionuclides, it is often not possible to distinguish levels resulting from worldwide fallout and natural sources from those associated from Hanford releases. Therefore, offsite doses in 1993 were estimated using the following methods:

- Doses from controlled effluents were estimated by applying environmental transport and dose calculation models to measured effluent monitoring data and selected environmental measurements.

- Doses from fugitive air emissions (for example, from contaminated soils) were estimated from measured airborne concentrations at Site perimeter locations.

- Doses from fugitive liquid releases (for example, ground water seeping into the Columbia River) were estimated based on differences in measured concentrations upstream and downstream from the Hanford Site.

\section{Program Description}

In the first surveillance zone, between the operational areas and the Site perimeter, air monitoring stations were located around each operational area (see Figure 5.2) because air transport is a potential key pathway for movement of radioactive materials off the Site. Surfacewater ponds, potentially accessible to wildlife, and drinking water sources were also sampled (see Figure 5.8). Ground water was sampled from wells located near operating areas and along potential transport pathways (see Figures 5.42 through 5.46). In addition to air and water surveillance, samples of soil, native vegetation, and wildlife were collected (see Figures 5.28 and 5.30). Direct radiation dose rates were also measured (Figures 5.34 through 5.36), and selected onsite roads were surveyed (Figure 5.39). 
In the second or perimeter zone, air monitoring stations, radiation measurement locations, and ground-water surveillance wells were located near or just inside the Site boundary. Agriculture is an important industry near the Site; therefore, milk, crops, soil, and native vegetation are monitored (see Figures 5.23 and 5.30) to detect any influence from Hanford on locally produced food and farm products. The Columbia River is included in the second zone. River water is monitored upstream from the Site at Priest Rapids Dam and downstream at Richland, Washington, where it is used for public drinking water. Water pumped from the Columbia River for irrigation is also monitored.

Surveillance in the third zone, consisting of nearby and distant communities, includes air, soil, water supplies, vegetation, and food products sampling, and direct radiation dose rate measurements. Table 5.1 summarizes the geographic distribution of measurement locations.

Surveillance is conducted using established quality assurance plans (see Section 7.0, "Quality Assurance") and written procedures (PNL 1992a, 1993). Sample scheduling, accountability, data storage, and data screening were managed and controlled by computerized systems. Laboratory analyses of samples for radioactivity and chemicals were conducted principally by International Technology Corporation and the Pacific Northwest Laboratory, both in Richland, Washington. Selected river water quality and chemistry analyses, and temperature and flow measurements were performed by the U.S. Geological Survey, Denver, Colorado.

\section{Ground-Water Surveillance}

The ground-water surveillance program conducted on the Site is described in the Hanford Site Environmental Monitoring Plan (DOE 1991b). Generally, the operating contractor performs facility monitoring while Pacific
Northwest Laboratory performs Sitewide monitoring. Ground-water monitoring is conducted at treatment, storage, and disposal facilities to support the RCRA monitoring requirements. Monitoring is generally conducted upgradient of, and immediately downgradient of, the waste management unit boundary of RCRA facilities. Ground-water monitoring is also conducted near other waste disposal facilities to support the operational ground-water monitoring program. These programs involve "point-of-compliance" monitoring adjacent to disposal facilities, both to assess the efficacy of liquid effluent controls and to provide early detection of unusual occurrences or unexpected events. Groundwater investigations of remedial investigation/feasibility studies for CERCLA sites are also conducted.

Ground-water surveillance is conducted to identify the extent and assess the impacts of ground-water contamination on the Hanford Site within a Sitewide perspective. Ground-water surveillance is conducted in the region between specific facilities and the Site perimeter. Sitewide ground-water data are reviewed in conjunction with data from the specific facility monitoring and characterization programs to provide an integrated assessment of ground-water quality and impacts. Trends of contaminant concentrations in ground water are constructed and assessed to aid interpretations. Watertable maps for the Hanford Site and portions of Franklin County are constructed from ground-water elevation measurements to describe ground-water recharge, movement, and discharge.

Sitewide ground-water surveillance is conducted using established quality assurance plans (see Section 7.0, "Quality Assurance") and written procedures (PNL 1993). Sample scheduling, accountability, and data storage are managed by computerized systems. Laboratory analyses were conducted primarily by International Technology Corporation for radioactivity, and by DataChem Laboratories and Pacific Northwest Laboratory for chemicals. 
Table 5.1. Environmental Surveillance Sample Types and Measurement Locations, 1993

\begin{tabular}{|c|c|c|c|c|c|c|c|c|}
\hline \multirow[b]{3}{*}{$\begin{array}{c}\text { Total } \\
\text { Number }\end{array}$} & \multicolumn{8}{|c|}{ Sample Locations } \\
\hline & \multirow[b]{2}{*}{ Onsite } & \multirow[b]{2}{*}{$\begin{array}{c}\text { Site } \\
\text { Perimeter }^{(b)} \\
\end{array}$} & \multirow[b]{2}{*}{$\begin{array}{c}\text { Nearby } \\
\text { Communities }^{(c)}\end{array}$} & \multirow[b]{2}{*}{$\begin{array}{c}\text { Distant } \\
\text { Communities }^{(c)}\end{array}$} & \multirow[b]{2}{*}{$\begin{array}{c}\text { COES } \\
\text { Stations }^{(c, d)} \\
\end{array}$} & \multicolumn{3}{|c|}{ Columbia River } \\
\hline & & & & & & Upstream $^{(\mathrm{c})}$ & $\begin{array}{l}\text { Hanford } \\
\text { Reach }^{(b)}\end{array}$ & Downstream $^{(c)}$ \\
\hline 39 & 20 & 10 & 4 & 2 & 3 & & & \\
\hline 454 & 454 & & & & & & & \\
\hline 7 & & & & & & & 7 & \\
\hline 7 & & & & & & 2 & 4 & 1 \\
\hline 1 & & 1 & & & & & & \\
\hline 13 & 8 & $5^{(1)}$ & & & & & & \\
\hline 9 & & & & & & 1 & 6 & 2 \\
\hline 3 & 3 & & & & & & & \\
\hline 10 & & 6 & 2 & 2 & & & & \\
\hline 11 & 9 & 2 & & & & & 2 & \\
\hline 36 & 19 & 14 & 1 & 2 & & & & \\
\hline 13 & 6 & 5 & & 2 & & & & \\
\hline 68 & 26 & $33^{(h)}$ & 4 & 2 & 3 & & & \\
\hline 5 & 5 & & & & & & & \\
\hline 16 & & 16 & & & & & & \\
\hline 1 & 1 & & & & & & & \\
\hline
\end{tabular}

(a) Surveillance Zone 1 .

(b) Surveillance Zone 2.

(c) Surveillance Zone 3.

(d) $\mathrm{COES}=$ community-operated environmental surveillance.

(e) Approximately 770 wells were sampled for all ground-water monitoring programs onsite.

(f) Includes four offsite water supplies.

(g) TLDs $=$ thermoluminescent dosimeters.

(h) Includes locations along the Columbia River. 


\title{
5.2 Air Surveillance
}

\author{
G. W. Patton
}

Atmospheric releases of pollutants from Hanford to the surrounding region are a potential source of human exposure. For that reason both radioactive and nonradioactive materials in air are monitored at a number of locations. The influence of Hanford emissions on local radionuclide concentrations was evaluated by comparing concentrations measured at distant locations within the region to concentrations measured at the Site perimeter. This section discusses sample collection, analytical methods, and the results of the air surveillance program. A complete listing of all analytical results summarized in this section is reported annually by Bisping (1994).

\section{Sample Collection and Analysis}

\section{Radiological Air Sampling}

Airborne radionuclides were sampled by a network of 39 continuously operating samplers: 20 on the Hanford Site, 10 near the Site perimeter, 4 in nearby communities, 2 in distant communities, and 3 community-operated environmental surveillance stations that were managed and operated by local school teachers (Figure 5.2 and Table 5.2). Air samplers on the Hanford Site were located primarily around major operational areas to maximize the ability to detect contaminants resulting from Site operations. Perimeter samplers were located around the Site, with emphasis on the prevailing downwind directions to the south and east of the Site. Continuous samplers located in Benton City, Richland, Kennewick, Mattawa, and Pasco provided concentrations at the nearest population centers. Samplers at the distant communities of Sunnyside and Yakima provided data from communities essentially unaffected by Site operations.

Samples were collected according to a schedule established before the monitoring year (Bisping 1993). Air sampling locations are listed in Table 5.2, along with specific analyses for each location. Airborne particles were sampled at each of these locations by continuously drawing air through a high-efficiency glass-fiber filter. The filters were collected every 2 weeks, field surveyed with hand-held instruments for total radioactivity to detect any unusual occurrences, stored for at least 7 days at the analytical laboratory, and then analyzed for total beta radioactivity. In addition, filters from most locations were also analyzed for total alpha radioactivity. The storage period was necessary to allow for the decay of short-lived, naturally occurring radionuclides (e.g., radon gas decay products) that would otherwise obscure detection of longer-lived radionuclides potentially present from Hanford emissions. Field measurements of radioactivity in samples are used to monitor changes in environmental conditions that could warrant attention before the more detailed and sensitive laboratory analyses are completed.

For most radionuclides, the amount of radioactive material collected on the filter during the 2-week period was too small to be readily measured. The sensitivity and accuracy of sample analysis was increased by combining biweekly samples for nearby locations (or in some cases a single location) into quarterly composite samples. The quarterly composite samples were analyzed for numerous specific gamma-emitting radionuclides (Appendix F). The quarterly composite samples were then combined to form annual composite samples (Table 5.2). Annual composites were analyzed for strontium and plutonium isotopes, and selected annual composites were also analyzed for uranium and americium isotopes.

Gaseous ${ }^{131} \mathrm{I}$ was sampled at four locations by drawing air through a cartridge containing chemically treated activated charcoal. These cartridges were exchanged biweekly and were located downstream of a particle filter. Iodine-131 has a short half-life ( 8 days) and is potentially present in the environment only around active nuclear reactors. With the shutdown of all DOE nuclear reactors on the Hanford Site, there is no active DOE source of this radioisotope and any ${ }^{131}$ I released to the environment from past operations at $100-\mathrm{N}$ and the FFTF would have decayed to undetectable amounts. Therefore, sampling for ${ }^{131}$ I on the Hanford Site was 


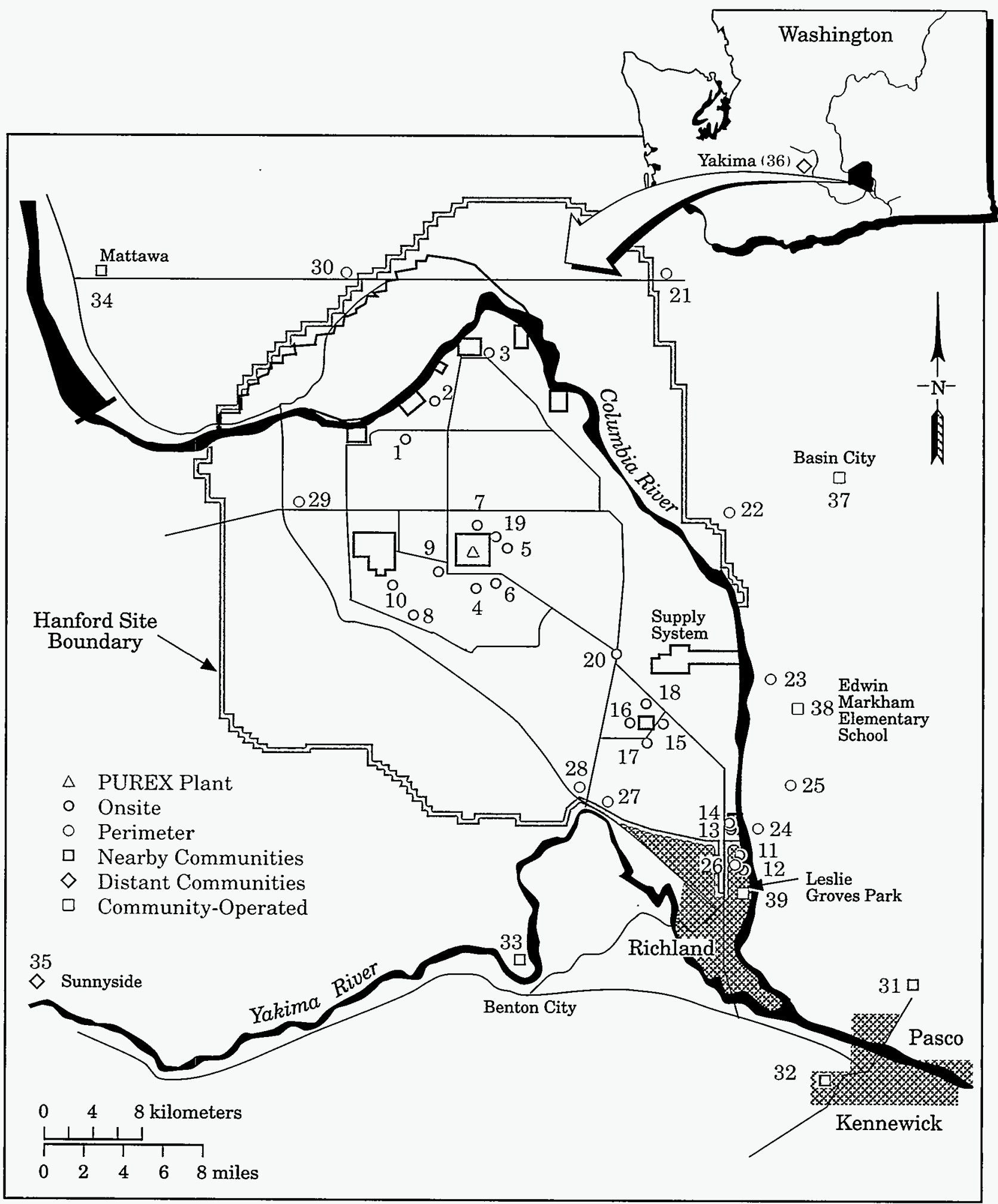

S9402063.1

Figure 5.2. Air Sampling Locations, 1993 (see Table 5.2 for location key) 
Table 5.2. Air Sampling Locations, Sample Composite Groups, and Analyses, 1993

\begin{tabular}{|c|c|c|c|c|}
\hline $\begin{array}{c}\text { Map }^{(a)} \\
\text { Location }\end{array}$ & Sampling Location & Analyses $^{(\mathbf{b})}$ & Composite Group & Analyses $^{(\mathfrak{c})}$ \\
\hline \multicolumn{5}{|l|}{ Onsite } \\
\hline 1 & $100-K$ & Beta, alpha, ${ }^{3} \mathrm{H}$ & \multirow{3}{*}{100 Areas } & \multirow{3}{*}{ Gamma, Sr, $\mathrm{Pu}$} \\
\hline 2 & $100-\mathrm{N}$ & Beta, alpha, VOC & & \\
\hline 3 & $100-\mathrm{D}$ & Beta, alpha & & \\
\hline 4 & $S$ of 200 -East & Beta, alpha & \multirow{3}{*}{ 200-East } & \multirow{3}{*}{ Gamma, Sr, Pu, U, Am } \\
\hline 5 & E of 200 -East & Beta, alpha & & \\
\hline 6 & 200-East SE & $\begin{array}{l}\text { Beta, alpha, }{ }^{3} \mathrm{H},{ }^{129} \mathrm{I}, \\
\text { VOC }\end{array}$ & & \\
\hline 7 & $\mathrm{~N}$ of 200 -East & $\mathrm{NRA}^{(c)}$ & & \multirow{3}{*}{ Gamma, Sr, Pu, U } \\
\hline 8 & Army Loop Camp & Beta, alpha & \multirow[t]{2}{*}{ 200-West, South, and East } & \\
\hline 9 & GTE Building & Beta, alpha, ${ }^{3} \mathrm{H}$ & & \\
\hline 10 & 200-West SE & Beta, alpha, VOC, $\mathrm{PCB}^{(\mathfrak{n})}$ & 200-West & Gamma, Sr, Pu, U \\
\hline 11 & 300 Water intake & Beta & \multirow{2}{*}{300 Area } & \multirow{2}{*}{ Gamma, Sr, Pu, U } \\
\hline 12 & 300-South Gate & Beta, alpha, ${ }^{3} \mathrm{H}$ & & \\
\hline 13 & $300 \mathrm{NE}$ & $\begin{array}{l}\text { Beta, alpha, }{ }^{3} \mathrm{H}, \\
\text { VOC, PCB }\end{array}$ & $300 \mathrm{NE}$ & Gamma, Sr, Pu, U \\
\hline 14 & 300 Trench & Beta, alpha, ${ }^{3} \mathrm{H}$ & & \multirow{5}{*}{ Gamma, Sr, $\mathrm{Pu}$} \\
\hline 15 & 400 -East & Beta, alpha, ${ }^{3} \mathrm{H}$ & \multirow{4}{*}{400 Area } & \\
\hline 16 & 400-West & Beta, alpha & & \\
\hline 17 & 400-South & Beta, alpha & & \\
\hline 18 & 400 -North & Beta, alpha & & \\
\hline 19 & B Pond & Beta, alpha & B Pond & Gamma, Sr, Pu,U \\
\hline 20 & Wye Barricade & Beta, alpha & Wye Barricade & Gamma, Sr, Pu, U, Am \\
\hline \multicolumn{5}{|l|}{ Perimeter } \\
\hline 21 & Berg Ranch & NRA & & \\
\hline 22 & Ringold Met. Tower & Beta, alpha, ${ }^{3} \mathrm{H},{ }^{129} \mathrm{I},{ }^{131} \mathrm{I}$ & Ringold Met. Tower & Gamma, $\mathrm{Sr}, \mathrm{Pu}$ \\
\hline 23 & W End of Fir Road & Beta, alpha & W End of Fir Road & Gamma, Sr, U, Am \\
\hline 24 & Byers Landing & Beta, alpha, ${ }^{3} \mathrm{H},{ }^{129} \mathrm{I},{ }^{131} \mathrm{I}$ & Byers Landing & Gamma, Sr, Pu, U, Am \\
\hline 25 & Dogwood Met. Tower & Beta, alpha, ${ }^{3} \mathrm{H}$ & Dogwood Met. Tower & Gamma, $\mathrm{Sr}, \mathrm{Pu}, \mathrm{U}, \mathrm{Am}$ \\
\hline 26 & Battelle Complex & NRA & & \\
\hline 27 & Horn Rapids Road & & & \\
\hline 28 & $\begin{array}{l}\text { Substation } \\
\text { Prosser Barricade }\end{array}$ & $\begin{array}{l}\text { Beta, alpha } \\
\text { Beta, alpha, }{ }^{3} \mathrm{H}\end{array}$ & Prosser Barricade & Gamma, Sr, Pu, U \\
\hline 29 & Yakima Barricade & Beta, alpha, VOC, ${ }^{(g)} \mathrm{PCB}^{(\mathrm{g})}$ & Yakima Barricade & Gamma, Sr, Pu \\
\hline 30 & Wahluke Slope & Beta, alpha, ${ }^{3} \mathrm{H}$ & Wahluke Slope & Gamma, Sr, Pu \\
\hline
\end{tabular}


Table 5.2. Air Sampling Locations, Sample Composite Groups, and Analyses, 1993 (contd)

\begin{tabular}{|c|c|c|c|c|c|}
\hline \multicolumn{6}{|c|}{$\operatorname{Map}^{(a)}$} \\
\hline \multicolumn{6}{|c|}{ Nearby Communities } \\
\hline $\begin{array}{l}31 \\
32\end{array}$ & & $\begin{array}{l}\text { Pasco } \\
\text { Kennewick }\end{array}$ & $\begin{array}{l}\text { Beta } \\
\text { Beta, alpha }\end{array}$ & \multirow[t]{2}{*}{ Tri-Cities } & \multirow[t]{2}{*}{$\mathrm{Gamma}, \mathrm{Sr}, \mathrm{Pu}$} \\
\hline 33 & & Benton City & NRA & & \\
\hline 34 & & Mattawa & NRA & & \\
\hline \multicolumn{6}{|c|}{ Distant Communities } \\
\hline 35 & & Sunnyside & Beta, alpha, ${ }^{3} \mathrm{H}$ & Sunnyside & Gamma, Sr, Pu, U \\
\hline 36 & & Yakima & Beta, alpha, ${ }^{3} \mathrm{H},{ }^{129} \mathrm{I},{ }^{131} \mathrm{I}$ & Yakima & Gamma, Sr, Pu, U, Am \\
\hline \multicolumn{6}{|c|}{ Community-Operated Environmental Stations } \\
\hline 37 & & Basin City & Beta, alpha, ${ }^{3} \mathrm{H}$ & Basin City Elem. School & Gamma, Sr, Pu, U \\
\hline 38 & & North Franklin County & Beta, alpha, ${ }^{3} \mathrm{H},{ }^{131} \mathrm{I}$ & Edwin Markham Elem. School & Gamma, Sr, Pu, U, Am \\
\hline 39 & & Richland & Beta, alpha, ${ }^{3} \mathrm{H}$ & Leslie Groves Park & Gamma, $\mathrm{Sr}, \mathrm{Pu}, \mathrm{U}$ \\
\hline (a) & \multicolumn{5}{|c|}{ See Figure 5.2.} \\
\hline (b) & \multicolumn{5}{|c|}{$\begin{array}{l}\text { Beta, alpha, and }{ }^{131} \text { I samples are collected biweekly (every } 2 \text { weeks), }{ }^{3} \mathrm{H} \text { samples are collected monthly, and }{ }^{129} \mathrm{I} \text { samples are } \\
\text { collected monthly and combined into a quarterly composite sample for each location (see Sample Collection and Analysis in } \\
\text { this section). }\end{array}$} \\
\hline (c) & \multirow{2}{*}{\multicolumn{5}{|c|}{$\begin{array}{l}\text { Gamma scans are performed on quarterly composite samples; } \mathrm{Sr}, \mathrm{Pu}, \mathrm{U} \text {, and Am analyses are performed on annual composite } \\
\text { samples (see Sample Collection and Analysis in this section). } \\
\text { VOC = Volatile organic compounds. }\end{array}$}} \\
\hline (d) & & & & & \\
\hline (e) & \multicolumn{5}{|c|}{ NRA = not routinely analyzed. } \\
\hline (f) & \multicolumn{5}{|c|}{$\mathrm{PCB}=$ polychlorinated biphenyl. } \\
\hline (g) & \multicolumn{5}{|c|}{ The volatile organic compounds and PCB samples were collected at Rattlesnake Springs. } \\
\hline
\end{tabular}

discontinued in 1993. Iodine-131 was sampled at a few locations offsite to maintain field sampling and analytical capability in the event of a restart of the FFTF.

Iodine-129 (16,000,000-year half-life) was sampled using a similar technique as ${ }^{131} \mathrm{I}$; however, a special lowbackground petroleum-charcoal cartridge was used for increased sensitivity. Samples were collected monthly at four locations and combined to form quarterly composite samples for each location.

Atmospheric water vapor was collected for ${ }^{3} \mathrm{H}$ analysis at 17 locations by continuously passing air through cartridges containing silica gel, which were exchanged every 4 weeks. The collected water was distilled from the silica gel and analyzed for its ${ }^{3} \mathrm{H}$ content.

A detailed description of all radiological sampling and analytical techniques is provided in the Hanford Site Environmental Monitoring Plan (DOE 1991b). Air monitoring was discontinued at several locations in 1993 to reflect the substantial decrease in Hanford Site air emissions following the 1990 reduction in PUREX Plant operations. Air sampling was discontinued at the Fitzner/Eberhardt ALE field laboratory, old Hanford townsite, Route 11A Mile 9, SW of B/C cribs, Rattlesnake Springs, and Vernita Bridge. In addition, air samples were collected but not routinely analyzed at the following locations: Benton City, Battelle complex, Berg Ranch, Mattawa, and north of the 200-East Area. Samples from these locations were stored in an archive facility in the event that later analysis would be required.

A portion of the environmental surveillance air samples was collected at three community operated environmental surveillance stations located at Basin City Elementary School in Basin City, Edwin Markham Elementary School in North Franklin County, and Leslie Groves Park in Richland (see Figure 5.2 and Table 5.2). These samples were collected by local teachers using the same 
equipment, procedures, and analytical laboratory as the routine surveillance program. This work is part of an ongoing DOE-sponsored program to improve public awareness of Hanford environmental monitoring programs and the effects of Site operations.

\section{Nonradiological Air Sampling}

Nonradiological air samples for volatile organic compounds and polychlorinated biphenyls (PCBs) were collected downwind of the 300 Area Process Trenches (Table 5.2, location \#13), at the southeast corner of the 200-West Area (Table 5.2, location \#10), and at a background location near Rattlesnake Springs (Table 5.2, near location \#29). Additional volatile organic compound samples were also collected at 200-East SE and 100-N (Table 5.2, locations \#6 and \#2). Air samples for volatile organic compounds were collected using EPA Method TO-2 (EPA 1988), which uses low-volume air samplers with adsorbent (carbon molecular sieve) traps. Air samples were analyzed by Air Toxics, Inc. (Rancho Cordova, California), using EPA Method TO-2 (EPA 1988). Air samples for PCB analysis were collected using EPA Method TO-4 (EPA 1988), utilizing highvolume air samplers equipped with glass-fiber filters and (polyurethane foam) adsorbent traps. Air samples were analyzed for PCBs by General Physics, Inc. (Gaithersburg, Maryland), using a combination of EPA TO-4 (sample media preparation and analytical extraction) and EPA SWA-846 Method 8080 (EPA 1986a) for analysis. Samples for both volatile organic compounds and PCB's were collected using primary and secondary adsorbent traps; the secondary trap was used at selected locations to monitor vapor penetration (breakthrough) through the primary trap.

\section{Results}

\section{Radiological Results}

Radiological air sampling results for onsite, Site perimeter, nearby communities, distant communities, and community-operated stations for total beta, total alpha, and specific radionuclides are summarized in Table 5.3. Numerous specific radionuclides (Appendix F) were analyzed in the quarterly composite gamma-scan analyses, but none of Hanford origin was detected consistently.
Total beta concentrations in air for 1993, as shown in Figure 5.3, peaked during the winter, repeating a pattern of natural annual radioactivity fluctuations (Eisenbud 1987). As shown in Table 5.3, the average total beta and total alpha concentrations were about the same onsite as at the Site perimeter and in nearby and distant communities, indicating that the observed levels were predominantly a result of natural sources and worldwide fallout. No differences were observed between annual average concentrations measured at the Site perimeter and distant locations for either total beta or total alpha radioactivity.

A summary of ${ }^{3} \mathrm{H}$ results from 1988 to 1993 is given in Table 5.4. Table 5.4 provides a consistent treatment of the historical data because previous Hanford Site reports used differing methods to report suspect ${ }^{3} \mathrm{H}$ results. As shown in Table 5.4, ${ }^{3} \mathrm{H}$ concentrations measured for 1993 were similar to the values reported from previous years and did not show the highly elevated concentrations and widely variable results reported for January to May 1992 (Woodruff et al. 1993). The January-to-May 1992 results are highly suspect and are likely the results of cross contamination because even the concentrations at the distant locations were high and variable. Tritium concentrations for a few individual samples for 1993 were elevated and suspected of having the same cross contamination problem as the above 1992 results ( 9 of 209 samples were $\geq 10 \mathrm{pCi} / \mathrm{m}^{3}$ ), but no sampling station measured consistently elevated concentrations. However, even the highest individual concentration reported for 1993 [600 $\mathrm{pCi} / \mathrm{m}^{3}$ at the $300 \mathrm{NE}$ location (June 29 to July 26, 1993)] was only $0.6 \%$ of the $100,000-\mathrm{pCi} / \mathrm{m}^{3}$ derived concentration guide. For 1993, the annual average ${ }^{3} \mathrm{H}$ concentration measured at the Site perimeter $\left(0.92 \pm 45 \% \mathrm{pCi} / \mathrm{m}^{3}\right)$ was similar to the annual average value at the distant locations $\left(0.83 \pm 62 \% \mathrm{pCi} / \mathrm{m}^{3}\right)$. The annual average ${ }^{3} \mathrm{H}$ concentration at the Site perimeter in 1993 was $0.0009 \%$ of the derived concentration guide.

All ${ }^{90} \mathrm{Sr}$ results for air samples collected onsite, at the Site perimeter, at community-operated environmental surveillance stations, and in nearby and distant communities were below detectable concentrations $\left(45 \mathrm{aCi} / \mathrm{m}^{3}\right)$ for 1993. (Because of extremely low concentrations, results for some radionuclides are reported in $\mathrm{aCi} / \mathrm{m}^{3}$ rather than $\mathrm{pCi} / \mathrm{m}^{3}$; one $\mathrm{aCi} / \mathrm{m}^{3}=0.000001 \mathrm{pCi} / \mathrm{m}^{3}$.) Moreover, this detectable concentration would only be $0.00009 \%$ of the $50,000,000-\mathrm{aCi} / \mathrm{m}^{3}\left(50-\mathrm{pCi} / \mathrm{m}^{3}\right)$ Derived Concentration Guide.

Quarterly air sampling for ${ }^{129} \mathrm{I}$ began in July 1984. Iodine- 129 was sampled downwind of the PUREX Plant 
Table 5.3. Airborne Radionuclide Concentrations in the Hanford Environs, 1993 Compared to Values from the Previous 5 Years

\begin{tabular}{|c|c|c|c|c|c|c|c|c|}
\hline \multirow[b]{2}{*}{ Radionuclide } & \multirow[b]{2}{*}{ Composite Group ${ }^{(a)}$} & \multicolumn{3}{|c|}{1993} & \multicolumn{3}{|c|}{$1988-1992$} & \multirow{2}{*}{$\begin{array}{c}1993 \\
\begin{array}{c}\text { Concentration } \\
\text { Guide }\end{array} \\
\mathrm{pCi} / \mathrm{m}^{3} \\
\end{array}$} \\
\hline & & $\begin{array}{c}\text { No. of } \\
\text { Samples } \\
\end{array}$ & $\frac{\operatorname{Maximum}^{(b)}}{\mathrm{pCi} / \mathrm{m}^{3}}$ & $\frac{\text { Average }^{(\mathrm{c})}}{\mathrm{pCi} / \mathrm{m}^{3}}$ & $\begin{array}{l}\text { No. of } \\
\text { Samples }\end{array}$ & $\frac{\text { Maximum }^{(\mathrm{b})}}{\mathrm{pCi} / \mathrm{m}^{3}}$ & $\frac{\text { Average }^{(\mathrm{c})}}{\mathrm{pCi} / \mathrm{m}^{3}}$ & \\
\hline & & & $\mathrm{aCi} / \mathrm{m}^{3}$ & $\mathrm{aCi} / \mathrm{m}^{3}$ & & $\mathrm{aCi} / \mathrm{m}^{3}$ & $\mathrm{aCi} / \mathrm{m}^{3}$ & $\mathrm{aCi} / \mathrm{m}^{3}$ \\
\hline${ }^{90} \mathrm{Sr}$ & $\begin{array}{l}\text { Onsite } \\
\text { Perimeter } \\
\text { Nearby Communities } \\
\text { Distant Communities } \\
\text { COES Stations }\end{array}$ & $\begin{array}{l}9 \\
7 \\
1 \\
2 \\
3\end{array}$ & $\begin{array}{r}15 \pm 29 \\
6.9 \pm 43 \\
-10 \pm 31 \\
-17 \pm 23 \\
1.8 \pm 36\end{array}$ & $\begin{array}{l}0.54 \pm 1,300 \% \\
-8.4 \pm 130 \% \\
-10 \pm 310 \% \\
-17 \pm 0.58 \% \\
-13 \pm 200 \%\end{array}$ & $\begin{array}{r}133 \\
87 \\
64 \\
57 \\
12\end{array}$ & $\begin{array}{c}4,200 \pm 140 \\
2,300 \pm 130 \\
6,300 \pm 110 \\
150 \pm 79 \\
64 \pm 36\end{array}$ & $\begin{aligned} & 83 \pm 98 \% \\
& 120 \pm 74 \% \\
& 160 \pm 130 \% \\
& 7.6 \pm 120 \% \\
& 1.6 \pm 1,000 \%\end{aligned}$ & $50,000,000$ \\
\hline${ }^{106} \mathrm{Ru}$ & $\begin{array}{l}\text { Onsite } \\
\text { Perimeter } \\
\text { Nearby Communities } \\
\text { Distant Communities } \\
\text { COES Stations }\end{array}$ & $\begin{array}{r}36 \\
28 \\
4 \\
8 \\
12\end{array}$ & $\begin{array}{r}2,000 \pm 3,200 \\
3,000 \pm 2,600 \\
3,000 \pm 2,300 \\
940 \pm 2,100 \\
950 \pm 2,100\end{array}$ & $\begin{aligned}-85 & \pm 580 \% \\
340 & \pm 140 \% \\
52 & \pm 4,500 \% \\
-530 & \pm 220 \% \\
-1100 & \pm 80 \%\end{aligned}$ & $\begin{array}{r}338 \\
249 \\
187 \\
160 \\
21\end{array}$ & $\begin{aligned} 14,000 & \pm 9,400 \\
8,600 & \pm 11,000 \\
12,000 & \pm 11,000 \\
20,000 & \pm 16,000 \\
2,400 & \pm 3,400\end{aligned}$ & $\begin{aligned} 96 & \pm 480 \% \\
130 & \pm 460 \% \\
-3.6 & \pm 21,000 \% \\
480 & \pm 180 \% \\
58 & \pm 910 \%\end{aligned}$ & $30,000,000$ \\
\hline${ }^{129} \mathrm{I}$ & $\begin{array}{l}\text { Onsite } \\
\text { Perimeter } \\
\text { Distant Communities }\end{array}$ & $\begin{array}{l}4 \\
8 \\
4\end{array}$ & $\begin{array}{c}52 \pm 0.45 \\
2.0 \pm 0.21 \\
0.10 \pm 0.010\end{array}$ & $\begin{array}{r}39 \pm 32 \% \\
1.2 \pm 31 \% \\
0.070 \pm 32 \%\end{array}$ & $\begin{array}{l}19 \\
40 \\
21\end{array}$ & $\begin{aligned} 500 & \pm 100 \\
18 & \pm 2.7 \\
0.97 & \pm 0.22\end{aligned}$ & $\begin{array}{r}120 \pm 51 \% \\
3.4 \pm 33 \% \\
0.24 \pm 42 \%\end{array}$ & $70,000,000$ \\
\hline${ }^{131} I$ & $\begin{array}{l}\text { Perimeter } \\
\text { Distant Community } \\
\text { COES Station }\end{array}$ & $\begin{array}{l}48 \\
22 \\
25\end{array}$ & $\begin{array}{l}3,900 \pm 4,000 \\
7,200 \pm 8,900 \\
3,300 \pm 4,300\end{array}$ & $\begin{array}{r}-190 \pm 250 \% \\
370 \pm 310 \% \\
550 \pm 103 \%\end{array}$ & $\begin{array}{l}484 \\
215 \\
139\end{array}$ & $\begin{aligned} 13,000 & \pm 11,000 \\
3,700 & \pm 6,000 \\
28,000 & \pm 19,000\end{aligned}$ & $\begin{array}{r}-160 \pm 150 \% \\
36 \pm 650 \% \\
410 \pm 140 \%\end{array}$ & $400,000,000$ \\
\hline${ }^{137} \mathrm{Cs}$ & $\begin{array}{l}\text { Onsite } \\
\text { Perimeter } \\
\text { Nearby Communities } \\
\text { Distant Communities } \\
\text { COES Stations }\end{array}$ & $\begin{array}{r}36 \\
28 \\
4 \\
8 \\
12\end{array}$ & $\begin{array}{l}310 \pm 240 \\
650 \pm 400 \\
280 \pm 260 \\
110 \pm 520 \\
230 \pm 290\end{array}$ & $\begin{array}{l}13 \pm 710 \% \\
52 \pm 160 \% \\
57 \pm 370 \% \\
-34 \pm 240 \% \\
-36 \pm 240 \%\end{array}$ & $\begin{array}{r}338 \\
249 \\
187 \\
160 \\
21\end{array}$ & $\begin{array}{l}1,200 \pm 870 \\
1,600 \pm 1,100 \\
1,600 \pm 1,100 \\
1,300 \pm 1,200 \\
390 \pm 270\end{array}$ & $\begin{array}{r}59 \pm 76 \% \\
-8.5 \pm 700 \% \\
34 \pm 260 \% \\
20 \pm 380 \% \\
53 \pm 100 \%\end{array}$ & $400,000,000$ \\
\hline
\end{tabular}


Table 5.3. Airborne Radionuclide Concentrations in the Hanford Environs, 1993 Compared to Values from the Previous 5 Years (contd)

\begin{tabular}{|c|c|c|c|c|c|c|c|}
\hline \multirow[b]{2}{*}{ Radionuclide } & \multirow[b]{2}{*}{ Composite Group ${ }^{(2)}$} & \multicolumn{3}{|c|}{1993} & \multicolumn{3}{|c|}{$1988-1992$} \\
\hline & & $\begin{array}{l}\text { No. of } \\
\text { Samples }\end{array}$ & $\frac{\mathrm{Maximum}^{(b)}}{\mathrm{aCi} / \mathrm{m}^{3}}$ & $\frac{\text { Average }}{\mathrm{aC \textrm {c }} / \mathrm{m}^{3}}$ & $\begin{array}{l}\text { No. of } \\
\text { Samples } \\
\end{array}$ & $\frac{\text { Maximum }^{(\mathfrak{)})}}{\mathrm{aCi} / \mathrm{m}^{3}}$ & $\frac{\text { Average }^{(c)}}{\mathrm{aCi} / \mathrm{m}^{3}}$ \\
\hline \multirow[t]{4}{*}{ U total $)^{(n)}$} & Onsite & 7 & $93 \pm 16$ & $53 \pm 35 \%$ & 102 & $6,200 \pm 73$ & $210 \pm 65 \%$ \\
\hline & Perimeter & 4 & $100 \pm 23$ & $58 \pm 56 \%$ & 34 & $130 \pm 15$ & $71 \pm 12 \%$ \\
\hline & Distant Communities & 2 & $61 \pm 9.7$ & $53 \pm 28 \%$ & 35 & $250 \pm 20$ & $57 \pm 25 \%$ \\
\hline & COES Stations & 3 & $77 \pm 17$ & $59 \pm 43 \%$ & 12 & $87 \pm 16$ & $55 \pm 18 \%$ \\
\hline \multirow[t]{5}{*}{${ }^{238} \mathrm{Pu}$} & Onsite & 9 & $0.19 \pm 0.66$ & $-0.10 \pm 140 \%$ & 133 & $2.7 \pm 2.0$ & $0.27 \pm 45 \%$ \\
\hline & Perimeter & 7 & $0.80 \pm 1.4$ & $-0.11 \pm 350 \%$ & 86 & $3.0 \pm 2.5$ & $0.039 \pm 350 \%$ \\
\hline & Nearby Communities & 1 & $-0.44 \pm 1.0$ & $-0.44 \pm 200 \%$ & 64 & $0.84 \pm 1.2$ & $-0.13 \pm 83 \%$ \\
\hline & Distant Communities & 2 & $-0.22 \pm 0.0$ & $-0.23 \pm 12 \%$ & 57 & $5.3 \pm 3.0$ & $0.22 \pm 140 \%$ \\
\hline & COES Stations & 3 & $0.31 \pm 0.63$ & $-0.014 \pm 2,300 \%$ & 12 & $1.8 \pm 1.6$ & $0.37 \pm 83 \%$ \\
\hline \multirow[t]{5}{*}{$239,240 \mathrm{Pu}$} & Onsite & 9 & $6.9 \pm 2.4$ & $1.7 \pm 77 \%$ & 133 & $86 \pm 11$ & $2.1 \pm 66 \%$ \\
\hline & Perimeter & 7 & $1.8 \pm 1.6$ & $0.84 \pm 61 \%$ & 86 & $2.5 \pm 2.0$ & $0.44 \pm 35 \%$ \\
\hline & Nearby Communities & 1 & $0.28 \pm 0.59$ & $0.28 \pm 210 \%$ & 64 & $2.2 \pm 1.5$ & $0.36 \pm 54 \%$ \\
\hline & Distant Communities & 2 & $1.0 \pm 1.4$ & $0.58 \pm 150 \%$ & 57 & $3.9 \pm 1.2$ & $0.31 \pm 81 \%$ \\
\hline & COES Stations & 3 & $1.8 \pm 1.6$ & $1.6 \pm 25 \%$ & 12 & $3.3 \pm 1.5$ & $1.2 \pm 51 \%$ \\
\hline \multirow[t]{4}{*}{${ }^{241} \mathrm{Am}$} & Onsite & 2 & $0.90 \pm 1.1$ & $0.41 \pm 240 \%$ & & $N A^{(8)}$ & $\mathrm{NA}$ \\
\hline & Perimeter & 2 & $0.43 \pm 1.2$ & $0.28 \pm 110 \%$ & & $\mathrm{NA}$ & NA \\
\hline & Distant Communities & 1 & $-0.47 \pm 1.0$ & $-0.47 \pm 220 \%$ & & $\mathrm{NA}$ & NA \\
\hline & COES Station & 1 & $-0.32 \pm 0.71$ & $-0.32 \pm 220 \%$ & & $\mathrm{NA}$ & $\mathrm{NA}$ \\
\hline \multirow[t]{5}{*}{ Total alpha } & Onsite & $457^{-}$ & $2,300 \pm 560$ & $520 \pm 6.8 \%$ & 1,084 & $56,000 \pm 2,600$ & $2,100 \pm 13 \%$ \\
\hline & Perimeter & 202 & $2,200 \pm 540$ & $540 \pm 9.0 \%$ & 593 & $32,000 \pm 2,300$ & $2,000 \pm 15 \%$ \\
\hline & Nearby Communities & 25 & $1,300 \pm 430$ & $660 \pm 19 \%$ & 107 & $16,000 \pm 1,500$ & $1,900 \pm 27 \%$ \\
\hline & Distant Communities & 49 & $4,800 \pm 780$ & $770 \pm 33 \%$ & 162 & $22,000 \pm 1,600$ & $1,900 \pm 25 \%$ \\
\hline & COES Stations & 73 & $1,800 \pm 490$ & $540 \pm 15 \%$ & 139 & $4,800 \pm 760$ & $580 \pm 31 \%$ \\
\hline
\end{tabular}

(a) Onsite, Site perimeter, nearby communities, and distant sampling locations are identified in Figure 5.2 and Table 5.2.

(b) Maximum single sample result \pm 2 sigma counting error. Negative concentration values are explained in the section, "Helpful Information."

(c) Average of all samples \pm 2 times the percent standard error of the mean (SEM).

(d) From DOE Derived Concentration Guide (see Appendix C).

(e) COES $=$ community-operated environmental surveillance (station). Stations are identified in Figure 5.2 and Table 5.2.

(f) Summation of Uranium-234, -235, and -238.

(g) NA = not applicable. Americium-241 sampling was initiated in 1993. 


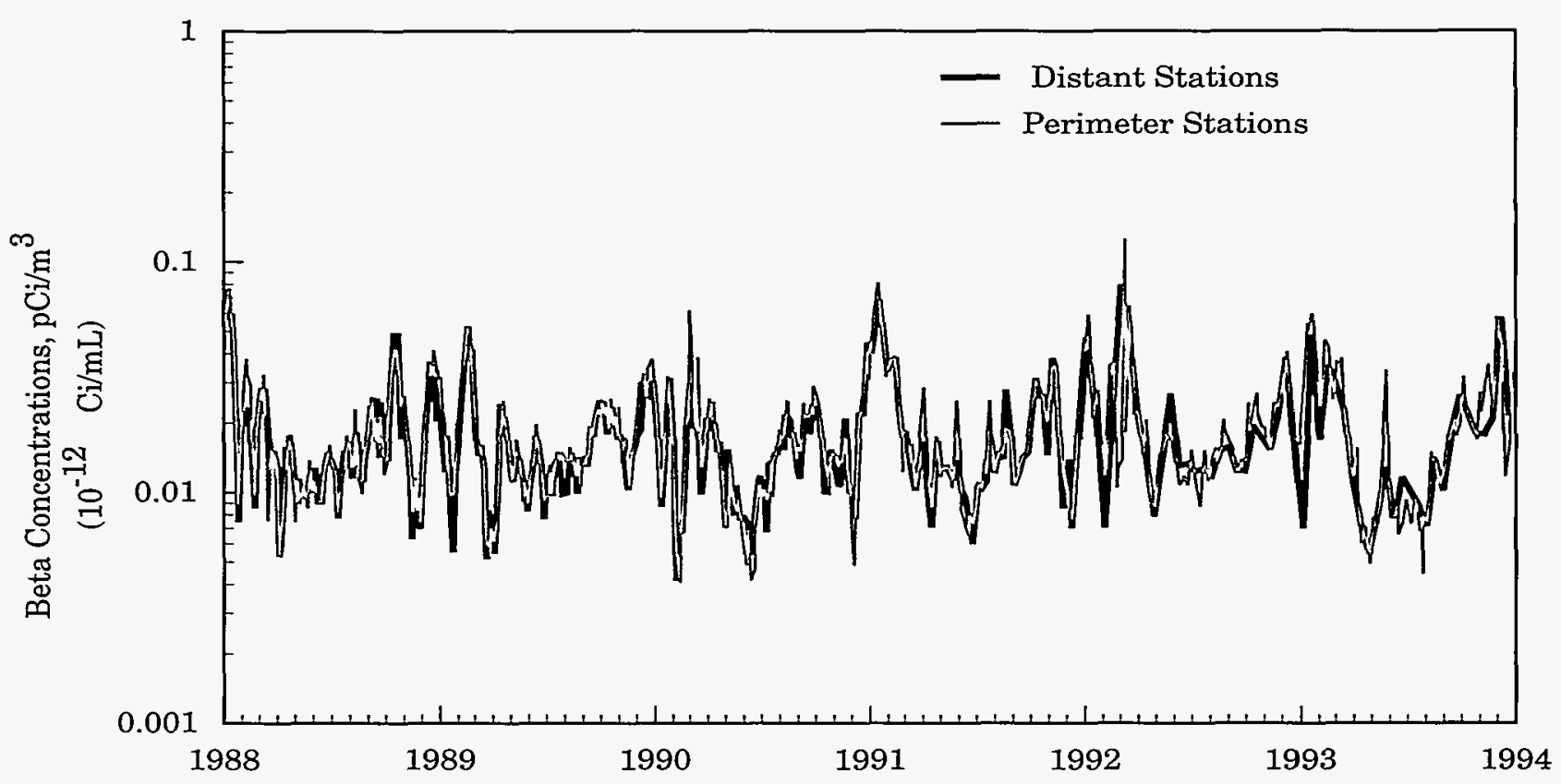

S9402063.44

Figure 5.3. Total Beta Radioactivity in Airborne Particulate Samples, 1988 Through 1993

(200-East SE location), at two downwind perimeter locations, and at a distant community location (Yakima) in 1993. Concentrations at the Site perimeter in 1993 were higher than those observed at Yakima (Figure 5.4), and the difference was statistically significant (two-tailed t-test, $5 \%$ significance level). The average onsite and Site perimeter concentrations decreased in 1989 in response to reduced PUREX Plant operations and have remained at similar levels from 1990 to 1993 . Onsite air concentrations of ${ }^{129} \mathrm{I}$ were influenced by minor emissions (0.0048 Ci, Table 3.1) from the PUREX Plant, storage of dissolved fuel rod solutions, and possible releases from waste storage tanks and cribs. The annual average ${ }^{129} I$ concentration at the downwind perimeter in 1993 $\left(1.2 \mathrm{aCi} / \mathrm{m}^{3} \pm 31 \%\right)$ was $0.000002 \%$ of the $70,000,000-\mathrm{aCi} / \mathrm{m}^{3}\left(70-\mathrm{pCi} / \mathrm{m}^{3}\right)$ Derived Concentration Guide.

Air concentrations of ${ }^{238} \mathrm{Pu}$ were below the detection limit $\left(1.5 \mathrm{aCi} / \mathrm{m}^{3}\right)$ for all onsite and offsite samples collected for 1993 (Table 5.3). The detection limit for ${ }^{238} \mathrm{Pu}$ is $0.005 \%$ of the $30,000-\mathrm{aCi} / \mathrm{m}^{3}\left(0.03-\mathrm{pCi} / \mathrm{m}^{3}\right)$ Derived Concentration Guide. The 1993 average ${ }^{239.240} \mathrm{Pu}$ concentrations for Hanford Site and offsite air samples are shown in Table 5.3 and Figure 5.5. The 1993 Site perimeter average annual ${ }^{239.240} \mathrm{Pu}$ concentration was $0.84 \mathrm{aCl} / \mathrm{m}^{3} \pm 61 \%$, which is $0.004 \%$ of the $20,000-\mathrm{aCi} / \mathrm{m}^{3}$ Derived Concentration Guide. The maximum Hanford Site ${ }^{239.240} \mathrm{Pu}$ concentration was measured at the 200-West Area $\left(6.9 \mathrm{aCi} / \mathrm{m}^{3}\right.$ or $0.03 \%$ of the Derived Concentration Guide). The average ${ }^{239,240} \mathrm{Pu}$ concentrations onsite showed a possible increasing trend from 1990 to 1992; however, the number of locations sampled was reduced and the sample compositing process was changed from quarterly in 1990 to annual in 1992. This trend was also influenced by both the elevated concentrations reported at the 200-West Area and the varying number of samples collected onsite. The 1993 air concentration of ${ }^{239.240} \mathrm{Pu}$ measured at the 200-West Area was within the range of values reported since the station was established in 1989. For all other individual onsite locations, no apparent increasing trend was observed.

Uranium concentrations $\left({ }^{234} \mathrm{U},{ }^{235} \mathrm{U}\right.$, and ${ }^{238} \mathrm{U}$ ) in airborne particulate matter in 1993 were similar at the Site perimeter and at distant communities (Table 5.3 and Figure 5.6). The maximum onsite air concentration was at the $300 \mathrm{Area}, 93 \pm 16 \mathrm{aCi} / \mathrm{m}^{3}$, which is $0.09 \%$ of the 100,000-aCi $/ \mathrm{m}^{3}$ Derived Concentration Guide. The 1993 annual average concentration for the Site perimeter was $58 \mathrm{aCi} / \mathrm{m}^{3} \pm 56 \%$, which was $0.06 \%$ of the Derived Concentration Guide. 
Table 5.4 Airborne Concentrations ${ }^{(a)}$ of Tritium $\left({ }^{3} \mathrm{H}\right)$ in the Hanford Environs $\left(\mathrm{pCi} / \mathrm{m}^{3}\right), 1988$ to 1993

\begin{tabular}{|c|c|c|c|c|c|}
\hline Composite Group ${ }^{(\mathbf{b})}$ & $\begin{array}{l}\text { No. of } \\
\text { Samples }\end{array}$ & Maximum $^{(\mathrm{c})}$ & $\begin{array}{c}\text { Average } \\
\text { (All Data) }\end{array}$ & $\begin{array}{c}\text { No. of } \\
\text { Samples }\end{array}$ & $\begin{array}{l}\text { Average Excluding } \\
\text { Data } \geq 100 \mathrm{pCi} / \mathrm{m}^{3(\mathrm{~d}, \mathrm{e})}\end{array}$ \\
\hline \multicolumn{6}{|l|}{1988} \\
\hline $\begin{array}{l}\text { Onsite } \\
\text { Perimeter } \\
\text { Distant Comm. }\end{array}$ & $\begin{array}{r}78 \\
104 \\
25\end{array}$ & $\begin{array}{l}13 \pm 2.4^{(n)} \\
7.4 \pm 2.1 \\
6.3 \pm 3.0\end{array}$ & $\begin{array}{c}2.1 \pm 23 \%(\mathrm{~g}) \\
1.2 \pm 22 \% \\
0.79 \pm 110 \%\end{array}$ & $\begin{array}{r}78 \\
104 \\
25\end{array}$ & $\begin{array}{c}2.1 \pm 23 \%(\mathrm{~g}) \\
1.2 \pm 22 \% \\
0.79 \pm 110 \%\end{array}$ \\
\hline
\end{tabular}

1989

$\begin{array}{lrrrrr}\text { Onsite } & 77 & 4.5 \pm 1.3 & 1.4 \pm 14 \% & 77 & 1.4 \pm 14 \% \\ \text { Perimeter } & 100 & 2.9 \pm 1.2 & 0.90 \pm 18 \% & 100 & 0.90 \pm 18 \% \\ \text { Distant Comm. } & 26 & 2.4 \pm 1.3 & 0.81 \pm 39 \% & 26 & 0.81 \pm 39 \%\end{array}$

1990

Onsite 48

Perimeter $\quad 96$

Distant Comm. $\quad 24$

$\begin{array}{lllll}48 & 71 \pm 2.3 & 3.1 \pm 47 \% & 48 & 3.1 \pm 47 \% \\ 96 & 12 \pm 1.3 & 1.5 \pm 14 \% & 96 & 1.5 \pm 14 \% \\ 24 & 3.4 \pm 1.4 & 1.3 \pm 17 \% & 24 & 1.3 \pm 17 \%\end{array}$

$1991^{\text {(b) }}$

Onsite $\quad 91$

Perimeter 68

Distant Comm.

COES Stations

$\begin{array}{rrrll}91 & 2,900 \pm 250 & 59 \pm 120 \% & 85 & 2.8 \pm 50 \% \\ 68 & 4,700 \pm 400 & 140 \pm 140 \% & 66 & 2.1 \pm 53 \% \\ 29 & 350 \pm 31 & 18 \pm 140 \% & 27 & 2.2 \pm 100 \% \\ 30 & 4,900 \pm 420 & 210 \pm 160 \% & 28 & 1.9 \pm 45 \%\end{array}$

$1992^{(i)}$

Onsite

Perimeter

90

$770 \pm 6.0$

$53 \pm 56 \%$

$82 \pm 78 \%$

$43 \pm 100 \%$

$380 \pm 5.4$

Distant Comm.

$1,600 \pm 8.4$

$120 \pm 86 \%$

$\begin{array}{ll}78 & 5.0 \pm 37 \% \\ 54 & 4.8 \pm 46 \% \\ 23 & 5.0 \pm 120 \% \\ 31 & 6.0 \pm 93 \%\end{array}$

$1993^{\circ}$

Onsite

$91 \quad 600 \pm 4.2$

$12 \pm 120 \%$

$9.9 \pm 1.2$

$0.90 \pm 45 \%$

$0.83 \pm 62 \%$

Distant Comm.

$3.8 \pm 4.1$

COES Stations

26

$120 \pm 3.6$

$4.5 \pm 160 \%$

$3.4 \pm 65 \%$
$0.90 \pm 45 \%$
$0.83 \pm 62 \%$
$0.95 \pm 42 \%$

(a) 1993 Derived Concentration Guide $=100,000 \mathrm{pCi} / \mathrm{m}^{3}$

(b) Onsite, Site perimeter, distant communities, and community-operated environmental surveillance stations are identified in Figure 5.2 and Table 5.2.

(c) Maximum single sample result \pm 2 sigma counting error.

(d) Average of samples \pm 2 times the percent standard error of the mean.

(e) Average was calculated by excluding results greater than $100 \mathrm{pCi} / \mathrm{m}^{3}$ to produce a more representative mean that was not influenced by highly suspect results.

(f) This value was incorrectly reported in the 1988 Hanford Site Environmental Report as $0.1+2.4 \mathrm{pCi} / \mathrm{m}^{3}$ (Jaquish and Bryce 1989).

(g) This value was incorrectly reported in the 1988 Hanford Site Environmental Report as $2.0 \pm 25 \% \mathrm{pCi} / \mathrm{m}^{3}$ (Jaquish and Bryce 1989).

(h) 1991 results reported in this table include some values that were excluded from the 1991 Hanford Site Environmental Report because of suspected laboratory contamination. These results are still considered highly suspect but have been included to provide a consistent treatment of the monitoring data. The suspect results were presented in the 1991 data summary (Bisping and Woodruff 1992).

(i) These results contain values that are suspect and may be the result of laboratory contamination (Woodruff et al. 1993). The results differ from the 1992 Hanford Site Environmental Report (Woodruff et al. 1993) to provide a consistent treatment of the data for this table.

(j) These results contain values that are suspect and may be the result of laboratory contamination as in (i). 


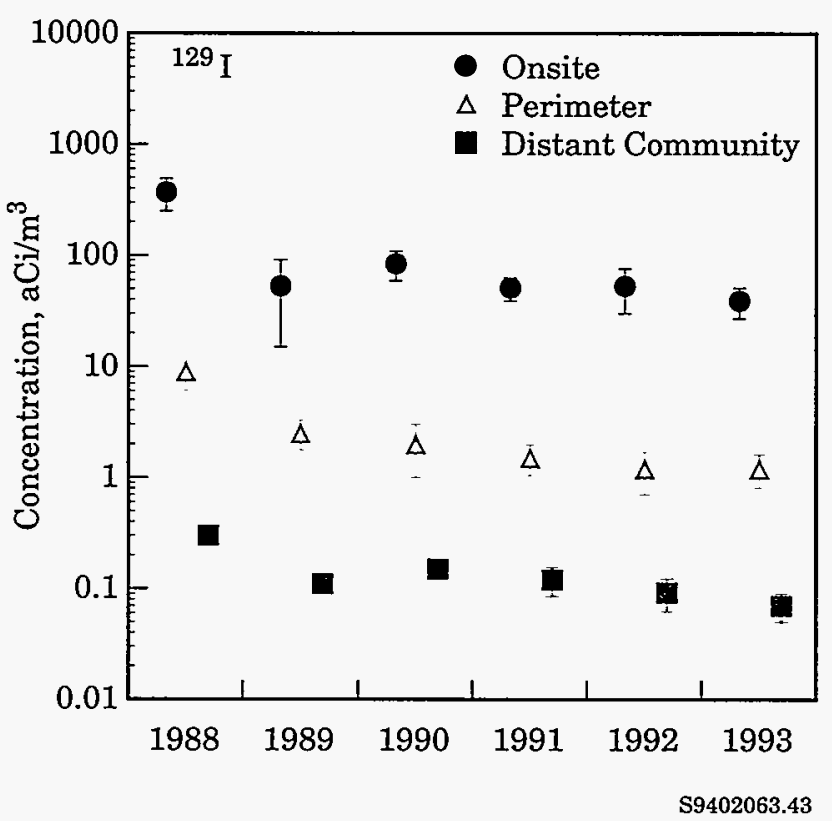

Figure 5.4. Annual Concentrations ( \pm 2 SEM) of lodine-129 ( $\left.{ }^{129}\right)$ in Air 1988 Through 1993. As a result of figure scale, some uncertainties (error bars) are concealed by point symbol.

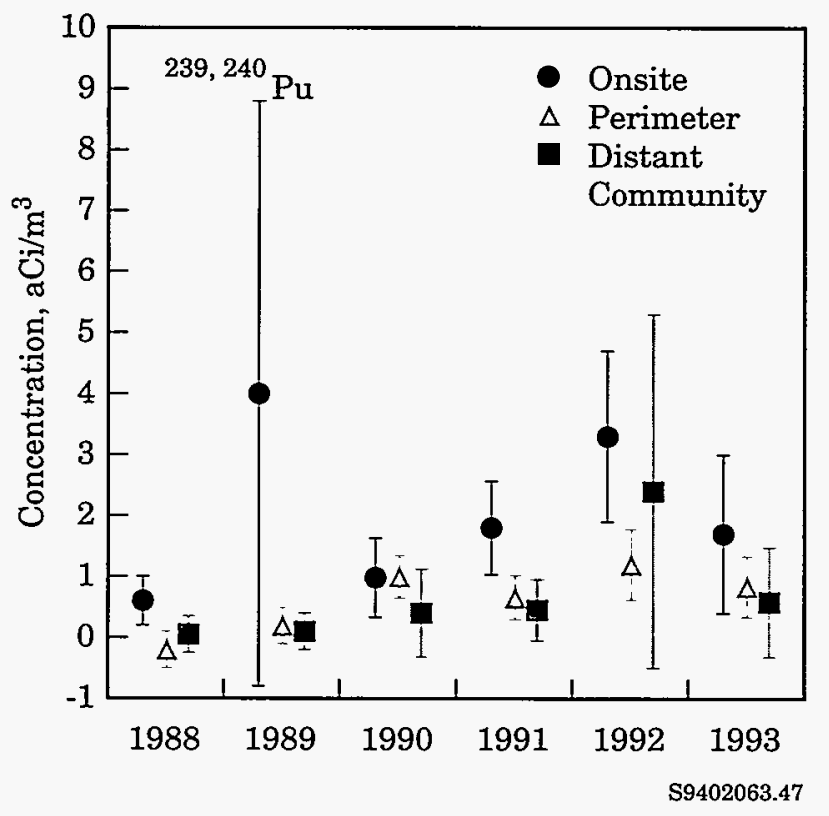

Six annual air composite samples were analyzed for ${ }^{241} \mathrm{Am}$ with all results (Table 5.3) being below a detectable concentration of $1 \mathrm{aCi} / \mathrm{m}^{3}$. The detectable concentration is $0.005 \%$ of the $20,000-\mathrm{aCi} / \mathrm{m}^{3}$ Derived Concentration Guide. Americium-241 was added to the sampling schedule in 1993 to estimate the regional background air concentrations before the beginning of largescale remediation work at Hanford.

Ruthenium-106 and ${ }^{137} \mathrm{Cs}$ associated with airborne particulate matter, and ${ }^{131} \mathrm{I}$ collected on charcoal cartridges, were routinely monitored through gamma-scan analyses. Results were generally below detectable concentrations both on and off the Hanford Site (only 9 of $88{ }^{137} \mathrm{Cs}$ samples, 2 of $88{ }^{106} \mathrm{Ru}$ samples, and 1 of 95 ${ }^{131}$ I samples had concentrations above the detection limit). The results obtained for 1993 samples are included in Table 5.3. Even the maximum individual measurements for these radionuclides were less than $0.01 \%$ of their Derived Concentration Guide.

\section{Nonradiological Results}

Seventeen air samples were collected for PCB analysis on the Hanford Site during 1993. PCBs were reported as the following Aroclor mixtures (Aroclor is a trade name for PCB mixtures marketed by Monsanto Corporation): Aroclor 1016 (A-1016), A-1221, A-1232, A-1242, A-1248, A-1254, and A-1260. Nine results for Aroclor- 1254 were above the detection limit, with results for detectable samples ranging from 0.25 to $3.9 \mathrm{ng} / \mathrm{m}^{3}$ (Table 5.5). Air volumes sampled ranged from 580 to $1500 \mathrm{~m}^{3}$. With the exception of the Aroclor- 1254 values, all results were below the detection limit of $50 \mathrm{ng} / \mathrm{sample}$ component, which yields air concentrations of $\leq 0.03$ to $\leq 0.1 \mathrm{ng} / \mathrm{m}^{3}$. The sampling method used (EPA Method TO-4) specifies a general detection limit of $1 \mathrm{ng} / \mathrm{m}^{3}$; therefore, the results below the detection limit exceeded the required sensitivity. The measured PCB concentrations were well below the National Institute of Occupational Safety and Health (DHHS 1985) occupational limit of $1,000 \mathrm{ng} / \mathrm{m}^{3}$ (10-hour time-weighted average). No regulatory limits for PCBs in ambient air have been established.

Figure 5.5. Annual Average Concentrations $\left( \pm 2\right.$ SEM) of Plutonium-239,240 $\left({ }^{239,240} \mathrm{Pu}\right)$ in Air, 1988 Through 1993 


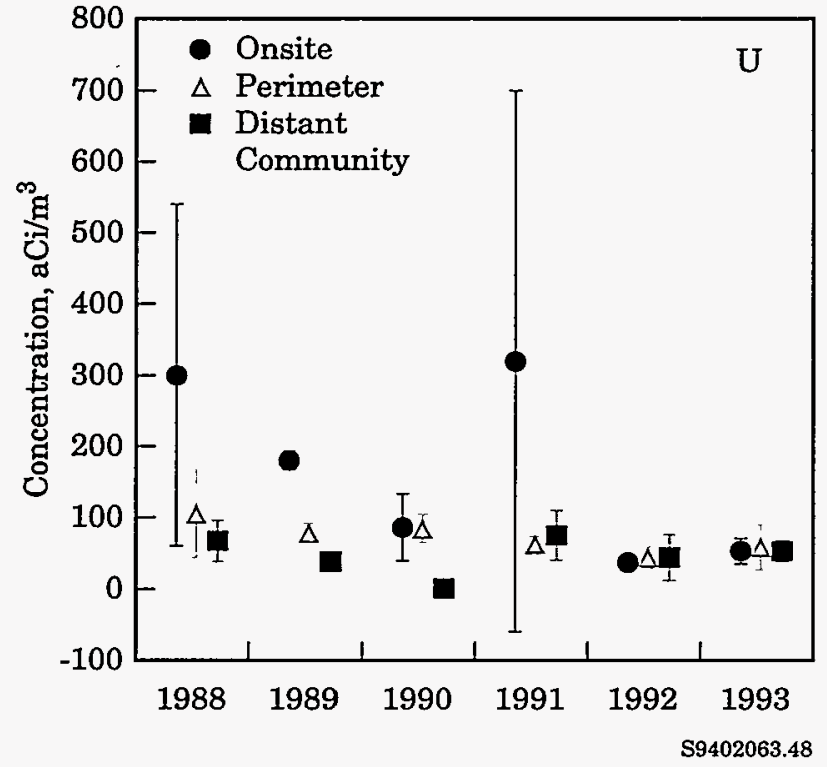

Figure 5.6. Annual Average Concentrations ( \pm 2 SEM) of Uranium $\left({ }^{234} \mathrm{U},{ }^{235} \mathrm{U},{ }^{238} \mathrm{U}\right.$ ) in Air, 1988 Through 1993. As a result of figure scale, some uncertainties (error bars) are concealed by point symbols.

Table 5.5. PCB Results( ${ }^{(a)}$ for Air Samples Collected on the Hanford Site $\left(\mathrm{ng} / \mathrm{m}^{3}\right), 1993$

\begin{tabular}{|c|c|c|c|}
\hline Date & $\underline{200-W e s t ~ A r e a ~}$ & 300 Area & $\begin{array}{c}\text { Rattlesnake } \\
\text { Springs }\end{array}$ \\
\hline $02 / 08 / 93$ & $<0.07^{(\mathrm{b})}$ & $<0.07$ & $<0.06$ \\
\hline $04 / 02 / 93$ & $<0.11$ & $<0.12$ & $<0.11$ \\
\hline $05 / 03 / 93$ & --- & $0.25^{(\mathrm{c})}$ & $<0.04$ \\
\hline $06 / 07 / 93$ & $0.44^{(\mathrm{c})}$ & $0.34^{(\mathrm{c})}$ & $<0.03$ \\
\hline $09 / 10 / 93$ & $2.8^{(\mathrm{c})}$ & $3.5^{(c)}$ & $3.9^{(\mathrm{c})}$ \\
\hline $12 / 17 / 93$ & $0.86^{(\mathrm{c})}$ & $1.2^{(\mathrm{c})}$ & $0.75^{(\mathrm{c})}$ \\
\hline
\end{tabular}

(a) PCB concentrations reported from the analysis of the following Aroclors: 1016, 1221, 1232, 1242, 1248, 1254, and 1260 .

(b) < indicates value for each Aroclor was below the given detection limit.

(c) Only Aroclor-1254 was detected. Aroclor-1254 has an occupational limit of $1,000 \mathrm{ng} / \mathrm{m}^{3}$ (10-h time-weighted average) (DHHS 1985).
Fourteen air samples were collected on the Hanford Site and analyzed for volatile organic compounds during 1993. The samples were analyzed for halogenated alkanes and alkenes, benzene, and alkylbenzenes. These compounds are widely used by modern society and are ubiquitous environmental contaminants. The results are given in Table 5.6, along with ambient air level goals (AALG) and occupational maximum allowable concentrations. All measured volatile organic compound concentrations were well below occupational maximum allowable concentration values. The AALG are nonregulatory, nonbinding limits that were developed by Calabrese and Kenyon (1991) for use as health-based guidelines for risk assessments and are somewhat analogous to the EPA's maximum contaminant level goals for water. The AALG values are used as a comparative tool in this report because no regulatory standards for ambient air concentrations have been established for these compounds.

Compounds that routinely approached or exceeded the AALG values were dichloromethane (methylene chloride), trichloromethane (chloroform), tetrachloromethane (carbon tetrachloride), and benzene. The concentrations of these compounds at the 300 Area, 200-West Area, and Rattlesnake Spring locations are shown in Figure 5.7. Benzene and chloroform concentrations at the 300 Area were slightly elevated relative to those at the background site at Rattlesnake Springs; however, the 300 Area concentrations may be influenced by sources both on the Site and in the nearby communities. Carbon tetrachloride and chloroform were used for past Site operations and are routinely detected in groundwater monitoring wells in the 200-West Area (see Section 5.8). However, there was little difference between average air concentrations of carbon tetrachloride measured onsite and at the background location. Dichloromethane concentrations in air were elevated relative to those at the background site for both the 200-West and 300 Area locations. Dichlorodifluoromethane (Freon 12) was identified in most volatile organic compound samples; however, measurement of an air concentration was not possible because the compound was not effectively retained on the adsorbent traps. Dichlorodifluoromethane is widely used as a refrigerant and is very stable in the atmosphere; thus, it is routinely detected by air monitoring stations worldwide. 
Table 5.6. Average Concentrations ( $\mathrm{ng} / \mathrm{L} \pm 2$ standard deviation) of Selected Volatile Organic Compounds in Air on the Hanford Site, 1993

\begin{tabular}{|c|c|c|c|c|c|c|c|}
\hline Compound & $\begin{array}{c}300 \text { Area } \\
\text { (3 samples) } \\
\end{array}$ & $\begin{array}{c}\text { 200-West Area } \\
\text { (4 samples) }\end{array}$ & $\begin{array}{c}\text { 200-East SE } \\
\text { (1 sample) } \\
\end{array}$ & $\begin{array}{c}100-\mathrm{N} \\
\text { (1 sample) }\end{array}$ & $\begin{array}{c}\text { Rattlesnake } \\
\text { Springs } \\
\text { (5 samples) }\end{array}$ & $\mathrm{MAC}^{(\mathrm{a})}$ & $\mathrm{AALG}^{(\mathbf{b})}$ \\
\hline trichlorofluoromethane & $0.38 \pm 0.16$ & $0.38 \pm 0.46$ & 0.13 & 0.12 & $0.13 \pm 0.19$ & $5,600^{(c)}$ & $N A^{(d)}$ \\
\hline dichloromethane & $0.083 \pm 0.15$ & $0.057 \pm 0.08$ & 0.001 & 0.002 & $0.010 \pm 0.02$ & 1,800 & 0.1 \\
\hline trichloromethane & $0.17 \pm 0.30$ & $0.014 \pm 0.04$ & 0.0 & 0.0 & $0.080 \pm 0.15$ & 9.78 & 0.022 \\
\hline trichlorotrifluoroethane $e^{(e)}$ & $0.36 \pm 0.28$ & $0.21 \pm 0.25$ & 0.26 & 0.18 & $0.23 \pm 0.13$ & NA & NA \\
\hline $1,1,1$, - trichloroethane & $0.79 \pm 0.78$ & $0.68 \pm 0.92$ & 0.42 & 0.26 & $0.66 \pm 0.54$ & 1,900 & 36,400 \\
\hline benzene & $0.70 \pm 0.88$ & $0.45 \pm 0.85$ & 0.21 & 0.26 & $0.50 \pm 0.64$ & 5 & 0.096 \\
\hline carbon tetrachloride & $0.74 \pm 0.51$ & $0.77 \pm 1.0$ & 0.40 & 0.31 & $0.66 \pm 0.38$ & 12.6 & 0.053 \\
\hline cis-1,3-dichloropropene & $0.003 \pm 0.01$ & $0.003 \pm 0.01$ & 0.0 & 0.0 & $0.002 \pm 0.00$ & 5 & NA \\
\hline trans-1,3-dichloropropene & $0.016 \pm 0.03$ & $0.002 \pm 0.01$ & 0.0 & 0.0 & $0.0075 \pm 0.01$ & 5 & NA \\
\hline toluene & $0.70 \pm 0.88$ & $0.33 \pm 0.82$ & 0.15 & 0.18 & $0.37 \pm 0.56$ & 375 & 1,400 \\
\hline m,p-xylene & $0.22 \pm 0.33$ & $0.12 \pm 0.28$ & 0.051 & 0.024 & $0.093 \pm 0.017$ & 435 & 57 \\
\hline o-xylene & $0.16 \pm 0.27$ & $0.090 \pm 0.21$ & 0.0 & 0.0 & $0.071 \pm 0.013$ & 435 & 290 \\
\hline
\end{tabular}

(a) MAC = maximum allowable concentrations; time-weighted average (8-h day, 40-h work week); from 29 CFR 1910, January 1989.

(b) AALG $=$ ambient air level goal (Calabrese and Kenyon 1991).

(c) Short-term exposure limit (no time-weighted average available).

(d) $\mathrm{NA}=$ not available.

(e) 1,1,2-trichloro-1,2,2-trifluorethane.

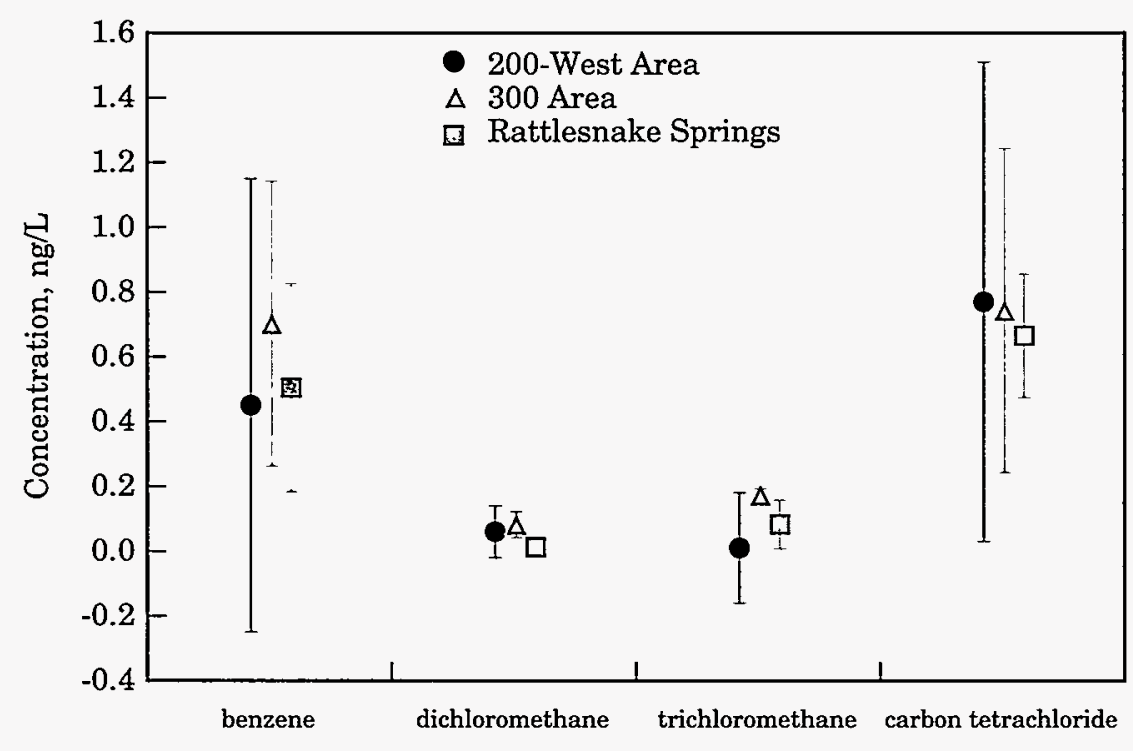

$\mathrm{S} 9402063.49$

Figure 5.7. Average Concentrations ( \pm 1 standard deviation) of Selected Volatile Organic Compounds in Air on the Hanford Site, 1993 


\title{
5.3 Surface-Water Surveillance
}

\author{
R. L. Dirkes
}

Surface water on and near the Hanford Site is monitored to determine the potential effects of Hanford operations. Surface water at Hanford includes the Columbia River, riverbank springs, ponds located on the Hanford Site, and offsite water systems directly east of and across the Columbia River from the Hanford Site. In addition, Columbia River sediments are included in this discussion. Tables 5.7 and 5.8 summarize the sample locations, sample types, frequencies, and analyses included in the surface-water surveillance activities during 1993. Sample locations are also identified in Figure 5.8. This section describes the surveillance effort and summarizes the results for these aquatic environments. Detailed analytical results are reported by Bisping (1994).

\section{Columbia River Water}

The Columbia River, which flows through the northern portion and forms part of the eastern boundary of the Hanford Site, is the dominant surface-water body on the Site. The river is used as a source of drinking water at onsite facilities and communities located downstream from the Hanford Site. In addition, the river near the Hanford Site is used for a variety of recreational activities, including hunting, fishing, boating, water skiing, and swimming. Water from the Columbia River downstream from the Site is also used extensively for crop irrigation.

Originating in the mountains of eastern British Columbia, Canada, the Columbia River drains a total area of approximately $70,800 \mathrm{~km}^{2}\left(27,300 \mathrm{mi}^{2}\right)$ en route to the Pacific Ocean. Flow of the Columbia River is regulated by 11 dams within the United States, 7 upstream and 4 downstream from the Site. Priest Rapids is the nearest dam upstream from the Site, and McNary is the nearest dam downstream. The Hanford Reach of the Columbia River extends from Priest Rapids Dam to the head of Lake Wallula (created by McNary Dam), near Richland. This Reach is the last stretch of the Columbia River in the United States above Bonneville Dam that remains unimpounded. The width of the river varies from approximately $300 \mathrm{~m}(984 \mathrm{ft})$ to $1,000 \mathrm{~m}$ (3,281 ft) within the Hanford Site. The Hanford Reach is currently under consideration for designation as a National Wild and Scenic River as a result of congressional action in 1988 (see Section 2.2).

Pollutants, both radiological and nonradiological, are known to enter the river along the Hanford Site. In addition to direct discharges of liquid effluents from Hanford facilities, contaminants in ground water from past discharges to the ground are known to seep into the river (Dirkes 1990; DOE 1992c; McCormack and Carlile 1984; Peterson 1992). Effluents from each direct discharge point are routinely monitored and reported by the responsible operating contractor; they are summarized in Section 3.1, "Facility Effluent Monitoring." Direct discharges are identified and regulated for nonradiological constituents under the National Pollutant Discharge Elimination System. The National Pollutant Discharge Elimination Systempermitted discharges at Hanford and the regulated parameters are listed in Table C.7, Appendix C.

The State of Washington has classified the stretch of the Columbia River from Grand Coulee Dam to the Washington-Oregon border, which includes the Hanford Reach, as Class A, Excellent (Ecology 1992). Water quality criteria and water use guidelines have been established in conjunction with this designation (Table C.1, Appendix C). The State of Washington and EPA Drinking Water Standards used in evaluating radionuclide concentrations in Columbia River water are provided in Table C.2, Appendix C.

\section{Sample Collection and Analysis}

Samples of Columbia River water were collected throughout 1993 at the locations shown in Figure 5.8. Samples were collected upstream from Hanford facilities at Priest Rapids Dam and near the Vernita Bridge to provide background data from locations unaffected by Site operations. Samples were collected from the 300 Area water intake and the Richland Pumphouse to 
Table 5.7. Surface-Water Surveillance, 1993

\begin{tabular}{|c|c|c|c|}
\hline Location & Sample Type & Frequency ${ }^{(\mathrm{a})}$ & Analyses \\
\hline \multicolumn{4}{|l|}{ Columbia River - Radiological } \\
\hline Priest Rapids Dam and Richland & $\begin{array}{l}\text { Cumulative } \\
\text { (collected weekly) }\end{array}$ & $\mathrm{M} \mathrm{Comp}^{(\mathrm{b})}$ & Alpha, beta, lo ${ }^{3} \mathrm{H}_{2}{ }^{(\mathrm{c})}$ gamma scan, ${ }^{90} \mathrm{Sr}$, \\
\hline Priest Rapids Dam and Richland & Particulate (filter) & $\begin{array}{l}\mathrm{M} \\
\mathrm{Q} \text { Comp }\end{array}$ & $\begin{array}{l}\text { Gamma scan } \\
\mathrm{Pu}^{(\mathrm{e})}\end{array}$ \\
\hline Priest Rapids Dam and Richland & Soluble (resin) & $\begin{array}{l}\mathrm{M} \\
\mathrm{Q} \text { Comp }\end{array}$ & $\begin{array}{l}\text { Gamma scan } \\
{ }^{129} \mathrm{I}, \mathrm{Pu}^{(\mathrm{e})}\end{array}$ \\
\hline Vernita Bridge and Richland & Grab (transects) & Q & Io ${ }^{3} \mathrm{H},{ }^{90} \mathrm{Sr}, \mathrm{U}^{(\mathrm{d})}$ \\
\hline $\begin{array}{l}100-N, 100-F \text {, Hanford Townsite, } \\
\text { and } 300 \text { Area }\end{array}$ & Grab (transects) & A & lo ${ }^{3} \mathrm{H},{ }^{90} \mathrm{Sr}, \mathrm{U}^{(\mathrm{d})}$ \\
\hline
\end{tabular}

Columbia River - Nonradiological

Vernita and Richland

Grab $\quad Q^{(n)}$

WQ-NASQAN, temperature, dissolved oxygen, turbidity, $\mathrm{pH}$, fecal coliforms, suspended solids, dissolved solids, conductivity, hardness as $\mathrm{CaCO}_{3}, \mathrm{P}, \mathrm{Cr}$, $\mathrm{N}$-Kjeldahl, dissolved oxygen content, $\mathrm{Fe}, \mathrm{NH}_{3}$

Vernita and Richland

Grab (transects) Q

$\mathrm{ICP}^{(\mathrm{g})}$ metals, anions, volatile organics

100-N, 100-F, Hanford Townsite, and 300 Area

Grab (transects)

A ICP metals, anions, volatile organics

Onsite Ponds

West Lake

Grab Q

$\mathrm{Q}$

Alpha, beta, ${ }^{3} \mathrm{H},{ }^{90} \mathrm{Sr}, \mathrm{U},{ }^{(d)}$ gamma scan

B Pond

Grab

M

Alpha, beta, ${ }^{3} \mathrm{H},{ }^{90} \mathrm{Sr}$, gamma scan

FFTF Pond

Grab

Q

Alpha, beta, ${ }^{3} \mathrm{H},{ }^{90} \mathrm{Sr}$, gamma scan

\section{Offsite Water}

Ringold Hatchery,

Mathews Corner,

White Bluffs shallow,

White Bluffs deep, and

Alexander Farm

Riverview Canal

Grab

A

Alpha, beta, ${ }^{3} \mathrm{H}, \mathrm{U},{ }^{\text {(d) }}$ gamma scan, ${ }^{129} \mathrm{I}$

\section{Riverbank Springs}

$100-\mathrm{B}, 100-\mathrm{K}, 100-\mathrm{N}, 100-\mathrm{D}$, $100-\mathrm{H}$, old Hanford townsite, and 300 Area

Grab A
Alpha, beta, ${ }^{3} \mathrm{H},{ }^{90} \mathrm{Sr},{ }^{99} \mathrm{Tc}$, gamma scan,

(a) $\mathrm{A}=$ annually; $\mathrm{M}=$ monthly; $\mathrm{Q}=$ quarterly; Comp = composite.

(b) $\mathrm{M}$ Comp is collected weekly and composited for monthly analysis.

(c) $10{ }^{3} \mathrm{H}=$ low-level tritium analysis.

(d) Isotopic uranium.

(e) Isotopic plutonium.

(f) Numerous water quality analyses are performed by the U.S. Geological Survey (USGS) in conjunction with the National Stream Quality Accounting Network (NASQAN) Program. Thermograph stations are operated and maintained by the USGS.

(g) ICP = inductively coupled plasma analysis method.

(h) Three samples during irrigation season. 
Table 5.8. Sediment Surveillance, 1993

\begin{tabular}{|c|c|c|}
\hline Location $^{(a)}$ & Frequency & Analyses \\
\hline \multicolumn{3}{|l|}{ River } \\
\hline $\begin{array}{l}\text { McNary Dam } \\
\text { Oregon shore } \\
1 / 3 \text { from Oregon shore } \\
2 / 3 \text { from Oregon shore } \\
\text { Washington shore }\end{array}$ & $\begin{array}{l}\text { A } \\
\text { A } \\
\text { A } \\
\text { A }\end{array}$ & $\begin{array}{l}\text { Gamma scan, }{ }^{90} \mathrm{Sr}, \mathrm{U}^{(b)}, \mathrm{Pu}^{(c)}, \text { ICP Metals } \\
\text { Gamma scan, }{ }^{90} \mathrm{Sr}, \mathrm{U}^{(b)}, \mathrm{Pu}^{(c)}, \text { ICP Metals } \\
\text { Gamma scan, }{ }^{90} \mathrm{Sr}, \mathrm{U}^{(b)}, \mathrm{Pu}^{(c)}, \text { ICP Metals } \\
\text { Gamma scan, }{ }^{90} \mathrm{Sr}, \mathrm{U}^{(b)}, \mathrm{Pu}^{(c)} \text {, ICP Metals }\end{array}$ \\
\hline $\begin{array}{l}\text { Priest Rapids Dam } \\
\text { Grant County shore } \\
1 / 3 \text { from Grant County shore } \\
2 / 3 \text { from Grant County shore } \\
\text { Yakima County shore }\end{array}$ & $\begin{array}{l}\text { A } \\
\text { A } \\
\text { A } \\
\text { A }\end{array}$ & $\begin{array}{l}\text { Gamma scan, }{ }^{90} \mathrm{Sr}, \mathrm{U}^{(b)}, \mathrm{Pu}^{(c)}, \text { ICP Metals } \\
\text { Gamma scan, }{ }^{90} \mathrm{Sr}, \mathrm{U}^{(b)}, \mathrm{Pu}^{(c)} \text {, ICP Metals } \\
\text { Gamma scan, }{ }^{90} \mathrm{Sr}, \mathrm{U}^{(b)}, \mathrm{Pu}^{(c)}, \text { ICP Metals } \\
\text { Gamma scan, }{ }^{90} \mathrm{Sr}, \mathrm{U}^{(b)}, \mathrm{Pu}^{(c)}, \text { ICP Metals }\end{array}$ \\
\hline White Bluffs Slough & A & Gamma scan, ${ }^{90} \mathrm{Sr}, \mathrm{U}^{(b)}, \mathrm{Pu}^{(\mathrm{c})}$, ICP Metals \\
\hline 100-F Slough & A & Gamma scan, ${ }^{90} \mathrm{Sr}, \mathrm{U}^{(\mathrm{b})}, \mathrm{Pu}^{(\mathrm{c})}, \mathrm{ICP}$ Metals \\
\hline Hanford Slough & A & Gamma scan, ${ }^{90} \mathrm{Sr}, \mathrm{U}^{(\mathrm{b})}, \mathrm{Pu}^{(\mathrm{c})}, \mathrm{ICP}$ Metals \\
\hline Richland & A & Gamma scan, ${ }^{90} \mathrm{Sr}, \mathrm{U}^{(b)}, \mathrm{Pu}^{(\mathrm{c})}$, ICP Metals \\
\hline \multicolumn{3}{|l|}{ Springs } \\
\hline 100-N Spring 8-13 & A & Gamma scan, ${ }^{90} \mathrm{Sr}, \mathrm{U}^{(b)}, \mathrm{Pu}^{(c)}$, ICP Metals \\
\hline Hanford Spring 28-2 & A & Gamma scan, ${ }^{90} \mathrm{Sr}, \mathrm{U}^{(b)}, \mathrm{Pu}^{(\mathrm{c})}, \mathrm{ICP}$ Metals \\
\hline 300 Area Spring 42-2 & A & Gamma scan, ${ }^{90} \mathrm{Sr}, \mathrm{U}^{(b)}, \mathrm{Pu}^{(\mathrm{c})}$, ICP Metals \\
\hline
\end{tabular}

(a) See Figure 5.8 .

(b) Includes ${ }^{235} \mathrm{U}$ and ${ }^{238} \mathrm{U}$ analyzed by low-energy photon analysis.

(c) Isotopic plutonium.

identify any increase in contaminant concentrations at these locations attributable to Hanford operations. The Richland Pumphouse is the first downstream point of river water withdrawal for a public drinking water supply. The river sampling locations and the methods used for sample collection are discussed in detail in the Hanford Site Environmental Monitoring Plan (DOE 1991b). In addition to the routine single-point intake fixed-location monitoring stations described in the environmental monitoring plan, routine sampling was performed along cross sections established at Vernita
Bridge, 100-N, 100-F, old Hanford townsite, 300 Area, and the Richland Pumphouse. The transect sampling was initiated as a result of findings of a special study conducted during 1987 and 1988 (Dirkes 1993). This study concluded that under certain flow conditions contaminants entering the river from Hanford are not completely mixed at routine Surface Environmental Surveillance Project river monitoring stations. This results in a slight conservative bias in the data generated using the routine single-point sampling systems at the 300 Area and the Richland Pumphouse. The cross 


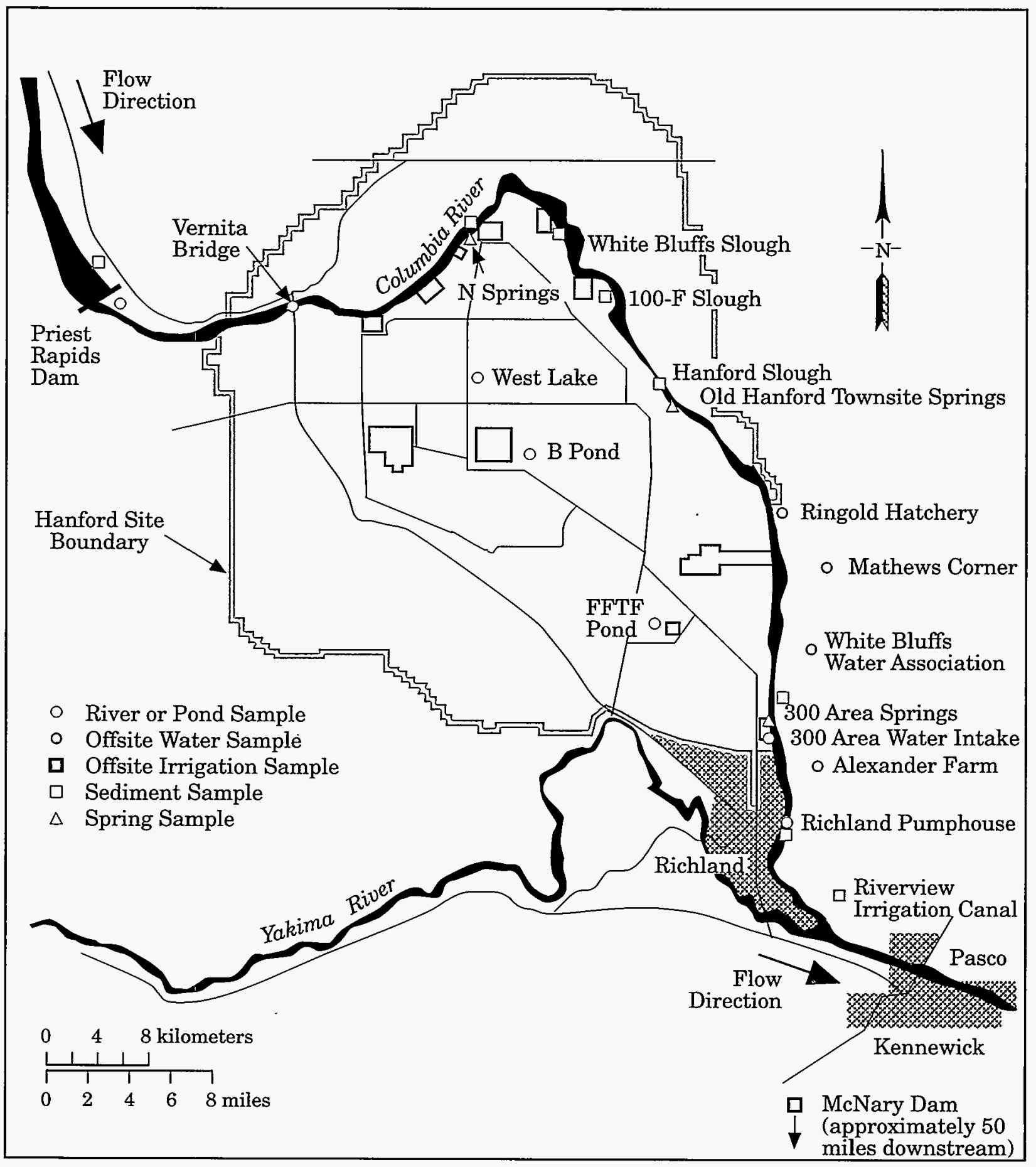

S9402063.91

Figure 5.8. Water and Sediment Sampling Locations, 1993 
sections at Vernita Bridge and the Richland Pumphouse were sampled quarterly during 1993 . Annual transect sampling was conducted at 100-N, 100-F, old Hanford townsite, and 300 Area sample locations.

Radiological analyses of water samples included total alpha, total beta, gamma scan, ${ }^{3} \mathrm{H},{ }^{90} \mathrm{Sr},{ }^{99} \mathrm{Tc},{ }^{129} \mathrm{I}{ }^{238} \mathrm{Pu}$, ${ }^{239,240} \mathrm{Pu}$, and isotopic uranium $\left({ }^{234} \mathrm{U},{ }^{235} \mathrm{U}\right.$, and ${ }^{238} \mathrm{U}$ ).

Alpha and beta measurements provided a general indication of the radioactive contamination. Gamma scans provided the ability to detect numerous specific radionuclides (Appendix F). Sensitive radiochemical analyses and, in some cases, special sampling techniques were used to determine the concentrations of ${ }^{3} \mathrm{H},{ }^{90} \mathrm{Sr}$, ${ }^{99} \mathrm{Tc},{ }^{129} \mathrm{I},{ }^{234} \mathrm{U},{ }^{235} \mathrm{U},{ }^{238} \mathrm{U},{ }^{238} \mathrm{Pu}$, and ${ }^{239,240} \mathrm{Pu}$ in river water during the year. Radionuclides of interest were selected based on their presence in effluent discharges or ground water near the river, and their importance in determining water quality, verifying effluent control and effluent monitoring systems, and determining compliance with applicable standards. Columbia River water samples collected along cross sections established near the Vernita Bridge, 100-N, 100-F, old Hanford townsite, 300 Area, and the Richland Pumphouse were also analyzed for metals, anions, and volatile organic compounds during 1993. Chemical constituents of interest were determined from reviews of existing surface- and ground-water data and various Remedial Investigation/ Feasibility Study work plans as well as preliminary risk assessments conducted by the Surface Environmental Surveillance Project (Dirkes et al. 1993; DOE 1992b; Evans et al. 1992).

In addition to monitoring conducted by the Surface Environmental Surveillance Project, nonradiological water quality monitoring was also performed by the U.S. Geological Survey (USGS) at Vernita Bridge and Richland (USGS 1988). During 1993, the USGS samples were collected along cross sections every 2 months at Vernita Bridge and quarterly at Richland. Numerous physical, biological, and chemical constituents were analyzed for at the USGS laboratory in Denver, Colorado. Results of the USGS monitoring activities are documented in Bisping (1994).

\section{Radiological Results for River Water}

Results of the radiological analyses of Columbia River water samples collected at Priest Rapids Dam, the 300 Area, and the Richland Pumphouse during 1993 are reported by Bisping (1994) and summarized in Tables A.1 through A.3, Appendix A. The data summaries also include the maximum individual result observed during the previous 5 years and the mean of all sample results for 1988 through 1992. Significant results are discussed and illustrated in the following paragraphs, with comparisons to previous years provided. Levels throughout the year were extremely low. Radionuclides consistently detected in river water during 1993 were ${ }^{3} \mathrm{H}$, ${ }^{90} \mathrm{Sr},{ }^{129} \mathrm{I},{ }^{234} \mathrm{U}$, and ${ }^{238} \mathrm{U}$. In addition, ${ }^{60} \mathrm{Co},{ }^{99} \mathrm{Tc},{ }^{137} \mathrm{Cs}$, ${ }^{235} \mathrm{U}$, and ${ }^{239,240} \mathrm{Pu}$ were occasionally measured above analytical detection levels during the year $(<50 \%$ of samples). Tritium and ${ }^{90} \mathrm{Sr}$ exist in worldwide fallout, as well as in effluents from Hanford facilities. Uranium, as well as ${ }^{3} \mathrm{H}$, occurs naturally in the environment in addition to being present in Hanford effluents.

Total alpha and total beta measurements are useful indicators of the general radiological quality of the river and provide an early indication of changes in the levels of radioactive contamination because results are obtained quickly. The 1993 average alpha and beta concentrations in Columbia River water at Priest Rapids Dam, the $\mathbf{3 0 0}$ Area, and the Richland Pumphouse were approximately $5 \%$ or less of the applicable Drinking Water Standard of 15 and $50 \mathrm{pCi} / \mathrm{L}$, respectively. Figures 5.9 and 5.10 illustrate the annual average total alpha and total beta concentrations, respectively, at Priest Rapids Dam and the Richland Pumphouse during the past 6 years. The 1993 alpha concentrations were similar to those previously reported. Total beta concentrations during 1993 were also similar to those observed during recent years. Statistical analyses (paired sample comparison and t-test of differences, Snedecor and Cochran 1980) of alpha and beta concentrations at Priest Rapids Dam and the Richland Pumphouse indicated the differences were not significant (5\% significance level).

Annual average ${ }^{3} \mathrm{H}$ concentrations at Priest Rapids Dam and the Richland Pumphouse during 1993 were $40 \mathrm{pCi} / \mathrm{L}$ $\pm 5 \%$ and $101 \mathrm{pCi} / \mathrm{L} \pm 19 \%$, respectively. Figure 5.11 compares the annual average ${ }^{3} \mathrm{H}$ concentrations at Priest Rapids Dam and the Richland Pumphouse from 1988 through 1993 . The general decline in ${ }^{3} \mathrm{H}$ concentrations in river water noted during the late 1980 s remains evident at Priest Rapids Dam and the Richland Pumphouse. The difference between the ${ }^{3} \mathrm{H}$ concentrations at Priest Rapids Dam and the Richland Pumphouse was significant (paired sample comparison, t-test of differences, 5\% significance level). The source of ${ }^{3} \mathrm{H}$ entering the river is ground-water seeping into the river along the Site (see Section 3.1, "Facility Effluent Monitoring," and 


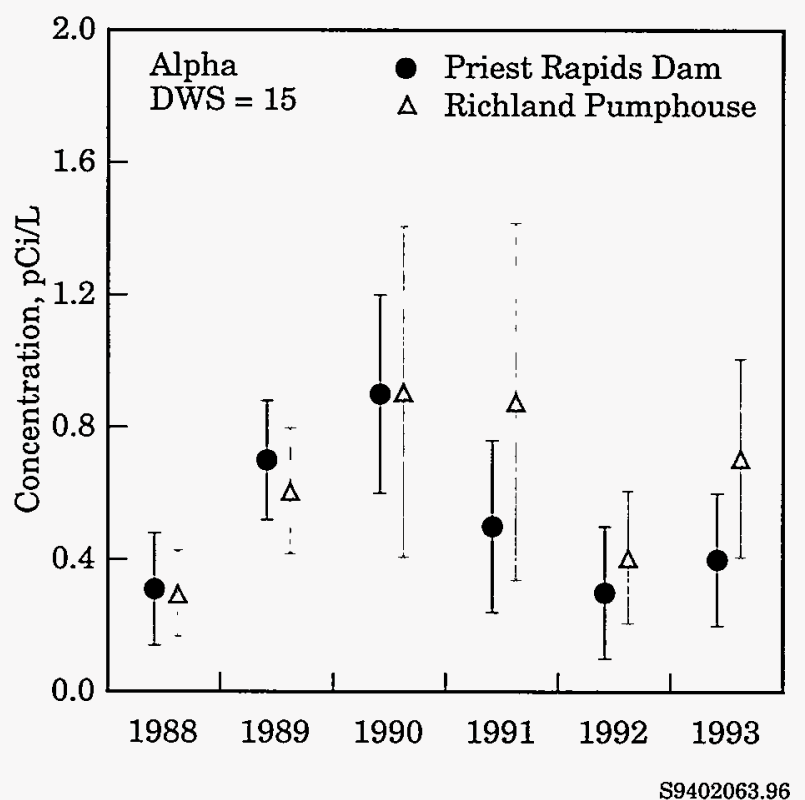

Figure 5.9. Annual Average Total Alpha Concentrations ( \pm 2 SEM) in Columbia River Water, 1988 Through 1993

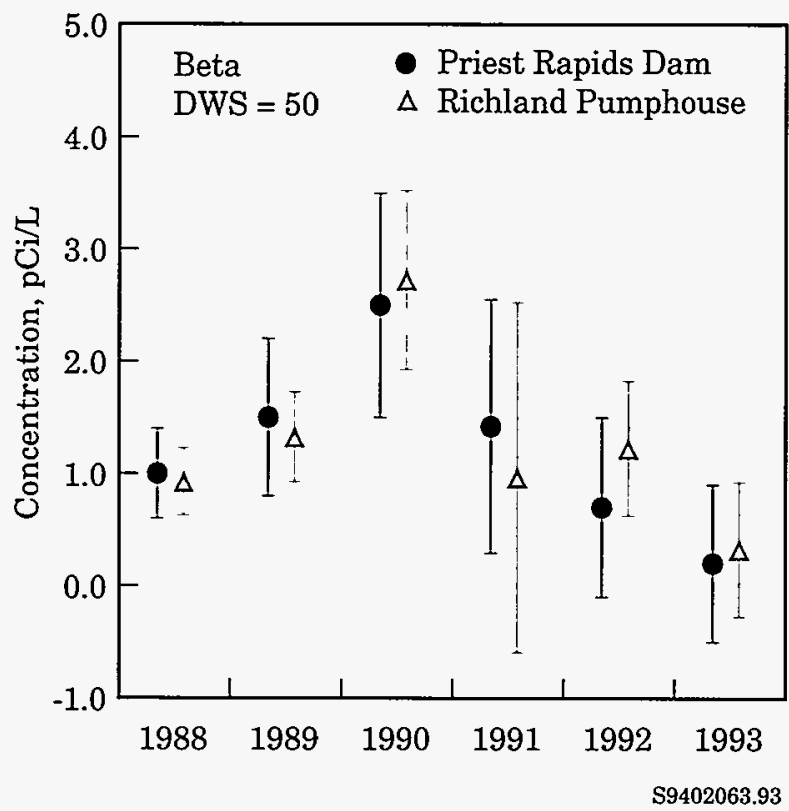

Figure 5.10. Annual Average Total Beta Concentrations ( \pm 2 SEM) in Columbia River Water, 1988 Through 1993

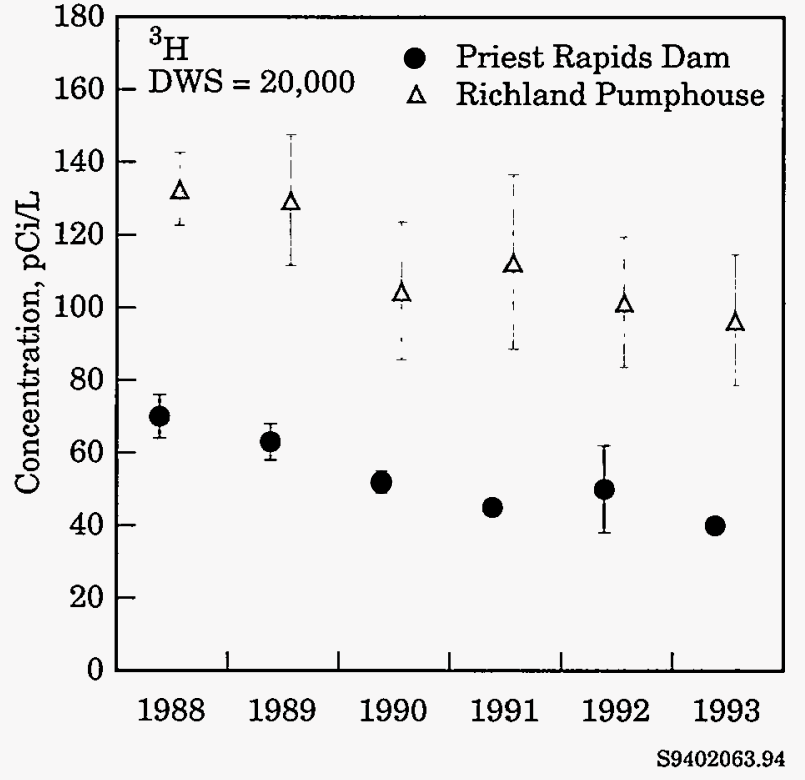

Figure 5.11. Annual Average Tritium $\left({ }^{3} \mathrm{H}\right)$ Concentrations ( \pm 2 SEM) in Columbia River Water, 1988 Through 1993. As a result of figure scale, some uncertainties (error bars) are concealed by point symbol.

Section 5.8, "Ground-Water Protection and Monitoring Program"). Tritium concentrations measured at the Richland Pumphouse, while representative of the water consumed by users of the city of Richland drinking water, tend to overestimate the average concentrations of ${ }^{3} \mathrm{H}$ in the river (Dirkes 1993). This bias is attributable to the contaminated 200 Area ground-water plume entering the river at the 300 Area, relatively close to the Richland sample intake; this plume is not completely mixed within the river at the Richland Pumphouse. Sampling along a cross section at the Richland Pumphouse during 1993 confirmed this concentration gradient in the river under certain flow conditions and is discussed in subsequent sections of this report. The degree of overestimation is highly variable and appears to be related to the flowrate of the river just before and during sample collection. All ${ }^{3} \mathrm{H}$ concentrations were less than $1 \%$ of the state of Washington and EPA Drinking Water Standard of $20,000 \mathrm{pCi} / \mathrm{L}$.

Annual average ${ }^{90} \mathrm{Sr}$ concentrations at Priest Rapids Dam and the Richland Pumphouse during 1993 were $0.09 \mathrm{pCi} / \mathrm{L} \pm 22 \%$ and $0.08 \mathrm{pCi} / \mathrm{L} \pm 25 \%$, respectively. Figure 5.12 shows the annual average ${ }^{90} \mathrm{Sr}$ concentrations 


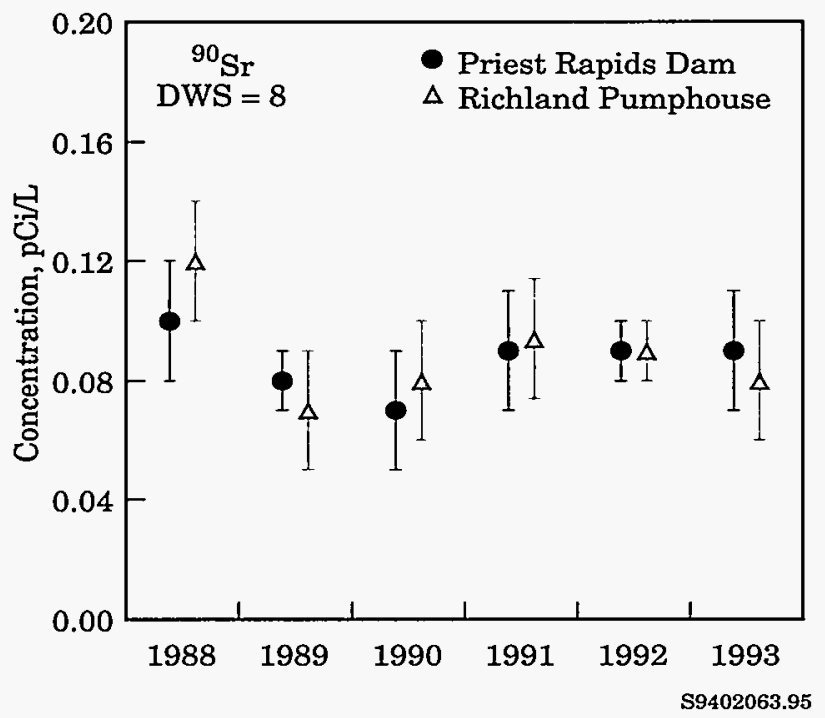

Figure 5.12. Annual Average Strontium-90 ( $\left.{ }^{90} \mathrm{Sr}\right)$ Concentrations ( \pm 2 SEM) in Columbia River Water, 1988 Through 1993

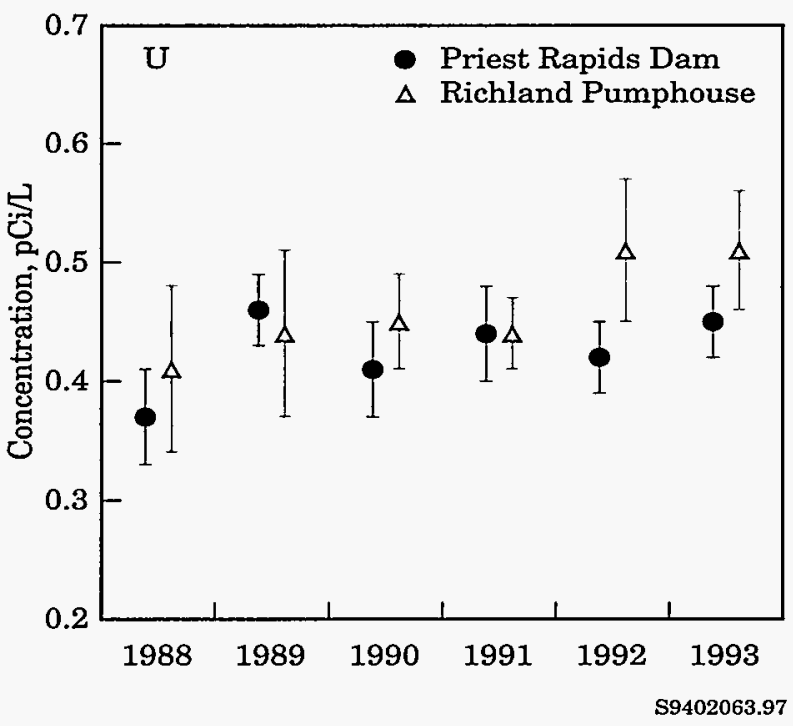

Figure 5.13. Annual Average Uranium Concentrations ( \pm 2 SEM) in Columbia River Water, 1988 Through 1993

at these locations from 1988 through 1993. Concentrations observed in 1993 were similar to those seen in recent years. The difference between the ${ }^{90} \mathrm{Sr}$ concentrations throughout the year at these locations was not significant (at the 5\% significance level). The primary source of ${ }^{90} \mathrm{Sr}$ attributable to Hanford entering the Columbia River has been the 100-N Area liquid waste disposal facilities, which are known to discharge to the river via ground-water seepage. Strontium-90 concentrations in Columbia River water during 1993 remained below the State of Washington and EPA Drinking Water Standard of $8 \mathrm{pCi} / \mathrm{L}$ (approximately 1\%).

Annual average uranium concentrations in river water during 1993 were slightly higher at the 300 Area and the Richland Pumphouse than at Priest Rapids Dam; $0.83 \mathrm{pCi} / \mathrm{L} \pm 28 \%, 0.51 \mathrm{pCi} / \mathrm{L} \pm 10 \%$, and $0.45 \mathrm{pCi} / \mathrm{L} \pm 7 \%$, respectively. Annual average uranium concentrations at the Richland Pumphouse and Priest Rapids Dam for 1988 through 1993 are shown in Figure 5.13. Uranium concentrations during 1993 were similar to those observed during recent years. Differences during the year were statistically significant ( $5 \%$ significance level). Although there is no direct discharge of uranium to the river, uranium is present in the ground water beneath the 300 Area as a result of past operations (see Section 5.8, "Ground-Water Protection and Monitoring Program") and has been detected at elevated levels in riverbank springs in this area (see Riverbank Springs in this section). Uranium, naturally occurring, is also known to be entering the river across from Hanford via seepage from the extensive irrigation practices east of the river and via irrigation canal outfalls (Dirkes 1990). There is currently no Drinking Water Standard directly applicable to uranium. However, uranium concentrations in the river during 1993 were well below the proposed Drinking Water Standard of $20 \mu \mathrm{g} / \mathrm{L}$ (equivalent to $30 \mathrm{pCi} / \mathrm{L}$ ) (EPA 1991).

The concentration of ${ }^{129} \mathrm{I}$ in Columbia River water was extremely low during 1993 and similar to levels observed during recent years. Figure 5.14 presents the annual average ${ }^{129}$ I concentrations for Priest Rapids Dam and the Richland Pumphouse for the years 1988 through 1993 (note the $\mathrm{aCi} / \mathrm{L}$ units). As has been the case in previous years, the concentration of ${ }^{129} \mathrm{I}$ at the Richland Pumphouse $(120 \mathrm{aCi} / \mathrm{L} \pm 22 \%)$ was higher than at Priest Rapids Dam $\left(5 \mathrm{aCi} / \mathrm{L} \pm 27 \%\right.$. The differences between ${ }^{129} \mathrm{I}$ concentrations at Priest Rapids Dam and the Richland Pumphouse were found to be statistically significant (5\% significance level), as has been the case over the years. The presence of ${ }^{129} \mathrm{I}$ at elevated levels at the Richland Pumphouse is attributable to the flow of contaminated ground water from the unconfined aquifer into the river. All ${ }^{129} \mathrm{I}$ sample results were less than one-tenth of $1 \%$ of the Drinking Water Standard of $1 \mathrm{pCi} / \mathrm{L}(1,000,000 \mathrm{aCi} / \mathrm{L})$. 


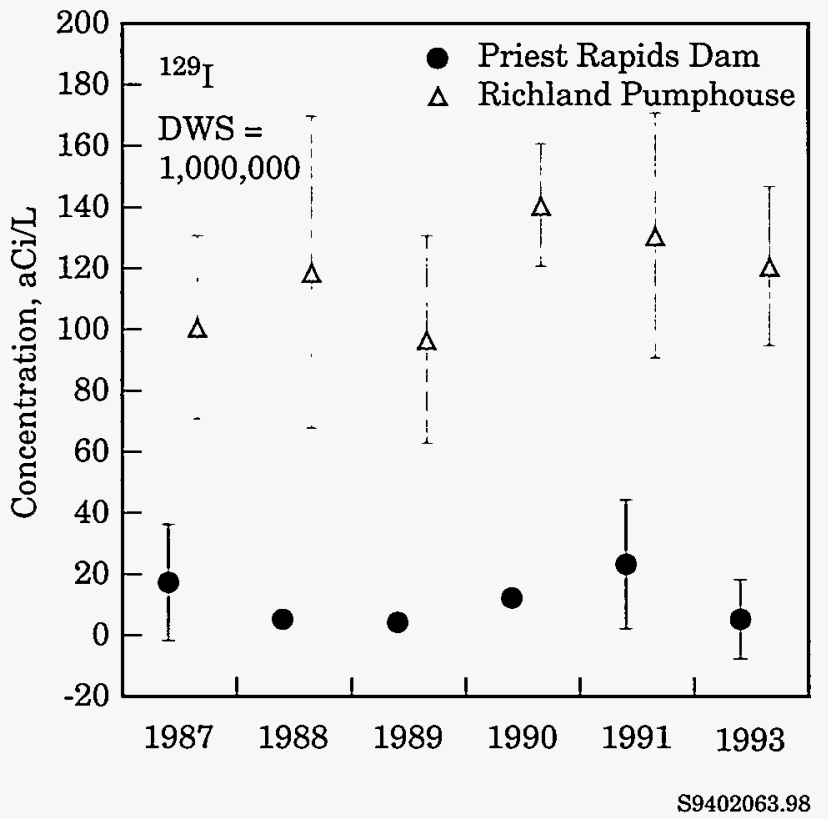

Figure 5.14. Annual Average lodine-129 ( $\left.{ }^{129} \mathrm{I}\right)$ Concentrations ( \pm 2 SEM) in Columbia River Water, 1988 Through 1993. As a result of figure scale, some uncertainties (error bars) are concealed by point symbol.

The concentrations of ${ }^{239.240} \mathrm{Pu}$ were greater than the detection level approximately $40 \%$ of the time at all locations. Priest Rapids Dam ${ }^{239.240} \mathrm{Pu}$ concentrations were not statistically different from those observed at the Richland Pumphouse during 1993 (5\% significance level).

During $1993,{ }^{60} \mathrm{Co},{ }^{99} \mathrm{Tc},{ }^{106} \mathrm{Ru},{ }^{131} \mathrm{I},{ }^{134} \mathrm{Cs}$, ${ }^{137} \mathrm{Cs}$, and ${ }^{238} \mathrm{Pu}$ were not consistently found in measurable quantities in Columbia River water at Priest Rapids Dam, the 300 Area water intake, or the Richland Pumphouse. The approximate minimum detectable concentrations for ${ }^{60} \mathrm{Co},{ }^{106} \mathrm{Ru},{ }^{131} \mathrm{I},{ }^{134} \mathrm{Cs},{ }^{137} \mathrm{Cs}$, and ${ }^{238} \mathrm{Pu}$ during 1993 were $1.5,10.0,1.0,1.5,1.5$, and $0.00001 \mathrm{pCi} / \mathrm{L}$, respectively.

Radiological results of samples collected along cross sections established at Vernita Bridge, 100-N Area, 100-F Area, old Hanford townsite, 300 Area, and the Richland Pumphouse during 1993 are presented in Table A.4, Appendix A. The average concentrations of ${ }^{90} \mathrm{~S} r$ and uranium found during cross-sectional sampling were similar to those obtained from the routine automatic composite samplers used at similar locations. Consistent with studies conducted during 1988 (Dirkes 1993), the average concentrations of ${ }^{3} \mathrm{H}$ measured along the cross section at the Richland Pumphouse were less than those measured using the single-point sample located near the western shoreline of the river at the Richland Pumphouse. The data indicate ${ }^{3} \mathrm{H}$ concentration gradient across the river at the Richland Pumphouse.

Elevated levels of ${ }^{3} \mathrm{H}$ were also evident near the Hanford shoreline at the 100-N, old Hanford townsite, and 300 Area transect locations. Uranium concentrations were slightly elevated along the 300 Area and Richland Pumphouse cross-sections. However, maximum concentrations of uranium at both locations were observed to be near the Franklin County shoreline opposite of Hanford, likely resulting from irrigation returns near the sampling cross-sections. It has been concluded that contaminants in the 200 Area groundwater plume entering the river at the 300 Area are not completely mixed at the Richland Pumphouse, which is consistent with past dispersion studies (Backman 1962; Dirkes 1993). As was observed with the composite sampling system results, the concentrations of radionuclides measured along the cross sections were well below state and federal Drinking Water Standards.

\section{Nonradiological Results for River Water}

Nonradiological water quality data were compiled by the Surface Environmental Surveillance Project and the USGS during 1993. A number of the parameters measured have no regulatory limits. These parameters are, however, useful as indicators of water quality and/or are indicative of Hanford-origin contaminants. Specific water quality measurement results are reported by Bisping (1994). In 1993, USGS results were comparable to results from recent years. Applicable standards for Class A-designated water were met. There was no indication during 1993 of any deterioration of the water quality along this stretch of the Columbia River resulting from Hanford operations. Potential sources of pollutants not associated with Hanford include irrigation return water and seepage associated with extensive irrigation north and east of the Columbia River.

Figure 5.15 shows Vernita Bridge and Richland results for the period 1988 through 1993 for several water quality parameters with respect to the applicable standards. Table A.5, Appendix A, summarizes the results obtained through the USGS national water quality network. The $\mathrm{pH}$ measurements upstream and downstream from the Site were in close agreement and 

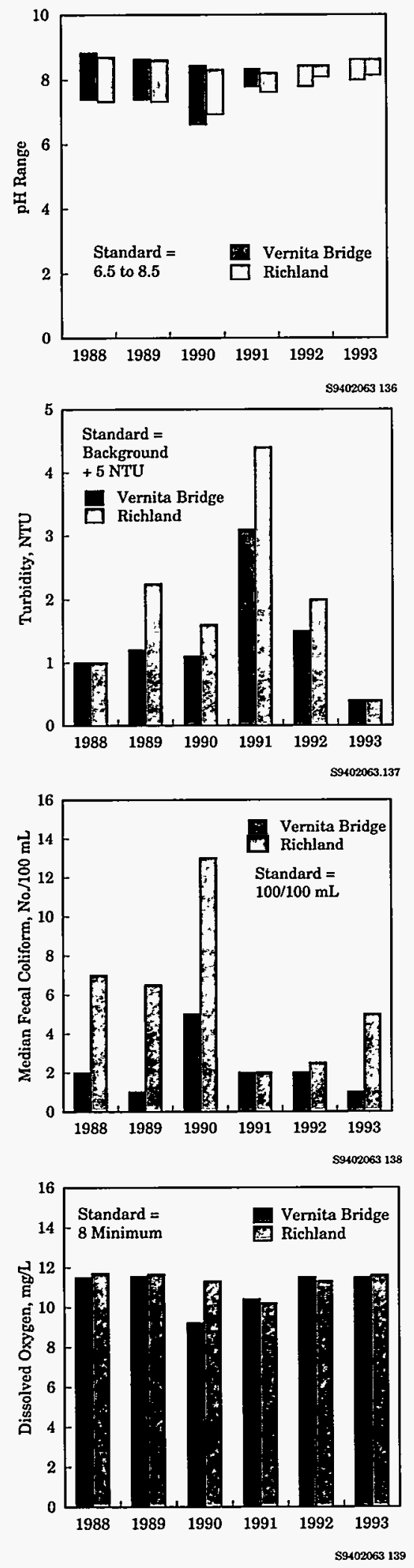

Figure 5.15. Columbia River Water Quality Measurements, 1988 Through 1993 were within the acceptable range for Class A waters. Turbidity, fecal coliform, and dissolved oxygen concentrations during 1993 were in compliance with Class A requirements at both locations as well.

Results of sampling conducted by the Surface Environmental Surveillance Project along cross sections of the Columbia River at Vernita Bridge, 100-N Area, 100-F Area, Hanford townsite, 300 Area, and the Richland Pumphouse are provided by Bisping (1994) and discussed in detail by Dirkes et al. (1993). Volatile organic compounds were not routinely detected during 1993. Several metals were detected both upstream and downstream from the Hanford Site at levels comparable to those reported by the USGS as part of their ongoing national water quality monitoring network and with concentrations observed in river water in the past (Dirkes 1990). Similarly, some anions were detected upstream and downstream from the Site at levels consistent with those reported by others.

The annual average flow rate of the Columbia River was $2,580 \mathrm{~m}^{3} / \mathrm{s}(91,200 \mathrm{cfs})$ during 1993 , slightly lower than recent years. The monthly average flow rates at Priest Rapids Dam are shown in Figure 5.16. The peak monthly average flow occurred during May, $4,105 \mathrm{~m}^{3} / \mathrm{s}$ $(145,000 \mathrm{cfs})$, and the lowest average monthly flow occurred during April, $1,727 \mathrm{~m}^{3} / \mathrm{s}(61,000 \mathrm{cfs})$. Daily average flow rates varied from 1,160 to $5,692 \mathrm{~m}^{3} / \mathrm{s}$ (41,000 to 201,000 cfs) during 1993.

\section{Columbia River Sediment}

\section{Sample Collection and Analysis}

Annual samples of Columbia River sediment were collected during 1993 at locations shown in Figure 5.8 and summarized in Table 5.5. Samples were collected upstream from the Hanford Site behind Priest Rapids Dam, downstream from the Site at Richland, and approximately 50 miles downstream from the Site at McNary Dam. Samples were also collected along the Hanford Reach from sloughs at White Bluffs, 100-F Area, and the old Hanford townsite. Samples were obtained from approximately $15 \mathrm{~cm}$ (6 in.) of the top sediment material using a dredge sampler. Analyses of the sediment samples include gamma scans (see Appendix F), ${ }^{90} \mathrm{Sr},{ }^{235} \mathrm{U},{ }^{238} \mathrm{U},{ }^{238} \mathrm{Pu}$, and ${ }^{239.240} \mathrm{Pu}$. 


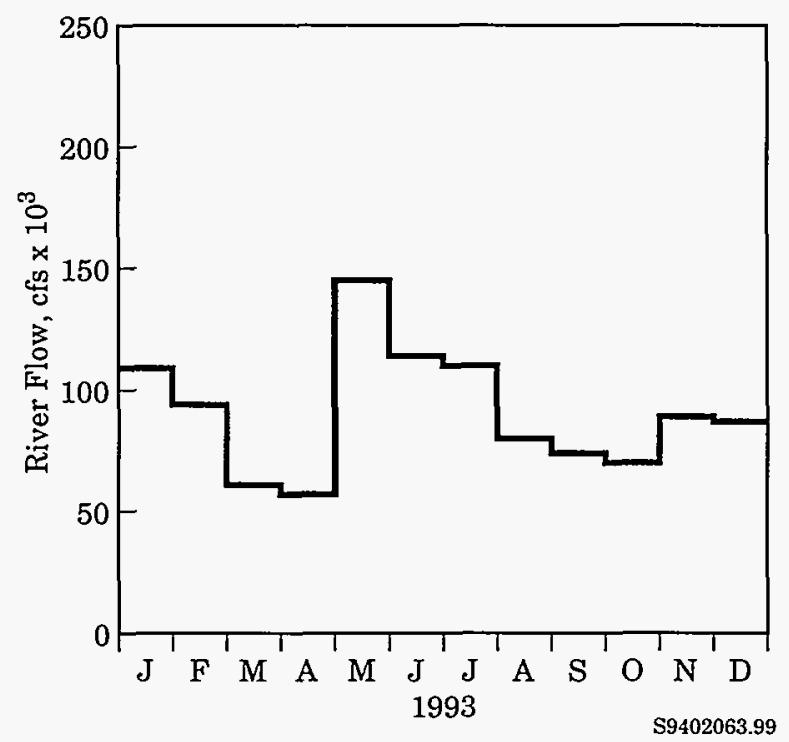

Figure 5.16. Monthly Average Columbia River Flow Rates During 1993 (measured at Priest Rapids Dam)

\section{Radiological Results for Sediments}

Surface sediments in the Columbia River are known to contain low levels of radionuclides of Hanford origin and from nuclear weapons testing fallout (Beasley et al. 1981; Robertson and Fix 1977; Woodruff et al. 1992).

Analytical results for surface sediment samples collected during 1993 are summarized in Table A.6, Appendix A, and presented in detail by Bisping (1994). Table A.6, Appendix A, also includes summary data for the years 1988 through 1993.

In general, the level of radioactivity in surface sediments behind McNary Dam was slightly higher than that behind Priest Rapids Dam during 1993. Radionuclide concentrations in sediments collected from the sloughs along the Hanford Reach and at Richland were generally comparable to those observed upstream from Hanford at Priest Rapids Dam.

Figure 5.17 shows the concentrations of selected radionuclides in Columbia River sediment at Priest Rapids Dam and McNary Dam for 1989 through 1993.
The concentrations of radionuclides measured during 1993 were similar to those seen in sediment samples collected during the previous 4 years. The concentrations of ${ }^{60} \mathrm{Co}$ during 1993, which were less than the detection level $(0.05 \mathrm{pCi} / \mathrm{g})$ in sediments behind Priest Rapids Dam, were highest in sediments collected from McNary pool. The levels of ${ }^{60} \mathrm{Co}$ in surface sediments behind McNary Dam have been relatively stable over the past 5 years. Concentrations of ${ }^{90} \mathrm{Sr},{ }^{137} \mathrm{Cs},{ }^{238} \mathrm{U},{ }^{238} \mathrm{Pu}$, and ${ }^{239.240} \mathrm{Pu}$ were similar at Priest Rapids Dam and McNary Dam during 1993.

\section{Riverbank Springs}

The seepage of ground water into the Columbia River has been known to occur for many years. Riverbank spring discharges were documented along the Hanford Reach long before the startup of Hanford operations (Jenkins 1922). These relatively small springs flow intermittently, apparently influenced primarily by changes in river level. Hanford-origin contaminants associated with these ground-water discharges have been documented to enter the river along the Hanford Reach (Dirkes 1990; DOE 1992c; McCormack and Carlile 1984; Peterson and Johnson 1992).

\section{Sample Collection and Analysis}

Samples of ground-water seepage were collected during 1993 at the locations identified in Figure 5.8. Sample collection methods are described in the Hanford Site Environmental Monitoring Plan (DOE 1991b). The analyses were selected based on findings of previous riverbank spring investigations, reviews of contaminant concentrations observed in nearby ground-water monitoring wells, and results of preliminary risk assessments. At a minimum, riverbank spring samples collected during 1993 were analyzed for total alpha, total beta, gamma scan, and ${ }^{3} \mathrm{H}$. Uranium, ${ }^{90} \mathrm{Sr},{ }^{99} \mathrm{Tc}$, and ${ }^{129} \mathrm{I}$ analyses were included for those locations where these constituents are known to exist in the local ground water as a result of past operations at Hanford. Riverbank springs were also analyzed for various nonradiological contaminants, including metals, anions, and volatile organic compounds. 

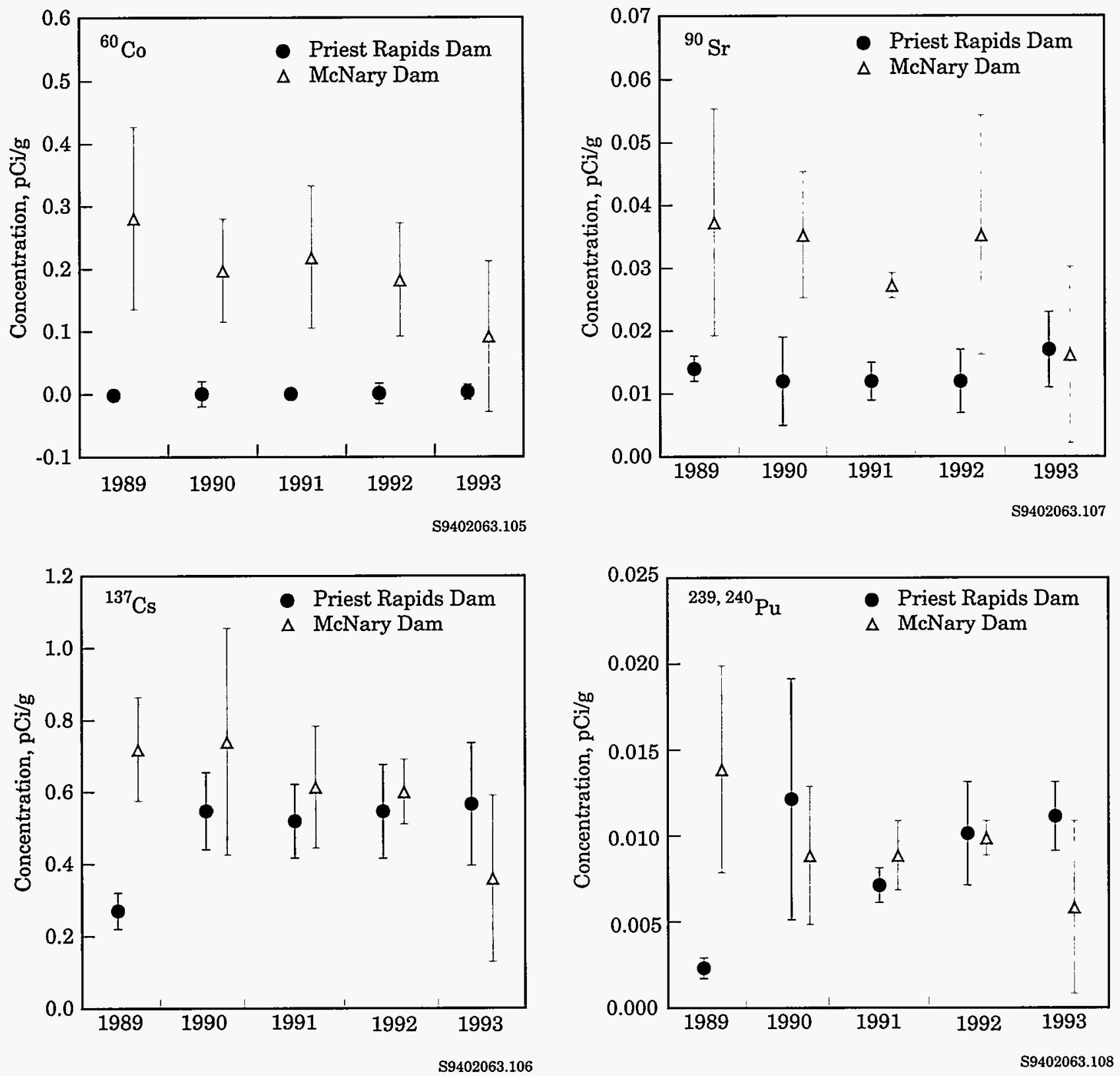

Figure 5.17. Radionuclide Concentrations ( \pm 2 SEM) in Columbia River Sediments at Priest Rapids Dam and McNary Dam, 1989 Through 1993. As a result of figure scale, some uncertainties (error bars) are concealed by point symbol. 


\section{Results}

Hanford-origin contaminants continued to be detected in spring water entering the Columbia River along the Hanford Site during 1993 . Tritium, ${ }^{60} \mathrm{Co},{ }^{90} \mathrm{Sr},{ }^{99} \mathrm{Tc}$, and uranium are known to be entering the river from Hanford along the 100 Areas. Tritium, ${ }^{99} \mathrm{Tc}$, and ${ }^{129} \mathrm{I}$ enter the river from the Old Hanford townsite to the 300 Area. Uranium is the primary radionuclide entering the river along the 300 Area. The concentrations of contaminants in the spring water, reported by Bisping (1994), were similar to those known to exist in the ground water near the river as a result of past operations at Hanford. The location and extent of the contaminated discharges agreed with recent riverbank spring investigations, ground-water monitoring results, ground-water model predictions, and results of seep sampling conducted by others (DOE 1992c; Peterson and Johnson 1992).

Radionuclide concentrations were less than DOE Derived Concentration Guides (see Appendix C), with the exception of ${ }^{90} \mathrm{Sr}$ near the $100-\mathrm{N}$ Area. Tritium, while less than the Derived Concentration Guide, was detected at concentrations greater than the EPA Drinking Water Standard in several springs. All other radionuclide concentrations were less than Drinking Water Standards.

Table 5.9 provides selected radionuclide concentrations measured in water collected from the shoreline near the 100-N Area referred to as N Springs during the years 1988 through 1993. The near-facility environmental monitoring program has historically sampled the riverbank seepage near the $100-\mathrm{N}$ Area on an annual basis and determined the discharge of contaminants entering the river through this pathway using data obtained from the 199-N-8T monitoring well, which is located very near the river (see Section 3.2). This well was also sampled as part of the Surface Environmental Surveillance Project on an annual basis during the years 1988 through 1991. In 1992, the Surface Environmental Surveillance Project sample was collected from the 199-N-46 well (cassion), which is located slightly inland from 199-N-8T. Concentrations of some contaminants (i.e., ${ }^{90} \mathrm{Sr}$ ) were significantly higher in water collected from 199-N-46 than 199-N-8T, likely as a result of its location relative to $199-\mathrm{N}-8 \mathrm{~T}$ and the differences in sampling protocols. In 1993, the Surface Environmental Surveillance Project N Springs sample was collected from actual ground-water seepage entering the river along the shoreline. Sampling in this manner is consis-
Table 5.9. Selected Radionuclide Concentrations in Riverbank Spring Water During the Years 1988 through 1993.

\begin{tabular}{|c|c|c|c|}
\hline \multirow[b]{2}{*}{ Year } & \multicolumn{3}{|c|}{ Concentration, $\mathrm{pCi} / \mathrm{L}$} \\
\hline & ${ }^{3} \mathrm{H}$ & Beta & ${ }^{20} \mathrm{Sr}$ \\
\hline $1988^{(a)}$ & $74,900 \pm 800$ & $12,300 \pm 200$ & $6,975 \pm 240$ \\
\hline $1989^{\text {(a) }}$ & $37,100 \pm 600$ & $10,800 \pm 70$ & $6,490 \pm 220$ \\
\hline $1990^{(a)}$ & $38,500 \pm 550$ & $8,520 \pm 140$ & $3,990 \pm 70$ \\
\hline $1991^{\text {(a) }}$ & $11,300 \pm 370$ & $7,150 \pm 290$ & $5,110 \pm 250$ \\
\hline $1992^{(b)}$ & $4,900 \pm 150$ & $24,100 \pm 180$ & $10,900 \pm 100$ \\
\hline $1993^{(c)}$ & $28,700 \pm 400$ & $3.5 \pm 2.1$ & $0.005 \pm 0.031$ \\
\hline \multicolumn{4}{|c|}{ 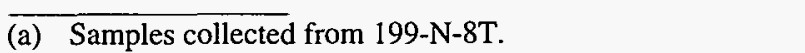 } \\
\hline \multicolumn{4}{|l|}{ (b) } \\
\hline \multicolumn{4}{|c|}{ shoreline spring. } \\
\hline
\end{tabular}

tent with the Surface Environmental Surveillance Project sampling protocol at other shoreline seep locations and avoids duplication of the near-facility environmental monitoring program.

During 1993, there was no visible seepage present directly adjacent to $199-\mathrm{N}-8 \mathrm{~T}$ during the 100-N Area field sampling activities. The nearest flowing seep, sampling during 1993, was located approximately $0.9 \mathrm{~km}(0.5 \mathrm{mi})$ downstream of the monitoring well. As a result of the proximity of this seep to the N Springs area, contaminant concentrations (i.e., ${ }^{90} \mathrm{Sr}$ ) observed during 1993 were significantly different than previous years and those contaminant concentrations measured during 1993 by the near-facility environmental monitoring program (Table 3.9, Section 3.2), reflecting the increased distance of the sample location from the contaminant source.

Concentrations of radionuclides of concern in the riverbank springs near the old Hanford townsite for the years 1988 through 1993 are provided in Figure 5.18. The levels of contaminants observed in this seep in recent years have been relatively consistent and comparable to those known to exist in the ground water near the river at this location as a result of past operations. Concentrations of ${ }^{3} \mathrm{H}$ during 1993 were within the range seen during the past 5 years and similar to local ground-water levels. The average concentration of ${ }^{99} \mathrm{Tc}$ during 1993 , $121 \pm 20 \mathrm{pCi} / \mathrm{L}$, was similar to those reported during past studies and indicative of ground-water concentrations (Dirkes 1990; Woodruff et al. 1992). The ${ }^{129}$ I concentration, $0.21 \pm 0.01 \mathrm{pCi} / \mathrm{L}$, was also similar to nearby ground-water concentrations during 1993 and similar to the ${ }^{129} I$ concentration observed during previous years. 

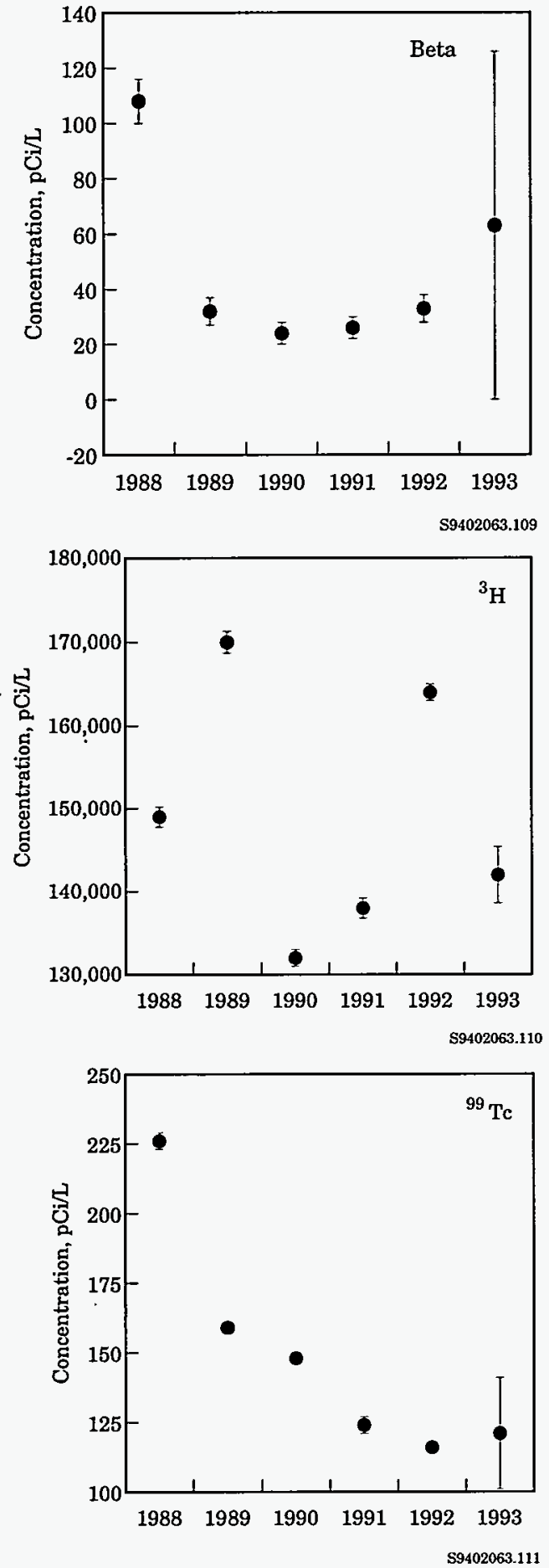

Figure 5.18. Radionuclide Concentrations ( \pm 2 SEM) in Riverbank Springs near the Old Hanford Townsite, 1988 Through 1993. Concentrations are \pm 2 sigma counting error for the years 1988 to 1992 and \pm 2 SEM for 1993. As a result of figure scale, some uncertainties (error bars) are concealed by point symbol.
Figure 5.19 shows the concentrations of constituents of concern in the 300 Area riverbank springs from 1988 through 1993. Radionuclide concentrations were within the range observed during the previous 5 years. Special arrangements to control the river water level during the 1992 riverbank spring sampling activities at the 300 Area maximized the contribution of ground water in the springs and minimized the bank-storage effect, resulting in elevated contaminant concentrations during 1992. The contaminant concentrations in 1993 were similar to those observed in the nearby ground water (see Section 5.8 for results) and those seen in the spring water before 1992. Tritium is attributable primarily to the expansion of the contaminated ground-water plume emanating from the 200 Areas. This plume has expanded into the 300 Area during recent years (Dirkes 1993). The concentrations of uranium in the spring water during 1993 was within the range observed in the ground water beneath the 300 Area (Section 5.8). The elevated alpha and beta concentrations are likely associated with the uranium present in the spring water.

\section{Onsite Ponds}

Three onsite ponds (see Figure 5.8) located near operational areas were sampled periodically during 1993.

B Pond, located near the 200-East Area, was excavated in the mid-1950s for disposal of process cooling water and other liquid wastes occasionally containing low levels of radionuclides. West Lake, located north of the 200-East Area, is recharged from ground water (Gephart et al. 1976). West Lake has not received direct effluent discharges from Site facilities. The FFTF Pond, located near the 400 Area, was excavated in 1978 for the disposal of cooling and sanitary water from various facilities in the 400 Area.

Westinghouse Hanford Company is responsible for monitoring effluents discharged to the ponds and for operational surveillance of the ponds (Manley and Diediker 1992). Although the ponds were inaccessible to the public and did not constitute a direct offsite environmental impact during 1993, they were accessible to migratory waterfowl, creating a potential biological pathway for the dispersion of contaminants (see "Wildlife Surveillance," Section 5.5). Periodic sampling of the ponds also provided an independent check on effluent control and monitoring systems. 

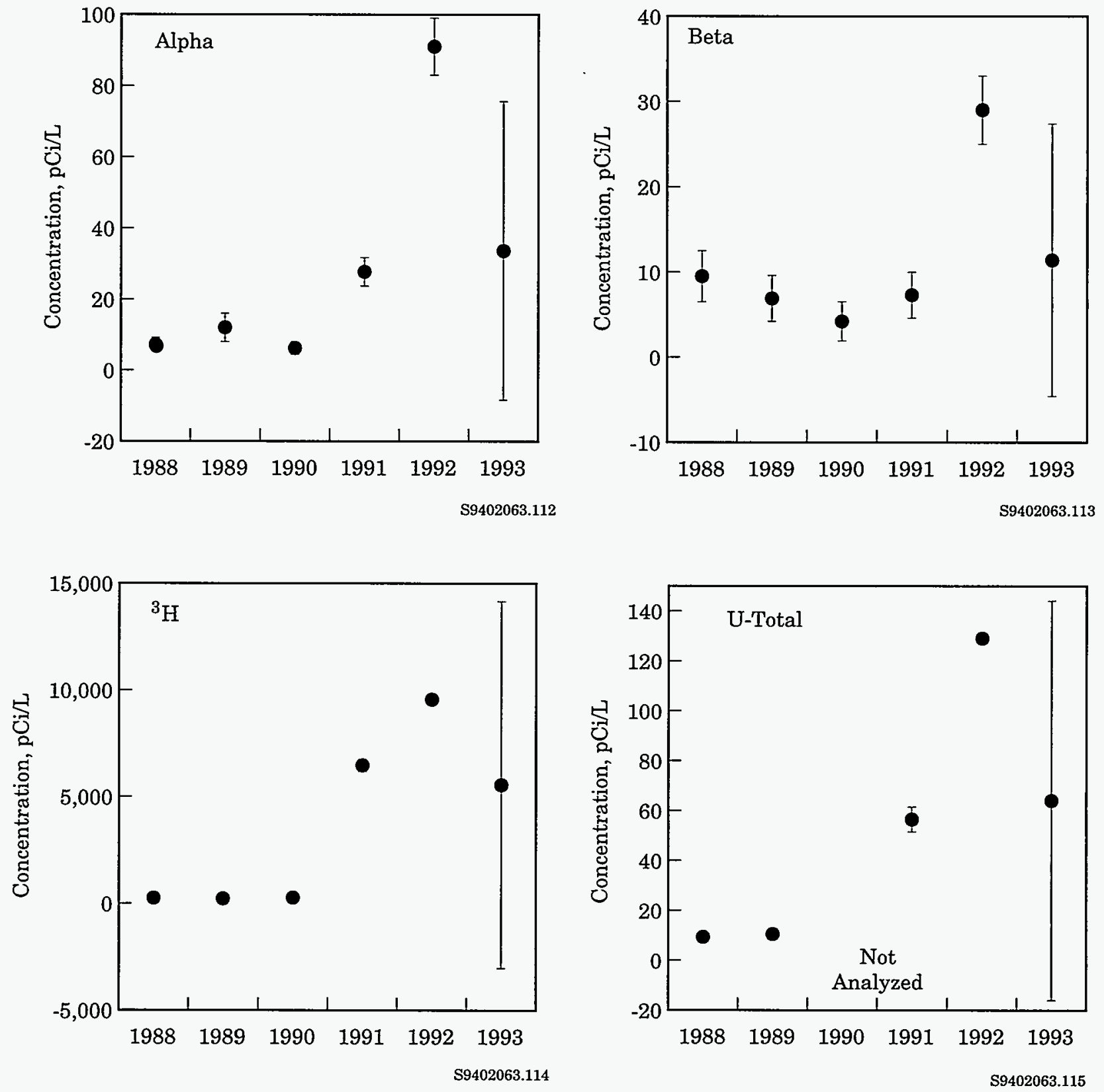

Figure 5.19. Constituents of Concern in 300 Area Riverbank Springs, 1988 to 1993 . Concentrations are \pm 2 sigma counting error for the years 1988 to 1992 and \pm 2 SEM for 1993. As a result of figure scale, some uncertainties (error bars) are concealed by point symbol. 


\section{Sample Collection and Analysis}

During 1993, grab samples were collected quarterly from the FFTF Pond and West Lake. Monthly samples were collected from B Pond. Unfiltered aliquots of all samples were analyzed for total alpha and total beta activities, gamma-emitting radionuclides, and ${ }^{3} \mathrm{H}$. Samples from B Pond were also analyzed for ${ }^{90} \mathrm{Sr}$ and ${ }^{99} \mathrm{Tc}$. West Lake samples were analyzed for ${ }^{90} \mathrm{Sr},{ }^{234} \mathrm{U},{ }^{235} \mathrm{U}$, and ${ }^{238} \mathrm{U}$ in addition to those constituents listed above.

\section{Results}

Analytical results from pond samples collected during 1993 are listed by Bisping (1994). Maximum, minimum, and average concentration values are provided for various radionuclides in each pond. In all cases, radionuclide concentrations in onsite pond water were less than applicable Derived Concentration Guides. Further discussion of individual constituents and comparisons with results obtained during previous years are provided below.

Annual average radionuclide concentrations in B Pond for the years 1988 through 1993 are shown in Figure 5.20. Total alpha and beta concentrations during the year were within the range observed during the previous 5 years and, as in past years, near the analytical detection limit. Concentrations of ${ }^{90} \mathrm{Sr}$ were comparable to those observed during the previous 5 years. Tritium concentrations in B Pond also remained in the range observed during recent years. Cesium-137 concentrations were generally less than the detection level, approximately $1.5 \mathrm{pCi} / \mathrm{L}$, during 1993 and were similar to recent years, with the exception of a single sample collected in March. B Pond is scheduled for decommissioning during 1994.

Figure 5.21 shows the annual average total beta and ${ }^{3} \mathrm{H}$ concentrations in FFTF Pond during the years 1988 through 1993. As in the past, total alpha and ${ }^{22} \mathrm{Na}$ concentrations were less than the detection levels $(1.5$ and $6.0 \mathrm{pCi} / \mathrm{L}$, respectively) during the year. Total beta concentrations in FFTF Pond water during 1993 were within the range observed during previous years. The concentrations of ${ }^{3} \mathrm{H}$ were comparable to those measured in FFTF Pond in the past. The ${ }^{3} \mathrm{H}$ concentrations observed in FFTF Pond are indicative of the levels of ${ }^{3} \mathrm{H}$ known to exist in the ground water beneath the 400 Area, from which the 400 Area obtains its water (Woodruff et al. 1993).
The 1988 through 1993 annual average contaminant concentrations in West Lake are shown in Figure 5.22. Average total alpha and total beta concentrations during 1993 were similar to those observed in the past. Total alpha and total beta concentrations in West Lake, which is recharged from ground water (Gephart et al. 1976), continued to be higher than the alpha and beta levels found in the other onsite ponds. These elevated levels are believed to result from high concentrations of naturally occurring uranium (Poston et al. 1991; Speer et al. 1976). Annual average uranium concentrations were higher than those reported during previous years as a result of a single elevated result during September. Strontium-90 concentrations during 1993 were similar to those observed during the previous 5 years, well within the range observed in the ground water near this pond. West Lake ${ }^{3} \mathrm{H}$ concentrations were similar to those observed during the mid-1980s. Gamma-emitting radionuclides remained less than the analytical detection levels (approximately $1 \mathrm{pCi} / \mathrm{L}$ for ${ }^{60} \mathrm{Co}$ and ${ }^{137} \mathrm{Cs}$ ).

\section{Offsite Water}

Water samples were collected from four water systems directly east of and across the Columbia River from the Hanford Site during 1993. Samples were also collected from an irrigation canal that obtains water from the Columbia River downstream from Hanford. As a result of public concerns about the potential for Hanfordassociated contaminants being present in offsite water, sampling was conducted to document the levels of radionuclides in the water used by the public. Consumption of food irrigated with Columbia River water downstream from the Site has been identified as one of the primary pathways contributing to the potential dose to the hypothetical maximally exposed individual (Jaquish and Mitchell 1988).

\section{Sample Collection, Analysis, and Results}

Grab samples were collected once from four offsite domestic water supplies during 1993 (see Figure 5.8). Analyses of these samples included total alpha, total beta, gamma scan, ${ }^{3} \mathrm{H},{ }^{129} \mathrm{I},{ }^{234} \mathrm{U},{ }^{235} \mathrm{U}$, and ${ }^{238} \mathrm{U}$. Results are presented by Bisping (1994). Alpha and beta concentrations are attributable to natural uranium concentrations in the ground water of this area. The 

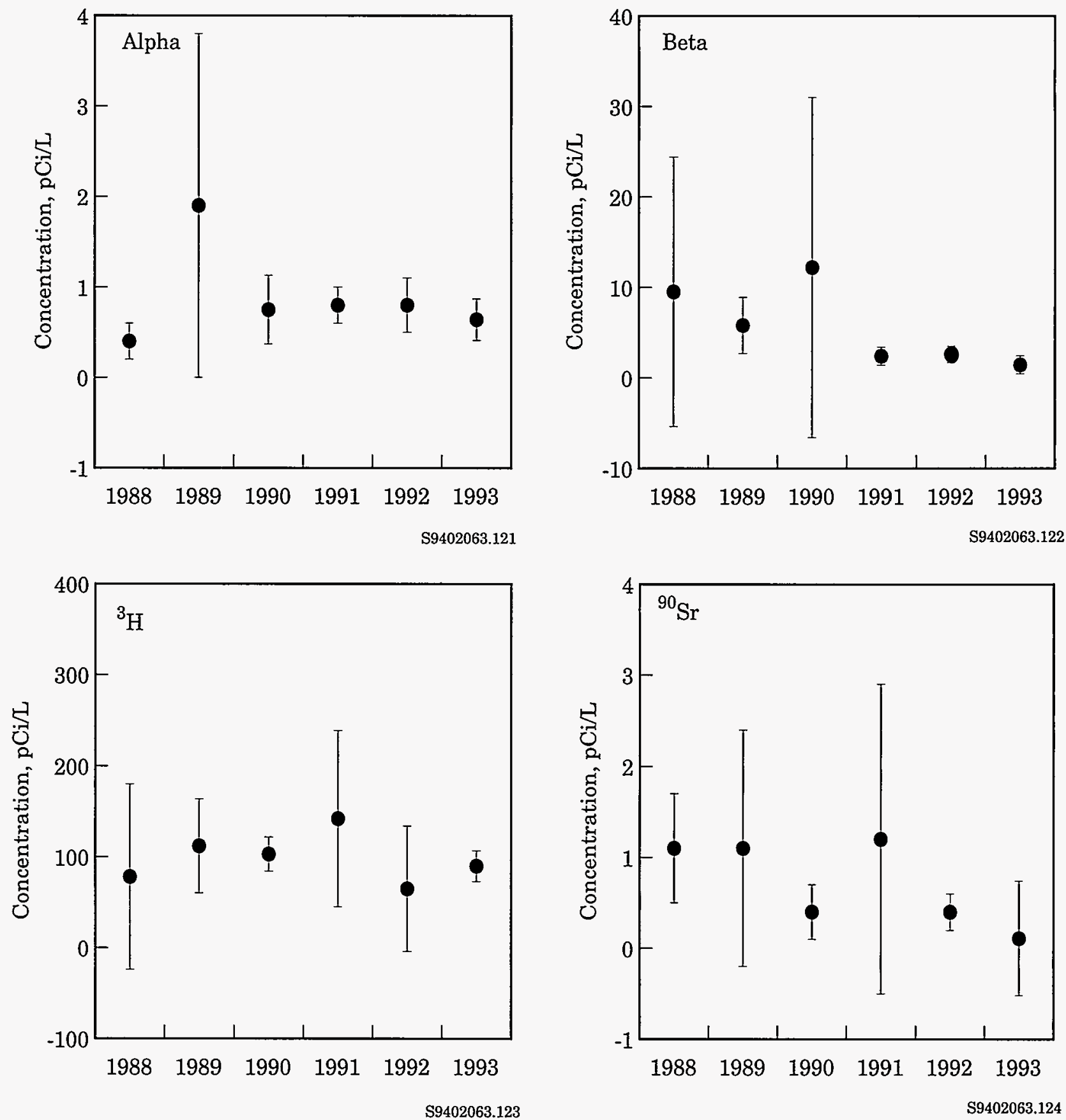

Figure 5.20. Annual Average Radionuclide Concentrations ( \pm 2 SEM) in B Pond, 1988 Through 1993 

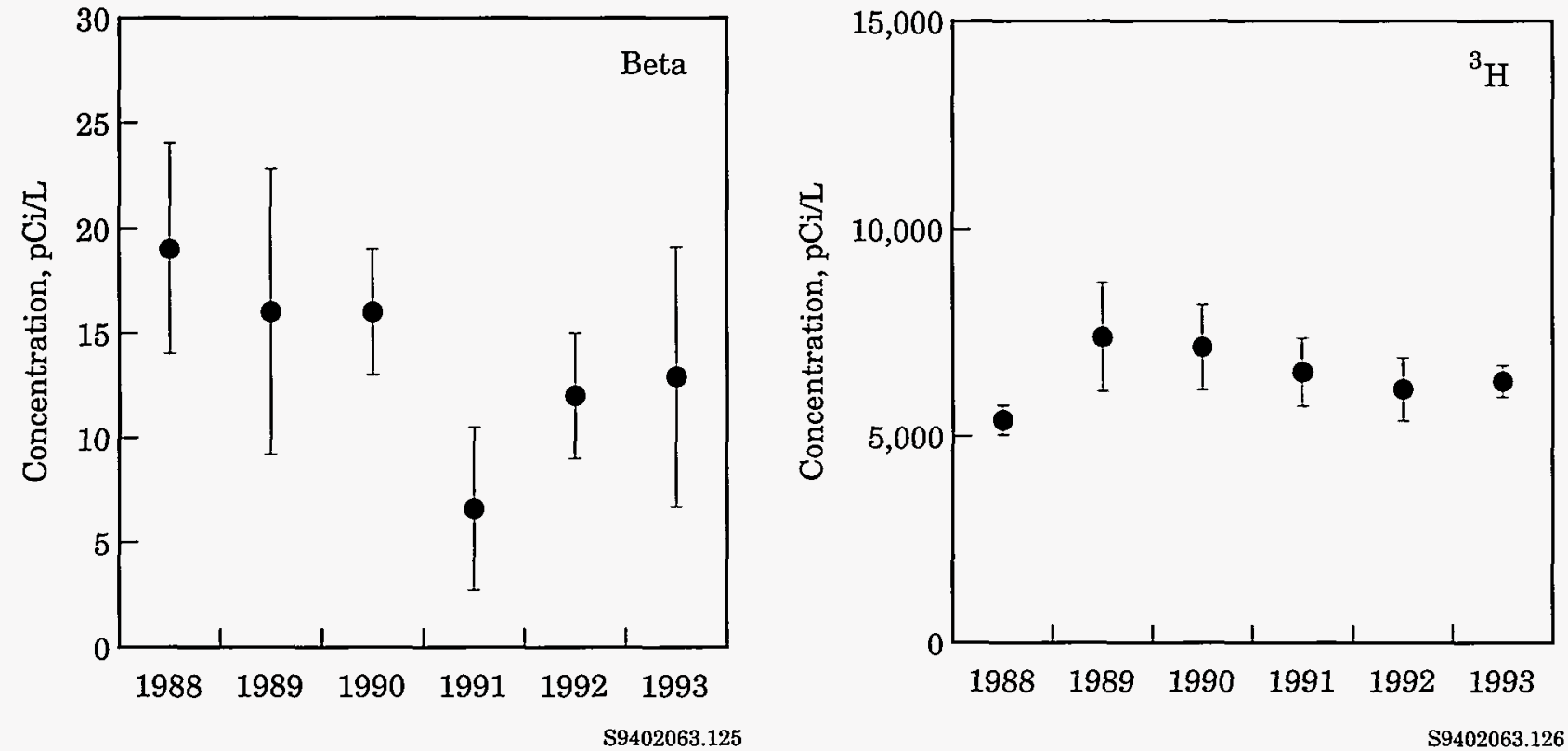

Figure 5.21. Average Total Beta and Tritium $\left({ }^{3} \mathrm{H}\right)$ Concentrations ( \pm 2 SEM) in FFTF Pond, 1988 Through 1993

concentrations observed in the offsite water supplies were comparable to those reported by the State of Washington and not attributable to Hanford operations (DOH 1994). Annual average radionuclide concentrations in offsite water during 1993 were within applicable Drinking Water Standards.

Water in the Riverview irrigation canal was sampled three times in 1993 during the irrigation season. These samples were analyzed for total alpha, total beta, gamma emitters, ${ }^{90} \mathrm{Sr},{ }^{234} \mathrm{U},{ }^{235} \mathrm{U}$, and ${ }^{238} \mathrm{U}$. Results are presented by Bisping (1994). Radionuclide concentrations were found in Riverview irrigation water during 1993 at the same levels observed in the Columbia River. Strontium90 was the radionuclide of most concern because it has been identified as one of the primary contributors to the calculated hypothetical dose to the public via the water pathway (Jaquish and Bryce 1989). The average concentration of ${ }^{90} \mathrm{Sr}$ in the irrigation water during 1993 , $0.08 \pm 0.004 \mathrm{pCi} / \mathrm{L}$, was similar to that reported for the Columbia River at Priest Rapids Dam and the Richland Pumphouse (see Columbia River Water subsection). 

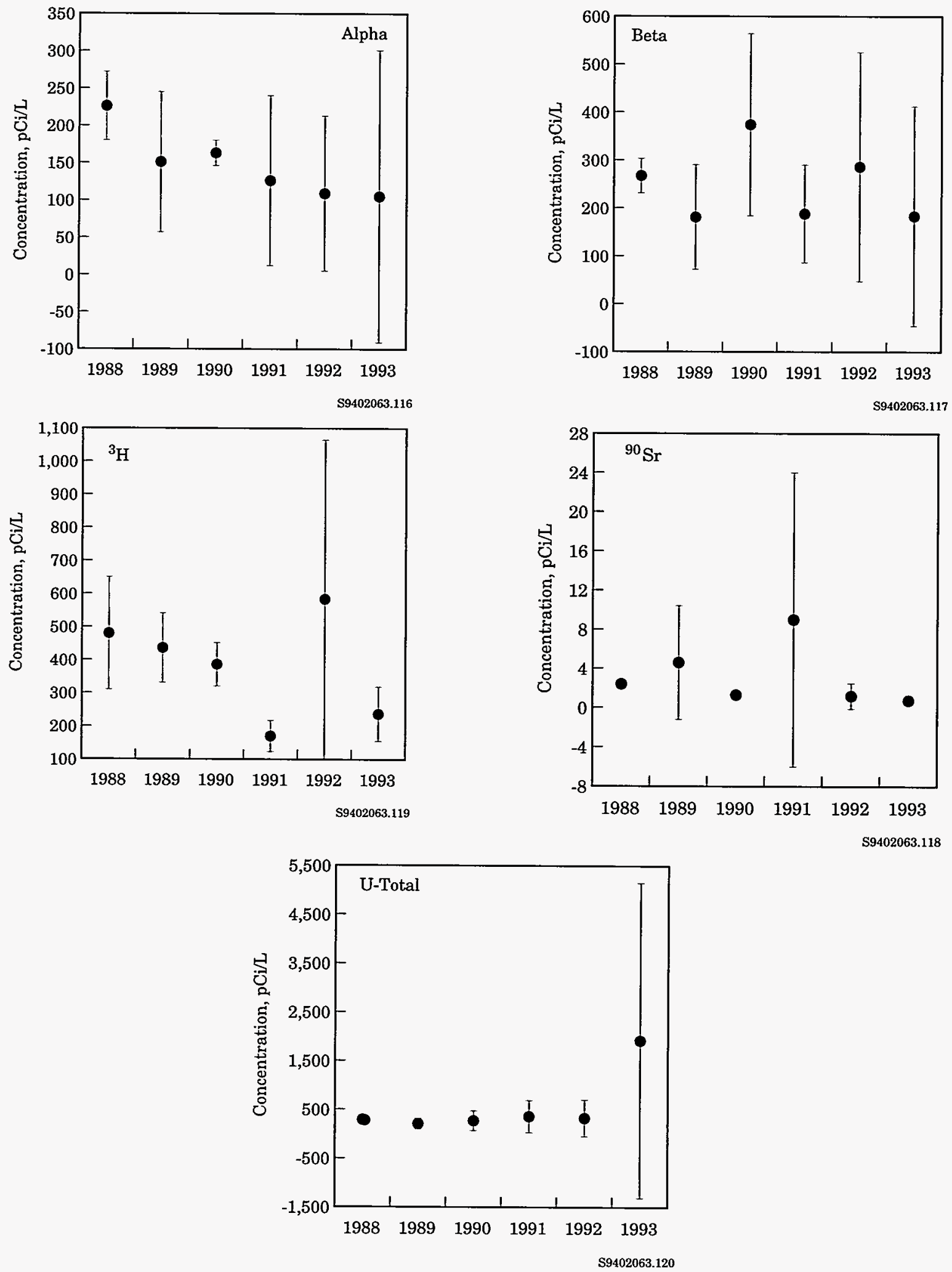

Figure 5.22. Annual Average Radionuclide Concentrations ( \pm 2 SEM) in West Lake, 1988 Through 1993. As a result of figure scale, some uncertainties (error bars) are concealed by point symbol. 


\title{
5.4 Food and Farm Product Surveillance
}

\author{
T. M. Poston
}

Alfalfa and a number of foodstuffs, including milk, wheat, beef, chickens, eggs, vegetables, fruits, and wine, were collected at several locations surrounding the Hanford Site (Figure 5.23). Samples were collected primarily from locations in the prevailing downwind directions (south and east of the Site) where airborne effluents from Hanford could be expected to be deposited. Samples were also collected in generally upwind directions, on the Site perimeter and at locations somewhat distant from the Site to provide information on background radioactivity. This section describes samples collected, radiological analyses performed, and summary results for 1993. Detailed analytical results are listed by Bisping (1994), some of which have been summarized in Appendix A. The potential dose to members of the public from the consumption of local food and farm products is addressed in Section 6.0, "Potential Radiation Doses from 1993 Hanford Operations." Results for liquids or fruits are reported in $\mathrm{pCi} / \mathrm{L}$ of liquid product or distillate. Plant material results are reported in pCi/g dry weight and animal products in $\mathrm{pCi} / \mathrm{g}$ wet weight. The concentrations in many samples were less than the limits of detection.

The food and farm product sampling approach addresses the potential influence of Hanford Site releases in two ways: by comparing results from several downwind locations to those from generally upwind or distant locations, and by comparing results from locations irrigated with Columbia River water withdrawn downstream from Hanford to those from locations irrigated with water from other sources. Specific details of the sampling design including sampling locations and radionuclides analyzed are reported by Bisping (1993) and DOE (1991b) and have been summarized in Table 5.10. Gamma scans (see Appendix F) and ${ }^{90} \mathrm{Sr}$ analyses were routinely performed for nearly all products. Selected farm products were specifically analyzed for additional radionuclides including ${ }^{3} \mathrm{H},{ }^{99} \mathrm{Tc},{ }^{129} \mathrm{I}$, uranium, and plutonium.

\section{Milk}

\section{Sample Collection and Analysis}

Samples of raw, whole milk were collected from East Wahluke and Sagemoor area dairy farms near the Site perimeter in the prevailingly downwind direction to evaluate possible Hanford impacts (Figure 5.23). Milk samples were also collected from a Sunnyside dairy to indicate the general background concentrations of radionuclides. Samples were collected monthly throughout the year from the Sagemoor area and quarterly from the other areas.

Milk was analyzed for ${ }^{3} \mathrm{H},{ }^{90} \mathrm{Sr},{ }^{129} \mathrm{I}$, and gamma emitters such as ${ }^{137} \mathrm{Cs}$ because these radionuclides have the potential to move through the air-pasture-cow-milk food chain. Tritium has been released into the atmosphere from Site facilities and to the Columbia River via shoreline ground-water seeps. Strontium-90 is released into the Columbia River through the N Springs. Iodine129 was released from the Hanford Site in the past. Cesium-137 was present in atmospheric fallout from weapons testing. Tritium and gamma analyses were conducted on each monthly sample, ${ }^{90} \mathrm{Sr}$ analyses were conducted on each quarterly sample, and ${ }^{129}$ I analyses were conducted on two semi-annual composite samples (one each from Sagemoor and Sunnyside).

\section{Results}

Tritium was measured in about 3 of the $20(15 \%)$ milk samples analyzed, with maximum concentrations near a detection limit of $300 \mathrm{pCi} / \mathrm{L}$. The low concentrations and the number of samples below the minimum detectable concentration indicate that there was no apparent difference between results upwind and downwind of the Site (Table 5.11). 


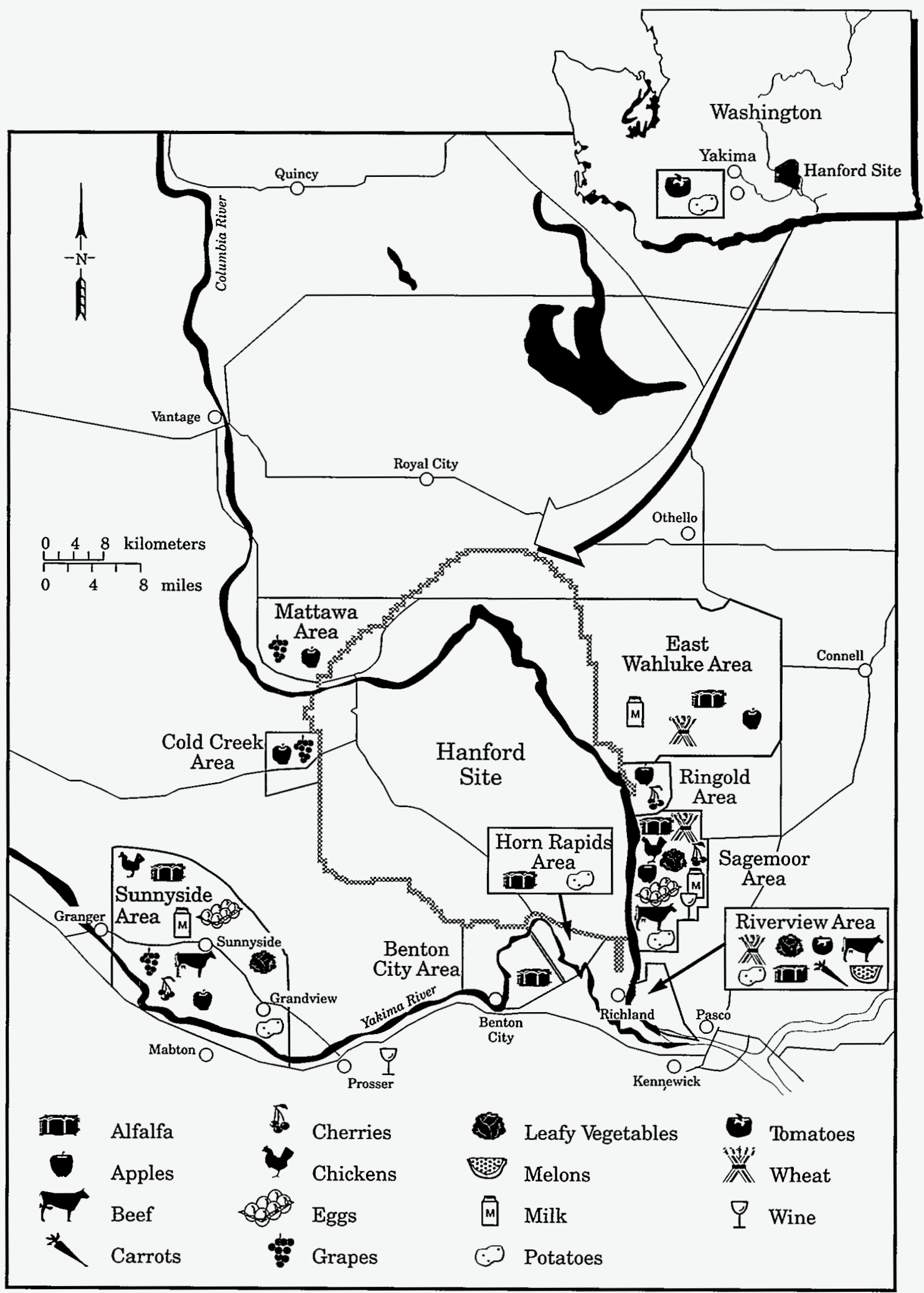

S9402063.83

Figure 5.23. Food and Farm Product Sampling Locations, 1993 
Table 5.10. Numbers of Locations, Sampling Frequencies, and Analyses Performed for Routinely Sampled Food and Farm Products, 1993(a)

\begin{tabular}{|c|c|c|c|c|c|c|c|c|c|c|}
\hline \multirow[b]{2}{*}{ Media } & \multicolumn{2}{|c|}{ Number of Locations } & \multirow{2}{*}{$\begin{array}{l}\text { Sampling } \\
\text { Frequency }^{(b)}\end{array}$} & \multicolumn{7}{|c|}{ Number of Locations Analyzed } \\
\hline & Upwind & Downwind & & ${ }^{3} \mathrm{H}$ & Gamma & ${ }^{90} \mathrm{Sr}$ & ${ }^{99} \mathrm{Tc}$ & ${ }^{129} \mathrm{I}$ & $\underline{U}$ & $\underline{\mathrm{Pu}}$ \\
\hline Milk & 1 & 2 & $\mathrm{M}, \mathrm{Q}$, or SA & 3 & 3 & 3 & 0 & 3 & 0 & 0 \\
\hline $\begin{array}{l}\text { Eggs, meat } \\
\text { and poultry }\end{array}$ & 1 & 2 & SA or A & 0 & 3 & 3 & 0 & 0 & 0 & 0 \\
\hline Vegetables & 2 & 4 & A & 2 & 6 & 6 & 3 & 1 & 2 & 3 \\
\hline Fruit & 2 & 3 & A & 5 & 5 & 5 & 0 & 2 & 0 & 3 \\
\hline $\begin{array}{l}\text { Wheat and } \\
\text { alfalfa }\end{array}$ & 1 & 4 & A & 0 & 5 & 5 & 0 & 0 & 0 & 2 \\
\hline Wine & 2 & 2 & A & 4 & 4 & 0 & 0 & 0 & 0 & 0 \\
\hline
\end{tabular}

(a) Media may include multiple varieties for each category. Not all analytes were assayed at all locations or for each variety of media.

(b) $\mathrm{M}=$ monthly; $\mathrm{Q}=$ quarterly; $\mathrm{SA}=$ semiannually; $\mathrm{A}=$ annually.

Strontium-90 was measured in 9 of $12(75 \%)$ milk samples analyzed in 1993, with no apparent differences between upwind and downwind locations (Table 5.11). Figure 5.24 shows the 6-year record for ${ }^{90} \mathrm{Sr}$ in milk samples from all 1993 sampling areas. Concentrations of ${ }^{90} \mathrm{Sr}$ have remained relatively constant over the past 6 years.

Iodine-129 was identified by high-resolution mass spectroscopy in all six milk samples tested (Table 5.11). In recent years, the levels of ${ }^{129} \mathrm{I}$ in milk collected from Sagemoor and East Wahluke (downwind locations) have persisted at levels two to four times greater than levels measured in Sunnyside (Figure 5.25); however, concentrations have been declining with the end of production activities onsite. Iodine-129 contributed only about $1 \%$ of the dose to the maximally exposed individual (MEI) through the consumption of food products (see Section 6.0).

About 3 of the 21 (14\%) milk samples collected and analyzed for ${ }^{137} \mathrm{Cs}$ in 1993 contained detectable concentrations $(>4.0 \mathrm{pCi} / \mathrm{L})$. There was no apparent difference between results upwind and downwind of the Site because of the large variation in the values. No other gamma emitters were consistently detectable (Appendix A, Table A.7).

\section{Beef, Chickens, and Eggs}

\section{Sample Collection and Analysis}

Samples of locally produced poultry and eggs (excluding shell) were collected twice annually from areas adjacent to the Hanford Site (Sagemoor and Sunnyside, Figure 5.23) and analyzed for ${ }^{90} \mathrm{Sr}$ and gamma emitters such as ${ }^{137} \mathrm{Cs}$. Beef was collected once in 1993 from the Sagemoor, Riverview, and Sunnyside areas. Beef samples are analyzed for ${ }^{90} \mathrm{Sr}$ and gamma emitters such as ${ }^{137} \mathrm{Cs}$. Strontium-90 is monitored because it is released into the Columbia River through the $\mathrm{N}$ Springs and known to accumulate in bone. Cesium-137 is monitored because it is present in Site wastes and found in atmospheric fallout from weapons testing. Both have the potential to move through the food chain to beef, chickens, and eggs.

\section{Results}

In $1993,{ }^{90} \mathrm{Sr}$ concentrations were less than the detection limit $(0.005 \mathrm{pCi} / \mathrm{g})$ in chicken and egg samples. No measurable concentrations of any byproduct gamma emitter, such as ${ }^{137} \mathrm{Cs}$, were found in chicken or egg samples. 
Table 5.11. Radionuclide Concentrations in Milk (pCi/L), 1993 Compared to Values from the Previous 5 Years

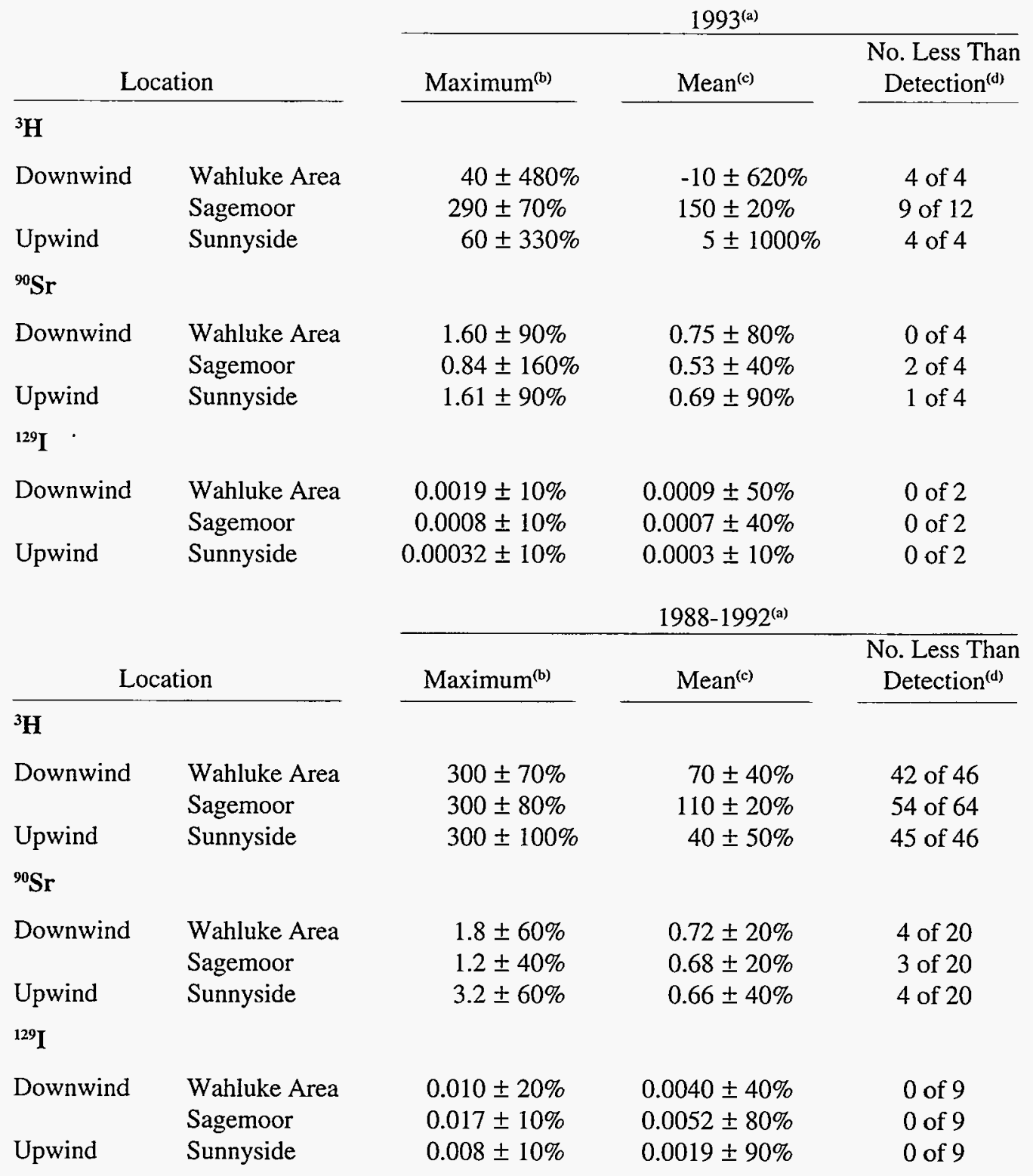

(a) Results have shown a decreasing trend over the period of 1988 to 1993.

(b) Maximum \pm 2 sigma analytical error, expressed as a percentage.

(c) Mean \pm 2 standard error of the calculated mean, expressed as a percentage.

(d) Number of samples with values less than the detection limit out of number of samples analyzed. Means are based on all samples collected. 


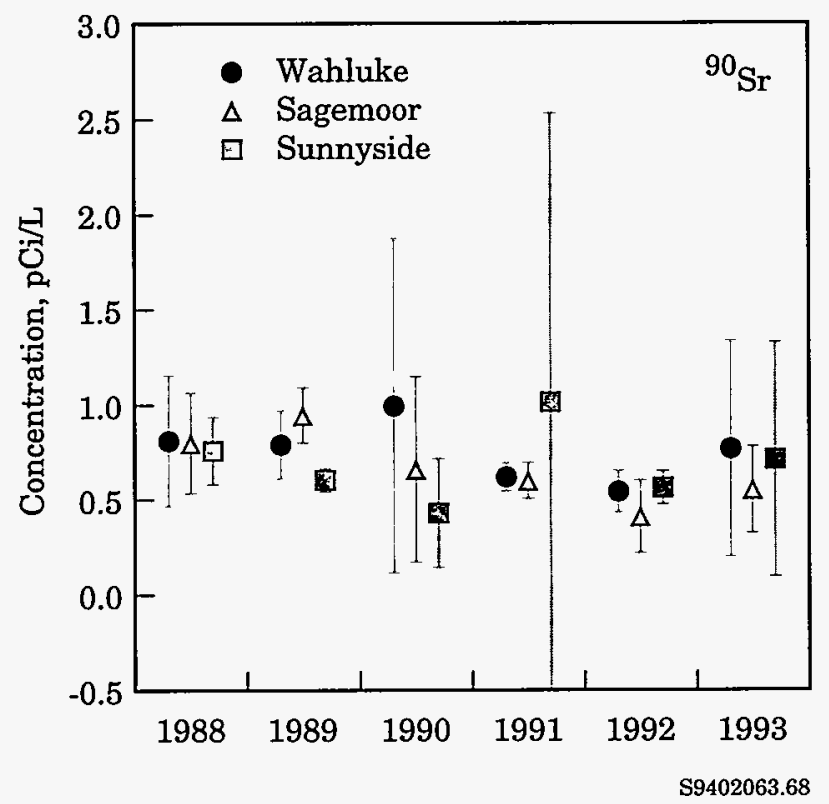

Figure 5.24. Strontium- $90\left({ }^{90} \mathrm{Sr}\right)$ Concentrations ( \pm 2 SEM) in Milk, 1988 Through 1993. As a result of figure scale, some uncertainties (error bars) are concealed by point symbol.

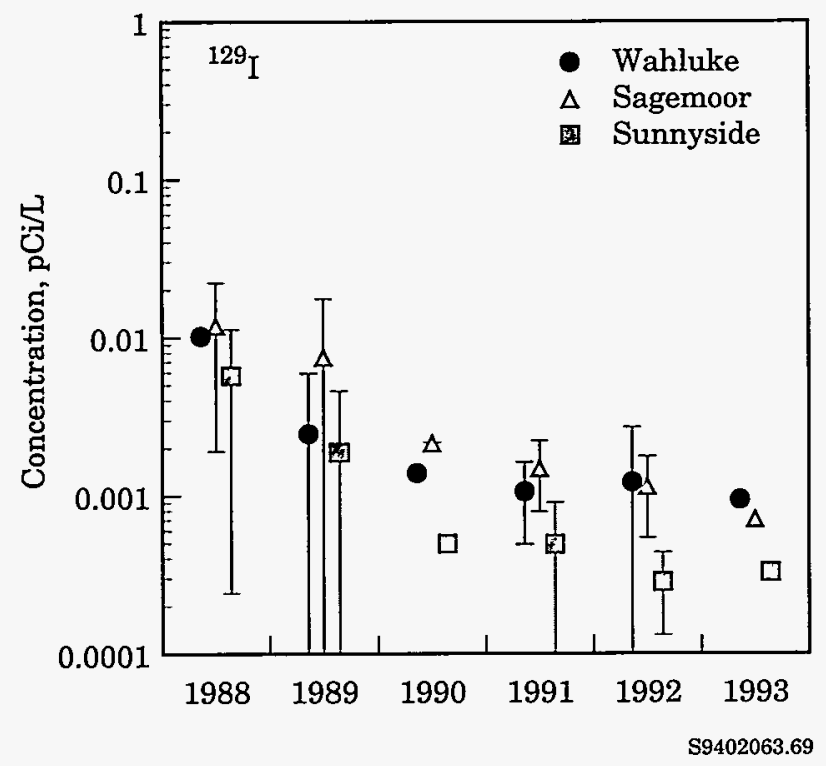

Figure 5.25. Average lodine-129 (129) Concentrations ( \pm 2 SEM) in Milk, 1988 Through 1993. As a result of figure scale, some uncertainties (error bars) are concealed by point symbol. Uncertainties for some annual averages for Sunnyside samples were less than zero and cannot be shown on a logscaled figure.
In 1993, concentrations of ${ }^{90} \mathrm{Sr}$ were less than the detection limit $(0.005 \mathrm{pCi} / \mathrm{g})$ in all beef samples. Cesium-137 was found in a beef sample collected from the upwind location (Sunnyside); however, the concentration was very low $(0.005 \mathrm{pCi} / \mathrm{g})$. Concentrations at Riverview and Sagemoor were less than the minimum detectable concentration $(0.02 \mathrm{pCi} / \mathrm{g})$. No other byproduct gamma emitters were found in 1993 beef samples.

\section{Vegetables}

\section{Sample Collection and Analysis}

Samples of leafy vegetables (cabbage, broccoli leaves, beet tops, or turnip greens), tomatoes, carrots, and potatoes were obtained during the summer from gardens and farms located within the sampling areas (see Figure 5.23). In conjunction with the Washington State Department of Health, tomatoes and potatoes were also sampled from Harrah, a farming community about 8 miles $(13 \mathrm{~km})$ south of Yakima and upwind of the Hanford Site. Samples were collected from the Riverview and Horn Rapids areas to assess potential contamination from the irrigation of crops at those locations. Irrigation water for Horn Rapids and Riverview is withdrawn from the Columbia River downstream from Hanford.

Leafy vegetables are sampled because of the potential deposition of airborne contaminants, and, at some locations, deposition from overhead irrigation. Three replicate samples of each vegetable were collected at each sampling location. If the results of one of the replicates deviated significantly from prior data, the remaining two replicates were also analyzed. All vegetable samples were analyzed for ${ }^{90} \mathrm{Sr}$ and gammaemitting radionuclides; in addition, tomatoes from selected locations were analyzed for ${ }^{3} \mathrm{H}$, and potatoes from selected locations were analyzed for ${ }^{99} \mathrm{Tc},{ }^{239.240} \mathrm{Pu}$, and uranium isotopes. Tritium is monitored because it has been released into the atmosphere from Site facilities and to the Columbia River via shoreline ground-water seeps. Strontium-90 is monitored because it is released into the Columbia River at the N Springs and is known to accumulate in some plants. Technetium-99 is monitored because it is known to enter the Columbia River through shoreline seeps and springs, has a long half-life, and can accumulate in farm products that may be irrigated with Columbia River water withdrawn downstream from 
Hanford. Iodine-129 is monitored because it can move through the air-vegetation-human food chain. Cesium137 is monitored because it is present in Hanford wastes and atmospheric fallout from weapons testing. Isotopes of uranium are monitored because they enter the Columbia River in springs near the 300 Area and are known to accumulate in soil and vegetation. Plutonium-238 and ${ }^{239.240} \mathrm{Pu}$ are monitored because of past releases and to assure the public that concentrations of plutonium isotopes are not a concern in vegetables.

\section{Results}

Many of the analytical results for vegetables were below the detection limits for specific radionuclides. For leafy vegetable samples in 1993, the only radionuclide measured above the detection limit was ${ }^{90} \mathrm{Sr}$ in one sample collected at Riverview $(0.027 \pm 30 \% \mathrm{pCi} / \mathrm{L}$; see Figure 5.26). For tomato samples in $1993,{ }^{3} \mathrm{H}$ was not detected above the detection limit of $300 \mathrm{pCi} / \mathrm{L}$ of sample distillate in the tomato sample collected at Riverview ( $15 \pm 470 \% \mathrm{pCi} / \mathrm{L}$ distillate) and the tomato sample collected at the upwind location at Harrah (60 $\pm 120 \% \mathrm{pCi} / \mathrm{L}$ distillate). No other byproduct radionuclides were detected in tomato samples in 1993.

No radionuclides were detected in carrot samples in 1993. Radionuclides analyzed in potatoes from Sunnyside and Horn Rapids were not detected above the detection limit for uranium isotopes $(<0.02 \mathrm{pCi} / \mathrm{g})$ and ${ }^{238} \mathrm{Pu}$ and ${ }^{239.240} \mathrm{Pu}$ isotopes $(<0.0004 \mathrm{pCi} / \mathrm{g})$.

\section{Fruit}

\section{Sample Collection and Analysis}

Samples of apples, cherries, concord grapes, and melons were collected in triplicate before or during harvest from the areas shown in Figure 5.23 (not all types were collected in each area). The edible portions were analyzed for ${ }^{3} \mathrm{H},{ }^{90} \mathrm{Sr}$, gamma emitters and, for selected samples, ${ }^{129} \mathrm{I}$ and ${ }^{239.240} \mathrm{Pu}$. Tritium was analyzed in the distillate collected from fruit samples.

\section{Results}

Measurable levels of radioactivity were not detected in apples, cherries, concord grapes, or melons collected in 1993 from either upwind or downwind locations. These

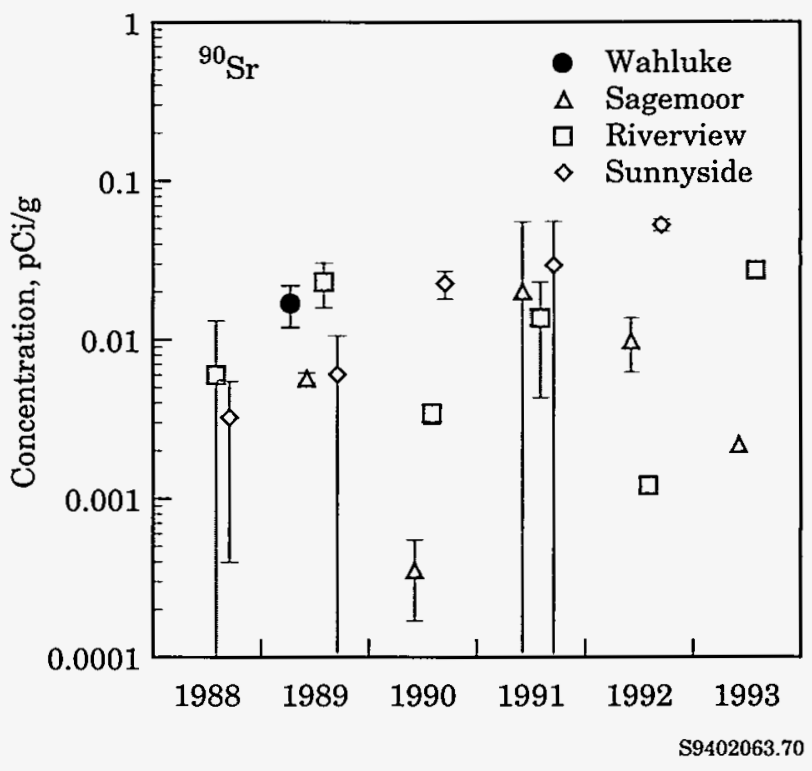

Figure 5.26. Strontium-90 ( $\left.{ }^{\circ 0} \mathrm{Sr}\right)$ Concentrations ( \pm 2 SEM) in Leafy Vegetables, 1988 Through 1993. As a result of figure scale, some uncertainties (error bars) are concealed by point symbol.

results are consistent with fruit measurements over recent years (Bisping and Woodruff 1990, 1991, 1992, 1993). Minimum levels of detection were $300 \mathrm{pCi} / \mathrm{L}$ plant distillate for ${ }^{3} \mathrm{H}, 0.005 \mathrm{pCi} / \mathrm{g}$ dry weight for ${ }^{90} \mathrm{Sr}, 1 \mathrm{pCi} / \mathrm{g}$ dry weight for ${ }^{129} \mathrm{I}, 0.02 \mathrm{pCi} / \mathrm{g}$ dry weight for ${ }^{137} \mathrm{Cs}$, and $0.0004 \mathrm{pCi} / \mathrm{g}$ dry weight for ${ }^{239.240} \mathrm{Pu}$.

\section{Wine}

\section{Sample Collection and Analysis}

Locally produced red and white wines (1993 vintage grapes) were analyzed for ${ }^{3} \mathrm{H}$ and gamma-emitting radionuclides. The wines were made from grapes grown at individual vineyards in the Sagemoor Area downwind of the Site and in the Yakima Valley near Prosser upwind of the Site. Three samples of each wine were obtained from each area. A duplicate sample for each variety was analyzed by the Washington State Department of Health.

\section{Results}

The results for ${ }^{3} \mathrm{H}$ in wine indicate no difference between upwind and downwind locations (Table 5.12). 
Table 5.12. Tritium $\left({ }^{3} \mathrm{H}\right)$ Concentrations in Wine ( $\left.\mathrm{pCi} / \mathrm{L}\right), 1993$ Compared to Values from the Previous 5 Years

\begin{tabular}{|c|c|c|c|c|}
\hline \multirow[b]{2}{*}{ Type of Wine } & \multirow[b]{2}{*}{ Location } & \multicolumn{3}{|c|}{1993} \\
\hline & & Maximum $^{(a)}$ & Mean $^{(b)}$ & $\begin{array}{l}\text { No. Less Than } \\
\text { Detection }^{(\mathbf{c})}\end{array}$ \\
\hline White wine & Columbia Basin & $\begin{array}{l}860 \pm 30 \% \\
940+10 \%\end{array}$ & $740 \pm 20 \%$ & 0 of 3 \\
\hline \multirow[t]{3}{*}{ Red wine } & $\begin{array}{l}\text { Columbia Basin } \\
\text { Yakima Valley }\end{array}$ & $\begin{array}{l}680 \pm 20 \% \\
640 \pm 10 \%\end{array}$ & $\begin{array}{l}470 \pm 70 \% \\
590 \pm 10 \%\end{array}$ & $\begin{array}{l}1 \text { of } 3 \\
0 \text { of } 3\end{array}$ \\
\hline & & & $1988-1992$ & \\
\hline & & Maximum $^{(a)}$ & Mean $^{(b)}$ & $\begin{array}{l}\text { No. Less Than } \\
\text { Detection }\end{array}$ \\
\hline White wine & $\begin{array}{l}\text { Columbia Basin } \\
\text { Yakima Valley }\end{array}$ & $\begin{array}{l}930 \pm 30 \% \\
820 \pm 40 \%\end{array}$ & $\begin{array}{l}370 \pm 30 \% \\
300 \pm 30 \%\end{array}$ & $\begin{array}{l}5 \text { of } 18 \\
6 \text { of } 17\end{array}$ \\
\hline Red wine & $\begin{array}{l}\text { Columbia Basin } \\
\text { Yakima Valley }\end{array}$ & $\begin{array}{l}790 \pm 30 \% \\
654 \pm 40 \%\end{array}$ & $\begin{array}{l}360 \pm 30 \% \\
330 \pm 40 \%\end{array}$ & $\begin{array}{l}2 \text { of } 15 \\
5 \text { of } 15\end{array}$ \\
\hline
\end{tabular}

(a) Maximum \pm sigma analytical error, expressed as a percentage.

(b) Mean \pm 2 standard error of the calculated mean, expressed as a percentage.

(c) Number of samples with values less than the detection limit out of number of samples analyzed.

Concentrations reported in 1993 are higher than those observed in 1992; however it is believed that the results are indicative of a contamination problem at the analytical laboratory and do not represent actual values. This belief was confirmed when measurements of replicate samples of the same wines by the Washington State Department of Health (Table 5.13) indicated less-thandetection concentrations of ${ }^{3} \mathrm{H}(<300 \mathrm{pCi} / \mathrm{L})$. The ${ }^{3} \mathrm{H}$ results for the Surface Environmental Surveillance Project samples are approximately two times the minimum detectable concentration of $300 \mathrm{pCi} / \mathrm{L}$. While there is no ${ }^{3} \mathrm{H}$ standard for wine; the standard for drinking water is $20,000 \mathrm{pCi} / \mathrm{L}$.

Table 5.13. Washington State Department of Health Radionuclide Concentrations $(\mathrm{pCi} / \mathrm{L})$ in Wine, 1993

\begin{tabular}{|c|c|c|}
\hline Type of Wine & Location & Concentration \\
\hline White wine & $\begin{array}{l}\text { Columbia Basin } \\
\text { Yakima Valley }\end{array}$ & $\begin{array}{r}95 \pm 30 \% \\
193 \pm 20 \%\end{array}$ \\
\hline Red wine & $\begin{array}{l}\text { Columbia Basin } \\
\text { Yakima Valley }\end{array}$ & $\begin{array}{l}261 \pm 10 \% \\
142 \pm 20 \%\end{array}$ \\
\hline
\end{tabular}

(a) Concentration in one replicate sample \pm 2 sigma counting error, expressed as a percentage.
One triplicate sample of Yakima valley red wine contained ${ }^{137} \mathrm{Cs}$ at $4.0 \pm 90 \% \mathrm{pCi} / \mathrm{L}$; no other samples contained byproduct gamma emitters above the minimum detectable concentration in 1993.

\section{Wheat and Alfalfa}

\section{Sample Collection and Analysis}

Samples of ripened wheat and mature alfalfa were collected from the areas shown in Figure 5.23. Three replicate samples of alfalfa were collected at each location and analyzed for ${ }^{9} \mathrm{Sr}$ and gamma emitters. Wheat from the Sagemoor area was analyzed for ${ }^{90} \mathrm{Sr}$, ${ }^{239,240} \mathrm{Pu}$, and gamma emitters.

\section{Results}

The only radionuclide detected in wheat was ${ }^{137} \mathrm{Cs}$ in one sample from the Sagemoor area $(0.11 \pm 90 \% \mathrm{pCi} / \mathrm{g})$. Results for wheat analysis are listed by Bisping (1994).

Alfalfa irrigated with Columbia River water withdrawn downstream from Hanford (Riverview and Horn Rapids) 
continued to show slightly higher concentrations of ${ }^{90} \mathrm{Sr}$ relative to other locations (Figure 5.27). In comparison, concentrations of ${ }^{90} \mathrm{Sr}$ in alfalfa from Benton City (which gets its water from the Yakima River) were equivalent to levels reported in Riverview, but less than concentrations at Horn Rapids (Table 5.14). Samples from Sagemoor (which uses Columbia Basin Irrigation Project water) and Sunnyside (which uses water from the Yakima River) had concentrations of ${ }^{90} \mathrm{Sr}$ lower than those at Riverview and Horn Rapids in 1993. Analysis of Columbia River water at Priest Rapids Dam and the Richland Pumphouse, however, indicated that ${ }^{90} \mathrm{Sr}$ concentrations in water from both locations were similar. Differences in ${ }^{90} \mathrm{Sr}$ concentrations in alfalfa, based on sources of irrigation water, appear significant. However, the actual concentrations at all locations are low and difficult to separate from the influence of fallout (Jaquish 1993). These levels do not present a significant hazard to humans and animals.

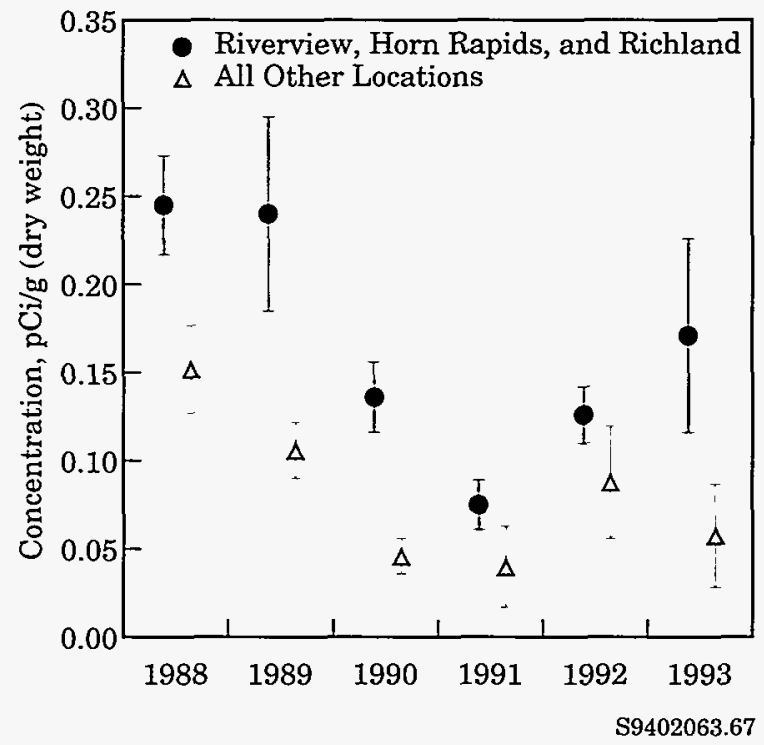

Figure 5.27. Strontium-90 ( $\left.{ }^{90} \mathrm{Sr}\right)$ Concentrations $( \pm 2$ SEM) in Alfalfa Routinely Collected at Riverview, Horn Rapids, and Richland (irrigated with Columbia River water) and All Other Sampling Locations, 1988 Through 1993.
Cesium-137 was the only byproduct gamma emitter detected (in 1 of the 15 samples from Sagemoor) in alfalfa $(0.01 \pm 90 \% \mathrm{pCi} / \mathrm{g})$.

Table 5.14. Strontium-90 $\left({ }^{90} \mathrm{Sr}\right)$ in Alfalfa Samples (pCi/g), 1993

\begin{tabular}{|c|c|c|c|}
\hline Location & Concentration $^{(\mathbf{a})}$ & $\begin{array}{c}\text { No. of } \\
\text { Samples }\end{array}$ & $\begin{array}{c}\text { Irrigation } \\
\text { Water Source }\end{array}$ \\
\hline Horn Rapids & $0.23 \pm 20 \%$ & 3 & Columbia River \\
\hline Riverview & $0.13 \pm 10 \%$ & 3 & Columbia River \\
\hline Sagemoor & $0.03 \pm 20 \%$ & 3 & Roosevelt Lake ${ }^{(b)}$ \\
\hline Benton City & $0.11 \pm 40 \%$ & 3 & Yakima River \\
\hline Sunnyside & $0.03 \pm 60 \%$ & 3 & Yakima River \\
\hline
\end{tabular}

(a) Concentrations are mean \pm 2 SEM, expressed as a percentage.

(b) Columbia Basin Irrigation Project water. 


\title{
5.5 Fish and Wildlife Surveillance
}

\author{
T. M. Poston
}

Contaminants in fish and wildlife species that inhabit the Columbia River and Hanford Site are monitored for several reasons. Wildlife have access to areas of the Site containing radioactive contamination, and fish can be exposed to contamination in spring water entering the river along the shoreline. Fish and some wildlife species exposed to Hanford effluents might be harvested and may potentially contribute to the dose people receive. In addition, detection of radionuclides in fish and wildlife may indicate that wildlife are entering restricted contaminated areas (for example, burrowing in burial grounds) or that radioactive material is moving out of these restricted areas (for example, through blowing dust). Consequently, samples are collected at various locations annually, generally during the hunting or fishing season, for selected species (Figure 5.28).

Many of the operating facilities are buffered by natural areas, such as the Fitzner/Eberhardt ALE Reserve. These buffer zones isolate nonnomadic species (for example, rabbits) from contact with the public. Therefore, these species are seldom hunted. More detailed rationale for selection of specific species can be found in DOE (1991b).

When radioactive material is found in fish or wildlife, it is important to determine what part of those materials originated at Hanford. Therefore, samples of fish and wildlife collected from distant locations unaffected by Hanford effluents (background locations) are analyzed, and results are compared to results from Hanford samples to identify any differences. Background sampling is conducted on a 5-year schedule of locations believed to be unaffected by Hanford releases.

For each species of fish or wildlife, contaminants (generally radionuclides but also metals for some species) are selected for analysis based on the potential for the contaminant to be found at the sampling site and the potential to accumulate in fish or wildlife (Table 5.15). Strontium-90 and ${ }^{137} \mathrm{Cs}$ have been the most frequently measured radionuclides in fish and wildlife.
Strontium is chemically similar to calcium; consequently, it accumulates in hard tissues high in calcium like bone, antlers, and egg shells. It has a long biological half-life in hard tissue and will document historical exposure of an organism. However, ${ }^{90} \mathrm{Sr}$ in consumed fish and wildlife generally does not contribute much to human dose because it does not accumulate in edible portions. The N Springs in the 100-N Area are the primary source of ${ }^{90} \mathrm{Sr}$ from Hanford to the Columbia River; however, the current contribution, relative to historical fallout from atmospheric weapons testing, is small (Jaquish 1993).

Cesium is particularly important because it is chemically similar to potassium and accumulates in the muscle tissue of fish and wildlife. It is more likely, therefore, to contribute to the dose received by hunters and fishers from the consumption of game and fish. It has a relatively short biological half-life and is an indicator of more recent exposure to radioactivity. Cesium-137 is also a major constituent of historical fallout radioactivity.

Fish and wildlife samples were analyzed by gamma scan to detect a number of gamma emitters (see Appendix F). However, gamma-scan results are not discussed below because concentrations were too low to measure, or because measured concentrations were considered artifacts of low background counts. Low background counts occur at random intervals during sample counting and can produce occasional spurious results.

Other specific radiochemical analyses were performed on fish and wildlife samples to measure ${ }^{99} \mathrm{Tc},{ }^{234} \mathrm{U},{ }^{235} \mathrm{U}$, ${ }^{238} \mathrm{U}$, ${ }^{238} \mathrm{Pu}$, and ${ }^{239,240} \mathrm{Pu}$. These radionuclides provide an indication of contaminant levels in edible portions of fish and wildlife to help estimate doses to consumers. These radionuclides are important because:

- Technetium-99 is known to enter the Columbia River in shoreline seeps and springs and has a long environmental half-life. In addition, its potential to accumulate in fish is not well known. 


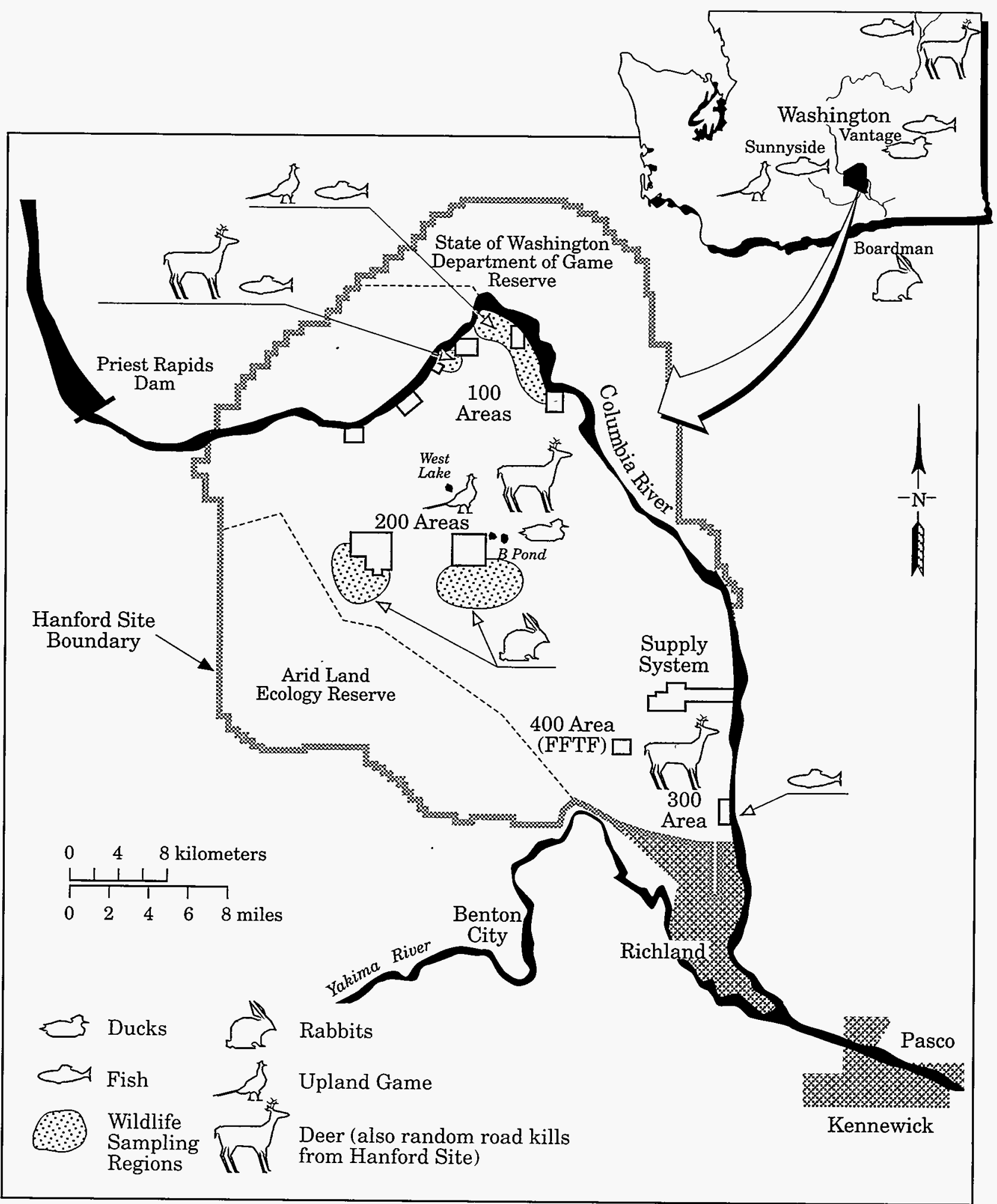

S9402063.45

Figure 5.28. Fish and Wildlife Sampling Locations, 1993 
Table 5.15. Locations, Species, and Radionuclides Sampled for Fish and Wildlife, 1993

\begin{tabular}{|c|c|c|c|c|c|c|c|}
\hline \multirow[b]{2}{*}{ Media } & \multirow{2}{*}{$\begin{array}{c}\text { Number of } \\
\text { Species }\end{array}$} & \multirow{2}{*}{$\begin{array}{c}\text { Onsite } \\
\text { Locations } \\
\end{array}$} & \multicolumn{5}{|c|}{ Radionuclides Sampled for, Number of Locations } \\
\hline & & & $\overline{\text { Gamma }}$ & ${ }^{90} \mathrm{Sr}^{(\mathrm{a})}$ & ${ }^{99} \mathrm{Tc}$ & $\underline{\mathrm{U}}$ & $\underline{\mathrm{Pu}^{(\mathbf{b})}}$ \\
\hline Fish & 2 & 2 & 2 & 2 & 1 & 1 & 0 \\
\hline Ducks (Mallard) & 1 & 1 & 1 & 1 & 1 & 0 & 0 \\
\hline Upland gamebirds & 3 & 3 & 3 & 3 & 0 & 0 & 0 \\
\hline Mule deer & 1 & 5 & 5 & 2 & 0 & 0 & 3 \\
\hline Jackrabbits & 1 & 2 & 2 & 2 & 0 & 0 & 2 \\
\hline
\end{tabular}

(a) Analyzed in bone and some muscle samples.

(b) Analyzed in liver only.

- Isotopes of uranium enter the Columbia River in springs near the 300 Area and have been reported at slightly elevated concentrations in soil and vegetation, which wildlife could contact or ingest.

- Isotopes of plutonium accumulate in liver and may ultimately be deposited in bone. Liver tissue was analyzed in selected wildlife to monitor potential exposure to terrestrial contamination.

Analysis of metals in environmental media at the Hanford Site is being conducted in association with Site cleanup and restoration activities and has only recently expanded to include wildlife. In conjunction with the near-facility environmental monitoring program (Section 3.2), special sampling was conducted in 1993 to monitor metals in pigeon and deer samples collected from the 200 Areas. A total of 13 metals were analyzed by inductively coupled plasma emmision spectroscopy and atomic absorption methods.

\section{Fish Sampling}

Carp and whitefish were collected from the Hanford Reach in the summer of 1993. In general, radionuclides were not consistently detected in fish flesh. Fish are very mobile and the length of time they reside at any given sampling location is unknown. This mobility may explain why analytical results in fish are generally variable. The 1993 results were compared to those for fish collected in 1990 and 1991 from areas distant from the Hanford Site to help quantify any contaminants from Hanford. Results from all 1993 samples are listed by Bisping (1994).

\section{Carp}

\section{Sample Collection and Analysis}

Carp were collected from the Columbia River between the 100-N and 100-D Areas because of the proximity of the N Springs with its release of ${ }^{90} \mathrm{Sr}$ to the river. Carp are also collected near the 300 Area because of the potential releases of uranium, ${ }^{90} \mathrm{Sr}$, and gamma-emitting radionuclides from ground-water seeps along the river shoreline at the 300 Area and upstream. In July 1993, three carp were collected between the $100-\mathrm{N}$ and 100-D Areas, and five carp were collected from the 300 Area. Background samples of carp were collected from the Columbia River near Vantage, Washington, in 1990 and 1991. Muscle tissues and carcass samples were analyzed. The only byproduct radionuclides found in Columbia River carp were ${ }^{90} \mathrm{Sr}$ in carcass and ${ }^{137} \mathrm{Cs}$ in muscle samples. 


\section{Results}

Muscle. Strontium-90 was not detected in carp muscle samples from either the 100 Areas or the 300 Area (less than the minimum detectable concentration of $0.005 \mathrm{pCi} / \mathrm{g})$.

Cesium-137 was detected in muscle tissues, and there was an indication that concentrations from samples collected along the Hanford Reach exceeded those in samples collected in 1990 and 1991 from Vantage. Cesium-137 was measured in about half of the 42 samples collected from 1990 to 1993 , at concentrations very close to the limits of detection (see Table A.11).

Carcass. Two of three 100 Areas carp carcass samples analyzed for ${ }^{90} \mathrm{Sr}$ were lost during analysis. The remaining carp carcass sample contained $0.06 \pm 16 \% \mathrm{pCi} / \mathrm{g}{ }^{90} \mathrm{Sr}$. Data for the preceding 5 years were higher than the 1993 concentration and indicate potential exposure to $\mathrm{N}$ Springs water containing elevated concentrations of ${ }^{90} \mathrm{Sr}$. The mean concentration of ${ }^{90} \mathrm{Sr}$ in five 300 Area carp carcass samples was $0.045 \pm 40 \% \mathrm{pCi} / \mathrm{g}$. Concentrations of ${ }^{90} \mathrm{Sr}$ in carcass samples from Vantage exceeded concentrations reported in Hanford Reach carp carcass in 1993.

No other byproduct radionuclides were detected in 1993 carp carcass samples. Carcass samples are analyzed as an indicator of exposure to ${ }^{90} \mathrm{Sr}$ and pose minimal risk to humans because carcass is not consumed.

\section{Whitefish}

\section{Sample Collection and Analysis}

Whitefish were collected because historically they have been the Columbia River sportfish that accumulated the highest concentrations of radioactivity. Whitefish are currently collected from the Columbia River along the $100-\mathrm{N}$ to 100-D Area shoreline and along the 300 Area shoreline. Background samples were collected in 1991 from the Kettle River, which enters the Columbia River upstream from Grande Coulee Dam. In July 1993, 10 whitefish samples were collected between the 100-N and 100-D Areas, and 9 whitefish samples were collected from the 300 Area. Strontium- 90 and ${ }^{137} \mathrm{Cs}$ in carcass samples were the only byproduct radionuclides found.

\section{Results}

Muscle. Strontium-90 was measured in 1 of the 10 muscle samples collected and analyzed in 1993 between the $100-\mathrm{N}$ and 100 -D Areas $(0.01 \pm 80 \% \mathrm{pCi} / \mathrm{g})$, but was not measured in the 9 muscle samples collected and analyzed from the 300 Area (minimum detectable concentration is $0.005 \mathrm{pCi} / \mathrm{g}$ ).

Cesium-137 was measured in half of the muscle samples collected between the 100-N and 100-D Areas and in none of those from the 300 Area (see Table A.12). Concentrations over the past 6 years have remained near the minimum detectable concentration $(0.02 \mathrm{pCi} / \mathrm{g})$.

No other radionuclides were detected in 1993 whitefish muscle samples (Bisping 1994).

Carcass. Mean and maximum concentrations of ${ }^{90} \mathrm{Sr}$ in whitefish carcasses were lower in 1993 than for the previous 5 years; however, ${ }^{90} \mathrm{Sr}$ was found in all carcass samples analyzed (see Table A.12). In comparison, whitefish carcass concentrations were approximately half those found in carp from the same areas in 1993. Mean concentrations of ${ }^{90} \mathrm{Sr}$ in whitefish carcasses sampled from the Kettle River in 1991 were approximately twice those reported in 300 Area whitefish carcass samples and almost three times those found in 100 Areas whitefish carcass samples. These higher concentrations may indicate potential exposure to elevated levels of fallout radioactivity in that area. The Kettle River drainage generally receives more precipitation, hence more fallout, than does the Hanford Site.

\section{Wildlife Sampling}

Wildlife sampled in 1993 for radioactive constituents included deer, jackrabbits, ducks, goose egg shells, pheasants, chuckars, and pigeons. Deer and pigeon samples were analyzed for metals.

\section{Deer}

\section{Sample Collection and Analysis}

Samples were taken from Hanford Site mule deer that were selectively hunted (two deer near the 200 Area 
ponds) or killed in road accidents (five deer). Samples included muscle, bone, antler, and liver, which were analyzed for radionuclides and metals. While deer hunting is not allowed onsite, deer can leave the Site, and a small number of deer potentially from Hanford are harvested annually from Columbia River islands and across the river in Grant and Franklin counties. Road kill sampling was employed to minimize impacts to the Hanford deer population. Radionuclide concentrations in animals collected on the Site were compared to concentrations in deer collected distant from the Site in 1992. These comparisons are useful in evaluating Hanford's impact.

\section{Results}

Muscle. Two of seven deer sampled at Hanford had positive measurements of ${ }^{137} \mathrm{Cs}$ in muscle (Table A.13). Both were collected near the 200 Areas. The maximum concentration of $0.37 \pm 10 \% \mathrm{pCi} / \mathrm{g}$ indicates exposure to elevated levels of ${ }^{137} \mathrm{Cs}$, possibly in B Pond, which is a source of water for wildlife near the 200 Areas. This was the highest onsite value recorded in the last 5 years, but was similar to concentrations measured in background deer samples collected in 1992 from Stevens County. Concentrations of ${ }^{137} \mathrm{Cs}$ in background deer muscle samples were generally high because the Stevens County area historically receives more precipitation and thus accumulates more deposition of fallout from atmospheric weapons testing than the arid Hanford Site.

Concentrations of metals in muscle from two deer collected near B Pond were low and difficult to interpret. There were distinct differences between antimony, cadmium, chromium, beryllium, nickel, silver, and zinc in deer muscle samples, but background levels must be determined before a definitive assessment can be made (Table 5.16).

Bone. Strontium-90 was detected in all deer bone samples analyzed in 1993, and the maximum concentration was $5.92 \pm 5 \% \mathrm{pCi} / \mathrm{g}$. Concentrations were lower than those observed in previous years; however, they exceeded concentrations measured in deer bone samples collected from Stevens County in 1992. These higher levels may indicate some route of low-level exposure onsite (Table A.13). During the last 5 years, concentrations of ${ }^{90} \mathrm{Sr}$ in bone have been elevated in deer collected near the 100-N Area relative to the rest of the Site. The likely source of these elevated concentrations is the N Springs.

Concentrations of metals in deer bone samples were low and difficult to interpret without background samples for comparison. There was agreement between results for both deer bone samples.

Table 5.16. Trace Metal Analysis (mg/kg) of Pigeon and Deer Samples Collected from the 200 Area Plateau, 1993

\begin{tabular}{|c|c|c|c|c|c|c|c|c|c|c|c|c|c|}
\hline & \multicolumn{13}{|c|}{ Metal(a) } \\
\hline & $\mathrm{Ag}$ & As & $\mathrm{Be}$ & $\mathrm{Cr}$ & $\mathrm{Cd}$ & $\mathrm{Cu}$ & $\mathrm{Hg}^{(\mathrm{b})}$ & $\mathrm{Ni}$ & $\mathrm{Pb}$ & $\mathrm{Sb}$ & $\mathrm{Se}^{(b)}$ & $\mathrm{Tl}$ & $\mathrm{Zn}$ \\
\hline \multicolumn{14}{|l|}{ Deer } \\
\hline Muscle & $<0.01$ & $<0.10$ & $<0.10$ & 0.38 & $<0.01$ & 6.3 & $<0.011$ & $<0.10$ & $<0.10$ & $<0.01$ & 0.24 & $<0.01$ & 160 \\
\hline Muscle & 0.03 & 0.26 & 0.25 & 1.3 & 0.08 & 7.2 & $<0.011$ & 0.17 & $<0.10$ & 0.11 & 0.36 & 0.04 & 120 \\
\hline Liver (Duplicate 1) & 0.19 & 0.84 & 0.46 & 0.7 & 1.9 & 63 & $<0.011$ & 0.71 & 0.19 & 0.19 & 0.41 & 0.09 & 100 \\
\hline Liver (Duplicate 2) & 0.29 & 1.4 & 0.96 & 0.64 & 2.2 & 61 & $<0.011$ & 1.1 & 0.26 & 0.51 & 0.48 & 0.18 & 100 \\
\hline Liver & 0.09 & 0.45 & 0.33 & 0.6 & 0.98 & 56 & $<0.011$ & 0.33 & 0.24 & 0.16 & 0.95 & 0.05 & 110 \\
\hline Bone & 0.52 & 3.3 & 1.7 & 1.5 & 1.2 & 2.4 & $<0.011$ & 12 & 1.3 & 0.94 & $<0.18$ & 0.33 & 98 \\
\hline Bone & 0.51 & 3.2 & 1.7 & 1.3 & 1.3 & 2.4 & $<0.011$ & 13 & 0.92 & 0.93 & $<0.18$ & 0.34 & 76 \\
\hline \multicolumn{14}{|l|}{ Pigeon } \\
\hline Feces & 0.15 & 1.9 & 0.53 & 14 & 7.1 & 22 & 0.013 & 6.4 & 5.9 & 0.35 & 0.6 & 0.11 & 1500 \\
\hline Muscle (Duplicate 1) & 0.16 & 0.69 & 0.34 & 1.3 & 0.48 & 18 & $<0.011$ & 1.1 & 0.45 & 0.3 & 0.89 & 0.07 & 35 \\
\hline Muscle (Duplicate 2) & 0.12 & 0.7 & 0.52 & 0.88 & 0.36 & 21 & $<0.011$ & 0.97 & 0.5 & 0.36 & 1.5 & 0.07 & 42 \\
\hline
\end{tabular}

(a) < indicates that the value was less than the detection limit for the specific metal.

(b) Mercury analyses were by cold vapor atomic absorbtion spectroscopy, selenium by graphite furnace atomic absorbtion spectroscopy, and all others by inductively coupled plasma emmision spectroscopy - mass spectroscopy. 
Antler. Mule deer antlers were collected in 1991, 1992, and 1993 and were analyzed for ${ }^{90} \mathrm{Sr}$ (Cadwell 1994). Initial results indicated that deer inhabiting the 100 Areas had a higher range of ${ }^{90} \mathrm{Sr}$ in antlers $(0.31$ to $0.68 \mathrm{pCi} / \mathrm{g})$ than deer near the Hanford townsite and south to the 300 Area $(0.10$ to $0.26 \mathrm{pCi} / \mathrm{g})$. Additional sampling is planned for 1994, including background locations for additional comparisons.

Liver. Isotopes of plutonium were detected in one of seven deer liver samples from the 200 Areas $(0.0004$ $\pm 90 \% \mathrm{pCi} / \mathrm{g}{ }^{239.240} \mathrm{Pu}$ ). This was the only measured concentration in 37 liver samples analyzed since 1988 and may be a false reading. Liver data for 1993 are summarized by Bisping (1994).

As with bone and muscle samples, concentrations of metals in deer liver samples were low and difficult to interpret without background samples for comparison (Table 5.16).

\section{Rabbits}

\section{Sample Collection and Analysis}

Rabbits have a small home range. They cannot be hunted for human consumption on the Hanford Site, and they cannot cross the Columbia River to areas where they could be hunted. However, rabbits are good indicators of potential exposure to contamination because they occupy burrows and can enter fenced restricted areas. Rabbit populations are cyclic and attempts to collect rabbits onsite in 1993 were only marginally successful (16 planned, 3 collected). Muscle, bone, and liver samples were taken from three jackrabbits collected from the 200 Areas and analyzed for radionuclide contaminants. Background samples of jackrabbits and cottontails were collected at Boardman, Oregon, in 1990.

\section{Results}

Muscle. Cesium-137 was measured in muscle from all three jackrabbits collected in 1993 (Table 5.16). Concentrations were roughly 10 times lower than maximum concentrations measured over the past 5 years (Table 5.17). However, concentrations were within the range measured in the past 5 years.

Bone. Strontium- 90 was found in all three rabbit bone samples at levels similar to concentrations observed previously (Table 5.18). The maximum concentration of $8.06 \mathrm{pCi} / \mathrm{g}$ indicates onsite exposure to low levels of ${ }^{90} \mathrm{Sr}$ in the 200-East Area.

Liver. No isotopes of plutonium were found above detection limits in liver samples from jackrabbits in 1993 $\left(<0.0004 \mathrm{pCi} / \mathrm{g}{ }^{239.240} \mathrm{Pu}\right.$ or ${ }^{238} \mathrm{Pu}$, see Table A.14).

\section{Ducks}

\section{Sample Collection and Analysis}

Resident mallard ducks were collected at B Pond in August 1993, and muscle tissues were analyzed for gamma emitters and ${ }^{90} \mathrm{Sr}$. Efforts to collect migratory ducks in November were unsuccessful because construction activities around B Pond inhibited ducks from using the pond. Sampling was also planned at West Lake, but water levels were low and duck collections were unsuccessful there. Background samples of mallard ducks were collected in 1992 near Vantage, Washington. In 1993, muscle was the only duck tissue monitored for radionuclide contamination.

\section{Results}

Cesium-137 was detected in the muscle of five of six mallard ducks sampled in August 1993 (Table 5.19). The muscle concentrations were comparable to those seen in previous collections of resident ducks and indicate a gradual reduction in tissue concentrations over the past 5 years (Figure 5.29). The mean concentration of ${ }^{137} \mathrm{Cs}$ in muscle was $0.3 \pm 90 \% \mathrm{pCi} / \mathrm{g}$ and was significantly higher than the background mean found in mallards collected near Vantage in $1992(0.004 \pm 160 \%)$. No other radionuclides were found above detection limits.

\section{Goose Egg Shells}

\section{Sample Collection and Analysis}

Because ${ }^{90} \mathrm{Sr}$ behaves similarly to calcium in the environment, goose egg shells have been monitored in the past for ${ }^{90} \mathrm{Sr}$ as an indicator of movement of ${ }^{90} \mathrm{Sr}$ in the environment (Rickard and Price 1990). In 1993, goose egg shells were collected from several islands in the Hanford Reach between the 100-D and 100-F Areas in conjunction with other wildlife monitoring. Background concentrations of ${ }^{90} \mathrm{Sr}$ in goose egg shells will be determined in 1995. 
Table 5.17. Summary of Cesium-137 ( $\left.{ }^{137} \mathrm{Cs}\right)$ in Rabbit Muscle (pCi/g wet), 1993 Compared to Values from the Previous 5 Years

\begin{tabular}{|c|c|c|c|c|c|c|}
\hline \multirow[b]{2}{*}{ Location/Species } & \multicolumn{3}{|c|}{1993} & \multicolumn{3}{|c|}{ 1988-1992 } \\
\hline & Maximum $^{(a)}$ & Mean $^{(b)}$ & $\begin{array}{c}\text { No. } \\
\text { Less Than } \\
\text { Detection }^{(\mathrm{c})} \\
\end{array}$ & Maximum $^{(\mathrm{a})}$ & Mean $^{(\mathbf{b})}$ & $\begin{array}{c}\text { No. } \\
\text { Less Than } \\
\text { Detection }^{(\mathrm{c})}\end{array}$ \\
\hline $\begin{array}{l}\text { 200-East Area/ } \\
\text { jackrabbit }\end{array}$ & $0.04 \pm 30 \%$ & --- & 0 of 2 & $0.25 \pm 20 \%$ & $0.03 \pm 400 \%$ & 10 of 16 \\
\hline $\begin{array}{l}\text { 200-West Area/ } \\
\text { jackrabbit }\end{array}$ & $0.01 \pm 80 \%$ & -- & 0 of 1 & $0.15 \pm 20 \%$ & $0.03 \pm 340 \%$ & 7 of 12 \\
\hline $\begin{array}{c}\text { Boardman }^{(\mathrm{d})} / \\
\text { jackrabbit } \\
\text { cottontail }\end{array}$ & --- & --- & --- & $\begin{array}{l}0.03 \pm 70 \% \\
0.03 \pm 130 \%\end{array}$ & $\begin{array}{l}0.005 \pm 200 \% \\
0.006 \pm 150 \%\end{array}$ & $\begin{array}{r}9 \text { of } 10 \\
10 \text { of } 10\end{array}$ \\
\hline
\end{tabular}

(a) Maximum is the concentration in $\mathrm{pCi} / \mathrm{g} \pm 2$ sigma counting error as a percentage.

(b) Mean is $\mathrm{pCi} / \mathrm{g} \pm 2$ standard error as a percentage.

(c) Number of samples with values less than the detection limit out of number of samples analyzed.

(d) Collected in 1990.

Table 5.18. Summary of Strontium-90 $\left({ }^{90} \mathrm{Sr}\right)$ in Rabbit Bone (pCi/g wet), 1993 Compared to Values from the Previous 5 Years

(a)

Location/Species

$\underline{\text { Maximum }^{(a)}}$

$8.06 \pm 3 \%$

$---$

0 of 1

$--\quad 0$ of 2

200-West Area/

jackrabbit

$$
0.012 \pm 30 \%
$$

$-$

$---$

No.

Less Than

Boardman $^{(\mathrm{d}) /}$

jackrabbit

cottontail

--
1993

$49 \pm 20 \%$

$11 \pm 60 \%$

0 of 16

Mean $^{(b)} \quad$ Detection ${ }^{(c)}$

$140 \pm 3 \%$

$14 \pm 590 \%$

0 of 12

1988-1992

No.

Less Than

$\underline{\text { Maximum }^{(a)}}$ Mean $^{(b)} \quad$ Detection $^{(\mathbf{c})}$

$--\quad 0.91 \pm 10 \%$

$0.36 \pm 20 \%$

$0.47 \pm 20 \%$

0 of 10

$0.27 \pm 10 \%$

0 of 10

(a) Maximum is the concentration in $\mathrm{pCi} / \mathrm{g} \pm 2$ sigma analytical propagated error as a percentage.

(b) Mean is $\mathrm{pCi} / \mathrm{g} \pm 2$ standard error as a percentage.

(c) Number of samples with values less than the detection limit out of number of samples analyzed.

(d) Collected in 1990. 
Table 5.19. Summary of Cesium-137 ( $\left.{ }^{137} \mathrm{Cs}\right)$ in Duck Muscle (pCi/g wet weight), 1993 Compared to Values from the Previous 5 Years

1993

Maximum $^{(\mathbf{a})} \quad$ Mean $^{(\mathrm{b})} \quad$\begin{tabular}{c}
$\begin{array}{c}\text { No. } \\
\text { Less Than } \\
\text { Detection }^{(\mathrm{c})}\end{array}$ \\
\hline
\end{tabular}

Location

B Pond

Vantage $^{(\mathrm{d})}$
$0.94 \pm 10 \%$

$0.33 \pm 90 \%$

1 of 6

\begin{tabular}{|c|c|c|}
\hline \multicolumn{3}{|c|}{ 1988-1992 } \\
\hline Maximum $^{(a)}$ & Mean $^{(\mathrm{b})}$ & $\begin{array}{c}\text { No. } \\
\text { Less Than } \\
\text { Detection }^{(\mathrm{c})}\end{array}$ \\
\hline $4.1 \pm 10 \%$ & $0.82 \pm 30 \%$ & 11 of 64 \\
\hline $0.03 \pm 40 \%$ & $0.004 \pm 160 \%$ & 7 of 9 \\
\hline
\end{tabular}

(a) Maximum is the concentration in $\mathrm{pCi} / \mathrm{g} \pm 2$ sigma analytical propagated error, expressed as a percentage.

(b) Mean is $\mathrm{pCi} / \mathrm{g} \pm 2$ standard error, expressed as a percentage.

(c) Number of samples with values less than the detection limit out of number of samples analyzed.

(d) Collected in 1992.

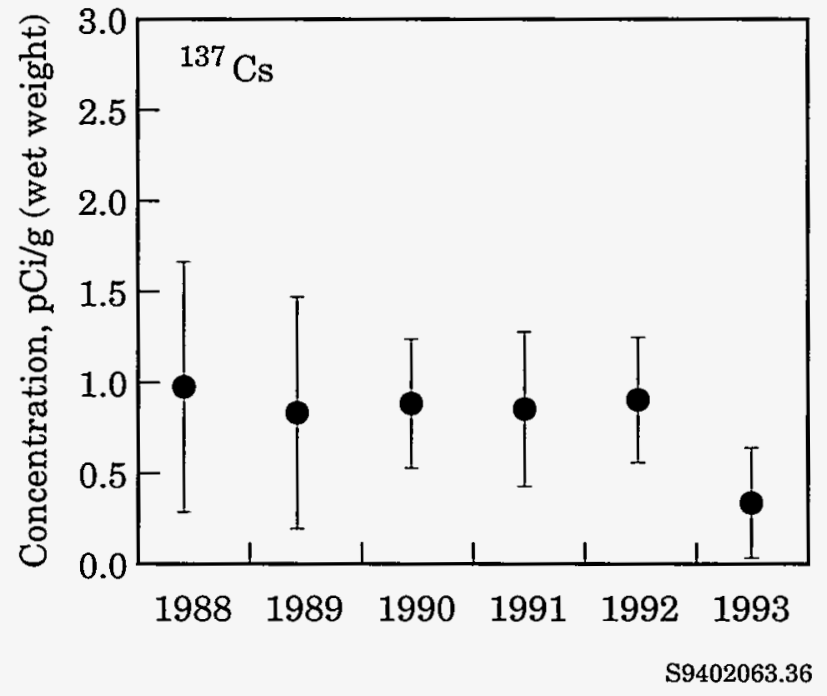

Figure 5.29. Concentrations ( \pm 2 SEM) of Cesium-137 $\left({ }^{137} \mathrm{Cs}\right)$ in Muscle Samples from Resident Ducks from B Pond, 1988 Through 1993

\section{Results}

Concentrations of ${ }^{90} \mathrm{Sr}$ in goose egg shells sampled in 1993 are similar to results from the previous 5 years and suggest that concentrations fluctuate around $1.0 \mathrm{pCi} / \mathrm{g}$
(Table 5.20). The only other available data on ${ }^{90} \mathrm{Sr}$ in waterfowl egg shells are for coots (Poston et al. 1991). Strontium-90 levels in coot egg shells collected at West Lake were about $5 \mathrm{pCi} / \mathrm{g}$. Concentrations in egg shells collected from Morgan Lake, Washington $[8 \mathrm{~km}(5 \mathrm{mi})$ northwest of Othello], were around $0.1 \mathrm{pCi} / \mathrm{g}$. These coot egg shell background concentrations may indicate that concentrations in Hanford Reach goose egg shells may be elevated slightly; however, differences in feeding habits may also affect ${ }^{90} \mathrm{Sr}$ concentrations in egg shells of different species.

Table 5.20. Concentrations of Strontium-90 $\left({ }^{90} \mathrm{Sr}\right)$ in Goose Egg Shells, Selected Years

\begin{tabular}{|c|c|c|}
\hline Year & Concentration $^{(\mathbf{a})}$ & $\begin{array}{l}\text { No. of } \\
\text { Samples }\end{array}$ \\
\hline 1987 & $1.26 \pm 17 \%$ & 15 \\
\hline 1988 & $0.84 \pm 18 \%$ & 51 \\
\hline 1991 & $1.01 \pm 34 \%$ & 17 \\
\hline 1992 & $0.61 \pm 44 \%$ & 11 \\
\hline 1993 & $0.92 \pm 16 \%$ & 13 \\
\hline
\end{tabular}

(a) Concentrations ( $\mathrm{pCi} / \mathrm{g}$ ) are means $\pm 2 \mathrm{SEM}$, expressed as a percentage. 


\section{Pheasants}

\section{Sample Collection and Analysis}

During the fall of 1993, four Chinese ringnecked pheasants were collected between the 100-D and 100-F Areas on the Hanford Site. This game bird has the potential to migrate across the Columbia River or move onto river islands where they may be hunted. Conversely, hunting pressure in Franklin County may force pheasants onto the Hanford Site. Samples of muscle were analyzed for gamma emitters, and bone samples were analyzed for ${ }^{90} \mathrm{Sr}$. For comparison, background pheasant samples were collected in 1991 from the Yakima Valley.

\section{Results}

Muscle. Cesium-137 was measured in three of four pheasants collected in 1993 (Table 5.20). The maximum concentration was comparable to maximum concentrations measured in background pheasant muscle collected in Yakima County in 1991. In both cases, values were at or below the minimum detectable concentration $(0.02 \mathrm{pCi} / \mathrm{g})$.

Bone. Measurements of ${ }^{90} \mathrm{Sr}$ in pheasant bone ranged from $0.09 \pm 50 \%$ to $0.21 \pm 50 \% \mathrm{pCi} / \mathrm{g}$ (see Bisping 1994).
These concentrations do not indicate any onsite exposure and are similar to the higher levels reported for background pheasant bone samples collected in 1991 from the Yakima Valley.

\section{Chukars}

\section{Sample Collection and Analysis}

Six chukar samples were collected near West Lake in September 1993. Muscle and bone samples were taken from each bird and analyzed for radioactive contaminants. Three samples of muscle were composited, as were three samples of bone (two birds for each composite sample). Chukar populations have small home ranges. They cannot be hunted on the Hanford Site, but are monitored to detect potential onsite exposure to, and movement of, contamination. No background samples for chukar are available.

\section{Results}

Muscle. Cesium-137 was detected in one of three composite chukar muscle samples $(0.01 \pm 60 \% \mathrm{pCi} / \mathrm{g}$; see Table 5.21). No other byproduct radionuclides were detected in chukar muscle.

Table 5.21. Summary of Cesium-137 ( $\left.{ }^{137} \mathrm{Cs}\right)$ in Upland Gamebird Muscle ( $\mathrm{pCi} / \mathrm{g}$ wet weight), $1993 \mathrm{Com}-$ pared to Values from the Previous 5 Years

\begin{tabular}{|c|c|c|c|c|c|c|}
\hline \multirow[b]{2}{*}{ Location } & \multicolumn{3}{|c|}{1993} & \multicolumn{3}{|c|}{$1988-1992$} \\
\hline & Maximum $^{(\mathrm{a})}$ & Mean $^{(\mathbf{b})}$ & $\begin{array}{c}\text { No. } \\
\text { Less Than } \\
\text { Detection }^{(c)}\end{array}$ & Maximum $^{(a)}$ & Mean $^{(b)}$ & $\begin{array}{r}\text { No. } \\
\text { Less T } \\
\text { Detecti }\end{array}$ \\
\hline \multicolumn{7}{|l|}{ Pheasants } \\
\hline $\begin{array}{l}100-\mathrm{D} \text { to } \\
100-\mathrm{F} \text { Areas }\end{array}$ & $0.01 \pm 60 \%$ & $0.01 \pm 20 \%$ & 1 of 4 & $0.02 \pm 60 \%$ & $0.007 \pm 80 \%$ & 20 of \\
\hline Yakima County(d) & -- & -- & --- & $0.007 \pm 180 \%$ & $0.001 \pm 680 \%$ & 10 of \\
\hline \multicolumn{7}{|l|}{ Chukar } \\
\hline West Lake & $0.01 \pm 60 \%$ & $0.01 \pm 100 \%$ & 2 of 3 & --- & --- & \\
\hline
\end{tabular}


Bone. The mean ${ }^{90} \mathrm{Sr}$ level in composite bone samples was $0.19 \pm 50 \% \mathrm{pCi} / \mathrm{g}$. For comparison, samples of pheasant bone collected in 1990 from a background location had a mean concentration of $0.06 \pm 30 \% \mathrm{pCi} / \mathrm{g}$. This difference suggests that the concentrations in the onsite chukar bone samples were elevated. The onsite chukar population had access to West Lake, an onsite seep pond north of the 200-East Area that contains elevated levels of ${ }^{90} \mathrm{Sr}$ in water and sediment (Poston et al. 1991).

\section{Pigeons}

\section{Sample Collection and Analysis}

Pigeon and pigeon feces were collected from the 200-East Area as part of a special study to evaluate pigeons as monitors of environmental pollution. Muscle samples were analyzed for trace metals, and bone was analyzed for ${ }^{90} \mathrm{Sr}$. There was inadequate mass to analyze for gamma-emitting radionuclides in pigeon muscle. A feces sample was analyzed for gamma emitters, ${ }^{90} \mathrm{Sr}$, and metals.

\section{Results}

There was no indication of metal accumulation in pigeon muscle; however, background levels have to be determined before tissue concentrations can be assessed. High concentrations of zinc in the feces sample may indicate that the bird was drinking or feeding from galvanized containers on farms adjacent to the Site (Table 5.16).

There was no indication of elevated concentrations of ${ }^{90} \mathrm{Sr}$ in pigeon bone. Concentrations in both samples were less than detection $(\leq 0.02 \mathrm{pCi} / \mathrm{g})$.

There was no indication of elevated concentrations of ${ }^{90} \mathrm{Sr}$ in the pigeon feces sample; however, the ${ }^{137} \mathrm{Cs}$ level was noteworthy $(0.27 \pm 20 \% \mathrm{pCi} / \mathrm{g})$. 


\title{
5.6 Soil and Vegetation Surveillance
}

\author{
E. J. Antonio
}

Soil is a valuable environmental monitoring medium because it can accumulate contaminants from both current air emissions and the resuspension of previously deposited material. Hence, soil sampling and analysis evaluates the long-term trends and estimates environmental radionuclide inventories (DOE 1991a). In 1993, 36 surface soil samples were taken to evaluate potential radiological impacts from Hanford operations. Nineteen of the 36 samples were collected within the Hanford Site boundary, 14 from locations near the Hanford Site perimeter, two from distant locations, and one from the nearby community of Benton City.

Vegetation surveillance is conducted to monitor atmospheric deposition of radioactive materials in offsite areas not under cultivation and onsite at locations adjacent to potential sources of environmental radioactivity. Thirteen perennial vegetation samples were obtained during 1993, six from onsite locations, two at distant locations, and five from perimeter locations (Figure 5.30). The objectives behind soil and vegetation analyses were to monitor accumulation of radionuclides released from Hanford facilities, compare current data with previous years' data to determine long-term trends, and add to the existing database of radionuclide concentrations in soils and vegetation both on and off the Hanford Site.

Radiological contributions from Hanford operations were assessed by comparing results from samples taken 1) onsite with those collected offsite, 2) around the Site perimeter with those collected at distant locations, and 3) at upwind perimeter locations with samples taken at downwind perimeter locations. Results obtained in 1993 were also compared to results from previous years.

\section{Sample Collection and Analysis}

Soil and vegetation samples were collected at locations shown in Figure 5.30 and summarized in Table 5.22.
Onsite soil sampling was concentrated around operational areas. One sample taken from south of the 300 Area originally had the location designation of "Offsite." This sample was reclassified for this report as a "perimeter" location and is included in statistical analyses as such. Soil samples designated as perimeter were taken from areas near the Site boundary or well away from operational areas. Perimeter locations were divided into two subgroups, upwind and downwind. Downwind perimeter locations (Ringold, Fir Road, Taylor Flats, Sagemoor area, Byers Landing, Riverview, and south of the 300 Area) are areas where the maximum effects from stack emissions would be expected to be found offsite. Upwind perimeter locations (Berg Ranch, Wahluke Slope, Vernita Bridge, Yakima Barricade, Rattlesnake Springs, Prosser Barricade, and Fitzner/ Eberhardt ALE Reserve) are sampled once every 3 years, and are not expected to be heavily influenced by Hanford releases to the air. Each soil sample is a composite of five plugs, collected within $10 \mathrm{~m}(33 \mathrm{ft})$ of one another, that measure $2.54 \mathrm{~cm}$ deep by $10.2 \mathrm{~cm}$ in diameter ( $1 \mathrm{in}$. by 4 in.) each.

Perennial vegetation samples consisted of new growth from shrub-steppe species, rabbitbush (Chrysothamnus) and sagebrush (Artemesia). Vegetation samples were collected from the same general areas as the soil samples.

\section{Results for Soil}

The radionuclides detected most consistently (greater than $50 \%$ of the time) in soil samples were ${ }^{7} \mathrm{Be},{ }^{40} \mathrm{~K},{ }^{90} \mathrm{Sr}$, ${ }^{137} \mathrm{Cs},{ }^{238} \mathrm{U},{ }^{239,240} \mathrm{Pu}$, and ${ }^{241} \mathrm{Am}$. Beryllium-7 is a naturally occurring, cosmogenic radionuclide with a half-life of 53 days and is not considered to be of Hanford origin. Potassium- 40 is a naturally occurring, primordial radionuclide with a half-life longer than one billion years and is not considered to be of Hanford origin. Strontium-90 and ${ }^{137} \mathrm{Cs}$ are both fission products and have half-lives of 28.8 years and 30 years, respectively; these radionuclides may be of Hanford origin or from 


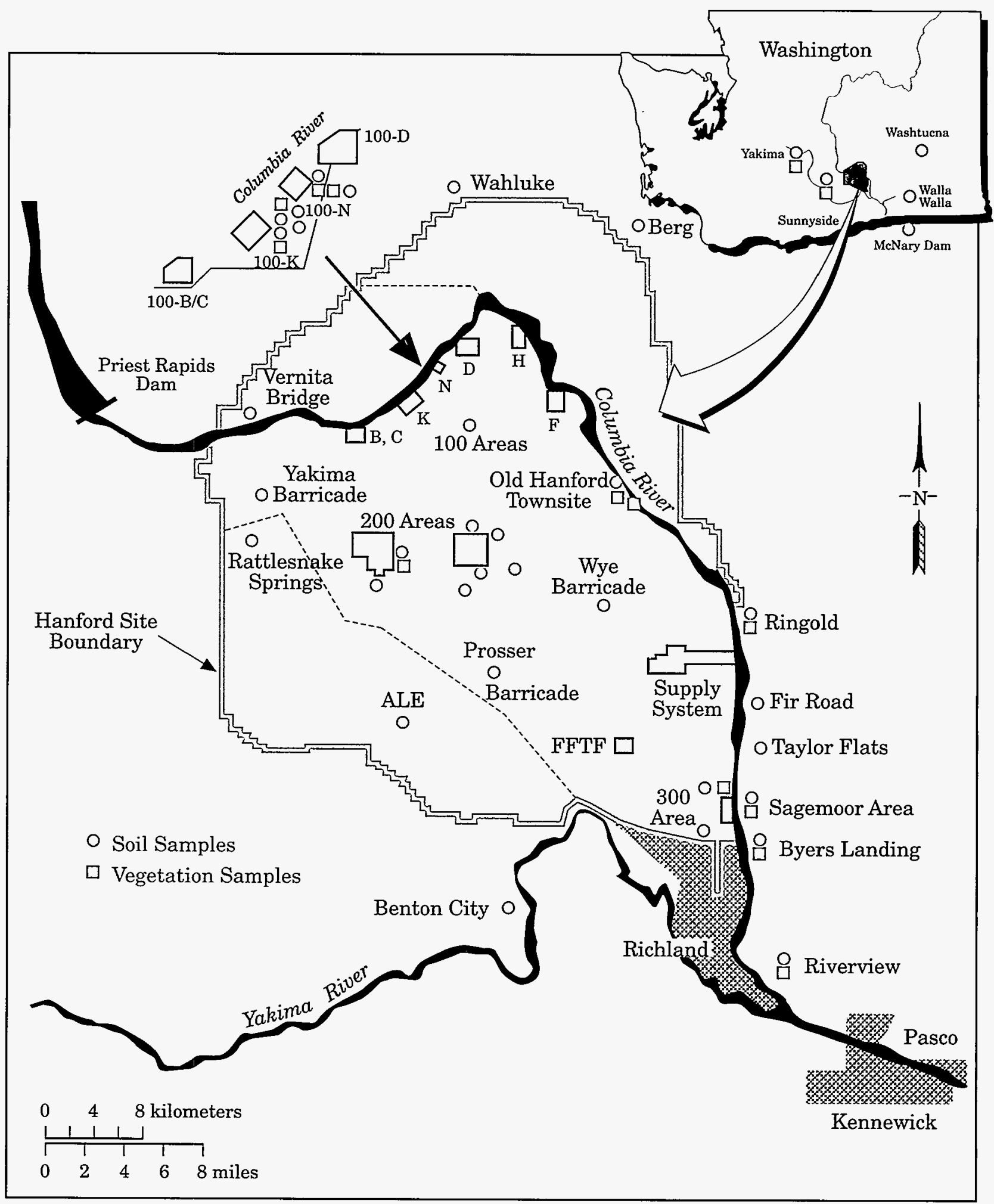

S9402063.92

Figure 5.30. Soil and Vegetation Sampling Locations, 1993 
Table 5.22. Soil and Vegetation Samples Collected, 1993

\begin{tabular}{|c|c|c|c|}
\hline General Location & $\begin{array}{c}\text { No. of } \\
\text { Samples }\end{array}$ & Frequency & Analytes \\
\hline \multicolumn{4}{|l|}{ Soil } \\
\hline Onsite & 19 & Annual to once every 3 years & $\mathrm{Gamma},{ }^{90} \mathrm{Sr}, U{ }_{\mathrm{LEP}}^{(a)}, \mathrm{Pu}^{(b)},{ }^{241} \mathrm{Am}$ \\
\hline Community & 1 & Once every 3 years & Gamma, ${ }^{90} \mathrm{Sr}, \mathrm{U}_{\mathrm{IFPS}}, \mathrm{Pu}$ \\
\hline Distant & 2 & Annual & Gamma, ${ }^{90} \mathrm{Sr}, \mathrm{U}^{\mathrm{LPP}}, \mathrm{Pu},{ }^{241} \mathrm{Am}$ \\
\hline Downwind Perimeter & 7 & Annual to once every 3 years & Gamma, ${ }^{90} \mathrm{Sr}, \mathrm{U}_{\mathrm{LFPS}}, \mathrm{Pu},{ }^{241} \mathrm{Am}$ \\
\hline Upwind Perimeter & 7 & Once every 3 years & Gamma, ${ }^{90} \mathrm{Sr}, \mathrm{U}_{\mathrm{IFPS}}, \mathrm{Pu}$ \\
\hline
\end{tabular}

\section{Vegetation}

$\begin{array}{lll}\text { Onsite } & 6 & \text { Annual to once every } 3 \text { years } \\ \text { Distant } & 2 & \text { Annual } \\ \text { Perimeter } & 5 & \text { Annual }\end{array}$

Gamma, ${ }^{90} \mathrm{Sr}, \mathrm{U}_{\text {iso }}{ }^{\text {(c) }}, \mathrm{Pu}$
Gamma, ${ }^{90} \mathrm{Sr}, \mathrm{U}_{\text {iss }}, \mathrm{Pu}$
Gamma, ${ }^{90} \mathrm{Sr}, \mathrm{U}_{\text {iso }}, \mathrm{Pu}$

(a) $U_{\text {LEPS }}$ is a method of analyzing for uranium by detecting low-energy photons.

(b) Isotopic plutonium.

(c) $\mathrm{U}_{\text {iso }}$ is a method of analyzing for uranium by detecting alpha particles.

atmospheric fallout. Uranium-238 is also a naturally occurring, primordial radionuclide having a half-life of 4.51 billion years and is naturally found in soils on and off the Hanford Site; however, ${ }^{238} \mathrm{U}$ is also a product of the PUREX Plant and, therefore, may be of Hanford origin. Plutonium isotopes in soils near the Hanford Site may be from historical Hanford operations or may be the result of atmospheric fallout. Americium-241 in soils on and off the Hanford Site may also be from historical Hanford operations or the result of fallout.

Radionuclide concentrations in soil are reported in Table 5.23 and Appendix A, Tables A.16 through A.19. Concentrations are shown in Figures 5.31 and 5.32. Nonparametric statistical methods were used to detect differences between locations. The Multi-Response Permutation Procedure (Mielke 1984) calculates the probability that the data sets are similar and represents that likelihood with a $\mathrm{p}$ value. A $\mathrm{p}$ value greater than or equal to 0.1 indicates the data sets are similar; a $p$ value of less than 0.1 suggests that they are not similar.

Statistical analyses indicated no significant differences between the onsite and offsite concentrations of ${ }^{137} \mathrm{Cs}$, ${ }^{238} \mathrm{U}$, and ${ }^{239.240} \mathrm{Pu}$ ( $\mathrm{p}$ values were $0.147,0.129$, and 0.188 , respectively). There was, however, a statistical difference between the onsite and offsite ${ }^{9} \mathrm{Sr}$ concentrations ( $p$ value $=0.0611$ ). The onsite data set had a higher median concentration $(0.116 \mathrm{pCi} / \mathrm{g})$ than the offsite data set $(0.0874 \mathrm{pCi} / \mathrm{g})$.

When the offsite data were split into "distant" and "perimeter" groupings (the onsite and community locations' data were not included in the analyses), no significant differences were detected in the isotopes mentioned above. P values for ${ }^{90} \mathrm{Sr},{ }^{137} \mathrm{Cs},{ }^{238} \mathrm{U}$, and ${ }^{239,240} \mathrm{Pu}$ were $0.175,0.133,0.325$, and 0.967 , respectively.

The 14 perimeter locations were further subdivided into seven "upwind" and seven "downwind" locations. Concentrations of ${ }^{90} \mathrm{Sr},{ }^{137} \mathrm{Cs},{ }^{238} \mathrm{U}$, and ${ }^{239.240} \mathrm{Pu}$ from the two designations were analyzed statistically. No significant differences were identified for ${ }^{137} \mathrm{Cs},{ }^{238} \mathrm{U}$, and ${ }^{239.240} \mathrm{Pu}$ ( $\mathrm{p}$ values were $0.333,0.189$, and 0.315 , respectively). Strontium- 90 concentrations were significantly different ( $\mathrm{p}$ value $=0.0245$ ), with the upwind perimeter locations having a higher median concentration $(0.0954 \mathrm{pCi} / \mathrm{g})$ than the downwind locations $(0.0595 \mathrm{pCi} / \mathrm{g})$. 
Table 5.23. Radionuclide Concentrations in Soil Samples Collected on and off the Hanford Site (units are pCi/g dry weight), 1993 Compared to Values from the Previous 5 Years

\begin{tabular}{|c|c|c|c|c|c|c|c|}
\hline \multirow[b]{2}{*}{ Location } & \multirow[b]{2}{*}{$\begin{array}{l}\text { Radio- } \\
\text { nuclide }\end{array}$} & \multicolumn{3}{|c|}{1993} & \multicolumn{3}{|c|}{$1988-1992$} \\
\hline & & $\begin{array}{l}\text { No. of } \\
\text { Samples }\end{array}$ & Maximum $^{(a)}$ & Mean $^{(b)}$ & $\begin{array}{l}\text { No. of } \\
\text { Samples }\end{array}$ & Maximum $^{(c)}$ & Mean $^{(d)}$ \\
\hline \multirow[t]{5}{*}{ Onsite } & ${ }^{90} \mathrm{Sr}$ & 19 & $0.58 \pm 3 \%$ & $0.17 \pm 41 \%$ & 51 & $2.7 \pm 3 \%$ & $0.32 \pm 40 \%$ \\
\hline & ${ }^{137} \mathrm{Cs}$ & 19 & $10.9 \pm 1 \%$ & $1.1 \pm 97 \%$ & 51 & $26 \pm 1 \%$ & $1.8 \pm 67 \%$ \\
\hline & ${ }^{238} U_{\text {LEPS }}{ }^{(e)}$ & 19 & $1.5 \pm 17 \%$ & $0.61 \pm 22 \%$ & 34 & $1.3 \pm 30 \%$ & $0.71 \pm 12 \%$ \\
\hline & ${ }^{238} \mathrm{U}^{\mathrm{LEPS}}{ }^{(\mathrm{S})}$ & 0 & --- & --- & 12 & $0.71 \pm 1 \%$ & $0.069 \pm 70 \%$ \\
\hline & ${ }^{2392400} \mathrm{Pu}$ & 19 & $0.28 \pm 2 \%$ & $0.026 \pm 113 \%$ & 51 & $1.0 \pm 10 \%$ & $0.71 \pm 10 \%$ \\
\hline \multirow[t]{5}{*}{ Perimeter } & ${ }^{90} \mathrm{Sr}$ & 13 & $0.14 \pm 8 \%$ & $0.075 \pm 25 \%$ & 44 & $0.34 \pm 4 \%$ & $0.14 \pm 18 \%$ \\
\hline & ${ }^{137} \mathrm{Cs}$ & 13 & $0.62 \pm 6 \%$ & $0.32 \pm 32 \%$ & 44 & $1.8 \pm 6 \%$ & $0.64 \pm 21 \%$ \\
\hline & ${ }^{238} U_{\text {LEPS }}$ & 13 & $1.1 \pm 44 \%$ & $0.68 \pm 24 \%$ & 32 & $1.5 \pm 21 \%$ & $0.77 \pm 10 \%$ \\
\hline & ${ }^{238} \mathrm{U}_{\mathrm{U}}^{\mathrm{LFT} 3}$ & 0 & --- & --- & 15 & $0.91 \pm 9 \%$ & $0.74 \pm 7 \%$ \\
\hline & ${ }^{239240} \mathrm{Pu}$ & 13 & $0.013 \pm 11 \%$ & $0.0073 \pm 30 \%$ & 44 & $0.033 \pm 7 \%$ & $0.013 \pm 20 \%$ \\
\hline \multirow[t]{5}{*}{ Distant } & ${ }^{90} \mathrm{Sr}$ & 2 & $0.24 \pm 45 \%$ & $0.17 \pm 82 \%$ & 24 & $0.35 \pm 4 \%$ & $0.11 \pm 34 \%$ \\
\hline & ${ }^{137} \mathrm{Cs}$ & 2 & $0.74 \pm 5 \%$ & $0.61 \pm 42 \%$ & 24 & $1.2 \pm 5 \%$ & $0.47 \pm 30 \%$ \\
\hline & ${ }^{238} \mathrm{U}_{\text {LEPS }}$ & 2 & $0.73 \pm 43 \%$ & $0.70 \pm 10 \%$ & 15 & $1.3 \pm 20 \%$ & $0.71 \pm 18 \%$ \\
\hline & ${ }^{238} \mathrm{U}_{\mathrm{iso}}^{\text {LES }}$ & 0 & -- & -- & 9 & $0.84 \pm 10 \%$ & $0.59 \pm 13 \%$ \\
\hline & 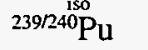 & 2 & $0.017 \pm 8 \%$ & $0.0094 \pm 157 \%$ & 24 & $0.029 \pm 11 \%$ & $0.0089 \pm 36 \%$ \\
\hline
\end{tabular}

(a) Maximum value \pm 2 sigma counting error expressed as a percentage of the maximum value.

(b) Mean value \pm 2 SEM expressed as a percentage of the mean value.

(c) Maximum value in previous 5 years \pm 2 SEM expressed as a percentage of the maximum value.

(d) Five-year mean value $\pm 2 \mathrm{SEM}$ expressed as a percentage of the mean value.

(e) ${ }^{238} U_{\text {LEPS }}$ is a method of analyzing for ${ }^{238} U$ by detecting low-energy photons.

(f) ${ }^{238} \mathrm{U}_{\text {iso }}$ is a method of analyzing for ${ }^{238} \mathrm{U}$ by detecting alpha particles.

Americium-241 was detected in five soil samples: at three onsite locations and at one perimeter, and one distant location. The onsite mean concentration was $0.014 \pm 0.024 \mathrm{pCi} / \mathrm{g}$. The ${ }^{241} \mathrm{Am}$ concentration in Sagemoor soil was $0.0030 \pm 0.0015 \mathrm{pCi} / \mathrm{g}$ and at Sunnyside was $0.0066 \pm 0.0023 \mathrm{pCi} / \mathrm{g}$. No statistical analyses were performed on these five data points.

Of the radionuclides measured, only ${ }^{90} \mathrm{Sr}$ showed a difference between onsite and offsite concentrations, with the onsite samples having a median concentration nearly twice that of the offsite samples.

\section{Results for Vegetation}

The five most consistently detected radionuclides associated with perennial vegetation during 1993 (and percent occurrence) were ${ }^{7} \mathrm{Be}(100 \%),{ }^{40} \mathrm{~K}(100 \%),{ }^{90} \mathrm{Sr}$ $(100 \%),{ }^{238} \mathrm{U}(54 \%)$, and ${ }^{239.240} \mathrm{Pu}(54 \%)$. Beryllium-7 and ${ }^{40} \mathrm{~K}$ are naturally occurring radionuclides and are not of Hanford origin. Strontium-90 is a fission product and may be of Hanford origin or from atmospheric fallout. Uranium-238 is a naturally occurring, primordial radionuclide and is naturally found in soils off the Hanford Site, ${ }^{238} \mathrm{U}$ is also a product of the PUREX Plant and therefore, may be of Hanford origin. Plutonium isotopes associated with perennial vegetation near the Hanford Site may be from historical Hanford operations or may be the result of atmospheric fallout. Historically, another radionuclide of interest has been ${ }^{137} \mathrm{Cs}$; it was positively identified in only $23 \%$ of the vegetation samples analyzed in 1993.

Radionuclide concentrations in vegetation are reported in Table 5.24 and are shown in Figure 5.33. No upwind/ downwind perimeter comparison was made because 

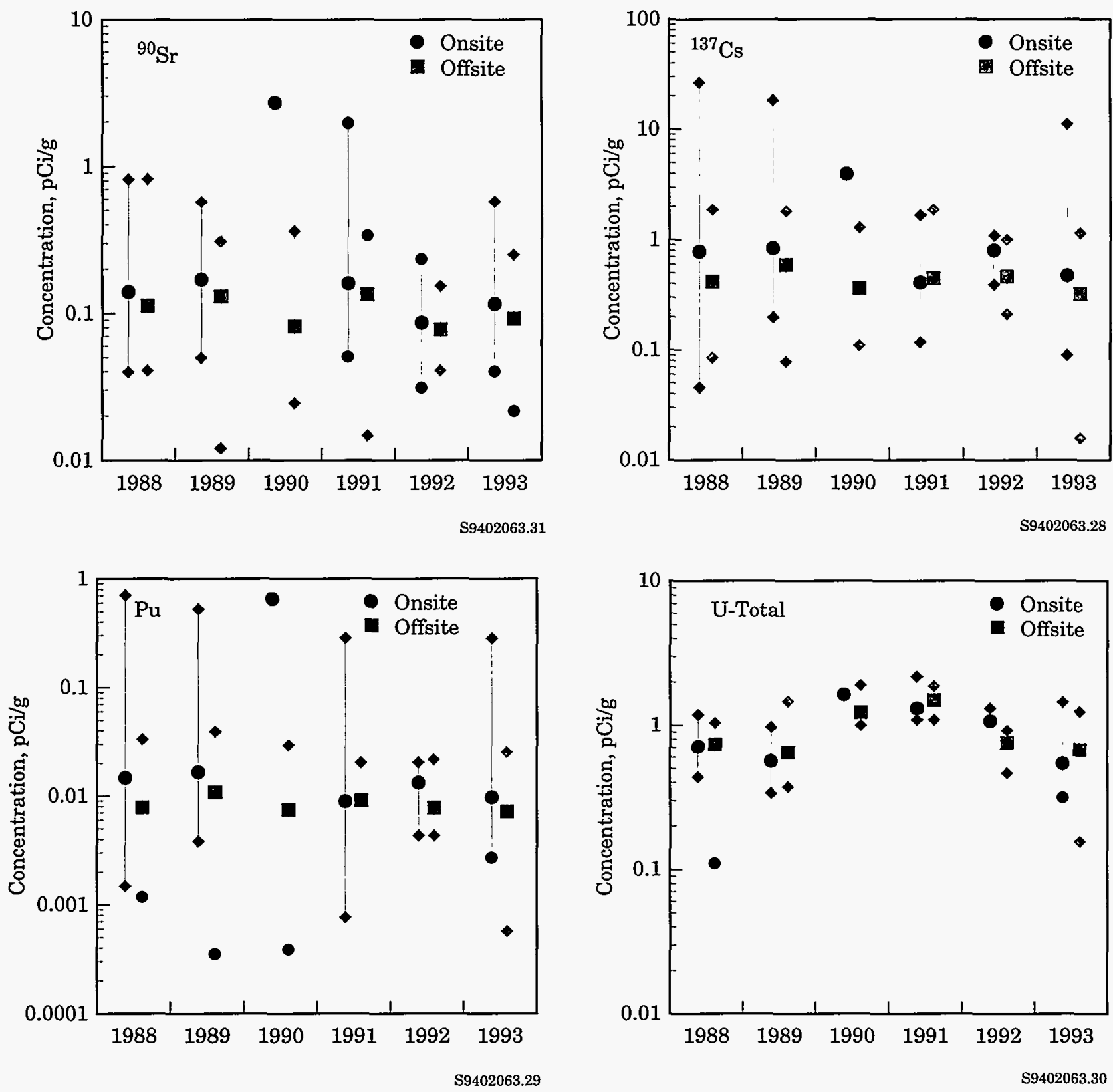

Figure 5.31. Selected Radionuclide Maximum, Median, and Minimum Concentrations in Soil (units are pCi/g dry weight), 1988 Through 1993. For the U-total graph, samples from 1988, 1989, 1992, and 1993 were analyzed by $U_{\text {LEPS }}$; onsite 1990 by $U_{\text {iso }}$ and offsite by $U_{\text {NAT }}$; and 1991 by $U_{\text {iso. }}$.

there were too few sampling locations for statistical analysis. Nonparametric statistical methods were used to detect differences between grouping categories, which were the same as those used in soil data comparisons.

Strontium-90 was identified in or on all perennial vegetation samples. There was no significant difference between the measured ${ }^{90} \mathrm{Sr}$ concentrations at perimeter locations and the distant locations $(p=0.19)$. These two categories were pooled, and the combined data were compared to the onsite ${ }^{90} \mathrm{Sr}$ concentration data. A difference was identified when comparing these groups $(p=0.014)$. Although graphically the results for the onsite and offsite groups overlap, indicating they are 

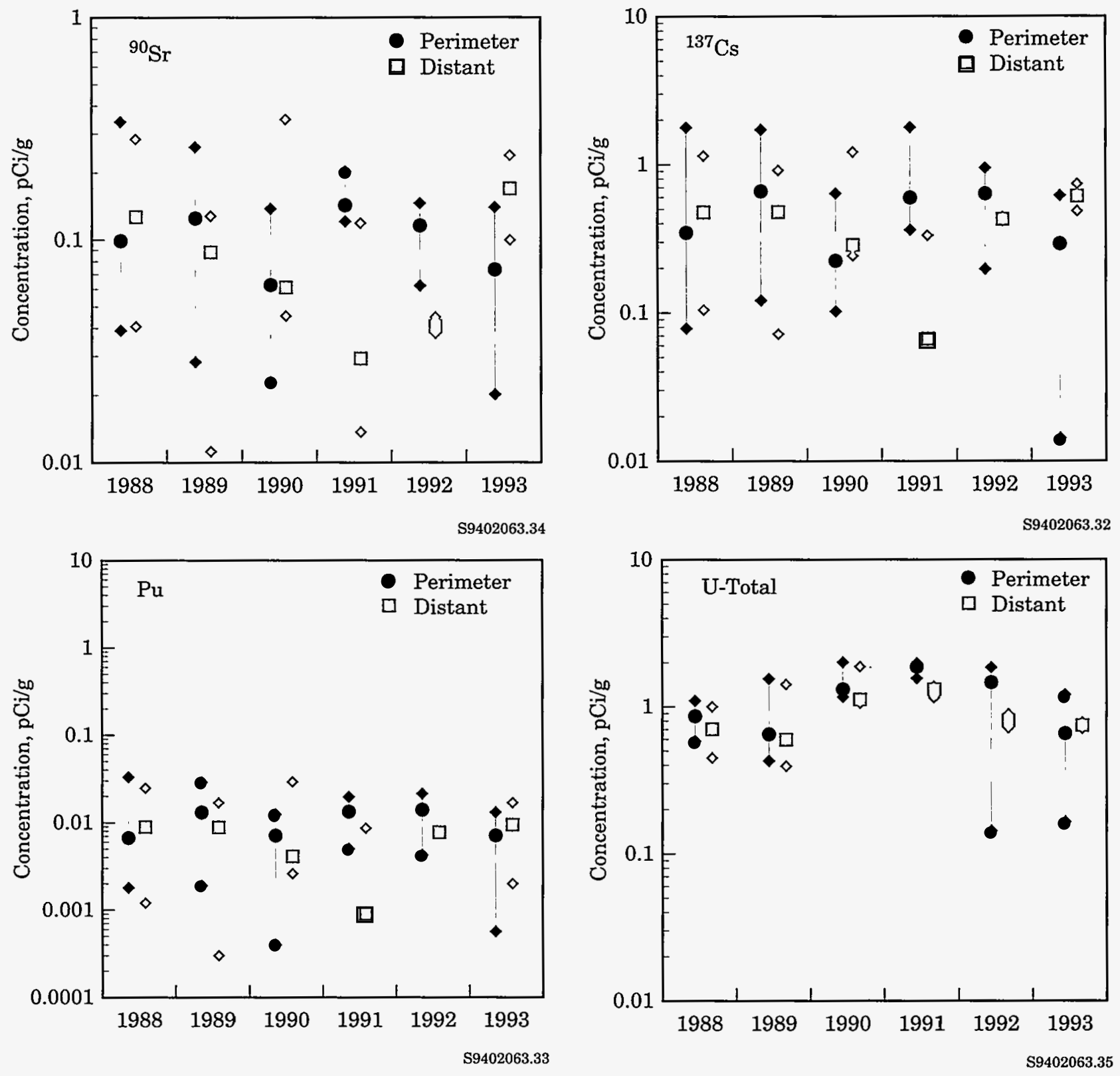

Figure 5.32. Selected Radionuclide Maximum, Median, and Minimum Concentrations in Soil at Perimeter and Distant Locations (units are $\mathrm{pCi} / \mathrm{g}$ (dry weight), 1988 Through 1993. As a result of figure scale, some values overlap.

similar, the Multi-Response Permutation Procedure indicated that they were indeed different, with the onsite vegetation samples having the higher maximum and median values.

Cesium-137 was identified in only $23 \%$ of the vegetation samples collected but is discussed here because of its historical interest. Statistical tests showed no significant difference between the concentrations measured at perimeter locations and those measured at distant locations $(p=1.00)$. The data for perimeter and distant locations were pooled and compared to onsite concentrations; no significant difference was found $(\mathrm{p}=0.94)$. 
Table 5.24. Radionuclide Concentrations in Vegetation Samples on and off the Hanford Site (units are $\mathrm{pCi} / \mathrm{g}$ dry weight), 1993 Compared to Values from the Previous 5 Years

\begin{tabular}{|c|c|c|c|c|c|c|c|}
\hline \multirow[b]{2}{*}{ Location } & \multirow[b]{2}{*}{$\begin{array}{l}\text { Radio- } \\
\text { nuclide }\end{array}$} & \multicolumn{3}{|c|}{1993} & \multicolumn{3}{|c|}{ 1988-1992 } \\
\hline & & $\begin{array}{c}\text { No. of } \\
\text { Samples }\end{array}$ & Maximum $^{(\mathrm{a})}$ & Mean $^{(\mathbf{b})}$ & $\begin{array}{c}\text { No. of } \\
\text { Samples }\end{array}$ & Maximum $^{(\mathbf{c})}$ & Mean $^{(d)}$ \\
\hline \multirow[t]{5}{*}{ Onsite } & ${ }^{90} \mathrm{Sr}$ & 6 & $2.2 \pm 2 \%$ & $0.45 \pm 157 \%$ & 46 & $0.41 \pm 5 \%$ & $0.092 \pm 28 \%$ \\
\hline & ${ }^{137} \mathrm{Cs}$ & 6 & $0.049 \pm 96 \%$ & $0.014 \pm 110 \%$ & 46 & $0.30 \pm 11 \%$ & $0.039 \pm 46 \%$ \\
\hline & $\mathrm{U}_{\mathrm{NAT}}{ }^{(e)}$ & 0 & -- & -- & 45 & 0.036 & $0.011 \pm 22 \%$ \\
\hline & $U_{i s o}^{N A}(f)$ & 6 & $0.0065 \pm 41 \%$ & $0.0023 \pm 79 \%$ & 1 & $0.0015 \pm 51 \%$ & \\
\hline & ${ }^{239,240} \mathrm{Pu}$ & 6 & $0.00068 \pm 40 \%$ & $0.00029 \pm 86 \%$ & 46 & 0.041 & $0.0016 \pm 113 \%$ \\
\hline \multirow[t]{5}{*}{ Perimeter } & ${ }^{90} \mathrm{Sr}$ & 5 & $0.016 \pm 30 \%$ & $0.012 \pm 18 \%$ & 46 & $0.36 \pm 4 \%$ & $0.06 \pm 32 \%$ \\
\hline & ${ }^{137} \mathrm{Cs}$ & 5 & $0.022 \pm 105 \%$ & $0.0045 \pm 361 \%$ & 46 & $0.045 \pm 60 \%$ & $0.01 \pm 38 \%$ \\
\hline & $U_{\mathrm{NAT}}$ & 0 & --- & --- & 46 & 0.06 & $0.016 \pm 25 \%$ \\
\hline & $U_{\text {iso }}^{\text {NAT }}$ & 5 & $0.0061 \pm 64 \%$ & $0.0034 \pm 64 \%$ & & & \\
\hline & ${ }^{239.240} \mathrm{Pu}$ & 5 & $0.00026 \pm 85 \%$ & $0.0002 \pm 18 \%$ & 46 & $0.00075 \pm 42 \%$ & $0.00019 \pm 24 \%$ \\
\hline \multirow[t]{5}{*}{ Distant } & ${ }^{90} \mathrm{Sr}$ & 2 & $0.016 \pm 25 \%$ & $0.015 \pm 11 \%$ & 22 & $0.74 \pm 3 \%$ & $0.066 \pm 99 \%$ \\
\hline & ${ }^{137} \mathrm{Cs}$ & 2 & $0.032 \pm 80 \%$ & $0.18 \pm 150 \%$ & 22 & $0.026 \pm 5 \%$ & $0.0097 \pm 41 \%$ \\
\hline & $\mathrm{U}_{\mathrm{NAT}}$ & 0 & --- & --- & 19 & 0.47 & $0.064 \pm 86 \%$ \\
\hline & $\mathrm{U}_{\text {iso }}$ & 2 & $0.0026 \pm 73 \%$ & $0.002 \pm 62 \%$ & 3 & $0.059 \pm 13 \%$ & $0.022 \pm 169 \%$ \\
\hline & ${ }^{239.240} \mathrm{Pu}$ & 2 & $0.00011 \pm 110 \%$ & $0.000074 \pm 92 \%$ & 22 & $0.0013 \pm 28 \%$ & $0.00032 \pm 46 \%$ \\
\hline
\end{tabular}

(a) Maximum value \pm 2 sigma counting error expressed as a percentage of the maximum value.

(b) Mean value \pm 2 SEM expressed as a percentage of the mean value.

(c) Maximum value in previous 5 years \pm 2 standard deviations expressed as a percentage of the maximum value.

(d) Five-year mean value \pm 2 SEM expressed as a percentage of the mean.

(e) $\mathrm{U}_{\mathrm{NAT}}$ is a chemical analysis and does not have counting error.

(f) $U_{\text {iso }}$ is a method of analyzing for ${ }^{238} \mathrm{U}$ by detecting alpha particles.

Uranium-238 concentrations in perennial vegetation from distant and perimeter locations were compared. No significant difference was identified $(p=0.43)$. No significant difference was found when comparing the combined concentrations from distant and perimeter locations to the onsite concentrations ( $p=0.67)$.

Plutonium-239, 240 concentrations in perennial vegetation from distant and perimeter locations were compared. No significant difference was identified $(p=0.48)$. No significant difference was found when comparing the combined concentrations from distant and perimeter locations to the onsite concentrations $(p=0.29)$. Based on the majority of these comparisons, ${ }^{90} \mathrm{Sr}$ excluded, no accumulation of radionuclides from Hanford airborne effluent was shown. Strontium- 90 was shown to be in higher concentrations in onsite soil and perennial vegetation than in offsite locations, which is consistent with results from previous years. The higher concentrations onsite are to be expected because sampling is primarily near operating areas. Radionuclide concentrations reported for soil and vegetation samples collected in 1993 remained low and near detection limits using state-of-the-art detection technologies. 

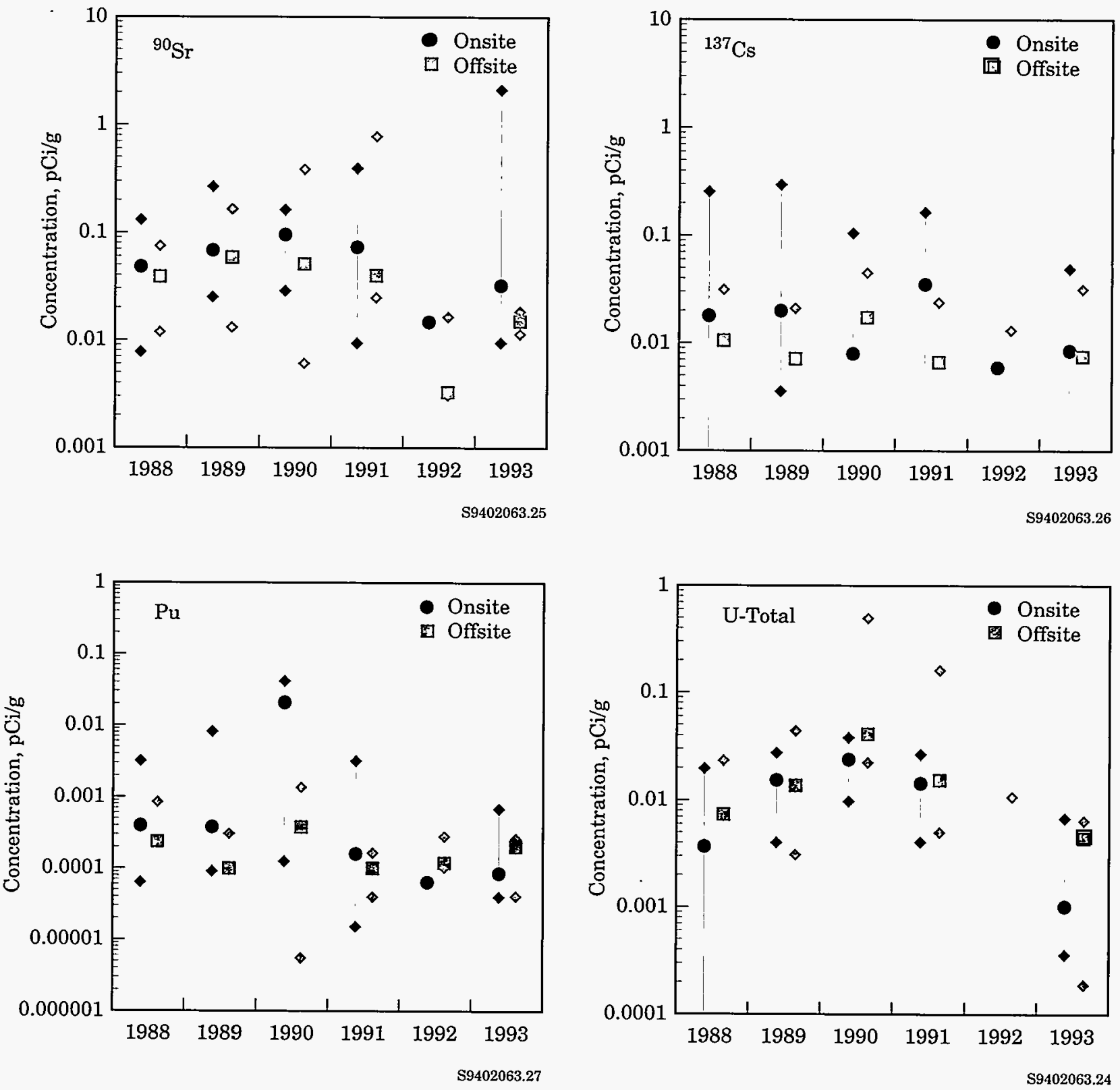

Figure 5.33. Selected Radionuclide Maximum, Median, and Minimum Concentrations in Vegetation (units are pCi/g dry weight), 1988 Through 1993. As a result of figure scale, some values overlap. 


\title{
5.7 External Radiation Surveillance
}

\author{
E. J. Antonio
}

External radiation is defined as radiation originating from a source outside the body. External radiation fields consist of a natural component and an artificial or human-made component. The natural component can be divided into 1) cosmic radiation, 2) primordial radionuclides in the earth's crust (primarily ${ }^{40} \mathrm{~K}$, ${ }^{232} \mathrm{Th}$, and ${ }^{238} \mathrm{U}$ ), and 3) an airborne component, primarily radon. The human-made component may be divided into nuclear medicine, nuclear power, nuclear research, nuclear waste management, and consumer products. Environmental radiation fields may be influenced by the presence of artificially produced radionuclides deposited as fallout from past atmospheric testing of nuclear weapons or those produced and released to the environment during the making or use of nuclear fuel. The interaction of radiation with matter results in energy being deposited in matter. The concept of radiation energy deposited in a mass of material is called radiation absorbed dose. A special unit called the rad was introduced for this concept in the early 1950s, and more recently, an International System (SI) unit called the gray (Gy) has been defined.

External radiation exposure rates were measured at locations on and off the Hanford Site using TLDs. External radiation and contamination surveys were also performed with portable radiation survey instruments at locations on and around the Hanford Site. This section describes how external radiation was measured, how surveys were performed, and the results of these measurements and surveys.

\section{External Radiation Measurements}

Thermoluminescence, or light output exhibited by TLDs, is proportional to the amount of radiation exposure (X) which is measured in units of roentgen ( $R$ ). The exposure is multiplied by a factor of 0.98 , to convert to a dose (D) in rad to soft tissue (USDHEW 1970). This conversion factor relating $\mathrm{R}$ to $\mathrm{rad}$ is, however, assumed to be unity (1) throughout this report for consistency with past reports. This dose is further modified by a quality factor, $\mathrm{Q}=1$ for beta and gamma radiation, and the product of all other modifying factors $(N)$. $N$ is assumed to be 1 to obtain dose equivalence $(\mathrm{H})$, measured in rem.

$$
\begin{aligned}
& D(\mathrm{rad})=X(\mathrm{R}) * 1.0 \\
& H(\mathrm{rem})=\mathrm{D} * \mathrm{~N} * \mathrm{Q}
\end{aligned}
$$

To convert to SI units of Gy and Sv, divide rad and rem by 100 , respectively.

An environmental TLD comprises three plastic cards that each hold four $\mathrm{LiF}$ (TLD 700) chips and one $\mathrm{CaF}_{2}$ :Dy (TLD 200) chip. The TLD is positioned $1 \mathrm{~m}(3.3 \mathrm{ft}$ ) above the ground at various locations both on and off the Hanford Site. The TLDs are collected and read quarterly, except for those at the 100-N Area shoreline, which are processed monthly. The 12 TLD 700 chips at each location are used to determine the average environmental dose at that location and that quantity is divided by the length of time the TLD was in the field to determine the average environmental dose rate. The three TLD 200 chips are included to determine doses in the event of a radiological emergency.

The TLDs are positioned at numerous locations onsite (Figure 5.34), around the Site perimeter, in nearby and distant communities, at community-operated environmental surveillance stations (Figure 5.35), and along the Hanford Reach of the Columbia River (Figure 5.36). All community and most of the onsite and perimeter locations are collocated with air monitoring stations. These locations were selected based on historical determinations of the highest potentials for public exposures (access areas, downwind population centers) from past and current Hanford operations.

Dose rates were also measured at three communityoperated stations located at Edwin Markham Elementary School north of Pasco, Basin City Elementary School in Basin City, and Leslie Groves Park in Richland. Each of these station is managed by local school teachers and measures dose rates using both TLDs and portable survey instruments. 


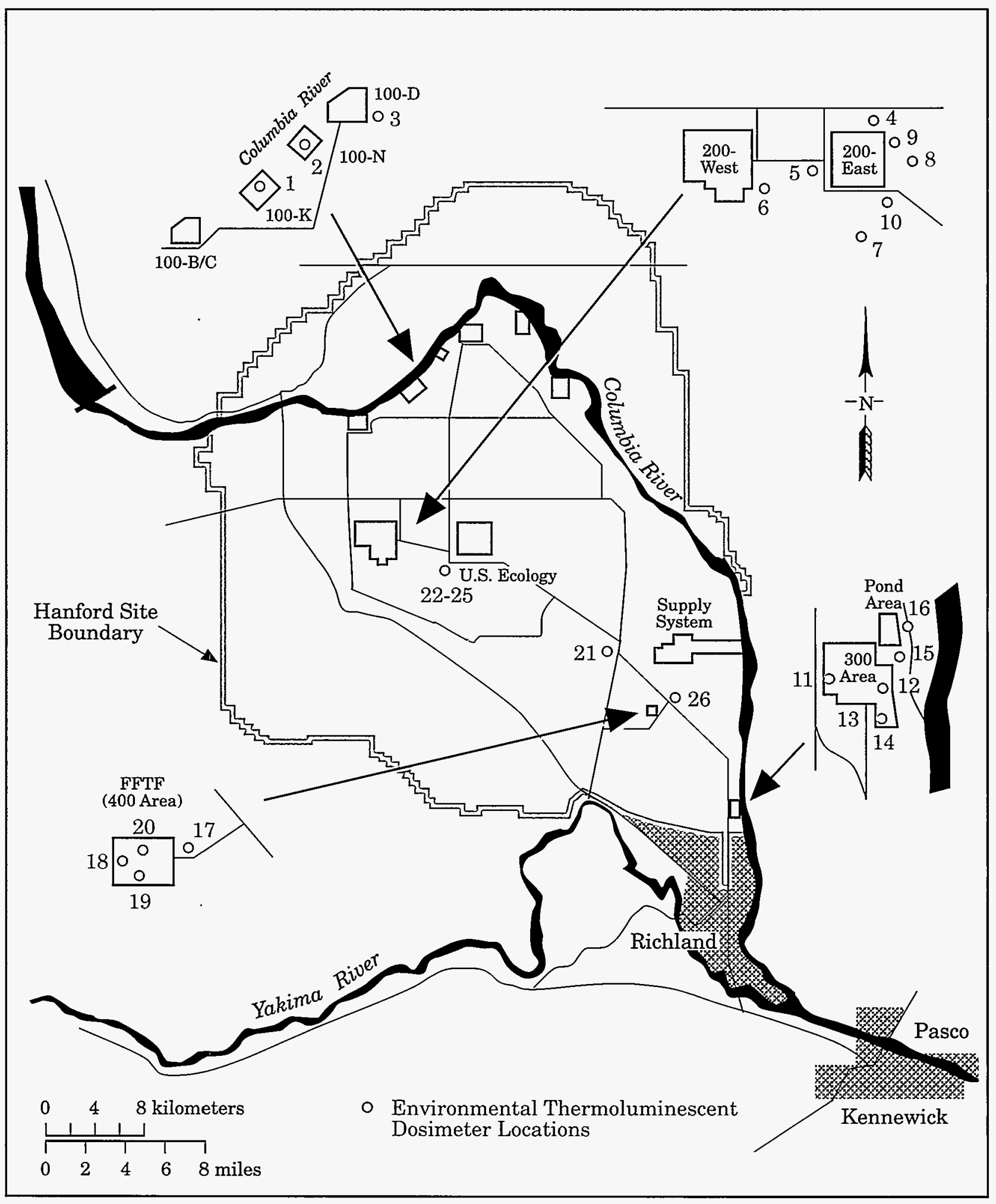

S9402063.61

Figure 5.34. Thermoluminescent Dosimeter (TLD) Locations and Station Numbers on the Hanford Site, 1993 


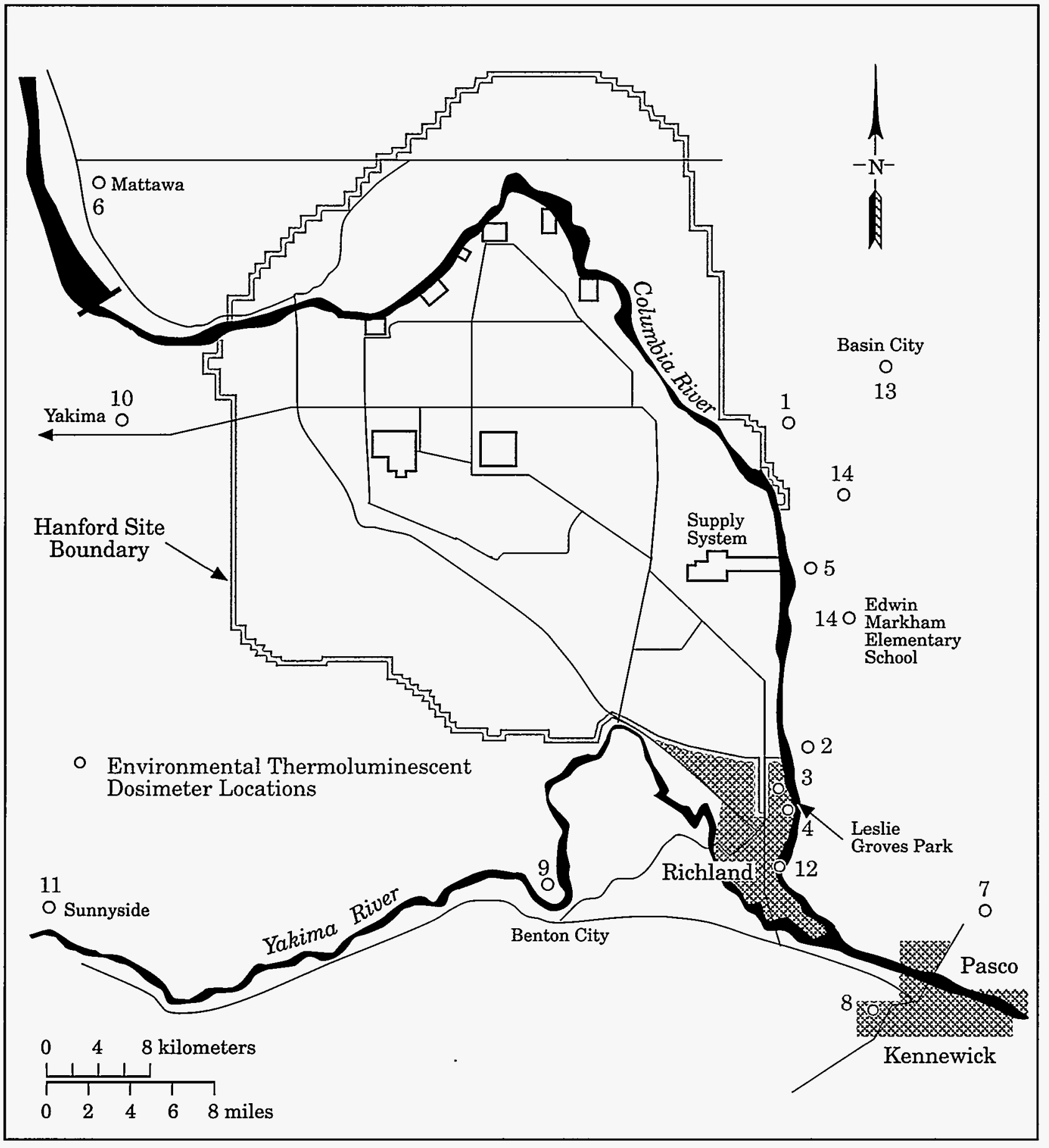

S9402063.59

Figure 5.35. Thermoluminescent Dosimeter (TLD) Measurement Locations and Station Numbers for Community, Distant, and Perimeter Sites, 1993 


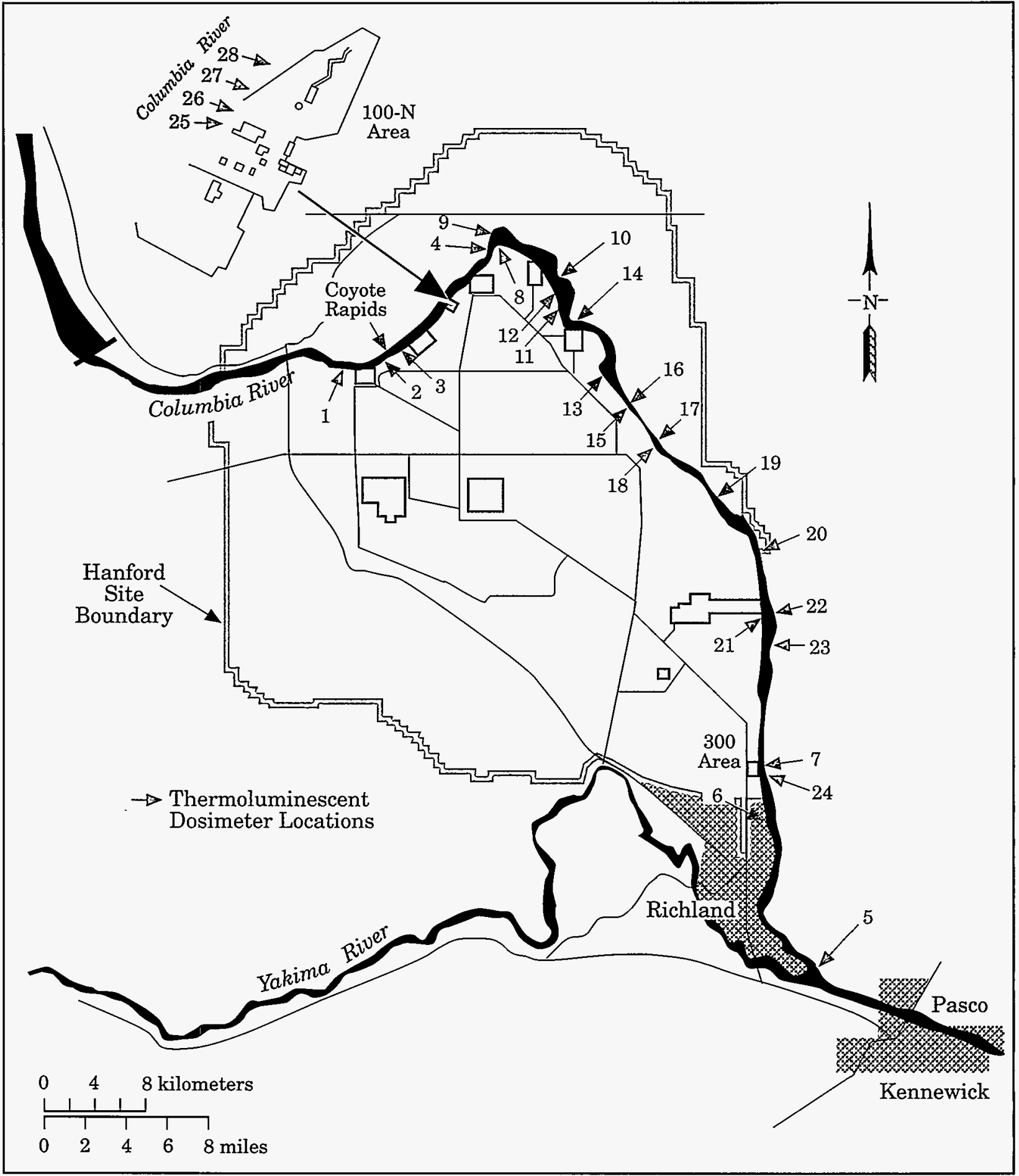

S9402063.60

Figure 5.36. Thermoluminescent Dosimeter (TLD) Locations and Station Numbers on the Hanford Reach of the Columbia River, 1993 
Twenty-eight locations have been established on the Columbia River shoreline upstream from the 100-B Area to just downstream of Bateman Island (mouth of the Yakima River). The general public has access to some of these locations. Historically, dose rates measured along the shoreline have been higher than typical background rates. Sula (1980) attributed these rates to ${ }^{60} \mathrm{Co}$ and ${ }^{154} \mathrm{Eu}$ in shoreline sediments as a result of liquid releases to the Columbia River during past reactor operations in the 100 Areas.

\section{External Radiation Results}

Perimeter and offsite locations, primarily downwind of the Site and near population centers, were monitored with TLDs. TLD exposures have been converted to dose equivalent rates by the process described above. Table 5.25 shows average dose rates for perimeter and offsite locations. Quarterly exposure rates were averaged by map location, ranked within the location classification, and then converted to dose equivalents per year.

Perimeter dose rates for 1993 were similar to those observed in 1992. Variations in natural background radiation can occur as a result of changes in annual cosmic radiation (up to $10 \%$ ) and terrestrial radiation (15 to $25 \%$, NCRP 1987). Other factors possibly affecting annual dose rates reported here may include variations in the sensitivity of individual TLDs zero-dose readings, fading, random errors in the readout equipment or procedures (Rathbun 1989), and changes in TLD station locations.

The average background external radiation dose rate (at distant locations) was $88 \mathrm{mrem} / \mathrm{yr} \pm 6 \%$ as compared to the perimeter average of $100 \mathrm{mrem} / \mathrm{yr} \pm 6 \%$. This difference in average dose rates may be due to natural geographic variations in terrestrial radiation [many of the perimeter locations are rich in ${ }^{40} \mathrm{~K}$ and thorium isotopes (Rathbun 1989)] and variations resulting from human activity. Human activities affecting the average dose rates may include landscape changes such as buildings and other construction, which may shield a portion of the terrestrial component. Figure 5.37 graphically displays a comparison between, and trends of, onsite, perimeter, and distant TLD locations during 1988 through 1993. Year-to-year variability is obvious for reasons stated above, and $10 \%$ variability is not unlikely (NCRP 1987).

Figure 5.36 shows locations of TLDs positioned along the Columbia River shoreline, and Table 5.26 shows the average measured dose rates for shoreline locations. Dose rates were highest near the $100-\mathrm{N}$ Area shoreline, two to three times higher than typical shoreline dose rates. The higher rates measured in the 100-N Area are attributed to past waste management practices in that area. The public does not have access to the $100-\mathrm{N}$ Area shoreline, but does have access to the adjacent water body. The dose implications associated with this access are discussed in Section 6.0.

Table 5.25. Dose Rates Measured by Thermoluminescent Dosimeters (TLDs) at Perimeter and Community Locations, 1993 Compared to Values from the Previous 5 Years

\begin{tabular}{|c|c|c|c|c|c|c|c|}
\hline \multirow[b]{3}{*}{ Location } & \multirow[b]{3}{*}{$\begin{array}{c}\text { Map } \\
\text { Location }^{(a)} \\
\end{array}$} & \multicolumn{6}{|c|}{ Dose Rate, mrem/yr } \\
\hline & & \multicolumn{3}{|c|}{1993} & \multicolumn{3}{|c|}{ 1988-1992 } \\
\hline & & $\begin{array}{c}\text { No. of } \\
\text { Samples }\end{array}$ & Maximum & Mean & $\begin{array}{c}\text { No. of } \\
\text { Samples }\end{array}$ & Maximum & Mean \\
\hline Perimeter & $1-5$ & 5 & $107 \pm 26 \%$ & $100 \pm 6 \%$ & 40 & $104 \pm 25 \%$ & $91 \pm 3 \%$ \\
\hline Nearby communities & $6-9$ & 4 & $95 \pm 18 \%$ & $88 \pm 5 \%$ & 38 & $90 \pm 24 \%$ & $81 \pm 3 \%$ \\
\hline Distant communities & $10-11$ & 2 & $95 \pm 6 \%$ & $88 \pm 6 \%$ & 20 & $82 \pm 32 \%$ & $78 \pm 4 \%$ \\
\hline COES stations & $12-14$ & 3 & $92 \pm 26 \%$ & $89 \pm 5 \%$ & 6 & $98 \pm 36 \%$ & $87 \pm 7 \%$ \\
\hline
\end{tabular}

(a) See Figure 5.35. 
Figure 5.34 displays the 28 onsite locations where TLDs were placed in 1993. Table 5.27 summarizes the results of 1993 measurements, which are divided by operational area. All areas had higher average dose rates than background. The highest average dose rate was seen in the 600 Area and is due to the waste-handling activities at U.S. Ecology, a non-DOE facility.

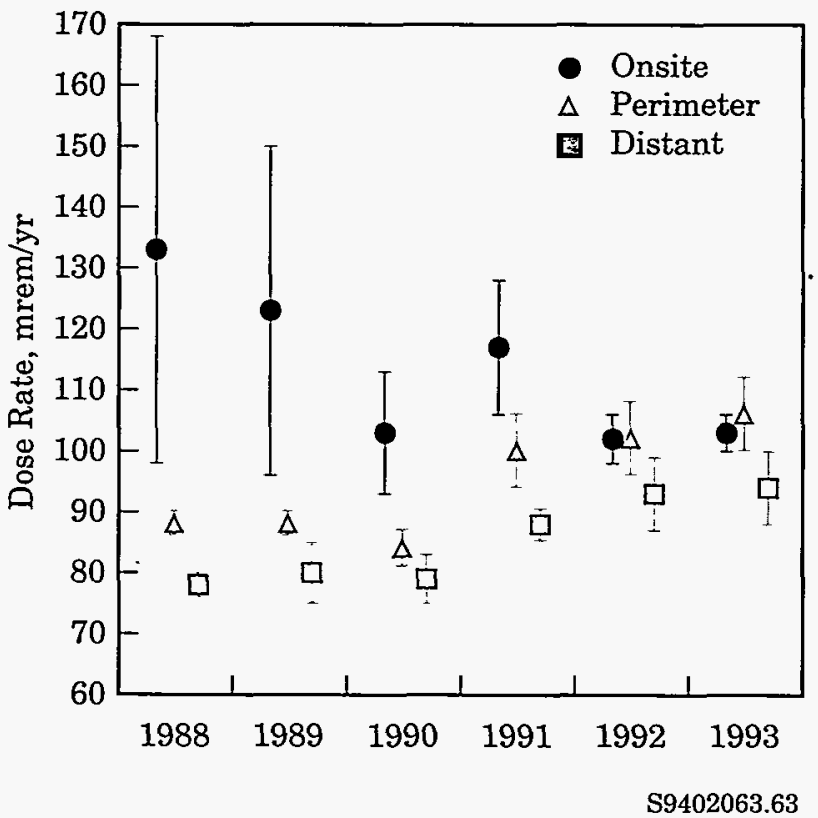

Figure 5.37. Annual Average Dose Rates, 1988 Through 1993

\section{Radiation Survey Results}

In 1993, radiation surveys consisted of an aerial survey and onsite road surveys. No railroads were surveyed.

Aerial radiological surveys of the Hanford Site perimeter, Columbia River shoreline, and around the perimeter of the 200 Areas were performed during 1993 in accordance with established procedures (PNL 1992a) to monitor for gamma or $\mathrm{x}$-ray-emitting contamination. Figure 5.38 shows the three flight patterns used during the surveys.

In 1993, Battelle's G-1, a Gulfstream jet, was used to perform the surveys. The G-1 was equipped with a global positioning system and an onboard computer that collected longitude and latitude coordinates every second. These coordinates coincided with output from the detection system, which consisted of a large sodiumiodide scintillation detector, securely fastened to the exterior of the jet, routed to a Ludlum Model 2200 rate meter, secured on the inside of the jet. Every second, the voltage output from the rate meter was routed to a strip chart recorder for immediate visual inspection of the data and to the onboard computer for post-survey analysis.

Elevated environmental exposure levels were recorded near the 300 Area shoreline, 100-N shoreline, and the $100-\mathrm{K}$ shoreline. The aerial survey identified these areas as being an order of magnitude higher than the "background" or average reading for Flight Path \#1, the

Table 5.26. Dose Rates Measured Along the Hanford Reach of the Columbia River, 1993 Compared to Values from the Previous 5 Years

\begin{tabular}{|c|c|c|c|c|c|c|}
\hline \multirow[b]{3}{*}{ Location } & \multirow[b]{3}{*}{ Map $_{\text {Location }^{(b)}}$} & \multicolumn{5}{|c|}{ Dose Rate, ${ }^{(a)} \mathrm{mrem} / \mathrm{yr}$} \\
\hline & & \multicolumn{2}{|c|}{1993} & \multicolumn{3}{|c|}{ 1988-1992 } \\
\hline & & Maximum & Mean $^{(c)}$ & $\begin{array}{l}\text { No. of } \\
\text { Samples }\end{array}$ & Maximum & Mean \\
\hline Typical shoreline area & $1-24$ & $136 \pm 26 \%$ & $108 \pm 2 \%$ & 62 & $127 \pm 34 \%$ & $103 \pm 5 \%$ \\
\hline $100-\mathrm{N}$ shoreline $\mathrm{e}^{(\mathrm{d})}$ & $25-28$ & $256 \pm 28 \%$ & $197 \pm 22 \%$ & 13 & $322 \pm 6 \%$ & $241 \pm 22 \%$ \\
\hline All shoreline & & $256 \pm 28 \%$ & $138 \pm 6 \%$ & 75 & $322 \pm 6 \%$ & $127 \pm 17 \%$ \\
\hline
\end{tabular}

(a) Quarterly integrated readings in $\mathrm{mR} / \mathrm{d}$ were converted to annual dose equivalent rates ( $\mathrm{mrem} / \mathrm{yr}$ ).

(b) All locations are shown in Figure 5.36.

(c) Means \pm 2 SEM computed using station averages.

(d) Monthly integrated exposure readings in $\mathrm{mR} / \mathrm{d}$ converted to annual dose equivalent rates in $\mathrm{mrem} / \mathrm{yr}$. 
Table 5.27. Dose Rates for Thermoluminescent Dosimeter (TLD) Locations on the Hanford Site, 1993 Compared to Values from the Previous 5 Years

\begin{tabular}{|c|c|c|c|c|c|c|}
\hline \multirow[b]{3}{*}{ Location } & \multirow[b]{3}{*}{$\begin{array}{c}\text { Map } \\
\text { Location }^{\left({ }^{b}\right)} \\
\end{array}$} & \multicolumn{5}{|c|}{ Dose Rate, ${ }^{(a)} \mathrm{mrem} / \mathrm{yr}$} \\
\hline & & \multicolumn{2}{|c|}{1993} & \multicolumn{3}{|c|}{ 1988-1992 } \\
\hline & & Maximum & Mean $^{(c)}$ & $\begin{array}{c}\text { No. of } \\
\text { Samples }\end{array}$ & Maximum & Mean \\
\hline 100 Areas & $1-3$ & $103 \pm 12 \%$ & $95 \pm 7 \%$ & 11 & $98 \pm 24 \%$ & $90 \pm 5 \%$ \\
\hline 200 Areas & $4-10$ & $106 \pm 26 \%$ & $100 \pm 4 \%$ & 26 & $99 \pm 26 \%$ & $92 \pm 3 \%$ \\
\hline 300 Area & $11-16$ & $104 \pm 19 \%$ & $93 \pm 4 \%$ & 18 & $99 \pm 25 \%$ & $91 \pm 3 \%$ \\
\hline 400 Area & $17-20$ & $110 \pm 27 \%$ & $103 \pm 5 \%$ & 16 & $95 \pm 29 \%$ & $88 \pm 4 \%$ \\
\hline 600 Area & $21-26$ & $155 \pm 10 \%$ & $107 \pm 9 \%$ & 34 & $150 \pm 41 \%$ & $104 \pm 5 \%$ \\
\hline
\end{tabular}

(a) Quarterly integrated readings in mrem were converted to annual dose equivalent rates.

(b) Locations are identified in Figure 5.34.

(c) Means $\pm 2 \mathrm{SEM}$ computed using station averages.

perimeter and shoreline path. Flight Path \#2, around the 200 Areas, identified an area between and south of the 200-East and 200-West Areas as being nearly twice the path average. Flight Path \#3, the outer perimeter path, had a maximum reading south and west of the 300 Area that was 2.3 times the flight path average. Overall, new locations with above-background activities were not identified, and the locations with above-background activities were confirmed to be generally where expected.

Onsite roads were surveyed using mobile scintillation detectors in early 1993. The detector consisted of four sodium-iodide crystals, mounted $0.46 \mathrm{~m}(1.5 \mathrm{ft})$ above ground level on the rear bumper of a four-wheel-drive truck. Output from the detectors and the associated electronics was recorded on strip charts for review and documentation after the surveys were complete. Between January and June 1993, road surveys revealed no areas of detectable contamination. Routes are shown in Figure 5.39. In June 1993, the ownership of the road monitor was transferred to Westinghouse Hanford Company.

Hand-held survey instruments were used to perform radiation surveys at certain Columbia River shoreline TLD locations. These surveys provided a coarse screening for elevated radiation fields. The shoreline surveys showed that radiation levels were comparable to levels observed at the same locations in previous years. The highest levels were reported at the 100-N Area shoreline and ranged from 5 to $115 \mathrm{mrem} / \mathrm{h}$ using a Bicron Micro Rem meter. Survey results are not tabulated by Bisping (1994), but are in the Surface Environmental Surveillance Project files at Pacific Northwest Laboratory. 


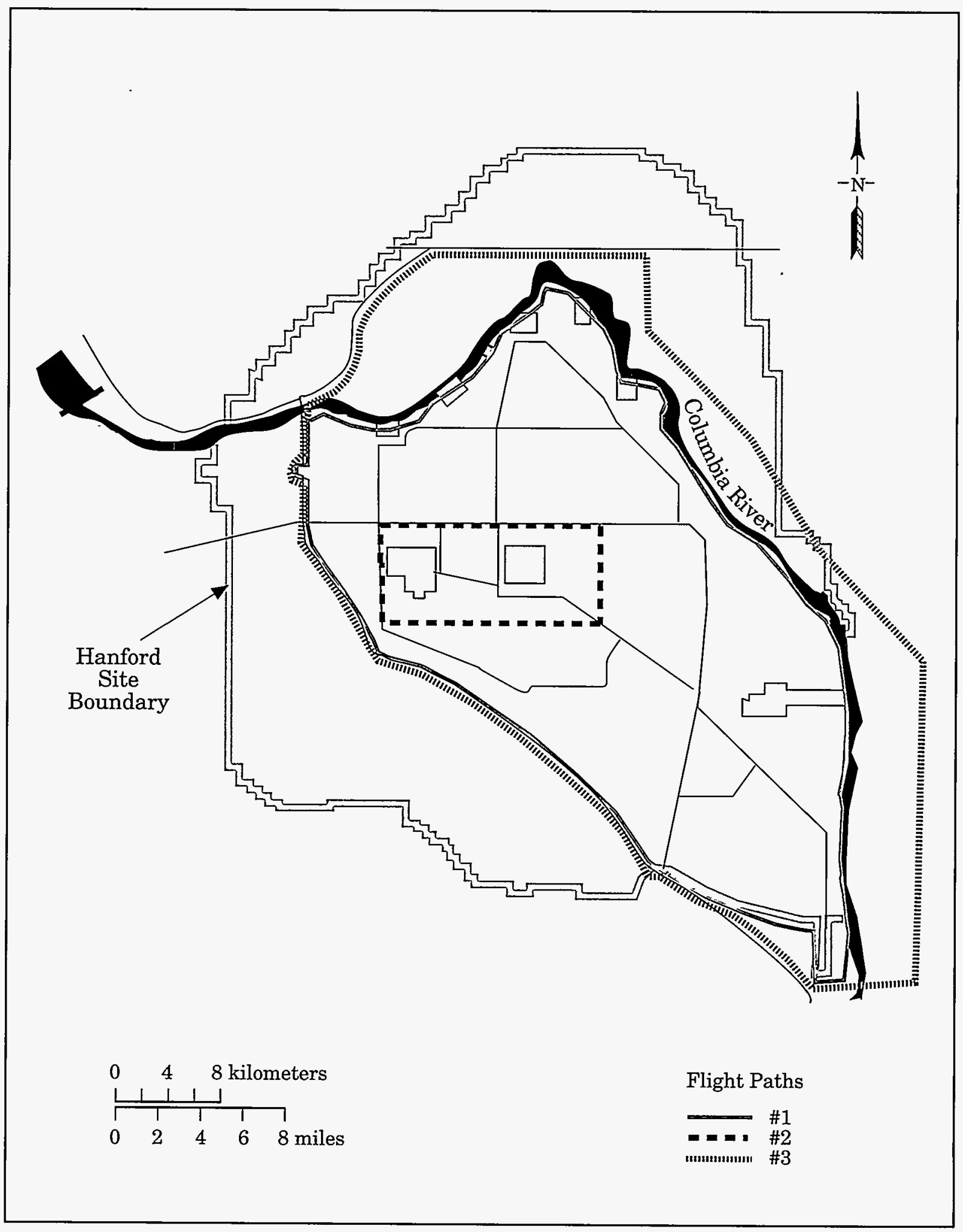

S9402063.64

Figure 5.38. Flight Patterns Used for Aerial Radiation Surveys, 1993 


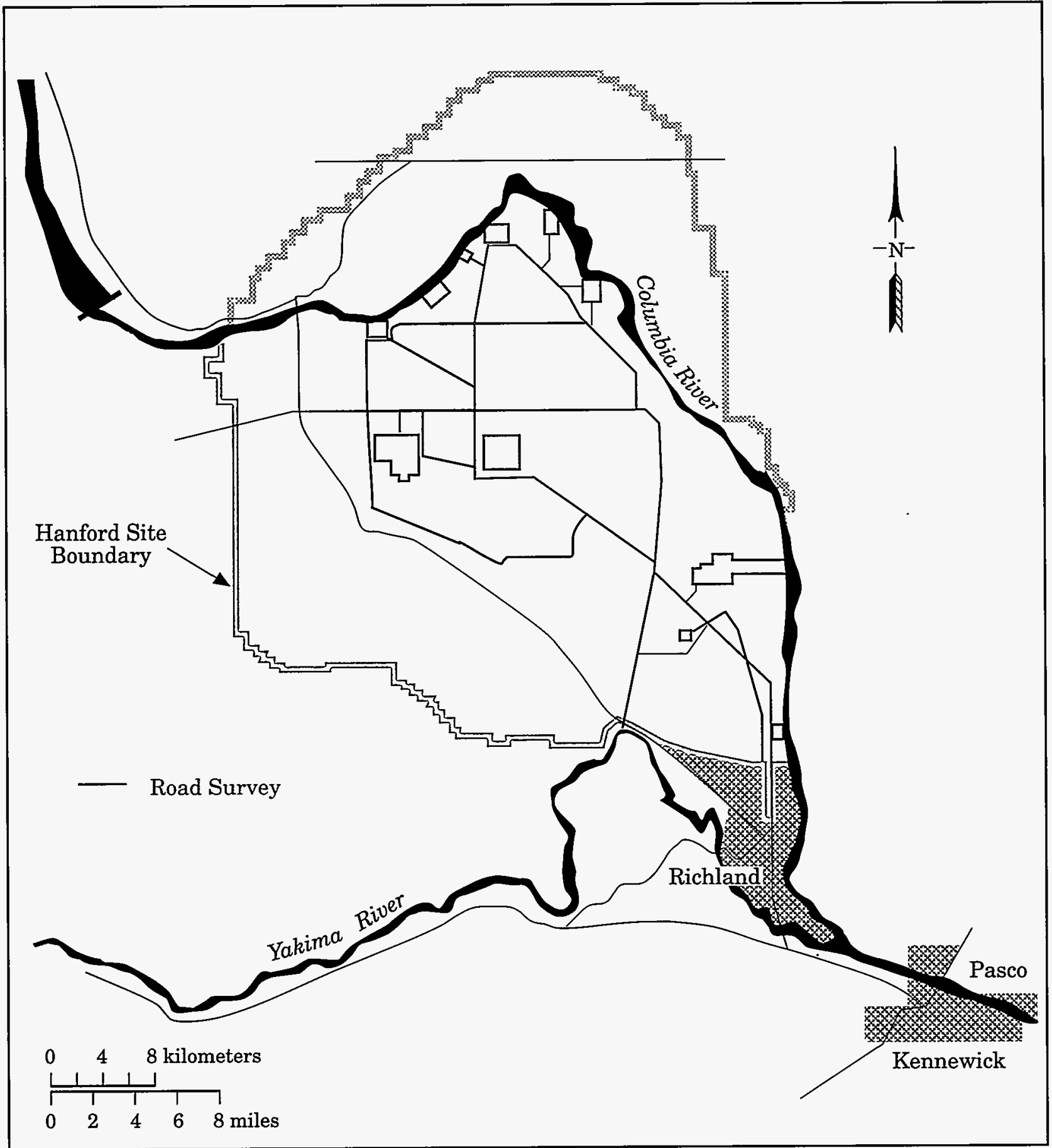

S9402063.62

Figure 5.39. Road Survey Routes, 1993 


\title{
5.8 Ground-Water Protection and Monitoring Program
}

\author{
P. E. Dresel
}

The strategy for protecting ground water at the Hanford Site is presented in the Hanford Site Ground-Water Protection Management Program (DOE 1989). Two of the key elements of this strategy are to 1) protect the unconfined aquifer from further contamination, and 2) conduct a monitoring program to provide an early warning when contamination of ground water does occur. These elements are reaffirmed by the recommendations of the Hanford Future Site Uses Working Group to "protect the Columbia River from contamination" and to "deal realistically and forcefully with ground-water contamination" (Drummond et al. 1992). The groundwater monitoring program at Hanford monitors and documents ground-water quality to effectively meet the needs of these elements. The monitoring program at Hanford has also been designed to assess the distribution and movement of existing ground-water contamination. The geology and hydrology of the Hanford Site are the major controls on the movement of contaminants in ground water.

\section{Geology}

The Hanford Site lies within the Pasco Basin, one of several topographic and structural basins within the Columbia Plateau. Principal geologic units beneath the Hanford Site include, in ascending order, the Columbia River Basalt Group, the Ringold Formation, and the deposits informally referred to as the Hanford formation. In places, these units are covered by up to a few meters of recent alluvial or windblown deposits. Structural deformation has created a series of roughly east-west trending folds, with low angle reverse faults typically near the bases of the folds. A few faults also cut across the folds, such as the Cold Creek and May Junction faults. These folds are most noticeable in the Columbia River Basalt Group and control the location of the Ringold Formation, which has also been folded but to a lesser extent. Thus the folding and faulting began before the deposition of the Ringold Formation and continued through the period of Ringold deposition. The stratigraphic and structural relationships between these units are displayed in Figure 5.40.

The Columbia River Basalt Group is composed of numerous basaltic lava flows. The rate of eruption of these lava flows slowed with time, allowing sediment to be deposited before the next basalt flow covered the landscape. These sediments now form water-bearing interbeds between many of the most recent basalt flows. Deposition of these sediments by rivers and lakes continued after eruption of the basalt flows ceased, creating the Ringold Formation. The Ringold Formation generally consists of an alternating sequence of sand and gravel main-channel river deposits and muddy overbank and lake deposits. In places, these layers are unconsolidated, while in others they are weakly to moderately cemented. Deposition of the Ringold Formation was followed by a period of nondeposition and erosion, which removed varying amounts of the sediment throughout the Pasco Basin. At the same time, the PlioPleistocene unit caliche and gravel and the windblown sand and silt of the early "Palouse" soil were deposited in the western portion of the basin. Catastrophic floods during the last ice age deposited the coarse gravels and sands of the Hanford formation on top of the Ringold, the Plio-Pleistocene unit, or the early "Palouse" soil. In areas near the basalt folds, the Ringold Formation has been eroded away, and the Hanford formation lies directly on the basalt. Many studies of the Hanford Site geology have been performed, and are discussed in more detail in DOE (1988c), Lindsey et al. (1991), and Lindsey et al. (1992).

\section{Ground-Water Hydrology}

Both confined and unconfined aquifers are present beneath the Hanford Site. The confined aquifers are 


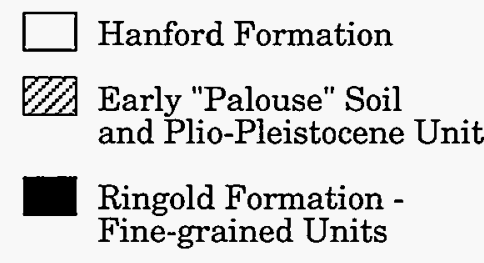

Ringold Formation Coarse-grained Units

$\rightarrow$ Water Table

$\rightleftharpoons$ Fault Line, Dashed Where Inferred

0122345 Kilometers

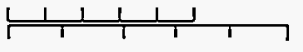

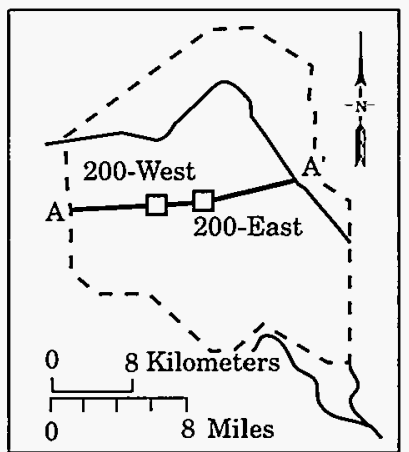

East

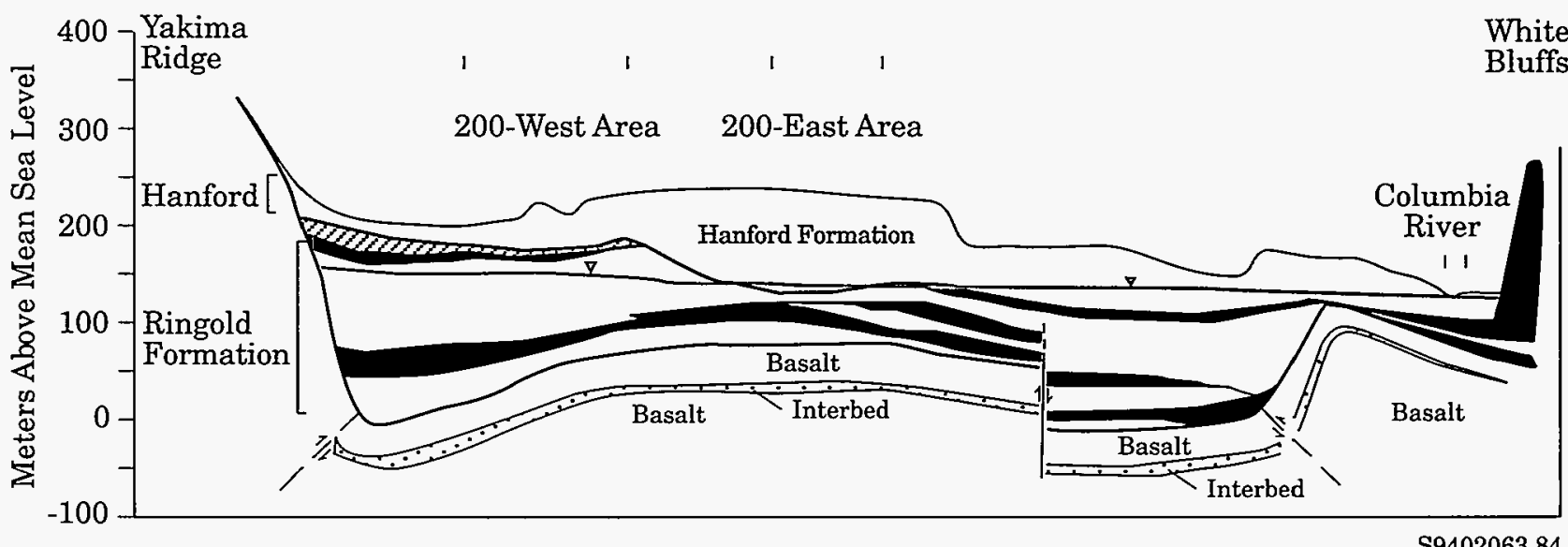

Figure 5.40. Geologic Cross Section of the Hanford Site

found primarily within interflows and interbeds of the Columbia River basalts, as well as below the relatively impervious clays and silts of the Ringold Formation. In general, the unconfined aquifer is located in the Ringold Formation and glaciofluvial sediments of the Hanford formation, as well as some more recent alluvial sediments in some areas adjacent to the Columbia River. This aquifer has been directly impacted by wastewater disposal at Hanford and is the most thoroughly monitored aquifer beneath the Site.

The saturated thickness of the unconfined aquifer is greater than $61 \mathrm{~m}(200 \mathrm{ft})$ in some areas of the Hanford Site and pinches out along the flanks of the basalt ridges. Depth from the ground surface to the water table ranges from less than $0.3 \mathrm{~m}(1 \mathrm{ft})$ near the Columbia River to

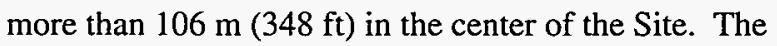
unconfined aquifer is bounded below by either the basalt surface or, in places, the relatively impervious clays and silts of the Ringold Formation. The water table defines the upper boundary of the unconfined aquifer. Laterally, the unconfined aquifer is bounded by the basalt ridges that surround the basin and by the Yakima and Columbia rivers. The basalt ridges have a low permeability and act as a barrier to lateral flow of ground water (Gephart et al. 1979) where they rise above the water table. Elevation of the water table in meters above mean sea level for the Hanford Site and adjacent portions of Franklin and Grant Counties is shown in Figure 5.41.

The water-table elevations shown in Figure 5.41 indicate the hydraulic gradient in the unconfined aquifer. Ground-water flow is generally perpendicular to the water-table contours from areas of higher elevation or head to areas of lower head. Areas of the Site where the contours are closer together are high-gradient areas where the "driving force" for ground-water flow is greater. However, sediments with low permeabilities 


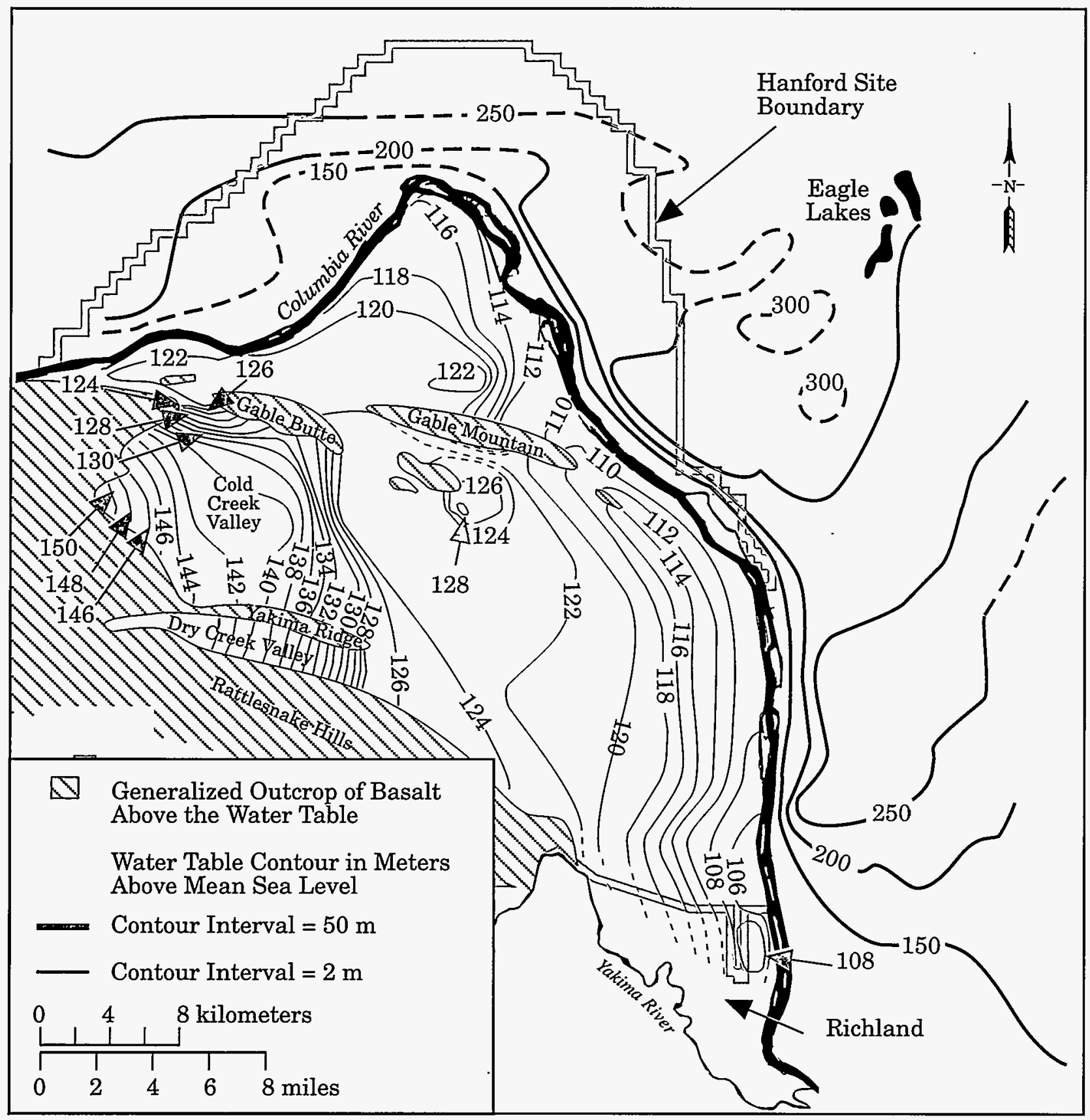

S9402063.3

Figure 5.41. Water-Table Elevations for the Unconfined Aquifer at Hanford and in Parts of Franklin and Grant Counties, June 1993

will inhibit ground-water flow so that high gradient does not necessarily mean high ground-water velocity. The permeability of the Ringold sediments is generally lower than that of the Hanford sediments, so lower velocities are often associated with Ringold sediments.
Recharge to the unconfined aquifer originates from several sources (Graham et al. 1981). Natural recharge occurs from infiltration of precipitation along the mountain fronts, runoff from intermittent streams such as Cold Creek and Dry Creek on the western margin of the 
Site, and limited infiltration of precipitation on areas of the Hanford Site that have loose soil. The unconfined aquifer is recharged by the Yakima River where it flows along the southern boundary of the Hanford Site. The Columbia River recharges the unconfined aquifer for short periods during high stages when river water is transferred to the aquifer along the river bank. The Columbia River is also the primary discharge area for the unconfined aquifer. The unconfined aquifer receives little, if any, recharge from infiltration of precipitation on vegetated areas of the Hanford Site because of a high rate of evapotranspiration from native soil and vegetation. However, studies described by Gee et al. (1992) suggest that in some years precipitation may contribute more than $10 \mathrm{~cm} / \mathrm{yr}$ ( $4 \mathrm{in} . / \mathrm{yr}$ ) recharge to the ground water in areas where soils are coarse textured and bare of vegetation.

Large-scale artificial recharge occurs from liquid-waste disposal in the operating areas and offsite agricultural irrigation. The operational discharge of water has created two major ground-water mounds in the $200 \mathrm{Ar}$ eas. The first of these mounds was created by past disposal at U Pond in the 200-West Area. This mound is slowly dissipating because the pond was decommissioned in 1984. The second mound was created by discharge to B Pond, east of the 200-East Area. These mounds have altered the unconfined aquifer's natural flow pattern, which is generally from the recharge areas in the west to the discharge areas (primarily the Columbia River) in the east. Water levels in the unconfined aquifer have changed continually during Site operations because of variations in the volume of wastewater discharge and are currently declining in response to the decrease in liquid-waste discharges from Hanford operations. Consequently, the movement of ground water and its associated constituents has also changed with time. Ground-water mounding has also occurred in some of the 100 Areas and the 300 Area. Ground-water mounding in these areas is not as significant as in the 200 Areas because of lower discharge volumes, high permeability and proximity to the Columbia River. In the 100 and 300 Areas, water levels are also greatly influenced by river stage.

Recharge from irrigation in the Cold Creek Valley enters the Hanford Site as ground-water flow across the western boundary. Recharge to ground water across the Columbia River from the Hanford Site is primarily from irrigation and irrigation canal leakage. As indicated in Figure 5.41, the water-table elevation to the east of the Columbia River is from 100 to $150 \mathrm{~m}$ (328 to $492 \mathrm{ft}$ ) higher than the water-table elevation on the Hanford Site.
As significant quantities of liquid effluents are discharged to the ground at Hanford facilities, these effluents percolate downward through the unsaturated zone to the water table. Radionuclide and chemical constituents move through the soil column at varying rates, and may eventually enter the ground water. Chemical processes such as adsorption onto soil particles, chemical precipitation, and ion exchange slow the movement of some radionuclides, such as ${ }^{90} \mathrm{Sr},{ }^{137} \mathrm{Cs}$, and ${ }^{239,240} \mathrm{Pu}$. Other radionuclides, such as ${ }^{3} \mathrm{H},{ }^{99} \mathrm{Tc}$, and ${ }^{129} \mathrm{I}$, and ions, such as nitrate, are not as readily retained by the soil and move vertically through the soil column at a rate nearly equal to the infiltrating water. When the liquid effluents reach the water table, their concentrations are reduced by dilution. As these constituents move with the ground water, radionuclide and chemical concentrations are further reduced by adsorption and spreading (dispersion), and radionuclide concentrations are reduced by radioactive decay.

\section{Ground-Water Protection}

The effort to protect ground-water quality is being implemented through programs to minimize wastes being discharged to the soil column and through site remediation activities being carried out in accordance with an agreement among the Ecology, DOE, and EPA. This agreement, called the Hanford Federal Facility Agreement and Consent Order or the Tri-Party Agreement, provides a framework for remediation of the Hanford Site over a 40-year period. A summary of accomplishments in waste minimization and site remediation is presented in Section 2.0, "Environmental Compliance Summary."

In 1987 Congress directed DOE to prepare a Plan and Schedule to Discontinue Disposal of Liquids Into the Soil Column at the Hanford Site (DOE 1987c). That document presents an implementation plan for providing alternative treatment and disposal of contaminated effluent discharged to the soil on the Hanford Site. The 33 major waste streams that have been identified will be addressed in two phases. Phase I projects are considered higher priority, and cessation or alternative treatment and disposal systems will be implemented by 1995 for those streams. Phase II streams will be dealt with after completion of Phase I projects. Preparations are being made to treat remaining Phase I streams before diverting them to a treated effluent disposal facility, which will be located east of the 200-East Area. In addition, plans are being made to discharge process condensate from the 
242-A Evaporator to a crib north of the 200-West Area. This discharge will also be treated to remove contaminants; however, the discharge will contain ${ }^{3} \mathrm{H}$ because there is currently no viable treatment technology for ${ }^{3} \mathrm{H}$ removal.

\section{Ground-Water Monitoring}

Ground-water monitoring at the Hanford Site is an integral part of the Hanford Site Ground-Water Protection Management Program (DOE 1989). The program includes monitoring at active waste disposal facilities to comply with RCRA (e.g., DOE 1993b), operational monitoring in and adjacent to reactor and chemical processing facilities, and environmental surveillance. Monitoring is also carried out during cleanup investigations under the CERCLA programs (DOE 1992e). The RCRA and operational monitoring programs are managed by the Site operating contractor. CERCLA characterizations are managed by the operating contractor and the U.S. Army Corps of Engineers. Additional details on RCRA-compliant monitoring are presented in Section 2.0, "Environmental Compliance Summary."

The environmental surveillance program assesses the impact of Hanford operations on ground water, both onsite and offsite, independently of the operating contractor's programs. The Hanford Ground-Water Surveillance Program has been designed to assess the distribution and movement of existing ground-water contamination, and to identify emerging ground-water contamination problems. The program integrates information on contaminant distribution and transport into a sitewide evaluation of ground-water quality.

\section{Sample Collection and Analysis}

Ground-water samples were collected as part of the Hanford Ground-Water Surveillance Program and other monitoring programs. The Hanford Ground-Water Surveillance Program utilizes the data from other programs to provide as complete an interpretation as possible. Wells monitored by the various programs in 1993 are shown in Figures 5.42 through 5.45. Groundwater monitoring was conducted at the facilities shown in Figure 5.46 to comply with RCRA (Hartman 1994).
Ground-water samples were collected from approximately 770 wells for the monitoring programs during 1993. The monitoring frequency for the wells was selected based on regulatory requirements, proximity to waste sources, and characteristics of the ground-water flow system at the sample location. Of the 770 wells sampled, 182 were sampled once, 237 were sampled twice, 177 were sampled approximately quarterly, and 59 were sampled more frequently during the year.

Each monitoring program has access to ground-water data collected by other programs through a common database used to store and manage data. This database, called the Hanford Environmental Information System, currently contains over one million ground-water monitoring result records. After the data are verified and/or validated, they are made available to federal and state regulators for retrieval.

Most ground-water monitoring wells on the Site are 10 to $20 \mathrm{~cm}$ (4 to $8 \mathrm{in}$.) in diameter. Monitoring wells for the unconfined aquifer are constructed with well screens or perforated casing generally in the upper 3 to $6 \mathrm{~m} \mathrm{(10} \mathrm{to}$ $20 \mathrm{ft}$ ) of the unconfined aquifer, extending across the water table. This construction allows sample collection at the top of the aquifer, where maximum concentrations of radionuclides tend to be found. Wells monitoring the shallowest of the confined aquifers have screens, perforated casing, or an open hole within the monitored aquifer. Wells drilled before 1985 were generally constructed with carbon steel casing. Wells recently constructed for RCRA monitoring projects and CERCLA characterizations have been constructed with stainlesssteel casing.

Samples were collected for all programs following documented sampling procedures (PNL 1993; WHC 1991b) based on EPA guidelines (EPA 1986c). Analytical techniques used are listed in Bryce et al. (1991), the Hanford Site Environmental Monitoring Plan (DOE $1991 b$ ), and CERCLA work plans. The species analyzed are listed in Table 5.28. Several of the parameters listed in Table 5.28 were seldom analyzed during 1993 because sufficient characterization has been obtained by past analyses.

Most ground-water samples collected onsite in 1993 were analyzed for ${ }^{3} \mathrm{H}$. Selected samples were analyzed for other radionuclides. Sample results for radionuclides are generally presented in $\mathrm{pCi} / \mathrm{L}$. However, the results 


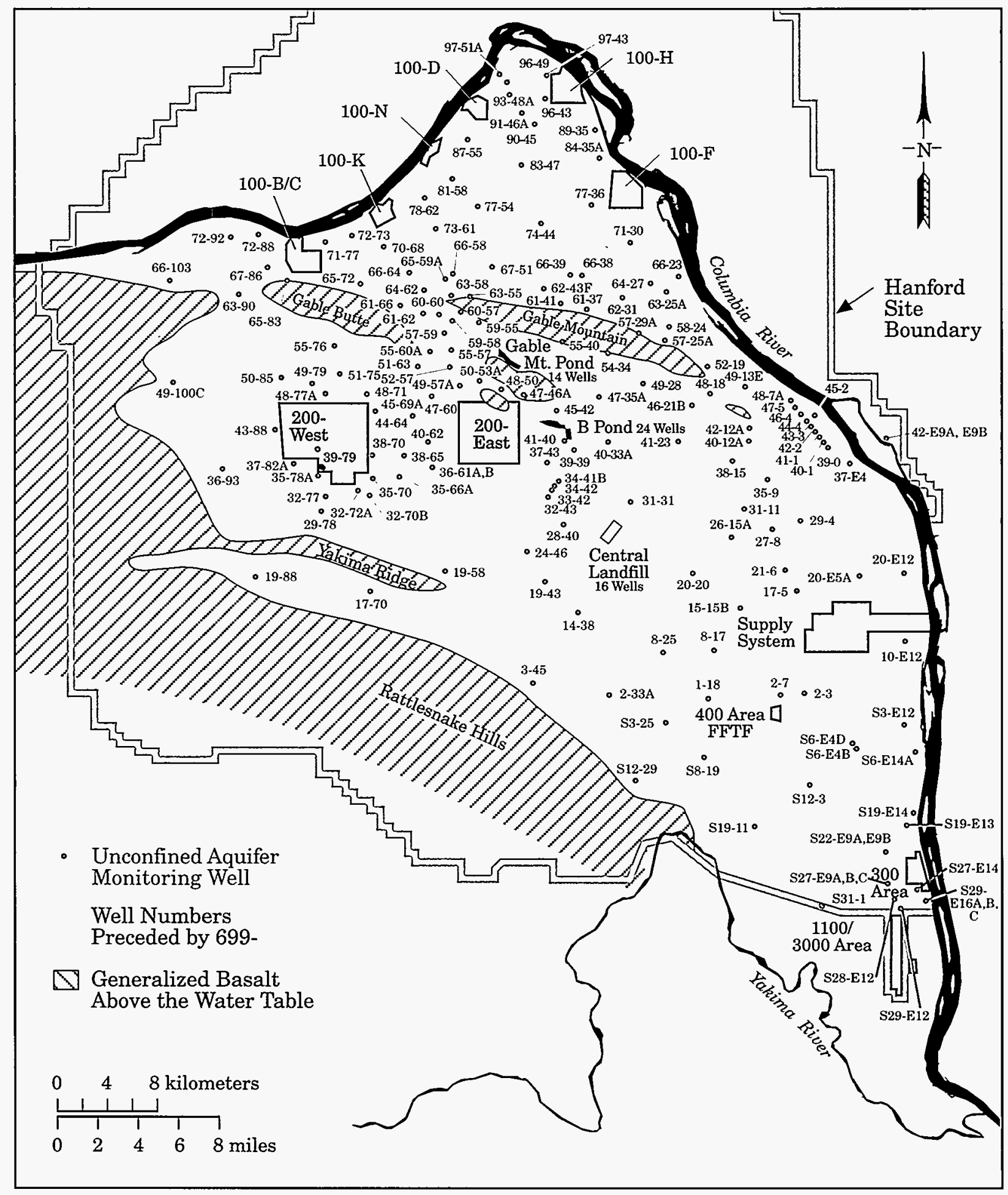

S9402063.142

Figure 5.42. Hanford Site Unconfined Aquifer Monitoring Well Locations, 1993 


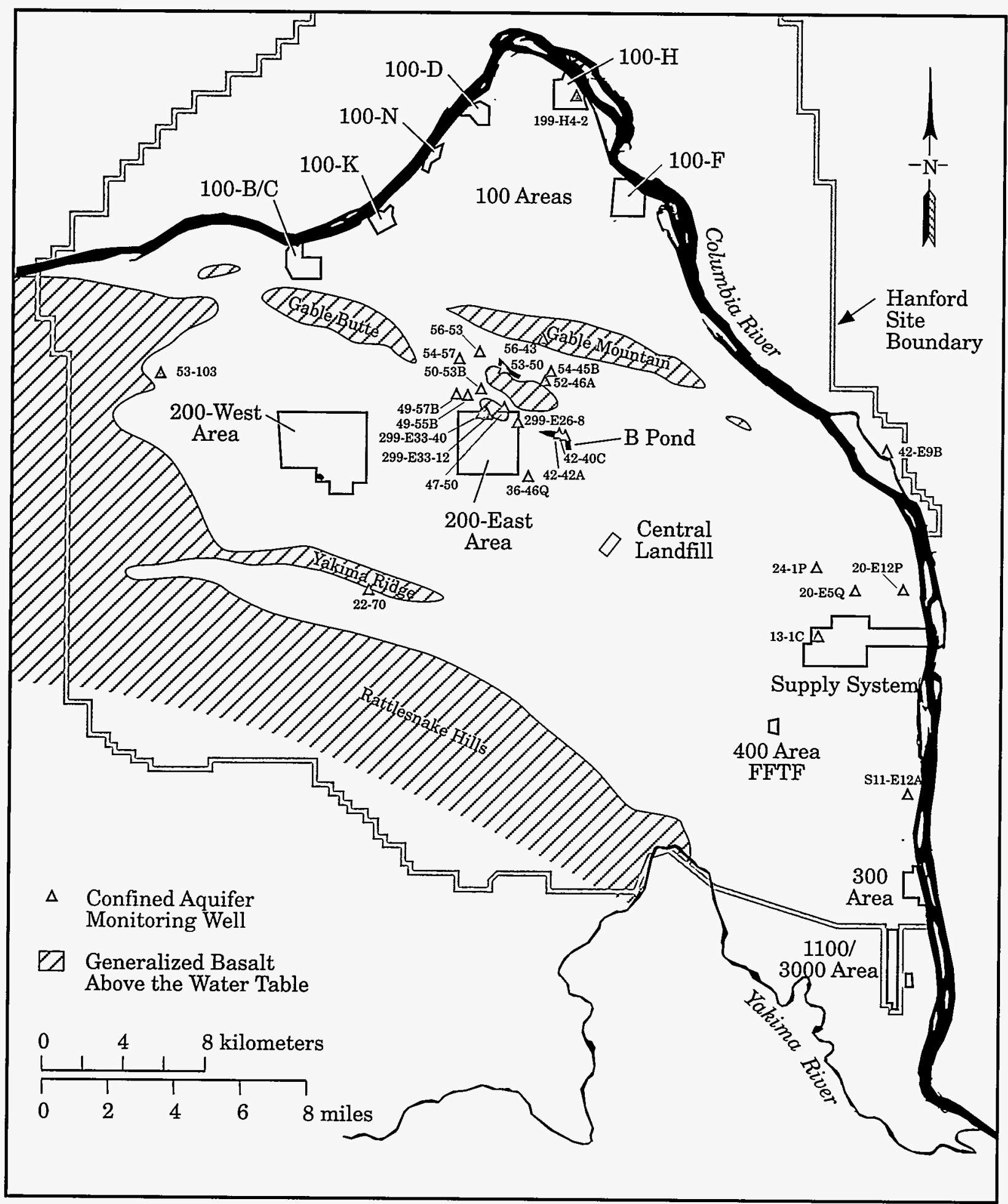

S9402063.52

Figure 5.43. Hanford Site Confined Aquifer Monitoring Well Locations, 1993 


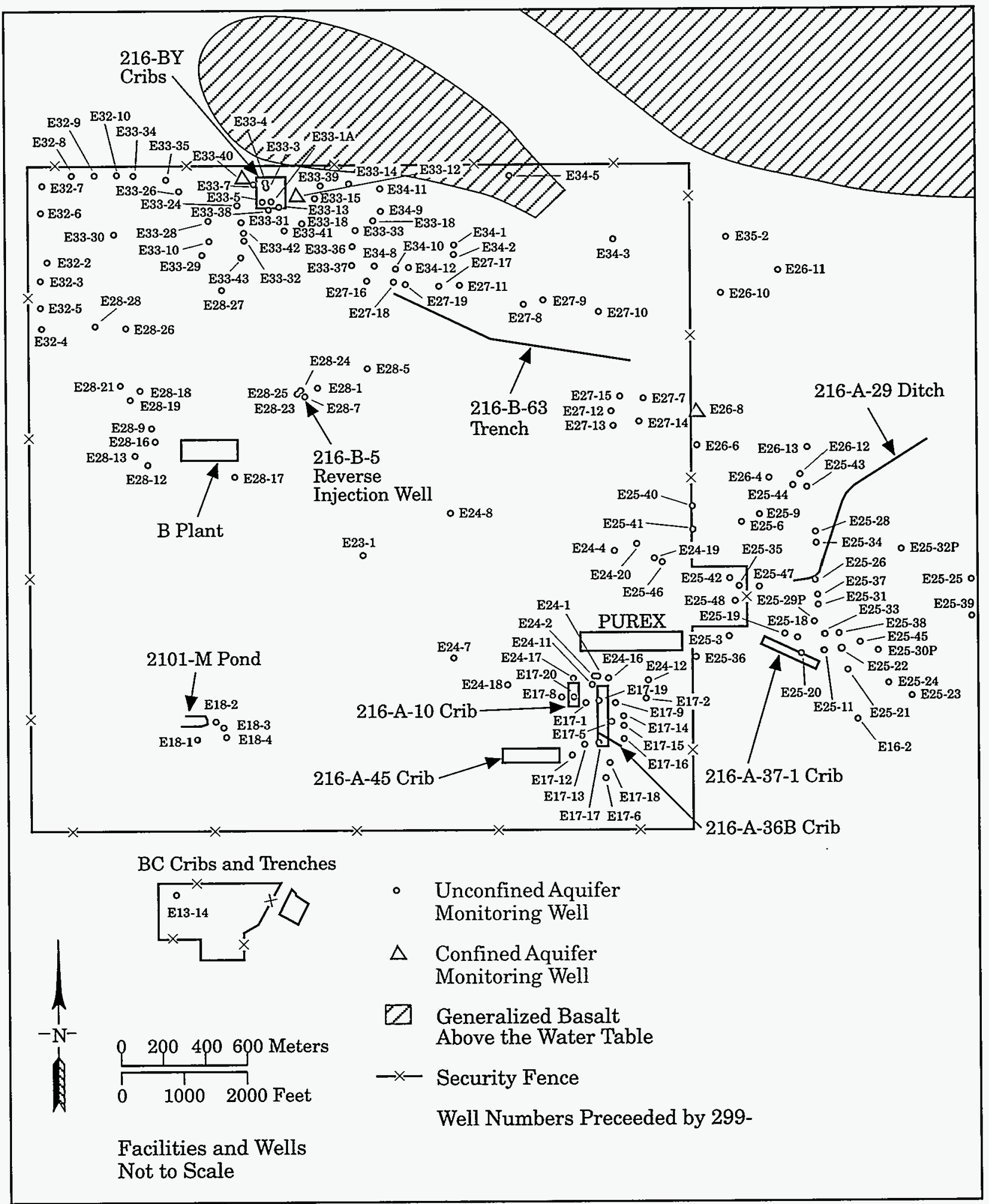

S9402063.51

Figure 5.44. Monitoring Well Locations in the 200-East Area, 1993 


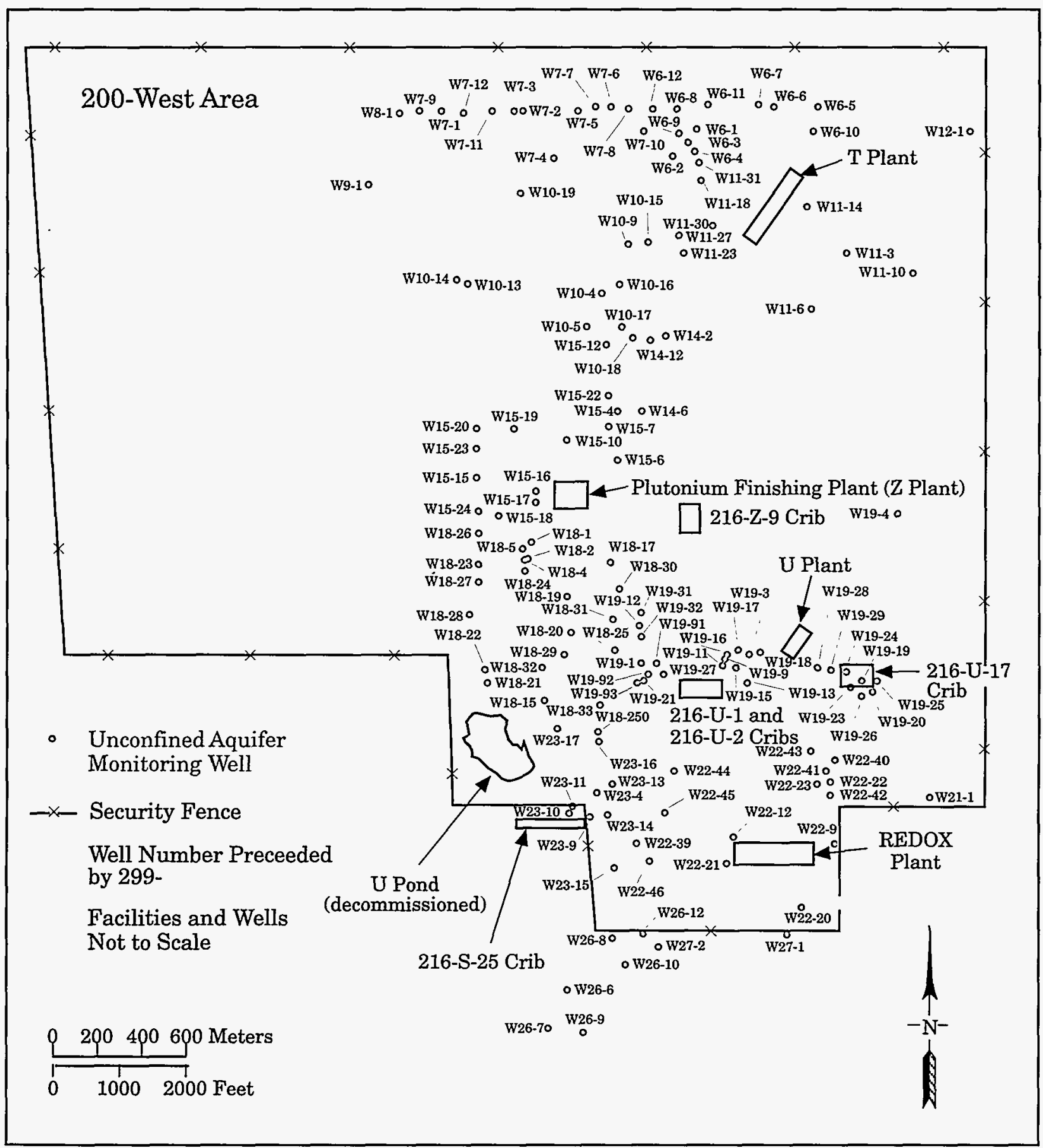

S9402063.50

Figure 5.45. Monitoring Well Locations in the 200-West Area, 1993 


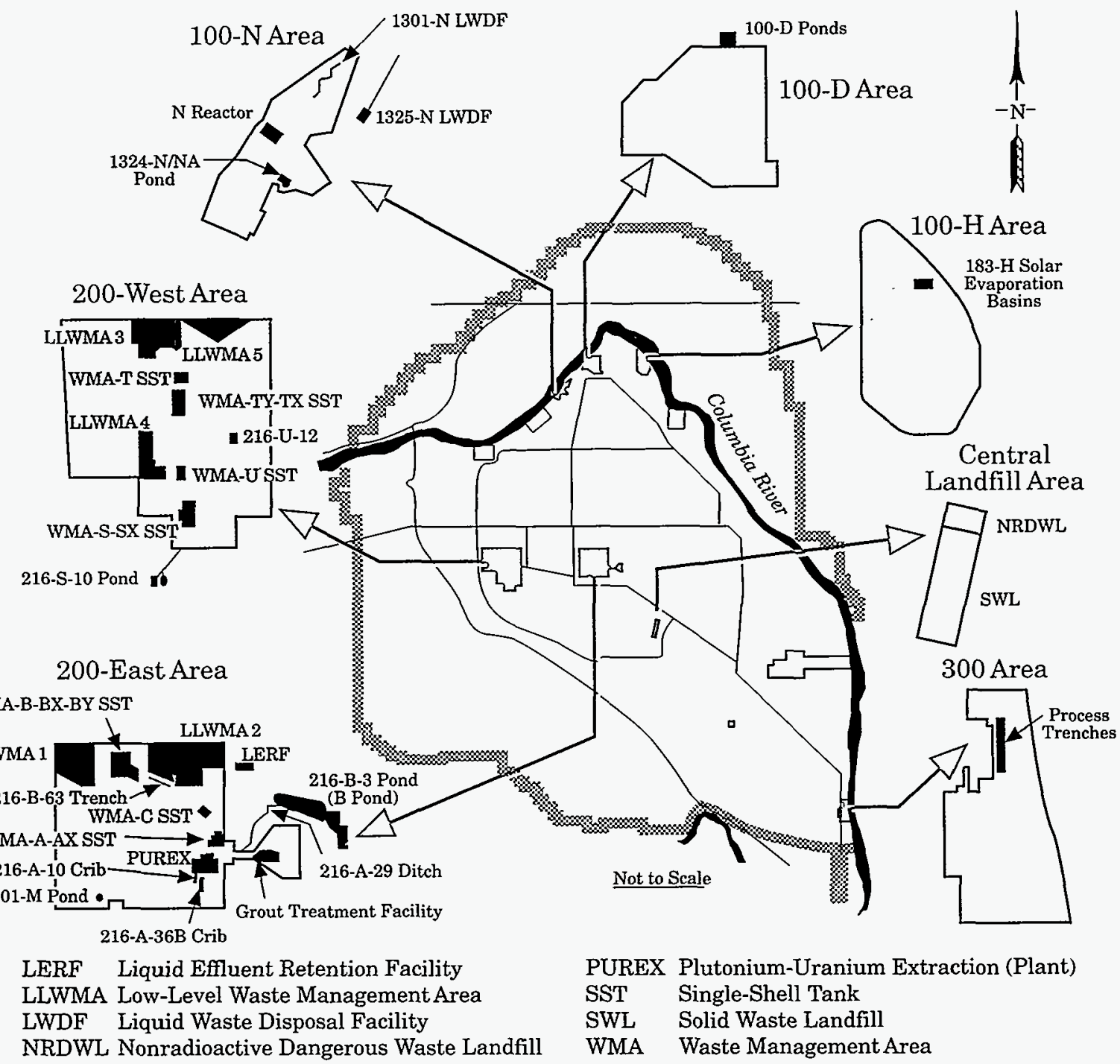

S9402063.143

Figure 5.46. Locations of RCRA Ground-Water Monitoring Projects and Landmarks on the Hanford Site

for total uranium, which is measured by laser fluorescence, are given in $\mu \mathrm{g} / \mathrm{L}$. The results for analysis of individual uranium isotopes are reported in $\mathrm{pCi} / \mathrm{L}$.

Nitrate analyses were performed on most samples collected during 1993 because of the extensive areas with elevated nitrate concentrations originating from onand offsite sources. Selected monitoring wells were used for additional chemical surveillance. Chemical sampling wells were chosen by considering the results of previous chemical analyses and the proximity to known active and inactive chemical disposal sites. Table 5.29 lists major contaminants found in each area and the type of operation that generated the contaminants.

\section{Data Interpretation}

Each analysis of a ground-water sample provides information on the composition of ground water at one time at one location in the aquifer. Uncertainty in the analyses results from a number of sources. Some of the 
Table 5.28. Radionuclides and Chemicals Analyzed for in Ground Water

\begin{tabular}{|c|c|}
\hline $\begin{array}{l}\text { Radiological } \\
\text { Parameters }\end{array}$ & Chemical Parameters \\
\hline${ }^{3} \mathrm{H}$ & $\mathrm{pH}$ (field and laboratory) \\
\hline${ }^{14} \mathrm{C}$ & Conductance (field) \\
\hline${ }^{60} \mathrm{Co}$ & Alkalinity \\
\hline${ }^{90} \mathrm{Sr}$ & Total carbon \\
\hline${ }^{99} \mathrm{Tc}$ & Total organic carbon \\
\hline${ }^{103} \mathrm{Ru}$ & Total organic halogens \\
\hline${ }^{106} \mathrm{Ru}$ & $\mathrm{B}, \mathrm{Be}, \mathrm{Na}, \mathrm{Mg}, \mathrm{Al}, \mathrm{K}, \mathrm{Co}, \mathrm{Si}$ \\
\hline${ }^{125} \mathrm{Sb}$ & $\mathrm{Ca}, \mathrm{V}, \mathrm{Cr}, \mathrm{Mn}, \mathrm{Fe}, \mathrm{Ni}$ \\
\hline${ }^{129} \mathbf{I}$ & $\mathrm{Cu}, \mathrm{Zn}, \mathrm{Sr}, \mathrm{Ag}, \mathrm{Cd}, \mathrm{Sb}, \mathrm{Ba}$ \\
\hline${ }^{13} \mathbf{I}$ & $\mathrm{F}, \mathrm{Cl}^{-}, \mathrm{NO}_{3}^{-}, \mathrm{PO}_{4}^{-3}, \mathrm{SO}_{4}^{-2}, \mathrm{NO}_{2}^{-}, \mathrm{Br}^{-}$ \\
\hline${ }^{137} \mathrm{Cs}$ & $\mathrm{CN}^{-}$ \\
\hline${ }^{241} \mathrm{Am}$ & $\mathrm{NH}_{4}^{+}$ \\
\hline Total alpha & Volatile organic compounds (VOCs) \\
\hline Total beta & Semivolatile organic constituents \\
\hline Plutonium isotopes & PCBs \\
\hline Uranium isotopes & Dioxins/furans \\
\hline \multirow[t]{3}{*}{ Uranium (total) } & Pesticides/herbicides \\
\hline & Biological oxygen demand/chemical oxygen demand \\
\hline & Dissolved oxygen \\
\hline
\end{tabular}

sources of uncertainty are discussed below. Several techniques used in this discussion to interpret the sample results, given these uncertainties, are also discussed.

Sampling techniques are designed to provide a sample that is reasonably representative of the constituent concentration in the aquifer when the sample is taken. However, there are limitations in collecting representative samples or even defining precisely the volume of the aquifer represented by the sample. Proper well construction and maintenance, well purging, sample preservation, and, in some instances, filtering are used to help ensure consistent and representative samples. Careful sample labeling protocols, chain-of-custody documentation, and bottle preparation avoid many gross errors in sample results. Duplicate samples and field blanks are used to assess the sampling procedure.
Uncertainties are inherent in laboratory analysis of samples. Gross errors can be introduced in the laboratory or during sampling. Gross errors include transcription errors, calculation errors, mislabeling results, or other errors that result from not following established procedures. Often, these gross errors can be recognized because unreasonably high or unreasonably low values result. Data review protocols are used to investigate and correct gross errors. Even if the source of a possible gross error cannot be identified, a marker is entered into the database indicating the review has occurred and the datum may be suspect.

Random errors are unavoidably introduced in the analytical procedures. Usually there are insufficient replicate analyses to assess the overall random error at each sample location. Instruments for analysis of radioactive constituents count the number of radioactive 
Table 5.29. Major Chemical and Radiological Ground-Water Contaminants and Their Link to Site Operations

$\frac{\text { Facilities Type }}{\text { Reactor operations }}$
Irradiated fuel processing
Plutonium purification

Fuel fabrication

\begin{tabular}{c} 
Area \\
\hline 100 \\
200
\end{tabular}

200

300

\section{Constituents Generated}

Tritium, ${ }^{60} \mathrm{Co},{ }^{90} \mathrm{Sr}, \mathrm{Cr}^{+6}, \mathrm{SO}_{4}^{-2}$

Tritium, ${ }^{90} \mathrm{Sr},{ }^{99} \mathrm{Tc},{ }^{129} \mathrm{I},{ }^{137} \mathrm{Cs}, \mathrm{Pu}, \mathrm{U}, \mathrm{CN}^{-}, \mathrm{Cr}^{+6}, \mathrm{~F}^{-}, \mathrm{NO}_{3}^{-}$

$\mathrm{Pu},{ }^{241} \mathrm{Am}$, carbon tetrachloride, chloroform, $\mathrm{NO}_{3}^{-}$

${ }^{99} \mathrm{Tc}, \mathrm{U}, \mathrm{Cr}^{+6}, \mathrm{Cu}$, trichloroethylene decay products at a detector, and background counts are subtracted out. The nature of radioactive decay and the instrument design result in a random counting error, which is reported with the analytical result. Generally, sample results less than the counting error indicate the constituent was not detected. The background subtraction may result in the reporting of results that are less than zero. Although below-zero results are physically impossible, the negative values are of use for some statistical analyses.

Systematic errors may result from instrument calibration, standard or sample preparation, chemical interferences in analytical techniques, as well as sampling methodology and sample handling. Sample and laboratory protocols have been designed to minimize systematic errors. The laboratories used by the Ground-Water Surveillance and other programs participate in interlaboratory comparisons in which many laboratories analyze blind samples prepared by the EPA. The laboratories used have compared favorably with other laboratories, indicating that systematic error is within acceptable limits.

In 1993, double-blind samples for specific constituents were analyzed as part of the Ground-Water Surveillance Program (see Section 7.0, "Quality Assurance," for further discussion of double-blind results). Several wells were also cosampled with the Washington State Department of Health for intercomparison. Cosampling data results for 1993 will be presented in the Environmental Radiation 1993 Annual Report, published by the Washington State Department of Health (DOH 1994).

The chemical composition of ground water may fluctuate from differences in the contaminant source, recharge, or the ground-water flow-field. The range of this concentration fluctuation can be estimated by taking many samples, but there is a limit to the number that can be practicably taken. Comparison of results through time help interpret this natural variability.

Overall sample uncertainty may be factored into data evaluation by considering the concentration trend in a given well over time. This often helps identify gross errors, and overall long-term trends can be distinguished from short-term variability. The interpretation of concentration trends depends on an understanding of chemical properties as well as site hydrogeology. The trend analysis in turn aids in refining the conceptual model of the chemical transport.

Plume maps presented in this section are diagrammatic representations of the interpretation of Site ground-water chemistry. Although analytical data are only available at specific points where wells were sampled, contours are drawn to join the approximate locations of equal chemical concentration or radionuclide activity. The contour maps are simplified representations of plume geometry because of map scale, the lack of detailed information, and the fact that plume depth and thickness cannot be fully represented on a two-dimensional map. Plume maps are a powerful tool because knowledge of concentrations in surrounding wells, ground-water flow, site geology, and other available information may be factored into the preparation. Integration of data from multiple sources minimizes the impact of uncertainty or error in any particular sample. 


\section{Results}

Ground-water monitoring information obtained for the RCRA monitoring program is reported by DOE (DOE 1993b), and information on drinking water supplies on the Hanford Site is reported by the Hanford Environmental Health Foundation (e.g., Thurman 1992). Onsite drinking water supply wells at the FFTF are discussed in Section 6.0, "Potential Radiation Doses from 1993 Hanford Operations." Information gathered in support of the CERCLA program is reported in remedial investigation reports (e.g., DOE 1992e). Sitewide ground-water monitoring results for the year are detailed in the Ground-Water Surveillance Programs' annual report (e.g., Dresel et al. 1993). Highlights of these results are discussed below.

One way to assess the impact of radionuclides and chemicals in ground water is to compare the concentrations to EPA's Drinking Water Standards and DOE's Derived Concentration Guides (Tables C.2, C.3, and C.6, Appendix C). Derived Concentration Guides are presented in DOE Order 5400.5. Specific drinking water standards have only been proposed for a few radiological constituents at the time this report was prepared.

Drinking water standards have been calculated for other radionuclides by considering the half-life of the isotope, the energy and nature of the radioactive decay for that isotope, and physiological factors such as the buildup of the isotope in particular organs. Drinking water standards are more restrictive than the Derived Concentration Guides because the Drinking Water Standards are based on an annual dose to the affected organ of $4 \mathrm{mrem} / \mathrm{yr}$ and the Derived Concentration Guides are based on an effective dose equivalent of $100 \mathrm{mrem} / \mathrm{yr}$ (see Appendix C, "Applicable Standards and Permits"). The Derived Concentration Guides are available only for radionuclides. Primary and secondary Drinking Water Standards may be given for some chemical constituents. Secondary Drinking Water Standards are based on aesthetic rather than health considerations.

\section{Radiological Monitoring Results for the Unconfined Aquifer}

Radionuclides analyzed in ground water are listed in Table 5.28. Ruthenium-103, ${ }^{106} \mathrm{Ru}$, and ${ }^{131} \mathrm{I}$ have relatively short half-lives and historically have been detected near operating reactors or liquid waste disposal facilities near active fuel reprocessing facilities. These radionuclides have not been observed in concentrations above the Drinking Water Standards, and in general, have not been detected since soon after the shutdown of $\mathrm{N}$ Reactor and the PUREX Plant. The detection limit for ${ }^{106} \mathrm{Ru}$ by gamma scan is higher than the Drinking Water Standard but the half-life of only 1 year indicates that it decays rapidly to concentrations less than the Drinking Water Standard. Gross (total) alpha and beta are used as indicators of radionuclide distribution and are not discussed in detail because the specific radionuclides contributing to these measurements are discussed. The distribution of ${ }^{3} \mathrm{H},{ }^{60} \mathrm{Co},{ }^{90} \mathrm{Sr},{ }^{99} \mathrm{Tc},{ }^{125} \mathrm{Sb},{ }^{129} \mathrm{I},{ }^{137} \mathrm{Cs}$, uranium, and plutonium will be discussed in the following sections. The types of operation resulting in the release of these radionuclides to ground water are listed in Table 5.29. The table also lists the locations where these operations were performed.

\section{Tritium}

Tritium was present in many waste streams discharged to the soil column and is the most mobile radionuclide onsite. As a result, ${ }^{3} \mathrm{H}$ reflects the extent of contamination in the ground water from Site operations and is the radionuclide most frequently monitored at the Hanford Site. Significant quantities of ${ }^{3} \mathrm{H}$ are associated with irradiation of nuclear fuel. The source of the ${ }^{3} \mathrm{H}$ is generally believed to be low-yield ternary fission (rare events, in which the nucleus decays into three atomic fragments) although irradiation of lithium impurities in the fuel could also be responsible. Tritium is released through decladding and dissolution of the fuel. Process condensates associated with the elevated temperature portions of the fuel processing cycle provide a release pathway for that ${ }^{3} \mathrm{H}$. Figure 5.47 shows the 1993 distribution of ${ }^{3} \mathrm{H}$ in the unconfined aquifer resulting from over 47 years of Site operations.

Tritium in the 100 Areas. Tritium concentrations greater than the 20,000-pCi/L Drinking Water Standard were detected in the $100-\mathrm{D}, 100-\mathrm{F}, 100-\mathrm{K}$, and $100-\mathrm{N}$ Areas. Tritium concentrations greater than the Drinking Water Standard were detected in five wells in the 100$\mathrm{D}$ Area. The maximum ${ }^{3} \mathrm{H}$ level reported was $73,000 \mathrm{pCi} / \mathrm{L}$ in monitoring well 199-D5-18. Many of the wells were installed recently by the CERCLA program, and long-term trend data are unavailable.

Only one well in the 100-F Area (199-F8-3) contained ${ }^{3} \mathrm{H}$ at concentrations greater than the Drinking Water Standard. This is the first year ${ }^{3} \mathrm{H}$ at levels greater than the Drinking Water Standard has been detected in the $100-\mathrm{F}$ Area. The level of $180,000 \mathrm{pCi} / \mathrm{L}$ is nine times 


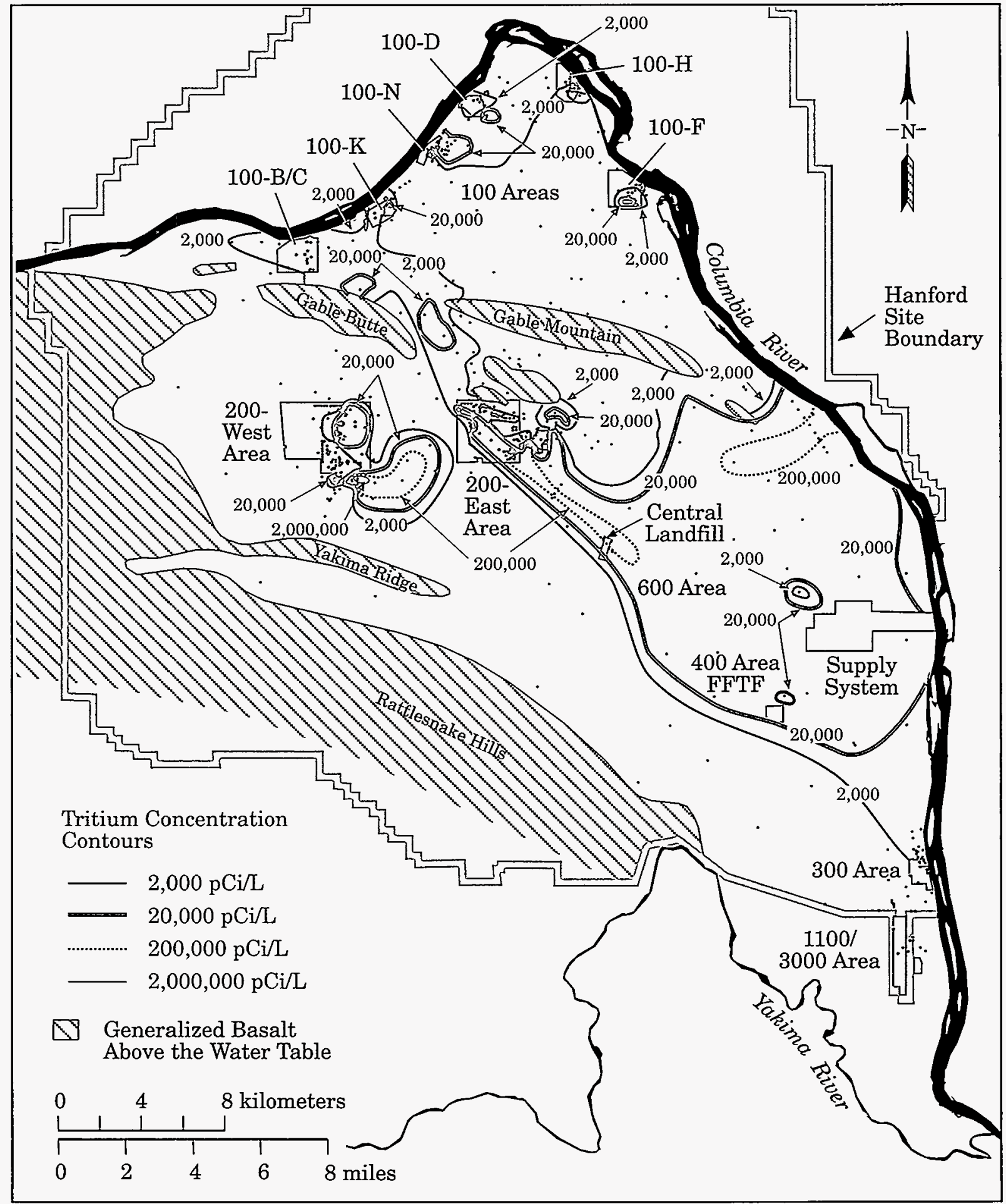

S9402063.4

Figure 5.47. Tritium $\left({ }^{3} \mathrm{H}\right)$ Concentrations in the Unconfined Aquifer, 1993 
the Drinking Water Standard. Contamination specific to the 100-F Area is being addressed by the CERCLA Program.

The 100-K Area well, 199-K-30, continued to contain the highest ${ }^{3} \mathrm{H}$ concentration within the 100 Areas, with a maximum concentration of $3,320,000 \mathrm{pCi} / \mathrm{L}$ reported in May 1993. This well contained ${ }^{3} \mathrm{H}$ in excess of the Derived Concentration Guide $(2,000,000 \mathrm{pCi} / \mathrm{L})$ on three sample dates in April and May 1993. Concentrations in all other 100-K Area wells remained less than the Derived Concentration Guide. The ${ }^{3} \mathrm{H}$ trend for well 199-K-30 is shown in Figure 5.48. Concentrations in this well fluctuate; the previous high value was in late 1987. Concentrations in well 199-K-27 also generally stayed greater than the Drinking Water Standard, with a maximum concentration of $359,000 \mathrm{pCi} / \mathrm{L}$ observed in 1993. Leakage of the K-East fuel storage basin is a likely source of ${ }^{3} \mathrm{H}$ in this area. An unusual occurrence report for this leakage was filed in February 1993 (see Section 2.4). Another potential source is past disposal to a french drain east of the reactor building (DOE 1993a).

Tritium in the 100-N Area is found in concentrations greater than the Drinking Water Standard in the northern part of the area, extending to the surrounding 600 Area. This plume is associated with two liquid waste disposal trenches, 1301-N Liquid Waste Disposal Facility and 1325-N Liquid Waste Disposal Facility. The maximum ${ }^{3} \mathrm{H}$ level reported in the $100-\mathrm{N}$ Area in 1993 was $104,000 \mathrm{pCi} / \mathrm{L}$. This value was approximately $25 \%$ higher than a replicate collected at the same time $(73,000 \mathrm{pCi} / \mathrm{L})$ and is higher than the time-series trend for the well; therefore, laboratory error is suspected.

Tritium in the 200 Areas. The highest ${ }^{3} \mathrm{H}$ concentrations in the 200-East Area continued to be in wells near cribs that received effluent from the PUREX Plant. Concentrations greater than the $2,000,000-\mathrm{pCi} / \mathrm{L}$ Derived Concentration Guide were detected in only one well in the 200-East Area, 299-E17-9. In 1993, the ${ }^{3} \mathrm{H}$ level detected in this well monitoring the 216-A-36B Crib was $3,540,000 \mathrm{pCi} / \mathrm{L}$. The ${ }^{3} \mathrm{H}$ trend in this well is shown in Figure 5.49. Concentrations in wells monitoring downgradient of the 216-A-10 Crib decreased to less than the Derived Concentration Guide in 1993. Tritium concentrations exceeding the Drinking Water Standard continued to occur in many wells affected by cribs near the PUREX Plant.
The movement of the widespread ${ }^{3} \mathrm{H}$ plume (see Figure 5.47) extending from the southeastern portion of the 200-East Area to the Columbia River was consistent with patterns noted earlier (Dresel et al. 1993; Woodruff et al. 1992). Separate ${ }^{3} \mathrm{H}$ pulses associated with the two episodes of PUREX operations can be distinguished in the plume. The $200,000-\mathrm{pCi} / \mathrm{L}$ lobe east of the 200-East Area near the Columbia River is a result of discharges to ground water during the operation of the PUREX Plant from 1956 to 1972 . Following an 11-year shutdown, plant operation began again in 1983 and ceased in December 1988. Elevated ${ }^{3} \mathrm{H}$ concentrations measured in several wells (e.g., wells 699-32-43 and 699-24-33) downgradient from the 200-East Area represent a second pulse of ${ }^{3} \mathrm{H}$ moving away from PUREX waste disposal facilities. Movement of the leading edge of this plume is clearly observable in well 699-24-33, Figure 5.50, which shows arrival of the plume in early 1987 following the passage of the plume from the earlier campaign. Tritium concentrations from the first plume were much higher than from the second. By contrast, a trend plot of the ${ }^{3} \mathrm{H}$ concentrations in well 699-40-1 located near the shore of the Columbia River (Figure 5.51) shows the arrival in the mid 1970s of the plume from the first campaign and no indication that the second pulse has yet arrived.

The ${ }^{3} \mathrm{H}$ plume resulting from Site activities has been monitored for much of the time the Site has been in operation, providing information on the change in extent of contamination over time. Figure 5.52 shows the extent of ${ }^{3} \mathrm{H}$ from 1964 to 1988 . This figure was created from maps in Wilson 1965; Raymond et al. 1976; Prater et al. 1984; and Jaquish and Bryce 1989. The contours in the original references were recalculated and interpreted to provide uniform contour intervals. Figure 5.52 shows that ${ }^{3} \mathrm{H}$ at concentrations greater than the Drinking Water Standard reached the Columbia River in approximately the mid 1970s.

The eastern portion of the ${ }^{3} \mathrm{H}$ plume continues to move to the east-southeast and discharge into the Columbia River. Figure 5.53 shows the trend of ${ }^{3} \mathrm{H}$ concentrations in well 699-S19-E13, located just north of the 300 Area. In recent years, this well has shown a general increase in ${ }^{3} \mathrm{H}$, reaching a maximum value of $12,200 \mathrm{pCi} / \mathrm{L}$ in February 1993. The plume has reached the 300 Area but is not expected to move farther south because of the influence on ground-water flow from the Yakima River and recharge at the North Richland Wellfield. The 


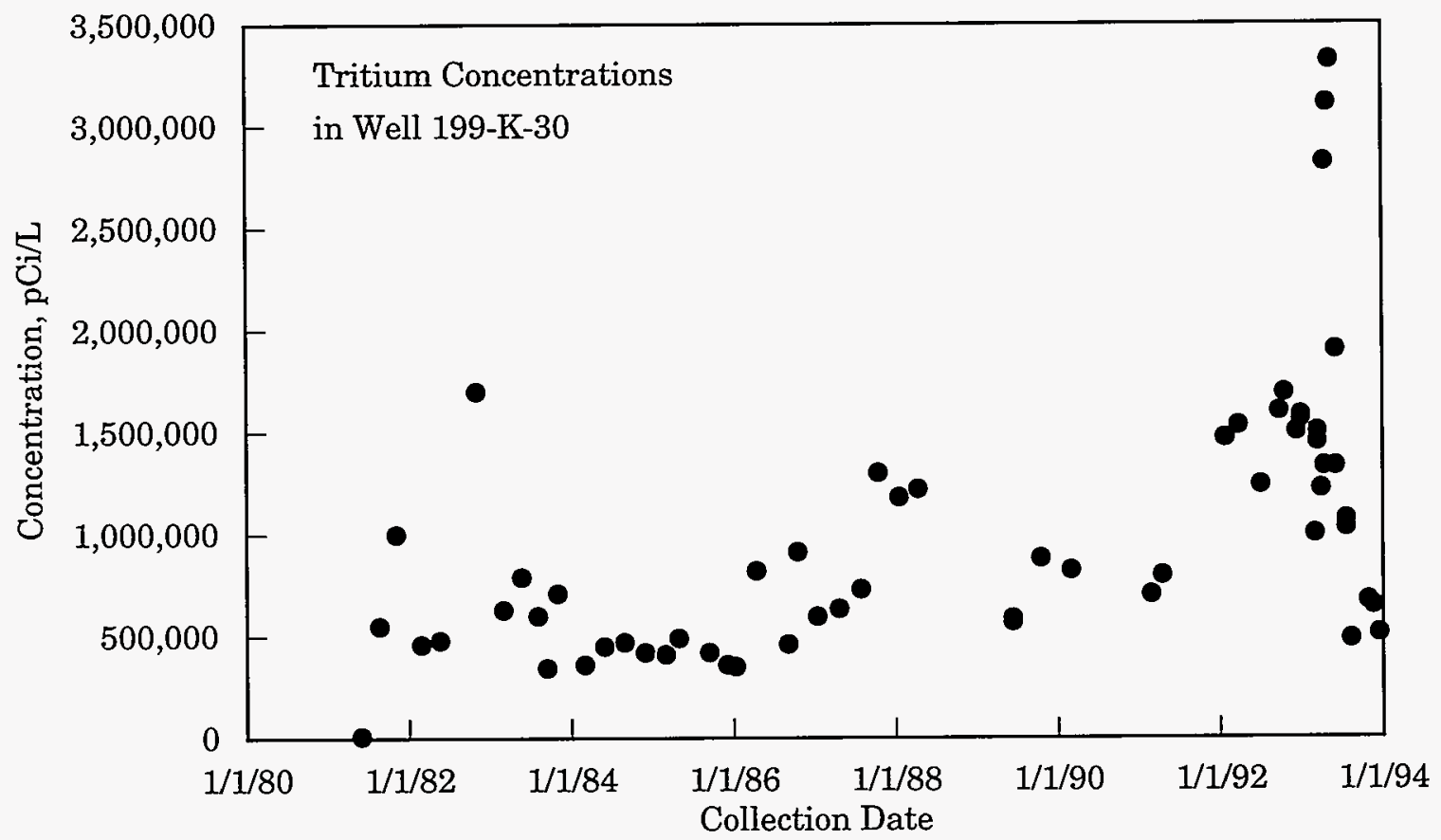

59402063.22

Figure 5.48. Tritium $\left({ }^{3} \mathrm{H}\right)$ Concentrations in Well 199-K-30, 1981 Through 1993

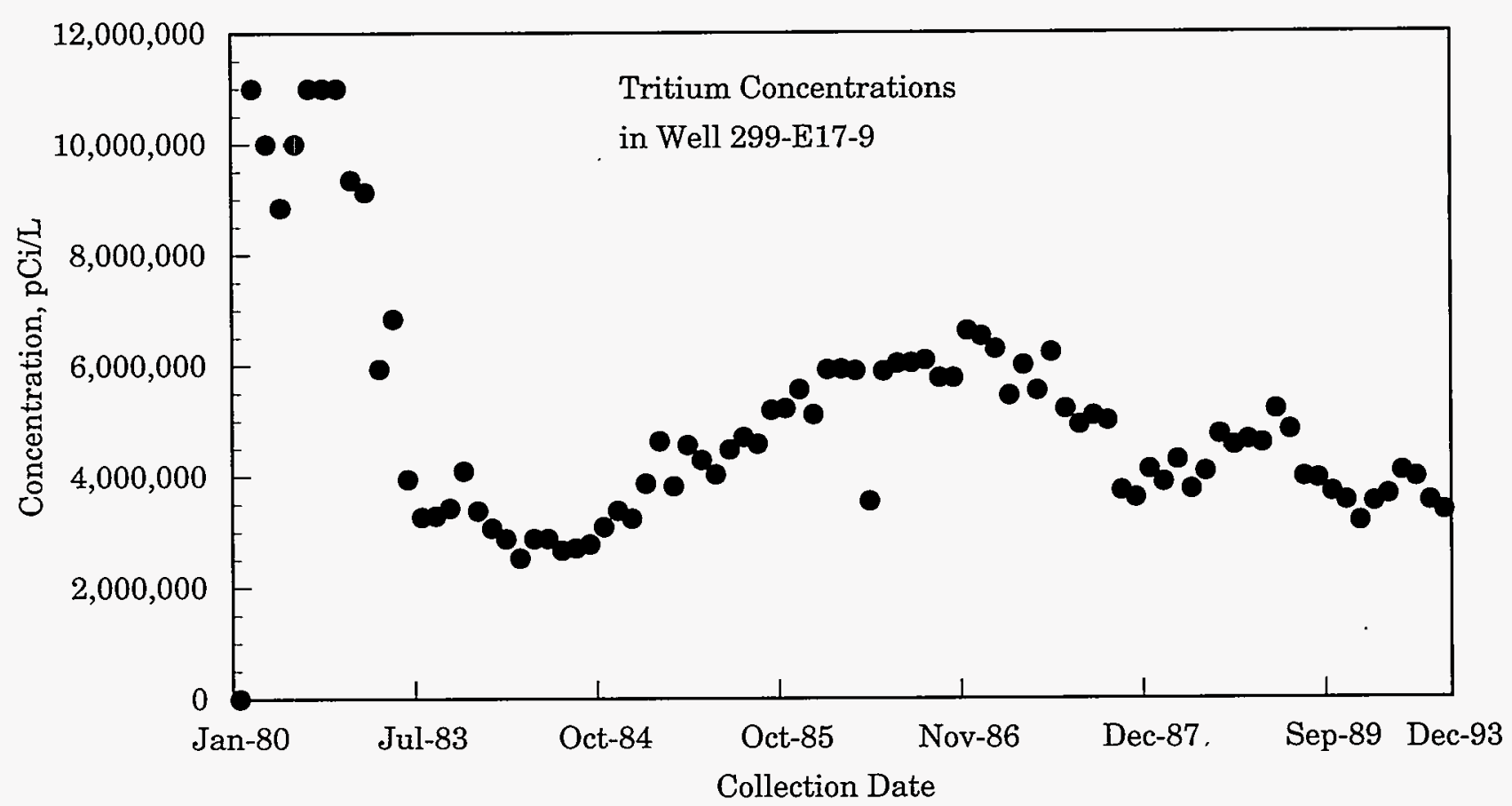

S9402063.144

Figure 5.49. Tritium $\left({ }^{3} \mathrm{H}\right)$ Concentrations in Well 299-E17-9, 1980 Through 1993 


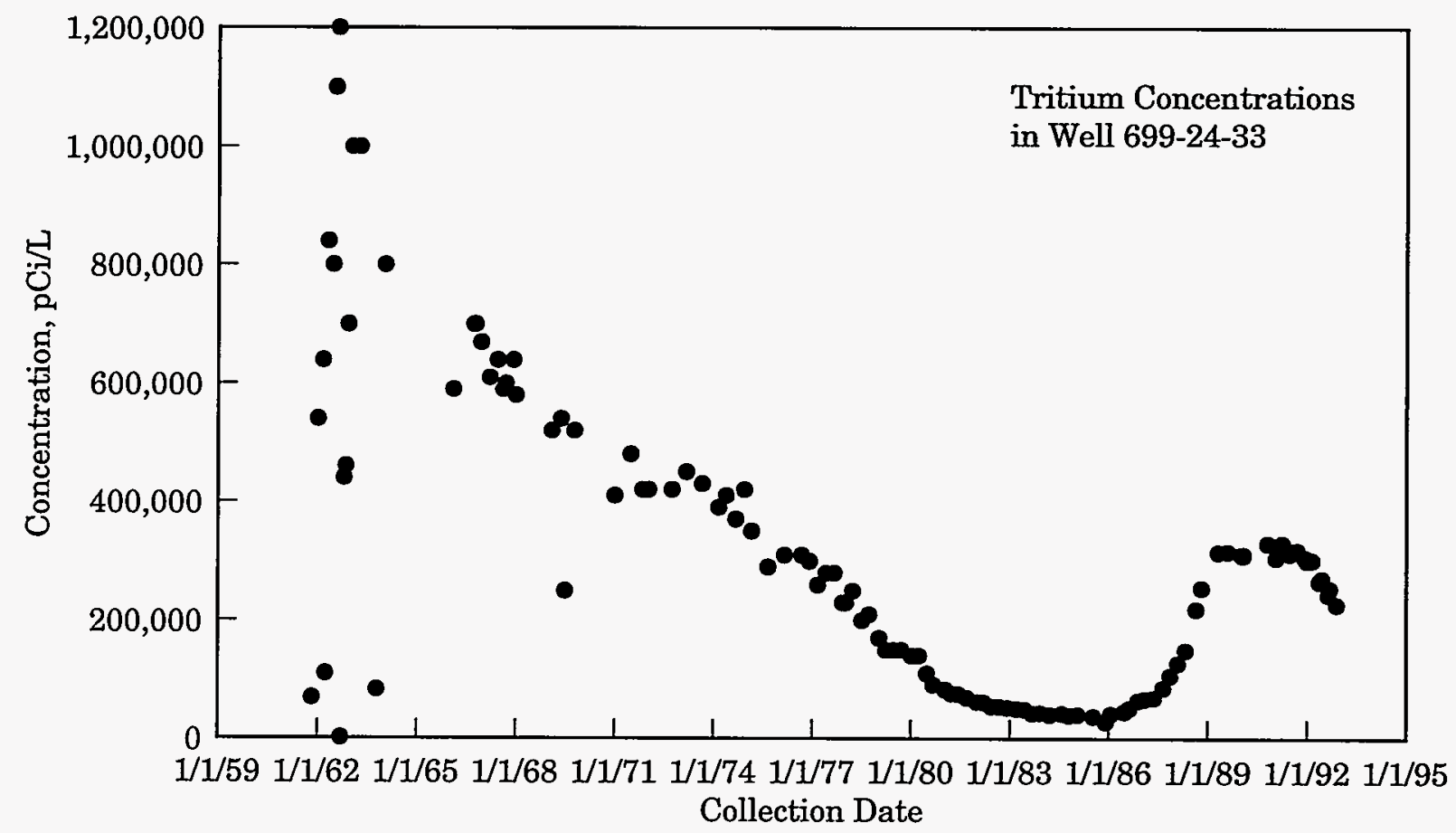

S9402063.18

Figure 5.50. Tritium $\left({ }^{3} \mathrm{H}\right)$ Concentrations in Well 699-24-33, 1962 Through 1993

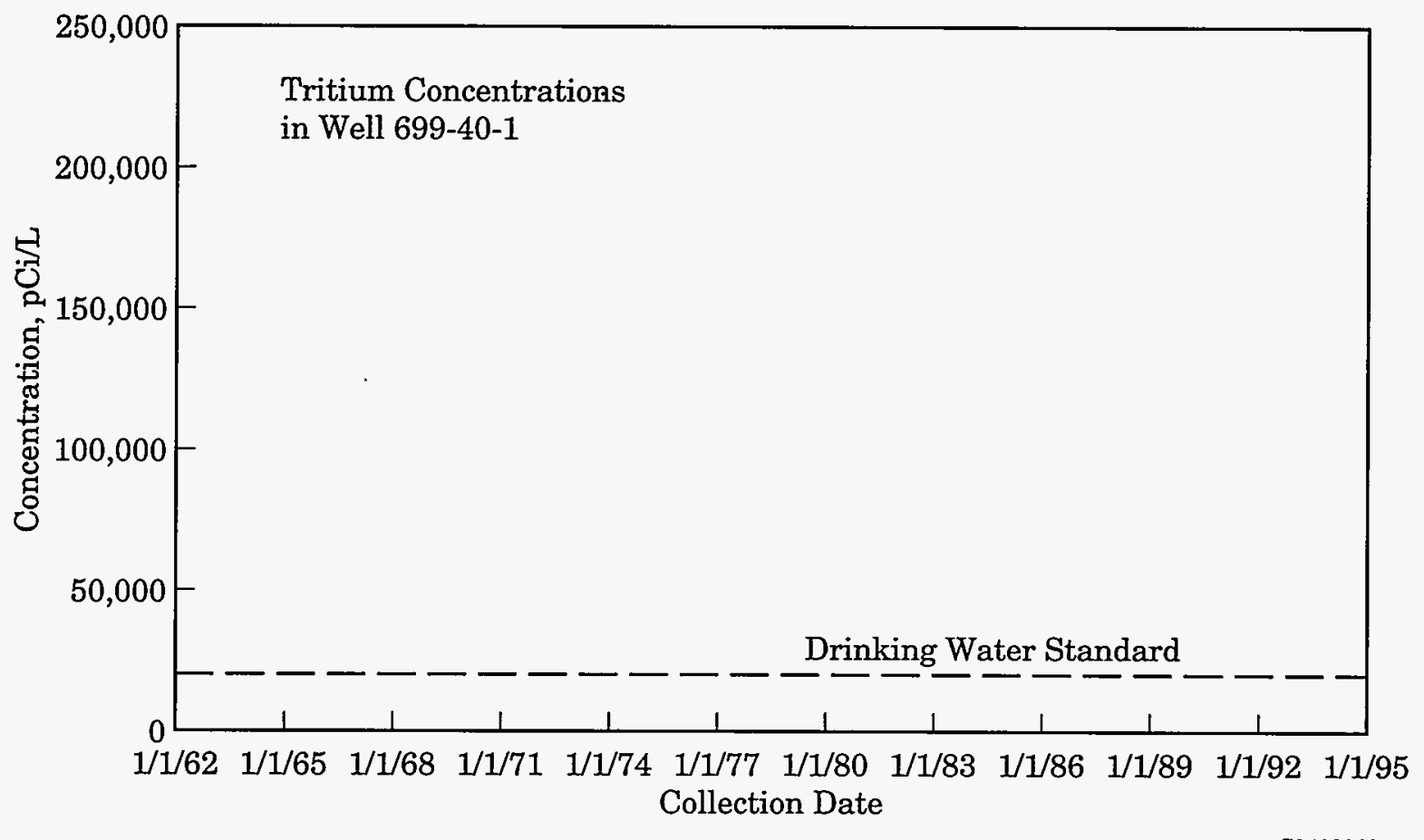

Figure 5.51. Tritium $\left({ }^{3} \mathrm{H}\right)$ Concentrations in Well 699-40-1, 1962 Through 1993 

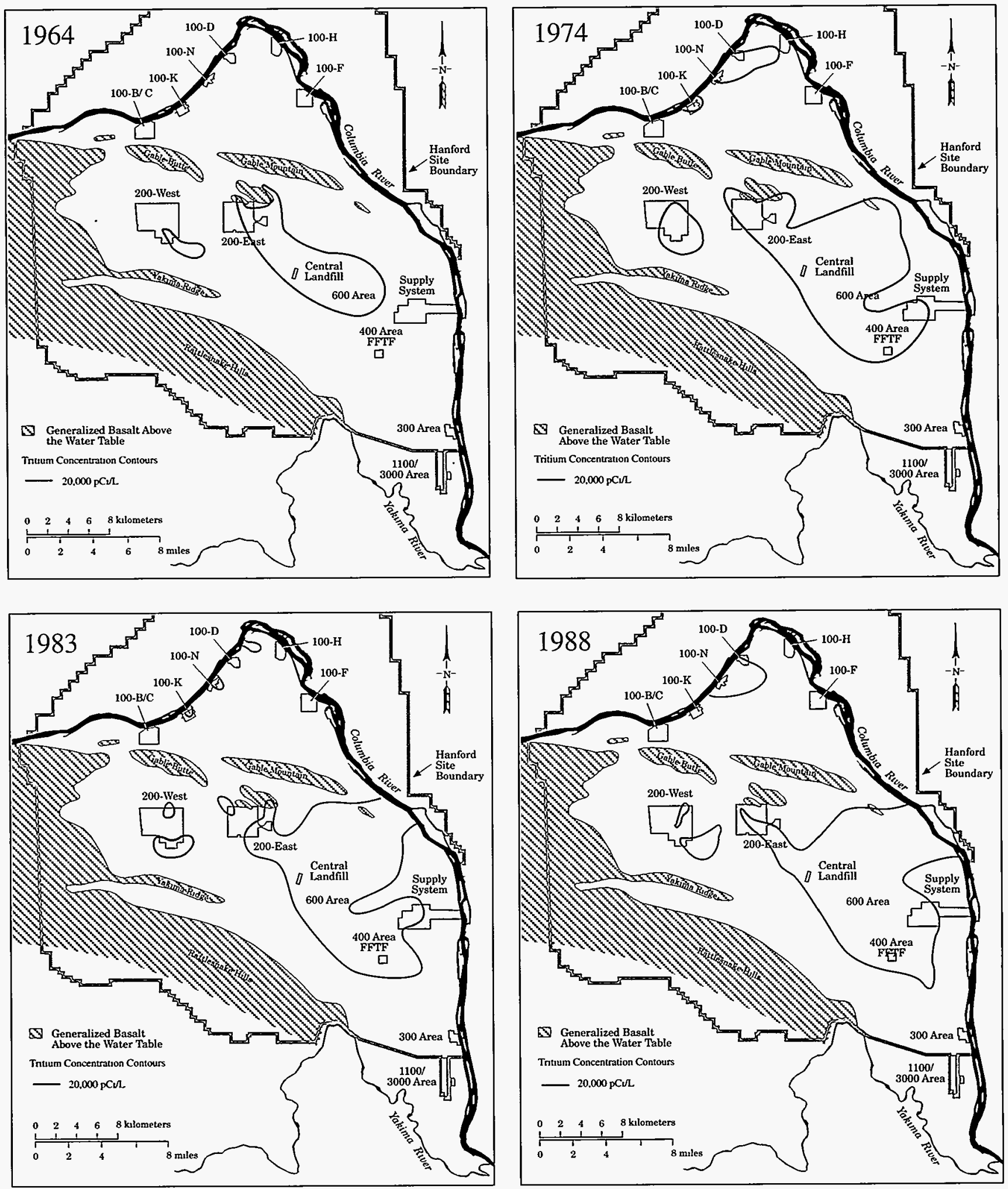

S9402063.76

Figure 5.52. Historical Tritium $\left({ }^{3} \mathrm{H}\right)$ Concentrations on the Hanford Site 


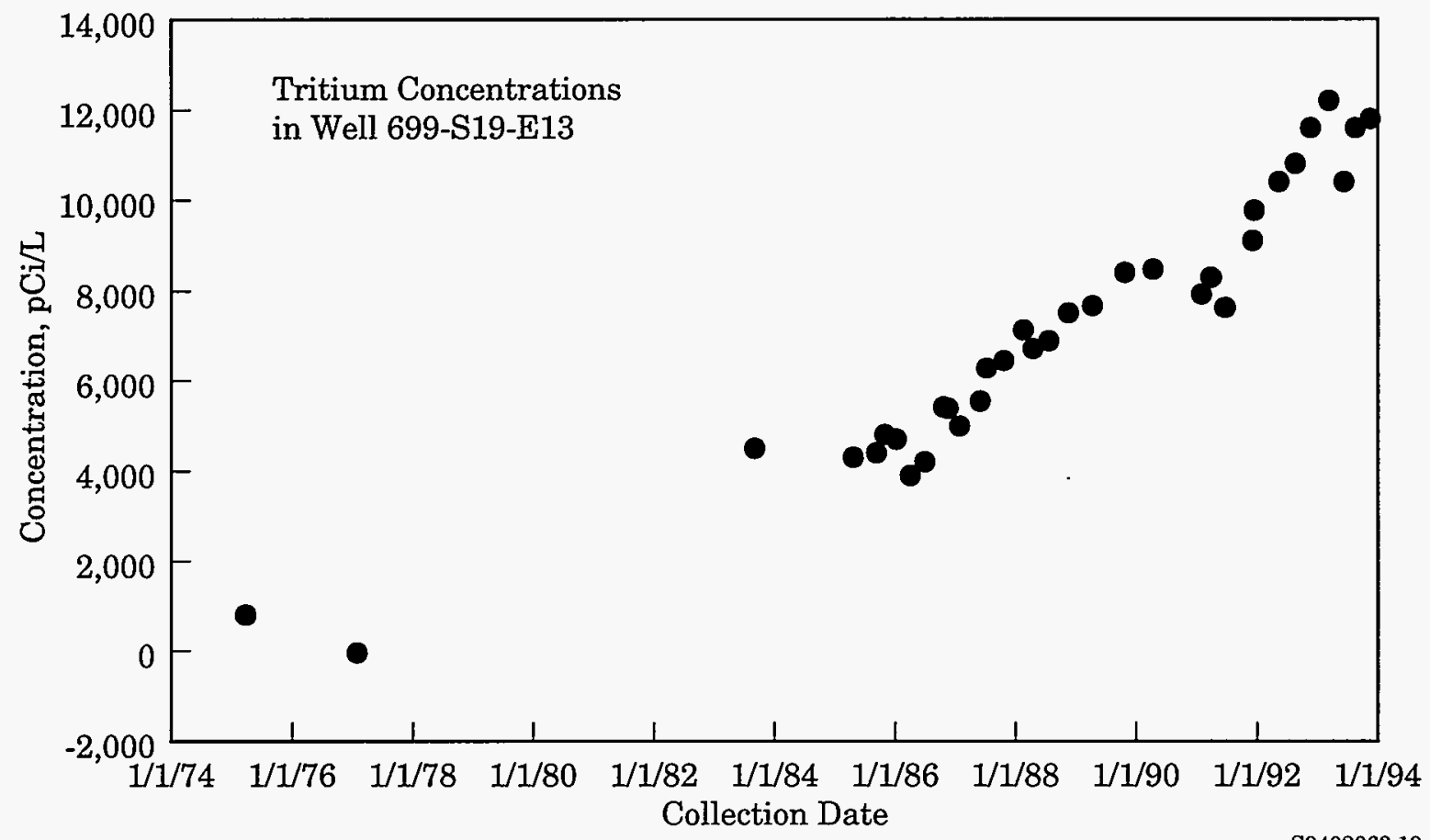

Figure 5.53. Tritium $\left({ }^{3} \mathrm{H}\right)$ Concentrations in Well 699-S19-E13, 1975 Through 1993

Yakima River is at a higher elevation and recharges the ground water in this area, which discharges to the Columbia River (Newcomer et al. 1991). As a result, as shown in Figure 5.54, ground water flows from west to east, limiting the extent of southward movement of the contaminant plume. Recharge ponds at the North Richland Wellfield are supplied with Columbia River water, which infiltrates to the ground water. The amount of recharge water exceeds the amount pumped at the wellfield, resulting in ground-water flow away from the wellfield. This further ensures that the Site ground water will not reach the wellfield.

The configuration of the western portion of the ${ }^{3} \mathrm{H}$ plume closely matches previous predictions of the direction of contaminant movement from the 200-East Area (Freshley and Graham 1988). Movement is forced to the south by the flow originating at the ground-water mound beneath $\mathrm{B}$ Pond. The water table near $\mathrm{B}$ Pond continues to rise as a result of the increased discharge of water to B Pond from 1984, when Gable Mountain Pond was deactivated, to 1988 . Flow to the southeast also appears to be promoted by a zone of high-permeability sediments stretching from the 200-East Area toward the 400 Area (Jacobson and Freshley 1990). The mound under B Pond is expected to start to dissipate in 1995 as flow is diverted to the treated effluent disposal facility. A new mound will presumably form farther east under the treated effluent disposal facility as long as it is used for disposal of Site effluent.

The extent of ${ }^{3} \mathrm{H}$ plumes in and around the 200-West Area is also consistent with previous observations. Tritium from sources near the Reduction-Oxidation (REDOX) Plant forms the most extensive and highest concentration plume in the 200-West Area. The REDOX Plant is located in the southeastern part of the 200-West Area and operated from 1951 through 1967. Only one well in the 200-West Area (299-W22-9) continued to show ${ }^{3} \mathrm{H}$ levels in excess of the Derived Concentration Guide during 1993; however, that well contained $3,590,000 \mathrm{pCi} / \mathrm{L}$, the highest ${ }^{3} \mathrm{H}$ of any ground-water monitoring well on the Site. The ${ }^{3} \mathrm{H}$ concentrations detected in well 299-W22-9 have decreased steadily since 1977 (Figure 5.55). The movement of ground water in the 200-West Area is slow because the Ringold 


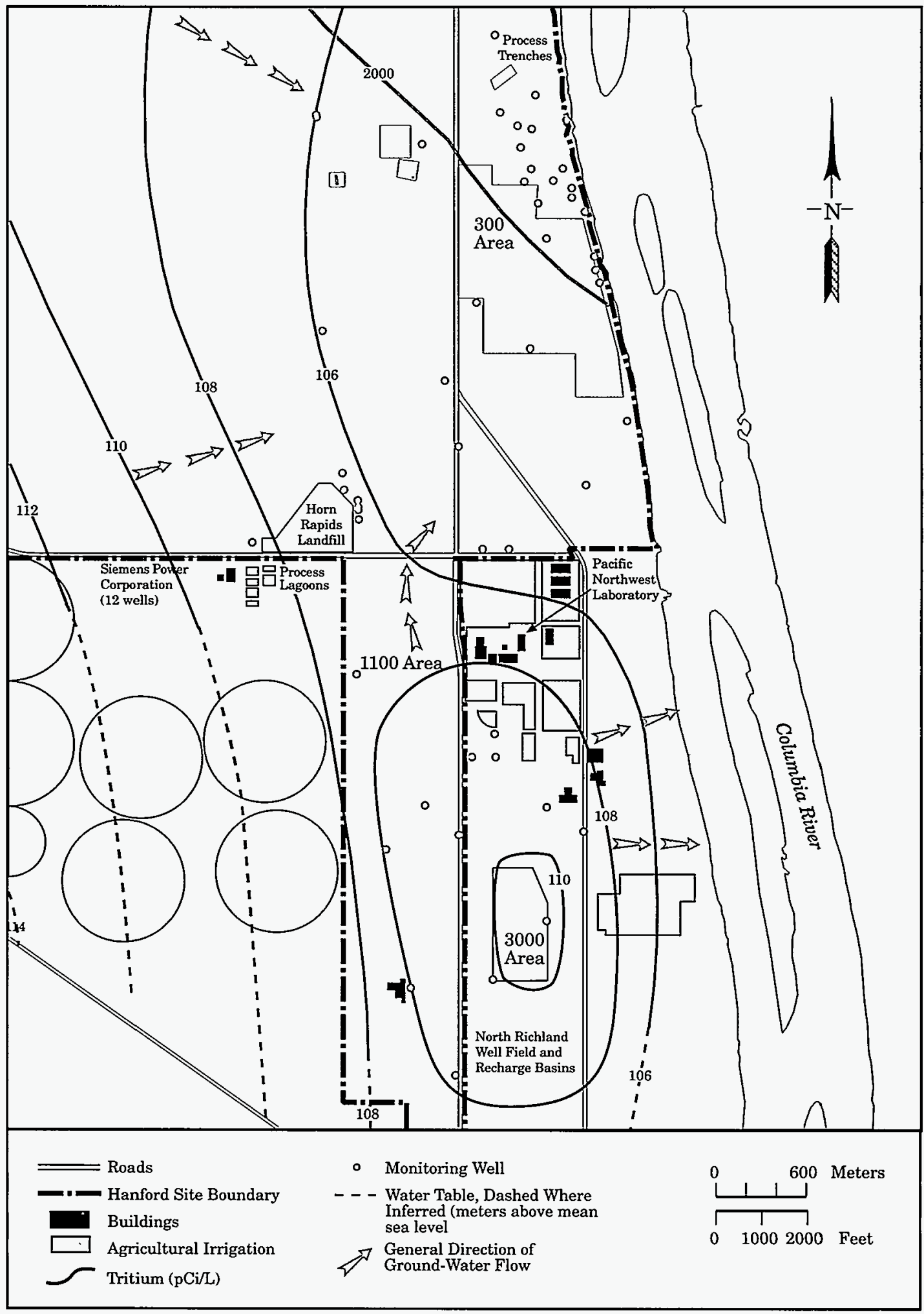

S9402063.66

Figure 5.54. Tritium $\left({ }^{3} \mathrm{H}\right)$ Concentrations Near the 300 Area, 1993 


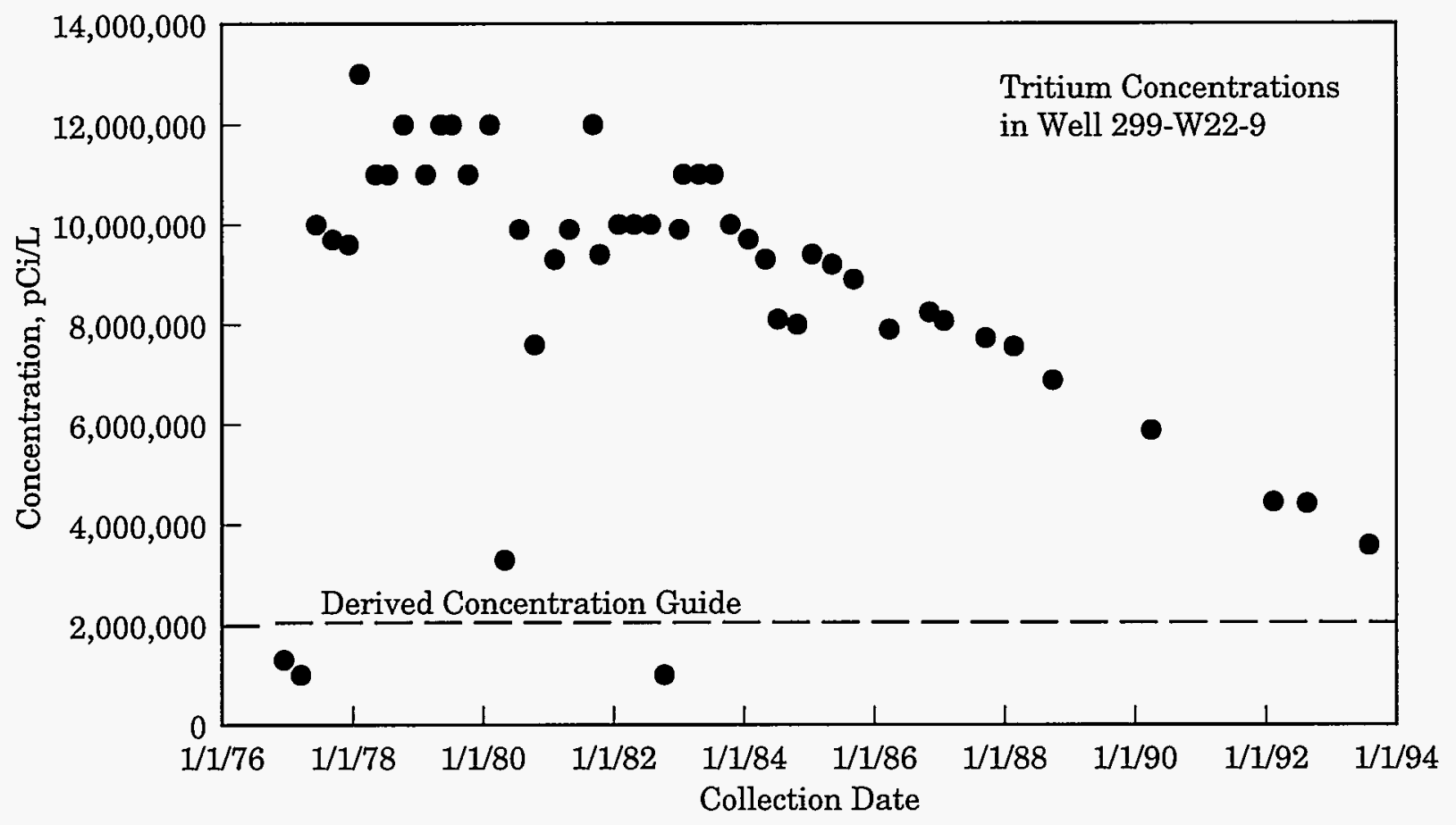

Figure 5.55. Tritium $\left({ }^{3} \mathrm{H}\right)$ Concentrations in Well 299-W22-9, 1976 Through 1993

sediments beneath the water table have low permeability. Dissipation of the plumes in the 200-West Area is also slow as a result of declining gradients since the closure of U Pond in 1984.

\section{Cobalt-60}

Cobalt-60 is a neutron activation product typically associated with wastes generated by processing of reactor effluent water. Cobalt-60 is normally present as a divalent transition metal cation and as such tends to be highly immobile in ground water but may be mobilized by complexing agents.

Cobalt-60 results reported in 1993 were generally at or below the detection limit of approximately $20 \mathrm{pCi} / \mathrm{L}$. The only values greater than the Drinking Water Standard of $100 \mathrm{pCi} / \mathrm{L}$ were reported in $100-\mathrm{N}$ Area wells $199-\mathrm{N}-33(423 \mathrm{pCi} / \mathrm{L})$ and $199-\mathrm{N}-49$ $(1,310 \mathrm{pCi} / \mathrm{L})$. Both values were considerably higher than previous results but less than the Derived Concentration Guide of 5,000 $\mathrm{pCi} / \mathrm{L}$. Two of the four 1993 samples from well $199-\mathrm{N}-34$ were greater than the detection limit, but less than the Drinking Water Standard. The water levels in these wells have declined to near the bottom of the well screen because of changes in discharge in the 100-N Area, and the high values appear related to increased suspended solids in the samples. Cobalt-60 adsorbs strongly to aquifer sediments. Thus, although the samples are probably not representative of mobile ground-water concentrations, they indicate that radionuclides continue to be present, adsorbed to solid particles.

Cobalt- 60 was detected near the PUREX Plant in the June 1993 sample from the 200-East Area well 299-E17-16 (65.8 pCi/L). This well consistently shows detectable but low levels of ${ }^{60} \mathrm{Co}$. Several 200-East Area wells near the BY Cribs had low levels of ${ }^{60} \mathrm{Co}$, with the highest reported value of $37 \mathrm{pCi} / \mathrm{L}$ from well

299-E33-12. These levels are associated with a plume that extends into the 600 Area to the northwest; however, the concentrations remained less than the Drinking Water Standard in all 1993 samples. The cobalt in the plume from the BY Cribs is apparently mobilized by reaction with cyanide or ferrocyanide, forming a dissolved cobalt species. It is possible that the cyanide is degrading and 
thus the cobalt is becoming less mobile with time. Only one 200-West Area well, 299-W14-12, contained detectable ${ }^{60} \mathrm{Co}$ in 1993 samples. The highest value reported in this well was $24.0 \mathrm{pCi} / \mathrm{L}$.

\section{Strontium-90}

Strontium-90 is produced as a high-yield fission product and is present in waste streams associated with fuel processing. Reactor operations may also result in the release of some ${ }^{90} \mathrm{Sr}$ associated with fuel element breaches. Strontium-90 is normally observed to have moderately high mobility in Hanford ground water.

Concentrations of ${ }^{90} \mathrm{Sr}$ were greater than the 8-pCi/L Drinking Water Standard in wells in the 100-B, 100-D, $100-\mathrm{F}, 100-\mathrm{H}, 100-\mathrm{K}, 100-\mathrm{N}, 200-E a s t$, and 600 Areas. Concentrations of ${ }^{90} \mathrm{Sr}$ were greater than the $1,000-\mathrm{pCi} / \mathrm{L}$ Derived Concentration Guide in the 100-N and 200-East Areas.

Strontium-90 in the 100 Areas. The extent of ${ }^{90} \mathrm{Sr}$ at levels greater than the Drinking Water Standard in the
100-B Area was defined further in 1992 and 1993. The maximum concentration detected in 1993 was $150 \mathrm{pCi} / \mathrm{L}$ in an April sample from monitoring well 199-B3-46.

The extent of ${ }^{90} \mathrm{Sr}$ greater than the Drinking Water Standard in the 100-B Area is shown in Figure 5.56. The sources for the ${ }^{90} \mathrm{Sr}$ appear to be liquid waste disposal sites near the B Reactor and liquid overflow trenches near the Columbia River (DOE 1993c).

Strontium-90 continues to be detected at levels greater than the Drinking Water Standard in the 100-D Area in well 199-D5-12. The maximum concentration in 1993 was $41 \mathrm{pCi} / \mathrm{L}$. This is the only well in the $100-\mathrm{D}$ Area with ${ }^{90} \mathrm{Sr}$ concentrations greater than the Drinking Water Standard.

Ground water within a small part of the 100-F Area has ${ }^{90} \mathrm{Sr}$ concentrations greater than the Drinking Water Standard. The maximum concentration detected in 1993 was $250 \mathrm{pCi} / \mathrm{L}$ in monitoring well $199-\mathrm{F} 5-3$. The $100-\mathrm{F}$ Area ${ }^{90} \mathrm{Sr}$ plume is shown in Figure 5.57. The extent of ${ }^{90} \mathrm{Sr}$ at levels greater than the Drinking Water Standard in the 100-H Area is also limited, as shown in

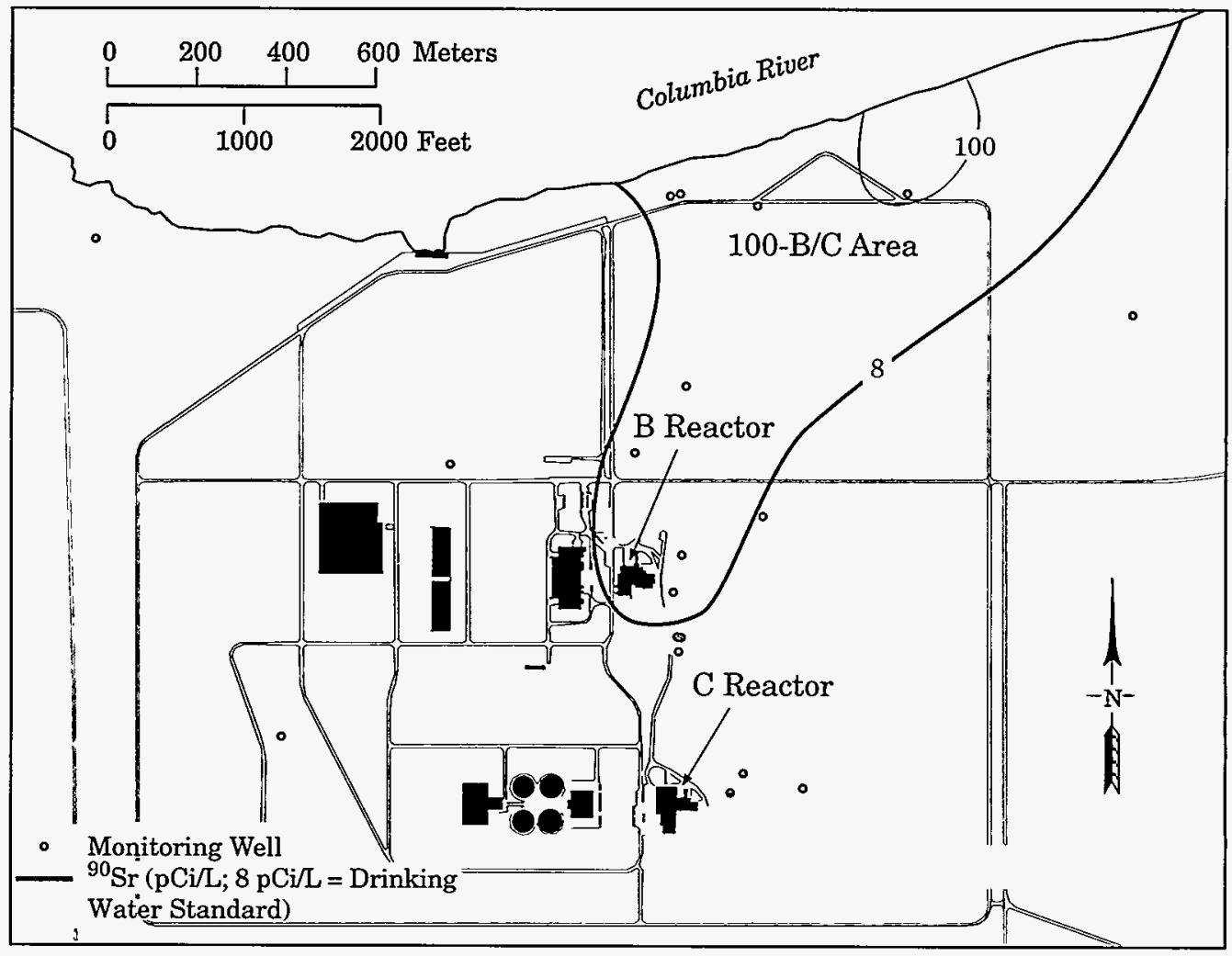

S9402063.7

Figure 5.56. Concentrations of Strontium-90 $\left({ }^{90} \mathrm{Sr}\right)$ in the Unconfined Aquifer in the 100-B Area, 1993 


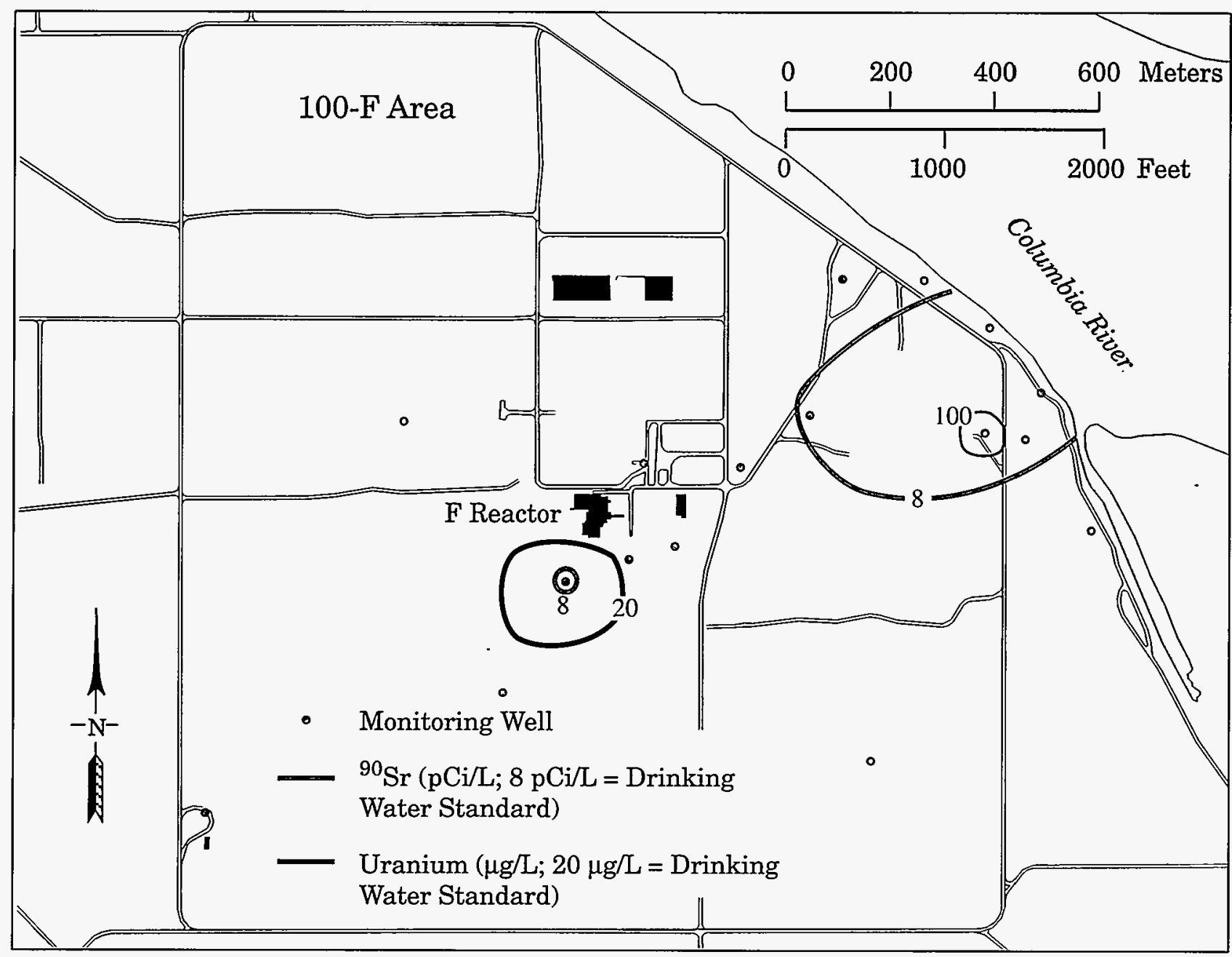

$\$ 9402063.10$

Figure 5.57. Concentrations of Strontium-90 $\left({ }^{90} \mathrm{Sr}\right)$ and Uranium in the Unconfined Aquifer in the 100-F Area, 1993

Figure 5.58. The maximum concentration detected in 1993 was $26 \mathrm{pCi} / \mathrm{L}$ in monitoring well 199-H4-13.

The extent of ${ }^{90} \mathrm{Sr}$ at levels greater than the Drinking Water Standard in the 100-K Area is shown in Figure 5.59. The maximum concentration detected in 1993 was $100 \mathrm{pCi} / \mathrm{L}$ in the March sample from monitoring well 199-K-21 near the Liquid Waste Disposal Trench. Strontium-90 is also found near the K-West reactor building.

Strontium-90 was detected in concentrations up to $6,160 \mathrm{pCi} / \mathrm{L}$ in the $100-\mathrm{N}$ Area in 1993 (well 199-N-67). This well is located between the 1301-N Liquid Waste
Disposal Facility and the Columbia River. The distribution of ${ }^{90} \mathrm{Sr}$ in the 100-N Area is shown in Figure 5.59. Strontium-90 discharges to the Columbia River in the $100-\mathrm{N}$ Area through springs along the shoreline, which are sampled as part of the surface water surveillance and near-facility environmental monitoring programs. The ${ }^{90} \mathrm{Sr}$ plume spread northward in the 1980 s as illustrated by the trend data from well 199-N-14 (Figure 5.60). The ${ }^{90} \mathrm{Sr}$ concentrations in this well have remained approximately level since 1989. Wells farther northeast do not show detectable ${ }^{90} \mathrm{Sr}$. The steady levels indicate the plume is not spreading at any discernible rate at this time. 


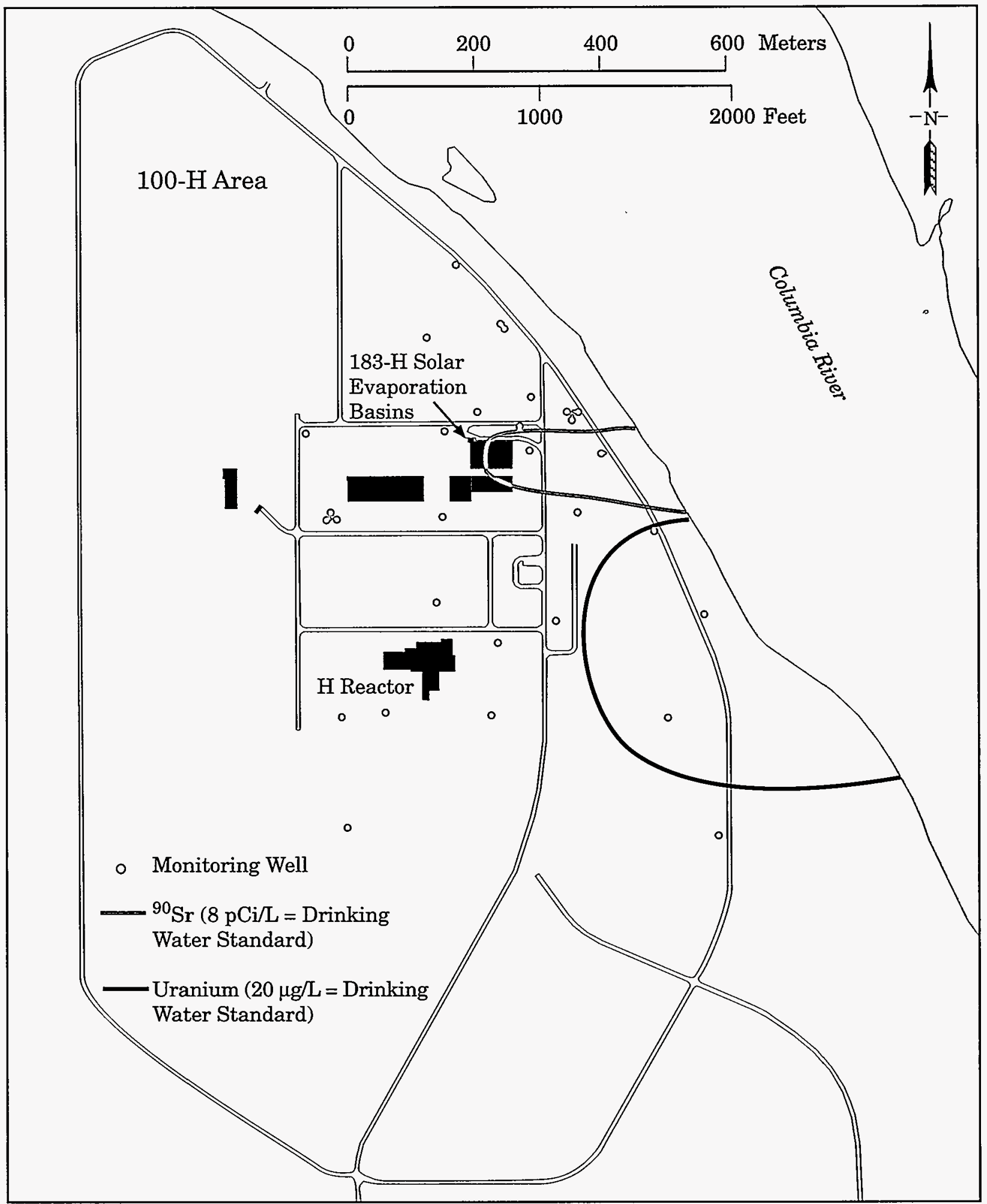

S9402063.85

Figure 5.58. Concentrations of Strontium-90 $\left({ }^{90} \mathrm{Sr}\right)$ and Uranium in the Unconfined Aquifer in the 100-H Area, 1993 


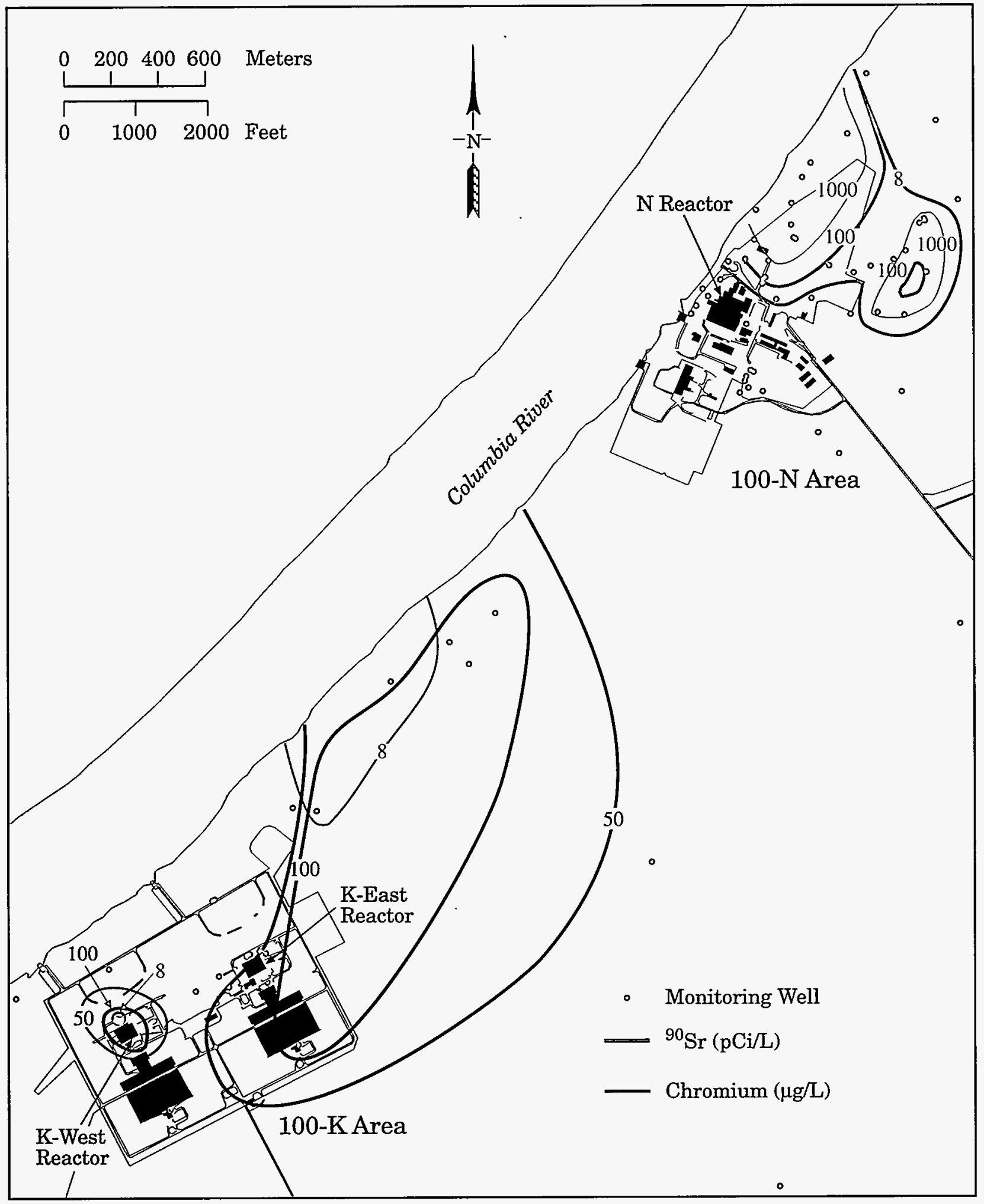

S9402063.8

Figure 5.59. Concentrations of Strontium- $90\left({ }^{90} \mathrm{Sr}\right)$ and Chromium in the Unconfined Aquifer in the 100-K and 100-N Areas, 1993 
Strontium-90 in the 200 Areas. Concentrations of ${ }^{90} \mathrm{Sr}$ in the 200 -East Area ranged up to $7,890 \mathrm{pCi} / \mathrm{L}$ in well 299-E28-23 near the 216-B-5 Reverse Injection Well. Two wells near the 216-A-36B Crib south of the PUREX Plant also contained ${ }^{9} \mathrm{~S} r$ at levels greater than the Drinking Water Standard. Strontium-90 distribution in the 200-East Area is shown in Figure 5.61.

Strontium-90 in the 600 Area. Concentrations of ${ }^{90} \mathrm{Sr}$ greater than the Drinking Water Standard but less than the Derived Concentration Guide are detected in several wells in the former Gable Mountain Pond area (Figure 5.61). Strontium-90 contamination in that area resulted from the accidental discharge of radioactive waste to the former Gable Mountain Pond during its early use. Strontium- 90 has since migrated through the sedimentary column to the ground water, which is relatively close to the surface at that location. Initial break-through occurred in 1980 in some areas. The depth to bedrock is also small in the former Gable Mountain Pond area, and ${ }^{90} \mathrm{Sr}$ has been detected in wells completed in the basalt just below the unconsolidated sediments. The maximum concentration of ${ }^{90} \mathrm{Sr}$ detected in the former Gable Mountain Pond area was $154 \mathrm{pCi} / \mathrm{L}$ in well 699-53-47A.

\section{Technetium-99}

Technetium-99 is produced as a fission product and is present in waste streams associated with fuel processing. Reactor operations may also result in the release of some ${ }^{99} \mathrm{Tc}$ associated with fuel element breaches. Technetium-99 is normally present in an anionic form and thus tends to migrate in Hanford ground water essentially unretarded.

Technetium- 99 was found at concentrations greater than the $900-\mathrm{pCi} / \mathrm{L}$ Drinking Water Standard in two areas of the Hanford Site. The first area is the northeastern part of the 200-East Area and a part of the 600 Area extending north toward the gap between Gable Mountain and Gable Butte (Figure 5.61). The source of this technetium was apparently the BY Cribs (DOE 1993c; Dresel et al. 1993). The ${ }^{99} \mathrm{Tc}$ plume is associated with ${ }^{3} \mathrm{H},{ }^{60} \mathrm{Co}$, and cyanide contamination.

Technetium-99 is also detected at levels greater than the Drinking Water Standard in the 200-West Area and the adjacent 600 Area (Figure 5.62). The largest ${ }^{99} \mathrm{Tc}$ plume in the 200-West Area originates in the cribs that received effluent from U Plant. The maximum ${ }^{99} \mathrm{Tc}$ concentration detected in the 200-West Area in 1993 was in this plume, in well 299-W19-24. This well had a concentration of $20,500 \mathrm{pCi} / \mathrm{L}$ of ${ }^{99} \mathrm{Tc}$. As shown in Figure 5.62 , several smaller areas with ${ }^{99} \mathrm{Tc}$ greater than the Drinking Water Standard were also found in the 200-West Area.

\section{Antimony-125}

Antimony- 125 is produced as a fission product and is present in waste streams associated with fuel processing. Reactor operations may also result in the release of some ${ }^{125} \mathrm{Sb}$ associated with fuel element breaches. Antimony-125 tends to migrate in Hanford ground water with low retardation but has generally not been observed in recent years because of its relatively short half-life (2.7 years).

Antimony-125 has been measured in the past in a few wells in the 100-N and 100-K Areas. In 1993 only one well, 199-N-33, in the 100-N Area, had concentrations greater than the Drinking Water Standard of $300 \mathrm{pCi} / \mathrm{L}$. The water levels in this well have declined to near the bottom of the well screen because of changes in discharge in the 100-N Area, and the high values appear related to increased suspended solids in the samples. Antimony-125 is strongly adsorbed to aquifer sediments. Thus, although the sample probably is not representative of mobile ground-water concentrations, it indicates that radionuclides continue to be present, adsorbed to solid particles.

\section{lodine-129}

The presence of ${ }^{129} \mathrm{I}$ in ground water is significant, because of its relatively low Drinking Water Standard $(1 \mathrm{pCi} / \mathrm{L})$, its potential for accumulation in the environment as a result of long-term releases from nuclear fuel reprocessing facilities (Soldat 1976), and its long halflife (16 million years). The relatively low fission yield for production of ${ }^{129} \mathrm{I}$ combined with its long half-life limits its specific activity in Hanford wastes. Iodine-129 may be released as a vapor during fuel dissolution and other elevated-temperature processes and thus may be associated with process condensate wastes. At Hanford, 


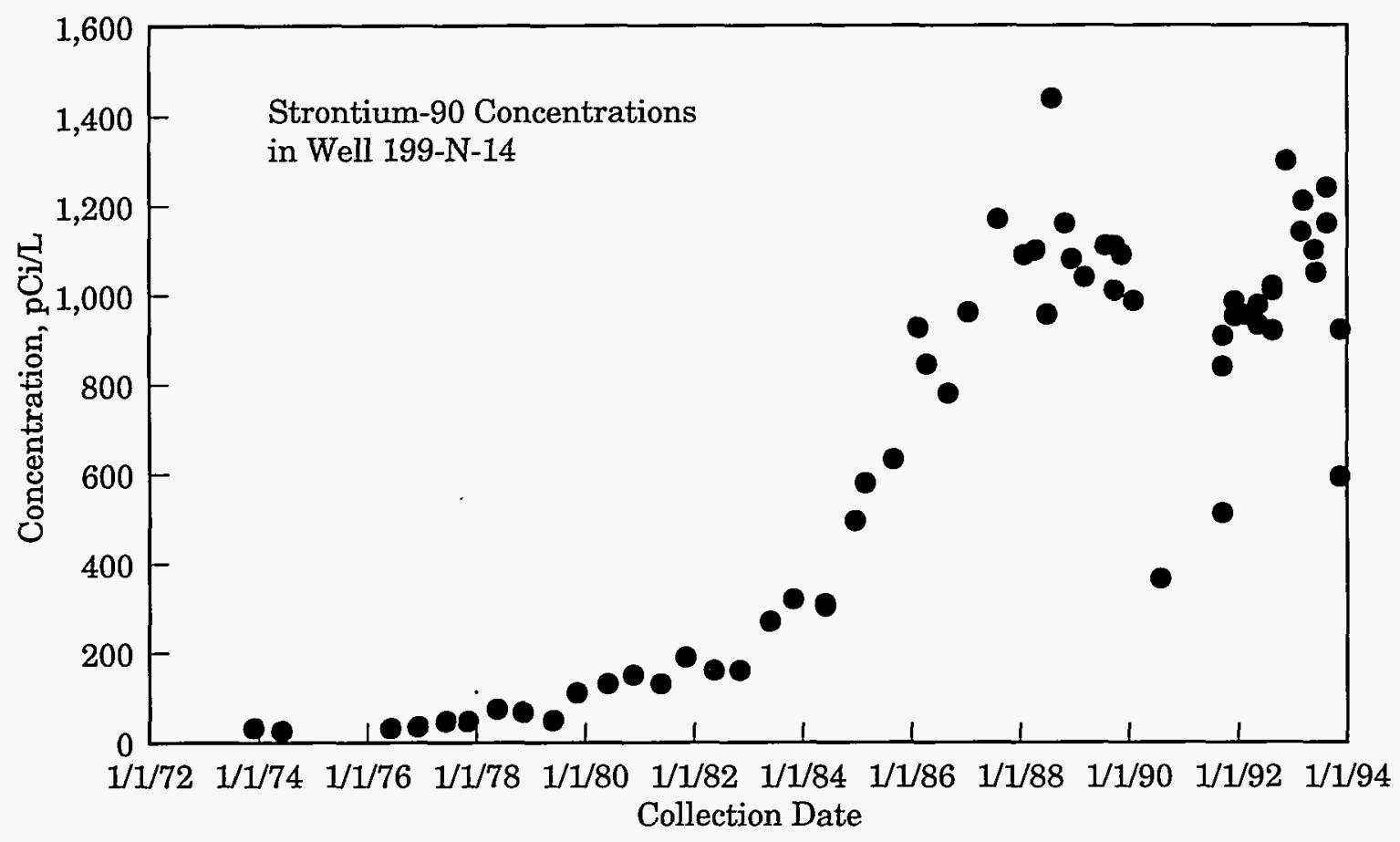

Figure 5.60. Strontium-90 ( $\left.{ }^{90} \mathrm{Sr}\right)$ Concentrations in Well 199-N-14, 1973 Through 1993

the main contributor of ${ }^{129}$ I to ground water has been liquid discharges to cribs in the 200 Areas. The highest concentrations observed onsite are downgradient from the PUREX and REDOX Plants, in the 200-East and 200-West Areas, respectively. No ${ }^{129}$ s samples were above the Derived Concentration Guide of $500 \mathrm{pCi} / \mathrm{L}$. Iodine- 129 extends into the 600 Area as shown in Figure 5.63.

The highest ${ }^{129} \mathrm{I}$ concentrations in the 200-East Area are in the northwest near the 216-BY Cribs and in the southeast near the PUREX Plant. The maximum concentration of ${ }^{129} \mathrm{I}$ detected in 1993 in the 200-East Area was $12 \mathrm{pCi} / \mathrm{L}$ in well $299-\mathrm{E} 17-9$. This well is located south of the PUREX Plant near the 216-A36B Crib. The ${ }^{129} \mathrm{I}$ plume from the PUREX area extends southeast into the 600 Area and appears coincident with the ${ }^{3} \mathrm{H}$ and nitrate plumes. The more limited extent of the ${ }^{129}$ I plume shown in Figure 5.63 results from the lower initial concentrations of ${ }^{129}$ than the initial concentrations of ${ }^{3} \mathrm{H}$ and nitrate. The ${ }^{129} \mathrm{I}$ plume likely had the same sources as the ${ }^{3} \mathrm{H}$ and nitrate plumes. Iodine- 129 has essentially the same high mobility in ground water as ${ }^{3} \mathrm{H}$ and nitrate.

The highest ${ }^{129} \mathrm{I}$ concentration observed in 1993 in Hanford ground water was $64.2 \mathrm{pCi} / \mathrm{L}$ in well 299-W14-12, in the central part of the 200-West Area. The ${ }^{129} \mathrm{I}$ plume extends northeast toward T Plant. A second, more extensive ${ }^{129}$ I plume is located in the southwest corner of the 200-West Area and extends into the 600 Area to the east. This plume is essentially coincident with the ${ }^{3} \mathrm{H}$ and nitrate plumes.

\section{Cesium-137}

Cesium-137 is produced as a high-yield fission product and is present in waste streams associated with fuel processing. Reactor operations may also result in the release of some ${ }^{137} \mathrm{Cs}$ associated with fuel element breaches. Cesium-137 is normally observed to be strongly sorbed on soil and thus is very immobile in Hanford ground water. 


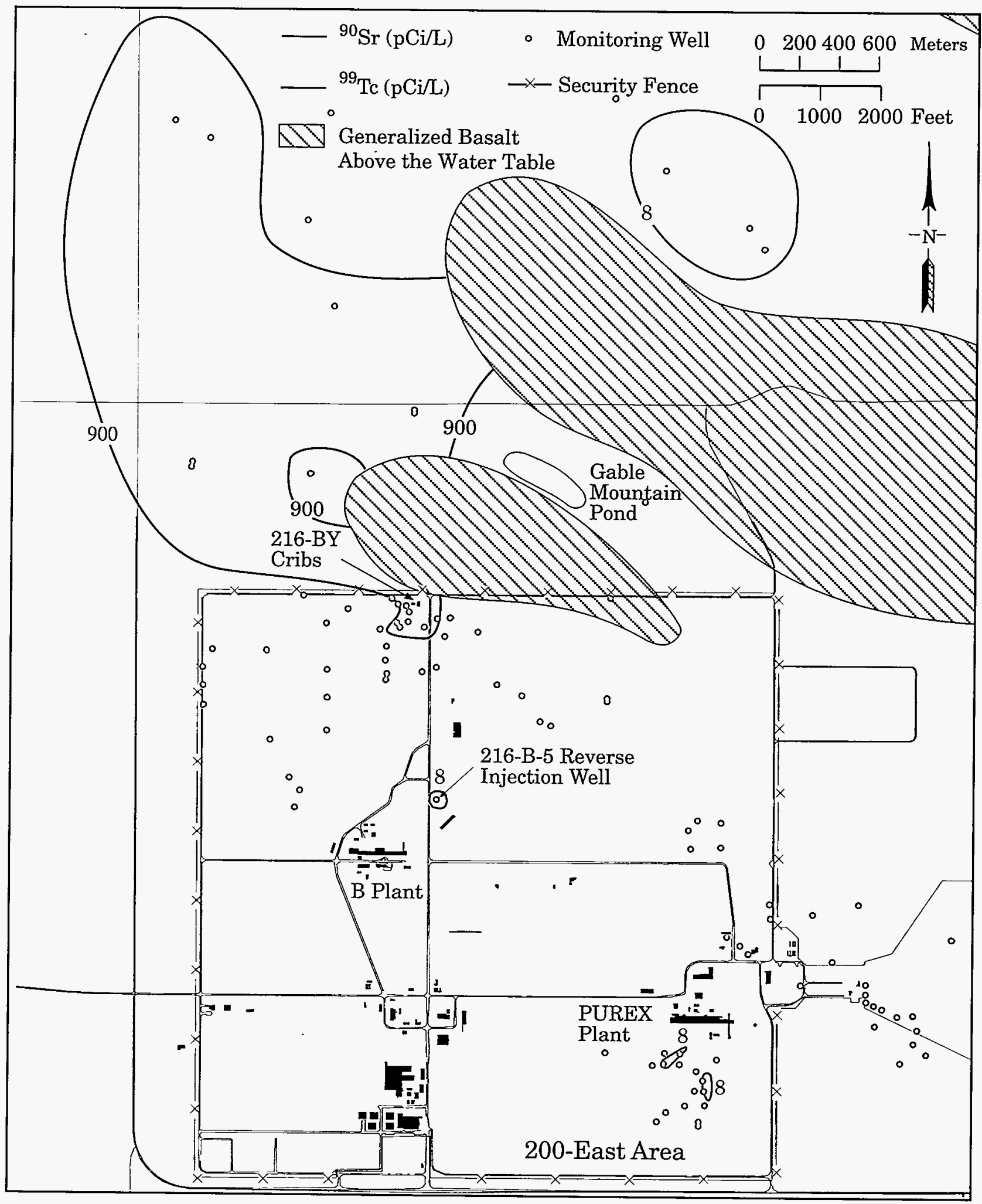

S9402063.6

Figure 5.61. Concentrations of Strontium-90 $\left({ }^{90} \mathrm{Sr}\right)$ and Technetium-99 $\left({ }^{99} \mathrm{Tc}\right)$ in the Unconfined Aquifer Near the 200-East Area, 1993 


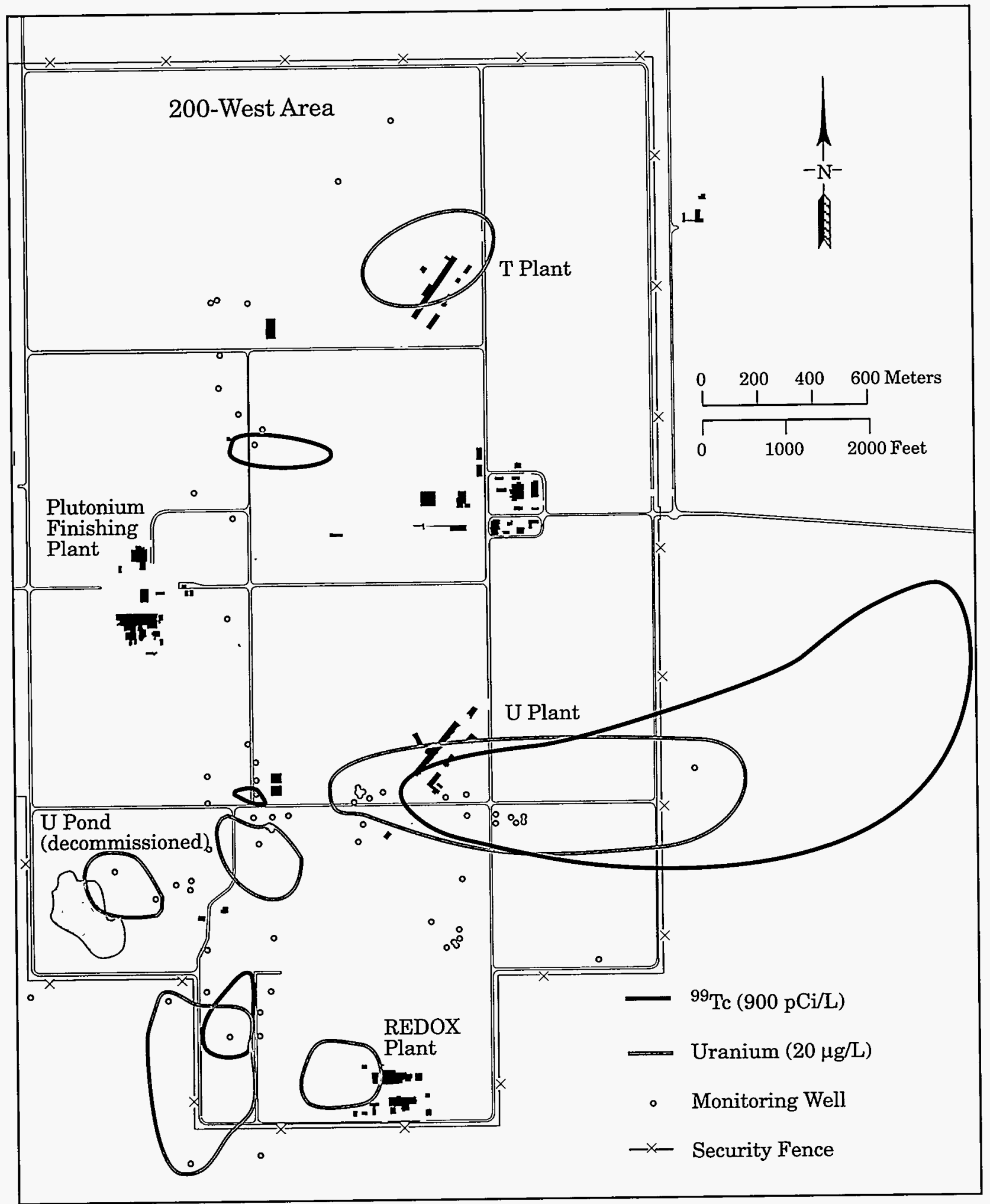

S9402063.5

Figure 5.62. Concentrations of Technetium-99 (99 Tc) and Uranium in the Unconfined Aquifer in the 200-West Area, 1993 


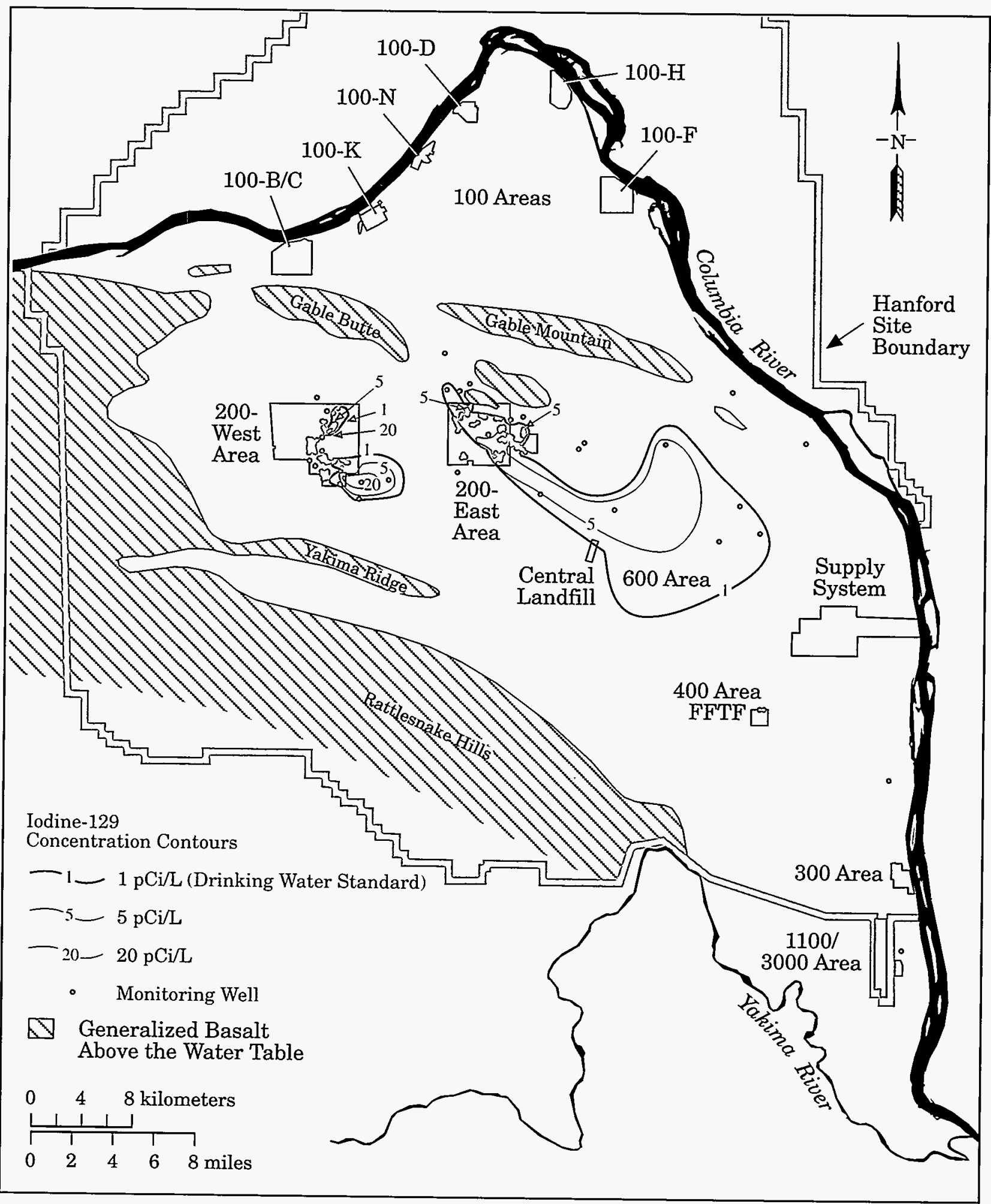

S9402063.11

Figure 5.63. Distribution of lodine-129 (129) in the Unconfined Aquifer, 1993 
Concentrations of ${ }^{137} \mathrm{Cs}$ were greater than the contractual detection limit $(20 \mathrm{pCi} / \mathrm{L})$ in two wells, 299-E28-23 and 299-E28-25, located near the 216-B-5 Reverse Injection Well. This well received ${ }^{137} \mathrm{Cs}$-bearing wastes from 1945 to 1947 . The 1993 sample from well 299-E28-23 contained $2,080 \mathrm{pCi} / \mathrm{L}$ and the samples from well $299-\mathrm{E}-28-25$ contained $537 \mathrm{pCi} / \mathrm{L}$ of ${ }^{137} \mathrm{Cs}$. The Drinking Water Standard for ${ }^{137} \mathrm{Cs}$ is $200 \mathrm{pCi} / \mathrm{L}$, and the Derived Concentration Guide is $3,000 \mathrm{pCi} / \mathrm{L}$. Cesium137 is restricted to the immediate vicinity of the injection well by its extremely low mobility in ground water.

\section{Uranium}

There are numerous possible sources of uranium released to the ground water at Hanford including fuel fabrication, fuel processing, and uranium recovery operations. Uranium may exist in several states including elemental uranium or uranium oxide as well as tetravalent and hexavalent cations. Only the hexavalent form has significant mobility in ground water largely by forming dissolved carbonate species. Uranium mobility is thus dependent on both oxidation state and $\mathrm{pH}$. Uranium is observed to migrate in Hanford ground water but is retarded relative to more mobile species such as ${ }^{3} \mathrm{H}$ and technetium.

The EPA has proposed a Drinking Water Standard of $20 \mu \mathrm{g} / \mathrm{L}$ for uranium. This is in contrast to other radionuclides where the standards are given in $\mathrm{pCi} / \mathrm{L}$. The reasons for the difference are that uranium is often analyzed by a fluorescence method which is calibrated in $\mu \mathrm{g} / \mathrm{L}$ and that there is evidence that uranium ingestion may cause kidney damage, which is assessed as a chemical hazard rather than a radiological hazard. However, uranium may be analyzed by an alphacounting method and has an associated risk through its radioactivity, so it is important to be able to convert between ground-water concentrations expressed in $\mu \mathrm{g} / \mathrm{L}$ and those expressed in $\mathrm{pCi} / \mathrm{L}$. The conversion factor depends on the proportions of ${ }^{234} U,{ }^{235} \mathrm{U}$, and ${ }^{238} \mathrm{U}$ in the ground water. The EPA considers the Drinking Water Standard of $20 \mu \mathrm{g} / \mathrm{L}$ to be equivalent to a standard of 30 $\mathrm{pCi} / \mathrm{L}$, based on a series of ground-water analyses throughout the United States (EPA 1986c). However, site-specific data for Hanford indicate that the proportion of the different uranium isotopes in ground water is nearly identical to the average proportion in natural rock. In this case, the uranium activity in $\mathrm{pCi} / \mathrm{L}$ should be multiplied by 1.49 to convert to the concentration in $\mu \mathrm{g} /$ L. This gives a proposed Drinking Water Standard equivalent of $13.4 \mathrm{pCi} / \mathrm{L}$. The site-specific conversion factor provides a more stringent standard for activity data and will be used in the discussion below.

Uranium has been detected at concentrations greater than the proposed Drinking Water Standard in the 100-F, 100-H, 200-East, 200-West, and 300 Areas. The highest concentrations detected onsite in 1993 were in the 200-West Area near the 216-U-1 and 216-U-2 cribs.

Uranium in the 100 Areas. In 1993, uranium was detected at concentrations greater than the proposed Drinking Water Standard at one location in the $100-\mathrm{F}$ Area, well 199-F8-2 (Figure 5.57). The uranium concentration in this well is generally decreasing with time, from a maximum of $414 \mu \mathrm{g} / \mathrm{L}$ in 1988 to the 1993 value of $27 \mu \mathrm{g} / \mathrm{L}$ (calculated from ${ }^{238} \mathrm{U}$ activity).

Uranium was detected at concentrations greater than the proposed Drinking Water Standard in two wells in the 100-H Area (Figure 5.58). The maximum concentration detected in 1993 was $350 \mu \mathrm{g} / \mathrm{L}$ in well 199-H4-3. This is considerably higher than the concentration detected in prior years.

Uranium in the 200 Areas. A few wells in the 200-East Area contained uranium at concentrations greater than the proposed Drinking Water Standard for at least one sampling event. The highest concentration detected in the 200-East Area was $22.6 \mu \mathrm{g} / \mathrm{L}$ in well 299-E28-26 in the northwestern part of the area. The concentration in this vicinity has remained relatively constant since 1981 .

The highest uranium levels in Hanford ground water occurred near U Plant in 200-West Area in wells adjacent to the inactive 216-U-1, 216-U-2, and 216-U-17 cribs (Figure 5.62). Uranium concentrations in these wells have been decreasing over the last 5 years following remediation activities associated with those cribs. A trend plot of uranium concentrations in samples from well 299-W19-3, immediately downgradient from the 216-U-1 and 216-U-2 cribs, is shown in Figure 5.64. The uranium levels in this well continue to decrease slowly but remain greater than the proposed Drinking Water Standard. The maximum concentration detected in this area was $3,320 \mu \mathrm{g} / \mathrm{L}$ in one sample from well 299-W19-29. Results from that well have been 


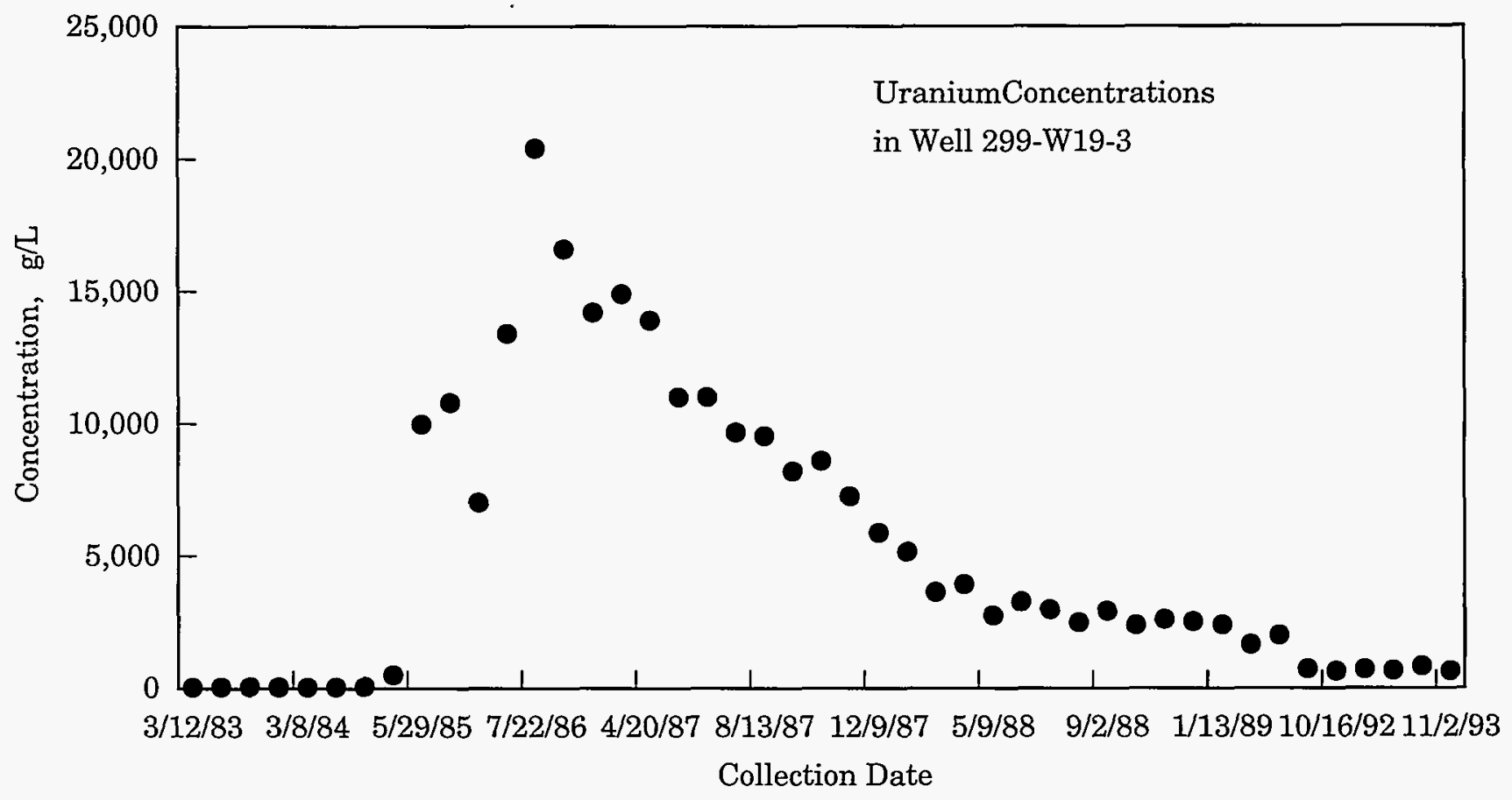

Figure 5.64. Uranium Concentrations in Well 299-W19-3, 1983 Through 1993

erratic since 1991, and further data are needed to interpret the trends. However, the 1993 concentration detected in well 299-W19-29 was greater than the Derived Concentration Guide. Other areas within the 200-West Area with uranium contamination are also shown in Figure 5.62.

Uranium in the $\mathbf{3 0 0}$ Areas. A plume of uranium exists in the unconfined aquifer beneath the 300 Area in the vicinity of uranium fuel fabrication facilities and inactive waste sites known to have received uranium waste. The plume extends downgradient from active and inactive Liquid Waste Disposal Facilities (Figure 5.65). An Expedited Response Action performed on the 300 Area Process Trenches in mid-1991 was aimed at reducing the uranium source in that area. Use of the trenches for disposal of cooling water and small quantities of nonhazardous maintenance and process waste (Borghese 1994) was resumed following completion of the remedial action, although current discharge to the trenches is much lower than in the past. Uranium levels in well 399-1-17A located near the trenches appear to have been reduced following that action; levels apparently stabilized about a factor of 10 below the maximum values seen in 1990. However, levels from a number of samples collected since the remediation remained greater than the proposed Drinking Water Standard. A trend plot showing the uranium concentrations in well 399-1-17A is shown in Figure 5.66.

\section{Plutonium}

Plutonium has been released to the soil column in several locations in both the 200-West and 200-East Areas. Plutonium is generally considered to bind strongly to sediments and thus has limited mobility in the aquifer.

Ground water sampled at 200-East Area wells located near the 216-B-5 Reverse Injection Well, ranged from 12.5 to $27.2 \mathrm{pCi} / \mathrm{L}$ of ${ }^{239,240} \mathrm{Pu}$ in 1993 . Plutonium-238 was also detected, but at considerably lower levels ranging from 0.06 to $0.44 \mathrm{pCi} / \mathrm{L}$. The $216-\mathrm{B}-5$ Reverse Injection Well received an estimated $244 \mathrm{Ci}$ of ${ }^{239,240} \mathrm{Pu}$ 


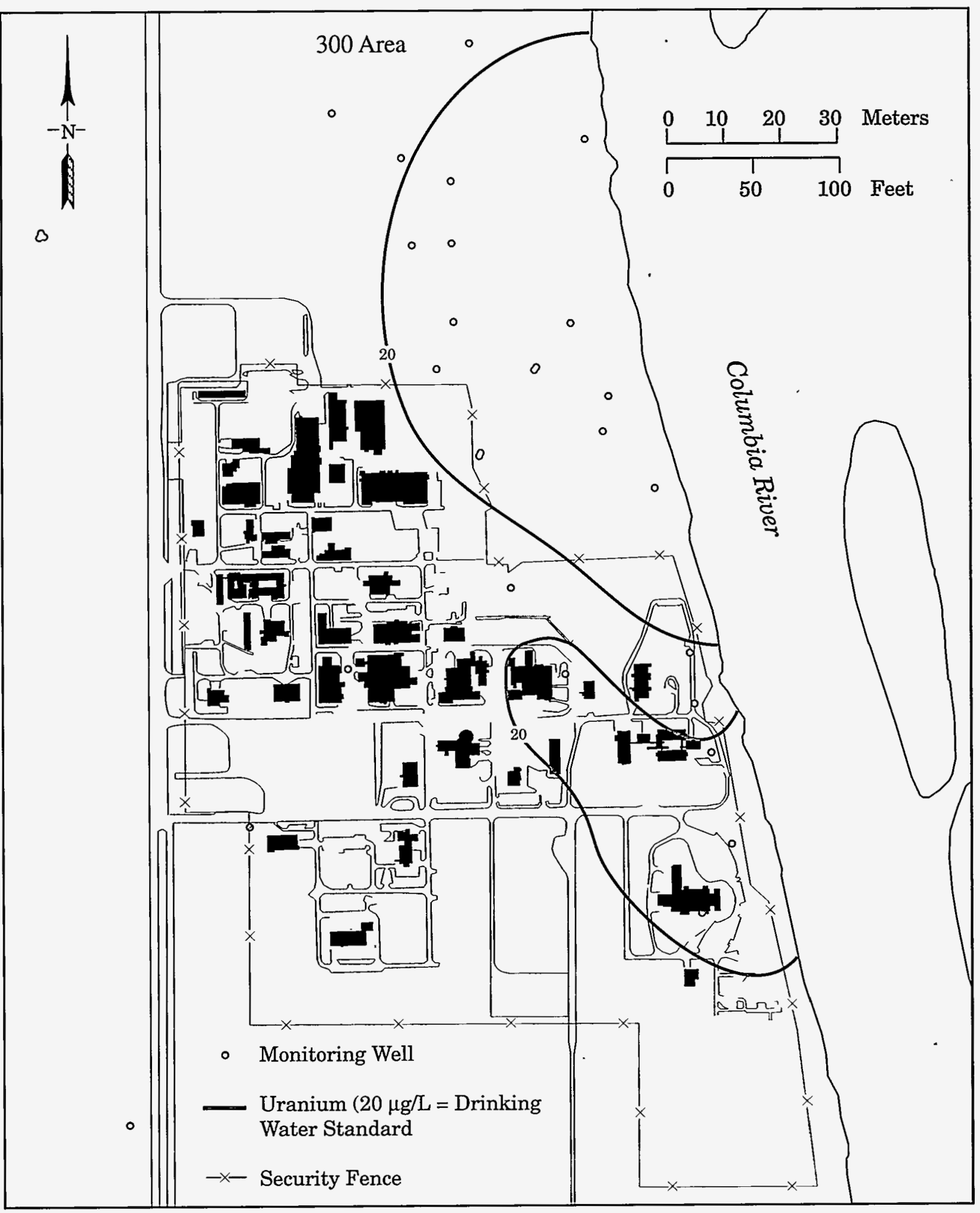

S9402063.135

Figure 5.65. Uranium Concentrations in the Unconfined Aquifer in the 300 Area, 1993 


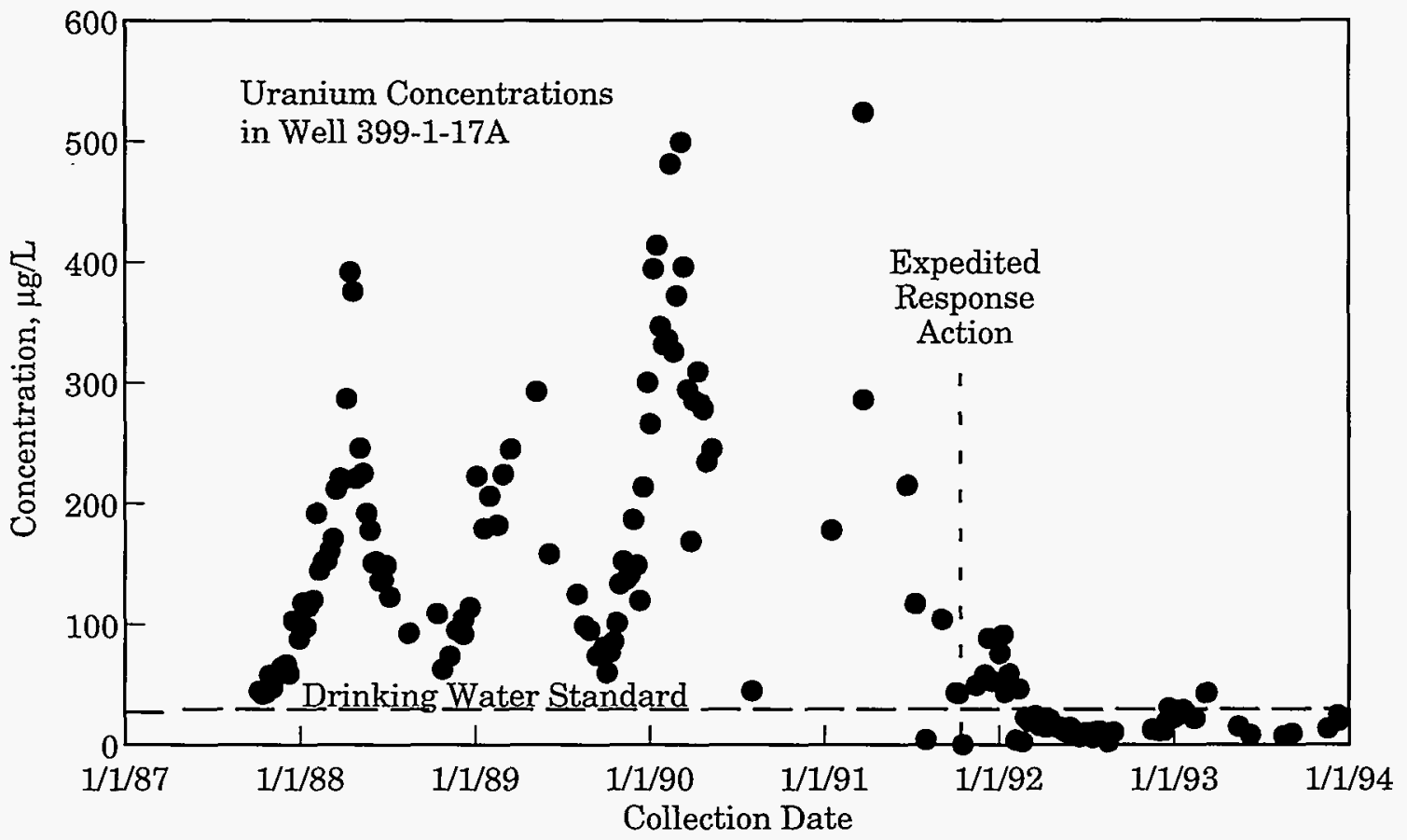

S9402063.23

Figure 5.66. Uranium Concentrations in Well 399-1-17A, 1987 Through 1993

during its operation from 1945 to 1947 (Stenner et al. 1988). The Derived Concentration Guide for ${ }^{239} \mathrm{Pu}$ is 30 $\mathrm{pCi} / \mathrm{L}$. There is no explicit Drinking Water Standard for ${ }^{239} \mathrm{Pu}$; however, the gross alpha Drinking Water Standard of $15 \mathrm{pCi} / \mathrm{L}$ would be applicable at a minimum. Alternately, if the Derived Concentration Guide (which is based on a 100-mrem dose standard) is converted to the 4-mrem dose equivalent used for the Drinking Water Standard, $1.2 \mathrm{pCi} / \mathrm{L}$ would be the relevant guideline.

\section{Chemical Monitoring Results for the Unconfined Aquifer}

Chemical analyses performed on ground-water samples by various monitoring programs at Hanford have identified eight hazardous chemicals occurring in ground water at concentrations greater than existing or proposed federal drinking water standards. These are nitrate, cyanide, fluoride, chromium, carbon tetrachloride, chloroform, trichloroethylene, and tetrachloroethylene.

A number of the parameters measured such as conductance, total carbon, total organic carbon, and total organic halogens are used as indicators of contamination.
These will not be discussed in detail in this report because the specific contaminant contributing to these parameters will be discussed. Other chemicals and parameters listed in Table 5.28 are indicators of the natural chemical composition of ground water and in general are not contaminants from operations at Hanford. These include alkalinity, $\mathrm{pH}$, sodium, magnesium, potassium, aluminum, silica, calcium, manganese, and iron. Chloride and sulfate are both naturally occurring and site-related constituents. There is no primary Drinking Water Standard for chloride or sulfate (the secondary standard for each is $250,000 \mu \mathrm{g} / \mathrm{L}$ and is based on aesthetic rather than health considerations) so they will not be discussed in detail. The analytical technique used to determine the concentration of metals in ground water provides results for a number of constituents such as antimony, barium, beryllium, boron, cadmium, copper, nickel, silver, strontium, vanadium, and zinc that are rarely observed at greater than background concentrations.

The following subsections present additional information on the eight chemical constituents occurring in ground water at concentrations greater than existing or proposed Drinking Water Standard. 


\section{Nitrate}

Most ground-water samples collected in 1993 were analyzed for nitrate. Nitrate was measured at concentrations greater than the Drinking Water Standard $(45 \mathrm{mg} / \mathrm{L}$ as $\mathrm{NO}_{3}^{-}$ion) in wells in all operational areas except the $100-\mathrm{B}, 300$, and 400 Areas. Although nitrate is associated primarily with process condensate liquid wastes, other liquids discharged to ground also contained nitrate. Nitrate contamination in the unconfined aquifer reflects the extensive use of nitric acid in decontamination and chemical reprocessing operations. Nitrate, like ${ }^{3} \mathrm{H}$, can be used to define the extent of contamination because nitrate is present in many waste streams and is mobile in ground water. However, additional offsite sources of nitrate are located to the west and southwest. The distribution of nitrate on the Hanford Site is shown in Figure 5.67; this distribution is similar to previous evaluations.

Nitrate in the $\mathbf{1 0 0}$ Areas. Nitrate is found at levels greater than the Drinking Water Standard in a large part of the 100-D Area. The major exception is near the 100-D ponds, where low-nitrate water is discharged. The highest nitrate value found in the 100-D Area in 1993 was $355 \mathrm{mg} / \mathrm{L}$ as $\mathrm{NO}_{3}^{-}$in well 199-D2-5.

The 100-F Area also contains nitrate in ground water at levels greater than the Drinking Water Standard. This plume appears to extend to the south into the 600 Area but the extent of nitrate at low levels in the 600 Area west and south of the 100-F Area suggests there is also an unknown source upgradient. The maximum nitrate detected in the $100-\mathrm{F}$ Area in 1993 was $122 \mathrm{mg} / \mathrm{L}$ in well 199-F7-3.

Nitrate in the 100-H Area is restricted to a small area downgradient of the 183-H Solar Evaporation Basins. The maximum concentration of nitrate detected in this area was $870 \mathrm{mg} / \mathrm{L}$ in well 199-H4-3. This was several times higher than the concentration detected in 1992.

Nitrate at levels greater than the Drinking Water Standard in the 100-K Area is found in the vicinity of the $\mathrm{K}$-East Reactor and downgradient. The maximum concentration detected in 1993 was $120 \mathrm{mg} / \mathrm{L}$ in well 199-K-30.

Nitrate is only found at levels greater than the Drinking Water Standard in two wells in the 100-N Area. The maximum detected in a 1993 sample was $54 \mathrm{mg} / \mathrm{L}$ in well $199-\mathrm{N}-26$, located in the southwestern part of the area.
Nitrate in the 200-East Area. The highest nitrate concentrations in the 200-East Area continued to be found near Liquid Waste Disposal Facilities that received effluent from PUREX operations. Nitrate concentrations in wells near the 216-A-10 and 216-A-36B cribs have generally tended to decrease in the past few years but remained greater than the Drinking Water Standard even though these facilities were removed from service in 1987. The maximum nitrate concentration detected in this vicinity was $130 \mathrm{mg} / \mathrm{L}$ in well $299-\mathrm{E} 17-20$ adjacent to the 216-A-10 Crib. High nitrate concentrations in the 600 Area north of the 200-East Area are apparently related to past disposal practices at the BY Cribs. Nitrate was detected in well 699-50-53A at $100 \mathrm{mg} / \mathrm{L}$ in 1993.

The configuration of the nitrate plume emanating from the 200-East Area shows the influence of two periods of PUREX operation and recent changes in the operation of B Pond. The location of B Pond is shown in Figure 5.42. Increases in the volume of low-nitrate process cooling water discharged to B Pond apparently resulted in an expanding area of lower nitrate ground water to the east and south of B Pond (see Figure 5.67). The nitrate ground-water plume related to PUREX operations discharges to the Columbia River along a stretch from east of Gable Mountain to the northern portion of the 300 Area. Further spread of the nitrate plume south of the 300 Area is restricted by ground-water flow from the Yakima River east- and northeastward to the Columbia River. Further consideration of the influence of groundwater flow in this area is discussed above with regard to the ${ }^{3} \mathrm{H}$ plume.

Nitrate in the 200-West Area. Nitrate concentrations greater than the Drinking Water Standard were widespread in ground water beneath the 200-West Area and adjacent part of the 600 Area. The major nitrate plumes were found in wells east of U Plant and wells in the north-central part of the 200-West Area. The highest nitrate concentrations across the Site continued to be found in wells east of U Plant near the 216-U-17 Crib, where the maximum concentration detected in 1993 was $1,200 \mathrm{mg} / \mathrm{L}$ in well $299-\mathrm{W} 19-26$. The presence of nitrate in wells near this crib was observed before February 1988 when the crib went into operation. The source of nitrate is believed to be wastes disposed of in the 216-U-1 and 216-U-2 Cribs. These cribs received over 1 million kilograms of nitrate during their operation from 1951 to 1967 (Stenner et al. 1988). Nitrate concentrations in wells located near the 216-U-1 and 216-U-2 Cribs west of U Plant continued to decrease, 


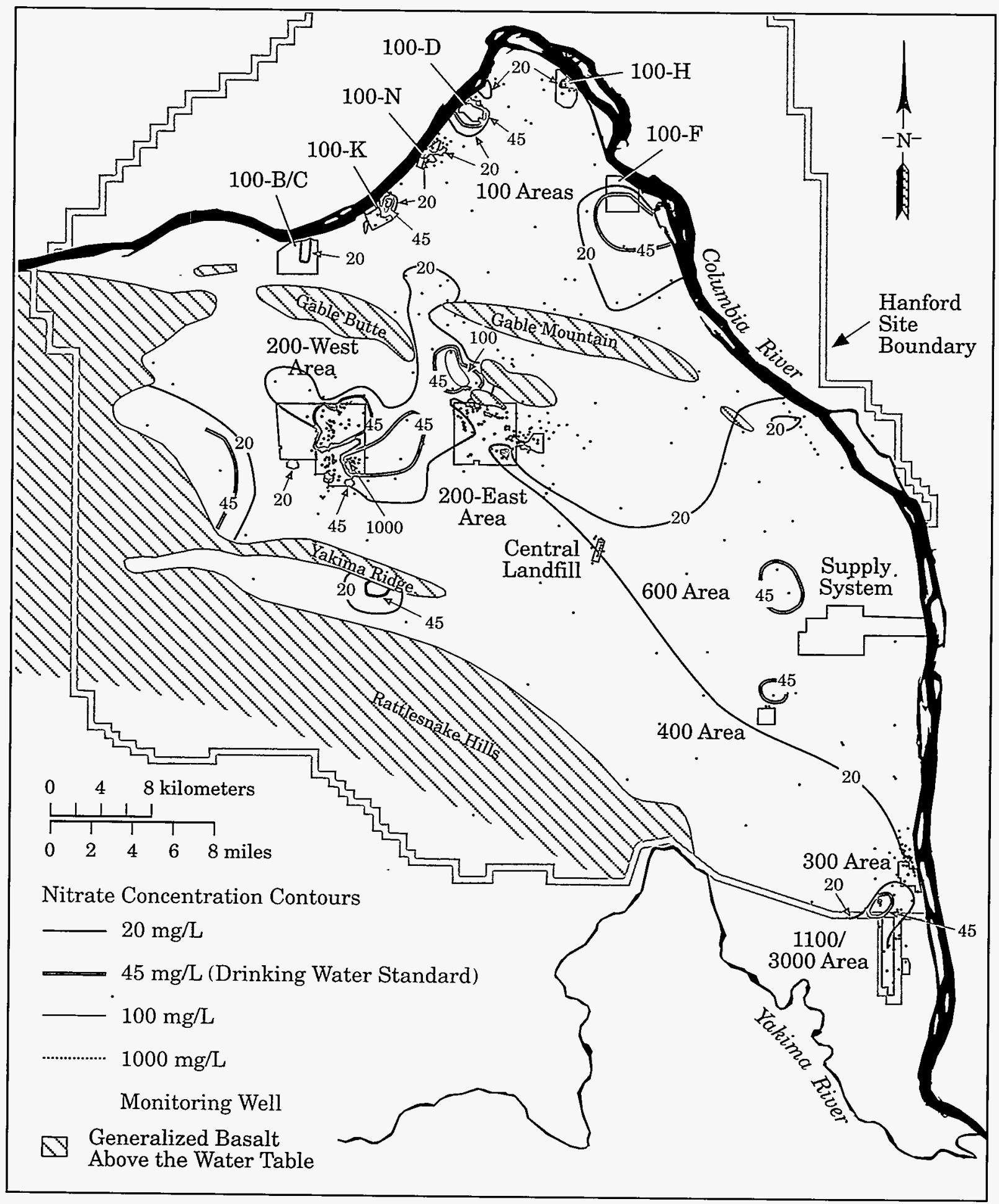

S9402063.12

Figure 5.67. Distribution of Nitrate $\left(\mathrm{NO}_{3}\right)$ in the Unconfined Aquifer, 1993 


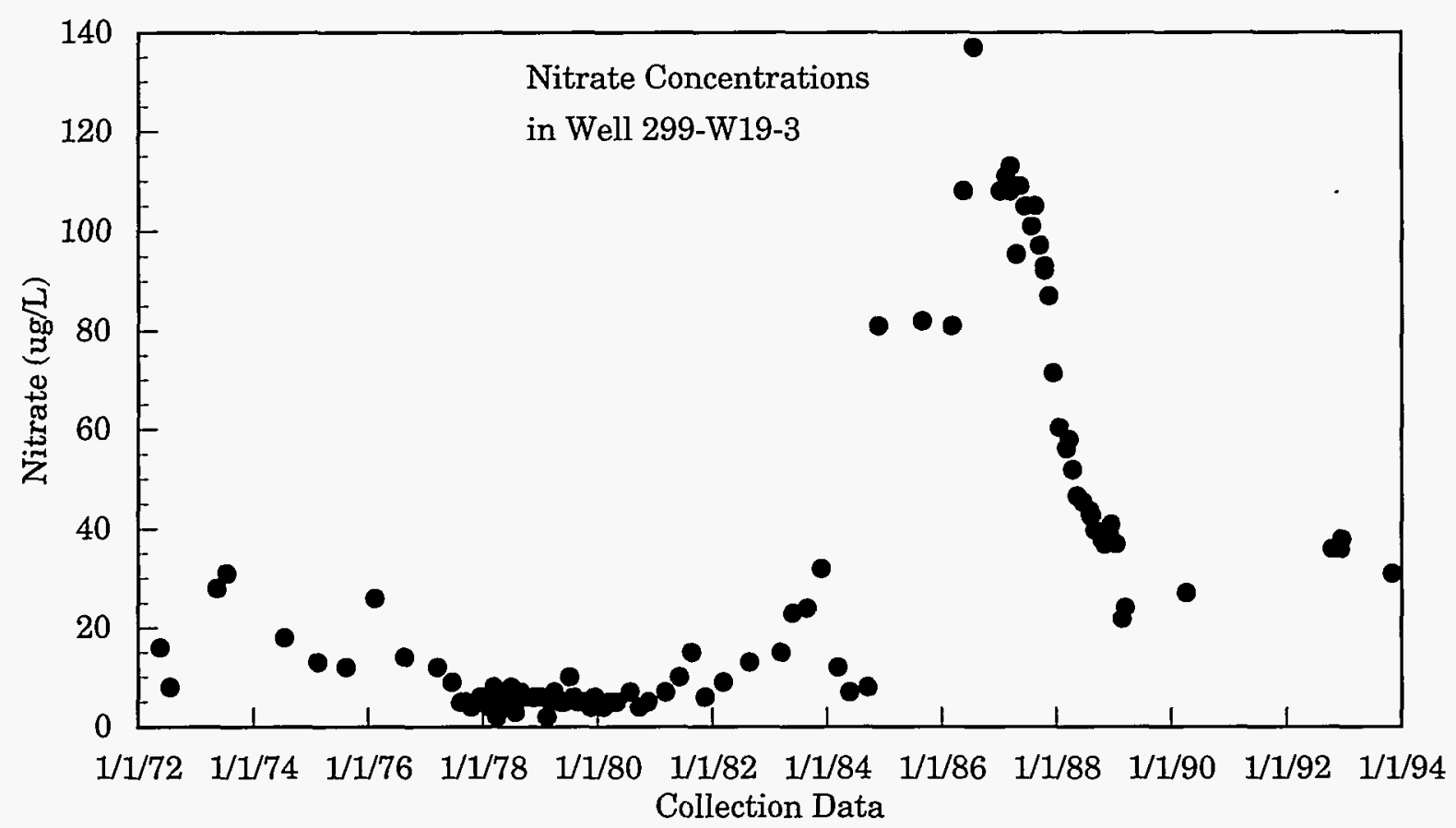

S9402063.146

Figure 5.68. Nitrate $\left(\mathrm{NO}_{3}\right)$ Concentrations in Well 299-W19-3, 1958 Through 1993

with concentrations in several of the wells dropping to less than the Drinking Water Standard. For example, the nitrate concentrations in well 299-W19-3 located near U Plant have decreased to less than the Drinking Water Standard as shown in Figure 5.68.

Several wells in the northwestern part of the 200-West Area continued to contain nitrate at concentrations greater than the Drinking Water Standard. These wells are located near several inactive Liquid Waste Disposal Facilities that received waste from early T Plant operations. Maximum concentrations in these wells in 1993 ranged up to $470 \mathrm{mg} / \mathrm{L}$ in well 299-W14-12, similar to levels observed in recent years.

Nitrate in Other Areas. Although most nitrate observed onsite is the result of Hanford operations, elevated nitrate concentrations in wells in the western part of the Site appear to be the result of increasing agricultural activity in Cold Creek Valley, west of Hanford. There is no known source of nitrate in that area associated with Site operations, and wells located between well 699-36-93 and Hanford waste disposal facilities show no evidence of plume passage. Nitrate levels have fluctuated considerably in wells upgradient of the 200 Areas over the past 30 years. Nitrate levels have been at or greater than the Drinking Water Standard in weIl 699-36-93 since 1985.

Nitrate concentrations near the city of Richland and in the 1100 Area, 3000 Area, and adjacent parts of the 600 Area are also apparently affected by offsite nitrate sources. These sources may include agriculture, food processing, urban horticulture, and nuclear fuel processing at offsite commercial facilities.

\section{Cyanide}

Waste fractionation activities performed in the late 1950s utilized large quantities of sodium and nickel ferrocyanide to recover ${ }^{137} \mathrm{Cs}$. Large volumes of aqueous super-

natant waste containing excess ferrocyanide were disposed to ground in both the north and south portions of the 200-East Area. Smaller quantities were also disposed to cribs in the 200-West Area. Analytical tests performed according to EPA procedures do not distinguish between ferrocyanide and free cyanide. Cyanide results reported here are thus normally assumed to be 
residual ferrocyanide associated with the discharges from the waste fractionation activities performed more than 30 years ago.

In past monitoring activities, cyanide was detected in samples collected from wells in and directly north of the 200-East Area. Samples taken from the 200-East Area in 1992 had a maximum cyanide concentration of $130 \mu \mathrm{g} / \mathrm{L}$ in one sample from well 299-E33-41, which is southeast of the BY Cribs. Other samples from this well do not confirm the presence of cyanide. Well 699-50-53A, north of the BY Cribs, continued to contain detectable cyanide $(199 \mu \mathrm{g} / \mathrm{L}$ in 1993). Cyanide concentrations in that well have shown a somewhat erratic but generally decreasing trend in the last 2 years. Wells containing cyanide often contain concentrations of several radionuclides, including ${ }^{60} \mathrm{Co}$. Although ${ }^{60} \mathrm{Co}$ is normally immobile in the subsurface, it appears to be chemically complexed and mobilized by cyanide or ferrocyanide. A chemical speciation study performed in 1988 indicated that approximately one-third of the cyanide is present as free cyanide and the rest may be present as ferrocyanide (Evans et al. 1989a, 1989b).

In past years, low-level cyanide contamination was found in two very limited locations in the 200-West Area. The northern location was located near the 216-T-26 Crib, which received a total estimated inventory of $6,000 \mathrm{~kg}$ of ferrocyanide in 1955-1956 (Stenner et al. 1988). The source for the other location farther south was uncertain. At least six wells in the 200-West Area have shown detectable cyanide in past years; however, measurements reported in 1993 showed that the cyanide plumes can no longer be detected. No formal Drinking Water Standard has been established for cyanide. A standard of $200 \mu \mathrm{g} / \mathrm{L}$ has been proposed by the EPA.

\section{Fluoride}

Fluoride currently has a primary Drinking Water Standard of $4.0 \mathrm{mg} / \mathrm{L}$ and a secondary standard of $2.0 \mathrm{mg} / \mathrm{L}$. Secondary standards are based primarily on aesthetic considerations and are not federally enforceable rules, although the State of Washington claims the right to require corrective action from drinking water suppliers if secondary standards are exceeded. Both standards will be used in the discussion below; however, it should be remembered that only the primary standard is based on health considerations. Fluoride was detected at levels greater than the primary Drinking Water Standard in the
200-West Area and greater than the secondary standard in the 200-East and 200-West Areas.

Fluoride concentrations greater than the $2.0-\mathrm{mg} / \mathrm{L}$ secondary standard occurred in one 200-East Area well, 299-E28-24, near the 216-B-5 Reverse Injection Well. The maximum concentration detected in this well in 1993 was $2.3 \mathrm{mg} / \mathrm{L}$.

A few wells in the 200-West Area near T Plant had fluoride concentrations greater than the secondary standard in 1993, although only two wells were greater than the primary Drinking Water Standard. A 200-West Area well (299-W10-15) showed a fluoride concentration of up to $4.8 \mathrm{mg} / \mathrm{L}$ in 1993. Well 299-15-4 showed the maximum fluoride onsite with a concentration of $7.2 \mathrm{mg} / \mathrm{L}$ in 1992. This well was not sampled in 1993 . Well 299-W10-9 showed a maximum fluoride concentration of $4.9 \mathrm{mg} / \mathrm{L}$ in 1993. A map depicting the area of fluoride concentrations greater than the secondary standard in the 200-West Area is shown in Figure 5.69. Aluminum fluoride nitrate use in the 200-West Area processes is the probable source of the fluoride plume.

\section{Chromium}

Chromium use on the Hanford Site has been extensive. In the 100 Areas sodium dichromate was added to cooling water as a corrosion inhibitor, and some residual chromium remains from that use. Hexavalent chromium was used for decontamination in the 100,200, and 300 Areas. Hexavalent chromium was used for oxidation state control in the REDOX process. In the hexavalent form, chromium is present in an anionic state. Hexavalent chromium is thus freely mobile in the ground water.

Both filtered and unfiltered samples were collected for chromium and other metals from many of the wells onsite. Unfiltered samples may contain metals present as particulate matter, while filtered samples are representative of the more mobile dissolved metals. Filtered samples may also contain some colloidal particles fine enough to pass through the filter. Drinking water standards are based on unfiltered concentrations; however, differences in well construction and pumping between monitoring wells and water-supply wells make it difficult to predict potential drinking water concentrations from monitoring well data. Comparison of filtered to unfiltered samples provides a greater understanding of the transport of chromium onsite. 


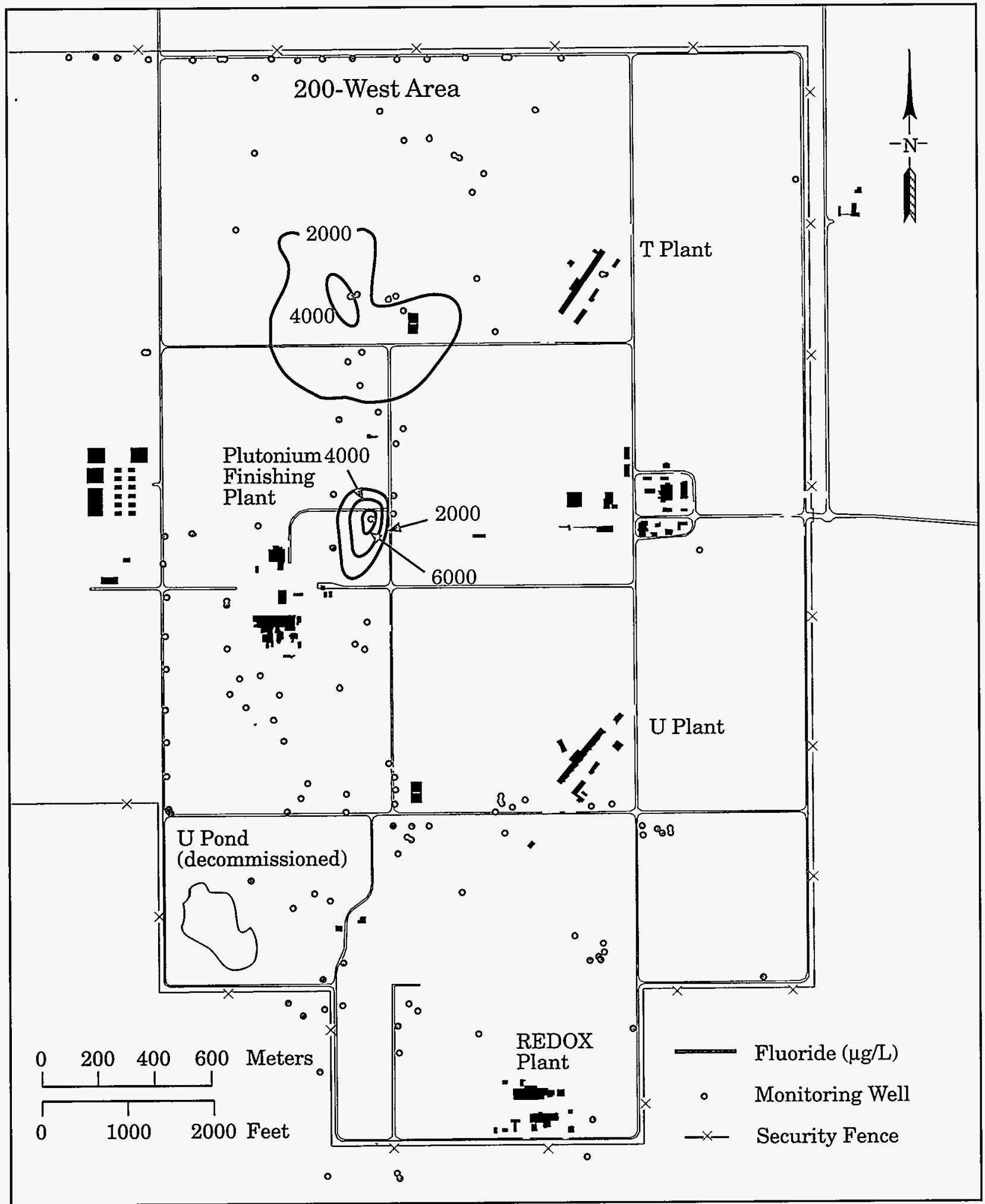

S9402063.13

Figure 5.69. Concentrations of Fluoride in the 200-West Area, 1993 


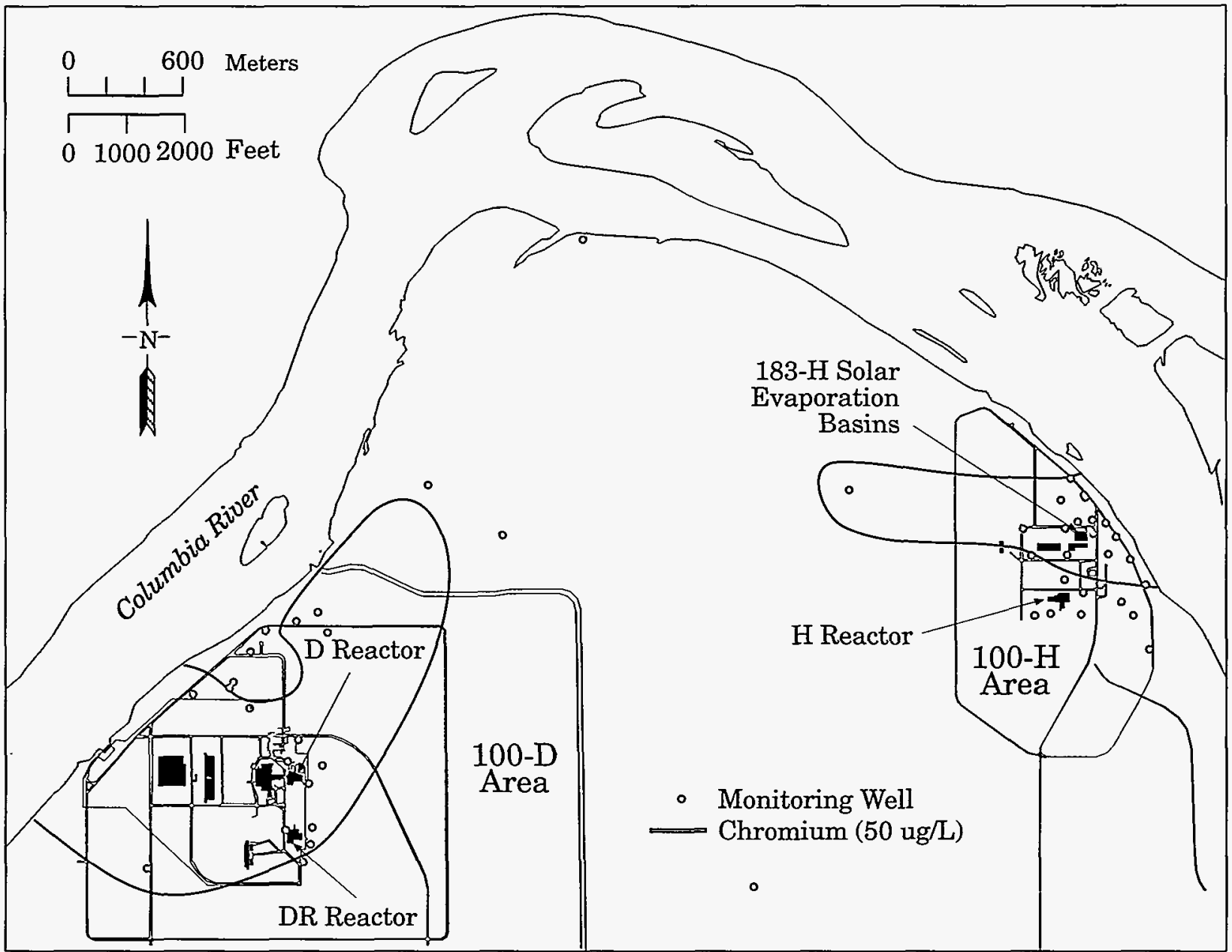

S9402063.9

Figure 5.70. Distribution of Chromium in the 100-D and 100-H Areas, 1993

Chromium in the 100 Areas. Chromium has been detected in ground water from wells in each of the 100 Areas. However, concentrations in the 100-B/C Area were less than the federal Drinking Water Standard of $100 \mu \mathrm{g} / \mathrm{L}$ (the Washington State maximum contaminant level is $50 \mu \mathrm{g} / \mathrm{L}$ ).

High chromium concentrations were detected at similar levels in both filtered and unfiltered samples from the 100-D Area. This indicates that the chromium concentrations are representative of the mobile concentrations in the ground water. The maximum chromium concentration from samples in the 100-D Area in 1993 was $1,910 \mu \mathrm{g} / \mathrm{L}$ in well 199-D5-15. The chromium distribution in the 100-D Area is shown in Figure 5.70.
Relatively few chromium analyses were available from the $100-\mathrm{F}$ Area in past years. Recent drilling activities in the 100-F Area have improved the coverage. The highest chromium level observed in 1993 in the $100-\mathrm{F}$ Area was $206 \mu \mathrm{g} / \mathrm{L}$ in well 199-F5-46.

Many samples from the $100-\mathrm{H}$ Area contained chromium at levels greater than the Drinking Water Standard (Figure 5.70). Chromium was often present at similar levels in both filtered and unfiltered samples. The maximum chromium concentration from 100-H Area samples in 1993 was $490 \mu \mathrm{g} / \mathrm{L}$ in well 199-H4-12C. Potential chromium sources in the $100-\mathrm{H}$ Area include disposal of sodium dichromate near the reactor building 
and to the 107-H Liquid Waste Disposal Trench, and chromium in acid wastes stored in the 183-H Solar Evaporation Basins (Peterson and Connelly 1992). Chromium was also detected in parts of the 600 Area upgradient from the $100-\mathrm{H}$ Area indicating an upgradient source.

Chromium is found in both filtered and unfiltered samples from the 100-K Area at levels greater than the Drinking Water Standard (Figure 5.59). In contrast, at the 100-N Area, samples from 1993 that contained chromium at concentrations greater than the Drinking Water Standard were unfiltered, and filtered samples from the same wells contained chromium at levels less than the Drinking Water Standard. Thus, the occasional and erratic high chromium concentrations at the $100-\mathrm{N}$ Area may result from greater amounts of particulate matter in the samples.

Chromium in the 200 Areas. Chromium at concentrations greater than the Drinking Water Standard in the 200-East Area is found only in unfiltered samples with the exception of samples from well 299-E24-19. The widespread presence of chromium associated with particulate matter in the 200-East Area may be related to the stainless-steel well construction. Chromium is a component of stainless steel, and it is not clear that the sample concentrations are representative of the ground water. Well 299-E24-19 has recently developed chromium concentrations of up to $3,000 \mu \mathrm{g} / \mathrm{L}$ in unfiltered and $1,800 \mu \mathrm{g} / \mathrm{L}$ in filtered samples. These concentrations are possibly related to well corrosion because nickel (another stainless-steel component) concentrations are also increasing. Some of the chromium and nickel may be associated with ultra-fine or colloidal particles that pass through the $0.45-\mu \mathrm{m}$ filters used in ground-water sampling.

Chromium contamination has been found at several locations in the 200-West Area. Chromium in the 200-West Area is found in both filtered and unfiltered samples, although the filtered concentrations tend to be somewhat lower in many instances. The highest filtered chromium concentration observed in that area in 1993 was $480 \mu \mathrm{g} / \mathrm{L}$ in well $299-W 14-12$.

Chromium in the 300 Area. Chromium has been detected at concentrations greater than the Drinking Water Standard in a few unfiltered samples from the 300 Area in the past. The concentrations in filtered samples were in all cases less than the Drinking Water Standard, and the detected values in the unfiltered samples were erratic. This difference suggests that the high chromium concentrations found in these monitoring wells represent particulate matter which may be related to well construction and are affected by the well purging procedures, the time between samples, or other effects that do not reflect the general ground-water quality. Very few chromium measurements were reported for 300 Area wells in 1993.

Chromium in Other Areas. Chromium greater than the Drinking Water Standard has also been detected in 600 Area RCRA monitoring wells near the Solid Waste Landfill and B Pond. Chromium in filtered samples, however, remained less than the Drinking Water Standard. In the B Pond area, high chromium was found in wells monitoring the top of the unconfined aquifer and what is referred to as the semi-confined aquifer. It appears that the stainless-steel well casings or well screens may be contributing particulate chromium to the unfiltered samples.

\section{Carbon Tetrachloride and Chloroform}

Carbon tetrachloride contamination was found in the unconfined aquifer beneath much of the 200-West Area. The contamination is believed to be from waste disposal operations associated with Z Plant. Carbon tetrachloride was used as the carrier solvent for tributyl phosphate in the final purification of weapons-grade plutonium. Carbon tetrachloride was also used in the same facility as a nonflammable thinning agent in association with lard oil for machining of plutonium. Carbon tetrachloride is immiscible in water but exhibits a relatively high solubility $\left(805 \mathrm{mg} / \mathrm{L}\right.$ at $\left.20^{\circ} \mathrm{C}\right)$. Carbon tetrachloride has been found to have a relatively high degree of mobility in ground water. Mobilization can also occur through vapor transport. A concentration of $8,100 \mu \mathrm{g} / \mathrm{L}$ was found in a well near $Z$ Plant first monitored in October 1988 (well 299-W15-16). Carbon tetrachloride concentrations in well 299-W15-16 remained fairly constant in 1993 , reaching a maximum of $7,000 \mu \mathrm{g} / \mathrm{L}$. Numerous other wells in the area had carbon tetrachloride levels ranging from 1,000 to $5,000 \mu \mathrm{g} / \mathrm{L}$. The distribution of carbon tetrachloride in the 200-West Area greater than the Drinking Water Standard is shown in Figure 5.71.

The carbon tetrachloride distribution in the 200-West Area ground water has remained relatively stable since the presence of the contaminant plume was first noted in 1987. Figure 5.71 shows the trends in carbon tetrachloride concentrations with time for wells located at the east, west, north, and south boundaries of the plume. Well 699-39-79 shows a major increase during 1987 and 


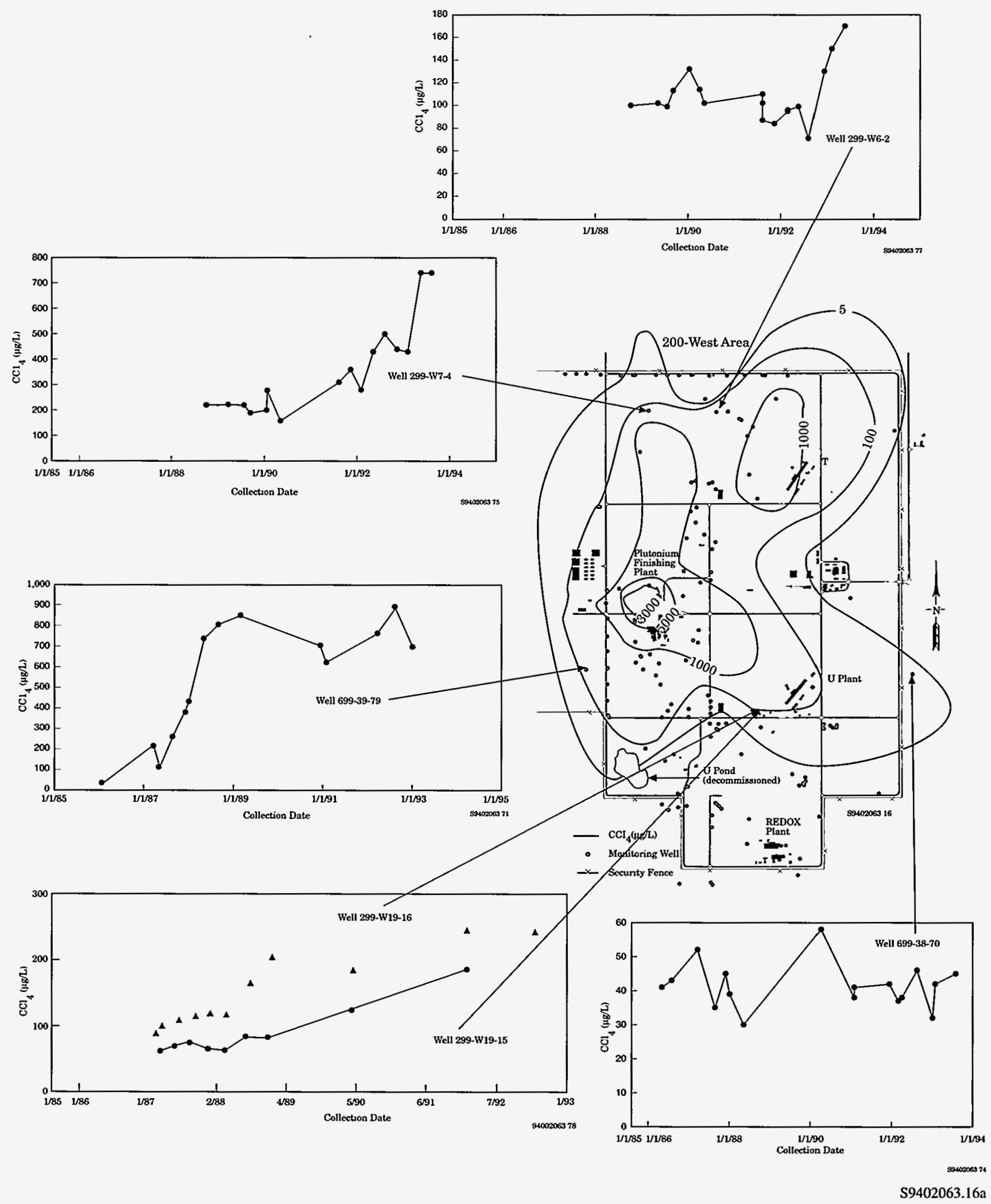

Figure 5.71. Distribution of Carbon Tetrachloride $\left(\mathrm{CCl}_{4}\right)$ in the 200-West Area, 1993 
1988 , indicating arrival of the bulk of the plume at that time. Since 1988 the concentration in well 699-39-79 has remained relatively constant. Wells $299-W 7-4$ and 299-W6-2 in the north show an increase in concentrations in recent years. Concentrations in wells 299-W19-16 and 299-W19-15 to the southeast of Z Plant have risen in recent years, while well 699-38-70 exhibits steady concentrations.

Changes in ground-water flow since decommissioning $\mathrm{U}$ Pond may influence the exact plume configuration and the concentrations at particular locations. Another potential influence is the continued spreading of carbon tetrachloride above the water table, in either the liquid or vapor phase. Free-phase liquid carbon tetrachloride above and possibly below the water table provides a continuing source of contamination. Thus, expansion of the carbon tetrachloride plume is expected to continue slowly.

The Drinking Water Standard for carbon tetrachloride is $5 \mu \mathrm{g} / \mathrm{L}$. In addition to carbon tetrachloride, significant amounts of other chlorinated hydrocarbon solvents were found in 200-West Area ground water, including trichloroethylene and chloroform. A chloroform concentration of $1,540 \mu \mathrm{g} / \mathrm{L}$ was measured in well 299-W15-8 in May 1990. The highest level recorded in 1993 was $300 \mu \mathrm{g} / \mathrm{L}$ in well 299-W18-2. The chloroform plume appears to be associated with, but not exactly coincident with, the carbon tetrachloride plume. The Drinking Water Standard for chloroform is $100 \mu \mathrm{g} / \mathrm{L}$ (total trihalomethanes), 20 times higher than that for carbon tetrachloride. The location of the chloroform plume is shown on Figure 5.72. Chloroform may result from the degradation of carbon tetrachloride either in the process or in the subsurface as the result of biodegradation.

\section{Trichloroethylene}

Trichloroethylene has a Drinking Water Standard of $5 \mu \mathrm{g} / \mathrm{L}$. Trichloroethylene has been detected in wells in the $100-\mathrm{B} / \mathrm{C}, 100-\mathrm{F}, 100-\mathrm{K}, 200-$ West, and 300 Areas, and the Solid Waste Landfill (in the 600 Area).

Trichloroethylene in the 100 Areas. Trichloroethylene was detected in 1993 at levels less than the Drinking Water Standard in 100-B/C Area wells. It was detected at levels greater than the Drinking Water Standard in the 100-F Area wells. The maximum concentration detected in the $100-\mathrm{F}$ Area in 1993 was $28 \mu \mathrm{g} / \mathrm{L}$ in a sample for well 199-F7-1. In addition, trichloroethylene was found at $27 \mu \mathrm{g} / \mathrm{L}$ in well $699-77-36$, west of the $100-\mathrm{F}$ Area.
Three wells in the 100-K Area contained trichloroethylene at levels above the Drinking Water Standard. The maximum concentration detected in 1993 was $19 \mu \mathrm{g} / \mathrm{L}$ in monitoring well 199-K-33.

Trichloroethylene in the $\mathbf{2 0 0}$ Areas. Trichloroethylene was detected in 1993 at levels greater than the Drinking Water Standard in the 200-West Area in two areas. The first location is to the west of T Plant, and concentrations up to $18 \mu \mathrm{g} / \mathrm{L}$ were detected in 1993. The other location is near the REDOX Plant. The maximum level found in 1993 in a well near the REDOX Plant (299-W22-20) was $32 \mu \mathrm{g} / \mathrm{L}$.

Trichloroethylene in the $\mathbf{3 0 0}$ Area. Trichloroethylene was detected in several wells throughout the 300 Area. The highest level detected in the northern half of the 300 Area was $11 \mu \mathrm{g} / \mathrm{L}$ in well $399-1-16 \mathrm{~B}$. This well monitors the lower portion of the unconfined aquifer system. Past samples have contained cis-1,2dichloroethylene (up to $120 \mu \mathrm{g} / \mathrm{L}$ in 1992) but this constituent was not reported in 1993 samples. The Drinking Water Standard for trichloroethylene and cis1,2-dichloroethylene are $5 \mu \mathrm{g} / \mathrm{L}$. Trichloroethylene was also detected at levels at or near the Drinking Water Standard in a few wells in the southern half of the 300 Area. The maximum concentration reported in 1993 was $6 \mu \mathrm{g} / \mathrm{L}$ in well 399-4-12.

Trichloroethylene in the 600 Area. Several wells at the Solid Waste Landfill contained trichloroethylene close to, but slightly less than, the Drinking Water Standard (maximum of $3.9 \mu \mathrm{g} / \mathrm{L}$ in well $699-22-34 \mathrm{~A}$ ). Solid Waste Landfill wells had shown trichloroethylene concentrations greater than the Drinking Water Standard in previous years. These wells also continued to show levels of tetrachloroethylene just greater than the $5-\mu \mathrm{g} / \mathrm{L}$ Drinking Water Standard. The source of the trichloroethylene in this area is apparently disposal of waste from vehicle maintenance operations in the mid-1980s through 1987.

\section{Tetrachloroethylene}

Tetrachloroethylene, also referred to as perchloroethylene, is detected at low levels in a number of areas of the Site including the 200-West Area, the 300 Area, and the southern portion of the 600 Area. A number of samples from wells in the 1100 and North Richland Areas contained low concentrations of tetrachloroethylene. The only area where tetrachloroethylene was detected at concentrations greater than the Drinking Water Standard 


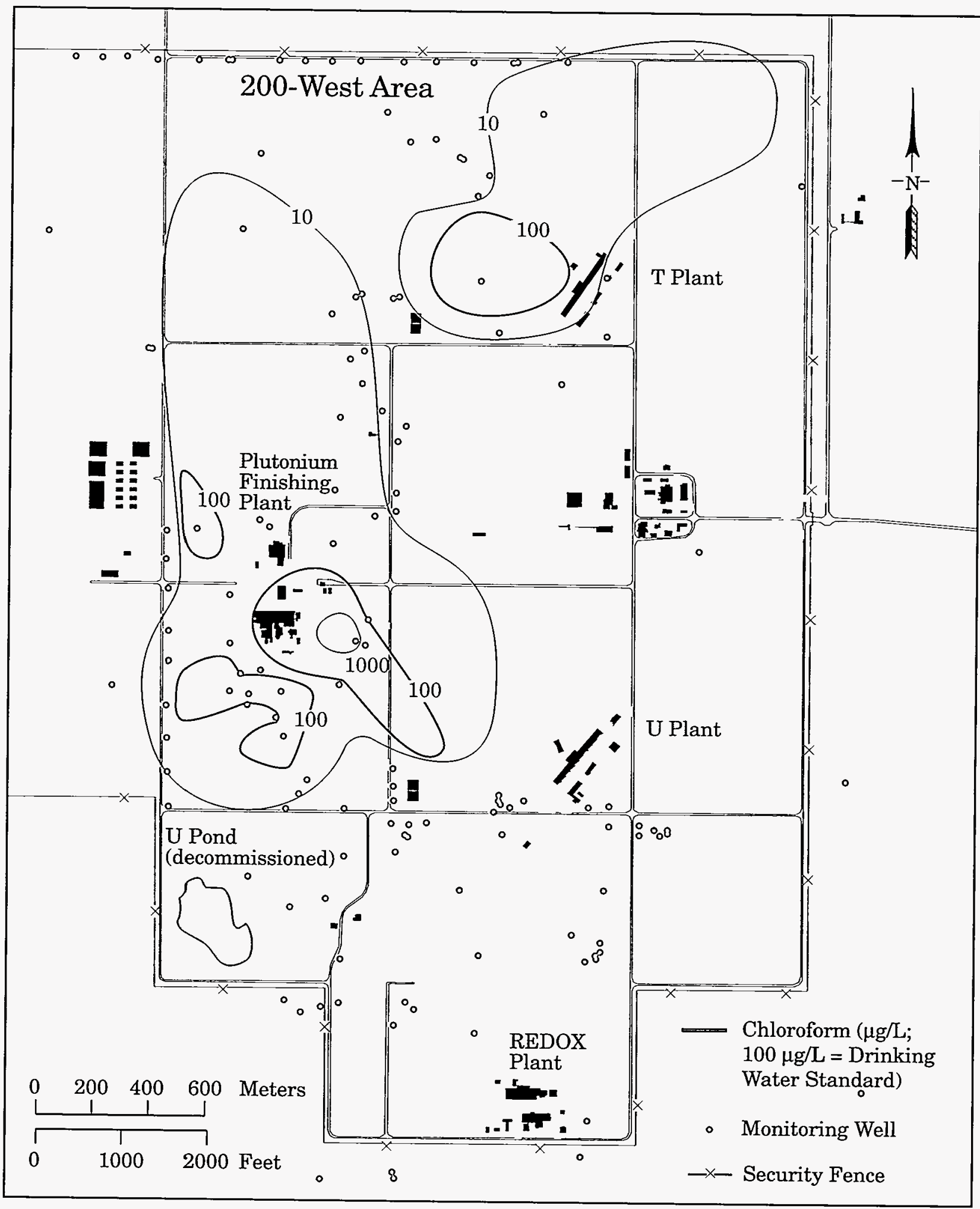

S9402063.14

Figure 5.72. Distribution of Chloroform in the Unconfined Aquifer near the 200-West Area, 1993 
is the Solid Waste Landfill, where the concentrations reached a maximum of $5.9 \mu \mathrm{g} / \mathrm{L}$ in well $699-23-34 \mathrm{~A}$. Tetrachloroethylene is commonly used as a degreasing solvent.

\section{Radiological and Chemical Monitoring Results for the Confined Aquifer}

The uppermost (Rattlesnake Ridge) confined aquifer was monitored to determine the extent of ground-water contamination resulting from interaction between the confined and unconfined aquifers. Intercommunication between aquifers has been previously identified by Gephart et al. (1979) and Graham et al. (1984). Groundwater samples from selected confined aquifer wells have been analyzed for a variety of radionuclides and hazardous chemicals. In most cases, no indication of contamination was observed. Detection of radionuclides in well 299-E33-12 is attributed to contamination by high-salt waste that migrated by density flow into the borehole when it was open to both the unconfined and the confined aquifer during drilling (Graham et al. 1984). The 1993 sample from well 299-E33-12 contained $820 \mathrm{pCi} / \mathrm{L}$ of ${ }^{3} \mathrm{H}$, similar to levels detected since 1991.

Intercommunication between the Rattlesnake Ridge confined aquifer and the unconfined aquifer north of the 200-East Area was indicated by the nitrate concentration in well 699-47-50, which was $8,700 \mu \mathrm{g} / \mathrm{L}$ in 1993 . This well is located near an erosional window (an area where the confining layer is absent) in the confining basalt flow (Graham et al. 1984). Elevated levels of ${ }^{3} \mathrm{H}$ have also been measured in ground water from the Rattlesnake Ridge interbed in well 699-42-40C located adjacent to $B$ Pond. This well contained a maximum of $8,320 \mathrm{pCi} / \mathrm{L}$ of ${ }^{3} \mathrm{H}$ in April 1993, continuing a generally increasing trend. Recent samples showed somewhat lower ${ }^{3} \mathrm{H}$ levels, suggesting an effect by dilute water more recently discharged to the pond. 


\section{Potential Radiation Doses from 1993 Hanford Operations}

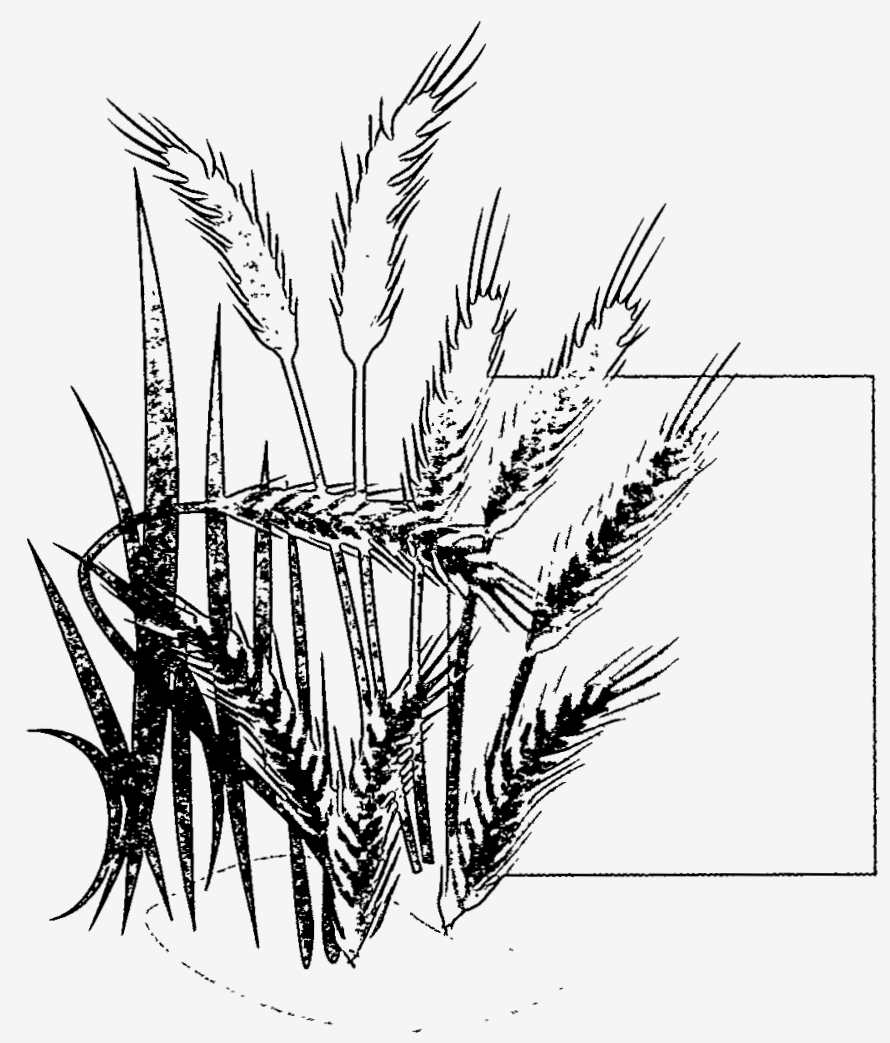




\title{
6.0 Potential Radiation Doses from 1993 Hanford Operations
}

\author{
J. K. Soldat
}

Present and past operations at Hanford have resulted in the release of radionuclides into the surrounding environment. Members of the public are potentially exposed to low levels of radiation from these effluents through a variety of pathways. The potential radiation doses ${ }^{(a)}$ to the public in 1993 from Hanford operations were calculated for the hypothetical maximally exposed individual (MEI) and for the general public residing within $80 \mathrm{~km}$ (50 $\mathrm{mi}$ ) of the Hanford Site. These doses were calculated from effluent releases reported by the operating contractors, and radionuclide measurements in environmental media, using Version 1.485 of the GENII code (Napier et al. 1988a, 1988b, 1988c) and Hanford Site-specific parameters listed in Appendix D and by Bisping (1994).

The potential dose to the MEI in 1993 from Hanford operations was $0.03 \mathrm{mrem}\left(3 \times 10^{-4} \mathrm{mSv}\right)$ compared to $0.02 \mathrm{mrem}\left(2 \times 10^{-4} \mathrm{mSv}\right)$ reported for 1992 . The potential dose to the local population of 380,000 persons (Beck et al. 1991) from 1993 operations was 0.4 personrem (0.004 person-Sv), compared to 0.8 person-rem (0.008 person-Sv) reported for 1992 . The 1993 average dose to the population was $0.001 \mathrm{mrem}\left(1 \times 10^{-5} \mathrm{mSv}\right)$ per person. The current DOE radiation limit for an individual member of the public is $100 \mathrm{mrem} / \mathrm{yr}$ ( $1 \mathrm{mSv} / \mathrm{yr}$ ), and the national average dose from natural sources is $300 \mathrm{mrem} / \mathrm{yr}$ ( $3 \mathrm{mSv} / \mathrm{yr})$. During 1993 the MEI potentially received $0.03 \%$ of the DOE dose limit and $0.01 \%$ of the natural background average dose. The average individual potentially received $0.001 \%$ of the standard and $0.0003 \%$ of the $300 \mathrm{mrem} / \mathrm{yr}$ received from typical natural sources.

The small additional dose to the MEI was a result of new experimental work initiated in the 300 Area during September 1993. This work entailed the release of radon isotopes ( $85 \mathrm{Ci}$ of ${ }^{220} \mathrm{Rn}$ and $1.5 \mathrm{Ci}$ of ${ }^{222} \mathrm{Rn}$ ) to the atmosphere from the 327 Building ventilation system (see Table 3.1). As a result, the MEI location was changed to a point $1.5 \mathrm{~km}(1 \mathrm{mi})$ across the river east from the 300 Area. The calculated potential dose from these releases to the MEI was $\left.0.01 \mathrm{mrem}\left(1 \times 10^{-4}\right) \mathrm{mSv}\right)$. The calculated potential dose to the population within $80 \mathrm{~km}$ $(50 \mathrm{mi})$ of the Hanford Site was 0.06 person-rem $\left(6 \times 10^{-}\right.$ ${ }^{4}$ person-Sv). Inhalation of the ${ }^{212} \mathrm{~Pb}$ decay product of the ${ }^{220} \mathrm{Rn}$ accounted for over $90 \%$ of these doses. These doses are included in the air pathway doses listed in Tables 6.1 and 6.2.

During 1993, radionuclides reached the environment in gaseous and liquid effluents from present and past Hanford operations. Gaseous effluents were released from operating stacks and ventilation exhausts. Liquid effluents were released from operating wastewater treatment facilities and in seepage of contaminated ground water into the Columbia River. These radioactive materials were then transported throughout the environment by wind and the Columbia River. Eventually, animals and people can be exposed to these radionuclides through external exposure, and inhalation and ingestion of contaminated air, water, and foodstuffs. Because of the many variables involved in the transport of the radionuclides in the environment and differing living habits of people, the assumptions used to describe the exposure scenarios are conservative (in other words, the doses are likely to be overestimated).

Potential radiation doses to the public from these releases were evaluated in detail to determine compliance with pertinent regulations and limits. The potential radiological impacts of 1993 Hanford operations were assessed in terms of the following:

- dose to a hypothetical MEI at an offsite location

- maximum dose rate from external radiation at a publicly accessible location on or within the Site boundary

(a) Unless stated otherwise the term "dose" in this chapter is the "effective dose equivalent" (see Glossary). 
Table 6.1. Doses to the Hypothetical Maximally Exposed Individual from Hanford Operations, 1993

\begin{tabular}{|c|c|c|c|c|c|c|}
\hline \multirow[b]{2}{*}{ Effluent } & \multirow[b]{2}{*}{ Pathway } & \multicolumn{5}{|c|}{$\begin{array}{c}\text { Operating Area Contribution } \\
\text { Doses, mrem }\end{array}$} \\
\hline & & $\begin{array}{r}100 \\
\text { Areas } \\
\end{array}$ & $\begin{array}{r}200 \\
\text { Areas } \\
\end{array}$ & $\begin{array}{r}300 \\
\text { Area } \\
\end{array}$ & $\begin{array}{r}400 \\
\text { Area } \\
\end{array}$ & $\begin{array}{l}\text { Pathway } \\
\text { Total }\end{array}$ \\
\hline \multirow[t]{3}{*}{ Air } & External(c) & $4 \times 10^{-8}$ & $2 \times 10^{-6}$ & $3 \times 10^{-4}$ & $3 \times 10^{-8}$ & $3 \times 10^{-4}$ \\
\hline & Inhalation & $8 \times 10^{-6}$ & 0.001 & 0.01 & $2 \times 10^{-5}$ & 0.01 \\
\hline & Foods $^{(d)}$ & $4 \times 10^{-7}$ & $6 \times 10^{-4}$ & $2 \times 10^{-4}$ & $2 \times 10^{-5}$ & $8 \times 10^{-4}$ \\
\hline \multirow[t]{4}{*}{ Water } & Recreation $^{(e)}$ & $2 \times 10^{-6}$ & $5 \times 10^{-5}$ & $6 \times 10^{-7}$ & --..(i) & $6 \times 10^{-5}$ \\
\hline & Foods $^{(g)}$ & $4 \times 10^{-4}$ & 0.008 & $1 \times 10^{-4}$ & --- & 0.008 \\
\hline & Fish $^{(\text {h) }}$ & $4 \times 10^{-4}$ & 0.004 & $1 \times 10^{-4}$ & --- & 0.004 \\
\hline & Total & $8 \times 10^{-4}$ & 0.01 & 0.01 & $4 \times 10^{-5}$ & 0.03 \\
\hline
\end{tabular}
(a) To convert these dose values to $\mathrm{mSv}$, divide them by 100 .
(b) Values rounded after adding.
(c) Includes air submersion and exposure to ground-deposited radionuclides.
(d) Includes consumption of all foodstuffs contaminated via deposition from the air.
(e) External exposure during river recreation plus inadvertent ingestion of water while swimming.
(f) There are no releases to the river from the 400 Area.
(g) Includes consumption of all foodstuffs contaminated via irrigation water.
(h) Consumption of fish taken from the Columbia River.

Table 6.2. Population Doses from Hanford Operations, 1993

\begin{tabular}{|c|c|c|c|c|c|c|}
\hline \multirow[b]{2}{*}{ Effluent } & \multirow[b]{2}{*}{ Pathway } & \multicolumn{5}{|c|}{$\begin{array}{l}\text { Operating Area Contribution } \\
\text { Doses, person-rem } \\
\text { (a,b) }\end{array}$} \\
\hline & & $\begin{array}{c}100 \\
\text { Areas } \\
\end{array}$ & $\begin{array}{c}200 \\
\text { Areas } \\
\end{array}$ & $\begin{array}{l}300 \\
\text { Area } \\
\end{array}$ & $\begin{array}{l}400 \\
\text { Area }\end{array}$ & $\begin{array}{l}\text { Pathway } \\
\text { Total }\end{array}$ \\
\hline \multirow[t]{3}{*}{ Air } & External(c) $^{(\mathbf{c})}$ & $8 \times 10^{-6}$ & $2 \times 10^{-4}$ & 0.003 & $1 \times 10^{-6}$ & 0.002 \\
\hline & Inhalation & 0.002 & 0.1 & 0.06 & 0.001 & 0.2 \\
\hline & Foods ${ }^{(d)}$ & $1 \times 10^{-4}$ & 0.07 & 0.01 & 0.001 & 0.09 \\
\hline \multirow[t]{5}{*}{ Water } & Recreation $^{(c)}$ & $9 \times 10^{-6}$ & $3 \times 10^{-4}$ & $3 \times 10^{-6}$ & $--^{(f)}$ & $3 \times 10^{-4}$ \\
\hline & Foods ${ }^{(g)}$ & $4 \times 10^{-4}$ & 0.008 & $1 \times 10^{-4}$ & --- & 0.009 \\
\hline & Fish $^{(\text {h) }}$ & $1 \times 10^{-4}$ & 0.001 & $4 \times 10^{-5}$ & --- & 0.002 \\
\hline & Drinking Water & 0.001 & 0.1 & $6 \times 10^{-4}$ & --- & 0.014 \\
\hline & Total & 0.004 & 0.3 & 0.07 & 0.003 & 0.4 \\
\hline
\end{tabular}

(a) To convert these dose values to person-Sv, divide them by 100 .

(b) Values rounded after adding.

(c) Includes air submersion and exposure to ground-deposited radionuclides.

(d) Includes consumption of all foodstuffs contaminated via deposition from the air.

(e) External exposure during river recreation plus inadvertent ingestion of water while swimming.

(f) There are no releases to the river from the 400 Area.

(g) Includes consumption of all foodstuffs contaminated via irrigation water and external exposure to ground contaminated via irrigation.

(h) Consumption of fish taken from the Columbia River. 
- dose to an avid sportsman who consumes wildlife exposed to radionuclide onsite

- dose to the population residing within $80 \mathrm{~km}$ (50 mi) of the operating areas

- absorbed dose rate ( $\mathrm{rad} / \mathrm{d}$ ) potentially received by animals associated with contaminant releases to the Columbia River.

To the extent possible, radiation dose assessments should be based on direct measurements of radiation dose rates and radionuclide concentrations in the surrounding environment. The amounts of most radioactive materials released during 1993 were generally too small to be measured directly once they were dispersed in the offsite environment. For many of the measurable radionuclides, it was difficult to identify the contributions from Hanford sources in the presence of contributions from world-wide fallout and from naturally occurring uranium and its decay products. Therefore, in nearly all instances, potential offsite doses were estimated using environmental pathway models that calculate concentrations of radioactive materials in the environment from effluent releases reported by the operating contractors.

As in the past, the differences in measured concentrations of certain radionuclides in samples of Columbia River water collected upstream and downstream of the Hanford Reach were used to estimate the doses to the public from these radionuclides entering the river with riverbank seepage of ground water. During $1992,{ }^{3} \mathrm{H}$, ${ }^{129} \mathrm{I}$, and isotopes of uranium were found in the Columbia River downstream of Hanford at greater concentrations than predicted from direct discharge from the 100 and 300 Areas.

Although the uncertainty associated with the radiation dose calculations has not been quantified, whenever Hanford-specific data were not available for parameter values (for example, vegetation uptake and consumption factors), conservative values were selected from the literature for use in environmental transport models. Thus, radiation doses calculated using environmental models should be viewed as maximum estimates of potential doses resulting from Hanford operations.

\section{Maximally Exposed Individual Dose}

The MEI is a hypothetical person who lives at a location and has a postulated lifestyle such that it is unlikely that other members of the public would receive higher radiation doses. This individual's characteristics were chosen to maximize the combined doses from all realistic environmental pathways of exposure to radionuclides in Hanford effluents. In reality, such a combination of maximized parameters is unlikely to apply to any single individual.

The location selected for the MEI can vary from year to year depending on the relative importance of the several sources of radioactive effluents released to the air and to the Columbia River from Hanford facilities. Historically, two separate locations in the Hanford environs have been identified as potential sites for the MEI: the Ringold area $26 \mathrm{~km}$ (16 mi) east of the 200 Areas separation facilities, and the Riverview irrigation district across the river from Richland (Figure 6.1). The principal differences between the two MEI locations are that Ringold is closer than Riverview to the Hanford facilities which had been the major contributors of airborne effluents in the past, but the MEI at Ringold does not drink water derived from the Columbia River. The MEI at Riverview, although farther from the Hanford sources of airborne radionuclides, can be exposed to the one additional pathway of consumption of drinking water derived from the Columbia River.

However, because of the small additional radiation dose contributed by the releases of ${ }^{220} \mathrm{Rn}$ and ${ }^{222} \mathrm{Rn}$ from the 300 Area mentioned above, a hypothetical MEI located $1.5 \mathrm{~km}$ ( $1 \mathrm{mi}$ ) directly across the Columbia River from the 300 Area was calculated to have received a slightly higher dose in 1993 than an MEI located at either Ringold or Riverview. The farms across from the 300 Area use water derived from the Columbia Irrigation System far upstream of the Hanford Site for irrigation and well water for sanitary purposes. Foods grown there would only contain radionuclides released with airborne effluents of Hanford origin. Therefore, the highly conservative assumption was made that the diet of the 


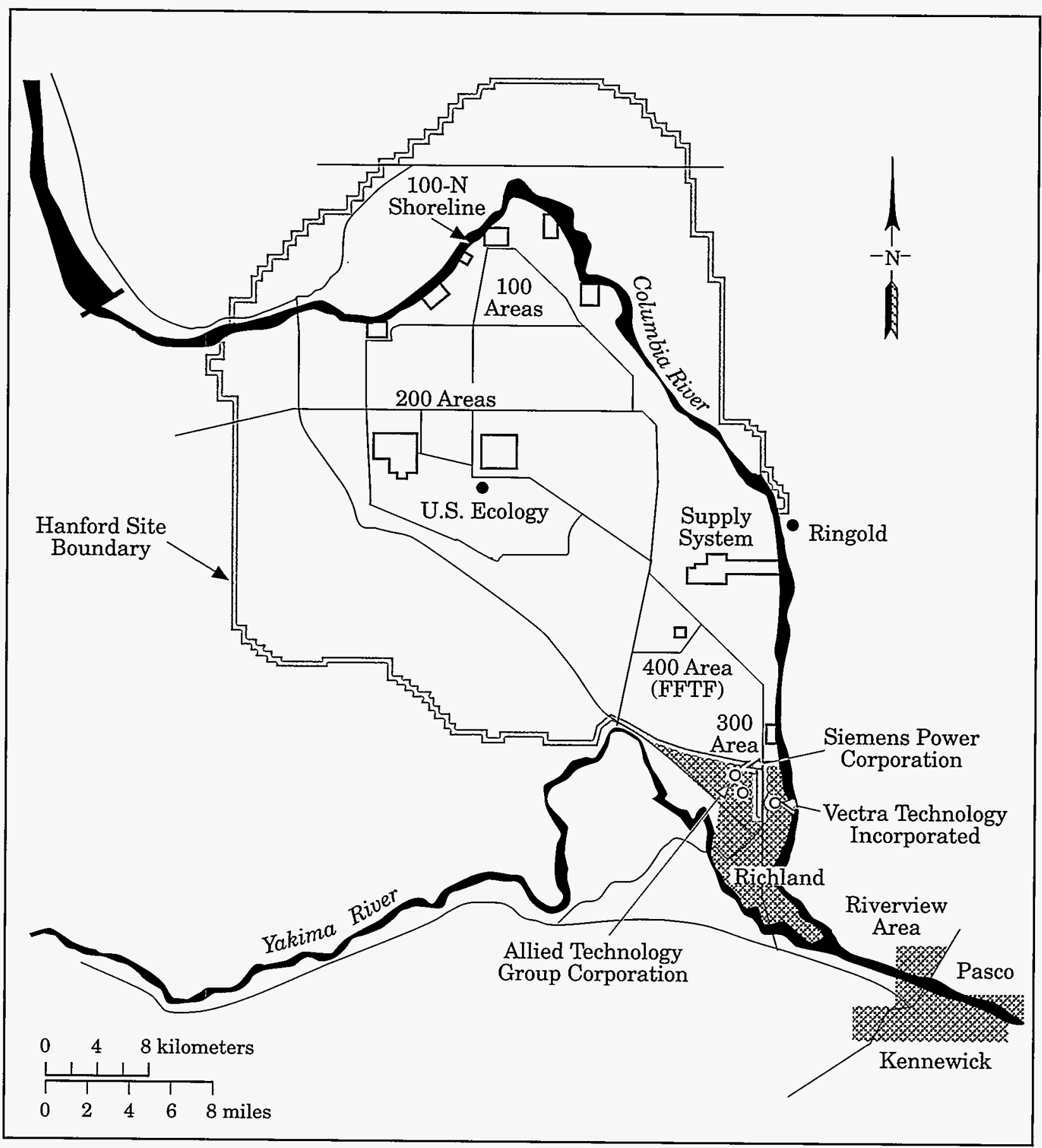

S9402063.141

Figure 6.1. Locations Important to Dose Calculations 
MEI residing across from the 300 Area consisted totally of foods purchased from the Riverview area where they could contain radionuclides present in both liquid and gaseous effluents from Hanford. The radiation dose from all pathways associated with airborne effluents is only slightly less for food produced in the Riverview area. However, the added contribution of the radionuclides in the Riverview irrigation water maximizes the potential dose from all air and water pathways combined.

The following exposure pathways were included in the calculation of doses potentially received by the hypothetical MEI for 1993: inhalation of and submersion in air downwind of the Site, consumption of foods contaminated by radionuclides deposited from the air and by irrigation with water from the Columbia River, direct exposure to radionuclides deposited on the ground, consumption of fish taken from the Columbia River, and external radiation during recreation activities on the Columbia River and its shoreline. The MEI for 1993 was postulated to be an individual who:

- was a resident of the closest farm $1.5 \mathrm{~km}(1 \mathrm{mi})$ across the Columbia River from the 300 Area

- consumed foodstuffs irrigated with Columbia River water grown in the Riverview Irrigation District

- used the Columbia River extensively for boating, swimming, and fishing, and consumed the fish caught

- drank well water that did not contain radionuclides of Hanford origin

- was exposed to the low levels of ${ }^{220} \mathrm{Rn}$ and ${ }^{222} \mathrm{Rn}$ released from the 300 Area in October, November, and December 1993.

Radiation doses to the MEI were calculated using the effluent data in Section 3.1, Tables 3.1,3.3, and 3.4, and measured quantities of radionuclides assumed to be present in the Columbia River from riverbank springs as input to the GENII code. The calculated doses for the MEI are summarized in Table 6.1. These values include the potential doses received from exposure to liquid and airborne effluents during 1993, as well as the future dose from radionuclides that were deposited in the body during 1993 via inhalation and ingestion. As releases from facilities and the doses from these sources decrease, the contribution of diffuse sources, such as wind-blown contaminated soil, becomes relatively more significant. An upper estimate of the dose from diffuse sources is discussed in a following subsection ("Comparison with Clean Air Act Standards"). This contribution is not included in the MEI dose. Site-specific parameters for food pathways, diet, and recreational activity used for the dose calculations are contained in Appendix D.

The total potential radiation dose to the hypothetical MEI in 1993 was calculated to be $0.03 \mathrm{mrem}\left(3 \times 10^{-4} \mathrm{mSv}\right)$ compared to 0.02 mrem $\left(2 \times 10^{-4} \mathrm{mSv}\right)$ calculated for in 1992. The primary pathways contributing to this dose as determined by the computer calculations were:

- inhalation of airborne radionuclides, principally the ${ }^{212} \mathrm{~Pb}$ decay product of the ${ }^{220} \mathrm{Rn}$ released from the 300 Area (50\%)

- consumption of food irrigated with Columbia River water containing radionuclides, principally ${ }^{3} \mathrm{H}$ and ${ }^{99} \mathrm{Tc}(29 \%)$

- consumption of fish containing radionuclides, principally isotopes of uranium, from the Columbia River (15\%).

The radiation dose limit for any member of the public from all routine DOE operations is $100 \mathrm{mrem} / \mathrm{yr}$ ( $1 \mathrm{mSv} / \mathrm{yr}$ ). The dose calculated for the MEI was $0.03 \%$ of the DOE limit.

The doses from Hanford operations for the MEI for 1989 through 1993 are illustrated in Figure 6.2. During each year the doses were estimated using methods and computer codes that were state-of-the-art at the time. During the period of 1989 through 1992, the MEI was located at either Ringold or Riverview, whichever location represented the maximum hypothetical dose. For 1993, the hypothetical MEI was located across the Columbia River from the 300 Area.

\section{Special Case Exposure Scenarios}

While characteristics that define the standard and historical MEI are selected to define a high exposure scenario that is unlikely to occur, they do not necessarily represent the scenario with the highest conceivable radiation dose. Low probability exposure scenarios exist 


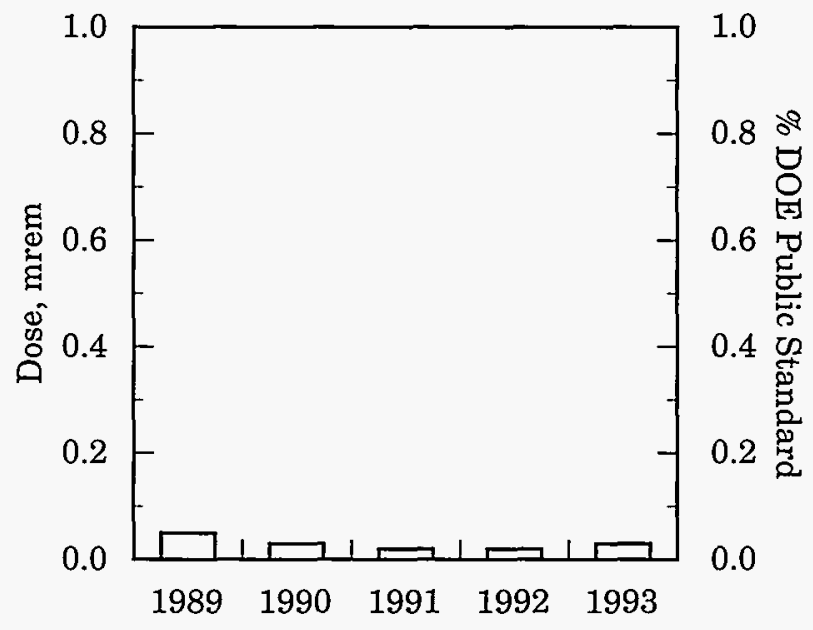

S9402063.127

Figure 6.2. Calculated Effective Dose Equivalent to the Hypothetical Maximally Exposed Individual, 1989 Through 1993

that could conceivably result in somewhat higher doses. Two potential scenarios include an individual who could spend time at the Site boundary location with the maximum external radiation dose rate, and a sportsman who might obtain contaminated wildlife that migrated from the Site. These special cases are discussed below, as well as the potential dose from consumption of drinking water at the FFTF Visitors Center.

\section{Maximum "Boundary" Dose Rate}

The "boundary" radiation dose rate is the external radiation dose rate measured at publicly accessible locations on or near the Site. The "boundary" dose rate was determined from radiation exposure measurements using radiation dosimeters (TLDs) at locations of expected elevated dose rates onsite and at representative locations offsite. These "boundary" dose rates should not be used to calculate annual doses to the general public because no one can actually reside at any of these "boundary" locations. However, these rates can be used to determine the dose to a specific individual who might spend some time at that location.

External radiation dose rates were measured in the vicinity of the $100-\mathrm{N}, 200,300$, and 400 (FFTF) Areas, as described in Section 5.7, "External Radiation Surveil- lance." The 200 Areas results were not used because these locations are not accessible to the general public. Radiation measurements made at the $100-\mathrm{N}$ Area shoreline (Figure 6.1) were consistently above the background level and represent the highest measured "boundary" dose rates. The Columbia River provides public access to an area within a few hundred meters of the N Reactor and supporting facilities.

The annual average dose rate at the location with the highest exposure rate along the $100-\mathrm{N}$ shoreline during 1993 was $0.03 \mathrm{mrem} / \mathrm{h}\left(3 \times 10^{-4} \mathrm{mSv} / \mathrm{h}\right)$, or about $0.02 \mathrm{mrem} / \mathrm{h}\left(2 \times 10^{-4} \mathrm{mSv} / \mathrm{h}\right)$ above the average background dose rate of $0.01 \mathrm{mrem} / \mathrm{h}\left(1 \times 10^{-4} \mathrm{mSv} / \mathrm{h}\right)$ normally observed at offsite shoreline locations. Therefore, for every hour someone spent at the 100-N Area shoreline, the external radiation dose received from Hanford operations would be about $0.02 \mathrm{mrem}$ $\left(2 \times 10^{-4} \mathrm{mSv}\right)$. This dose would be in addition to the annual dose calculated for the hypothetical MEI. In practice, the public can approach the shoreline by boat, but they are legally restricted from stepping onto the shoreline.

The FFTF Visitors Center, located southeast of the FFTF Reactor building (Figure 6.1), provides public access to the 400 Area. Dose rates measured at this location during 1993 were essentially equal to normal background radiation levels in the vicinity of Hanford $[0.01 \mathrm{mrem} / \mathrm{h}$ $\left.\left(1 \times 10^{-4} \mathrm{mSv} / \mathrm{h}\right)\right]$.

\section{Sportsman Dose}

Wildlife have access to areas of the Site that contain contamination and could thereby become contaminated. The potential also exists for contaminated wildlife to move offsite. For this reason, sampling is conducted onsite to estimate maximum contamination that might possibly exist in animals hunted offsite. This is a unique and relatively low probability scenario that is not included in the MEI calculation.

Listed below are examples of the estimated radiation doses that could have resulted if wildlife containing the maximum concentrations measured in onsite wildlife in 1993 migrated offsite, were hunted, and were consumed. These are very low doses and qualitative observations suggest that the significance of this pathway is further reduced because of the relatively low migration offsite and the inaccessibility of onsite wildlife to hunters. Not all of the maximum values were observed in the same 
animal of each species sampled. However, the maximum values were compounded to arrive at an upper limit to the potential concentrations. These doses would be in addition to the MEI dose.

- The dose from eating $1 \mathrm{~kg}^{(\mathrm{a})}$ of meat containing the maximum concentration of ${ }^{137} \mathrm{Cs}$ measured in a deer collected onsite is estimated to be $0.02 \mathrm{mrem}$ $\left(2 \times 10^{-4} \mathrm{mSv}\right)$.

- The dose from eating $1 \mathrm{~kg}$ of meat containing the maximum concentration of ${ }^{137} \mathrm{Cs}$ measured in any duck collected onsite is estimated to be $0.05 \mathrm{mrem}$ $\left(5 \times 10^{-4} \mathrm{mSv}\right)$.

- The dose from eating $1 \mathrm{~kg}$ of meat containing the maximum concentration of ${ }^{60} \mathrm{Co}$ and ${ }^{137} \mathrm{Cs}$ measured in any pheasant collected onsite is estimated to be $1 \times 10^{-3} \mathrm{mrem}\left(1 \times 10^{-5} \mathrm{mSv}\right)$.

- The dose from eating $1 \mathrm{~kg}$ of meat containing the maximum concentration of ${ }^{137} \mathrm{Cs}$ measured in a rabbit collected onsite is estimated to be $0.02 \mathrm{mrem}$ $\left(2 \times 10^{-4} \mathrm{mSv}\right)$.

- The dose from eating $1 \mathrm{~kg}$ of meat containing the maximum concentration of ${ }^{137} \mathrm{Cs}$ measured in a carp collected from the Hanford Reach of the Columbia River is estimated to be $1 \times 10^{-3} \mathrm{mrem}\left(1 \times 10^{-5} \mathrm{mSv}\right)$.

The methodology for calculating doses from consumption of wildlife are addressed in more detail in a recent report (Soldat et al. 1990).

\section{FFTF Visitors Center Drinking Water}

During 1993, ground water was used as a drinking water source at the FFTF Visitors Center (Figure 6.1). This water is sampled and analyzed throughout the year in accordance with applicable drinking water regulations. Radionuclide concentrations during 1993 were well below applicable drinking water standards, but concentrations of ${ }^{3} \mathrm{H}$ and ${ }^{129} \mathrm{I}$ were detected at levels greater than typical background values. Based on these measurements, the potential dose received by a member of the public from drinking $1 \mathrm{~L}(\sim 1 \mathrm{qt})$ of drinking water during a visit to the FFTF Visitors Center was calculated to be $4 \times 10^{-4} \mathrm{mrem}\left(4 \times 10^{-6} \mathrm{mSv}\right)$. The maximum organ dose

(a) $1 \mathrm{~kg}=2.2 \mathrm{lb}$. (thyroid) was calculated to be $5 \times 10^{-4} \mathrm{mrem}$ $\left(5 \times 10^{-6} \mathrm{mSv}\right)$. These doses are very small percentages of the DOE limit of 4 mrem effective dose equivalent (0.04 mSv).

\section{Comparison with Clean Air Act Standards}

Limits for radiation dose to the public from airborne emissions at DOE facilities are provided in 40 CFR 61, Subpart H, of the Clean Air Act Amendments. The regulation specifies that no member of the public shall receive a dose of more than $10 \mathrm{mrem} / \mathrm{yr}(0.1 \mathrm{mSv} / \mathrm{yr})$ from exposure to airborne radionuclide effluents released at DOE facilities. It also requires that each DOE facility submit an annual report that supplies information about atmospheric emissions for the preceding year and their potential offsite impacts. The following summarizes information that is provided in more detail in the 1993 air emissions report (Diediker et al. 1994).

The 1993 air emissions from monitored Hanford facilities including radon releases from the 300 Area resulted in a potential dose to an MEI across from the 300 Area of $0.02 \mathrm{mrem}\left(2 \times 10^{-4} \mathrm{mSv}\right)$, which is $0.2 \%$ of the limit. Therefore, the estimated annual dose from monitored stack releases at the Hanford Site during 1993 was well below the Clean Air Act standard. The Clean Air Act requires the use of CAP-88-PC or other EPA models to demonstrate compliance with the standard, and the assumptions embodied in these codes differ slightly from standard assumptions used at the Hanford Site for reporting to DOE via this document. Nevertheless, the result of calculations performed with CAP-88-PC for air emissions from Hanford facilities agrees reasonably well with that calculated using the GENII code $(0.02 \mathrm{mrem}$ or $2 \times 10^{-4} \mathrm{mSv}$ ).

The 1990 amendments to the Clean Air Act (40 CFR 61, Subpart $\mathrm{H}$ ) also require DOE facilities to estimate the dose to a member of the public for radionuclides released from diffuse and unmonitored sources as well as from monitored point sources. The EPA has not specified or approved methods for estimating emissions from diffuse sources, and standardization is difficult because of the wide variety of such sources at DOE sites. Estimates of potential diffuse source emissions at the Hanford Site have been developed using environmental surveillance measurements of airborne radionuclides at the Site perimeter. 
During 1993, the dose to the MEI across the river from 300 Area was $0.03 \mathrm{mrem}\left(3 \times 10^{-4} \mathrm{mSv}\right)$ which, as in 1992, was greater than the estimated dose at that location from stack emissions during $1993\left(0.02\right.$ mrem or $2 \times 10^{-4}$ $\mathrm{mSv}$ ). Based on these results, the combined dose from stack emissions and diffuse and unmonitored sources during 1993 was also much less than the EPA standard.

\section{Population Dose}

Pathways of exposure to the population from releases of radionuclides to the atmosphere include inhalation, air submersion, and consumption of contaminated food. Pathways of exposure associated with Hanford-generated radionuclides present in the Columbia River include consumption of drinking water, fish, and irrigated foods, and external exposure during aquatic recreation. The regional population dose from 1993 Hanford operations was estimated by calculating the radiation dose to the population residing within an $80-\mathrm{km}(50-\mathrm{mi})$ radius of the onsite operating areas. Results of the dose calculations are shown in Table 6.2. Food pathway, dietary, residency, and recreational activity assumptions for these calculations are given in Appendix D.

The potential dose calculated for the population was 0.4 person-rem ( 0.004 person-Sv) in 1993, compared to 0.8 person-rem ( 0.008 person-Sv) in 1992. The $80-\mathrm{km}$ (50-mi) population doses attributed to Hanford operations from 1989 through 1993 are compared in Figure 6.3.

Primary pathways contributing to the 1993 dose to the population were:

- inhalation of radionuclides (principally ${ }^{239,240} \mathrm{Pu}$ and ${ }^{241} \mathrm{Am}$ ) that were released to the air from the PUREX Plant stack (43\%).

- consumption of drinking water contaminated with radionuclides (principally ${ }^{3} \mathrm{H}$ ) released to the Columbia River at Hanford (32\%)

- consumption of foodstuffs contaminated with radionuclides (principally ${ }^{129} \mathrm{I}$ ) released with gaseous effluents primarily from the PUREX Plant stack ( $20 \%$ of the total dose)

The average per capita dose from 1993 Hanford operations, based on a population of 380,000 within $80 \mathrm{~km}$ $(50 \mathrm{mi})$, was $0.001 \mathrm{mrem}\left(1 \times 10^{-5} \mathrm{mSv}\right)$. This dose

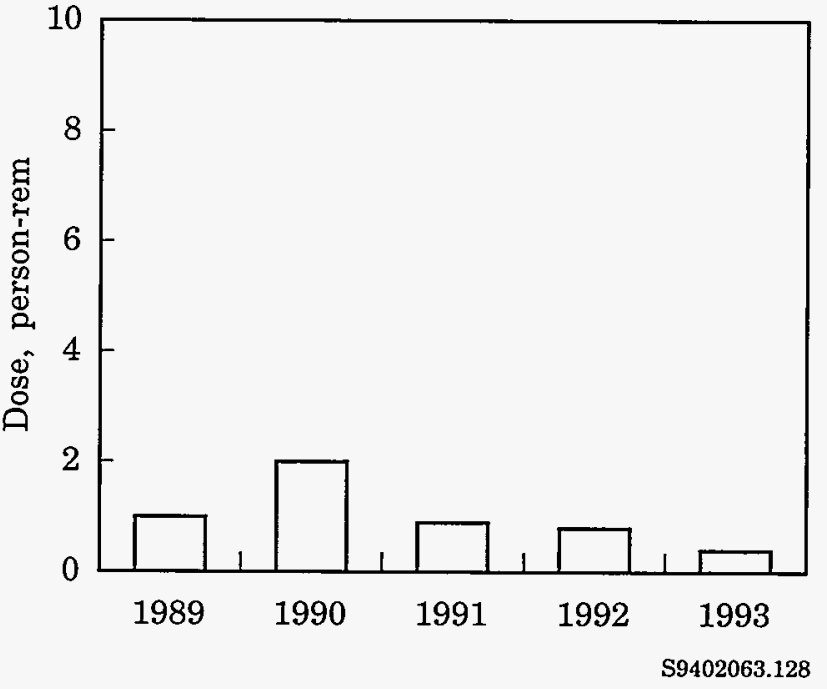

Figure 6.3. Calculated Effective Dose Equivalent to the Population Within $80 \mathrm{~km}$ (50 mi) of the Hanford Site, 1989 Through 1993

estimate may be compared with doses from other routinely encountered sources of radiation, such as natural terrestrial and cosmic background radiation, medical treatment and $x$ rays, natural radionuclides in the body, and inhalation of naturally occurring radon. The national average radiation doses from these other sources are illustrated in Figure 6.4. The estimated per capita dose to individual members of the public from Hanford sources is a small fraction (approximately $0.0003 \%$ ) of the annual per capita dose ( $300 \mathrm{mrem}$ ) from natural background sources.

The doses to the MEI and to the $80-\mathrm{km}$ (50-mi) population from Hanford effluents are compared to appropriate standards and natural background radiation in Table 6.3. This table shows that the calculated doses from Hanford operations in 1993 are a small percentage of the standards and of natural background.

\section{Doses from Other Than DOE Sources}

DOE maintains an awareness of other artificial sources of radiation (other than DOE artificial sources), which if combined with the DOE sources might have the potential to exceed a dose contribution to any member of the public of $10 \mathrm{mrem}(0.1 \mathrm{mSv})$. Various non-DOE 


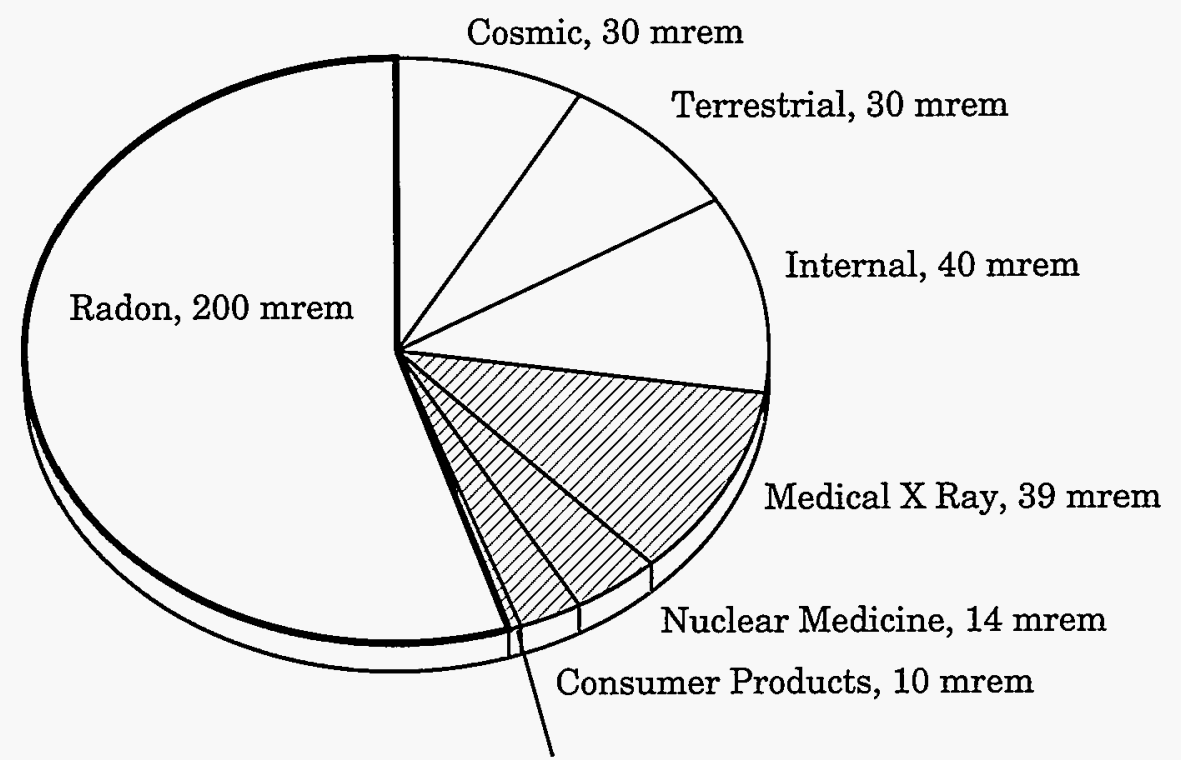

$\begin{array}{lll}\text { Natural, 300 mrem } & \text { Occupational } & 1 \mathrm{mrem} \\ & \text { Fallout } & <1 \mathrm{mrem} \\ \text { Consumer Products } & \text { Nuclear Fuel Cycle } & 0.04 \mathrm{mrem} \\ \text { and Medical, 65 mrem } & \text { Miscellaneous } & 0.04 \mathrm{mrem}\end{array}$

S9402063.129

Figure 6.4. National Annual Average Radiation Doses from Various Sources (mrem) (NCRP 1987)

Table 6.3. Summary of Doses to the Public in the Vicinity of Hanford from Various Sources, 1993

\begin{tabular}{|c|c|c|}
\hline Source & $\begin{array}{c}\begin{array}{c}\text { Maximum Individual, } \\
\mathrm{mrem}^{(\mathrm{a})}\end{array} \\
\end{array}$ & $\begin{array}{c}\text { 80-km Population, } \\
\text { person-rem }^{(\mathrm{a})}\end{array}$ \\
\hline All Hanford effluents ${ }^{(b)}$ & 0.03 & 0.4 \\
\hline DOE limit & 100 & --- \\
\hline Percent of DOE limit & $0.03 \%$ & --- \\
\hline Background radiation & 300 & 110,000 \\
\hline $\begin{array}{l}\text { Hanford doses percent of } \\
\text { background }\end{array}$ & $0.01 \%$ & $0.0004 \%$ \\
\hline Doses from gaseous effluents ${ }^{(c)}$ & 0.02 & -- \\
\hline EPA air standard & 10 & --- \\
\hline Percent of EPA standard & $0.2 \%$ & --- \\
\hline
\end{tabular}

(a) To convert the dose values to mSv or person-Sv, divide them by 100 .

(b) Calculated with the GENII code (Napier et al. 1988a, 1988b, 1988c).

(c) Calculated with the EPA CAP-88-PC code. 
industrial sources of public radiation exposure exist at or near Hanford. These include the low-activity commercial radioactive waste burial ground at Hanford operated by U.S. Ecology, the nuclear generating station at Hanford operated by Washington Public Power Supply System (Supply System), the nuclear fuel production plant operated by Siemens Power Corporation, the commercial low-activity radioactive waste compacting facility operated by Allied Technology Group Corporation, and a commercial decontamination facility operated by Vectra Technology, Inc. (Figure 6.1). With information gathered from the mentioned companies, it was conservatively determined that the total 1993 individual dose from their combined activities is on the order of $0.05 \mathrm{mrem}$ $\left(5 \times 10^{-4} \mathrm{mSv}\right)$. Therefore, the combined dose from Hanford area non-DOE and DOE sources to a member of the public for 1993 was well below any regulatory dose limit.

\section{Hanford Public Radiation Dose in Perspective}

Several scientific studies (NRC 1980, 1990; UNSCEAR 1988) have been performed to estimate the potential risk of developing detrimental health effects from exposure to low levels of radiation. These studies have provided vital information to those government and scientific organizations that recommend radiation dose limits and standards for public and occupational safety.

Although no increase in the incidence of health effects from low doses of radiation has actually been confirmed by the scientific community, most scientists accept the conservative hypothesis that low-level doses might increase the probability that certain types of effects, such as cancer, could occur. Regulatory agencies conservatively (cautiously) assume that the probability of these types of health effects at low doses (down to zero) is proportional to the probability of these same health effects observed historically at much higher doses (in atomic bomb victims, radium dial painters, etc.). Therefore, using conservative assumptions, one can postulate that even the natural background radiation (which is many hundreds of times greater than radiation from Hanford releases) increases each person's probability or chance of developing a detrimental health effect.
Scientists do not agree about how to translate the available data on health effects into the numerical probability (risk) of detrimental effects from low-level radiation doses. Some scientific studies have even indicated that low radiation doses may be beneficial (HPS 1987). Because cancer and hereditary diseases in the general population may be caused by a multitude of sources (e.g., genetic defects, sunlight, chemicals, and background radiation), some scientists doubt that the risk from low-level radiation exposure can ever be determined accurately. The EPA has used a probability value of approximately 4 per 10 million $\left(4 \times 10^{-7}\right)$ for the risk of developing a fatal cancer after receiving a dose of $1 \mathrm{mrem}(0.01 \mathrm{mSv})$ in developing Clean Air Act regulations (EPA 1989). Recent data (NRC 1990) support the reduction of even this small risk value, possibly to zero, for certain types of radiation when the dose is spread over an extended time.

Government agencies are trying to determine what level of risk is safe for members of the public exposed to pollutants from industrial activities (for example, DOE facilities, nuclear power plants, chemical plants, and hazardous waste sites). All of these industrial activities are considered beneficial to people in some way, such as providing electricity, national defense, waste disposal, and consumer products. These government agencies have a complex task in establishing environmental regulations that control levels of risk to the public without unnecessarily reducing the needed benefits from the industry.

The public is subjected to some incremental risks from exposure to industrial pollutants (radiological and nonradiological). These risks can be kept in perspective by comparing them to the increased risks involved in other typical activities. For instance, two added risks that an individual receives from flying on an airline are the risks of added radiation dose (stronger cosmic radiation field at higher altitude) and the possibility of being in an aircraft accident. Table 6.4 compares the estimated risks from various radiation doses to the risks of some activities encountered in everyday life.

Another way of looking at the risk of detrimental health effects from Hanford radioactive releases is illustrated in Table 6.5. Listed are some activities considered approximately equal in risk to the hypothetical risk from the potential radiation dose received by the MEI from Hanford releases in 1993. 
Table 6.4. Estimated Risk from Various Activities and Exposures ${ }^{(a)}$

Activity or Exposure Per Year

Riding or driving in a passenger vehicle (300 miles)

Home accidents

Drinking 1 can of beer or 4 ounces of wine per day (liver cancer/cirrhosis)

Pleasure boating (accidents)

Firearms, sporting (accidents)

Smoking 1 pack of cigarettes per day (lung/heart/other diseases)

Eating 4 tablespoons of peanut butter per day (liver cancer)

Eating 90 pounds of charcoal-broiled steaks (gastrointestinal-tract cancer)

Drinking chlorinated tap water (trace chloroform-cancer)

Taking contraceptive pills (side effects)

Flying as an airline passenger (cross country roundtrip-accidents)

Flying as an airline passenger (cross country roundtrip-radiation)

Natural background radiation dose ( $300 \mathrm{mrem}, 3 \mathrm{mSv}$ )

Dose of $1 \mathrm{mrem}(0.01 \mathrm{mSv})$

Dose to the maximally exposed individual living near Hanford in 1993 (0.03 mrem, $0.0003 \mathrm{mSv}$ )
Risk of Fatality

$2 \times 10^{-6(b)}$

$100 \times 10^{-6(b)}$

$10 \times 10^{-6}$

$6 \times 10^{-6(b)}$

$10 \times 10^{-6(b)}$

$3600 \times 10^{-6}$

$8 \times 10^{-6}$

$1 \times 10^{-6}$

$3 \times 10^{-6}$

$20 \times 10^{-6}$

$8 \times 10^{-6(b)}$

0 to $5 \times 10^{-6}$

0 to $120 \times 10^{-6}$

0 to $0.4 \times 10^{-6}$

0 to $0.01 \times 10^{-6}$

(a) These values are generally accepted approximations with varying levels of uncertainty; there can be significant variation as a result of differences in individual lifestyle and biological factors (Ames et al. 1987; Atallah 1980; Dinman 1980; Travis and Hester 1990; Wilson and Crouch 1987).

(b) Real actuarial values. Other values are predicted from statistical models. For radiation dose, the values are reported in a possible range from the least conservative (0) to the currently accepted most conservative value.

Table 6.5. Activities Comparable in Risk to That from the 0.03-mrem Dose Calculated for the 1993 Maximally Exposed Individual

Driving or riding in a car $3 \mathrm{~km}(2 \mathrm{mi})$

Smoking $1 / 40$ of a cigarette

Flying $7 \mathrm{~km}(4 \mathrm{mi})$ on a commercial airline

Eating 2 tablespoons of peanut butter

Eating one $0.4-\mathrm{kg}$ (18-ounce) charcoal-broiled steak

Drinking about $3 \mathrm{~L}$ ( 3 quarts) of chlorinated tap water

Being exposed to natural background radiation for about

1 hour in a typical terrestrial location

Drinking about one-half of a can of beer or one-third a

glass of wine per week for a year 


\section{Dose Rates to Animals}

Conservative (upper) estimates have been made of the potential radiation dose to "native aquatic animal organisms," in accordance with a DOE Order 5400.5 interim requirement for management and control of liquid discharges. Potential radiation dose rates during 1993 were calculated for several possible exposure modes, including exposure to water entering the Columbia River from springs near the 100-N Area, and internally deposited radionuclides measured in samples of animals collected from the Columbia River and onsite.

Because the volumetric flow of the springs at the $100-\mathrm{N}$ Area is so low, no aquatic animal can live directly in this seep water. Exposure to the radionuclides from the springs cannot occur until the seep water has been noticeably diluted in the Columbia River. The unlikely assumption was made that a few aquatic animals might be exposed to the maximum concentration of radionuclides measured in the seep water (see Table 3.9) after dilution at only 10 to 1 by the river. Radiation doses were calculated for several different types of aquatic animals, using highly conservative assumptions and the computer code CRITR2 (Baker and Soldat 1992). The animal receiving the highest potential dose was calculated to be a duck consuming aquatic plants. However, even if such a duck spent $100 \%$ of its time in the one-tenth seep water consuming only plants growing there, it would only receive a radiation dose rate of $0.08 \mathrm{rad} / \mathrm{d}$. This dose rate is $8 \%$ of the limit of $1 \mathrm{rad} / \mathrm{d}$ given for native aquatic animal organisms in DOE Order 5400.5.

Doses were also estimated for clams, fish, and waterfowl exposed to Columbia River water containing a mixture of all the radionuclides reaching the Columbia River from Hanford sources during 1993. The highest potential dose was $1 \times 10^{-5} \mathrm{rad} / \mathrm{d}$ for a plant-eating duck.

Dose estimates based on the maximum concentrations of ${ }^{60} \mathrm{Co}$ and ${ }^{137} \mathrm{Cs}$ measured in muscle of animals collected onsite ranged from $5 \times 10^{-7} \mathrm{rad} / \mathrm{d}$ for gamebirds to $2 \times 10^{-5} \mathrm{rad} / \mathrm{d}$ for the maximum duck. A low concentration $(0.026 \mathrm{pCi} / \mathrm{g})$ of ${ }^{90} \mathrm{Sr}$ was detected in only one of five samples of carp muscle. The ${ }^{90} \mathrm{Sr}$ was probably from a small piece of bone that could have been present in this sample. Even if the ${ }^{90} \mathrm{Sr}$ was actually a constituent of the muscle, the radiation dose to the muscle would have been only $2 \times 10^{-6} \mathrm{rad} / \mathrm{d}$. 


\section{Quality Assurance}

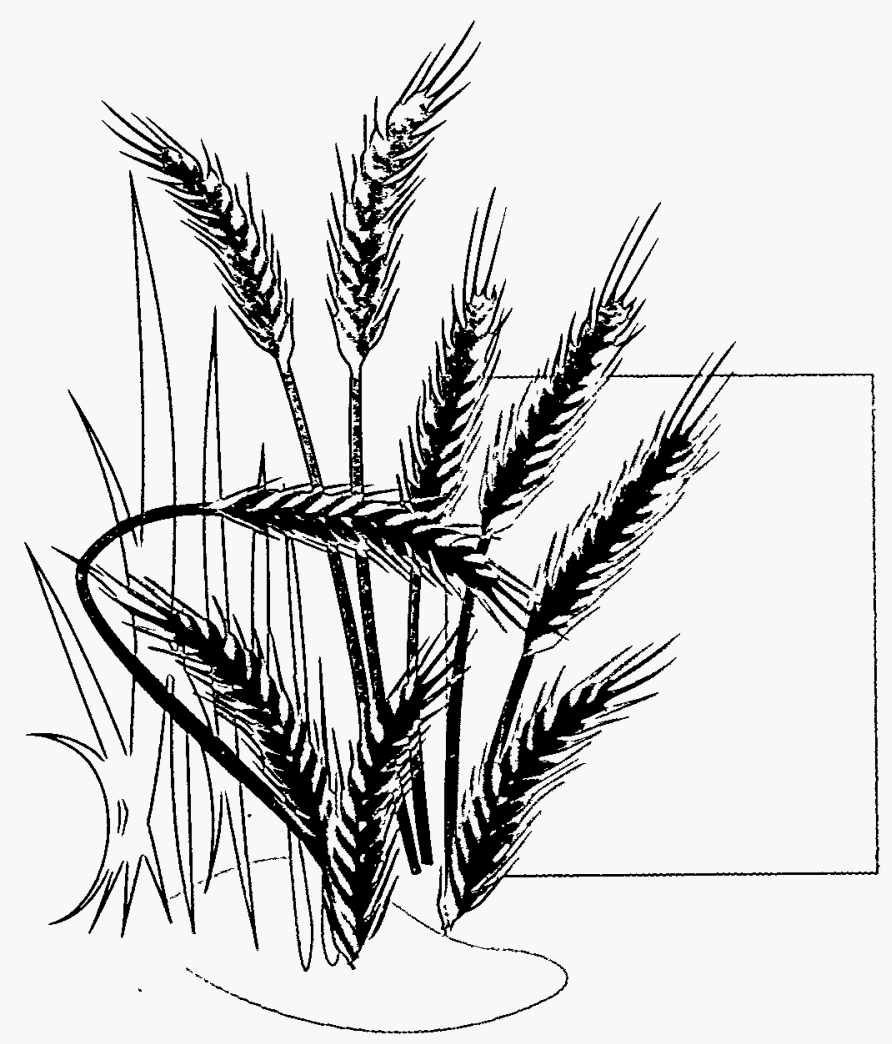




\title{
7.0 Quality Assurance
}

\author{
B. M. Gillespie, L. P. Diediker, and J. W. Schmidt
}

Quality assurance (QA) and quality control $(\mathrm{QC})$ practices encompass all aspects of Hanford Site environmental monitoring and surveillance programs. Samples are analyzed according to documented standard analytical procedures. Analytical data quality is verified by a continuing program of internal laboratory $\mathrm{QC}$, participation in interlaboratory cross-checks, replicate sampling and analysis, submittal of blind standard samples and blanks, and splitting samples with other laboratories.

QA/QC for ground-water environmental surveillance also includes procedures and protocols for 1) documenting instrument calibrations, 2) activities conducted in the field and laboratory, 3 ) maintenance of wells to ensure representative samples are collected, and 4) using dedicated sampling pumps to avoid cross-contamination.

This section discusses specific measures taken to ensure quality in project management, sample collection, and analytical results.

\section{Environmental Surveillance}

Comprehensive QA programs, including various QC practices, are maintained to ensure the quality of data collected through the surveillance programs. QA plans are maintained for all surveillance activities, defining the appropriate controls and documentation required to meet the guidance of the American Society of Mechanical Engineers (ASME) NQA-1 QA program document (U.S. nuclear industry's standard, ASME 1989) and DOE Orders.

\section{Project Management Quality Assurance}

Site surveillance and related programs, such as processing of TLDs and performing dose calculations, are subject to an overall QA program. This program implements the requirements of Richland Operations Office Order DOE 5700.6C, "Quality Assurance," and is based on ASME NQA-1, Quality Assurance Program Requirements for Nuclear Facilities (ASME 1989). The program is defined in a QA manual (PNL 1992b). The manual provides guidance for implementation by addressing 18 QA elements. These are:

1. Organization

2. Quality Assurance Program

3. Design Control

4. Procurement Document Control

5. Instructions, Procedures, and Drawings

6. Document Control

7. Control of Purchased Items and Services

8. Identification and Control of Items

9. Control of Processes

10. Inspection

11. Test Control

12. Control of Measuring and Test Equipment

13. Handling, Storage, and Shipping

14. Inspection, Test, and Operating Status

15. Control of Nonconforming Items

16. Corrective Action

17. Quality Assurance Records

18. Audits.

The environmental surveillance projects have current $Q A$ plans that describe the specific QA elements that apply to each project. These plans are approved by a QA organization that conducts surveillances and audits to verify compliance with the plans. Work performed through contracts, such as sample analysis, must meet the same QA requirements. Potential equipment and services suppliers are audited before awarding contracts for services or approving the purchase of materials that could have a significant impact on a project's quality. 


\section{Sample Collection Quality Assurance/Quality Control}

Environmental surveillance samples were collected by staff trained to conduct sampling according to approved and documented procedures (PNL 1992a). Continuity of all sampling location identities is maintained through documentation. Field duplicates are collected for specific media, and results are addressed in the individual media sections of 5.0, "Environmental Surveillance Information."

Samples for ground-water monitoring are collected by trained staff according to approved and documented procedures (PNL 1993). Chain-of-custody procedures are followed (EPA 1986a) that provide for the use of evidence tape in sealing sample bottles to maintain the integrity of the samples during shipping. A field QC program, designed specifically for the ground-water surveillance project, was initiated this year. Full trip blanks and field duplicates were obtained during field operations. Summaries of the 1993 results are provided in Tables 7.1 and 7.2.

\section{Analytical Results Quality Assurance/Quality Control}

Routine hazardous and nonhazardous chemical analyses for environmental and ground-water surveillance water samples are performed by DataChem Laboratories, Inc., Salt Lake City, Utah. The laboratory participates in the EPA Water Pollution and Water Supply Performance Evaluation Studies. DataChem Laboratories maintains an internal QC program that meets the requirements of EPA SW-846 (EPA 1986a), which are audited and reviewed. The Pacific Northwest Laboratory submits additional QC blind spiked samples for analysis.

Routine radiochemical analyses for environmental and ground-water surveillance samples are performed by International Technology Corporation's (IT) Richland Laboratory. IT's Richland Laboratory participates in the DOE's Quality Assessment Program and the EPA's Laboratory Intercomparison Studies. An additional QC blind spiked sample program for each project is also conducted. IT's Richland Laboratory also maintains an

Table 7.1. Summary of Ground-Water Surveillance Full Trip Blank Samples, 1993(a)

\begin{tabular}{|c|c|c|}
\hline Constituents & 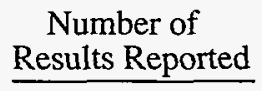 & $\begin{array}{l}\text { Number Within } \\
\text { Control Limits } \\
\end{array}$ \\
\hline Total alpha, total beta & 4 & 4 \\
\hline${ }^{60} \mathrm{Co},{ }^{106} \mathrm{Ru},{ }^{125} \mathrm{Sb},{ }^{137} \mathrm{Cs}$ & 16 & 15 \\
\hline${ }^{129} \mathrm{I}$ & 4 & 4 \\
\hline${ }^{90} \mathrm{Sr}$ & 2 & 2 \\
\hline${ }^{99} \mathrm{Tc}$ & 7 & 6 \\
\hline${ }^{3} \mathrm{H}$ & 20 & 18 \\
\hline Total uranium & 7 & 2 \\
\hline ICP metals & 9 & \\
\hline $\mathrm{Al}, \mathrm{K}, \mathrm{Mn}$ & & 7 \\
\hline $\mathrm{Ba}, \mathrm{Ca}, \mathrm{Na}$ & & 4 \\
\hline $\mathrm{Cr}, \mathrm{Fe}, \mathrm{Zn}$ & & 6 \\
\hline $\mathrm{Ag}, \mathrm{Be}, \mathrm{Cd}, \mathrm{Sb}, \mathrm{Sn}$ & & 9 \\
\hline $\mathrm{Co}, \mathrm{Cu}, \mathrm{Mg}, \mathrm{Ni}, \mathrm{V}$ & & 8 \\
\hline Anions & 13 & \\
\hline phosphate, bromide and nitrite & & 13 \\
\hline chloride, sulfate & & 12 \\
\hline fluoride, nitrate & & 8 \\
\hline Volatile organic constituents & 140 & 140 \\
\hline
\end{tabular}

(a) The field quality control program was initiated in July 1993.

(b) Control limit is less than detection level (method detection level for hazardous constituents and below total propograted error for radioactive constituents). 
Table 7.2. Summary of Ground-Water Surveillance Field Duplicate Samples, $1993^{(a)}$

\section{Constituents}

\section{Radionuclides}

Gamma isotopes $\left({ }^{60} \mathrm{Co},{ }^{137} \mathrm{Cs}\right.$, ${ }^{106} \mathrm{Ru}$, and ${ }^{125} \mathrm{Sb}$ )

${ }^{129}$ I

${ }^{3} \mathrm{H}$

Total uranium

ICP metals (18 elements each report)

Ions

Bromide, chloride, fluoride, nitrate, nitrite, phosphate, sulfate

Cyanide

\section{Alkalinity}

Volatile organic constituents
Number of Results Reported
Number Above

Detection Level
Number Within Control Limits( ${ }^{(b)}$

(a) The field QC program was initiated in July 1993.

(b) Control limits are as follows: If the result is less than 5 times detection level, then duplicate results must be \pm detection level. If the result is greater than 5 times detection level, then results must be $\pm 20 \%$ Relative Percent Difference. If either value is less than detection level then Relative Percent Difference was not calculated.

(c) NA = Not applicable because sample results were below detection level.

internal QC program, which is audited and reviewed. For the environmental surveillance samples, a final QC check of data is performed by a computerized screening of results against project-specific criteria. Anomolous results are reported, and discrepencies resolved and documented. Additional information on these QC efforts is provided in the following subsections.

\section{U.S. Department of Energy and U.S. Environmental Protection Agency Comparison Studies}

DataChem Laboratories participated in the EPA Water Pollution and Water Supply Performance Evaluation Studies. Standard water samples were distributed blind to participating laboratories. These samples contained specific organic and inorganic analytes with concentrations unknown to the analyzing laboratories. After analysis, the results were submitted to EPA for comparison to known values and other participating laboratory concentrations. Summaries of the results during the year are provided in Table 7.3. Approximately $98 \%$ of the results during the year were within the typically used "3-sigma control limits" $( \pm 3$ standard errors of the mean).

IT's Richland Laboratory participated in the DOE's Quality Assessment Program and EPA's Laboratory Intercomparison Studies Program. These programs provide standard samples of various environmental media (water, air filters, soil, and vegetation) containing specific amounts of one or more radionuclides that are unknown by the participating laboratory. After sample analysis, the results were forwarded to DOE or EPA for comparison with known values and results from other laboratories. Both EPA and DOE have established criteria for evaluating the accuracy of results (Jarvis and Siu 1981; Sanderson 1985). Summaries of the 1993 results for the programs are provided in Tables 7.4 and 7.5. Approximately $89 \%$ of the results during the year were within the typically used "3-sigma control limits" ( \pm 3 standard errors of the mean). 
Table 7.3. Summary Results of DataChem Laboratories EPA Water Pollution and Water Supply Performance Evaluation Studies, 1993

$\begin{array}{ll}\text { Analytes } & \text { Results Reported } \\ \text { Sontrol Limits }\end{array}$

\section{Metals}

$\mathrm{Ag}, \mathrm{Al}, \mathrm{As}, \mathrm{Be}, \mathrm{Cd}, \mathrm{Co}, \mathrm{Cr}, \mathrm{Cu}, \mathrm{Fe}, \mathrm{Hg}$,

$\mathrm{Mn}, \mathrm{Mo}, \mathrm{Ni}, \mathrm{Pb}, \mathrm{Sb}, \mathrm{Se}, \mathrm{Sr}, \mathrm{Ti}, \mathrm{V}, \mathrm{Zn}$

161

160

Other inorganic tests

$\mathrm{pH}$, conductivity, total dissolved solids, total hardness, calcium, potassium, magnesium, sodium, alkalinity, chloride, fluoride, sulfate, ammonia, nitrate, chemical oxygen demand, etc.

Organic tests

total organic carbon, PCBs, pesticides, volatile organic constituents, other

(a) Control limits from EPA (1982).

Table 7.4. Summary of International Technology Corporation Performance on DOE Quality Assessment Program Samples, 1993

\begin{tabular}{|c|c|c|c|}
\hline Media & Radionuclides & $\begin{array}{c}\begin{array}{c}\text { Number of } \\
\text { Results }\end{array} \\
\text { Reported for Each }\end{array}$ & $\begin{array}{c}\text { Number } \\
\text { Within Control } \\
\text { Limits }^{(a)}\end{array}$ \\
\hline \multirow[t]{2}{*}{ Air filters } & $\begin{array}{l}{ }^{7} \mathrm{Be},{ }^{54} \mathrm{Mn},{ }^{57} \mathrm{Co},{ }^{60} \mathrm{Co},{ }^{134} \mathrm{Cs}, \\
{ }^{137} \mathrm{Cs},{ }^{144} \mathrm{Ce},{ }^{238} \mathrm{Pu},{ }^{239} \mathrm{Pu},{ }^{241} \mathrm{Am},\end{array}$ & 2 & 2 \\
\hline & ${ }^{90} \mathrm{Sr}$ & 2 & 0 \\
\hline \multirow[t]{2}{*}{ Soil } & ${ }^{40} \mathrm{~K},{ }^{90} \mathrm{Sr},{ }^{137} \mathrm{Cs},{ }^{239} \mathrm{Pu},{ }^{241} \mathrm{Am}$ & 2 & 2 \\
\hline & ${ }^{238} \mathrm{Pu},{ }^{234} \mathrm{U},{ }^{238} \mathrm{U}, \mathrm{U}$ total & 1 & 1 \\
\hline \multirow[t]{2}{*}{ Vegetation } & ${ }^{238} \mathrm{Pu},{ }^{239} \mathrm{Pu},{ }^{241} \mathrm{Am}$ & 2 & 2 \\
\hline & ${ }^{40} \mathrm{~K},{ }^{90} \mathrm{Sr},{ }^{137} \mathrm{Cs}$ & 2 & 1 \\
\hline \multirow[t]{3}{*}{ Water } & $\begin{array}{l}{ }^{3} \mathrm{H},{ }^{54} \mathrm{Mn},{ }^{60} \mathrm{Co},{ }^{90} \mathrm{Sr},{ }^{134} \mathrm{Cs},{ }^{137} \mathrm{Cs}, \\
{ }^{144} \mathrm{Ce},{ }^{238} \mathrm{Pu},{ }^{239} \mathrm{Pu},{ }^{241} \mathrm{Am}\end{array}$ & 2 & 2 \\
\hline & $\mathrm{U}$ total & 3 & 3 \\
\hline & ${ }^{234} \mathrm{U},{ }^{238} \mathrm{U}$ & 1 & 1 \\
\hline
\end{tabular}

(a) Control limits are from Sanderson (1985). 
Table 7.5. Summary of International Technology Corporation Performance on EPA Intercomparison Program Samples, 1993

\begin{tabular}{|c|c|c|c|}
\hline Media & Radionuclides & $\begin{array}{l}\text { Results } \\
\text { Reported for Each } \\
\end{array}$ & $\begin{array}{c}\text { Within Control } \\
\text { Limits }\end{array}$ \\
\hline \multirow[t]{2}{*}{ Air filters } & Total alpha, ${ }^{90} \mathrm{Sr},{ }^{137} \mathrm{Cs}$ & 1 & 1 \\
\hline & Total beta & 1 & 0 \\
\hline \multirow[t]{4}{*}{ Water } & ${ }^{65} \mathrm{Zn},{ }^{106} \mathrm{Ru},{ }^{133} \mathrm{Ba}, \mathrm{Pu}$-isotopic & 1 & 1 \\
\hline & ${ }^{3} \mathrm{H},{ }^{60} \mathrm{Co},{ }^{89} \mathrm{Sr},{ }^{134} \mathrm{Cs},{ }^{137} \mathrm{Cs}$ & 2 & 2 \\
\hline & ${ }^{90} \mathrm{Sr},{ }^{226} \mathrm{Ra},{ }^{228} \mathrm{Ra}, \mathrm{U}$ total & 3 & 3 \\
\hline & Total alpha, total beta & 4 & 4 \\
\hline
\end{tabular}

(a) Control limits are from Jarvis and Siu (1981).

\section{Pacific Northwest Laboratory Evaluations}

In addition to DOE and EPA interlaboratory QC programs, a QC program is maintained by PNL to evaluate analytical contractor precision and accuracy and to conduct special intercomparisons. This program includes the use of blind spiked samples and replicate samples. Blind spiked QC samples and blanks were prepared and submitted to check the accuracy and precision of analyses at DataChem Laboratories and IT's Richland Laboratory. In 1993, blind spiked samples were submitted for air filters, vegetation, soil, water, and ground water. Overall, 67\% of the DataChem Laboratories blind spiked determinations were within control limits and 79\% of IT's Richland Laboratory blind spiked determinations were within control limits (Table 7.6 and 7.7).

The Pacific Northwest Laboratory also participates in a Quality Assurance Task Force, a program conducted by the Washington Department of Health. Organizations, both public and private, from Idaho, Oregon, and Washington participate in analyzing the intercomparison samples. No samples were designated for analysis in 1993 but plans for a 1994 intercomparison study are under way.
Table 7.6. Summary of Ground-Water Surveillance Project Quarterly ${ }^{(a)}$ Blind Spiked Determinations

$\begin{array}{lccc}\text { Constituents } & \begin{array}{c}\text { Number of } \\ \text { Results Report }{ }^{(b)}\end{array} & \begin{array}{c}\text { Number Within } \\ \pm 30 \% \text { RPD }^{(\mathbf{c})}\end{array} \\ { }^{3} \mathrm{H} & 9 & 9 \\ { }^{60} \mathrm{Co} & 9 & 8 \\ { }^{90} \mathrm{Sr} & 9 & 9 \\ { }^{99} \mathrm{Tc} & 9 & 8 \\ { }^{129} \mathrm{I} & 9 & 5 \\ { }^{137} \mathrm{Cs} & 9 & 9 \\ { }^{239} \mathrm{Pu} & 9 & 5 \\ \text { U total } & 9 & 6 \\ & & \\ \text { Chloroform } & 6 & \text { (d) } \\ \text { Carbon tetrachloride } & 6 & \text { (d) } \\ \text { Trichloroethylene } & 6 & \text { (d) } \\ & & \\ \text { Chromium } & 6 & 3 \\ \text { Cyanide } & 6 & 3 \\ \text { Fluoride } & 6 & 5 \\ \text { Nitrate } & 6 & \end{array}$

(a) Submission of quarterly blind samples began in the second quarter of 1993. Only radiochemical blind samples were submitted that quarter.

(b) Blind samples were submitted in triplicate each quarter and compared to actual spike value.

(c) $\mathrm{RPD}=$ Relative Percent Difference.

(d) None of the data results fell within $\pm 30 \%$ of the spiked constitutent concentrations. Problems with preparation of the standards and laboratory analysis hindered accurate evaluation of spike concentrations. 
Table 7.7. Summary of Surface Environmental Surveillance Project Blind Spiked Determinations, 1993

\begin{tabular}{lccc} 
Sample Media & \multicolumn{1}{c}{ Radionuclides } & $\begin{array}{c}\text { Number of } \\
\text { Results } \\
\text { Reported }\end{array}$ & $\begin{array}{c}\text { Number } \\
\text { Within Control } \\
\text { Limits }\end{array}$ \\
\cline { 2 - 3 } Air filters & $\begin{array}{c}{ }^{54} \mathrm{Mn},{ }^{57} \mathrm{Co},{ }^{60} \mathrm{Co},{ }^{90} \mathrm{Sr},{ }^{134} \mathrm{Cs},{ }^{137} \mathrm{Cs},{ }^{144} \mathrm{Ce}, \\
\text { Soil }\end{array}$ & 9 & 9 \\
Water & ${ }^{40} \mathrm{~K},{ }^{90} \mathrm{Sr},{ }^{137} \mathrm{Cs},{ }^{234} \mathrm{U},{ }^{238} \mathrm{U},{ }^{239.240} \mathrm{Pu},{ }^{241} \mathrm{Am}$ & 21 & 18 \\
Vegetation & ${ }^{3} \mathrm{H},{ }^{134} \mathrm{Cs},{ }^{137} \mathrm{Cs},{ }^{144} \mathrm{Ce},{ }^{234} \mathrm{U},{ }^{238} \mathrm{U},{ }^{239,240} \mathrm{Pu},{ }^{241} \mathrm{Am}$ & 33 & 24
\end{tabular}

(a) Control limits of $\pm 30 \%$.

\section{Laboratory Internal Quality Assurance Programs}

The DataChem Laboratories and IT's Richland Laboratory are required to maintain an internal $\mathrm{QC}$ program. These programs are reviewed and audited periodically for compliance. At the DataChem Laboratories, the QC program meets the QC criteria of EPA SW-846 (EPA 1986a). This program also requires the laboratory to maintain a system for reviewing and analyzing the results of the $\mathrm{QC}$ samples to detect problems arising from contamination, inadequate calibrations, calculations, or procedure performance. Method Detection Level determinations are performed biannually.

IT's Richland Laboratory internal QC program involves routine calibrations of counting instruments, yield determinations of radiochemical procedures, frequent radiation check sources and background counts, replicate and spiked sample analyses, matrix and reagent blanks, and maintenance of control charts to indicate analytical deficiencies. Available calibration standards traceable to the National Institute of Standards and Technology were used for radiochemical calibrations.

In 1993, one inspection of the DataChem Laboratories and two inspections of IT's Richland Laboratory were conducted. These inspections documented conformance with contractual requirements of the analytical facility and provided the framework for identifying and resolving potential performance problems. Responses to audit and inspection findings are documented by written communication, and corrective actions verified by follow-up audits and inspections.

Internal laboratory $\mathrm{QC}$ program data are summarized by the laboratories in quarterly reports. The results of the QC sample summary reports and the observations noted by each laboratory were found to indicate an acceptably functioning QC program.

Verification of minimum detectable concentration requirements for specific radionuclide-media combinations (for example, ${ }^{90} \mathrm{Sr}$ in air) are requested for IT's Richland Laboratory surface monitoring contract. Minimum detectable concentration verification is conducted (when requested) for up to five radionuclide-media combinations for analyses performed during each month. Equation 37 from Chapter 6 in EPA 520/1-80-012 (EPA 1980a) is used in the minimum detectable concentration calculations, which involves the use of factors such as the average counting efficiencies and background for detection instruments, length of time for background and sample counts, sample volumes, radiochemical yields, and a predesignated uncertainty multiplier. The minimum detectable concentration verification is used to document historical performance to project detection goals. As of this report writing, 12 minimum detectable concentration verification reports had been completed for 59 radionuclide-media combinations, indicating that 41 minimum detectable concentrations had been achieved. Ten of the eighteen radionuclide-media 
combinations not meeting minimum detectable concentration requirements involved ${ }^{3} \mathrm{H}$ analyses, four involved gamma-spectrometry analyses, three are ${ }^{90} \mathrm{Sr}$ analyses, and one involved ${ }^{99} \mathrm{Tc}$ analysis. The cause for ${ }^{3} \mathrm{H}$ and gamma-spectrometry minimum detectable concentrations not meeting requirements are being pursued through technical meetings with the contractor.

\section{Media Audits and Comparisons}

Additional audits and comparisons are conducted on several specific types of samples. The Washington Department of Health routinely cosampled various environmental media and measured external radiation levels at multiple locations during 1993. Media that were cosampled with the Washington State Department of Health included 22 ground-water wells, one surfacewater site, beef, vegetables, fruit, wine, wheat and alfalfa, carp, ducks, birds (pheasant), soil, and vegetation. These data will be available in the Washington Department of Health report, Environmental Radiation 1993 Annual Report, 32nd Edition, when published. The National Food and Drug Administration also cosampled vegetables, fruit and wheat. The data are presented in Table 7.8.

Quality Control for environmental TLDs includes the audit exposure of three environmental TLDs per quarter to known values of radiation (between 17 and $28 \mathrm{mR}$ ). A summary of 1993 results is shown in Table 7.9. On average, the TLD measurements are biased $2 \%$ higher than the known values.

\section{Effluent Monitoring}

The Site effluent monitoring programs are subject to the QA programs defined in Quality Assurance Manual (WHC 1989), and Quality Assurance Manual (PNL 1992b). These QA programs comply with DOE Order 5700.6C, "Quality Assurance" (1989 edition, without addenda), using ASME NQA-1, Quality Assurance Program Requirements for Nuclear Facilities (ASME 1989), as their basis. The programs also adhere to the EPA guidelines in Interim Guidelines and Specifications for Preparing Quality Assurance Project Plans (EPA 1980b) and Data Quality Objectives for Remedial Response Activities (EPA 1987).

The facility effluent and near-facility environmental monitoring programs each have a QA project plan describing applicable QA elements. These plans are approved by contractor QA groups, who conduct surveillances and audits to verify compliance with the plans. Work performed through contracts, such as sample analysis, must meet the requirements of these plans. Suppliers are audited before the contract selection is made for equipment and services that may significantly impact the quality of a project.

\section{Sample Collection Quality Assurance}

Effluent and near-facility environmental monitoring samples are collected by staff trained for the task in accordance with approved procedures. Established nearfacility sample locations are accurately identified and documented to ensure continuity of data for those sites. Sample locations are described in Operational Environmental Monitoring (WHC 1991b) for Westinghouse Hanford Company sampling and in controlled manuals that are not publicly distributed.

\section{Analytical Results Quality Assurance}

Pacific Northwest Laboratory's effluent samples are analyzed by IT's Richland Laboratory and Pacific Northwest Laboratory Radiation Protection Section. The 222-S Analytical Laboratory, located in the 200-West Area of the Site, analyzes most routine Westinghouse Hanford Company effluent samples and many nearfacility environmental samples for chemical and radioactive constituents. Low-level radioactive environmental samples taken for the near-facility environmental monitoring program are sent to IT's Richland Laboratory for analysis. Samples that have a potential of higher levels of contamination are submitted to the 222-S Analytical Laboratory.

The quality of the analytical data are assured by several means. Counting room instruments, for instance, are kept within calibration limits through daily checks, the results of which are stored in a computer database to efficiently control tracking. Radiochemical standards used in analyses are regularly measured and the results reported and tracked. Formal, written laboratory procedures are used in analyzing samples. Analytical procedural control is ensured through administrative procedures. Chemical technologists at the laboratory qualify to perform analyses through formal classroom and on-the-job training. 
Table 7.8. Comparison of Food and Drug Administration (FDA) Cosampling, 1993

\begin{tabular}{|c|c|c|c|}
\hline Media & Radionuclides & $\begin{array}{l}\text { PNL Value }(\mathrm{pCi} / \mathrm{g}) \\
\pm 2 \text { sigma } \\
\end{array}$ & $\begin{array}{l}\text { FDA Value }(\mathrm{pCi} / \mathrm{g}) \\
\pm 2 \text { sigma }^{(a)} \\
\end{array}$ \\
\hline \multicolumn{4}{|l|}{ Riverview Area } \\
\hline Apples & $\begin{array}{l}{ }^{3} \mathrm{H} \\
{ }^{90} \mathrm{Sr} \\
{ }^{106} \mathrm{Ru} \\
{ }^{131} \mathrm{I} \\
{ }^{137} \mathrm{Cs}\end{array}$ & $\begin{array}{c}<193 \\
<0.00289 \\
<0.0457^{(b)} \\
\mathrm{NA}^{(\mathrm{c})} \\
<0.00540\end{array}$ & $\begin{array}{l}0.30 \pm 0.1 \\
2.4 \pm 0.9 \\
N D \\
N D^{(d)} \\
N D\end{array}$ \\
\hline Potatoes & $\begin{array}{l}{ }^{3} \mathrm{H} \\
{ }^{90} \mathrm{Sr} \\
{ }^{106} \mathrm{Ru} \\
{ }^{131} \mathrm{I} \\
{ }^{137} \mathrm{Cs}\end{array}$ & $\begin{array}{c}\mathrm{NA} \\
<0.00266 \\
<0.0314 \\
\mathrm{NA} \\
<0.00357\end{array}$ & $\begin{array}{l}0.5 \pm 0.71 \\
\text { ND } \\
\text { ND } \\
\text { ND } \\
\text { ND }\end{array}$ \\
\hline Leafy vegetables & $\begin{array}{l}{ }^{3} \mathrm{H} \\
{ }^{90} \mathrm{Sr} \\
{ }^{106} \mathrm{Ru} \\
{ }^{131} \mathrm{I} \\
{ }^{137} \mathrm{Cs}\end{array}$ & $\begin{array}{c}\text { NA } \\
0.027 \pm 0.008 \\
0.068 \pm 0.054 \\
\text { NA } \\
<0.00699\end{array}$ & $\begin{array}{l}\text { ND } \\
21.67 \pm 5.37 \\
\text { ND } \\
\text { ND } \\
\text { ND }\end{array}$ \\
\hline \multicolumn{4}{|l|}{ Sagemoor Area } \\
\hline Apples & $\begin{array}{l}{ }^{3} \mathrm{H} \\
{ }^{90} \mathrm{Sr} \\
{ }^{106} \mathrm{Ru} \\
{ }^{131} \mathrm{I} \\
{ }^{137} \mathrm{Cs}\end{array}$ & $\begin{array}{c}<194 \\
<0.00200 \\
<0.0462 \\
\mathrm{NA} \\
<0.00481\end{array}$ & $\begin{array}{l}\text { ND } \\
\text { ND } \\
\text { ND } \\
\text { ND } \\
\text { ND }\end{array}$ \\
\hline Potatoes & $\begin{array}{l}{ }^{3} \mathrm{H} \\
{ }^{90} \mathrm{Sr} \\
{ }^{106} \mathrm{Ru} \\
{ }^{131} \mathrm{I} \\
{ }^{137} \mathrm{Cs}\end{array}$ & $\begin{array}{c}\mathrm{NA} \\
<0.00281 \\
<0.0252 \\
\mathrm{NA} \\
<0.00323\end{array}$ & $\begin{array}{l}0.30 \pm 0.14 \\
\text { ND } \\
\text { ND } \\
\text { ND } \\
\text { ND }\end{array}$ \\
\hline Wheat & $\begin{array}{l}{ }^{3} \mathrm{H} \\
{ }^{90} \mathrm{Sr} \\
{ }^{106} \mathrm{Ru} \\
{ }^{131} \mathrm{I} \\
{ }^{137} \mathrm{Cs}\end{array}$ & $\begin{array}{c}\text { NA } \\
(\mathrm{e}) \\
0.0436 \pm 0.0331 \\
\text { NA } \\
0.00411 \pm 0.00367\end{array}$ & $\begin{array}{l}\text { ND } \\
4.65 \pm 0.35 \\
\text { ND } \\
\text { ND } \\
\text { ND }\end{array}$ \\
\hline
\end{tabular}

\footnotetext{
(a) 2 sigma Total Propogated Uncertainty; PNL = Pacific Northwest Laboratory.

(b) <values are 2 sigma total propogated uncertainties.

(c) NA = not analyzed (PNL did not request analysis).

(d) ND $=$ not detected.

(e) Analysis requested but data not received from laboratory.
} 
Table 7.9. Comparison of Thermoluminescent Dosimeter Results with Known Exposure, 1993

\begin{tabular}{|c|c|c|c|}
\hline Quarter & $\begin{array}{l}\text { Known } \\
\text { Exposure, } \\
\text { mR } \\
\end{array}$ & $\begin{array}{l}\text { Determined, } \\
\mathrm{mR}( \pm S D)^{(a)}\end{array}$ & $\begin{array}{c}\% \\
\text { Differer } \\
\end{array}$ \\
\hline First & $\begin{array}{l}20 \\
24 \\
28\end{array}$ & $\begin{array}{l}19.4 \pm 3.36 \\
23.7 \pm 2.16 \\
28.0 \pm 2.72\end{array}$ & $\begin{array}{r}-3.0 \\
-1.3 \\
0.0\end{array}$ \\
\hline Second & $\begin{array}{l}18 \\
22 \\
27\end{array}$ & $\begin{array}{l}18.0 \pm 0.9 \\
21.1 \pm 1.5 \\
26.4 \pm 0.9\end{array}$ & $\begin{array}{r}0.0 \\
-4.1 \\
-2.2\end{array}$ \\
\hline Third & $\begin{array}{l}19 \\
23 \\
26\end{array}$ & $\begin{array}{l}19.6 \pm 1.52 \\
23.4 \pm 2.64 \\
27.1 \pm 1.68\end{array}$ & $\begin{array}{l}3.2 \\
1.7 \\
4.2\end{array}$ \\
\hline Fourth & $\begin{array}{l}17 \\
21 \\
25\end{array}$ & $\begin{array}{l}17.9 \pm 3.05 \\
22.7 \pm 3.93 \\
27.7 \pm 5.56\end{array}$ & $\begin{array}{r}5.3 \\
8.1 \\
10.8\end{array}$ \\
\hline
\end{tabular}

For years the 222-S Analytical Laboratory has participated in the EPA Environmental Monitoring and Surveillance Laboratory intercomparison program and the DOE Environmental Measurements Laboratory Quality Assessment Program. Participation in these programs allows the Laboratory to compare its abilities for analyzing environmental and effluent samples with those of other laboratories across the nation. Performance in these programs provides an analytical baseline to compare with analysis results obtained in the future waste sampling and characterization facility. Analytical summaries of the Laboratory's participation in the two programs are shown in Tables 7.10 and 7.11.

(a) One sigma standard deviation.

Table 7.10. 222-S Analytical Laboratory Performance on DOE Quality Assessment Program Samples, 1993

\begin{tabular}{|c|c|c|c|}
\hline Sample Media & Radionuclides & $\begin{array}{c}\text { Number } \\
\text { of Results } \\
\text { Reported } \\
\end{array}$ & $\begin{array}{c}\text { Number } \\
\text { Within Control } \\
\text { Limits }^{(\mathrm{a})} \\
\end{array}$ \\
\hline Air Filters & $\begin{array}{l}{ }^{7} \mathrm{Be},{ }^{54} \mathrm{Mn},{ }^{57} \mathrm{Co},{ }^{60} \mathrm{Co},{ }^{90} \mathrm{Sr},{ }^{134} \mathrm{Cs}, \\
{ }^{137} \mathrm{Cs},{ }^{144} \mathrm{Ce},{ }^{238} \mathrm{Pu},{ }^{239} \mathrm{Pu},{ }^{241} \mathrm{Am}, \mathrm{U}\end{array}$ & 18 & 16 \\
\hline Soil & ${ }^{40} \mathrm{~K},{ }^{90} \mathrm{Sr},{ }^{137} \mathrm{Cs},{ }^{239} \mathrm{Pu}$ & 7 & 5 \\
\hline Vegetation & ${ }^{40} \mathrm{~K},{ }^{90} \mathrm{Sr},{ }^{137} \mathrm{Cs},{ }^{238} \mathrm{Pu},{ }^{239} \mathrm{Pu}$ & 7 & 4 \\
\hline Water & $\begin{array}{l}{ }^{3} \mathrm{H},{ }^{54} \mathrm{Mn},{ }^{60} \mathrm{Co},{ }^{90} \mathrm{Sr},{ }^{134} \mathrm{Cs},{ }^{137} \mathrm{Cs}, \\
{ }^{144} \mathrm{Ce},{ }^{238} \mathrm{Pu},{ }^{239} \mathrm{Pu}\end{array}$ & 20 & 16 \\
\hline
\end{tabular}

(a) Control limits are from Sanderson (1985). 
Table 7.11. 222-S Analytical Laboratory Performance on EPA Intercomparison Program Samples, 1993

\begin{tabular}{|c|c|c|c|}
\hline Sample Media & Radionuclides & $\begin{array}{c}\text { Number } \\
\text { of Results } \\
\text { Reported } \\
\end{array}$ & $\begin{array}{c}\text { Number } \\
\text { Within Contro } \\
\text { Limits }^{(a)} \\
\end{array}$ \\
\hline Air filters & Total alpha, total beta & 2 & $1^{\text {(b) }}$ \\
\hline $\begin{array}{l}\text { Alpha, beta, and gamma } \\
\text { emitters in water }\end{array}$ & $\begin{array}{l}\text { Total alpha, total beta, }{ }^{(c)} \\
{ }^{60} \mathrm{Co},{ }^{65} \mathrm{Zn},{ }^{106} \mathrm{Ru},{ }^{133} \mathrm{Ba}, \\
{ }^{134} \mathrm{Cs},{ }^{137} \mathrm{Cs}\end{array}$ & 18 & $13^{(\text {b) }}$ \\
\hline Water & $\mathrm{U}$ (natural) ${ }^{239} \mathrm{Pu}$ & 2 & 2 \\
\hline Tritium in water & ${ }^{3} \mathrm{H}$ & 1 & 0 \\
\hline
\end{tabular}

(a) Control limits are from Jarvis and Siu (1981).

(b) The levels of the EPA samples are usually less than $50 \mathrm{pCi} / \mathrm{L}$ and the sample size $500 \mathrm{~mL}$, which places them at or below background levels at the 222-S Analytical Laboratory.

(c) Performance differences exist in analyzing beta samples because the instruments at the 222-S Analytical Laboratory are calibrated with a ${ }^{60} \mathrm{Co}$ source but the EPA known values are based on ${ }^{90} \mathrm{Sr}$ calibration. 
References

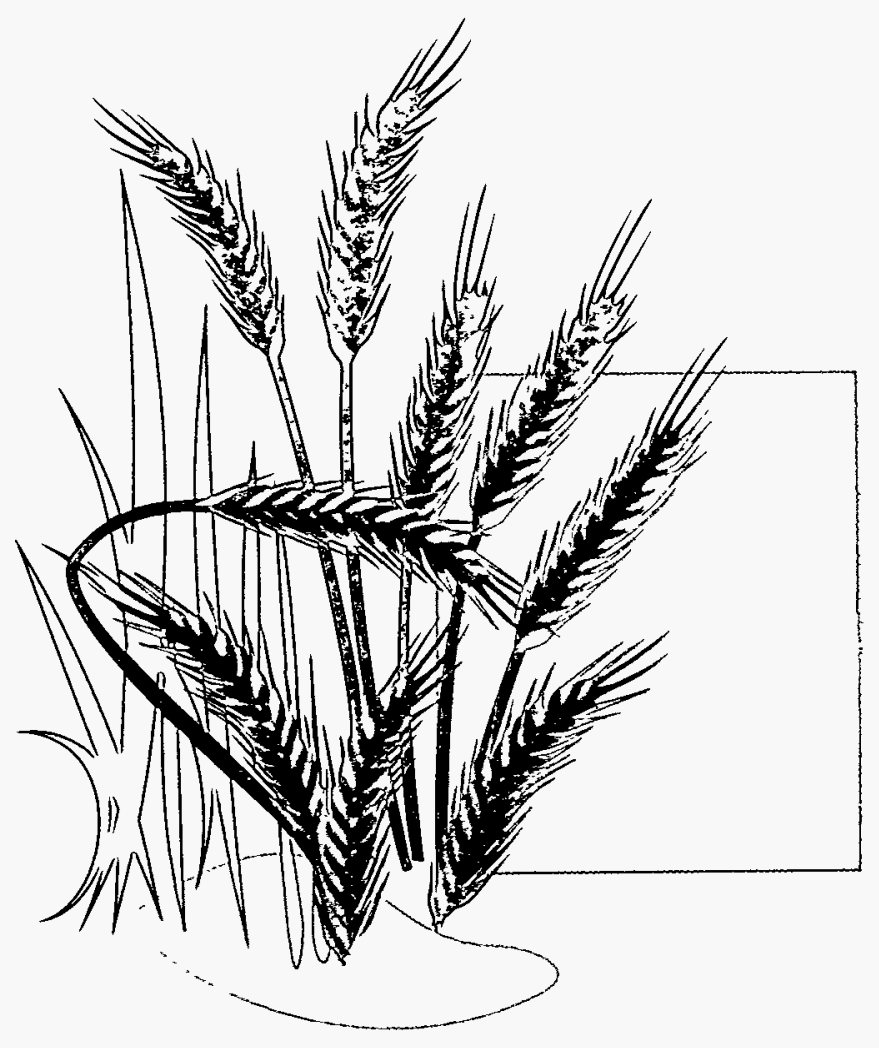




\subsection{References}

3 CFR 369-373, Executive Order 12780, "Federal Agency Recycling and the Council on Federal Recycling and Procurement Policy." Code of Federal Regulations.

10 CFR 1021, U.S. Department of Energy, "Compliance with the National Environmental Policy Act." Code of Federal Regulations.

29 CFR 1910, U.S. Department of Labor, "Occupational Safety and Health Administration." Code of Federal Regulations.

40 CFR 52, U.S. Environmental Protection Agency, "Prevention of Significant Deterioration of Air Quality." Code of Federal Regulations.

40 CFR 61, U.S. Environmental Protection Agency, "National Emission Standards for Hazardous Air Pollutants ." Code of Federal Regulations.

40 CFR 300, U.S. Environmental Protection Agency, "The National Oil and Hazardous Substances Pollution Contingency Plan." Code of Federal Regulations.

40 CFR 761, U.S. Environmental Protection Agency, "Polychlorinated Biphenyls (PCBs) Manufacturing, Processing, Distribution in Commerce, and Use Prohibitions." Code of Federal Regulations.

40 CFR 1500-1508, Council on Environmental Quality, "Regulations for Implementing the Procedural Provisions of the National Environmental Policy Act." Code of Federal Regulations.

50 CFR 17, U.S. Department of Interior, U.S. Fish and Wildlife Service, "Endangered and Threatened Wildlife and Plants." Code of Federal Regulations.

55 FR 42633, U.S. Department of Energy, "Intent to Prepare a Programmatic Environmental Impact Statement on the Department of Energy's Proposed Integrated Environmental Restoration and Waste Management Program, and to Conduct Public Scoping Meetings." Federal Register.
57 FR 37959, U.S. Department of Energy, "Intent to Prepare the Hanford Remedial Action Environmental Impact Statement, Richland, Washington." Federal Register.

58 FR 39528, U.S. Department of Energy, "Revised Notice of Intent to Prepare a Programmatic Environmental Impact Statement for Reconfiguration of the Nuclear Weapons Complex." Federal Register.

58 FR 48509, U.S. Department of Energy, "Record of Decision: Decommissioning of Eight Surplus Production Reactors at the Hanford Site, Richland, Washington." Federal Register.

59 FR 4052, U.S. Department of Energy, "Intent to Prepare Hanford Tank Waste Remediation System Environmental Impact Statement, Richland, Washington." Federal Register.

American Society of Mechanical Engineers (ASME). 1989. Quality Assurance Program for Nuclear Facilities, ASME NQA-1-1989 Edition. American Society of Mechanical Engineers, New York.

American Society for Testing and Materials (ASTM). 1989. Standard Guide for Establishing a Quality Assurance Program for Analytical Chemical Laboratories Within the Nuclear Industry. ASTM C 1009-89, American Society for Testing Materials, Philadelphia, Pennsylvania.

Ames, B. N., R. Magaw, and L. S. Gold. 1987. "Ranking Possible Carcinogenic Hazards." Science 236:271-280.

Anderson, J. D., and D. L. Hagel. 1994. Summary of Radioactive Solid Waste Received in the 200 Areas During Calendar Year 1993. WHC-EP-0125-6, Westinghouse Hanford Company, Richland, Washington.

Atallah, S. 1980. "Assessing and Managing Industrial Risk." Chemical Engineering 9/8/80:94-103. 
Backman, G. E. 1962. Dispersion of 300 Area Liquid Effluent in the Columbia River. HW-73672, Hanford Atomic Products Operation, General Electric Company, Richland, Washington.

Baker, D. A., and J. K. Soldat. 1992. Methods for Estimating Doses to Organisms from Radioactive Materials Released into the Aquatic Environment. PNL-8150, Pacific Northwest Laboratory, Richland, Washington.

Beasley, T. M., L. A. Ball, and J. E. Andrews III. 1981. "Hanford-Derived Plutonium in Columbia River Sediments." Science 214(20):913-915.

Beck, D. M., B. A. Napier, M. J. Scott, A. G. Thurman, M. D. Davis, D. B. Pittenger, S. F. Shindle, and N. C. Batishko. 1991. Hanford Area 1990 Population and 50-Year Projections. PNL-7803, Pacific Northwest Laboratory, Richland, Washington.

Bisping, L. E. 1993. Environmental Surveillance Master Sampling Schedule. PNL-9215, Pacific Northwest Laboratory, Richland, Washington.

Bisping, L. E. 1994. Hanford Site Environmental Data 1993 - Surface and Columbia River. PNL-9824, Pacific Northwest Laboratory, Richland, Washington.

Bisping, L. E., and R. K. Woodruff. 1990. Hanford Site Environmental Data for Calendar Year 1989-Surface and Columbia River. PNL-7360, Pacific Northwest Laboratory, Richland, Washington.

Bisping, L. E., and R. K. Woodruff. 1991. Hanford Site Environmental Data for Calendar Year 1990-Surface and Columbia River. PNL-7929, Pacific Northwest Laboratory, Richland, Washington.

Bisping, L. E., and R. K. Woodruff. 1992. Hanford Site Environmental Data for Calendar Year 1991-Surface and Columbia River. PNL-8149, Pacific Northwest Laboratory, Richland, Washington.

Bisping, L. E., and R. K. Woodruff. 1993. Hanford Site Environmental Data for Calendar Year 1992-Surface and Columbia River. PNL-8683, Pacific Northwest Laboratory, Richland, Washington.
Borghese, J. V. 1994. "300 Area Process Trench." In Annual Report for RCRA Groundwater Monitoring Projects at Hanford Site Facilities for 1993. DOE/ RL-93-88, Geosciences Group, Westinghouse Hanford Company, editors. U. S. Department of Energy, Richland, Washington.

Bryce, R. W., J. C. Evans, and K. B. Olsen. 1991. Ground-Water Sample Collection and Analysis Plan for the Ground-Water Surveillance Project. PNL-7872, Pacific Northwest Laboratory, Richland, Washington.

Cadwell, L. L. 1994. Wildlife Studies on the Hanford Site: 1993 Highlights Report. PNL-7380, Pacific

- Northwest Laboratory, Richland, Washington.

Calabrese, E. J., and E. M. Kenyon. 1991. Air Toxics and Risk Assessment. Lewis Publishers, Chelsea, Michigan.

Chatters, J. C., ed. 1989. Hanford Cultural Resources Management Plan. PNL-6942, Pacific Northwest Laboratory, Richland, Washington.

Curn, B. L., and S. P. Thomas. 1994. Environmental Releases for Calendar Year 1993. WHC-EP-0527-3, Westinghouse Hanford Company, Richland, Washington.

Cushing, C. E., ed. 1992. Hanford Site National Environmental Policy Act (NEPA) Characterization. PNL-6415, Rev. 5, Pacific Northwest Laboratory, Richland, Washington.

Diediker, L. P., B. L. Curn, K. Rhoads, E. G. Damberg, J. K. Soldat, and S. J. Jette. 1994. Radionuclide Air Emissions Report for the Hanford Site. Calendar Year 1993, DOE/RL-94-51. U.S. Department of Energy, Richland Operations Office, Richland, Washington.

Dinman, B. D. 1980. "The Reality and Acceptance of Risk." Journal of the American Medical Association (JAMA) (11):1226-1228.

Dirkes, R. L. 1990. 1988 Hanford Riverbank Springs Characterization Report. PNL-7500, Pacific Northwest Laboratory, Richland, Washington.

Dirkes, R. L. 1993. Columbia River Monitoring: Distribution of Tritium in Columbia River Water at the Richland Pumphouse. PNL-8531, Pacific Northwest Laboratory, Richland, Washington. 
Dirkes, R. L., G. W. Patton, and B. L. Tiller. 1993. Columbia River Monitoring: Summary of Chemical Monitoring Along Cross Sections at Vernita Bridge and Richland. PNL-8654, Pacific Northwest Laboratory, Richland, Washington.

DOE - See U.S. Department of Energy.

Dresel, P. E., D. R. Newcomer, J. C. Evans, W. D. Webber, F. A. Spane, Jr., R. G. Raymond, and B. E. Optiz. 1993. Hanford Site Ground-Water Monitoring for 1992. PNL-8716, Pacific Northwest Laboratory, Richland, Washington.

Drummond, M., and Future Site Uses Working Group. 1992. The Future of Hanford: Uses and Cleanup. U.S. Department of Energy, Richland, Washington.

Eberhardt, L. E., R. G. Anthony, and W. H. Rickard. 1989. "Survival of Juvenile Canada Geese During the Rearing Period." Journal of Wildlife Management 53:372-377.

Eisenbud, M. 1987. Environmental Radioactivity from Natural, Industrial, and Military Sources. Third Edition, Chapter 5, Academic Press Inc., New York.

Emery, R. M., and M. C. McShane. 1980. "Nuclear Waste Ponds and Streams on the Hanford Site: An Ecological Search for Radiation Effects." Health Physics 38:787-809.

EPA - See U.S. Environmental Protection Agency.

Evans, J. C., R. W. Bryce, and D. R. Sherwood. 1989a. Hanford Site Ground-Water Monitoring for January Through June 1988. PNL-6886, Pacific Northwest Laboratory, Richland, Washington.

Evans, J. C., R. W. Bryce, D. R. Sherwood, M. L. Kemmer, and D. R. Newcomer. 1989b. Hanford Site Ground-Water Monitoring for July Through December 1988. PNL-7120, Pacific Northwest Laboratory, Richland, Washington.

Evans, J. C., R. W. Bryce, and D. J. Bates. 1992. Hanford Site Ground-Water Monitoring for 1990. PNL-8073, Pacific Northwest Laboratory, Richland, Washington.

Executive Order 12580, "Superfund Implementation, January 23, 1987."
Freshley, M. D., and M. J. Graham. 1988. Estimation of Ground-Water Travel Time at the Hanford Site:

Description, Past Work, and Future Needs. PNL-6328, Pacific Northwest Laboratory, Richland, Washington.

Gee, G. W., M. J. Fayer, M. L. Rockhold, and M. D. Campbell. 1992. "Variations in Recharge at the Hanford Site." Northwest Science 66(4): 237.

Gephart, R. E., P. A. Eddy, R. C. Arnett, and G. A. Robinson. 1976. Geohydrologic Study of the West Lake Basin. ARH-CD-775, Atlantic Richfield Hanford Company, Richland, Washington.

Gephart, R. E., R. C. Arnett, R. G. Baca, L. S. Leonhart, F. A. Spane, Jr., D. A. Palumbo, and S. R. Strait. 1979. Hydrologic Studies Within the Columbia Plateau, Washington: An Integration of Current Knowledge. RHO-BWI-ST-5, Rockwell Hanford Operations, Richland, Washington.

Gilmore, T. J., D. R. Newcomer, S. K. Wurstner, F. A. Spane. 1992. Calculation of Groundwater Discharge to the Columbia River in the 100 Area. PNL-8057, Pacific Northwest Laboratory, Richland, Washington.

Graham, M. J., M. D. Hall, S. R. Strait, and W. R. Brown. 1981. Hydrology of the Separations Area. RHO-ST-42, Rockwell Hanford Operations, Richland, Washington.

Graham, M. J., G. V. Last, and K. R. Fecht. 1984. An Assessment of Aquifer Intercommunication in the $B$ Pond - Gable Mountain Pond Area of the Hanford Site. RHO-RE-ST-12P, Rockwell Hanford Operations, Richland, Washington.

Hanford Federal Facility Agreement and Consent Order. 1989 (Tri-Party Agreement) (as amended). 89-10, Rev. 1, Washington State Department of Ecology, U.S. Environmental Protection Agency, and the U.S. Department of Energy.

Hanlon, B. M. 1993. Tank Farm Surveillance and Waste Status Summary Report for October 1993. WHC-EP-0182-67, Westinghouse Hanford Company, Richland, Washington.

Hartman, M. J. 1994. "Introduction." In Annual Report for RCRA Groundwater Monitoring Projects at the Hanford Site Facilities for 1993. DOE/RL-93-88, U.S. Department of Energy, Richland, Washington. 
Health Physics Society (HPS). 1987. Health Physics Society Official Journal: Special Issue on Radiation Hormesis 52(5).

Heart of America Northwest et al. versus Westinghouse Hanford Company. 820 F. Supp. 1265 (E. D. Wash. 1993), April 15, 1993.

Jacobson, E. A., and M. D. Freshley. 1990. An Initial Inverse Calibration of the Ground-Water Flow Model for the Hanford Unconfined Aquifer. PNL-7144, Pacific Northwest Laboratory, Richland, Washington.

Jaquish, R. E. 1993. Contribution of Hanford Liquid Effluents to Strontium-90 Levels in Offsite Soils. PNL-8817, Pacific Northwest Laboratory, Richland, Washington.

Jaquish, R. E., and R. W. Bryce. 1989. Hanford Site Environmental Report for Calendar Year 1988. PNL-6825, Pacific Northwest Laboratory, Richland, Washington.

Jaquish, R. E., and P. J. Mitchell. 1988. Environmental Monitoring at Hanford for 1987. PNL-6464, Pacific Northwest Laboratory, Richland, Washington.

Jarvis, A. B., and L. Siu. 1981. Environmental Radioactivity Laboratory Intercomparison Studies Program: Fiscal Year 1980-81. EPA-600/4-81-004, U.S. Environmental Protection Agency, Las Vegas, Nevada.

Jenkins, O. P. 1922. Underground Water Supply of the Region About White Bluffs and Hanford. State of Washington, Department of Conservation and Development, Olympia, Washington.

Johnson, V. G. 1993. Westinghouse Hanford Company Operational Groundwater Status Report, 1990-1992. WHC-EP-0595, Westinghouse Hanford Company, Richland, Washington.

Lee, J. L. 1993. Waste Tank Operations Resumption of Work Performance Upgrade Plan. WHC-SA-2250-VA, Westinghouse Hanford Company, Richland, Washington.

Lindsey, K. A., M. P. Connelly, and B. N. Bjornstad. 1991. Geologic Setting of the 200 West Area: An Update. WHC-SD-EN-TI-008, Rev. 0, Westinghouse Hanford Company, Richland, Washington.
Lindsey, K. A., B. N. Bjornstad, J. W. Lindberg, and K. M. Hoffman. 1992. Geologic Setting of the 200 East Area; An Update. WHC-SD-EN-TI-012, Westinghouse Hanford Company, Richland, Washington.

Manley, C. L., and L. P. Diediker. 1992. Environmental Releases for Calendar Year 1991. WHC-EP-0527-1, Westinghouse Hanford Company, Richland, Washington.

McCormack, W. D., and J. M. V. Carlile. 1984. Investigation of Ground-Water Seepage from the Hanford Shoreline of the Columbia River. PNL-5289, Pacific Northwest Laboratory, Richland, Washington.

Mielke, P. W. 1984. Handbook of Statistics. Amsterdam, North Holland Publishing Company, Amsterdam, Holland.

Napier, B. A., R. A. Peloquin, D. L. Strenge, and J. V. Ramsdell. 1988a. Conceptual Representation. Volume I of GENII - The Hanford Environmental Radiation Dosimetry Software System. PNL-6584, Vol. 1, Pacific Northwest Laboratory, Richland, Washington.

Napier, B. A., R. A. Peloquin, D. L. Strenge, and J. V. Ramsdell. 1988b. User's Manual. Volume 2 of GENII - The Hanford Environmental Radiation Dosimetry Software System. PNL-6584, Vol. 2, Pacific Northwest Laboratory, Richland, Washington.

Napier, B. A., R. A. Peloquin, D. L. Strenge, and J. V. Ramsdell. 1988c. Code Maintenance Manual. Volume 3 of GENII - The Hanford Environmental Radiation Dosimetry Software System. PNL-6584, Vol. 3, Pacific Northwest Laboratory, Richland, Washington.

National Council on Radiation Protection and Measurements (NCRP). 1987. Ionizing Radiation Exposure of the Population of the United States. NCRP Report No. 93, Bethesda, Maryland.

National Parks Service. 1992. Hanford Reach of the Columbia River, Draft Comprehensive River Conservation Study and Environmental Impact Statement. U.S. Department of Interior, Seattle, Washington.

National Research Council (NRC), Committee on the Biological Effects of Ionizing Radiation. 1980. The Effects on Populations of Exposure to Low Levels of Ionizing Radiation. National Academy Press, Washington, D.C. 
National Research Council (NRC), Committee on the Biological Effects of Ionizing Radiation. 1990. Health Effects of Exposure to Low Levels of Ionizing Radiation. National Academy Press, Washington, D.C.

Newcomer, D. R., K. D. Pohlod, and J. P. McDonald. 1991. Water-Table Elevations on the Hanford Site, 1990. PNL-7693, Pacific Northwest Laboratory, Richland, Washington.

Pacific Northwest Laboratory (PNL). 1992a. Surface Environmental Surveillance Procedures Manual. PNL-MA-580, Pacific Northwest Laboratory, Richland, Washington.

Pacific Northwest Laboratory (PNL). 1992b. Quality Assurance Manual, PNL-MA-70. PNL-7000, Richland, Washington.

Pacific Northwest Laboratory (PNL). 1993. Procedures for Ground-Water Investigations. PNL-6894, Rev. 1, Richland, Washington.

Peterson, R. E. 1992. Hydrologic and Geologic Data Available for the Region North of Gable Mountain, Hanford Site, Washington. WHC-SD-EN-TI-006, Westinghouse Hanford Company, Richland, Washington.

Peterson, R. E., and V. G. Johnson. 1992. Riverbank Seepage of Groundwater Along the 100 Areas Shoreline, Hanford Site. WHC-EP-0609, Westinghouse Hanford Company, Richland, Washington.

Peterson, R. E., and M. P. Connelly. 1992. Characterization of a Chromium Plume in Groundwater Along the Columbia River Shoreline, Hanford Site, Washington. WHC-SA-1674-VA, Westinghouse Hanford Company, Richland, Washington.

Poston, T. M., K. R. Price, and D. R. Newcomer. 1991. An Evaluation of the Chemical, Radiological, and Ecological Conditions of West Lake on the Hanford Site. PNL-7662, Pacific Northwest Laboratory, Richland, Washington.

Prater, L. S., J. T. Rieger, C. S. Cline, E. J. Jensen, T. L. Liikala, K. R. Oster, and P. A. Eddy. 1984. GroundWater Surveillance at the Hanford Site for CY 1993. PNL-5041, Pacific Northwest Laboratory, Richland, Washington.
Public Law 100-605, November 4, 1988 [H.R.3614], "An Act to Authorize a Study of the Hanford Reach of the Columbia River, and for Other Purposes."

Public Law 101-510, Section 3137, "Safety Measures for Waste Tanks at Hanford Nuclear Reservation," November 5, 1990. (Note: This is section 3137 of the National Defense Authorization Act for Fiscal Year 1991. This does not have a USC number.)

Rathbun, L. A. 1989. The Determination of the Penetrating Radiation Dose at Hanford. PNL-7124, Pacific Northwest Laboratory, Richland, Washington.

Raymond, J. R., D. A. Myers, J. J. Fix, V. L. McGhan, and P. M. Schrotke. 1976. Environmental Monitoring Report on Radiological Status of the Ground Water Beneath the Hanford Site January-December 1974. BNWL-1970, Pacific Northwest Laboratory, Richland, Washington.

Revised Code of Washington (RCW) 17.21, "Washington Pesticide Application Act 1961," as amended.

Rickard, W. H., and K. R. Price. 1990. "Strontium-90 in Canada Goose Eggshells and Reed Canary Grass from the Columbia River, Washington." Environ. Monit. Assess. 1990; 14:71-76.

Robertson, D. E., and J. J. Fix. 1977. Association of Hanford Origin Radionuclides with Columbia River Sediment. BNWL-2305, Pacific Northwest Laboratory, Richland, Washington.

Sackschewsky, M. R., D. S. Landeen, G. I. Baird, W. H. Rickard, and J. L. Downs. 1992. Vascular Plants of the Hanford Site. WHC-EP-0054, Westinghouse Hanford Company, Richland, Washington.

Sanderson, C. G. 1985. Semi-Annual Report of the Department of Energy, Operational Safety, Health and Environment Division, Quality Assessment Program Data Report. EML-439, Environmental Measurements Laboratory, U.S. Department of Energy, New York.

Schmidt, J. W., A. R. Johnson, B. M. Markes, S. M. McKinney, and C. J. Perkins. 1994. Westinghouse Hanford Company Operational Environmental Monitoring Annual Report, Calendar Year 1993.

WHC-EP-0573-2, Westinghouse Hanford Company, Richland, Washington. 
Shleien, B. 1992. The Health Physics and Radiological Health Handbook. Revised Edition, Scinta, Inc., Silver Spring, Maryland.

Snedecor, G. W., and W. G. Cochran. 1980. Statistical Methods. 7th ed. Iowa State University Press, Ames, Iowa.

Soldat, J. K. 1976. "Radiation Doses from Iodine-129 in the Environment." Health Physics 30:61-70.

Soldat, J. K., K. R. Price, and W. H. Rickard. 1990. Methodology Used to Compute Maximum Potential Doses from Ingestion of Edible Plants and Wildlife Found on the Hanford Site. PNL-7539, Pacific Northwest Laboratory, Richland, Washington.

Speer, D. R., J. J. Fix, and P. J. Blumer. 1976. Environmental Surveillance at Hanford for CY-1975.

BNWL-1979, Battelle, Pacific Northwest Laboratories, Richland, Washington.

Stenner, R. D., K. H. Cramer, K. A. Higley, S. J. Jette, D. A. Lamar, T. J. McLaughlin, D. R. Sherwood, and N. C. Van Houten. 1988. Hazard Ranking System Evaluation of CERCLA Inactive Waste Sites at Hanford. PNL-6456, Pacific Northwest Laboratory, Richland, Washington.

Stone, W. A., J. M. Thorp, O. P. Gifford, and D. J. Hoitink. 1983. Climatological Summary for the Hanford Area. PNL-4622, Pacific Northwest Laboratory, Richland, Washington.

Sula, M. J. 1980. Radiological Survey of Exposed Shorelines and Islands of the Columbia River Between Vernita and the Snake River Confluence. PNL-3127, Pacific Northwest Laboratory, Richland, Washington.

Thurman, P. A. 1992. Hanford Sanitary Water Quarterly Surveillance, CY 1991. HEHF-88, Hanford Environmental Health Foundation, Environmental Health Sciences, Richland, Washington.

Travis, C. C., and S. T. Hester. 1990. "Background Exposure to Chemicals: What Is the Risk?" Risk Analysis 10(4).

United Nations Scientific Committee on the Effects of Atomic Radiation (UNSCEAR). 1988. Sources, Effects and Risks of lonizing Radiation. Report E.88.1X.7, United Nations, New York.
U.S. Department of Energy (DOE). 1986. Environmental Assessment, Reference Repository Location, Hanford Site, Washington. DOE/RW-0070, U.S. Department of Energy, Washington, D.C.

U.S. Department of Energy (DOE). 1987a. Effluent Information System (EIS)/Onsite Discharge Information System (ODIS). DOE/ID-187 (87), Idaho Field Office, Idaho Falls, Idaho.

U.S. Department of Energy (DOE). 1987b. Final Environmental Impact Statement, Disposal of Hanford Defense High-Level, Transuranic and Tank Wastes. DOE/EIS-0113, U.S. Department of Energy, Richland, Washington.

U.S. Department of Energy (DOE). 1987c. Plan and Schedule to Discontinue Disposal of Liquids Into the Soil Column at the Hanford Site. U.S. Department of Energy, Richland, Washington.

U.S. Department of Energy (DOE). 1988a. Internal Dose Conversion Factors for Calculation of Dose to the Public. DOE/EH-0071, U.S. Department of Energy, Washington, D.C.

U.S. Department of Energy (DOE). 1988b. External Dose-Rate, Conversion Factors for Calculation of Dose to the Public. DOE/EH-0070, U.S. Department of Energy, Washington, D.C.

U.S. Department of Energy (DOE). 1988c. Consultation Draft, Site Characterization Plan, Reference Repository Location, Hanford Site, Washington. DOE/ RW-0164, Vol. 1 and 2, U.S. Department of Energy, Richland, Washington.

U.S. Department of Energy (DOE). 1989. Hanford Site Ground-Water Protection Management Program. DOE/ RL-89-12, U.S. Department of Energy, Richland, Washington.

U.S. Department of Energy (DOE). 1990. Tiger Team Assessment of the Hanford Site. DOE/EH-0139, U.S. Department of Energy, Washington, D.C.

U.S. Department of Energy (DOE). 1991a. Environmental Regulatory Guide for Radiological Effluent Monitoring and Environmental Surveillance. DOE/ EH-0173T, U.S. Department of Energy, Washington, D.C. 
U.S. Department of Energy (DOE). 1991b. Hanford Site Environmental Monitoring Plan. DOE/RL 91-50, U.S. Department of Energy, Richland, Washington.

U.S. Department of Energy (DOE). 1992a. Decommissioning of Eight Surplus Production Reactors at the Hanford Site, Richland, Washington. Final Environmental Impact Statement, DOE/EIS-0119F, U.S. Department of Energy, Richland, Washington.

U.S. Department of Energy (DOE). 1992b. Engineering Evaluation of the 618-9 Burial Ground Expedited Response Action. DOE-RL-91-38, U.S. Department of Energy, Richland, Washington.

U.S. Department of Energy (DOE). 1992c. Sampling and Analysis of 100 Area Springs. DOE/RL-92-12, U.S. Department of Energy, Richland, Washington.

U.S. Department of Energy (DOE). 1992d. Environment, Safety and Health Progress Assessment of the Hanford Site. DOE/EH 0271, U.S. Department of Energy, Washington, D.C.

U.S. Department of Energy (DOE). 1992e. Final Remedial Investigation/Feasibility Study - Environmental Assessment Report for the 1100-EM-1 Operative Unit, Hanford. DOE/RL-92-67, U.S. Department of Energy, Richland, Washington.

U.S. Department of Energy (DOE). 1993a. Limited Field Investigation Report for the 100-KR-4 Operable Unit. DOE/RL-93-79, U.S. Department of Energy, Richland, Washington.

U.S. Department of Energy (DOE). 1993b. Annual Report for RCRA Ground-Water Monitoring Projects at Hanford Site Facilities for 1992. DOE-RL-93-09. Department of Energy, Richland, Washington.

U.S. Department of Energy (DOE). 1993c. Limited Field Investigation Report for the 100-BC-5 Operable Unit. DOE/RL-93-37 Draft A, U.S. Department of Energy, Richland, Washington.

U.S. Department of Energy (DOE). 1993d. United States Department of Energy Richland Operations Office Environmental Protection Implementation Plan, November 9, 1993, to November 9, 1994. DOE/RL-93-97, U.S. Department of Energy, Richland, Washington.
U.S. Department of Energy (DOE). 1993e. 1992 Hanford Toxic Chemical Release Inventory Emergency Planning and Community Right-to-Know Act Section 313. DOE/RL-93-42, U.S. Department of Energy, Richland, Washington.

U.S. Department of Energy (DOE). 1994a. 1993 Hanford Tier Two Emergency and Hazardous Chemical Inventory. DOE/RL-94-04, U.S. Department of Energy, Richland, Washington.

U.S. Department of Energy (DOE). 1994b. Hanford Site Annual Dangerous Waste Report for Calendar Year 1993. DOE/RL-94-10, U.S. Department of Energy, Richland Operations Office, Richland, Washington.

U.S. Department of Energy (DOE). 1994c. The Waste Minimization/Pollution Prevention Cross Cut Plan 1994. DOE/FM-0145, U.S. Department of Energy, Washing- . ton, D.C.

U.S. Department of Energy Idaho Operations Office (DOE-IO). 1993. Implementation Plan for the DOE Programmatic Spent Nuclear Fuel Management and Idaho National Engineering Laboratory Environmental Restoration and Waste Management Program Environmental Impact Statement. U.S. Department of Energy, Idaho Falls, Idaho.

U.S. Department of Health and Human Services (DHHS). 1985. NIOSH Pocket Guide to Chemical Hazards. Publication No. 85-114, U.S. Department of Health and Human Services, Washington, D.C.

U.S. Department of Health, Education and Welfare (USDHEW). 1970. Radiological Health Handbook, Revised Edition. U.S. Department of Health, Education, and Welfare, Rockville, Maryland.

U.S. Environmental Protection Agency (EPA). 1980a. Upgrading Environmental Radiation Data: Health Physics Society Committee Report HPSR-1 (1980). EPA 520/1-80-012, U.S. Environmental Protection Agency, Washington, D.C.

U.S. Environmental Protection Agency (EPA). 1980b. Interim Guidelines and Specifications for Preparing Quality Assurance Project Plans. EPA/005/80, U.S. Environmental Protection Agency, Washington, D.C. 
U.S. Environmental Protection Agency (EPA). 1982. Methods for Chemical Analysis of Water and Wastes. EPA-600/4-82-055, U.S. Environmental Protection Agency, Washington, D.C.

U.S. Environmental Protection Agency (EPA). 1986a. Test Methods for Evaluating Solid Waste: Physical Chemical Methods. 3rd ed, SW-846, Office of Solid Waste and Emergency Response, Washington, D.C.

U.S. Environmental Protection Agency (EPA). 1986b. Environmental Radiation Data. Report 46 Revised Edition, September 1986, EPA 520/5-87-004, Office of Radiation Programs, Eastern Environmental Radiation Facility (EERF), Montgomery, Alabama.

U.S. Environmental Protection Agency (EPA). 1986c. Ground-Water Monitoring Technical Enforcement Guidance Document. OWSER 9950-1, U.S. Environmental Protection Agency, Washington, D.C.

U.S. Environmental Protection Agency (EPA). 1987. Data Quality Objectives for Remedial Response Activities. EPA/540/G-87/003 and 004, U.S. Environmental Protection Agency, Washington, D.C.

U.S. En̨vironmental Protection Agency (EPA). 1988. Compendium of Methods for the Determination of Toxic Organic Compounds in Ambient Air. EPA/600/4-89/ 017, Atmospheric Research and Exposure Assessment Laboratory, U.S. Environmental Protection Agency, Research Triangle Park, North Carolina.

U.S. Environmental Protection Agency (EPA). 1989. Risk Assessment Methodology: Draft Environmental Impact Statement for Proposed NESHAPS for Radionuclides, Vol. 1, Background Information Document. EPA 520/1-89-005, U.S. Environmental Protection Agency, Washington, D.C.

U.S. Environmental Protection Agency (EPA). 1991. Radionuclides in Drinking Water. Office of Ground Water and Drinking Water, U.S. Environmental Protection Agency, Washington, D.C.

U.S. Geological Survey (USGS). 1988. Water Resources Data Washington Water Year 1986. Report WA-86-1, U.S. Geological Survey, Denver, Colorado.

Washington Administrative Code (WAC) 16-228, Pesticide Regulations, Washington State Department of Agriculture.
Washington Administrative Code (WAC) 173-216, State Waste Discharge Permit Program, Washington State Department of Ecology.

Washington Administrative Code (WAC) 173-303, Dangerous Waste Regulations, Washington State Department of Ecology.

Washington Administrative Code (WAC) 246-247, Radiation Protection--Air Emissions, Washington State Department of Health.

Washington Natural Heritage Program. 1990. Endangered, Threatened, and Sensitive Vascular Plants of Washington. Department of Natural Resources, Olympia, Washington.

Washington Department of Ecology (Ecology). 1992. Water Quality Standards for Waters of the State of Washington. Washington Administrative Code, Chapter 173-201a, Olympia, Washington.

Washington Department of Health (DOH). 1994. Environmental Radiation 1993 Annual Report, 32nd Edition. Washington State Department of Health, Office of Radiation Protection, Olympia, Washington.

Washington State 216 Consent Order Agreement DE 91NM-177.

Westinghouse Hanford Company (WHC). 1989. Quality Assurance Manual. WHC-CM-4-2, Westinghouse Hanford Company, Richland, Washington.

Westinghouse Hanford Company (WHC). 1991a. Environmental Compliance. WHC-CM-7-5; Westinghouse Hanford Company, Richland, Washington.

Westinghouse Hanford Company (WHC). 1991b. Operational Environmental Monitoring. WHC-CM-7-4, Westinghouse Hanford Company Richland, Washington.

Westinghouse Hanford Company (WHC). 1993. Environmental Assessment Tank 241-C-103 Vapor Phase Characterization. Letter to the U.S. Department of Energy, March 1993, Westinghouse Hanford Company, Richland, Washington.

Wilson, R. H., Editor. 1965. Evaluation of Radiological Conditions in the Vicinity of Hanford for 1964. BNWL-90, Pacific Northwest Laboratory, Richland, Washington. 
Wilson, R., and E.S.C. Crouch. 1987. "Risk Assessment and Comparisons: An Introduction." Science 236 (4799):267-270.

Woodruff, R. K., R. W. Hanf, and R. E. Lundgren, eds. 1992. Hanford Site Environmental Report for Calendar Year 1991. PNL-8148, Pacific Northwest Laboratory, Richland, Washington.

Woodruff, R. K., R. W. Hanf, and R. E. Lundgren, eds. 1993. Hanford Site Environmental Report for Calendar Year 1992. PNL-8682, Pacific Northwest Laboratory, Richland, Washington. 


\section{U.S. Department of Energy Orders}

DOE Order 5000.3B. "Occurrence Reporting and Processing of Operations Information."

DOE Order 5400.1. "General Environmental Protection Program."

DOE Order 5400.5. "Radiation Protection of the Public and the Environment."

DOE Order 5440.1E. "National Environmental Policy Act Compliance Program."
DOE Order 5484.1. "Environmental Protection, Safety, and Health Protection Information Reporting Requirements."

DOE Order 5700.6C. "Quality Assurance."

DOE Order 5820.2A. "Radioactive Waste Management." 


\section{Acts}

American Antiquities Preservation Act. See: Antiquities Act of 1906, June 8, 1906. 34 Stat. 225 (Title 16, secs. 431, 432, 433).

American Indian Religious Freedom Act. Public Law 95-341, August 11, 1978. 92 Stat. 469 (Title 42).

Archaeological Resources Protection Act. Public Law 96-95, October 31, 1979. 93 Stat. 721 (Title 16).

Clean Air Act. Public Law 88-206, 42 USC 7401 et seq, as amended.

Clean Water Act. Public Law 95-217, December 27, 1977. 91 Stat. 1566 and Public Law 96-148.

Comprehensive Environmental Response, Compensation, and Liability Act (CERCLA). Public Law 96-150, December 11, 1980. 94 Stat. 2767 (Title 26).

Emergency Planning and Community Right-to-Know Act of 1986. Public Law 99-499, October 17, 1986, 100 Stat. 1728 (Title 3), (Codified as amended at Title 42 USC 11001 et seq.).

Endangered Species Act. 1973. Public Laws 93-205 through 100-707.
Federal Insecticide, Fungicide, and Rodenticide Act. 1975. Public Laws 94-51 through 94-140.

National Environmental Policy Act (NEPA). 1969. Public Laws 91-190, as amended (42 USC 4321 et seq.).

National Historic Preservation Act. Public Law 89-665, October 15, 1966, 80 Stat. 915-919 (Title 16).

Native American Graves Protection and Repatriation Act. Public Law 101-601, November 16, 1990 (25 USC 3001 et seq.).

Pollution Prevention Act. Public Law 101-508, 1990, 104 Stat. 1388-321 (41 USC 13101 et seq.).

Resource Conservation and Recovery Act. Public Law 94-580, October 21, 1976, 90 Stat. 2795 (Title 42).

Safe Drinking Water Act. Public Law 93-523, December 16, 1974, 88 Stat. 1660 (Title 21).

Superfund Amendments and Reauthorization Act. Public Law 99-499, October 17, 1986, 100 Stat. 1613 (Title 10).

Toxic Substances Control Act. Public Law 94-469, as amended (15 USC 2601 et seq.). 


\section{Appendixes}

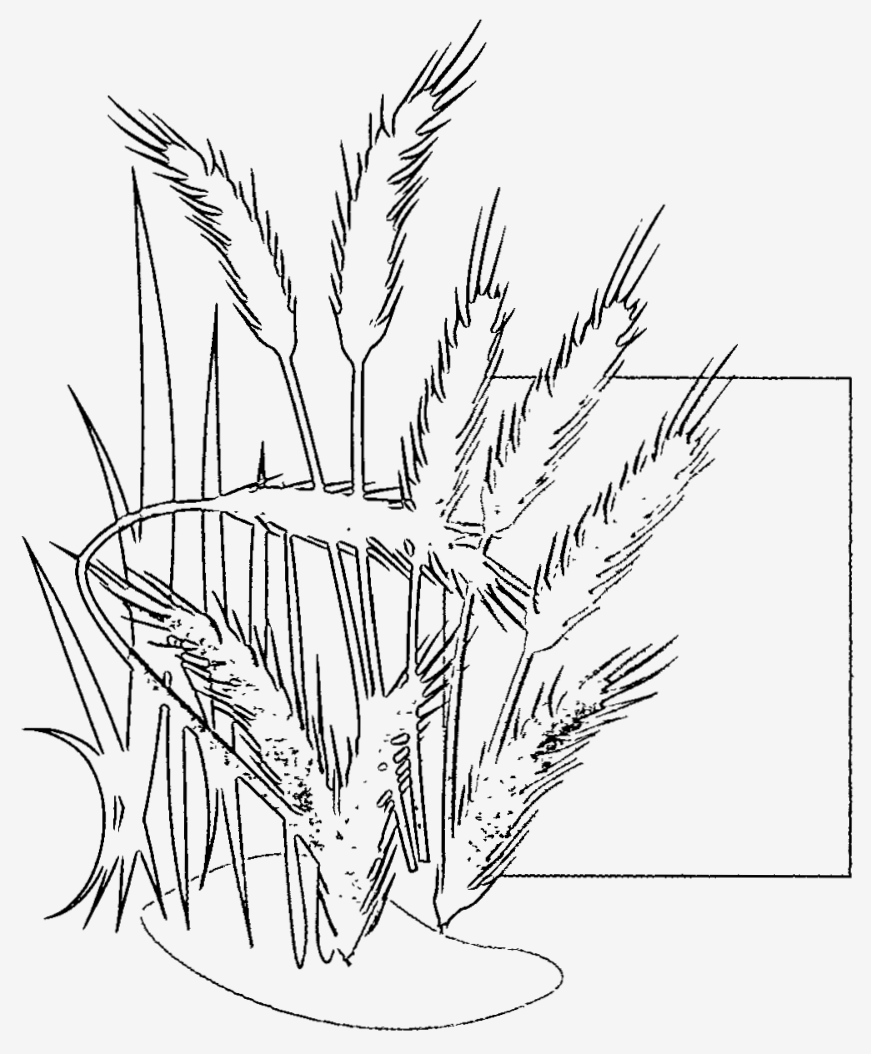




\section{Appendix A}

\section{Monitoring Results for 1993}




\section{Appendix A}

\section{Additional Monitoring Results for 1993}

This Appendix contains additional information on 1993 monitoring results, supplementing the data summarized in the main body of the report. More detailed information is available in the companion 1994 report by
L. E. Bisping, Hanford Site Environmental Data for Calendar Year 1993-Surface and Columbia River (PNL-9824, Pacific Northwest Laboratory, Richland, Washington). 
Table A.1. Radionuclide Concentrations Measured in Columbia River Water at Priest Rapids Dam, 1993 Compared to Values from the Previous 5 Years

$\frac{\text { Radionuclide }^{(b)}}{\text { Composite System }}$
Alpha
Beta
${ }^{3} \mathrm{H}$
${ }^{90} \mathrm{Sr}$
${ }^{209} \mathrm{Tc}$
${ }^{234} \mathrm{U}$
${ }^{238} \mathrm{U}$
$\mathrm{U}-\mathrm{Total}$

\begin{tabular}{ll}
\multicolumn{2}{c}{1993} \\
\hline No. of & Concentration, $\mathrm{pCi} / \mathrm{L}^{(\mathrm{a})}\left(10^{-9} \mu \mathrm{Ci} / \mathrm{mL}\right)$ \\
& Maximum
\end{tabular}

\begin{tabular}{ccc} 
& \multicolumn{2}{c}{ 1988-19 } \\
\hline $\begin{array}{cc}\text { No. of } \\
\text { Samples }\end{array}$ & & \multicolumn{1}{c}{ Concen } \\
\cline { 3 - 3 } & & Maximum \\
& & \\
57 & & $1.7 \pm 1.2$ \\
58 & & $5.2 \pm 2.5$ \\
58 & & $114 \pm 4$ \\
58 & & $0.18 \pm 0.08$ \\
46 & & $4.1 \pm 1.2$ \\
58 & & $0.34 \pm 0.08$ \\
58 & & $0.04 \pm 0.02$ \\
58 & & $0.24 \pm 0.05$ \\
58 & & $0.55 \pm 0.06$
\end{tabular}

Drinking

Water

Standard ${ }^{(\mathrm{c})}$

\section{Continuous System}

${ }^{129} \mathrm{I} \mathrm{D}$

${ }^{239.240} \mathrm{Pu} \mathrm{P}$

$\mathrm{D}$

$\begin{array}{ll}12 & 0.9 \pm 0.8 \\ 12 & 2.1 \pm 2.1 \\ 12 & 48 \pm 3 \\ 12 & 0.11 \pm 0.04 \\ 12 & 0.39 \pm 0.10 \\ 12 & 0.30 \pm 0.06 \\ 12 & 0.03 \pm 0.02 \\ 12 & 0.22 \pm 0.05 \\ 12 & 0.53 \pm 0.06\end{array}$

$\begin{aligned} 0.4 & \pm 50 \% \\ 0.2 & \pm 350 \% \\ 40 & \pm 5 \% \\ 0.09 & \pm 22 \% \\ 0.007 & \pm 177 \% \\ 0.25 & \pm 8 \% \\ 0.014 & \pm 36 \% \\ 0.18 & \pm 6 \% \\ 0.45 & \pm 7 \%\end{aligned}$

$\begin{array}{ll}4 & 0.000007 \pm 0.000001 \\ 4 & 0.00010 \pm 0.00004 \\ 4 & 0.00020 \pm 0.00009\end{array}$
$0.000005 \pm 20 \%$
$0.00003 \pm 133 \%$
$0.00008 \pm 100 \%$
16
$0.000050 \pm 0.000005$
$0.00010 \pm 0.00008$
$0.00063 \pm 0.00019$

$0.000013+54 \%$

$0.00003 \pm 33 \%$

$0.00007 \pm 86 \%$
$0.6 \pm 150 \%$
$1.4 \pm 21 \%$
$56 \pm 52 \%$
$0.09 \pm 67 \%$
$0.2 \pm 165 \%$
$0.23 \pm 35 \%$
$0.008 \pm 212 \%$
$0.18 \pm 33 \%$
$0.42 \pm 31 \%$

15
50
20,000
8
900
$--(d$
---
---
---

(a) Maximum values are \pm 2 sigma counting errors. Averages are \pm 2 times the standard error of the calculated mean, expressed as a percentage.

(b) Radionuclides measured using the continuous system show the particulate (P) and dissolved (D) fractions separately. Other radionuclides are based on samples collected by the composite system (see text).

(c) The drinking water standards are in $\mathrm{pCi} / \mathrm{L}$ from State of Washington and Environmental Protection Agency (see Table C.2, Appendix C).

(d) Dashes indicate no concentration guides provided in drinking water standard. 
Table A.2. Radionuclide Concentrations Measured in Columbia River Water at the 300 Area, 1993 Compared to Values from the Previous 5 Years

\begin{tabular}{|c|c|c|c|c|c|c|c|}
\hline \multirow[b]{3}{*}{ Radionuclide(b) $^{(b)}$} & \multicolumn{3}{|c|}{1993} & \multicolumn{3}{|c|}{ 1988-1992 } & \multirow{3}{*}{$\begin{array}{c}\text { Drinking } \\
\text { Water } \\
\text { Standard }\end{array}$} \\
\hline & \multirow{2}{*}{$\begin{array}{c}\text { No. of } \\
\text { Samples }\end{array}$} & \multicolumn{2}{|c|}{ Concentration, $\mathrm{pCi} / \mathrm{L}^{(\mathrm{a})}\left(10^{-9} \mu \mathrm{Ci} / \mathrm{mL}\right)$} & \multirow{2}{*}{$\begin{array}{c}\text { No. of } \\
\text { Samples }\end{array}$} & \multicolumn{2}{|c|}{ Concentration $^{(\mathrm{a})}, \mathrm{pCi} / \mathrm{L}$} & \\
\hline & & Maximum & Average & & Maximum & Average & \\
\hline \multicolumn{8}{|l|}{ Composite System } \\
\hline Total alpha & 4 & $1.1 \pm 0.5$ & $0.5 \pm 80 \%$ & 16 & $1.4 \pm 1.0$ & $0.7 \pm 100 \%$ & 15 \\
\hline Total beta & 4 & $1.3 \pm 0.9$ & $1.0 \pm 30 \%$ & 20 & $2.4 \pm 1.0$ & $1.1 \pm 136 \%$ & 50 \\
\hline${ }^{3} \mathrm{H}$ & 4 & $182 \pm 4$ & $154 \pm 19 \%$ & 19 & $206 \pm 5$ & $146 \pm 49 \%$ & 20,000 \\
\hline${ }^{90} \mathrm{Sr}$ & 4 & $0.10 \pm 0.04$ & $0.10 \pm 4 \%$ & 20 & $0.41 \pm 0.34$ & $0.11 \pm 145 \%$ & 8 \\
\hline${ }^{99} \mathrm{Tc}$ & 4 & $0.13 \pm 0.10$ & $0.07 \pm 86 \%$ & 16 & $52 \pm 1$ & $3.6 \pm 722 \%$ & 900 \\
\hline${ }^{234} \mathrm{U}$ & 4 & $0.56 \pm 0.08$ & $0.45 \pm 29 \%$ & 20 & $0.44 \pm 0.07$ & $0.30 \pm 37 \%$ & $---(\mathbf{d})$ \\
\hline${ }^{235} \mathrm{U}$ & 4 & $0.02 \pm 0.02$ & $0.02 \pm 50 \%$ & 20 & $0.04 \pm 0.02$ & $0.01 \pm 200 \%$ & --- \\
\hline${ }^{238} \mathrm{U}$ & 4 & $0.48 \pm 0.07$ & $0.37 \pm 24 \%$ & 20 & $0.40 \pm 0.07$ & $0.24 \pm 42 \%$ & $-\cdots$ \\
\hline U-Total & 4 & $1.1 \pm 1.1$ & $0.83 \pm 28 \%$ & 20 & $0.79 \pm 0.10$ & $0.56 \pm 38 \%$ & --- \\
\hline
\end{tabular}

(a) Maximum values are \pm 2 sigma counting errors. Averages are \pm 2 times the standard error of the calculated mean, expressed as a percentage.

(b) Radionuclides measured using the continuous system show the particulate (P) and dissolved (D) fractions separately. Other radionuclides are based on samples collected by the composite system (see text).

(c) The drinking water standards are in $\mathrm{pCi} / \mathrm{L}$ from State of Washington and Environmental Protection Agency (see Table C.2, Appendix C).

(d) Dashes indicate no concentration guides provided in drinking water standard. 
Table A.3. Radionuclide Concentrations Measured in Columbia River Water at the Richland Pumphouse, 1993 Compared to Values from the Previous 5 Years

Radionuclide ${ }^{(b)}$
Composite System
Total alpha
Total beta
${ }^{3} \mathrm{H}$
${ }^{90} \mathrm{Sr}$
${ }^{99} \mathrm{Tc}$
${ }^{234} \mathrm{U}$
${ }^{235} \mathrm{U}$
${ }^{238} \mathrm{U}$
$\mathrm{U}-\mathrm{Total}$

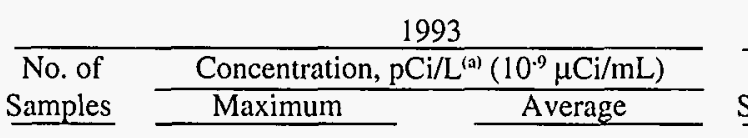

$\begin{array}{lc}\frac{1988-1992}{\text { No. of }} & \text { Concentration }{ }^{(\mathrm{il})}, \mathrm{pCi} / \mathrm{L} \\ { } } & \text { Maximum }\end{array}$

Drinking

Water

Standard ${ }^{(c)}$

Continuous System

${ }^{129} \mathrm{I} \mathrm{D}$

239.240 Pu P

D

$\begin{array}{ll}12 & 1.7 \pm 1.0 \\ 12 & 2.8 \pm 2.3 \\ 12 & 162 \pm 4 \\ 12 & 0.14 \pm 0.04 \\ 12 & 0.25 \pm 0.10 \\ 12 & 0.36 \pm 0.05 \\ 12 & 0.02 \pm 0.02 \\ 12 & 0.32 \pm 0.05 \\ 12 & 0.69 \pm 0.07\end{array}$
$0.7 \pm 43 \%$
$0.3 \pm 200 \%$
$0.08 \pm 250 \%$
$0.07 \pm 100 \%$
$0.28 \pm 11 \%$
$0.22 \pm 14 \%$
$0.51 \pm 10 \%$

47

$3.4 \pm 1.3$

$9.2 \pm 2.9$

$211 \pm 5$

$0.18 \pm 0.06$

$6.5 \pm 0.9$

$0.45 \pm 0.06$

$0.04 \pm 0.02$

$0.36 \pm 0.05$

$0.84 \pm 0.08$

$1.4 \pm 221 \%$

$116+57 \%$

$0.09 \pm 67 \%$

$0.3 \pm 1067 \%$

$0.24 \pm 46 \%$

$0.009 \pm 222 \%$

$0.20 \pm 45 \%$

$0.45 \pm 44 \%$

15
50
20,000
8
900
$\cdots--(d)$
---
---
---

(a) Maximum values are \pm 2 sigma counting errors. Averages are \pm 2 times the standard error of the calculated mean, expressed as a percentage.

(b) Radionuclides measured using the continuous system show the particulate (P) and dissolved (D) fractions separately. Other radionuclides are based on samples collected by the composite system (see text).

(c) The drinking water standards are in $\mathrm{pCi} / \mathrm{L}$ from State of Washington and Environmental Protection Agency (see Table C.2, Appendix C).

(d) Dashes indicate no concentration guides provided in drinking water standard. 
Table A.4. Radionuclide Concentrations Measured in Columbia River Water Along Cross Sections Established along the Hanford Reach, 1993

\begin{tabular}{|c|c|c|c|c|}
\hline \multirow[b]{2}{*}{ Radionuclide } & \multirow{2}{*}{$\begin{array}{l}\text { No. of } \\
\text { Samples }\end{array}$} & \multicolumn{3}{|c|}{ Concentration, ${ }^{(3)} \mathrm{pCi} / \mathrm{L}$} \\
\hline & & Maximum & Minimum & Average \\
\hline \multicolumn{5}{|l|}{ Vernita Bridge } \\
\hline${ }^{3} \mathrm{H}$ & 16 & $100 \pm 3$ & $34 \pm 2$ & $43 \pm 17 \%$ \\
\hline${ }^{90} \mathrm{Sr}$ & 15 & $0.14 \pm 0.05$ & $0.07 \pm 0.02$ & $0.09 \pm 11 \%$ \\
\hline${ }^{234} \mathrm{U}$ & 15 & $0.30 \pm 0.05$ & $0.22 \pm 0.05$ & $0.26 \pm 4 \%$ \\
\hline${ }^{235} \mathrm{U}$ & 15 & $0.03 \pm 0.02$ & $0.001 \pm 0.009$ & $0.011 \pm 36 \%$ \\
\hline${ }^{238} \mathrm{U}$ & 15 & $0.27 \pm 0.05$ & $0.15 \pm 0.04$ & $0.20 \pm 10 \%$ \\
\hline U-Total & 15 & $0.55 \pm 0.08$ & $0.40 \pm 0.07$ & $0.47 \pm 4 \%$ \\
\hline
\end{tabular}

\section{Richland Pumphouse}

${ }^{3} \mathrm{H}$

${ }^{90} \mathrm{Sr}$

${ }^{234} \mathrm{U}$

${ }^{235} \mathrm{U}$

${ }^{238} \mathrm{U}$

U-Total

100-N Area

${ }^{3} \mathrm{H}$

${ }^{90} \mathrm{Sr}$

${ }^{234} \mathrm{U}$

${ }^{235} \mathrm{U}$

${ }^{238} \mathrm{U}$

U-Total

100-F Area

${ }^{3} \mathrm{H}$

${ }^{90} \mathrm{Sr}$

${ }^{234} \mathrm{U}$

${ }^{235} \mathrm{U}$

${ }^{238} \mathrm{U}$

U-Total

Old Hanford Townsite

${ }^{3} \mathrm{H}$

${ }^{90} \mathrm{Sr}$

${ }^{234} \mathrm{U}$

${ }^{235} \mathrm{U}$

${ }^{238} \mathrm{U}$

U-Total

300 Area

$\begin{array}{ll}{ }^{3} \mathrm{H} & 10 \\ { }^{90} \mathrm{Sr} & 10 \\ { }^{234} \mathrm{U} & 10 \\ { }^{235} \mathrm{U} & 10 \\ { }^{238} \mathrm{U} & 10 \\ \mathrm{U}-T \text { Total } & 10\end{array}$

$$
\begin{gathered}
0.5 \pm 3 \\
0.20 \pm 0.03 \\
0.63 \pm 0.18 \\
0.03 \pm 0.02 \\
0.49 \pm 0.16 \\
1.15 \pm 0.24
\end{gathered}
$$

$$
\begin{gathered}
29 \pm 2 \\
0.04 \pm 0.03 \\
0.20 \pm 0.07 \\
-0.002 \pm 0.008 \\
0.13 \pm 0.04 \\
0.39 \pm 0.07
\end{gathered}
$$

$43 \pm 7 \%$

$0.10 \pm 10 \%$

$0.28 \pm 7 \%$

$0.010 \pm 30 \%$

$0.22 \pm 9 \%$

$0.51 \pm 8 \%$

$$
\begin{aligned}
41 & \pm 2 \\
0.04 & \pm 0.05 \\
0.24 & \pm 0.05 \\
0.003 & \pm 0.008 \\
0.15 & \pm 0.04 \\
0.41 & \pm 0.06
\end{aligned}
$$

$$
\begin{aligned}
& 65 \pm 62 \% \\
& 0.08 \pm 25 \% \\
& 0.29 \pm 10 \% \\
& 0.008 \pm 38 \% \\
& 0.18 \pm 6 \% \\
& 0.48 \pm 6 \%
\end{aligned}
$$

$$
\begin{gathered}
38 \pm 3 \\
0.08 \pm 0.04 \\
0.22 \pm 0.05 \\
-0.02 \pm 0.02 \\
0.17 \pm 0.05 \\
0.42 \pm 0.08
\end{gathered}
$$

$$
\begin{aligned}
40 & \pm 3 \% \\
0.11 & \pm 9 \% \\
0.26 & \pm 8 \% \\
0.010 & \pm 80 \% \\
0.20 & \pm 10 \% \\
0.47 & \pm 4 \%
\end{aligned}
$$

$\begin{aligned} 49 & \pm 14 \% \\ 0.10 & \pm 40 \% \\ 0.28 & \pm 7 \% \\ 0.010 & \pm 30 \% \\ 0.19 & \pm 11 \% \\ 0.48 & \pm 6 \%\end{aligned}$
$42 \pm 2$

$0.07 \pm 0.05$

$0.23 \pm 0.05$

$0.004 \pm 0.009$

$0.15 \pm 0.04$

$0.43 \pm 0.07$
$45 \pm 13 \%$

$0.14 \pm 21 \%$

$0.35 \pm 23 \%$

$0.013 \pm 31 \%$

$0.27 \pm 33 \%$

$0.64 \pm 27 \%$

(a) Maximum and minimum values are \pm 2 sigma counting errors. Averages are \pm 2 times the standard error of the calculated mean (2 SEM). 
Table A.5. Columbia River Water Quality Data, 1993

\begin{tabular}{|c|c|c|c|c|c|}
\hline \multirow{2}{*}{ Analysis $^{(a)}$} & \multirow[b]{2}{*}{ Units } & \multicolumn{4}{|c|}{ Vernita Bridge (upstream) } \\
\hline & & $\begin{array}{c}\text { No. of } \\
\text { Samples }\end{array}$ & Maximum & Minimum & $\begin{array}{l}\text { Annual } \\
\text { Average }\end{array}$ \\
\hline Temperature & ${ }^{\circ} \mathrm{C}$ & 5 & 19.5 & 4.0 & 12.4 \\
\hline Dissolved oxygen & $\mathrm{mg} / \mathrm{L}$ & 5 & 14.6 & 9.4 & 11.5 \\
\hline Turbidity & NTU $U^{(c)}$ & 5 & 1.1 & 0.4 & 0.7 \\
\hline $\mathrm{pH}$ & $\mathrm{pH}$ units & 5 & 8.6 & 8.0 & 8.4 \\
\hline Fecal coliform & $\# / 100 \mathrm{~mL}$ & 5 & 24 & $<1$ & $1^{(\mathrm{d})}$ \\
\hline Suspended solids, $105^{\circ} \mathrm{C}$ & $\mathrm{mg} / \mathrm{L}$ & 5 & 3 & 1 & 2.4 \\
\hline Dissolved solids, $180^{\circ} \mathrm{C}$ & $\mathrm{mg} / \mathrm{L}$ & 5 & 91 & 68 & 79 \\
\hline Specific conductance & $\mu \mathrm{S} / \mathrm{cm}^{(n)}$ & 5 & 158 & 123 & 142 \\
\hline Hardness, as $\mathrm{CaCO}_{3}$ & $\mathrm{mg} / \mathrm{L}$ & 5 & 74 & 59 & 66 \\
\hline Phosphorus, total & $\mathrm{mg} / \mathrm{L}$ & 5 & 0.02 & $<0.01$ & $<0.01$ \\
\hline Chromium, dissolved & $\mu \mathrm{g} / \mathrm{L}$ & 5 & $\mathrm{NR}^{(g)}$ & NR & NR \\
\hline Nitrogen, Kjeldahl & $\mathrm{mg} / \mathrm{L}$ & 5 & $<0.2$ & $<0.2$ & $<0.2$ \\
\hline Total organic carbon & $\mathrm{mg} / \mathrm{L}$ & 5 & 2.4 & 1.1 & 1.7 \\
\hline Iron, dissolved & $\mu \mathrm{g} / \mathrm{L}$ & 5 & 9 & $<3$ & 4.6 \\
\hline Ammonia, dissolved & $\mathrm{mg} / \mathrm{L}$ & 5 & 0.03 & $<0.01$ & $<0.01$ \\
\hline
\end{tabular}

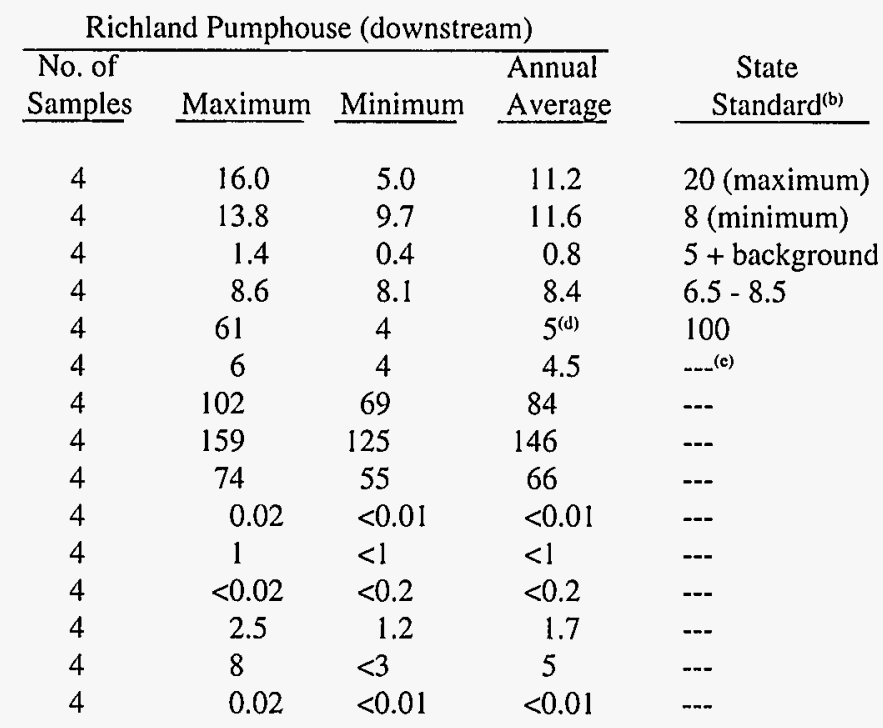

(a) Provisional data from USGS sampling program, subject to revision.

(b) See Appendix C

(c) NTU = nephelometric turbidity units.

(d) Annual median.

(e) Dashes indicate no standard available.

(f) $\mu$ Siemens $/ \mathrm{cm}$.

(g) NR $=$ not reported. 
Table A.6. Radionuclide Concentrations in Columbia River Sediment, 1993 Compared to Values from the Previous 5 Years

\begin{tabular}{|c|c|c|c|c|c|c|c|}
\hline \multirow[b]{3}{*}{ Location } & \multirow[b]{3}{*}{$\underline{\text { Radionuclide }}$} & \multicolumn{3}{|c|}{1993} & \multicolumn{3}{|c|}{$1988-1992$} \\
\hline & & \multirow{2}{*}{$\begin{array}{l}\text { No. of } \\
\text { Samples }\end{array}$} & \multicolumn{2}{|c|}{ Concentration, $\mathrm{pCi} / \mathrm{L}^{(a)}$} & \multirow{2}{*}{$\begin{array}{c}\text { No. of } \\
\text { Samples }\end{array}$} & \multicolumn{2}{|c|}{ Concentration, $\mathrm{pCi} / \mathrm{L}^{(\mathrm{a})}$} \\
\hline & & & Maximum & Average & & Maximum & Average \\
\hline \multirow[t]{5}{*}{ Priest Rapids Dam } & ${ }^{60} \mathrm{Co}$ & 4 & $0.02 \pm 0.01$ & $0.007 \pm 171 \%$ & 20 & $0.02 \pm 0.02$ & $-0.0005 \pm 11.4 \%$ \\
\hline & ${ }^{90} \mathrm{Sr}$ & 4 & $0.022 \pm 0.006$ & $0.017 \pm 30 \%$ & 20 & $0.072 \pm 0.006$ & $0.015 \pm 40 \%$ \\
\hline & ${ }^{137} \mathrm{Cs}$ & 4 & $0.72 \pm 0.05$ & $0.56 \pm 30 \%$ & 20 & $0.80 \pm 0.07$ & $0.43 \pm 19 \%$ \\
\hline & ${ }^{238} U^{(b)}$ & 4 & $1.3 \pm 0.3$ & $1.0 \pm 20 \%$ & & $1.0 \pm 0.1$ & $0.79 \pm 5 \%$ \\
\hline & ${ }^{239,240 \mathrm{Pu}}$ & 4 & $0.013 \pm 0.002$ & $0.011 \pm 18 \%$ & 20 & $0.014 \pm 0.002$ & $0.006 \pm 33 \%$ \\
\hline \multirow{5}{*}{ White Bluffs Slough(c) } & ${ }^{60} \mathrm{Co}$ & 1 & $0.07 \pm 0.02$ & & 4 & $0.098 \pm 0.024$ & $0.06 \pm 50 \%$ \\
\hline & ${ }^{90} \mathrm{Sr}$ & 1 & $-0.001 \pm 0.006$ & & 4 & $0.013 \pm 0.004$ & $0.009 \pm 33 \%$ \\
\hline & ${ }^{137} \mathrm{Cs}$ & 1 & $0.91 \pm 0.03$ & & 4 & $0.73 \pm 0.42$ & $0.42 \pm 67 \%$ \\
\hline & ${ }^{238} U^{(b)}$ & 1 & $1.4 \pm 0.3$ & & 4 & $2.3 \pm 0.1$ & $1.0 \pm 70 \%$ \\
\hline & ${ }^{239,240} \mathrm{Pu}$ & 1 & $0.004 \pm 0.001$ & & 4 & $0.0004 \pm 0.0010$ & $0.002 \pm 100 \%$ \\
\hline \multirow{5}{*}{ 100-F Slough ${ }^{(c)}$} & ${ }^{60} \mathrm{Co}$ & 1 & $-0.002 \pm 0.006$ & & 4 & $0.06 \pm 0.02$ & $0.034 \pm 50 \%$ \\
\hline & ${ }^{90} \mathrm{Sr}$ & 1 & $0.0002 \pm 0.0055$ & & 4 & $0.005 \pm 0.003$ & $0.004 \pm 25 \%$ \\
\hline & ${ }^{137} \mathrm{Cs}$ & 1 & $0.075 \pm 0.009$ & & 4 & $0.76 \pm 0.03$ & $0.30 \pm 103 \%$ \\
\hline & ${ }^{238} U^{(b)}$ & 1 & $0.88 \pm 0.26$ & & 4 & $1.4 \pm 0.1$ & $0.9 \pm 44 \%$ \\
\hline & ${ }^{230,240} \mathrm{Pu}$ & 1 & $0.0007 \pm 0.0004$ & & 4 & $0.0015 \pm 0.0006$ & $0.0010 \pm 50 \%$ \\
\hline \multirow[t]{5}{*}{ Hanford Slough ${ }^{(c)}$} & ${ }^{60} \mathrm{Co}$ & 1 & $-0.002 \pm 0.007$ & & 4 & $0.08 \pm 0.02$ & $0.04 \pm 75 \%$ \\
\hline & ${ }^{90} \mathrm{Sr}$ & 1 & $0.003 \pm 0.006$ & & 4 & $0.021 \pm 0.006$ & $0.010 \pm 70 \%$ \\
\hline & ${ }^{137} \mathrm{Cs}$ & 1 & $0.026 \pm 0.009$ & & 4 & $0.52 \pm 0.03$ & $0.23 \pm 87 \%$ \\
\hline & ${ }^{238} \mathrm{U}^{(b)}$ & 1 & $0.94 \pm 0.31$ & & 4 & $2.1 \pm 0.1$ & $1.1 \pm 45 \%$ \\
\hline & ${ }^{239,240} \mathrm{Pu}$ & 1 & $0.0017 \pm 0.0006$ & & 4 & $0.0035 \pm 0.0006$ & $0.0020 \pm 75 \%$ \\
\hline \multirow{5}{*}{ Richland $^{(d)}$} & ${ }^{60} \mathrm{Co}$ & 1 & $0.05 \pm 0.01$ & & 3 & $0.08 \pm 0.02$ & $0.05 \pm 60 \%$ \\
\hline & ${ }^{90} \mathrm{Sr}$ & 1 & $-0.001 \pm 0.005$ & & 3 & $0.003 \pm 0.003$ & $0.002 \pm 50 \%$ \\
\hline & ${ }^{137} \mathrm{Cs}$ & 1 & $0.31 \pm 0.02$ & & 3 & $0.41 \pm 0.03$ & $0.33 \pm 33 \%$ \\
\hline & ${ }^{238} U^{(b)}$ & 1 & $1.1 \pm 0.3$ & & 3 & $2.3 \pm 0.2$ & $1.7 \pm 41 \%$ \\
\hline & ${ }^{239.240} \mathrm{Pu}$ & $i$ & $0.0020 \pm 0.0007$ & & 3 & $0.0030 \pm 0.0006$ & $0.002 \pm 50 \%$ \\
\hline
\end{tabular}


Table A.6. Radionuclide Concentrations in Columbia River Sediment, 1993 Compared to Values from the Previous 5 Years (contd)

Location

McNary Dam

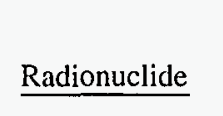

${ }^{60} \mathrm{Co}$
${ }^{90} \mathrm{Sr}$
${ }^{137} \mathrm{Cs}$
${ }^{238} \mathrm{U}^{(b)}$
${ }^{239.240} \mathrm{Pu}$
1993

\begin{tabular}{ll}
\hline \multicolumn{2}{c}{1993} \\
\hline No. of & \multicolumn{2}{c}{ Concentration, $\mathrm{pCi} / \mathrm{L}^{(\mathrm{a})}$} \\
\cline { 2 - 2 } Samples & Maximum
\end{tabular}

4
4
4
4
4
$0.27 \pm 0.02$
$0.034 \pm 0.005$
$0.60 \pm 0.02$
$1.4 \pm 0.3$
$0.012 \pm 0.002$

$0.09 \pm 133 \%$

$0.016 \pm 88 \%$

$0.35 \pm 66 \%$

$1.0 \pm 40 \%$

$0.006 \pm 83 \%$

\begin{tabular}{|c|c|c|}
\hline \multirow{3}{*}{$\begin{array}{l}\text { No. of } \\
\text { Samples }\end{array}$} & \multicolumn{2}{|c|}{$1988-1992$} \\
\hline & \multicolumn{2}{|c|}{ Concentration, $\mathrm{pCi} / \mathrm{L}^{(\mathrm{a})}$} \\
\hline & Maximum & Average \\
\hline 20 & $0.44 \pm 0.04$ & $0.23 \pm 5 \%$ \\
\hline 20 & $0.064 \pm 0.008$ & $0.036 \pm 17 \%$ \\
\hline 20 & $1.19 \pm 0.08$ & $0.66 \pm 12 \%$ \\
\hline 20 & $1.4 \pm 0.3$ & $0.9 \pm 11 \%$ \\
\hline 20 & $0.022 \pm 0.002$ & $0.010 \pm 20 \%$ \\
\hline
\end{tabular}

(a) Maximum values are \pm 2 sigma counting errors. Averages are \pm 2 times the standard error of the calculated mean, expressed as a percentage.

(b) Uranium-238 was analyzed by low-energy photon spectra method.

(c) Sampling at White Bluffs, 100-F, and Hanford sloughs was initiated in 1989

(d) Sampling at Richland was initiated in 1990. 
Table A.7. Radionuclide Concentrations Measured in Riverbank Spring Water During 1993

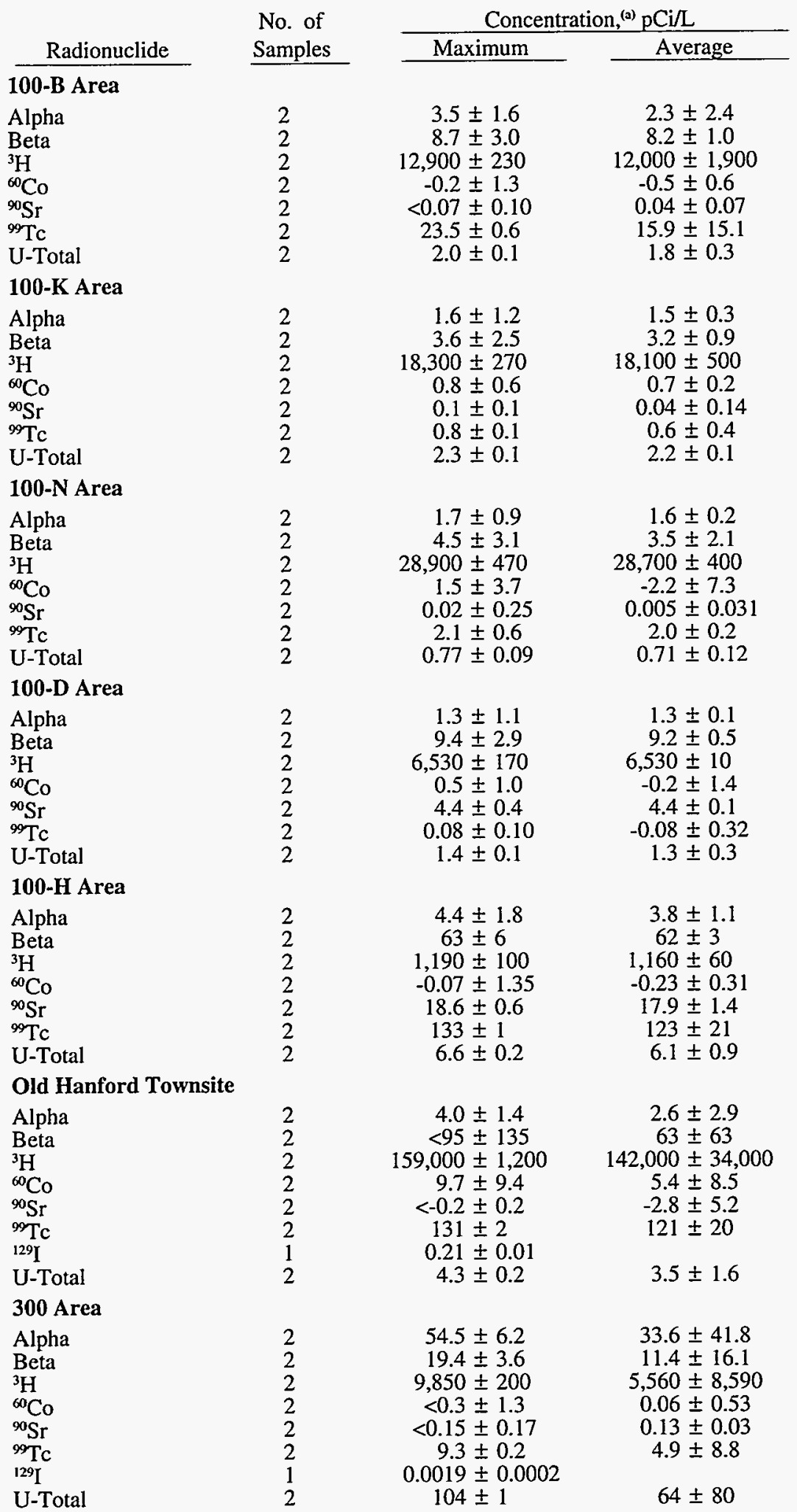

(a) Maximum values are \pm 2 sigma counting error. Averages are \pm 2 times the standard error of the mean. 
Table A.8. Summary of Cesium-137 $\left({ }^{137} \mathrm{Cs}\right)$ in Milk (pCi/L), 1993 Compared to Values from the Previous 5 Years

1993

Sampling

Location

Maximum $^{(a)} \quad$ Mean $^{(b)} \quad \begin{gathered}\text { No. Less Than } \\ \text { Detection }^{(c)}\end{gathered}$

\begin{tabular}{lll}
\multicolumn{3}{c}{$1988-1992$} \\
Maximum $^{(a)}$ & Mean $^{(b)}$ & $\begin{array}{c}\text { No. Less Than } \\
\text { Detection }^{(c)}\end{array}$ \\
\hline
\end{tabular}

Downwind

Wahluke

Sagemoor

$$
\begin{aligned}
& 4.29 \pm 60 \% \\
& 4.40 \pm 50 \%
\end{aligned}
$$$$
\begin{array}{r}
2.40 \pm 70 \% \\
-0.41 \pm 40 \%
\end{array}
$$

2 of 4

12 of 13
$7.69 \pm 100 \%$
$7.82 \pm 50 \%$
$0.32 \pm 150 \%$
$0.63 \pm 50 \%$

46 of 47

119 of 130

\section{Upwind}

Sunnyside

$0.85 \pm 380 \%$

$-0.99 \pm 40 \%$

4 of 4

$4.51 \pm 90 \%$

$0.53 \pm 70 \%$

80 of 85

(a) Maximum is \pm 2 sigma analytical propagated error, expressed as a percentage.

(b) Mean is \pm 2 SEM, expressed as a percentage.

(c) Number of samples with values less than the detection limit out of number of samples analyzed.

Table A.9. Strontium-90 ( ${ }^{\circ 0} \mathrm{Sr}$ ) in Leafy Vegetables (pCi/dry weight), 1993 Compared to Values from the Previous 5 Years
1993

\begin{tabular}{l} 
Sampling \\
Location \\
\hline
\end{tabular}

$\begin{array}{cc}\text { Noximum } & \text { (a) } \\ \text { Mean }^{(b)} & \begin{array}{c}\text { Noss Than } \\ \text { Detection }\end{array}\end{array}$

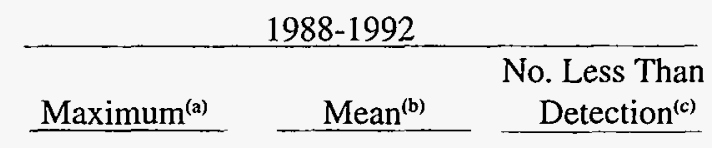

Downwind

Wahluke

Sagemoor

Riverview

$\begin{array}{cc}\text { NS (d) } & \text { NS } \\ 0.011 \pm 50 \% & 0.0096 \pm 40 \% \\ 0.0012 \pm 220 \% & ---\end{array}$
NS
0 of 3
1 of 1
$0.021 \pm 30 \%$
$0.053 \pm 20 \%$

$0.010 \pm 60 \%$

$0.0071 \pm 120 \%$

$0.0096 \pm 50 \%$

3 of 8

4 of 12

5 of 15

Upwind

Sunnyside

$$
0.027 \pm 30 \% \quad 0.024 \pm 10 \%
$$

0 of 3

$0.026 \pm 30 \%$

$0.059 \pm 60 \%$

8 of 15

(a) Maximum is \pm 2 sigma analytical propagated error, expressed as a percentage.

(b) Mean is \pm 2 SEM, expressed as a percentage.

(c) Number of samples with values less than the detection limit out of number of samples analyzed.

(d) $\mathrm{NS}=$ no sample. 
Table A.10. Cobalt-60 ( $\left({ }^{60} \mathrm{Co}\right)$, Strontium-90 $\left({ }^{90} \mathrm{Sr}\right)$, and Cesium-137 $\left({ }^{137} \mathrm{Cs}\right)$ in Riverview Carrots (pCi/g dry weight), 1993 Compared to Values from the Previous 5 Years

1993

Maximum $^{(a)}$
$0.0011 \pm 70 \%$
$0.012 \pm 40 \%$

No. Less Than

Radionuclide

${ }^{60} \mathrm{Co}$

${ }^{90} \mathrm{Sr}$

${ }^{137} \mathrm{Cs}$

$\mathrm{Mean}^{(\mathbf{b})}$ (a) Maximum is \pm 2 sigma analytical propagated error, expressed as a percentage.

(b) Mean is \pm 2 SEM, expressed as a percentage.

(c) Number of samples with values less than the detection limit out of number of samples analyzed.
$1988-1992$

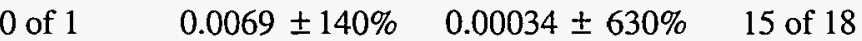

1 of $3 \quad 0.013 \pm 40 \% \quad 0.0064 \pm 30 \% \quad 3$ of 15

1 of $1 \quad 0.0076 \pm 70 \% \quad 0.00071 \pm 230 \%$
No. Less Than Detection $^{(\mathbf{c})}$

14 of 15 
Table A.11. Annual Average ( \pm 2 SEM) Concentration of Strontium-90 $\left({ }^{90} \mathrm{Sr}\right.$ ) in Alfalfa (pCi/g dry weight), 1982 to 1992

\begin{tabular}{|c|c|c|c|c|c|c|c|c|c|c|c|}
\hline & 1982 & 1983 & 1984 & 1985 & 1986 & 1987 & 1988 & 1989 & 1990 & 1991 & 1992 \\
\hline Benton City & $0.097 \pm 10 \%$ & $0.052 \pm 46 \%$ & $0.053 \pm 38 \%$ & $0.076 \pm 11 \%$ & $0.209 \pm 18 \%$ & $0.043 \pm 37 \%$ & $0.151 \pm 7 \%$ & $0.150 \pm 4 \%$ & $0.041 \pm 10 \%$ & $N S^{(a)}$ & $0.119 \pm 57 \%$ \\
\hline Horn Rapids/Richland & NS & NS & NS & NS & NS & NS & NS & NS & $0.116 \pm 2 \%$ & NS & $0.201 \pm 30 \%(b)$ \\
\hline Riverview & $0.090 \pm 11 \%$ & $0.061 \pm 16 \%$ & $0.125 \pm 5 \%$ & $0.111 \pm 41 \%$ & $0.154 \pm 45 \%$ & $0.034 \pm 6 \%$ & $0.245 \pm 11 \%$ & $0.240 \pm 23 \%$ & $0.155 \pm 12 \%$ & $0.075 \pm 19 \%$ & $0.113 \pm 28 \%$ \\
\hline North Riverview & NS & NS & NS & NS & NS & NS & NS & NS & NS & NS & $0.0033 \pm 91 \%$ \\
\hline Sagemoor & $0.117 \pm 32 \%$ & $0.020 \pm 30 \%$ & $0.135 \pm 19 \%$ & $0.085 \pm 12 \%$ & $0.192 \pm 35 \%$ & $0.112 \pm 5 \%$ & $0.174 \pm 25 \%$ & $0.081 \pm 5 \%$ & $0.036 \pm 11 \%$ & $0.030 \pm 7 \%$ & $0.057 \pm 39 \%$ \\
\hline Sunnyside & $0.029 \pm 14 \%$ & $0.072 \pm 67 \%$ & $0.091 \pm 33 \%$ & $0.095 \pm 25 \%$ & $0.118 \pm 36 \%$ & $0.071 \pm 14 \%$ & $0.076 \pm 8 \%$ & $0.114 \pm 33 \%$ & NS & NS & $0.068 \pm 91 \%$ \\
\hline Wahluke & $0.009 \pm 67 \%$ & $0.066 \pm 73 \%$ & $0.062 \pm 39 \%$ & $0.110 \pm 13 \%$ & $0.219 \pm 19 \%$ & $0.023 \pm 9 \%$ & $0.153 \pm 8 \%$ & $0.095 \pm 21 \%$ & $0.036 \pm 11 \%$ & NS & $0.050 \pm 80 \%$ \\
\hline
\end{tabular}

(a) NS = no sample.

(b) Mean is for samples collected as part of routine sampling and part of a special study 
Table A.12. Summary of Strontium-90 $\left({ }^{90} \mathrm{Sr}\right)$ in Carp Carcass and Cesium-137 $\left({ }^{137} \mathrm{Cs}\right)$ in Carp Muscle (pCi/g wet weight), 1993 Compared to Values from 1990 Through 1992

1993

1993

Location
${ }^{90} \mathrm{Sr}$ in Carcass
${ }^{100-\mathrm{N} \text { to } 100-\mathrm{D}}$
Areas

300 Area

Vantage $^{(\mathrm{d})}$

${ }^{137}$ Cs in Muscle

$100-\mathrm{N}$ to $100-\mathrm{D}$

Areas

300 Area

Vantage $^{(\mathrm{d})}$

$\underline{\text { Maximum }^{(a)}} \quad$ Mean $^{(b)}$

$$
0.059 \pm 20 \%
$$

$0.075 \pm 10 \%$

$0.045 \pm 40 \%$
Less Than

$\underline{\text { Detection }^{(\mathrm{c})}}$

0 of 1
0 of 5

$0.420 \pm 20 \%$

$0.11 \pm 80 \% \quad 0$ of 11

$0.046 \pm 20 \%$

$0.022 \pm 110 \% \quad 0$ of 5

$0.110 \pm 20 \%$

$0.059 \pm 20 \% \quad 0$ of 13

$1990-1992$

No.

Less Than

Detection $^{(\mathbf{c})}$

(a) Maximum is the concentration in $\mathrm{pCi} / \mathrm{g} \pm 2$ sigma analytical error, expressed as a percentage.

(b) Mean is $\mathrm{pCi} / \mathrm{g} \pm 2$ standard error, expressed as a percentage. Not calculated on two or less samples.

(c) Number of samples with values less than the detection limit out of number of samples analyzed.

(d) Collected in 1990 and 1991. 
Table A.13. Concentrations of Strontium-90 $\left({ }^{90} \mathrm{Sr}\right)$ in Whitefish Carcass and Cesium-137 $\left({ }^{137} \mathrm{Cs}\right)$ in Whitefish Muscle (pCi/g wet weight), 1993 Compared to Values from the Previous 5 Years

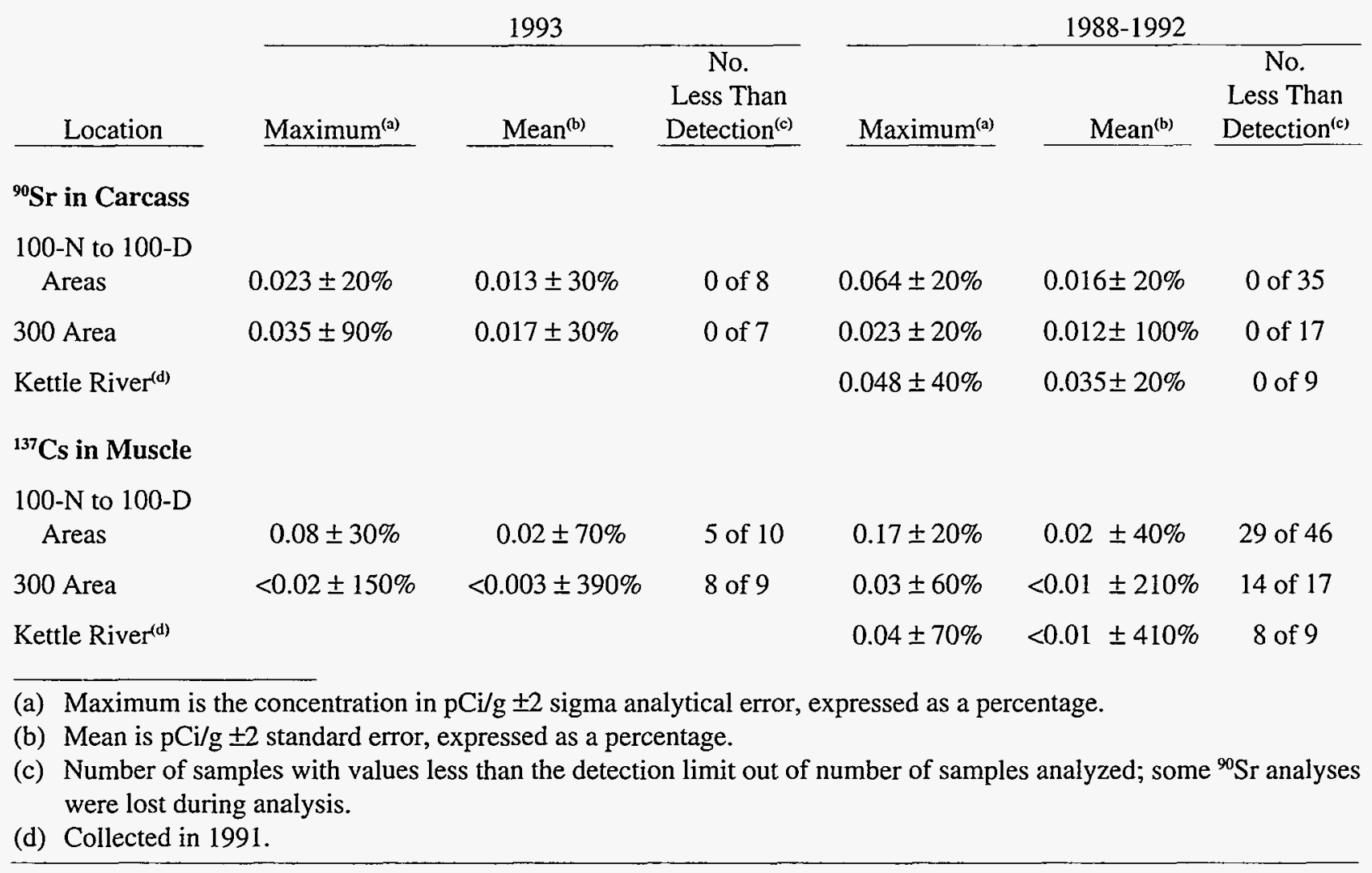


Table A.14. Summary of Strontium-90 ( $\left.{ }^{90} \mathrm{Sr}\right)$ in Deer Bone and Cesium-137 $\left({ }^{137} \mathrm{Cs}\right)$ in Deer Muscle (pCi/g wet weight), 1993 Compared to Values from the Previous 5 Years

1993

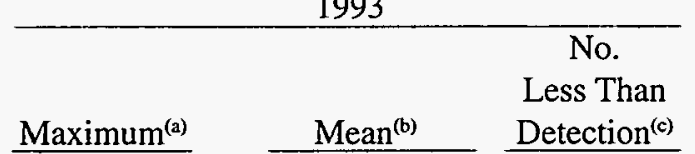

Location

${ }^{90} \mathrm{Sr}$ in Bone
Site $^{(d)}$

100-N Area

Stevens County ${ }^{(e)}$

${ }^{137} \mathrm{Cs}$ in Muscle

Site $^{(\mathrm{d})}$

$100-\mathrm{N}$ Area

$3.28 \pm 3 \%$

$5.92 \pm 5 \%$

Stevens County ${ }^{(e)}$
$<0.002 \pm 240 \%$
0 of 1

0 of 2
$1988-1992$

\begin{tabular}{|c|c|c|}
\hline Maximum $^{(a)}$ & Mean $^{(b)}$ & $\begin{array}{c}\text { No. } \\
\text { Less Than } \\
\text { Detection }^{(\mathfrak{c})}\end{array}$ \\
\hline $0.46 \pm 10 \%$ & & 0 of 1 \\
\hline $58.3 \pm 2 \%$ & $12.2 \pm 130 \%$ & 7 of 7 \\
\hline $0.8 \pm 20 \%$ & & 0 of 2 \\
\hline $0.01 \pm 70 \%$ & $0.003 \pm 40 \%$ & 6 of 22 \\
\hline $0.03 \pm 30 \%$ & $0.01 \pm 120 \%$ & 4 of 7 \\
\hline $0.52 \pm 10 \%$ & & 0 of 2 \\
\hline
\end{tabular}

(a) Maximum is the concentration in $\mathrm{pCi} / \mathrm{g} \pm 2$ sigma analytical error, expressed as a percentage.

(b) Mean is $\mathrm{pCi} / \mathrm{g} \pm 2$ standard error, expressed as a percentage. Not calculated for two or less samples.

(c) Number of samples with values less than the detection limit out of number of samples analyzed.

(d) Exclusive of 100-N Area.

(e) Collected in 1992. 
Table A.15. Summary of Plutonium-238 ( $\left.{ }^{238} \mathrm{Pu}\right)$ and Plutonium-239,240 $\left({ }^{239,240} \mathrm{Pu}\right)$ in Rabbit Liver, 1993 Compared to Values from the Previous 5 Years ( $\mathrm{pCi} / \mathrm{g}$ wet weight)

$1988-1992$

$$
\text { No. }
$$

Less Than

Location/Species

Maximum $^{(\mathrm{a})}$

$\operatorname{Mean}^{(c)}$

$$
<-0.0001 \pm 180 \%
$$

0 of 1

$<0.0003 \pm 150 \%$

$$
\text { jackrabbit }
$$

200-West Area/ jackrabbit

$$
<-0.0001 \pm 320 \%
$$

0 of 1

$<0.0005 \pm 160 \%$

Boardman, OR ${ }^{(d) /}$ jackrabbit cottontail

${ }^{239,240} \mathrm{Pu}$

200-East Area/
jackrabbit 200-West Areal jackrabbit

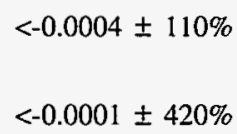

0 of 1

$0.0055 \pm 40 \%$

$<-0.000001 \pm 4,300 \%$

$<-0.00001 \pm 1,000 \%$

$<0.00006 \pm 240 \%$
$<0.0002 \pm 240 \%$

Boardman, $\mathrm{OR}^{(\mathrm{d}) /}$ jackrabbit cottontail

(a) Maximum is the concentration in $\mathrm{pCi} / \mathrm{g} \pm 2$ sigma analytical error, expressed as a percentage.

(b) Number of samples with values less than the detection limit out of number of samples analyzed.

(c) Mean is $\mathrm{pCi} / \mathrm{g} \pm 2$ standard error, expressed as a percentage. Not calculated for two or less samples.

(d) Collected in 1990.

$0.00007 \pm 90 \%$

16 of 16

$0.00009 \pm 160 \%$

12 of 12

10 of 10

10 of 10

No.

Less Than

Detection $^{(\mathrm{c})}$

16 of 16

12 of 12

10 of 10

10 of 10 
Table A.16. Strontium-90 $\left({ }^{90} \mathrm{Sr}\right)$ Concentrations in Soil, (a) 1988 Through 1993

\section{Onsite}

Above 100-D Pumphouse

1 Mile NE of 100-N Area

1 Mile E of $100-\mathrm{N}$ Area

100 Area Fire Station

200-East N Central

$\mathrm{E}$ of 200 -East

200-East SE

SW of BC Cribs

$S$ of 200 -East

E of 200-West

2 Miles $S$ of 200 -West

FFTF

SE of FFTF

$\mathrm{N}$ of 300 Area

Hanford Townsite

Wye Barricade

100-N Springs Shoreline

Generating Plant (HGP)

100-K Area

400-E

\section{Onsite Average}

\section{Offsite}

Riverview

Byers Landing

Sagemoor

Taylor Flats No. 2

W End Fir Road

Ringold

Berg Ranch

Wahluke Slope No. $2^{(\mathrm{c})}$

Vernita Bridge ${ }^{(c)}$

Yakima Barricade ${ }^{(\mathrm{c})}$

Rattlesnake Springs

ALE

$\vec{\nabla}$

ALesser Banicade(e)

S of 300 Area $^{(c)}$

Benton City
Concentration, $\mathrm{pCi} / \mathrm{g}$ (dry weight) ${ }^{(\mathrm{b})}$

1990

$-$

1992
$0.0866 \pm 0.00753$


$0.235 \pm 0.0125$
$0.0311 \pm 0.00495$

$\begin{array}{ll}0.11 \pm 0.01 & 0.18 \pm 0.01 \\ 0.22 \pm 0.01 & 0.17 \pm 0.01 \\ 0.28 \pm 0.02 & 0.31 \pm 0.01 \\ 0.77 \pm 0.02 & 0.58 \pm 0.01 \\ 0.57 \pm 0.02 & 0.41 \pm 0.02 \\ 0.59 \pm 0.02 & 0.13 \pm 0.01 \\ 0.04 \pm 0.01 & 0.12 \pm 0.01 \\ 0.23 \pm 0.01 & 0.28 \pm 0.01 \\ 0.71 \pm 0.27 & 0.50 \pm 0.02 \\ 0.14 \pm 0.01 & 0.14 \pm 0.01 \\ 0.09 \pm 0.01 & 0.05 \pm 0.01 \\ 0.07 \pm 0.01 & 0.06 \pm 0.01 \\ 0.13 \pm 0.01 & 0.15 \pm 0.01 \\ 0.13 \pm 0.01 & 0.28 \pm 0.01 \\ 0.14 \pm 0.01 & 0.11 \pm 0.01\end{array}$

$0.31 \pm 0.13$

$0.23 \pm 0.08$

$0.23 \pm 0.01$

$0.10 \pm 0.01$

$0.20 \pm 0.01$

$0.06 \pm 0.01$

$0.08 \pm 0.01$

$0.26 \pm 0.01$

$0.10 \pm 0.01$

$0.09 \pm 0.01$

$0.07 \pm 0.01$

$0.07 \pm 0.01$

$0.04 \pm 0.01$

$0.34 \pm 0.01$

$0.11 \pm 0.01$

$0.27 \pm 0.01$

$0.43 \pm 0.02$
$0.07 \pm 0.01$

$0.13 \pm 0.01$

$0.03 \pm 0.01$

$0.16 \pm 0.01$

$0.20 \pm 0.01$

$0.15 \pm 0.01$

$0.09 \pm 0.01$

$0.07 \pm 0.01$

$0.12 \pm 0.01$

$0.13 \pm 0.01$

$0.09 \pm 0.01$

$0.26 \pm 0.01$

$0.24 \pm 0.01$

$0.30 \pm 0.01$

$0.17 \pm 0.01$
2.70

$$
\begin{aligned}
0.152 & \pm 0.012 \\
0.16 & \pm 0.012 \\
0.131 & \pm 0.011 \\
0.409 & \pm 0.0129 \\
0.345 & \pm 0.013 \\
0.173 & \pm 0.0142 \\
0.102 & \pm 0.0096 \\
0.214 & \pm 0.013 \\
0.374 & \pm 0.018 \\
0.157 & \pm 0.0118 \\
0.0959 & \pm 0.00718 \\
0.0506 & \pm 0.00765 \\
0.167 & \pm 0.00936 \\
0.0574 & \pm 0.0062 \\
0.23 & \pm 0.016 \\
1.97 & \pm 0.063
\end{aligned}
$$

$2.70 \pm 0.0714$

$0.299 \pm 0.229$

$0.145 \pm 0.0117$

$0.121 \pm 0.0081$

$0.122 \pm 0.00956$

$0.0378 \pm 0.00772$

$0.0229 \pm 0.00488$

$0.121 \pm 0.0121$

$0.138 \pm 0.012$

$0.0628 \pm 0.00766$

$0.203 \pm 0.014$

$0.143 \pm 0.012$

$0.326 \pm 0.0122$
$0.07 \pm 0.006$

$0.08 \pm 0.007$

$0.08 \pm 0.006$

$0.22 \pm 0.013$

$0.54 \pm 0.018$

$0.35 \pm 0.014$

$0.17 \pm 0.010$

$0.10 \pm 0.008$

$0.18 \pm 0.011$

$0.58 \pm 0.019$

$0.041 \pm 0.006$

$0.049 \pm 0.007$

$0.094 \pm 0.008$

$0.12 \pm 0.009$

$0.09 \pm 0.008$

$0.19 \pm 0.012$

$0.12 \pm 0.008$

$0.15 \pm 0.013$

$0.040 \pm 0.006$

$0.17 \pm 0.071$

$0.031 \pm 0.005$

$0.087 \pm 0.02$

$0.073 \pm 0.008$

$0.046 \pm 0.005$

$0.0202 \pm 0.0043$

$0.059 \pm 0.009$

$0.14 \pm 0.011$

$0.051 \pm 0.006$

$0.092 \pm 0.012$

$0.095 \pm 0.016$

$0.074 \pm 0.008$

$0.105 \pm 0.011$

$0.103 \pm 0.012$

$0.076 \pm 0.007$

$0.18 \pm 0.011$ 


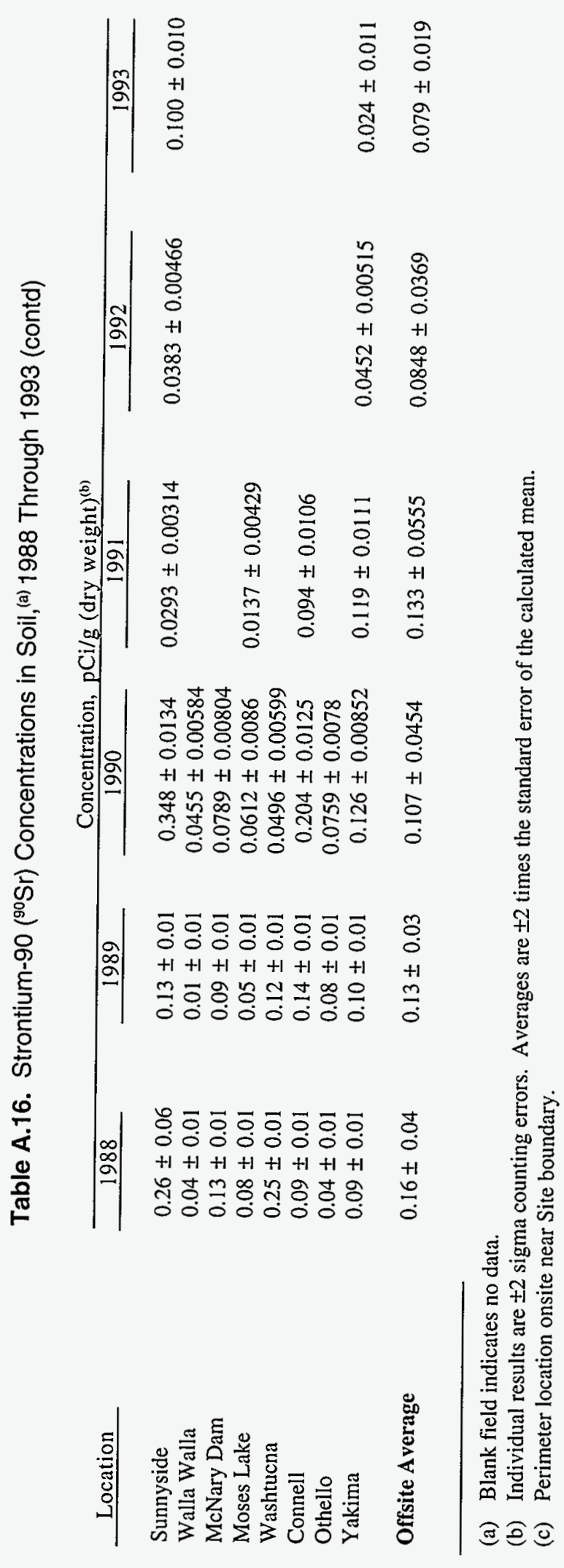


Table A.17. Cesium-137 ( $\left.{ }^{137} \mathrm{Cs}\right)$ Concentrations in Soil, (a) 1988 Through 1993

Concentration, pCi/g (dry weight $)^{(\mathrm{b})}$

Location

\section{Onsite}

Above 100-D Pumphouse 1 Mile NE of 100-N Area

1 Mile $E$ of $100-N$ Area

100 Area Fire Station

200-East N Central

$\mathrm{E}$ of 200-East

200-East SE

SW of BC Cribs

$S$ of 200 -East

$\mathrm{E}$ of $200-$ West

2 Miles S of 200-West

NE of FFTF

SE of FFTF

$\mathrm{N}$ of 300 Area

Hanford Townsite

Wye Barricade

100-N Springs Shoreline

100-N Shore (HGP)

100-K Area

\section{Onsite Average}

\section{Offsite}

Riverview

Byers Landing

Sagemoor

Taylor Flats No. 2

W End Fir Road

Ringold

Berg Ranch

Wahluke Slope No. $2^{(c)}$

Vernita Bridge ${ }^{(c)}$

Yakima Barricade ${ }^{(\mathrm{c})}$

Rattlesnake Springs

ALE

Prosser Barricade ${ }^{(c)}$

$S$ of 300 Area $^{(\mathrm{c})}$

Benton City

\begin{tabular}{|c|c|}
\hline 1988 & 1989 \\
\hline $0.80 \pm 0.05$ & $0.96 \pm 0.05$ \\
\hline $0.74 \pm 0.05$ & $0.63 \pm 0.05$ \\
\hline $1.2 \pm 0.1$ & $1.1 \pm 0.1$ \\
\hline $26 \pm 0.1$ & $18 \pm 0.2$ \\
\hline $1.8 \pm 0.1$ & $2.1 \pm 0.1$ \\
\hline $1.6 \pm 0.1$ & $0.59 \pm 0.04$ \\
\hline $0.04 \pm 0.02$ & $0.52 \pm 0.04$ \\
\hline $0.58 \pm 0.04$ & $0.80 \pm 0.04$ \\
\hline $5.4 \pm 1.7$ & $3.0 \pm 0.1$ \\
\hline $0.49 \pm 0.04$ & $0.63 \pm 0.04$ \\
\hline $0.24 \pm 0.03$ & $0.19 \pm 0.02$ \\
\hline $0.12 \pm 0.02$ & $0.22 \pm 0.03$ \\
\hline $0.51 \pm 0.04$ & $1.2 \pm 0.1$ \\
\hline $0.88 \pm 0.06$ & $1.2 \pm 0.1$ \\
\hline
\end{tabular}

$0.56 \pm 0.04 \quad 0.39 \pm 0.04$

$2.9 \pm 3.2$

$1.3 \pm 0$.

$0.52 \pm 0.03$

$1.0 \pm 0.1$

$0.39 \pm 0.04$

$0.28 \pm 0.03$

$1.8 \pm 0.06$

$0.35 \pm 0.03$

$0.22 \pm 0.03$

$0.19 \pm 0.04$

$0.08 \pm 0.02$

$0.08 \pm 0.02$

$1.0 \pm 0.1$

$0.33 \pm 0.03$

$0.77 \pm 0.04$

$0.91 \pm 0.06$

$0.12+0.02$

$1.3 \pm 0.1$

$1.7 \pm 0.1$

$0.53 \pm 0.04$

$0.66 \pm 0.05$

$0.54 \pm 0.04$

$0.96 \pm 0.06$

$0.86 \pm 0.05$

$1.1 \pm 0.1$

$0.76 \pm 0.05$

1990

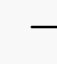

$0.768 \pm 0.06$

$0.312 \pm 0.042$

$0.295 \pm 0.029$

$1.13 \pm 0.053$

$0.408 \pm 0.035$

$0.346 \pm 0.032$

$0.357 \pm 0.041$

$3.86 \pm 0.105$

$1.6 \pm 0.065$

$0.496 \pm 0.043$

$0.387 \pm 0.038$

$0.142 \pm 0.024$

$0.709 \pm 0.043$

$0.271 \pm 0.028$

$0.66 \pm 0.04$

$0.11 \pm 0.022$

$1.04 \pm 0.0405$
$0.37 \pm 0.0307$

$0.764 \pm 0.0346$

$0.52 \pm 0.019$

$0.45 \pm 0.017$

$0.34 \pm 0.014$

$1.15 \pm 0.047$

$10.9 \pm 0.13$

$2.29 \pm 0.058$

$0.52 \pm 0.033$

$0.39 \pm 0.036$

$0.17 \pm 0.026$

$1.47 \pm 0.045$

$0.16 \pm 0.023$

$0.19 \pm 0.027$

$0.39 \pm 0.036$

$0.68 \pm 0.042$

$0.35 \pm 0.029$

$0.65 \pm 0.069$

$0.45 \pm 0.017$

$0.54 \pm 0.037$

$0.540 \pm 0.192$

$0.725 \pm 0.0337$

$1.14 \pm 1.11$

$1.78 \pm 0.105$

$0.597 \pm 0.038$

$0.473 \pm 0.036$

$0.197 \pm 0.039$

$0.852 \pm 0.0377$

$0.106 \pm 0.0244$

$0.102 \pm 0.0206$

$0.583 \pm 0.0422$

$0.726 \pm 0.05$

$0.421 \pm 0.0611$

$0.637 \pm 0.0421$

$0.25 \pm 0.03 \quad 0.224 \pm 0.029$

$0.46 \pm 0.03$ 
Table A.17. Cesium-137 ( ${ }^{137} \mathrm{Cs}$ ) Concentrations in Soil, ${ }^{\text {(a) }} 1988$ Through 1993 (contd)

\section{Location}

Sunnyside

Walla Walla

McNary Dam

Moses Lake

Washtucna

Connell

Othello

Yakima

\section{Offsite Average}

\begin{tabular}{|c|c|}
\hline 1988 & 1989 \\
\hline $1.0 \pm 0.3$ & $0.48 \pm 0.04$ \\
\hline $0.23 \pm 0.03$ & $0.07 \pm 0.03$ \\
\hline $0.48 \pm 0.04$ & $0.54 \pm 0.04$ \\
\hline $0.38 \pm 0.04$ & $0.18 \pm 0.03$ \\
\hline $0.97 \pm 0.06$ & $0.91 \pm 0.05$ \\
\hline $0.46 \pm 0.04$ & $0.67 \pm 0.05$ \\
\hline $0.22 \pm 0.03$ & $0.54 \pm 0.04$ \\
\hline $0.11 \pm 0.02$ & $0.56 \pm 0.04$ \\
\hline
\end{tabular}

$0.59 \pm 0.18$

$0.74 \pm 0.27$
Concentration, $\mathrm{pCi} / \mathrm{g}$ (dry weight) ${ }^{(\mathrm{b})}$

1990
$1.22 \pm 0.064$
$0.333 \pm 0.0619$
$0.276 \pm 0.0398$
$0.243 \pm 0.0346$
$0.288 \pm 0.0497$
$1.19 \pm 0.0905$
$0.344 \pm 0.0413$
$0.599 \pm 0.0459$

1991
$0.0668 \pm 0.0258$
$-0.0017 \pm 0.0201$
$0.334 \pm 0.0388$
$0.334 \pm 0.0353$

$\begin{array}{cc}\frac{1992}{0.420 \pm 0.0315} & 0.74 \pm 0.036 \\ & \\ 0.445 \pm 0.0271 & 0.49 \pm 0.059 \\ 0.547 \pm 0.2891 & 0.39 \pm 0.13\end{array}$

(a) Blank field indicates no data.

(b) Individual results are \pm 2 sigma counting errors. Averages are \pm 2 times the standard error of the calculated mean.

(c) Perimeter location onsite near Site boundary. 
Table A.18. Plutonium-239,240 $\left({ }^{239,240} \mathrm{Pu}\right)$ Concentrations in Soil, (a) 1988 Through 1993

Location

\section{Onsite}

Above 100-D Pumphouse

1 Mile NE of $100-\mathrm{N}$ Area

1 Mile E of 100-N Area

100 Area Fire Station

200-East N Central

$\mathrm{E}$ of 200-East

200-East SE

SW of BC Cribs

$S$ of 200 -East

E of 200-West

Miles S of $200-$ West

NE of FFTF

SE of FFTF

$\mathrm{N}$ of 300 Area

Hanford Townsite

Wye Barricade

100-N Springs Shoreline

100-N Shore (HGP)

100-K Area

400-E

Onsite Average

\section{Offsite}

\section{Riverview}

Byers Landing

Sagemoor

Taylor Flats No. 2

W End Fir Road

Ringold

Berg Ranch

Wahluke Slope No. $2^{\text {(c) }}$

Vernita Bridge ${ }^{(c)}$

Yakima Barricade ${ }^{(\mathrm{c})}$

Rattlesnake Springs

ALE

Prosser Barricade ${ }^{(c)}$

$S$ of 300 Area $^{(\mathrm{c})}$

\section{Concentration, $\mathrm{pCi} / \mathrm{g}$ (dry weight) ${ }^{(\mathrm{b})}$

1988

1989

1990 \\ $1990 \quad 1991$ 1991}

$0.11 \pm 0.01$

$0.019 \pm 0.002$

$0.027 \pm 0.002$

$0.066 \pm 0.03$

$0.017 \pm 0.001$

$0.036 \pm 0.002$

$0.001 \pm 0.001$

$0.013 \pm 0.001$

$0.67 \pm 0.12$

$0.015 \pm 0.001$

$0.005 \pm 0.001$

$0.003 \pm 0.001$

$0.011 \pm 0.001$

$0.021 \pm 0.002$

$0.008 \pm 0.001$

$0.017 \pm 0.002$

$0.013 \pm 0.00$

$0.026 \pm 0.003$

$0.031 \pm 0.003$

$0.018 \pm 0.002$

$0.011 \pm 0.001$

$0.014 \pm 0.001$

$0.015 \pm 0.002$

$0.53 \pm 0.01$

$0.022 \pm 0.002$

$0.004 \pm 0.001$

$0.006 \pm 0.001$

$0.024 \pm 0.002$

$0.027 \pm 0.003$

$0.007 \pm 0.001$

$0.10 \pm 0.11$

$0.022 \pm 0.002$

$0.009 \pm 0.001$

$0.020 \pm 0.002$

$0.004 \pm 0.001$

$0.004 \pm 0.001$

$0.033 \pm 0.002$

$0.008 \pm 0.001$

$0.007 \pm 0.001$

$0.003 \pm 0.001$

$0.003 \pm 0.001$

$0.003 \pm 0.001$

$0.026 \pm 0.002$

$0.006 \pm 0.001$

$0.017 \pm 0.001$

$0.051 \pm 0.069$

$0.008 \pm 0.001$

$0.014 \pm 0.002$

$0.019 \pm 0.001$

$0.015 \pm 0.001$

$0.028 \pm 0.002$

$0.029 \pm 0.003$

$0.009 \pm 0.002$

$0.005 \pm 0.001$

$0.013 \pm 0.002$

$0.011 \pm 0.00$

$0.011 \pm 0.001$

$0.021 \pm 0.002$

$0.018 \pm 0.002$

$0.025 \pm 0.002$

$\begin{array}{cl} & \\ 0.0129 & \pm 0.00129 \\ 0.0177 & \pm 0.00197 \\ 0.00488 & \pm 0.000934 \\ 0.017 & \pm 0.0014 \\ 0.00895 & \pm 0.00121 \\ 0.00799 & \pm 0.00114 \\ 0.00844 & \pm 0.00151 \\ 0.0104 & \pm 0.00118 \\ 0.286 & \pm 0.00546 \\ 0.0214 & \pm 0.00289 \\ 0.0085 & \pm 0.00118 \\ 0.00395 \pm 0.0125 & \pm 0.000731 \\ 0.0173 & \pm 0.00161 \\ 0.00368 & \pm 0.000846 \\ 0.0168 & \pm 0.00255 \\ 0.000769 & \pm 0.000774\end{array}$

$0.000769 \pm 0.000774$

$0.0204 \pm 0.00177$

$0.0133 \pm 0.00128$

$0.0127 \pm 0.00805$

$0.00427 \pm 0.000659$

$0.0204 \pm 0.00155$

$0.00661 \pm 0.000801$

$0.000381 \pm 0.000285$

$0.0112 \pm 0.00117$

$0.0183 \pm 0.00214$

$0.0214 \pm 0.00175$

$0.0124 \pm 0.00144$

$0.00711 \pm 0.00098$

$0.00502 \pm 0.000938$

$0.0201 \pm 0.00173$ $0.00434 \pm 0.000799$

1992

$0.0097 \pm 0.0011$ $0.0097 \pm 0.0011$ $0.0081 \pm 0.0013$

$0.027 \pm 0.0019$

$0.020 \pm 0.0014$

$0.023 \pm 0.0015$

$0.011 \pm 0.0011$

$0.0096 \pm 0.00097$

$0.0035 \pm 0.00056$

$0.28 \pm 0.0054$

$0.0059 \pm 0.00077$

$0.0032 \pm 0.00067$

$0.01 \pm 0.001$

$0.015 \pm 0.0012$

$0.0083 \pm 0.00092$

$0.016 \pm 0.0018$

$0.011 \pm 0.0013$

$0.0081 \pm 0.0011$

$0.0027 \pm 0.00055$

$0.026 \pm 0.029$

$0.00141+0.0007610 .00936 \pm 0.00105$
$0.002 \pm 0.00053$

$0.013 \pm 0.0015$

$0.011 \pm 0.0013$

$0.0052 \pm 0.0012$

$0.00057 \pm 0.00034$

$0.0063 \pm 0.00098$

$0.013 \pm 0.0011$

$0.0040 \pm 0.0081$

$0.011 \pm 0.0011$

$0.0092 \pm 0.0011$

$0.0073 \pm 0.00084$

$0.0059 \pm 0.00071$

$0.0071 \pm 0.00088$

$0.0036 \pm 0.00065$ 


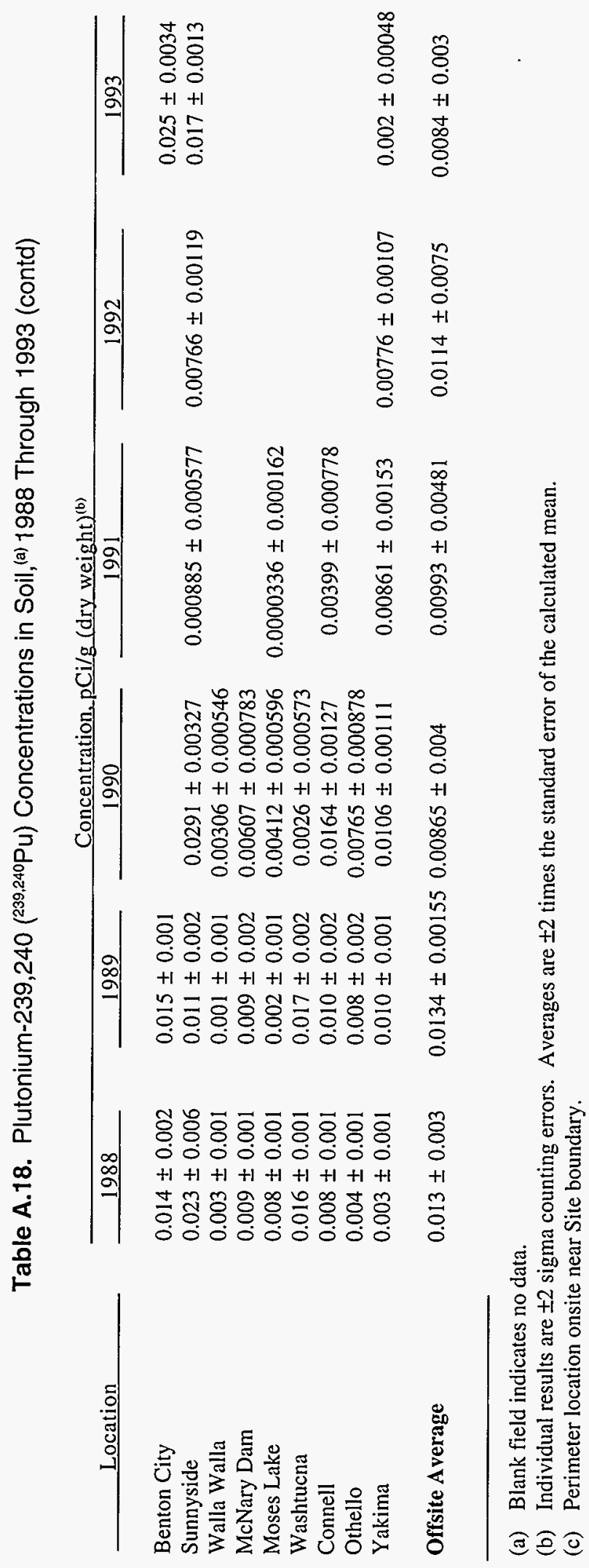


Table A.19. Uranium Concentrations in Soil, (a) 1988 Through 1993

\begin{tabular}{l}
\multicolumn{1}{c}{ Location } \\
\hline Onsite \\
Above 100-D Pumphouse \\
1 Mile NE of 100-N \\
1 Mile E of 100-N \\
100 Area Fire Station \\
200-East N Central \\
E of 200-East \\
200-East SE \\
SW of BC Cribs \\
S of 200-East \\
E of 200-West \\
2 Miles S of 200-West \\
NE of FFTF \\
SE of FFTF \\
N of 300 Area \\
Hanford Townsite \\
Wye Barricade \\
100-N Springs Shoreline \\
100-N Shore (HGP) \\
100-K Area \\
400-E \\
Onsite Average \\
Offsite \\
Riverview \\
Byers Landing \\
Sagemoor \\
Taylor Flats No. 2 \\
W End Fir Road \\
Ringold \\
Berg Ranch \\
Wahluke Slope No. ${ }^{(e)}$ \\
Vernita Bridge \\
Yakima Barricade \\
Rattlesnake Springs \\
ALE \\
Prosser Barricade(e) \\
S of 300 Area ${ }^{(e)}$ \\
Benton City \\
\end{tabular}

$\frac{\text { Total Uranium, }}{{ }^{(b)} \mathrm{pCi} / \mathrm{g}(\mathrm{dry} \text { weight })^{(\mathrm{c})}}$

$\begin{array}{cc}0.78 \pm 0.45 & 0.35 \pm 0.20 \\ 0.71 \pm 0.44 & 0.67 \pm 0.22 \\ 0.88 \pm 0.30 & 0.97 \pm 0.29 \\ 0.64 \pm 0.50 & 0.44 \pm 0.26 \\ 1.2 \pm 0.3 & 0.40 \pm 0.23 \\ 1.2 \pm 0.3 & 0.91 \pm 0.28 \\ 0.61 \pm 0.48 & 0.85 \pm 0.26 \\ 0.66 \pm 0.33 & 0.39 \pm 0.23 \\ 0.77 \pm 0.31 & 0.97 \pm 0.29 \\ 0.65 \pm 0.33 & 0.39 \pm 0.22 \\ 0.54 \pm 0.45 & 0.72 \pm 0.29 \\ 0.76 \pm 0.32 & 0.56 \pm 0.17 \\ 0.90 \pm 0.47 & 0.34 \pm 0.19 \\ 0.44 \pm 0.46 & 0.42 \pm 0.28 \\ 0.45 \pm 0.45 & 0.66 \pm 0.20\end{array}$

$0.74 \pm 0.15$

$0.90 \pm 0.46$

$0.90 \pm 0.48$

$0.63 \pm 0.31$

$0.93 \pm 0.55$

$0.86 \pm 0.34$

$0.83 \pm 0.35$

$0.55 \pm 0.46$

$0.68 \pm 0.49$

$0.58 \pm 0.32$

$1.0 \pm 0.5$

$0.78 \pm 0.45$

$0.68 \pm 0.36$

$0.81 \pm 0.43$

$0.94 \pm 0.33$

$1.1 \pm 0.4$

$0.58 \pm 0.20$

$0.42 \pm 0.23$

$0.75 \pm 0.29$

$0.87 \pm 0.24$

$0.56 \pm 0.21$

$0.50 \pm 0.19$

$0.80 \pm 0.24$

$1.1 \pm 0.3$

$0.58 \pm 0.20$

$0.40 \pm 0.19$

$0.84 \pm 0.25$

$1.5 \pm 0.3$

$0.61 \pm 0.22$

$1.1 \pm 0.3$

$0.45 \pm 0.19$

$1.44 \pm 0.159$
$1.31 \pm 0.137$
$1.2 \pm 0.108$
$1.17 \pm 0.158$
$1.77 \pm 0.29$
$1.34 \pm 0.132$
$1.2 \pm 0.148$
$1.89 \pm 0.17$
$1.5 \pm 0.129$
$1.31 \pm 0.124$
$1.31 \pm 0.165$
$1.48 \pm 0.165$
$2.17 \pm 0.145$
$1.66 \pm 0.121$
$1.25 \pm 0.0767$
$1.09 \pm 0.104$

1.64
${ }^{238} \mathrm{U}^{\text {(d) }} \mathrm{pCi} / \mathrm{g}$ (dry weight) ${ }^{(\mathrm{c})}$

\begin{tabular}{|c|c|c|}
\hline 1991 & 1992 & 1993 \\
\hline & $1.31 \pm 0.0388$ & $0.36 \pm 0.26$ \\
\hline $1.44 \pm 0.159$ & & $0.53 \pm 0.28$ \\
\hline $1.31 \pm 0.137$ & & $1.45 \pm 0.25$ \\
\hline $1.2 \pm 0.108$ & & $0.59 \pm 0.45$ \\
\hline $1.17 \pm 0.158$ & & $0.41 \pm 0.30$ \\
\hline $1.77 \pm 0.29$ & & $0.39 \pm 0.24$ \\
\hline $1.34 \pm 0.132$ & & $0.42 \pm 0.19$ \\
\hline $1.2 \pm 0.148$ & & $0.60 \pm 0.23$ \\
\hline $1.89 \pm 0.17$ & & $0.42 \pm 0.26$ \\
\hline $1.5 \pm 0.129$ & & $0.66 \pm 0.26$ \\
\hline $1.31 \pm 0.124$ & & $0.54 \pm 0.23$ \\
\hline \multicolumn{3}{|l|}{$1.31 \pm 0.165$} \\
\hline $1.48 \pm 0.165$ & & $0.56 \pm 0.18$ \\
\hline $2.17 \pm 0.145$ & & $0.85 \pm 0.24$ \\
\hline $1.66 \pm 0.121$ & & $0.75 \pm 0.26$ \\
\hline $1.25 \pm 0.0767$ & & $0.32 \pm 0.19$ \\
\hline \multirow[t]{4}{*}{$1.09 \pm 0.104$} & $1.07 \pm 0.344$ & $0.43 \pm 0.28$ \\
\hline & $1.06 \pm 0.453$ & $1.16 \pm 0.30$ \\
\hline & & $0.71 \pm 0.33$ \\
\hline & & $0.45 \pm 0.22$ \\
\hline $1.44 \pm 0.147$ & $1.15 \pm 0.142$ & $0.61 \pm 0.13$ \\
\hline $1.75 \pm 0.124$ & $0.460 \pm 0.176$ & $0.45 \pm 0.24$ \\
\hline $1.46 \pm 0.118$ & $0.911 \pm 0.224$ & $0.89 \pm 0.26$ \\
\hline \multirow[t]{3}{*}{$1.85 \pm 0.127$} & $0.742 \pm 0.204$ & $1.13 \pm 0.50$ \\
\hline & & $0.84 \pm 0.48$ \\
\hline & & $0.90 \pm 0.29$ \\
\hline \multirow[t]{4}{*}{$1.75 \pm 0.13$} & $0.752 \pm 0.36$ & $0.61 \pm 0.20$ \\
\hline & & $0.30 \pm 0.46$ \\
\hline & & $0.15 \pm 0.45$ \\
\hline & & $0.88 \pm 0.45$ \\
\hline \multirow[t]{4}{*}{$1.5 \pm 0.0811$} & & $0.61 \pm 0.47$ \\
\hline & & $0.51 \pm 0.38$ \\
\hline & & $1.01 \pm 0.49$ \\
\hline & & $0.51 \pm 0.35$ \\
\hline $1.56 \pm 0.122$ & & $0.67 \pm 0.19$ \\
\hline
\end{tabular}


Table A.19. Uranium Concentrations in Soil, (a) 1988 Through 1993 (contd)

\begin{tabular}{l} 
Location \\
\hline Sunnyside \\
Walla Walla \\
McNary Dam \\
Moses Lake \\
Washtucna \\
Connell \\
Othello \\
Yakima \\
Offsite Average
\end{tabular}

\begin{tabular}{c} 
Total \\
\hline 1988 \\
$0.70 \pm 0.39$ \\
$0.66 \pm 0.34$ \\
$0.59 \pm 0.33$ \\
$0.42 \pm 0.29$ \\
$0.73 \pm 0.39$ \\
$0.53 \pm 0.30$ \\
$0.58 \pm 0.30$ \\
$1.0 \pm 0.5$
\end{tabular}

${ }^{\left({ }^{(b)}\right.} \mathrm{pCi} / \mathrm{g}$ (dry weight) ${ }^{(\mathrm{c})}$

1990

$1.0 \pm 0.3$

$1.3 \pm 0.3$

$0.56 \pm 0.21$

$0.37 \pm 0.19$

$0.72 \pm 0.24$

$0.69 \pm 0.29$

$0.64 \pm 0.18$

$0.45 \pm 0.22$

$1.17 \pm 0.138$

$1.43 \pm 0.107$

$1.76 \pm 0.118$

$0.99 \pm 0.0955$

$1.05 \pm 0.0977$

$1.21 \pm 0.113$

$1.07 \pm 0.101$

$0.75 \pm 0.11$

$0.73 \pm 0.13$

$1.02 \pm 0.0922$

$1.16 \pm 0.105$

1991
$1.29 \pm 0.108$
$1.23 \pm 0.117$
$1.16 \pm 0.105$
$1.08 \pm 0.0978$

${ }^{238} \mathrm{U}^{(\mathrm{d})} \mathrm{pCi} / \mathrm{g}$ (dry weight) ${ }^{(\mathrm{c})}$ 


\section{Appendix B}

Glossary 


\section{Appendix B}

\section{Glossary}

activation product - Material made radioactive by exposure to radiation from a source such as a nuclear reactor's neutrons.

air submersion dose - Radiation dose received from external exposure to radioactive materials present in the surrounding atmosphere.

aquifer - Permeable geologic unit that can hold and/or transmit significant quantities of water.

background radiation - Radiation in the natural environment, including cosmic rays from space and radiation from naturally occurring radioactive elements in the air, in the earth, and in our bodies. In the United States, the average person receives about 300 millirems (mrem) of background radiation per year.

bank storage - Hydrologic term that describes river water that flows into and is retained in permeable stream banks during periods of high river stage. Flow is reversed during periods of low river stage.

becquerel (Bq) - Unit of activity equal to one nuclear transformation per second $(1 \mathrm{~Bq}=1 / \mathrm{s})$. The conventional unit of activity, the curie, is related to the becquerel according to $1 \mathrm{Ci}=3.7 \times 10^{10} \mathrm{~Bq}$.

boundary dose rate - Dose rate measured or calculated at publicly accessible locations on or near the Hanford Site.

composite sample - Sample formed by mixing discrete samples taken at different points in time or from different locations.

confined aquifer - An aquifer bounded above and below by less permeable layers. Ground water in the confined aquifer is under a pressure greater than atmospheric pressure.

continuous sample - Sample formed by the continuous collection of the medium or contaminants within the medium during the entire sample period. controlled area - An area to which access is controlled to protect individuals from exposure to radiation or radioactive and/or hazardous materials.

cosmic radiation - High-energy subatomic particles and electromagnetic radiation from outer space that bombard the earth. Cosmic radiation is part of natural background radiation.

curie (Ci) - A unit of radioactivity equal to 37 billion $\left(3.7 \times 10^{10}\right)$ nuclear transformations per second.

decay - The decrease in the amount of any radioactive material with the passage of time, due to the spontaneous emission from the atomic nuclei of nucleons or either alpha or beta particles, often accompanied by gamma radiation. When a radioactive material decays, the material may be converted to another radioactive species (decay product) or to a nonradioactive material.

Derived Concentration Guides (DCG) - Concentrations of radionuclides in air and water that an individual could continuously consume, inhale or be immersed in at average annual rates, without receiving an effective dose equivalent of greater than $100 \mathrm{mrem} / \mathrm{yr}$.

detection level - Minimum amount of a substance that can be measured with a $99 \%$ confidence that the analytical result is greater than zero.

dispersion - Process whereby effluents are spread or mixed as they are transported by ground water or air.

dosimeter - Portable device for measuring the total accumulated exposure or absorbed dose from ionizing radiation fields.

Effective Dose - See "Effective Dose Equivalent" under "Radiation Dose."

effluent - Liquid or gaseous waste streams released from a facility. 
effluent monitoring - Sampling or measuring specific liquid or gaseous effluent streams for the presence of pollutants.

exposure - Subjecting a target (usually living tissue) to radiation or chemicals. Also used as a term describing external radiation air ionization (see "Roentgen").

fallout - Radioactive materials that are released into the earth's atmosphere following a nuclear explosion or atmospheric release and that eventually fall to earth.

fission - A nuclear reaction involving the splitting or breaking apart of a nucleus into at least two other nuclei, accompanied with a release of various types of energy. For example, when a heavy atom, such as uranium, is split, large amounts of energy including radiation and neutrons are released along with the new nuclei (which are fission products).

fission products - Elements formed from fissioning. Many fission products are radioactive.

glaciofluvial sediments - Sedimentary deposits consisting of material transported by, suspended in, or laid down by the meltwater streams flowing from melting glacier ice.

grab sample - A sample that is randomly collected or "grabbed" from the collection site.

ground water - Subsurface water that is in the pore spaces of soil and geologic units.

gray (Gy) - Unit of absorbed dose in the International System of Units (SI) equal to 1 joule per kilogram. $1 \mathrm{~Gy}=100 \mathrm{rad}$.

half-life - Length of time in which a radioactive substance will lose one half of its radioactivity by decay. Half-lives range from a fraction of a second to billions of years, and each radionuclide has a unique half-life.

ion exchange - The reversible exchange of one species of ion for a different species of ion within a medium.

irradiation - Exposure to radiation.

isotopes - Different forms of the same chemical element that are distinguished by different numbers of neutrons in the nucleus. A single element may have many isotopes; some may be radioactive and some may be nonradioac- tive (stable). For example, the three isotopes of hydrogen are protium, deuterium, and tritium.

kurtosis - measure of the degree of peakedness of a data distribution.

maximally exposed individual - A hypothetical member of the public residing near the Hanford Site who, by virtue of location and living habits, could receive the highest possible radiation dose from radioactive effluents released from Hanford.

mean - Average value of a series of measurements.

The mean, $X$, was computed as:

$$
\mathrm{X}=\frac{1}{\mathrm{n}} \sum_{\mathrm{i}=1}^{\mathrm{n}} \mathrm{X}_{\mathrm{i}}
$$

where $X_{i}$ is the ith measurement and $n$ is the number of measurements.

median - Middle value in a set of results when the data are ranked in increasing or decreasing order.

millirem (mrem) - A unit of radiation dose equivalent that is equal to one one-thousandth $(1 / 1000)$ of a rem. According to DOE standards, an individual member of the public may receive no more than 100 mrem per year from a site's operation. This limit does not include radiation received for medical treatment or the approximately $300 \mathrm{mrem}$ that people receive annually from natural background radiation.

minimum detectable concentration - Smallest amount or concentration of a radioactive or nonradioactive element that can be reliably detected in a sample.

mode - the value of the piece of data that occurs with the greatest frequency.

noble gas - Any of a group of chemically and biologically inert gases that includes argon, krypton, and xenon. These gases are not retained in the body following inhalation. The principal exposure pathways from radioactive noble gases are direct external dose from the surrounding air (see "Air Submersion Dose") .

offsite locations - Sampling and measurement locations outside the Hanford Site boundary. 
onsite locations - Sampling and measurement locations within the Hanford Site boundary.

operable unit - A discrete area for which an incremental step can be taken toward comprehensively addressing site problems. The cleanup of a site can be divided into a number of operable units, depending on the complexity of the problems associated with the site.

outfall - End of a drain or pipe that carries waste water or other effluents into a ditch, pond, or river.

plume - The cloud of a pollutant in air, surface water, or ground water formed after the pollutant is released from a source.

plutonium - A heavy, radioactive, anthropogenic metallic element consisting of several isotopes. One important isotope is ${ }^{239} \mathrm{Pu}$, which is produced by the irradiation of ${ }^{238} \mathrm{U}$. Routine analysis cannot distinguish between the ${ }^{239} \mathrm{Pu}$ and ${ }^{240} \mathrm{Pu}$ isotopes; hence, the term ${ }^{239.240} \mathrm{Pu}$ as used in this report is symbolic of the presence of one or both of these isotopes in the analytical results.

Quality Assurance - Actions that provide confidence that an item or process meets or exceeds that user's requirements and expectations.

Quality Control - Comprises all those actions necessary to control and verify the features and characteristics of a material, process, product, or service to specified requirements. Quality Control is an element of quality assurance.

radiation - The energy emitted in the form of rays or particles, such as those thrown off by transforming (disintegrating) atoms. For this report, radiation refers to ionizing types of radiation; not radiowaves, microwaves, radiant light, or other types of nonionizing radiation. The ionizing rays or particles typically consist of alpha, beta, or gamma radiation.

- alpha radiation - Least penetrating type of radiation. Alpha radiation can be stopped by a sheet of paper or the outer dead layer of skin, and can cause biological damage only if sufficient quantities are emitted inside the body.

- beta radiation - One form of radiation emitted from a nucleus during radioactive decay. Beta radiation can be stopped by an inch of wood or a thin sheet of aluminum, and may cause biological damage if a sufficient amount is internal, or occasionally external, to the body.

- external radiation - Radiation originating from a source outside the body.

- gamma radiation - Form of electromagnetic, highenergy radiation emitted from a nucleus. Gamma rays are essentially the same as $x$ rays. They require heavy shielding, such as concrete or steel, to be stopped, and may cause biological damage when originating internally or externally to the body in sufficient amounts.

- internal radiation - Radiation originating from a source within the body as a result of the inhalation, ingestion, skin absorption, or implantation of natural or anthropogenic radionuclides in body tissues (e.g., uranium dust in the lungs, radioiodine in the thyroid).

radiation dose - For the purpose of this report, radiation doses are defined as follows:

- absorbed dose - Amount of energy deposited by radiation in a given amount of material. Absorbed dose is measured in units of "rads" or "grays."

- collective effective dose equivalent - Sum of the effective dose equivalents for individuals composing a defined population. The units for this are "personrem" or "person-sievert."

- committed dose equivalent - Total dose equivalent accumulated in an organ or tissue in the 50 years following a single intake of radioactive materials into the body.

- dose equivalent - Product of the absorbed dose, the quality factor, and any other modifying factors. The dose equivalent is a quantity for comparing the biological effectiveness of different kinds of radiation on a common scale. The unit of dose equivalent is the rem. A millirem is one onethousandth of a rem.

- effective dose equivalent - A value used for estimating the total risk of potential health effects from radiation exposure. This estimate is the sum of the committed effective dose equivalent (see above) 
from internal deposition of radionuclides in the body and the effective dose equivalent from external radiation received during a year.

radioactivity - Property possessed by some isotopes of elements of emitting radiation (such as alpha, beta, or gamma rays) spontaneously in their decay process to stable element isotopes.

radioisotope - Radioactive isotope of a specified element. Carbon-14 is a radioisotope of carbon. Tritium is a radioisotope of hydrogen.

- long-lived radioisotope - A radionuclide that decays at such a slow rate that a quantity will exist for an extended period (typically many years).

- short-lived radioisotope - A radionuclide that decays so rapidly that a given quantity is transformed almost completely into decay products within a short period (typically less than a few months).

radionuclide - Radioactive atomic species or isotope of an element. There are several hundred known radionuclides, both anthropogenic and naturally occurring. Radionuclide and radioisotope are terms that are sometimes used interchangeably, although they are theoretically different terms.

rem - Acronym for roentgen equivalent man; a unit of dose equivalent that indicates the potential for impact on human cells.

risk - The probability that a detrimental health effect will occur.

roentgen - Unit of $x$ ray or gamma radiation exposure in air, typically used for describing external radiation levels. An exposure of 1 roentgen (R) is approximately equal to a 1-rem dose to human tissue.

sievert (Sv) - Unit of dose equivalent in the International System of Units (SI) equal to $100 \mathrm{rem}$.

skewness - measure of the lack of symetry in a frequency distribution.

spent fuel - Nuclear fuel that has been exposed in a nuclear reactor; this fuel contains uranium, activation products, fission products, and plutonium. standard deviation - An indication of the dispersion or variability of a set of results around their average.

standard error of the mean - An indication of the dispersion or variability of an estimated mean from the average of other estimates of the same mean.

The standard error of $\mathrm{X}$ was computed as

$$
\mathrm{SE}=\sqrt{\frac{\mathrm{S}^{2}}{n}}
$$

where $S^{2}$, the variance of the $n$ measurements, was computed as

$$
S_{M}^{2}=\frac{1}{n-1} \sum_{i=1}^{n}\left(X_{i}-X\right)^{2}
$$

This estimator, $S^{2}$, includes the variance among the samples and the counting variance. The estimated $\mathrm{S}^{2}$ may occassionally be less than the average counting variance.

taxon - A group of organisms constituting one of the categories or formal units in taxonomic classification (i.e., kingdom, phylum, class, order, family, genus, or species) and characterized by common characteristics in varying degrees of distinction.

thermoluminescent dosimeter (TLD) - A material that, after being exposed to beta and/or gamma radiation, emits light when processed and heated. The amount of light emitted is proportional to the amount of radiation (dose) to which the TLD has been exposed.

unconfined aquifer - An aquifer containing ground water that is not confined above by relatively impermeable rocks. The pressure at the top of the unconfined aquifer is equal to that of the atmosphere. At Hanford, the unconfined aquifer is the uppermost aquifer and is most susceptible to contamination from Site operations.

uncontrolled area - Area on or near a nuclear facility to which public access is not restricted.

vadose zone - underground area from the surface to the top of the water table or aquifer.

water table - Theoretical surface represented by the elevation of water surfaces in wells penetrating only a short distance into the unconfined aquifer. 
whole-body dose - Radiation dose that involves

exposure of the entire body. Whole-body dose typically refers to external radiation exposure.

wind rose - Star-shaped diagram showing how often winds of various speeds blow from different directions, usually based on yearly averages. 


\section{Appendix C}

\section{Standards and Permits}




\section{Appendix C}

\section{Standards and Permits}

Operations at the Hanford Site must conform to a variety of governmental standards and permits designed to ensure the biological and physical quality of the environment for either public health, ecological, or aesthetic considerations. The primary environmental quality standards and permits applicable to Hanford operations in 1993 are listed in the following tables. The State of Washington has promulgated water quality standards for the Columbia River, Washington Administrative Code (WAC), 173-201. The Hanford Reach of the Columbia River has been designated as Class A (Excellent). This designation requires that the water be usable for substantially all needs, including drinking water, recreation, and wildlife. Class A water standards are summarized in Table C.1. Drinking water standards promulgated by the U.S. Environmental Protection Agency (EPA) in 40 Code of Federal Regulations (CFR) 141 are summarized in Tables C.2 and C.3. Benton-Franklin Counties Clean Air Authority air quality standards are shown in Table C.4. Applicable radiation standards pursuant to the Clean Air Act for sources of radionuclide emissions to the air, 40 CFR 61, are summarized in Table C.5.

Environmental radiation protection standards are published in U.S. Department of Energy (DOE) Order 5400.5, "Radiation Protection of the Public and the Environment." This DOE order establishes new limits for public radiation dose and gives guidance for keeping radiation exposures to members of the public as low as reasonably achievable (ALARA). These standards are based on guidelines recommended by authoritative organizations, such as the International Commission on Radiological Protection and the National Council on Radiation Protection and Measurements. The DOE has initiated a policy for creating and implementing public radiation protection standards that are generally consis- tent with the standards used by the U.S. Nuclear Regulatory Commission (NRC) in regulating and licensing non-DOE nuclear facilities (i.e., nuclear power plants). Table C.5 shows the radiation standards from DOE Order 5400.5. These standards govern allowable public exposures to ionizing radiation from $D O E$ operations.

In Order 5400.5, the DOE established Derived Concentration Guides (DCGs) that reflect the concentrations of individual nuclides in water or air that would result in an effective dose equivalent of $100 \mathrm{mrem}$ per year caused by ingestion of water or inhalation of air at average annual intake rates. Derived Concentration Guides are not exposure limits, but are simply reference values that are provided to allow for comparisons of radionuclide concentrations in environmental media. Table C. 6 lists selected DCGs for radionuclides of particular interest at the Hanford Site. The DCGs are useful reference values but do not generally represent concentrations in the environment that ensure compliance with either the DOE, the Clean Air Act, or drinking water dose standards.

Permits required for regulated releases to water and air have been issued by the EPA under the National Pollutant Discharge Elimination System (NPDES) of the Clean Water Act and the Prevention of Significant Deterioration (PSD) requirements of the Clean Air Act. Also, under authority granted by the Clean Air Act, the Washington State Department of Health has issued a permit for Hanford radioactive air emissions. Permits for collecting wildlife for environmental sampling are issued by the Washington State Department of Fish and Wildlife and the U.S. Fish and Wildlife Service. Current permits are listed in Table C.7. 
Table C.1. Washington State Water Quality Standards for the Hanford Reach of the Columbia River

Parameter

Fecal coliform

Dissolved oxygen

Temperature

$\mathrm{pH}$

Turbidity

Toxic, radioactive, or deleterious materials

Aesthetic value

\section{Permissible Levels}

1) $\leq 100$ organisms $/ 100 \mathrm{~mL}$

2) $\leq 10 \%$ of samples may exceed 200 organisms $/ 100 \mathrm{~mL}$

$>8 \mathrm{mg} / \mathrm{L}$

1) $\leq 20^{\circ} \mathrm{C}\left(68^{\circ} \mathrm{F}\right)$ due to human activities

2) When natural conditions exceed $20^{\circ} \mathrm{C}$, no temperature increase in receiving water of greater than $0.3^{\circ} \mathrm{C}$ allowed; nor shall increases at any time exceed $34 /(\mathrm{T}+9)$, where $\mathrm{T}=$ highest existing temperature in ${ }^{\circ} \mathrm{C}$ outside of dilution zone.

1) 6.5 to 8.5 range

2) $<0.5$ unit induced variation

$\leq 5 \mathrm{NTU}^{(a)}$ over background turbidity

Concentrations shall be below those of public health significance, or which cause acute or chronic toxic conditions to the aquatic biota, or which may adversely affect any water use.

Shall not be impaired by the presence of materials or their effects, excluding those of natural origin, which offend the senses of sight, smell, touch, or taste.

(a) NTU = nephelometric turbidity units. 
Table C.2. Selected Radiological Drinking Water Standards: U.S. Environmental Protection Agency, National Primary Drinking Water Regulations (40 CFR 141); and State of Washington, Rules and Regulations of the State Board of Health Regarding Public Water Systems (WAC 248-54)

Contaminant

Total alpha (excluding uranium)

Combined ${ }^{226} \mathrm{Ra}$ and ${ }^{228} \mathrm{Ra}$

Radium-226 (State of Washington only)

Beta and gamma radioactivity from anthropogenic radionuclides
Limit

$15 \mathrm{pCi} / \mathrm{L}$

$5 \mathrm{pCi} / \mathrm{L}$

$3 \mathrm{pCi} / \mathrm{L}$

Annual average concentration shall not produce an annual dose from anthropogenic radionuclides equivalent to the total body or any internal organ dose greater than $4 \mathrm{mrem} / \mathrm{yr}$. If two or more radionuclides are present, the sum of their annual dose equivalents shall not exceed $4 \mathrm{mrem} / \mathrm{yr}$.

Compliance may be assumed if annual average concentrations of total beta, ${ }^{3} \mathrm{H}$, and ${ }^{90} \mathrm{Sr}$ are less than $50,20,000$, and $8 \mathrm{pCi} / \mathrm{L}$, respectively.

The following list provides the annual average concentrations for anthropogenic radionuclides of interest. These radionuclides are assumed to yield an annual dose of 4 mrem to the indicated organ. Data are taken from the National Interim Primary Drinking Water Regulations, Table IV-2A (EPA 1976).

\begin{tabular}{|c|c|c|}
\hline Radionuclide & Critical Organ & Concentration, $\mathrm{pCi} / \mathrm{L}$ \\
\hline${ }^{3} \mathrm{H}$ & Whole body & 20,000 \\
\hline${ }^{14} \mathrm{C}$ & Fatty tissue & 2,000 \\
\hline${ }^{60} \mathrm{Co}$ & GI (LLI) $)^{(a)}$ & 100 \\
\hline${ }^{89} \mathrm{Sr}$ & Bone & 20 \\
\hline${ }^{89} \mathrm{Sr}$ & Bone marrow & 80 \\
\hline${ }^{90} \mathrm{Sr}$ & Bone marrow & 8 \\
\hline${ }^{95} \mathrm{Zr}$ & GI (LLI) & 200 \\
\hline${ }^{95} \mathrm{Nb}$ & GI (LLI) & 300 \\
\hline${ }^{99} \mathrm{Tc}$ & GI (LLI) & 900 \\
\hline${ }^{103} \mathrm{Ru}$ & GI (LLI) & 200 \\
\hline${ }^{106} \mathrm{Ru}$ & GI (LLI) & 30 \\
\hline${ }^{125} \mathrm{Sb}$ & GI (LLI) & 300 \\
\hline${ }^{129} \mathrm{I}$ & Thyroid & 1 \\
\hline${ }^{131} I$ & Thyroid & 3 \\
\hline${ }^{134} \mathrm{Cs}$ & GI (S) $)^{(b)}$ & 20,000 \\
\hline${ }^{137} \mathrm{Cs}$ & Whole body & 200 \\
\hline
\end{tabular}

(a) GI (LLI) = gastrointestinal tract (lower large intestine).

(b) (S) = stomach. 
Table C.3. Selected Chemical Drinking Water Standards: U.S. Environmental Protection Agency, National Primary Drinking Water Regulations (40 CFR 141); and State of Washington, Public Water Supplies (WAC 248-54)

\begin{tabular}{|c|c|}
\hline Chemical Constituent & Concentration \\
\hline As & $50 \mu \mathrm{g} / \mathrm{L}$ \\
\hline $\mathrm{Ba}$ & $1 \mathrm{mg} / \mathrm{L}$ \\
\hline $\mathrm{CCl}_{4}$ & $5 \mu \mathrm{g} / \mathrm{L}$ \\
\hline $\mathrm{Cd}$ & $10 \mu \mathrm{g} / \mathrm{L}$ \\
\hline $\mathrm{Cr}$ & $50 \mu \mathrm{g} / \mathrm{L}$ \\
\hline $\mathrm{Cu}$ & $1 \mathrm{mg} / \mathrm{L}$ \\
\hline $\mathrm{F}^{-}$ & $2 \mathrm{mg} / \mathrm{L}$ \\
\hline $\mathrm{Hg}$ & $2 \mu \mathrm{g} / \mathrm{L}$ \\
\hline $\mathrm{NO}_{3}^{-}$ & $45 \mathrm{mg} / \mathrm{L}$ \\
\hline $\mathrm{Pb}$ & $150 \mu \mathrm{g} / \mathrm{L}$ \\
\hline $\mathrm{Se}$ & $10 \mu \mathrm{g} / \mathrm{L}$ \\
\hline
\end{tabular}

Table C.4. Benton-Franklin Counties Clean Air Authority Ambient Air Quality Standards ${ }^{(a)}$

Parameter

$\mathrm{NO}_{2}$

$\frac{\text { Type of Standard }}{\text { (b) }}$

Secondary and primary
Sampling Period

Annual average
Permissible Level

$100 \mu \mathrm{g} / \mathrm{m}^{3}$

(a) Benton-Franklin-Walla Walla Counties Air Pollution Control Authority (1980).

(b) Primary standards for ambient air quality define levels of air quality to protect the public health. Secondary standards define levels of air quality to protect the public welfare from any known or anticipated adverse effects of a pollutant. 
Table C.5. Radiation Standards (Dose Limits ${ }^{(a)}$ ) for Protection of the Public from All Routine DOE Activities

All Pathways [limits from DOE Order 5400.5]

The effective dose equivalent for any member of the public from all routine DOE activities ${ }^{(b)}$ shall not exceed the values given below.

\begin{tabular}{cc}
\multicolumn{2}{c}{ Effective Dose Equivalent(c) } \\
\cline { 1 - 1 } mrem/yr & $\frac{\mathrm{mSv} / \mathrm{yr}}{}$ \\
100 & 1 \\
500 & 5
\end{tabular}

Dose to Native Aquatic Animal Organisms from Liquid Discharges [interim limits from DOE Order 5400.5]

Radioactive material in liquid wastes discharged to natural waterways shall not cause an absorbed dose ${ }^{(e)}$ to native aquatic animal organisms that exceeds 1 rad per day (10 mGy per day).

Drinking Water Pathway Only [limits from 40 CFR 141 and DOE Order 5400.5]

Radionuclide concentrations in DOE-operated public drinking water supplies shall not cause persons consuming the water to receive an effective dose equivalent greater than $4 \mathrm{mrem}(0.04 \mathrm{mSv})$ in a year. DOE activities shall not cause private or public drinking water systems downstream of the facility discharge to exceed the radiological drinking water limits in 40 CFR 141 (Table C.2).

Air Pathways Only [limits from 40 CFR 61]

$\frac{\text { Effective Dose Equivalent }}{\text { mrem/yr }} \underline{\mathrm{mSv} / \mathrm{yr}}$

Public Dose Limit at Location of Maximum Annual Air Concentration as a Consequence of Routine DOE Activities $^{(\mathbf{b})}$

(a) Radiation doses received from natural background, residual weapons testing and nuclear accident fallout, and medical consumer product exposures are excluded from the implementation of these dose limits.

(b) "Routine DOE activities" implies normal, planned activities and does not include actual or potential accidental or unplanned releases.

(c) Effective dose equivalent is expressed in rem (or millirem) with the corresponding value in sievert (or millisievert) in parentheses.

(d) Authorized temporary annual dose limits may be greater than $100 \mathrm{mrem} / \mathrm{yr}$ (but cannot exceed $500 \mathrm{mrem} / \mathrm{yr}$ ) if unusual circumstances exist that make avoidance of doses greater than $100 \mathrm{mrem}$ to the public impracticable. The Richland Operations Office is required to request and receive specific authorization from DOE Headquarters for an increase from the routine public dose limit to a temporary annual dose limit.

(e) Absorbed dose is expressed in rad (or millirad) with the corresponding value in gray (or milligray) in parentheses. 
Table C.6. Selected Derived Concentration Guides $(a, b, c)$

\begin{tabular}{|c|c|c|}
\hline Radionuclide & $\begin{array}{c}\text { Water, } \\
\mathrm{pCi} / \mathrm{L} \\
\left(10^{-9} \mu \mathrm{Ci} / \mathrm{mL}\right) \\
\end{array}$ & $\begin{array}{c}\text { Air, } \\
\mathrm{pCi} / \mathrm{m}^{3} \\
\left(10^{-12} \mu \mathrm{Ci} / \mathrm{mL}\right) \\
\end{array}$ \\
\hline${ }^{3} \mathrm{H}$ & $2,000,000$ & 100,000 \\
\hline${ }^{14} \mathrm{C}$ & 70,000 & 500,000 \\
\hline${ }^{51} \mathrm{Cr}$ & $1,000,000$ & 60,000 \\
\hline${ }^{54} \mathrm{Mn}$ & 50,000 & 2,000 \\
\hline${ }^{60} \mathrm{Co}$ & 5,000 & 80 \\
\hline${ }^{65} \mathrm{Zn}$ & 9,000 & 600 \\
\hline${ }^{85} \mathrm{Kr}$ & $N S^{(d)}$ & $3,000,000$ \\
\hline${ }^{90} \mathrm{Sr}$ & 1,000 & 50 \\
\hline${ }^{99} \mathrm{Tc}$ & 100,000 & 2,000 \\
\hline${ }^{103} \mathrm{Ru}$ & 50,000 & 2,000 \\
\hline${ }^{106} \mathrm{Ru}$ & 6,000 & 30 \\
\hline${ }^{125} \mathrm{Sb}$ & 60,000 & 1,000 \\
\hline${ }^{129} \mathrm{I}$ & 500 & 70 \\
\hline${ }^{131} \mathrm{I}$ & 3,000 & 400 \\
\hline${ }^{137} \mathrm{Cs}$ & 3,000 & 400 \\
\hline${ }^{144} \mathrm{Ce}$ & 7,000 & 30 \\
\hline${ }^{234} \mathrm{U}$ & 500 & 0.09 \\
\hline${ }^{235} \mathrm{U}$ & 600 & 0.1 \\
\hline${ }^{238} \mathrm{U}$ & 600 & 0.1 \\
\hline${ }^{238} \mathrm{Pu}$ & 40 & 0.03 \\
\hline${ }^{239} \mathrm{Pu}$ & 30 & 0.02 \\
\hline${ }^{240} \mathrm{Pu}$ & 30 & 0.02 \\
\hline${ }^{241} \mathrm{Am}$ & NS & 0.02 \\
\hline
\end{tabular}

(a) Concentration of a specific radionuclide in water or air that could be continuously consumed or inhaled at average annual rates and not exceed an effective dose equivalent of $100 \mathrm{mrem} / \mathrm{yr}$. An exception is the limit for ${ }^{85} \mathrm{Kr}$, which is based on the skin dose limit of 5 rem from immersion in a plume.

(b) Values in this table represent the lowest, most conservative derived concentration guides considered potentially applicable to Hanford operations, and may be adjusted upward (larger) if accurate solubility information is available.

(c) From DOE Order 5400.5.

(d) $\mathrm{NS}=$ No standard. 
Table C.7. Environmental Permits

\section{Clean Water Act Permit}

NPDES Permit No. WA-000374-3, issued to the DOE, Richland Operations Office by Region 10 of the EPA, covers nonradioactive discharges to the Columbia River from eight outfalls. The following are measurements required for NPDES-permitted discharges at Hanford:

\begin{tabular}{|c|c|c|c|}
\hline \multirow[b]{2}{*}{ Measurement } & \multicolumn{3}{|c|}{ Location } \\
\hline & $\begin{array}{l}\text { 100-K Area } \\
\text { (2 discharges) }\end{array}$ & $\begin{array}{c}100-\mathrm{N} \text { Area } \\
\text { (5 discharges) } \\
\end{array}$ & $\begin{array}{c}300 \text { Area } \\
\text { (1 discharge) }\end{array}$ \\
\hline Flow rate & $\mathrm{X}$ & $\mathrm{X}$ & $\mathrm{X}$ \\
\hline Suspended solids & $\mathrm{X}$ & $\mathrm{X}$ & $\mathrm{X}$ \\
\hline Temperature & $\mathrm{X}$ & $\mathrm{X}$ & $--^{\text {(a) }}$ \\
\hline $\mathrm{pH}$ & $\mathrm{X}$ & $\mathrm{X}$ & $X$ \\
\hline Chlorine & $\mathrm{X}$ & $\mathrm{X}$ & $-\cdots$ \\
\hline Oil and grease & $-\ldots$ & $\mathrm{X}$ & --- \\
\hline Heat discharged & --- & $\mathrm{X}$ & -- \\
\hline Settleable solids & --. & -- & $x$ \\
\hline Iron & --- & $\mathrm{X}$ & -- \\
\hline Ammonia & --- & $\mathrm{X}$ & -- \\
\hline Chromium & --- & $\mathrm{X}$ & -- \\
\hline
\end{tabular}

(a) Dashed line indicates no measurement required.

\section{Clean Air Act Permits}

PSD Permit No. PSD-X80-14, issued to the Richland Operations Office by Region 10 of the EPA, covers emission of $\mathrm{NO}_{\mathrm{x}}$ to the atmosphere from the Plutonium Uranium Extraction (PUREX) Plant and the Uranium Oxide $\left(\mathrm{UO}_{3}\right)$ Plant. No expiration date.

Radioactive Air Emission Permit No. FF-01, issued to the Richland Operations Office by the Washington State Department of Health under authority granted by the Clean Air Act, covers operations on the Hanford Site having a potential to emit radioactive airborne effluents. Initially issued August 15, 1991, the permit is for a 2-year period.

\section{Wildlife Sampling Permits}

Scientific Study or Collection Permit No. 107, issued by Washington State Department of Wildlife to Pacific Northwest Laboratory for 1993, covers the collection of wildlife, including gamefish, for environmental monitoring purposes. Renewed annually.

Scientific Collection Permit No. 93-33, issued by Washington State Department of Fisheries to Pacific Northwest Laboratory for 1993, covers the collection of food fish and shellfish for environmental monitoring purposes. Renewed annually.

Federal Fish and Wildlife Permit No. 671877, issued by the U.S. Fish and Wildlife Service to Pacific Northwest Laboratory, covers the collection of migratory wildlife. Valid for two years.

Copies of the regulations concerning these permits may be obtained from the following organizations:

State of Washington

Department of Ecology

Olympia, WA 98504

U.S. Environmental Protection Agency

Region 10

1200 Sixth Avenue

Seattle, WA 98101
U.S. Department of Energy

Richland Operations Office

Richland, WA 99352 


\section{References}

40 CFR 61. U.S. Government Printing Office, "National Emissions Standard for Hazardous Air Pollutants; Standards for Radionuclides." Code of Federal Regulations.

40 CFR 141. U.S. Government Printing Office, "National Primary Drinking Water Regulations." Code of Federal Regulations.

Benton-Franklin-Walla Walla Counties (Tri-Counties) Air Pollution Control Authority. 1980. General Regulation 80-7. Air Pollution Control Authority, Richland, Washington.

Clean Air Act. Public Law 88-206, as amended, 42 USC 7401 et seq.
Clean Water Act. Public Law 95-217, December 27, 1977, 91 Stat. 1566 and Public Law 96-148.

DOE Order 5400.5. 1990. "Radiation Protection of the Public and the Environment."

U.S. Environmental Protection Agency (EPA). 1976. National Interim Primary Drinking Water Regulations. EPA-570/9-76-003, Office of Water Supply, Washington, D.C.

Washington Administrative Code (WAC) 173-201, "Water Quality Standards for Waters of the State of Washington," Washington State Department of Ecology.

Washington Administrative Code (WAC) 248-54, "Public Water Supplies," Washington State Department of Social and Health Services. 1983. 


\section{Appendix D \\ Dose Calculations}




\title{
Appendix D
}

\section{Dose Calculations}

\begin{abstract}
J. K. Soldat
The radiation dose that the public could have potentially received in 1993 from Hanford operations was calculated in terms of the "effective dose equivalent." These dose quantities are given in units of millirem (mrem) [milli-sievert (mSv)] ${ }^{(\mathrm{a})}$ for individuals and in units of person-rem (person-Sv) for the collective dose received by the total population within an $80-\mathrm{km}(50 \mathrm{mi})$ radius of the Site. These quantities provide a way to uniformly express the radiation dose, regardless of the type or

internally consistent mathematical models that use sitespecific dispersion and uptake parameters. These programs are incorporated in a master code, GENII (Napier et al. 1988a, 1988b, 1988c), which employs the dosimetry methodology described in International Commission on Radiological Protection (ICRP) Reports (1979a, 1979b, 1980, 1981a, 1981b, 1982a, 1982b, 1988). The assumptions and input data used in these calculations are described below.
\end{abstract} source of radiation or the means by which it is delivered. The values given in this report may be compared to standards for radiation protection (Table C.5, Appen$\operatorname{dix} \mathrm{C}$ ). This appendix describes how the doses in this report were calculated.

Releases of radionuclides from the Hanford Site activities are usually too low to be measured in offsite air, drinking water, and food crops. Therefore, in most cases, the dose calculations were based on measurements made at the point of release (stacks and effluent streams), and environmental concentrations were estimated from these effluent measurements by environmental transport models.

The transport of radionuclides from the environment to the point of exposure is predicted by empirical models of exposure pathways. These models calculate concentrations of radionuclides in air, water, and foods. Radionuclides taken into the body by inhalation or ingestion may be distributed among different organs and retained for various times. In addition, long-lived radionuclides deposited on the ground become possible sources for long-term external exposure and uptake by agricultural products. Dietary and exposure parameters were applied to calculate radionuclide intakes and radiation doses to the public. Standardized computer programs were used to perform the calculations. These programs contain

(a) $1 \mathrm{rem}(0.01 \mathrm{~Sv})=1000 \mathrm{mrem}(10 \mathrm{mSv})$.

\section{Types of Dose Calculations Performed}

Calculations of radiation doses to the public from radionuclides released into the environment are performed to demonstrate compliance with applicable standards and regulations.

The U.S. Department of Energy (DOE) requires that estimates of radiation exposure to the general public be in terms of the "effective dose equivalent." The effective dose equivalent is representative of the total risk of potential health effects from radiation exposure. The adoption and use of the effective dose equivalent was previously recommended by the ICRP (1977). In addition to implementing the effective dose equivalent requirement for offsite population dose calculations, the DOE has also adopted the biokinetic models and metabolic parameters for radionuclides given by the ICRP in 1977 for estimating radiation dose. As in the past, when concentrations of radionuclides in the environment are too low to measure, then DOE specifies that the doses are to be calculated from effluent data using environmental transport and dosimetry models.

The calculation of the effective dose equivalent takes into account the long-term (50-year) internal exposure from radionuclides taken into the body during the current 
year. The effective dose equivalent is the sum of individual committed ( 50 -year) organ doses multiplied by weighting factors that represent the proportion of the total health-effect risk that each organ would receive from uniform irradiation of the whole body. Internal organs may also be irradiated from external sources of radiation. The external exposure received during the current year is added to the committed internal dose to obtain the total effective dose equivalent. In this report, the effective dose equivalent is expressed in rem (or millirem), with the corresponding value in sievert (or millisievert) in parentheses. The numerous transfer factors used for pathway and dose calculations have been documented in GENII (Napier et al. 1988a, 1988b, 1988c) and by Schreckhise et al. (1993).

The following types of radiation doses were estimated:

1. "Boundary" Dose Rate ( $\mathrm{mrem} / \mathrm{h}$ and $\mathrm{mrem} / \mathrm{yr}$ ). The external radiation dose rates during the year in areas accessible by the general public were determined from measurements obtained near operating facilities.

2. "Maximally Exposed Individual" Dose (mrem). The maximally exposed individual is a hypothetical member of the public who lives at a location and has a postulated lifestyle such that it is unlikely that other members of the public would receive higher doses. All potentially significant exposure pathways to this hypothetical individual were considered, including the following:

- inhalation of airborne radionuclides

- submersion in airborne radionuclides

- ingestion of foodstuffs contaminated by radionuclides deposited on vegetation and the ground by both airborne deposition and irrigation water drawn from the Columbia River downstream of the N Reactor

- exposure to ground contaminated by both airborne deposition and irrigation water

- ingestion of fish taken from the Columbia River

- recreation along the Columbia River, including boating, swimming, and shoreline activities.
3. 80-km Population Doses (person-rem). Regulatory limits have not been established for population doses. However, evaluation of the collective population doses to all residents within an $80-\mathrm{km}(50-\mathrm{mi})$ radius of Hanford Site operations is required by DOE Order 5400.5 . The $80-\mathrm{km}$ (50-mi) population dose represents the summed products of the individual doses for the number of individuals involved for all potential exposure pathways.

The pathways assigned the maximally exposed individual were assumed to be applicable to the offsite population. Consideration was given, however, to the fraction of the offsite population actually affected by each pathway. The exposure pathways for the population are as follows:

- Drinking Water. The cities of Richland and Pasco obtain their municipal water directly, and Kennewick indirectly, from the Columbia River downstream from the Hanford Site. A total population of approximately 70,000 in the three cities drinks water derived from the Columbia River.

- Irrigated Food. Columbia River water is withdrawn for irrigation of small vegetable gardens and farms in the Riverview district of Pasco in Franklin County. Enough food is grown in this district to feed an estimated 2,000 people. Commercial crops are also irrigated by Columbia River water in the Horn Rapids area of Benton County.

- River Recreation. These activities include swimming, boating, and shoreline recreation. An estimated 125,000 people who reside within $80 \mathrm{~km}$ (50 mi) of the Hanford Site are assumed to be affected by these pathways.

- Fish Consumption. Population doses from the consumption of fish obtained locally from the Columbia River were calculated from an estimated total annual catch of $15,000 \mathrm{~kg} / \mathrm{yr}$ (without reference to a specified human group of consumers).

\section{Data}

The data that are needed to perform dose calculations based on measured effluent releases include information on initial transport through the atmosphere or river, transfer or accumulation in terrestrial and aquatic 
pathways, and public exposure. By comparison, radiation dose calculations based on measured concentrations of radionuclides in food require data describing only dietary and recreational activities and exposure times. These data are discussed in the following sections.

\section{Population Distribution and Atmospheric Dispersion}

Geographic distributions of the population residing within an $80-\mathrm{km}(50-\mathrm{mi})$ radius of the four Hanford Site operating areas are shown in the Hanford Site Environmental Data for Calendar Year 1993-Surface and Columbia River (Bisping 1994). These distributions are based on 1990 Bureau of Census data (Beck et al. 1991). These data influence the population dose by providing estimates of the number of people exposed to radioactive effluents and their proximity to the points of release.

Atmospheric dispersion data are also shown in the Hanford Site Environmental Data for Calendar Year 1993-Surface and Columbia River (Bisping 1994).

These data describe the transport and dilution of airborne radioactive material, which influences the amounts of radionuclides being transported through the air to specific locations.

\section{Terrestrial and Aquatic Pathways}

Important parameters affecting the movement of radionuclides within potential exposure pathways, such as irrigation rates, growing periods, and holdup periods, are listed in Table D.1. Certain parameters are specific to the lifestyles of either "maximally exposed" or "average" individuals.

\section{Public Exposure}

The potential offsite radiation dose is related to the extent of external exposure to or intake of radionuclides released from Hanford Site operations. Tables D.2 through D.4 give the parameters describing the diet, residency, and river recreation assumed for "maximally exposed" and "average" individuals.

Table D.1. Food Pathway Parameters Used in Dose Calculations, 1993

\begin{tabular}{|c|c|c|c|c|c|}
\hline & \multicolumn{2}{|c|}{ Holdup, days ${ }^{(a)}$} & \multirow{2}{*}{$\begin{array}{c}\text { Growing } \\
\text { Period, } \\
\text { days } \\
\end{array}$} & \multirow[b]{2}{*}{$\begin{array}{l}\text { Yield, } \\
\mathrm{kg} / \mathrm{m}^{2}\end{array}$} & \multirow{2}{*}{$\begin{array}{c}\text { Irrigation } \\
\text { Rate, } \\
\mathrm{L} / \mathrm{m}^{2} / \text { month }\end{array}$} \\
\hline & $\begin{array}{l}\text { Maximally Exposed } \\
\text { Individual } \\
\end{array}$ & $\begin{array}{c}\text { Average } \\
\text { Individual } \\
\end{array}$ & & & \\
\hline Leafy vegetables & 1 & 14 & 90 & 1.5 & 150 \\
\hline Other vegetables & 5 & 14 & 90 & 4 & 170 \\
\hline Fruit & 5 & 14 & 90 & 2 & 150 \\
\hline Cereal & 180 & 180 & 90 & 0.8 & 0 \\
\hline Eggs & 1 & 18 & 90 & 0.8 & 0 \\
\hline Milk & 1 & 4 & & & \\
\hline Hay & $(100)^{(b)}$ & $(100)$ & 45 & 2 & 200 \\
\hline Pasture & $(0)$ & $(0)$ & 30 & 1.5 & 200 \\
\hline Red meat & 15 & 34 & & & \\
\hline Hay & $(100)$ & $(100)$ & 45 & 2 & 200 \\
\hline Grain & (180) & $(180)$ & 90 & 0.8 & 0 \\
\hline Poultry & 1 & 34 & 90 & 0.8 & 0 \\
\hline Fish & 1 & 1 & --- & --- & --- \\
\hline Drinking water & 1 & 1 & --- & --- & -- \\
\hline
\end{tabular}

(a) Holdup is the time between harvest and consumption.

(b) Values in ( ) are the holdup in days between harvest and consumption by farm animals. 
Table D.2. Dietary Parameters Used in Dose Calculations, 1993

\begin{tabular}{|c|c|c|}
\hline & Con & $\mathrm{gg} / \mathrm{yr}$ \\
\hline & Maximally & \\
\hline & Exposed & Average \\
\hline & Individual & Individual \\
\hline Leafy vegetables & 30 & 15 \\
\hline Other vegetables & 220 & 140 \\
\hline Fruit & 330 & 64 \\
\hline Grain & 80 & 72 \\
\hline Eggs & 30 & 20 \\
\hline Milk $^{(a)}$ & 270 & 230 \\
\hline Red meat & 80 & 70 \\
\hline Poultry & 18 & 8.5 \\
\hline Fish & 40 & $--^{(b)}$ \\
\hline Drinking water ${ }^{(a)}$ & 730 & 440 \\
\hline
\end{tabular}

(a) Units L/yr.

(b) Average individual consumption not identified; radiation doses were calculated based on estimated total annual catch of $15,000 \mathrm{~kg}$.

Table D.3. Residency Parameters Used in Dose Calculations, 1993

\begin{tabular}{lcc} 
& \multicolumn{2}{c}{ Exposure, $\mathrm{h} / \mathrm{yr}$} \\
Parameter & $\begin{array}{c}\text { Maximally } \\
\text { Exposed } \\
\text { Individual }\end{array}$ & $\begin{array}{c}\text { Average } \\
\text { Individual }\end{array}$ \\
Ground contamination & 4,383 & 2,920 \\
Air submersion & 8,766 & 8,766 \\
Inhalation $^{(a)}$ & 8,766 & 8,766
\end{tabular}

(a) Inhalation rates: Adult $270 \mathrm{~cm}^{3} / \mathrm{s}$. 
Table D.4. Recreational Parameters Used in Dose Calculations, 1993

\begin{tabular}{lcc} 
& \multicolumn{2}{c}{ Exposure, $\mathrm{h} / \mathrm{yr}^{(\mathrm{a})}$} \\
\cline { 2 - 3 } Parameter & $\begin{array}{c}\text { Maximally } \\
\text { Exposed } \\
\text { Individual }\end{array}$ & $\begin{array}{c}\text { Average } \\
\text { Individual }\end{array}$ \\
Shoreline & 500 & 17 \\
Boating & 100 & 5 \\
Swimming & 100 & 10
\end{tabular}

(a) Assumed river water travel times from $100-\mathrm{N}$ to the point of aquatic recreation were $8 \mathrm{~h}$ for the maximally exposed individual and $13 \mathrm{~h}$ for the average individual. Correspondingly lesser times were used for other locations.

\section{Dose Calculation Documentation}

The Hanford Dose Overview Panel has the responsibility for defining standard, documented computer codes and input parameters to be used for radiation dose calculations for the public in the vicinity of the Hanford Site.
Only those procedures, models, and parameters previously defined by the Hanford Dose Overview Panel were used to calculate the radiation doses (Schreckhise et al. 1993). The calculations were then reviewed by the Dose Overview Panel. Summaries of dose calculation documentation for this report are shown in Tables D.5 through D.9 and Hanford Site Environmental Data for Calendar Year 1993-Surface and Columbia River (Bisping 1994). 
Table D.5. Documentation of 100-N Area Airborne Release Dose Calculations, 1993

Facility name

Releases

Meteorological conditions

$\overline{\mathrm{X}} / \mathrm{Q}^{\prime}$

Release height

Population distribution

Computer code

Doses calculated

Pathways considered

Files addressed

\section{0-N Area}

See Table 3.1

1993 annual average, calculated from data collected at the 100-N Area and the Hanford Meteorology Station from January 1993 through December 1993, using the computer code HANCHI

Maximally Exposed Individual at residence, $5.9 \times 10^{-9}$ at $41 \mathrm{~km}$ SE; Maximally Exposed Individual at food source, $3.8 \times 10^{-9}$ at $53 \mathrm{~km} \mathrm{SSE}$; $80-\mathrm{km}$ population, $1.7 \times 10^{-3}$ person-s $/ \mathrm{m}^{3}$

89-m effective stack height

375,000 (see Table D-1, Bisping (1994)]

GENII, Version $1.485,12-3-90$

Chronic, 1-year exposure, 50-year committed internal dose equivalent, and annual effective dose equivalent to individual and population

External exposure to plume and ground deposits Inhalation

Ingestion of locally produced foods

Radionuclide Library, Rev. 7-1-92

Food Transfer Library, Rev. 8-29-88

External Dose Factor Library, Rev. 5-9-88

Internal Dose Factor Library, Rev. 12-3-90 
Table D.6. Documentation of 100-N Area Liquid Release Dose Calculations, 1993

Facility name

Releases

Mean river flow

Shore-width factor

Population distribution

Computer code

Doses calculated

Pathways considered

Files addressed
100-N Area

See Table 3.4

$91,200 \mathrm{cfs}\left(2,580 \mathrm{~m}^{3} / \mathrm{s}\right)$

0.2

70,000 for drinking water pathway 125,000 for aquatic recreation 2,000 for consumption of irrigated foodstuffs $15,000 \mathrm{~kg} / \mathrm{yr}$ total harvest of Columbia River fish

GENII, Version $1.485,12-3-90$

Chronic, 1-year exposure, 50-year committed internal dose equivalent, and annual effective dose equivalent to individual and population

External exposure to irrigated soil, to river water, and to shoreline sediments

Ingestion of aquatic foods, and irrigated farm products

Radionuclide Library, Rev. 7-1-92

Food Transfer Library, Rev. 8-29-88

External Dose Factor Library, Rev. 5-9-88

Internal Dose Factor Library, Rev. 12-3-90

Bioaccumulation Factor Library, Rev. 10-26-92 
Table D.7. Documentation of 200 Area Airborne Release Dose Calculations, 1993

Facility name

Releases

Meteorological conditions

$\overline{\mathrm{X}} / \mathrm{Q}^{\prime}$

Release height

Population distribution

Computer code

Doses calculated

Pathways considered

Files addressed
200 Areas

See Table 3.1

1993 annual average, calculated from data collected at the Hanford Meteorology Station from January 1993 through December 1993, using the computer code HANCHI

Maximally Exposed Individual at residence, $1.4 \times 10^{-8}$ at $34 \mathrm{~km}$ $\mathrm{SE}$; Maximally Exposed Individual at food source, $1.1 \times 10^{-8}$ at $43 \mathrm{~km} \mathrm{SE}$; $80-\mathrm{km}$ population, $2.0 \times 10^{-3}$ person-s $/ \mathrm{m}^{3}$

89-m effective stack height

376,000 [see Table D-2, Bisping (1994)]

GENII, Version $1.485,12-3-90$

Chronic, 1-year exposure, 50-year committed internal dose equivalent, and annual effective dose equivalent to individual and population

External exposure to plume and ground deposits Inhalation

Ingestion of locally produced foods

Radionuclide Library, Rev. 7-1-92

Food Transfer Library, Rev. 8-29-88

External Dose Factor Library, Rev. 5-9-88

Internal Dose Factor Library, Rev. 12-3-90 
Table D.8. Documentation of 300 Area Airborne Release Dose Calculations, 1993

Facility name

Releases

Meteorological conditions

$\bar{X} / Q^{\prime}$

Release height

Population distribution

Computer code

Doses calculated

Pathways considered

Files addressed
300 Area

See Table 3.1

1993 annual average, calculated from data collected at the 300 Area and the Hanford Meteorology Station from January 1993 through December 1993, using the computer code HANCHI

Maximally Exposed Individual at residence, $1.2 \times 10^{-6}$ at $1.5 \mathrm{~km}$ E; Maximally Exposed Individual at food source, $9.4 \times 10^{-8}$ at $13 \mathrm{~km} \mathrm{SSE} ; 80-\mathrm{km}$ population, $7.6 \times 10^{-3}$ person-s $/ \mathrm{m}^{3}$

$10 \mathrm{~m}$

282,000 [see Table D-3, Bisping (1994)]

GENII, Version $1.485,12-3-90$

Chronic, 1-year exposure, 50-year committed internal dose equivalent, and annual effective dose equivalent to individual and population

External exposure to plume and ground deposits Inhalation

Ingestion of locally produced foods

Radionuclide Library, Rev 7-1-92

Food Transfer Library, Rev. 8-29-88

External Dose Factor Library, Rev. 5-9-88 
Table D.9. Documentation of 400 Area Airborne Release Dose Calculations, 1993

Facility name

Releases

Meteorological conditions

$\overline{\mathrm{X}} / \mathrm{Q}^{\prime}$

Release height

Population distribution

Computer code

Doses calculated

Pathways considered

Files addressed
400 Area

See Table 3.1

1993 annual average, calculated from data collected at the 400 Area and the Hanford Meteorology Station from January 1993 through December 1993, using the computer code HANCHI

Maximally Exposed Individual at residence, $8.7 \times 10^{-8}$ at $11 \mathrm{~km}$ SE; Maximally Exposed Individual at food source, $3.1 \times 10^{-8}$ at $22 \mathrm{~km} \mathrm{SE} ; 80-\mathrm{km}$ population, $4.9 \times 10^{-3}$ person-s $/ \mathrm{m}^{3}$

$10 \mathrm{~m}$

283,000 [see Table D-4, Bisping (1994)]

GENII, Version 1.485, 12-3-90

Chronic, 1-year exposure, 50-year committed internal dose equivalent, and annual effective dose equivalent to individual and population

External exposure to plume and ground deposits Inhalation

Ingestion of locally produced foods

Radionuclide Library, Rev 7-1-92

Food Transfer Library, Rev. 8-29-88

External Dose Factor Library, Rev. 5-9-88

Internal Dose Factor Library, Rev. 12-3-90 


\section{References}

Beck, D. M., and B. A. Napier, M. J. Scott, A. G. Thurman, M. D. Davis, D. B. Pittenger, S. F. Shindle, andN. C. Batishko. 1991. Hanford Area 1990 Population and 50-Year Projections. PNL-7803, Pacific Northwest Laboratory, Richland, Washington.

Bisping, L. E. 1994. Hanford Site Environmental Data for Calendar Year 1993-Surface and Columbia River. PNL-9824, Pacific Northwest Laboratory, Richland, Washington.

DOE Order 5400.5. "Radiation Protection of the Public and the Environment."

International Commission on Radiological Protection (ICRP). 1977. ICRP Publication 26, Recommendations of the International Commission on Radiological Protection. Annals of the ICRP, Vol. 1, No. 3, Pergamon Press, Elmsford, New York.

International Commission on Radiological Protection (ICRP). 1979a. ICRP Publication 30, Part 1, Limits for Intakes of Radionuclides by Workers. Annals of the ICRP, Vol. 2, No. 3/4. Pergamon Press, Elmsford, New York.

International Commission on Radiological Protection (ICRP). 1979b. ICRP Publication 30, Supplement to Part 1, Limits for Intakes of Radionuclides by Workers. Annals of the ICRP, Vol. 3, No. 1-4, Pergamon Press, Elmsford, New York.

International Commission on Radiological Protection (ICRP). 1980. ICRP Publication 30, Part 2, Limits for Intakes of Radionuclides by Workers. Annals of the ICRP, Vol. 4, No. 3/4, Pergamon Press, Elmsford, New York.

International Commission on Radiological Protection (ICRP). 1981a. ICRP Publication 30, Supplement to Part 2, Limits for Intakes of Radionuclides by Workers. Annals of the ICRP, Vol. 5, No. 1-6, Pergamon Press, Elmsford, New York.

International Commission on Radiological Protection (ICRP). 1981b. ICRP Publication 30, Part 3 Including Addendum to Parts 1 and 2, Limits for Intakes of Radionuclides by Workers. Annals of the ICRP, Vol. 6, No. 2/ 3, Pergamon Press, Elmsford, New York.
International Commission on Radiological Protection (ICRP). 1982a. ICRP Publication 30, Supplement A to Part 3, Limits for Intakes of Radionuclides by Workers. Annals of the ICRP, Vol. 7, No. 1-3, Pergamon Press, Elsmford, New York.

International Commission on Radiological Protection (ICRP). 1982b. ICRP Publication 30, Supplement B to Part 3 Including Addendum to Supplements to Parts 1 and 2, Limits for Intakes of Radionuclides by Workers. Annals of the ICRP, Vol. 8, No. 1-3, Pergamon Press, Elmsford, New York.

International Commission on Radiological Protection (ICRP). 1988. ICRP Publication 30, Part 4, Limits for Intakes of Radionuclides by Workers: an Addendum. Annuals of the ICRP, Vol. 19, No. 4, Pergamon Press, Elmsford, New York.

Napier, B. A., R. A. Peloquin, D. L. Strenge, and J. V. Ramsdell. 1988a. Conceptual Representation. Volume 1 of GENII - The Hanford Environmental Radiation Dosimetry Software System. PNL-6584, Vol. 1, Pacific Northwest Laboratory, Richland, Washington.

Napier, B. A., R. A. Peloquin, D. L. Strenge, and J. V. Ramsdell. 1988b. User's Manual. Volume 2 of GENII - The Hanford Environmental Radiation Dosimetry Software System. PNL-6584, Vol. 2, Pacific Northwest Laboratory, Richland, Washington.

Napier, B. A., R. A. Peloquin, D. L. Strenge, and J. V. Ramsdell. 1988c. Code Maintenance Manual. Volume 3 of GENII - The Hanford Environmental Radiation Dosimetry Software System. PNL-6584, Vol. 3, Pacific Northwest Laboratory, Richland, Washington.

Schreckhise, R. G., K. Rhoads, J. S. Davis, B. A. Napier, and J. V. Ramsdell. 1993. Recommended Environmental Dose Calculation Methods and Hanford-Specific Parameters. PNL-3777 Rev. 2, Pacific Northwest Laboratory, Richland, Washington. 


\section{Appendix E}

RCRA and CERCLA Monitoring Documents 


\title{
Appendix $E$
}

\section{RCRA and CERCLA Monitoring Documents}

\author{
J. M. Nickels
}

The following lists RCRA ground-water monitoring publications for 1993:

- U.S. Department of Energy. 1993. Quarterly Report of RCRA Ground Water Monitoring Data for September 30, 1992 through December 31, 1992. DOE/RL 92-26-4, U.S. Department of Energy, Richland, Washington.

- U.S. Department of Energy. 1993. Annual Report for RCRA Ground Water Monitoring Projects at the Hanford Site Facilities for 1993. DOE/RL 93-88,

U.S. Department of Energy, Richland, Washington.

Below are the CERCLA ground-water monitoring publications for 1993:

- U.S. Department of Energy. 1993. 200-W Ground Water Aggregate Area Management Study Report. DOE/RL 92-16, U.S. Department of Energy, Richland, Washington.

(a) Actual publication date was 1994.
- U.S. Department of Energy. 1993. 200-E Ground Water Aggregate Area Management Study Report. DOE/RL 92-19, U.S. Department of Energy, Richland, Washington.

- U.S. Department of Energy. 1993. Hanford Site Physical Separations CERCLA Treatability Test Plan. DOE/RL 92-21, U.S. Department of Energy, Richland, Washington.

- U.S. Department of Energy. 1994. North Slope (Wahluke Slope) Expedited Response Action Cleanup Plan. DOE/RL 93-047, U.S. Department of Energy, Richland, Washington. ${ }^{\text {(a) }}$ 


\section{Appendix F}

\section{Radionuclides Detected by Gamma Spectroscopy (Gamma Scan)}




\section{Appendix F}

\section{Radionuclides Detected by Gamma Spectroscopy (Gamma Scan)}

One of the more common forms of radiation is gamma radiation. Gamma radiation is emitted by many radionuclides. Gamma spectroscopy, sometimes called a gamma scan, is used in the environmental surveillance program to detect the presence of the radionuclides shown in Table F.1. These radionuclides may be natural or result from Hanford activities. They include activation products formed by the absorption of a neutron by a stable element and fission products that occur following fission (splitting) of nuclear fuel radionuclides like ${ }^{235} \mathrm{U}$ or ${ }^{239} \mathrm{Pu}$. These radionuclides may not be discussed in the main body of this report if they are below detection levels.

Table F.1. Radionuclides Analyzed by Gamma-Spectroscopy

\begin{tabular}{l}
\multicolumn{1}{c}{ Radionuclide } \\
\hline Beryllium-7 \\
Sodium-22 \\
Sodium-24 \\
Potassium-40 \\
Manganese-54 \\
Cobalt-58 \\
Cobalt-60 \\
Iron-59 \\
Zinc-65 \\
Zirconium/Niobium-95 \\
Molybdenum-99 \\
Ruthenium-103 \\
Ruthenium-106 \\
Antimony-125 \\
Iodine-131 \\
Cesium-134 \\
Cesium-137 \\
Barium/Lanthanum-140 \\
Cerium-141 \\
Cerium/Praseodymium-144 \\
Europium-152 \\
Europium-154 \\
Europium-155
\end{tabular}

Symbol

${ }^{7} \mathrm{Be}$

${ }^{22} \mathrm{Na}$

${ }^{24} \mathrm{Na}$

${ }^{40} \mathrm{~K}$

${ }^{54} \mathrm{Mn}$

${ }^{58} \mathrm{Co}$

${ }^{60} \mathrm{Co}$

${ }^{59} \mathrm{Fe}$

${ }^{65} \mathrm{Zn}$

${ }^{95} \mathrm{Zr} / \mathrm{Nb}$

${ }^{99} \mathrm{Mo}$

${ }^{103} \mathrm{Ru}$

${ }^{106} \mathrm{Ru}$

${ }^{125} \mathrm{Sb}$

${ }^{131} \mathrm{I}$

${ }^{134} \mathrm{Cs}$

${ }^{137} \mathrm{Cs}$

${ }^{140} \mathrm{Ba} / \mathrm{La}$

${ }^{141} \mathrm{Ce}$

${ }^{144} \mathrm{Ce} / \mathrm{Pr}$

${ }^{152} \mathrm{Eu}$

${ }^{154} \mathrm{Eu}$

${ }^{155} \mathrm{Eu}$
Source

Natural

Activation product

Activation product

Natural

Activation product

Activation product

Activation product

Activation product

Activation product

Activation product and fission product

Activation product and fission product

Activation product and fission product

Fission product

Activation product

Fission product

Activation product

Fission product

Fission product

Activation product and fission product

Fission product

Activation product

Activation product

Activation product 


\section{Appendix G}

Threatened and Endangered Species 


\title{
Appendix G
}

\section{Threatened and Endangered Species}

\author{
L. L. Cadwell
}

Threatened and endangered plants and animals identified on the Hanford Site, as listed by the federal government [50 Code of Federal Regulations (CFR) 17] and Washington State (Washington Natural Heritage Program 1990), are shown in Table G.1. No plants or mammals on the federal list are known to occur on the Hanford Site. Several species of plants and animals, however, are under consideration for formal listing by the federal government and Washington State (Table G.2). One species, eatonella (eatonella nivea) is listed by the State as threatened. However, it has not been sighted on Hanford. It is known to exist near the Site and occupies habitats similar to those found at Hanford. Surveys have not been completed for this species. Washington State plant species of concern are listed in Table G.3.

Table G.1. Threatened ( $T$ ) and Endangered (E) Species

\begin{tabular}{l} 
Common Name \\
\hline Plants \\
Columbia milk-vetch \\
Columbia yellowcress \\
Hoover's desert parsley \\
Northern wormwood
\end{tabular}

Birds

Aleutian Canada goose

Peregrine falcon

Bald eagle

White pelican

Sandhill crane

Ferruginous hawk

Mammals

Pygmy rabbit

\begin{tabular}{l} 
Scientific Name \\
\hline \\
Astragalus columbianus \\
Rorippa columbiae \\
Lomatium tuberosum \\
Artemisia campestris \\
borealis var. wormskioldii \\
\\
Branta canadensis leucopareia \\
Falco peregrinus \\
Haliaeetus leucocephalus \\
Pelecanus erythrorhychos \\
Grus canadensis \\
Buteo regalis
\end{tabular}

Federal State 
Table G.2. Candidate Species

Common Name

\section{Molluscs}

Shortfaced lanx

Columbia pebblesnail

\section{Birds}

Common loon

Swainson's hawk

Ferruginous hawk

Western sage grouse

Sage sparrow

Burrowing owl

Loggerhead shrike

Northern goshawk

Black tern

\section{Mammals}

Merriam's shrew

Townsend's big-eared bat

Pygmy rabbit

\section{Plants}

Columbia milk-vetch

Columbia yellowcress

Hoover's desert parsley
Scientific Name

Federal

State

Fisherola $(=$ Lanx) nuttalli

Fluminicola (= Lithoglyphus)

columbiana

$\mathrm{X}$

$\mathrm{X}$

$\mathrm{X}$

Gavia immer

$\mathrm{X}$

Buteo swainsoni

Buteo regalis

Centrocercus urophasianus phaios

Amphispiza belli

Athene cunicularia

Lanius ludovicianus

Accipter gentilis

Chlidonias miger

$\begin{array}{cc} & \mathrm{X} \\ \mathrm{X} & \mathrm{X} \\ \mathrm{X} & \mathrm{X} \\ & \mathrm{X} \\ & \mathrm{X} \\ \mathrm{X} & \mathrm{X} \\ \mathrm{X} & \mathrm{X} \\ \mathrm{X} & \end{array}$

Sorex merriami

$X$

Plecotus townsendii

$\mathrm{X}$

$\mathrm{X}$

$\mathrm{X}$
Astragalus columbianus $\quad \mathrm{X}$

Rorippa columbiae

Lomatium tuberosum
$X$
$X$

$\mathrm{X}$ 
Table G.3. Washington State Plant Species of Concern Occurring on the Hanford Site

\begin{tabular}{l}
\multicolumn{1}{c}{ Common Name } \\
\hline Dense sedge \\
Gray cryptantha \\
Bristly cyptantha \\
Shining flatsedge \\
Piper's daisy \\
Southern mudwort \\
False-pimpernel \\
Dwarf evening primrose \\
Tooth-sepal dodder \\
Thompson's sandwort \\
Robinson's onion \\
Squill onion \\
Columbia River mugwort \\
Stalked-pod milkvetch \\
Medic milkvetch \\
Crouching milkvetch \\
Rosy balsamroot \\
Palouse thistle \\
Smooth cliffbrake \\
Fuzzy-tongue penstemon
\end{tabular}

\begin{tabular}{l}
\multicolumn{1}{c}{ Scientific Name } \\
\hline Carex densa \\
Cryptantha leucophaea \\
Cryptantha interrupta \\
Cyperus rivularis \\
Erigeron piperianus \\
Limosella acaulis \\
Lindernia anagallidea \\
Oenothera pygmaea \\
Cuscuta denticulata \\
Arenaria franklinii \\
v. thompsonii \\
Allium robinsonii \\
Allium syscillioides \\
Artemisia lindleyana \\
Astragalus sclerocarpus \\
Astragalus speirocarpus \\
Astragalus succumbens \\
Balsamorhiza rosea \\
Cirsium brevifolium \\
Pellaea glabella \\
Penstemon eriantherus
\end{tabular}

\begin{tabular}{l} 
Status ${ }^{(a)}$ \\
\hline$S$ \\
$S$ \\
$S$ \\
$S$ \\
S \\
S \\
S \\
S \\
M1 \\
\\
M2 \\
M3 \\
M3 \\
M3 \\
M3 \\
M3 \\
M3 \\
M3 \\
M3 \\
M3 \\
M3
\end{tabular}

The following species may inhabit the Hanford Site, but have not been recently collected, and the known collections are questionable in terms of location and/or identification.

Palouse milkvetch

Few-flowered blue-eyed Mary

Coyote tobacco

$\begin{array}{ll}\text { Astragalus arrectus } & \mathrm{S} \\ \text { Collinsia sparsiflora } & \mathrm{S} \\ \text { Nicotiana attenuata } & \mathrm{S}\end{array}$

(a) Abbreviations: $\mathrm{S}=$ Sensitive; taxa vulnerable or declining, and could become endangered or threatened without active management or removal of threats; $\mathrm{M} 1$ = Monitor Group 1, taxa for which there are insufficient data to support listing as threatened, endangered, or sensitive; M2 = Monitor Group 2, taxa with unresolved taxonomic questions; $\mathrm{M} 3=$ Monitor Group 3, taxa that are more abundant and/or less threatened than previously assumed.

\section{References}

50 CFR 17, U.S. Department of Interior, U.S. Fish and Wildlife Service, "Endangered and Threatened Wildlife and Plants." Code of Federal Regulations.
Washington Natural Heritage Program. 1990. Endangered, Threatened, and Sensitive Vascular Plants of Washington. Department of Natural Resources, Olympia, Washington. 


\section{Appendix $\mathrm{H}$}

\section{Erratta from 1992 Hanford Site Environmental Report}




\section{Appendix $\mathrm{H}$}

\section{Erratta from 1992 Hanford Site Environmental Report}

The following lists errors in the published 1992 environmental report (Hanford Site Environmental Report for Calendar Year 1992, Woodruff, R. K., R. W. Hanf, and R. E. Lundgren, editors. 1993. PNL-8682, Pacific
Northwest Laboratory, Richland, Washington). Individuals, organizations, and agencies who were on the distribution list for the 1992 report have already received a copy of this erratta. 


\section{On page xi in Summary section, 1st paragraph under "Potential Radiation Doses from 1992 Hanford Operations" replace with the following paragraph:}

In 1992, potential public doses resulting from exposure to Hanford liquid and gaseous effluents were evaluated to determine compliance with pertinent regulations and limits. These doses were calculated from reported effluent releases and environmental surveillance data using Version 1.485 of the GENII code (Napier et al. 1988a, $1988 b, 1988 c$ ) and Hanford Site-specific parameters. Specific information on sample collection and analyses and the sample results used in these calculations are briefly discussed in the summary sections discussing effluent monitoring and environmental surveillance.

\section{On page $x i$ in Summary section, 2nd column, 3rd paragraph, replace with the following paragraph:}

In addition to the doses estimated from monitored stack releases, the potential radiation dose to the MEI from diffuse and unmonitored sources was estimated using 1992 data to be about $0.09 \mathrm{mrem} / \mathrm{yr}\left(9 \times 10^{-4} \mathrm{mSv} / \mathrm{yr}\right)$.

On page 22 in Section 2.2, 2nd column, 5th paragraph, replace with the following paragraph:

6. In November 1992, Ecology issued a noncompliance letter to WHC on alleged violations at the single shell tank 241-T-101. The violations were associated with the leak detection capabilities of the tank. With the letter, Ecology initiated a Tri-Party Agreement change request to add new milestones to the Tri-Party Agreement. New milestones have been approved by DOE, EPA, and Ecology, and are being completed on schedule.
On page 37 in Section 2.3, 1st column, last paragraph, replace with the following paragraph:

In September 1992, the liquid level in single-shell tank 241-T-101 was noted to have dropped $6.6 \mathrm{~cm}$ (2.6 in.) from a previously established liquid level of $112.3 \mathrm{~cm}$ (44.2 in.). The level decrease was discovered following maintenance on the liquid level indicating transmitter,

On page 37 in Section 2.3, 2nd column, 1st paragraph, replace with the following:

which had been operating sporadically since December 1991. A review of the level history was initiated to identify any trends. The in-tank photographs were reviewed as were the drywell monitoring and surface level history data. The level decrease was confirmed by alternate level measurements and corresponded to a 28,388 -L (7,500-gal) liquid loss in the tank. In October, this tank was declared an assumed leaker based on liquid level measurements. Similar investigations are under way for tanks 241-SX-103 and 241-SX-105.

On page 47 in Section 2.5, 1st column, 1st paragraph under "Hanford Site Waste Safety Issues," replace with the following paragraph:

At various times in the past 10 months, surface-level monitoring instrumentation on single-shell tank 241-T101 has shown unexpected fluctuations in waste surface levels. Extensive investigations have been conducted to determine the cause of the problem. Similar investigations are under way for single-shell tanks 241-SX-103 and 241-SX-105. 
On page 52 in Section 3.1, Figure 3.1, upper right graph $\left({ }^{85} \mathrm{Kr}\right)$, replace with the following:

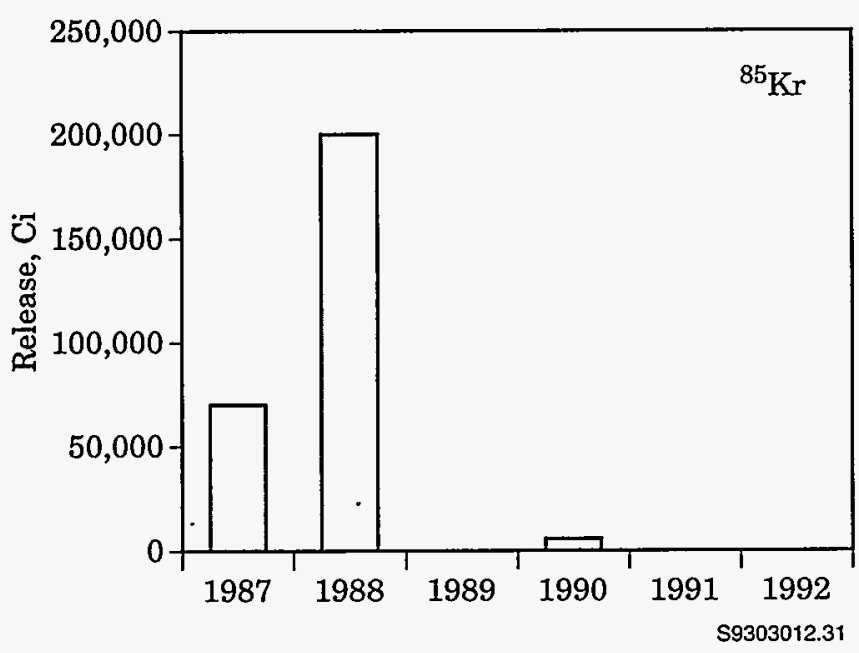

On page 143 in Section 5.5, Figure 5.31, replace with the following:
On page 56 in Section 3.1, 3rd table, bottom right hand corner, replace with the following table:

Table 3.5. Nonradioactive Liquid Effluents Discharged to Ground Disposal Facilities, 1992

Release, $\mathrm{kg}$

Constituent 200 Areas 300 Area 400 Area

Total organic

carbon

$5.0 \times 10^{3}$

Nitrates

$1.4 \times 10^{-3}$

$5.1 \times 10^{4}$

Nitrites

$3.3 \times 10^{2}$

$2.2 \times 10^{1}$

Sulfates

$1.1 \times 10^{4}$

$2.9 \times 10^{3}$

Fluorine

$1.8 \times 10^{2}$

$3.1 \times 10^{1}$

Copper

Chromium

12

$5.5 \times 10^{-1}$

Lead

13

$8.4 \times 10^{-1}$

Cadmium

3.5

$2.6 \times 10^{-1}$

Silver

3.2

$1.9 \times 10^{-1}$

Chlorine

6.8

$1.1 \times 10^{4} 9.3 \times 10^{3}$

On page 79 in Section 4.1, 2nd column, 1st paragraph under "Results of 1992 Monitoring," replace with the following paragraph:

The weather in 1992 was much warmer and wetter than normal. In fact, 1992 was the warmest year on record and the seventh consecutive year with an above-normal annual average temperature. The average temperature for 1992 was $13.6^{\circ} \mathrm{C}\left(56.4^{\circ} \mathrm{F}\right), 1.7^{\circ} \mathrm{C}\left(3.1^{\circ} \mathrm{F}\right)$ abovenormal $\left[11.9^{\circ} \mathrm{C}\left(53.3^{\circ} \mathrm{F}\right)\right]$. Ten months during 1992 were warmer than normal, with nine months at least $0.6^{\circ} \mathrm{C}$ $\left(1.1^{\circ} \mathrm{F}\right)$ above normal, and five months more than $2.0^{\circ} \mathrm{C}$ $\left(3.6^{\circ} \mathrm{F}\right)$ above normal. Only two months were colder than normal, and both by less than $1.0^{\circ} \mathrm{C}\left(1.8^{\circ} \mathrm{F}\right)$. June (a record warm month) had the largest positive departure, $3.9^{\circ} \mathrm{C}\left(7.0^{\circ} \mathrm{F}\right)$ above normal; while December, at $0.8^{\circ} \mathrm{C}$ $\left(1.4^{\circ} \mathrm{F}\right)$ below normal, had the largest negative departure. 
On page 110 in Section 5.2, Table 5.4 on

top of page, last column in table, replace with the following column:

AALG $^{(b)}$
$N^{(d)}$
NA
0.1
0.022
NA
36,400
0.096
0.053
NA
NA
1400
57
290

\section{On page 52 in Section 3.1, Figure 3.1, replace figure caption with the following:}

Figure 3.1. Radioactive Emissions to the Atmosphere (Krypton-85, lodine-129, and Plutonium-239, 240), and Liquid Effluent Releases of Tritium to Ground Disposal Facilities, and Strontium-90 to the Columbia River, 1987 through 1992. Releases of some radionuclides have been very low over the last few years and appear to be zero (no bar) on the graphs. 


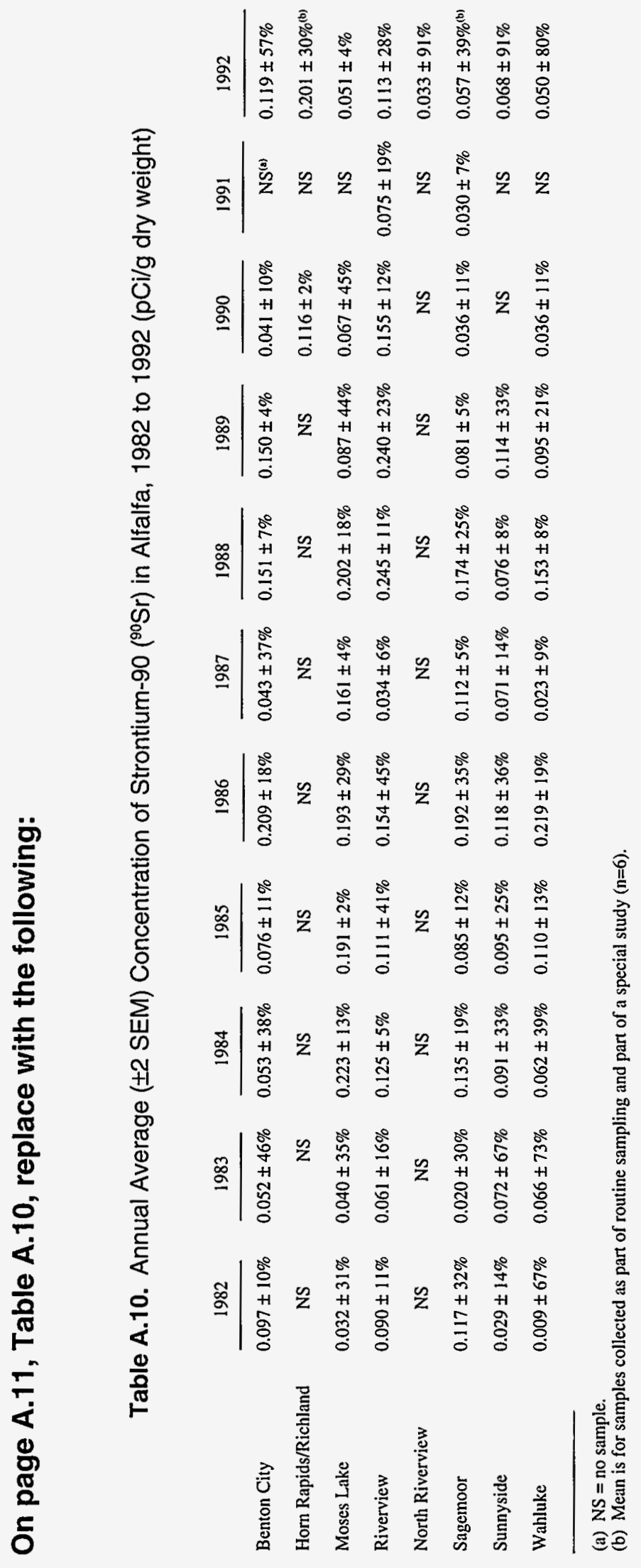


The following corrections can be penciled or inked into your reports in the appropriate locations:

Page 137, Table 5.10. Change the number of samples from Horn Rapids from 3 to 6 .

Page 203, Figure 6.1. Change Advanced Technology Group Corporation to Allied Technology Group Corporation

Page 206, FFTF Visitors Center Drinking Water, line 10 . Change $(<l q t)$ to $(\sim 1 q t)$

Page 209, Figure 6.4, figure key. The key box for Consumer Products and Medical, 65 mrem, should be blue with lines, as on figure. The lines can be hand-drawn on the page.

Page D.6, Table D.5, Meteorological conditions. Delete the words [see Table D-5, Bisping and Woodruff (1993)].

Page D.6, Table D.5, $\bar{X} / Q^{\prime}$. The sentence should read $3.9 \times 10^{-9} \mathrm{~s} / \mathrm{m}^{3}$ at $53 \mathrm{~km} \mathrm{SSE}$;

Page D.7, Table D.6, Releases. Sentence should read See Table 3.4

Page D.8, Table D.7, Meteorological conditions. Delete the words [see Table D-6, Bisping and Woodruff (1993)]
Page D.8, Table D.7, $\bar{X} / Q^{\prime}$. The sentence should read $1.1 \times 10^{-8} \mathrm{~s} / \mathrm{m}^{3}$ at $43 \mathrm{~km} \mathrm{SE}$;

Page D.8, Table D.7, Doses calculated. Delete the words (whole-body) from the sentence.

Page D.9, Table D.8, Meteorological conditions. Delete the words [see Table D-7, Bisping and Woodruff (1993)]

Page D.9, Table D.8, $\bar{X} / Q^{\prime}$. The sentence should read $8.9 \times 10^{-8} \mathrm{~s} / \mathrm{m}^{3}$ at $13 \mathrm{~km} \mathrm{SSE}$;

Page D.9, Table D.8, Doses calculated. Delete the words (whole-body) from the sentence.

Page D.10, Table D.9, Meteorological conditions. Delete the words [see Table D-8, Bisping and Woodruff (1993)]

Page D.10, Table D.9, $\bar{X} / Q^{\prime}$. The sentence should read $4.2 \times 10^{-8} \mathrm{~s} / \mathrm{m}^{3}$ at $22 \mathrm{~km} \mathrm{SSE}$;

Page D.10, Table D.9, Doses calculated. Delete the words (whole-body) from the sentence. 


\section{Distribution}

No. of

Copies

Hanford Site Contractors

Pacific Northwest Laboratory (PNL)

Westinghouse Hanford Company (WHC)

Hanford Environmental Health

Foundation (HEHF)

Kaiser Engineers Hanford (KEH)

DOE, EPA, State and Federal

Agencies, Other DOE Sites, Other Companies, or Nuclear Facilities

DOE Richland Operations Office (RL)

DOE Headquarters (DOE-HQ)

Environmental Protection Agency (EPA)

Washington State Agencies

Oregon State Agencies

Other DOE Sites and Federal Agencies,

Other Companies or Nuclear Facilities

Libraries, Universities, and

Schools
No. of

Copies

Public and Elected Officials

25

226 Professional Organizations,

111 Public Interest Groups, and

Native American Officials

44

Farmers Contributing Samples

for Analyses

29

Owners and/or Administrators

of Islands in the Hanford Reach

of the Columbia River

(Excluding DOE)

7

Community-Operated

Environmental Surveillance

Station Managers

5

Interested Citizens and Others

\section{5}

